GERT OOSTINDIE \& INGE KLINKERS

\title{
Gedeeld Koninkrijk
}

De ontmanteling van de Nederlandse Antillen en de vernieuwing van de trans-Atlantische relaties

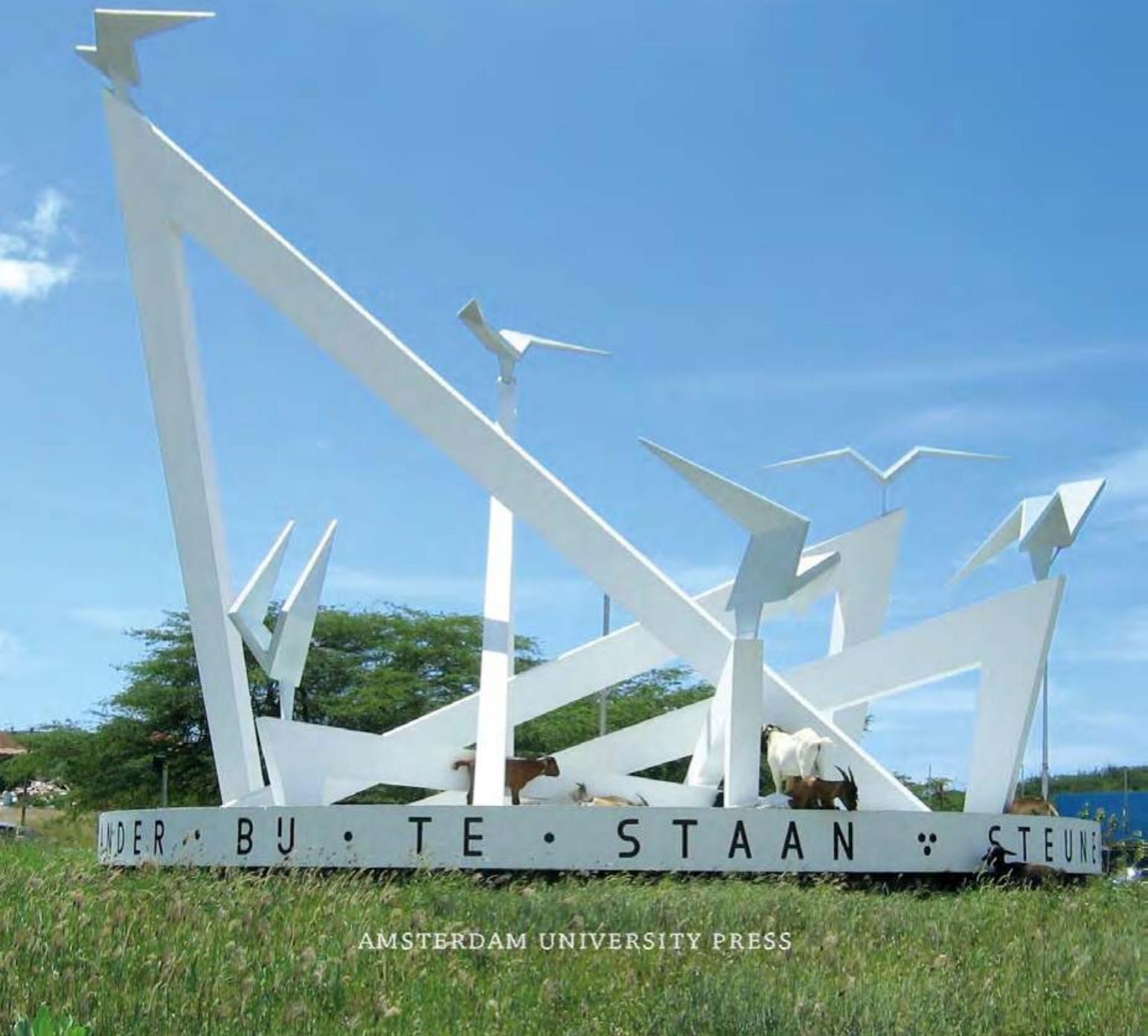


GEDEELD KONINKRIJK 

GERT OOSTINDIE \& INGE KLINKERS

\section{Gedeeld Koninkrijk}

De ontmanteling van de Nederlandse Antillen en de vernieuwing van de trans-Atlantische relaties 
Deze publicatie verschijnt als online publicatie in de OAPEN library (www.oapen.org) en in gedrukte vorm.

OAPEN (Open Access Publishing in European Networks) is een samenwerkingsverband voor het ontwikkelen en implementeren van een duurzaam Open Access publicatiemodel voor wetenschappelijke boeken in de geesteswetenschappen en sociale wetenschappen. De OAPEN Library heeft tot doel de zichtbaarheid en vindbaarheid van kwalitatief hoogwaardig wetenschappelijk onderzoek te verbeteren door het bijeenbrengen van peer reviewed Open Access publicaties uit heel Europa.

Afbeelding omslag: Het Statuut- of Autonomiemonument op Curaçao Foto: Carel de Haseth

Ontwerp omslag en binnenwerk: Sander Pinkse Boekproductie

ISBN 9789089643919

e-ISBN 9789048515486

NUR $688 / 697$

(c) G.J. Oostindie \& I.A.J. Klinkers / Amsterdam University Press, Amsterdam 2012

Alle rechten voorbehouden. Niets uit deze uitgave mag worden verveelvoudigd, opgeslagen in een geautomatiseerd gegevensbestand, of openbaar gemaakt, in enige vorm of op enige wijze, hetzij elektronisch, mechanisch, door fotokopieën, opnamen of enige andere manier, zonder voorafgaande schriftelijke toestemming van de uitgever.

Voor zover het maken van kopieën uit deze uitgave is toegestaan op grond van artikel 16B Auteurswet $1912 j^{\circ}$ het Besluit van 20 juni 1974, Stb. 351, zoals gewijzigd bij het Besluit van 23 augustus 1985, Stb. 471 en artikel 17 Auteurswet 1912, dient men de daarvoor wettelijk verschuldigde vergoedingen te voldoen aan de Stichting Reprorecht (Postbus 3051, 2130 KB Hoofddorp). Voor het overnemen van gedeelte(n) uit deze uitgave in bloemlezingen, readers en andere compilatiewerken (artikel 16 Auteurswet 1912) dient men zich tot de uitgever te wenden. 


\section{Inhoud}

Woord vooraf 7

Overzicht kabinetten, bewindspersonen, beknopte chronologie 15

1. Ruimte voor nieuwe keuzes 21

Het naoorlogse Nederlandse dekolonisatiebeleid 21

Geen eeuwig edict? 28

De knelpunten 31

Consensus en dispuut 36

2. De Koninkrijksrelaties: instituties, spelers, dossiers

De institutionele vormgeving en werking van de

Koninkrijksrelaties 40

De rol van de Raad van State van het Koninkrijk 50

Het politieke speelveld 55

De Nederlandse bewindslieden 60

Permanente dossiers: financiën en deugdelijk bestuur 69

Permanente dossiers: migratie 75

Permanente dossiers: de internationale dimensie 89 Het democratisch deficit en de roep om een visie op het

Koninkrijk 95

(On)denkbare modellen 103 
Startschot: het referendum op Sint Maarten 111

Een nieuw bestuursmodel: de werkgroep-Jesurun 123

Het Hoofdlijnenakkoord: groen licht voor staatkundige wijzigingen 134

Van start-RTC tot 'Partners in het Koninkrijk' 151

De impasse voorbij: de Slotverklaring van 2 november $2006 \quad 167$

Een omstreden keuze met voorspelbare politieke en bestuurlijke risico's 176

4. Het proces: chronologie en resultaten 179

De start van de transitiefase, zonder Curaçao 181

De terugkeer van Curaçao, voortdurende impasses 186

Naar de toetsings-RTC, december $2008 \quad 195$

Koortsachtige onderhandelingen 213

Bonairiaans intermezzo 223

Het laatste jaar 228

Afspraken en concessies 248

\section{Epiloog 251}

Recapitulatie 251

Het migratiedossier 254

De versterking van het Koninkrijk en de betekenis van autonomie 256

Het experiment van Caraïbisch Nederland 262

Schaken en domino 266

Een nieuwe visie op het gedeelde Koninkrijk? 272

Noten 283

Bibliografie 361

Fotoverantwoording 368

Afkortingen 369

Index 372 


\section{Woord vooraf}

Op 10 oktober 2010 werd het land de Nederlandse Antillen opgeheven. '10/10/10' was de staatsrechtelijke bekroning van een opmerkelijke fase in een toch al uitzonderlijk proces van dekolonisatie, een proces dat indruist tegen wat velen lang als een logische uitkomst hadden beschouwd, namelijk dat de zes eilanden uiteindelijk gezamenlijk de onafhankelijkheid zouden aanvaarden. Het tegenovergestelde gebeurde. Het staatsrechtelijke verband van de Nederlandse Antillen werd ontmanteld. Het Koninkrijk der Nederlanden telt nu vier landen - Nederland, Aruba, Curaçao en Sint Maarten - en drie min of meer in Nederland geïntegreerde eilanden, Bonaire, Sint Eustatius en Saba, die voorlopig als openbare lichamen door het leven zullen gaan.

Gedeeld Koninkrijk biedt een beschrijving en analyse van de context, het politieke en bestuurlijke proces en de voorlopige uitkomst van deze opmerkelijke variant in het wereldwijde dekolonisatieproces. Wij hebben ons daarbij laten leiden door een brede vraagstelling: Waarom werd gekozen voor volledige ontmanteling van de Nederlandse Antillen, waarom net in dit tijdsbestek en niet eerder, welke verwachtingen leefden er bij de verschillende partijen omtrent het proces en de resultaten, hoe harmonieus of conflictueus waren de relaties, hoe verliep het proces staatkundig, politiek, ambtelijk c.q. organisatorisch, welke uitkomsten tekenden zich af en hoe werden deze door de betrokkenen gewaardeerd, welke partijen en/of overwegingen legden in de besluitvorming en uitvoering het meeste gewicht in de schaal?

De titel Gedeeld Koninkrijk behoeft wellicht enige toelichting. Het 'gedeelde' van het Koninkrijk is drievoudig bedoeld: gedeeld in de zin van opgedeeld, tussen een Europees en een Caraïbisch deel, dat laatste nu nog verder opgedeeld. Verdeeld, omdat er sprake is van grote materiële en immateriële verschillen tussen de delen van het Rijk. Maar toch ook gedeeld, in de zin van gemeenschappelijk, te beginnen 
met het gemeenschappelijke Nederlandse burgerschap zoals dat in het Statuut voor het Koninkrijk der Nederlanden verankerd ligt. De ondertitel De ontmanteling van de Nederlandse Antillen en de vernieuwing van de trans-Atlantische relaties spreekt voor zich en is programmatisch.

Op de omslag prijkt het 'Autonomiemonument' dat in 1955 aan de Rijkseenheidboulevard op Curaçao werd onthuld door koningin Juliana. De tekst op de sokkel - 'Steunend op eigen kracht doch met de wil elkander bij te staan' - was ontleend aan de 'decemberrede' van koningin Wilhelmina, waarin zij in 1942 vanuit Londen de koloniën een hervorming van het koloniale bestel aankondigde. Voor Indonesië bleek het too little, too late, voor Suriname en de Nederlandse Antillen mondde het uit in het Statuut van 1954. Het monument wilde verbondenheid uitdrukken, van de zes eilanden onderling en met $\mathrm{Ne}-$ derland, en overigens ook met Suriname. Na 10/10/10 symboliseert het monument een gedeeld verleden, maar onbedoeld evenzeer de verdeeldheid die maakte dat de zes eilanden nu wel elk voor zich een eigen band met Nederland hebben, maar staatkundig los van elkaar zijn komen te staan.

De ontmanteling van de Nederlandse Antillen vloeit min of meer logisch voort uit het dekolonisatieproces van de afgelopen decennia, dat wij eerder analyseerden in Knellende Koninkrijksbanden (2001). De eerste mijlpaal in dit proces was het genoemde Statuut voor het Koninkrijk der Nederlanden, dat het Koninkrijk definieerde als een verband van drie in hoge mate autonome landen (Nederland, de Nederlandse Antillen en Suriname). Het Statuut functioneert, naar inhoud vrijwel ongewijzigd, nog altijd als de grondwet van het transAtlantische Koninkrijk en zal dat ook na 10/10/10 blijven doen.

In de afgelopen 55 jaar veranderde Den Haag, min of meer kamerbreed, enkele malen van koers, van omarming van de Statutaire partners tot een beleid gericht op een snelle soevereiniteitsoverdracht, tot de erkenning dat dit voor de Nederlandse Antillen niet realistisch en mogelijk ook onwenselijk was. Uiteindelijk zou Den Haag accepteren dat de Antillen - zowel het land als de afzonderlijke eilanden - de onafhankelijkheid als uitkomst afwezen en ging vervolgens inzetten op een sterkere betrokkenheid bij de vormgeving van de randvoorwaarden voor het lokale bestuur. Een systematische vergelijking met de situatie in andere niet-soevereine delen van de Caraïben maakt begrijpelijker waarom de wens tot onafhankelijkheid in de Antillen niet sterk leeft en, zo was onze voorspelling in Knellende Koninkrijksbanden en ook in Decolonising the Caribbean (2003), alleen daarom al geen reëel bestuurlijk perspectief zou zijn voor de komende decennia.

De politieke agenda voor het Koninkrijk werd daarom vanaf 1990 
niet zozeer gedomineerd door de voorbereiding van een toekomstig afscheid, maar juist door de vraag hoe, binnen de postkoloniale ordening van het Statuut, de relaties tussen Nederland en de eilanden van wat ooit was aangeduid als 'Curaçao en onderhoorigheden' optimaal invulling zouden kunnen krijgen. In staatsrechtelijke zin waren er twee centrale kwesties. Enerzijds betrof dat de houdbaarheid van de Statutaire autonomie, die door de versterking van de Haagse bemoeienis vanaf de jaren negentig onder druk zou komen te staan. Anderzijds ging het om het centrifugalisme op de eilanden. Het was duidelijk dat, met het bereiken van de status aparte van Aruba in 1986, verdere desintegratie van de Nederlandse Antillen een terugkerend agendapunt zou worden.

De kern van het proces zoals dat zich het afgelopen decennium heeft afgetekend, werd inderdaad gevormd door deze twee kwesties. De formulering en uitvoering van Haags beleid aan beide zijden van de oceaan riep daarbij principiële staatsrechtelijke en politieke vragen op over de betekenis van de Caraïbische autonomie - waarbij uiteraard ook vaak werd verwezen naar de, gezien de voortschrijdende Europese integratie, afnemende betekenis van de Nederlandse autonomie.

Deze debatten werden niet in een vacuüm gevoerd. De bredere context was die van groeiende interdependentie tussen alle burgers van het Koninkrijk. Ook dit was niets nieuws. Anno 2000 was weinig meer over van de trans-Atlantische afstand die in 1945 of 1954 nog zo kenmerkend was geweest. De Nederlandse bestuurlijke betrokkenheid was sterk toegenomen, evenals het belang van Haagse financiële ondersteuning van de eilanden. Van nog grotere betekenis was de demografische brug die over de oceaan werd geslagen. In de laatste decennia nam de migratie vanuit de Antillen, in het bijzonder vanuit Curaçao, richting Nederland sterk toe. De Antilliaanse - in dit 'Woord vooraf' gebruikt als aanduiding van de bewoners van alle zes eilanden - gemeenschap werd transnationaal. Dit betekende dat eilandelijke sociaaleconomische problemen zich ook vertaalden in een integratieproblematiek in Nederland, die weer een negatieve weerslag had op de wijze waarop in de Haagse politiek werd gesproken over 'het Antillendossier'.

De notie van intensivering van de trans-Atlantische relaties behoeft de kanttekening dat deze niet aan beide zijden even sterk woog. Voor de Antilliaanse eilanden is Nederland veel belangrijker dan andersom. In de politieke en bestuurlijke praktijk wordt de formele gelijkwaardigheid die de relaties tussen de autonome landen van het Koninkrijk behoort te karakteriseren doorkruist door de sterke asymmetrie in schaal, rijkdom, macht en cultureel kapitaal. Antil- 
liaanse gevoelens van onvrede over ongelijkheid waren de keerzijde van de Nederlandse 'terugkeer' op de eilanden, door critici wel als 'rekolonisatie' veroordeeld.

In deze beladen context speelde het proces van ontmanteling van de Nederlandse Antillen zich af. Het ging gelijktijdig om het opbreken van het land, om oplossing van een ernstige financiële crisis en om een mede hierdoor vereiste versterking, of althans nadere omschrijving van de bevoegdheden van de door Nederland gedomineerde Koninkrijksregering. Verschillende partijen stelden uiteenlopende en soms tegenstrijdige prioriteiten. Het draagvlak voor het gevoerde beleid was ongelijk en fluctueerde in de loop der jaren, zozeer dat de nu bereikte uitkomst meermalen aan een zijden draadje hing en hoe dan ook niet in alle opzichten strookt met de aanvankelijke doeleinden van de verschillende betrokken spelers. Er werden vele compromissen gesloten. Of de uitkomst van dit pragmatische transAtlantische 'polderen' uiteindelijk de toets der kritiek kan doorstaan, is een vraag die, zoals in het slothoofdstuk zal blijken, uiteenlopend wordt beantwoord.

De lange voorgeschiedenis van de ontmanteling van de Nederlandse Antillen en de herinrichting van het Koninkrijk wordt in dit boek summier beschreven; het zwaartepunt ligt op de processen van het laatste decennium. In het openingshoofdstuk resumeren wij de hoofdlijnen van wat voorafging en de bredere context waarin werd gekozen voor een nieuw beleid.

Het proces van ontmanteling werd in gang gezet door de in 2000 in een referendum opnieuw tot uiting gebrachte wens van Sint Maarten om een aparte status binnen het Koninkrijk te verwerven. Uiteindelijk zou Den Haag zijn verzet hiertegen opgeven. De kernvraag luidt vervolgens hoe een betrekkelijk ingrijpende herziening van de relaties binnen het Koninkrijk tot stand kwam. Het draait dan om de identificatie van oude en nieuwe knelpunten en een vaststelling van hun gewicht voor de verschillende partijen, en van relevante verschuivingen in het politieke krachtenveld.

De vernieuwing van de Koninkrijksrelaties kan niet goed worden begrepen zonder kennis van de institutionele vormgeving van deze relaties en van de belangrijkste 'dossiers', in het bijzonder de kwaliteit van bestuur, de rechtshandhaving, de economische en financiële ontwikkeling en de Antilliaanse migratie naar Nederland. In hoofdstuk twee worden deze thema's en hun gewicht in de debatten over de herinrichting van het Koninkrijk behandeld. Daarbij schenken we ook ruime aandacht aan de institutionele hoofdrolspelers en politieke conjuncturen in de betrokken landen en eilanden. Aruba komt 
hier wat meer aan de orde dan in andere hoofdstukken. Daar was dat minder passend, eenvoudig omdat Aruba de discussies over de verdere ontmanteling van de Nederlandse Antillen grotendeels van een comfortabele afstand kon beschouwen, vooral waakzaam waar de eigen, zwaarbevochten autonomie mogelijk in gevaar kon komen.

Het referendum op Sint Maarten betekende in 2000 het startschot voor de debatten over een Koninkrijk-nieuwe-stijl. In hoofdstuk drie wordt onderzocht waarom, gegeven de brede wens tot herziening van de relaties, tussen 2004 en 2006 werd gekozen voor een specifiek model om dit te verwezenlijken. De strategische keuzes waren niet onomstreden en bovendien niet zonder politieke en bestuurlijke risico's.

Het gehele traject vanaf het akkoord over ontmanteling, sanering van de Antilliaanse overheidsfinanciën en gelijktijdige versterking van het Koninkrijk tot aan het bereiken van de magische deadline van 10/10/10 wordt besproken in het vierde hoofdstuk. Hierbij wordt in het bijzonder onderzocht in hoeverre planning en vooral uitkomst van het gehele proces afweken van de aanvankelijke voornemens, en hoe eventuele verschillen kunnen worden verklaard en gewaardeerd.

In de Epiloog kijken we nogmaals naar het krachtenveld waarin deze herinrichting werd verwezenlijkt. In Nederland verminderde de aanvankelijk brede consensus over het gezamenlijk gevoerde beleid, maar de sterkste bedreiging hiervoor kwam toch van de eilandelijke oppositie, in het bijzonder op Curaçao. Al dan niet onwillig werd ook Den Haag betrokken bij deze formeel interne zaken. Mede op grond van gesprekken met hoofdrolspelers wordt het proces geëvalueerd, maar bovendien het perspectief verruimd.

De pendant van het proces van ontmanteling van de Nederlandse Antillen was een modernisering van het Koninkrijk, waarbij Nederland tegenover een tegemoetkomen aan eilandelijk separatisme een versterking van het Koninkrijk en daarmee van de eigen rol opeiste en zo de grenzen van de Caraïbische autonomie verengde.

Alle partijen in het proces meenden in het belang van de burgers in het Koninkrijk te handelen, in het bijzonder de burgers in de Nederlandse Antillen en Aruba. Het blijft een betwiste kwestie of de gekozen weg inderdaad de beste was, of het gehele proces en de uitkomst ervan het onderlinge vertrouwen hebben versterkt of juist niet, en of er, ook in breder verband bezien, mogelijk betere alternatieven zouden zijn geweest.

Bij het schrijven van dit boek hebben wij behalve van publiekelijk toegankelijke overheids- en perspublicaties en interviews, vooral ruim gebruikgemaakt van de nog gesloten archieven van het ministerie 
van Binnenlandse Zaken en Koninkrijksrelaties (BZK). In dit zogeheten Digidoc worden ambtelijke stukken gearchiveerd. Slechts een bescheiden deel van de onderzochte documenten is uiteindelijk expliciet in dit boek verwerkt, c.q. mocht door ons worden gebruikt. Het archiefonderzoek heeft ons echter wel een goed beeld gegeven van het werk van het meest betrokken ministerie. Hoe dan ook blijft het voor iedere onderzoeker altijd een vraag welke gedachten en gesprekken níet zijn bewaard. Een oud probleem voor de historicus, dat echter in tijden van veel vluchtiger communicatiemiddelen (telefoon, e-mail, sms) sterker dan ooit voorheen telt.

Uit interviews met betrokken politici en adviseurs aan beide zijden van de oceaan hebben wij, met hun toestemming, ruim geput. Gesprekken met de vicevoorzitter van de Raad van State H.D. Tjeenk Willink, met gouverneurs F.M. de los Santos Goedgedrag en E.B. Holiday en met ambtenaren, voornamelijk aan Nederlandse zijde, dienden vooral om ons begrip te scherpen. In deze, maar ook in veel andere gesprekken werd ons off the record meer verteld dan wij expliciet konden gebruiken, althans, toeschrijven.

Gedeeld Koninkrijk verschijnt gelijktijdig in boekvorm en in een open access digitale editie. Anders dan in onze voorgaande boeken verwijzen wij slechts summier naar secundaire literatuur. Er zijn het afgelopen decennium verschillende studies verschenen die nuttig zijn voor een goed begrip van de politieke ontwikkelingen in de nietsoevereine Caraïben als geheel, dan wel over de Koninkrijksrelaties in het bijzonder. Wij hebben kennis genomen van - en in sommige gevallen ook zelf bijgedragen aan - deze literatuur, maar het bleek voor dit toch vooral op primaire bronnen gebaseerde boek niet zinvol deze literatuur apart te bespreken. ${ }^{1}$

Met nadruk zij vermeld dat conform de opdracht slechts onderzoek is gedaan in de archieven van het ministerie van Binnenlandse Zaken en Koninkrijksrelaties en in openbare bronnen; het boek geeft een beeld van het Nederlandse beleid. Aard noch omvang van de onderzoeksopdracht liet een onderzoek in Antilliaanse of Arubaanse archieven toe. Dit is uiteraard een beperking. Een ruim aantal interviews met hoofdrolspelers aan beide zijden van de oceaan stelde ons niettemin in staat het perspectief in zoverre te verbreden dat het Haagse beleid dat hier centraal staat van meerdere zijden van commentaar kon worden voorzien.

Wij menen, met de opdrachtgever, dat het proces dat in dit boek wordt beschreven en geduid niet slechts van belang is voor de betrokken Caraïbische (ei)landen, maar ook voor het Koninkrijk als geheel. Daarbij gaat het niet alleen, en zeker niet eens in de eerste plaats, om bestuurlijke regelingen. De hier beschreven staatkundige veranderin- 
gen mogen dan primair de burgers van het Koninkrijk in de Caraïben raken, zij onderstrepen toch ook dat de eeuwenoude banden blijven bestaan, al dan niet harmonieus. Net als de koloniale geschiedenis is ook deze recente postkoloniale geschiedenis een gedeeld verhaal. Het is niet overbodig de Nederlandse lezers hieraan te herinneren. Te vaak wordt vergeten dat de burgers van het Koninkrijk niet alleen aan de Noordzee, maar ook aan de Caraïbische Zee wonen.

Over ons eigen perspectief kunnen wij kort zijn. De focus van dit boek ligt als gezegd op het Nederlandse beleid. Dit impliceert geenszins dat voor de auteurs een Nederlands perspectief maatgevend is, maar wel een bewuste verenging van het blikveld. Waar in dit boek over 'Den Haag' wordt gesproken, bedoelen wij bovendien de Nederlandse regering, het Nederlandse parlement, en in bredere zin het reilen en zeilen rond het Binnenhof. Uiteraard vergadert in Den Haag ook de Rijksministerraad, de facto de regering van het trans-Atlantische Koninkrijk. Wanneer wij doelen op dit orgaan geven wij dat expliciet aan. Naar zal blijken is dit slechts sporadisch het geval.

Het Antilliaanse perspectief, het politieke denken en handelen, de maatschappelijke ontwikkelingen en de reacties op het Nederlandse optreden komen slechts indirect aan de orde, namelijk als factoren die in het Nederlandse beleid een rol speelden of hadden moeten spelen. In het bijzonder de interviews met hoofdrolspelers op de eilanden boden de mogelijkheid dit perspectief te verdiepen. Maar ook dan nog zou een studie van hetzelfde proces, geschreven op basis van Antilliaanse (ei)landelijke bronnen, zonder twijfel ten minste andere accenten en mogelijk ook wel andere zienswijzen hebben opgeleverd. Wij kunnen slechts de hoop uitspreken dat zo'n onderzoek mettertijd zal worden verricht.

Wij besluiten met enkele woorden van dank. Allereerst aan allen die wij op de Antillen - onze pragmatische aanduiding voor de Koninkrijksdelen die tot voor kort 'de Nederlandse Antillen en Aruba' heetten - of in Nederland mochten vragen naar hun ervaringen en meningen. Voorts aan Annika Ockhorst M.A., die ons gedurende bijna een jaar voortreffelijk bijstond als onderzoeksassistent.

Voorts danken wij de begeleidingscommissie, bestaande uit mr.dr. A.G. Croes, drs. C.P. de Haseth, prof.dr. S. Legêne en prof.dr. J.J.C. Voorhoeve alsmede, van de zijde van het ministerie van BZK, DG drs. A.C. van Es, na haar vertrek vervangen door DG drs. G-J. Buitendijk, en J. Felida M.A., respectievelijk drs. A.A. Dalenoort, die achtereenvolgens het secretariaat voerden. De commissie had een dubbele rol. Enerzijds waarborgde zij de wetenschappelijke integriteit van het onderzoek, anderzijds behoedde zij de auteurs voor uitglijders. Tot 
ons genoegen was zij voornamelijk in de tweede hoedanigheid van belang.

Tot slot een woord van erkentelijkheid aan de opdrachtgever. Het ministerie van BZK, en in het bijzonder staatssecretaris drs. A.Th.B. Bijleveld-Schouten en vervolgens minister mr. J.P.H. Donner, heeft alle medewerking verleend aan het door het departement zelf geïnitieerde onderzoek, zonder de auteurs inhoudelijk te sturen. Dit gezegd hebbende, rest ons slechts te benadrukken dat de verantwoordelijkheid voor de tekst van dit boek uiteindelijk bij de auteurs ligt, niet bij de opdrachtgever of begeleidingscommissie.

$\mathrm{GO} / \mathrm{IK}$

september 2011 


\section{Overzicht kabinetten, bewindspersonen, beknopte chronologie}

Kabinetten Nederland, 2000-2010

2e kabinet-Kok

aug. 1998-jul. 2002 PVDA-VVD-D66

1e kabinet-Balkenende

jul. 2002-mei 2003

CDA-LPF-VVD

2e kabinet-Balkenende

mei 2003-jul. 2006

CDA-VVD-D66

ze kabinet-Balkenende

jul. 2006-feb. 2007

CDA-VVD (rompkabinet)

4e kabinet-Balkenende

feb. 2007-feb. 2010

CDA-PVDA-CU (daarna

demissionair)

Staatssecretaris van Binnenlandse Zaken en Koninkrijksrelaties

G.M. de Vries (VVD) 3 augustus 1998

Minister van Binnenlandse Zaken en Koninkrijksrelaties

J.W. Remkes (VVD) 22 juli 2002

Ministers voor Bestuurlijke Vernieuwing en Koninkrijksrelaties

Th.C. de Graaf (D66) 27 mei 2003
A. Pechtold (D66)
30 maart 2005
A. Nicolaï (VVD)
7 juli 2006

Staatssecretaris van Binnenlandse Zaken en Koninkrijksrelaties
A.Th.B. Bijleveld-
22 februari 2007
Schouten (CDA)

Minister van Binnenlandse Zaken en Koninkrijksrelaties

J.P.H. Donner (CDA) 14 oktober 2010 
KABINETTEN, GOUVERNEURS EN GEVOLMACHTIGDE MINISTERS NEDERLANDSE ANTILLEN EN ARUBA

Kabinetten Nederlandse Antillen, 2000-2010

3e kabinet-Pourier nov. 1999-jun. 2002 PAR-PNP-DP SXM-FOLMAN-UPB-DP Bon-

WIPM-SEA

1e kabinet-Ys

jun. 2002-jul. 2003 PAR-PNP-PLKP-DP SXMUPB-DP Statia

kabinet-Komproe jul.-aug. $2003 \quad$ FOL-PNP-PLKP-UPB-DP SXM

kabinet-Louisa-Godett aug. 2003-jun. 2004 FOL-PNP-PLKP-UPB-DP

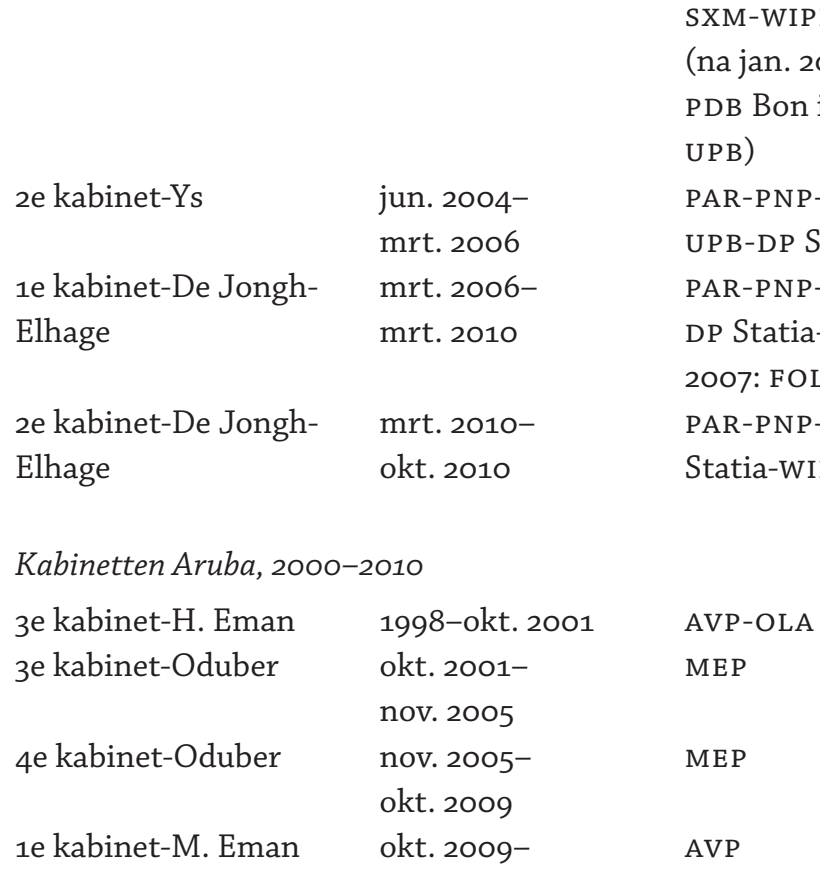

Gouverneurs van de Nederlandse Antillen, 2000-2010

J.M. Saleh 18 juli 1989

F.M. de los Santos

1 juli 2002-10 oktober 2010

Goedgedrag

Gouverneur van Curaçao, 2010-

F.M. de los Santos 10 oktober 2010

Goedgedrag 
Gouverneur van Sint Maarten, 2010-

E.B. Holiday $\quad 10$ oktober 2010

Gouverneurs van Aruba, 2000-2010

O. Koolman 29 januari 1992

F.J. Refunjol 11 mei 2004-

Gevolmachtigde ministers van de Nederlandse Antillen, 2000-2010

C.P. de Haseth (PAR) 30 december 1999

M.H.P.P. Adriaens (FOL) 22 juli 2003

C.P. de Haseth (PAR) 3 juni 2004

P.R.J. Comenencia 23 juli 2004

(PAR)

M. van der Plank (PAR) 4 juli 2009

Gevolmachtigde ministers van Aruba, 2000-2010

A.G. Croes (AVP) 30 augustus 1994

A.A. Tromp-Yarzagaray 30 oktober 2001

(MEP)

F.W. Croes (MEP) 8 november 2005

E.B. Abath (AVP) 1 november 2009

BEKNOPTE CHRONOLOGIE

23 juni $2000 \quad$ Referendum Sint Maarten

9 september $2003 \quad$ Voorlichting Raad van State van het Koninkrijk over de verhouding van de Nederlandse Antillen en Aruba tot de Europese Unie

10 september 2004 Referendum Bonaire

8 oktober 2004 Rapport werkgroep-Jesurun, Nu kan het... nu moet het!

5 november $2004 \quad$ Referendum Saba

10 december $2004 \quad$ Ongevraagd advies Raad van State van het Koninkrijk over de Koninkrijksrelaties naar aanleiding van vijftig jaar Statuut

8 april 2005 Referenda Curaçao en Sint Eustatius

22 oktober 2005 Hoofdlijnenakkoord Nederlandse Antillen, Nederland, Curaçao, Sint Maarten, Bonaire, Sint Eustatius en Saba 
22 oktober 2005

26 november 2005

18 september 2006

11 oktober 2006

2 november 2006

12 februari 2007

18

1 juli 2007

28 augustus 2007

29 augustus 2008

15 december 2008

15 december 2008

15 mei 2009

1 januari 2010

9 maart 2010

15 april 2010

11 mei 2010

6 juli 2010

20-21 augustus 2010

1 september 2010

4 september 2010

7 september 2010
Intentieverklaring Nederland, Bonaire, Sint Eustatius en Saba

Start-RTC te Willemstad

Voorlichting Raad van State van het Konink-

rijk inzake de hervorming van de staatkundige

verhoudingen van de Antilliaanse eilanden

binnen het Koninkrijk

Slotverklaring Miniconferentie Nederland, Bonaire, Sint Eustatius en Saba

Slotverklaring Nederland, de Nederlandse

Antillen, Curaçao en Sint Maarten

Overgangsakkoord Nederland, de Neder-

landse Antillen, Sint Maarten, Bonaire, Sint

Eustatius en Saba

Eerste streefdatum opheffing Nederlandse

Antillen niet gehaald

Toetredingsakkoord Nederland, Nederlandse

Antillen en Curaçao

Voorlichtingen Raad van State van het

Koninkrijk over versnelling van het transitie-

proces en over gefaseerde herstructurering

BES-eilanden

Tweede streefdatum opheffing Nederlandse

Antillen niet gehaald

Toetsings-RTC te Willemstad

Referendum Curaçao

(Informele) derde streefdatum ontmanteling

Nederlandse Antillen verloopt

Tweede Kamer aanvaardt de eerste zeven BESwetten

Tweede Kamer aanvaardt consensusrijkswetten

Eerste Kamer aanvaardt zonder stemming BES-wetten

Eerste Kamer aanvaardt consensusrijkswetten en reglementen

Staten van de Nederlandse Antillen aanvaar-

den wijziging Statuut

Officiële publicatie in het Staatsblad van

pakket rijks- en BES-wetgeving

Staten Aruba aanvaarden wijziging Statuut

Rijksministerraad stelt Staatsregelingen

Curaçao en Sint Maarten vast 
8 september 2010

9 september 2010

9 oktober 2010

10 oktober 2010
Kamer aanvaardt Inwerkingtredings-KB voor Statuutwijziging

Slot-RTC in Den Haag, ondertekening Slotverklaring

Laatste Statenvergadering Nederlandse Antillen

Transitiedatum ontmanteling Nederlandse Antillen en herstructurering Koninkrijk 



\section{Ruimte voor nieuwe keuzes}

Wanneer wij enige afstand nemen van de vaak hectische processen rond de ontmanteling van de Nederlandse Antillen springt een zekere ironie in deze geschiedenis direct in het oog. Ooit was het Haagse beleid erop gericht om de zes eilanden als een staatkundige eenheid naar de onafhankelijkheid te loodsen. Met elkaar, los van Nederland, luidde het devies. $\mathrm{Nu}$ is het tegengestelde bereikt: met een beroep op het zelfbeschikkingsrecht hebben de eilanden elkaar losgelaten, terwijl de band van de afzonderlijke eilanden met het (voormalige) moederland juist is versterkt. Een ontnuchterende conclusie voor wie nog vanuit koloniaal perspectief redeneert. Zomin als de resultaten van het kolonialisme altijd beantwoordden aan de Nederlandse motieven, zomin reflecteerde de uitkomst van het dekolonisatieproces altijd de voorkeuren van Den Haag.

Dit hoofdstuk biedt een samenvatting van de hoofdlijnen van het naoorlogse dekolonisatiebeleid in het Caraïbisch gebied, gevolgd door een analyse van de aard van de Koninkrijksrelaties rond en kort na de eeuwwisseling, de al dan niet publiekelijk besproken knelpunten en het ontstaan van een betrekkelijk breed gedeelde consensus dat vernieuwing van de verhoudingen nodig en mogelijk was. Tot slot wordt kort vooruitgeblikt op de voorlopige uitkomst van het vernieuwingsproces. ${ }^{1}$

\section{Het naoorlogse Nederlandse dekolonisatiebeleid}

Sinds de vroege zeventiende eeuw was Nederland - toen nog een republiek - een koloniale macht in Azië, Afrika en de Amerika's. Na de napoleontische oorlogen ging een deel van het koloniale bezit verloren aan Groot-Brittannië. Het door Willem I, de eerste vorst van het Koninkrijk der Nederlanden, ingezette koloniale beleid getuigde aanvankelijk nog van vertrouwen in de bijdrage die 'de West' kon leve- 
ren aan het moederland. Rond het midden van de negentiende eeuw tekende zich echter een nieuwe werkelijkheid af. Indië was voortaan de onbetwiste parel in de kroon, de koloniën in de Caraïben werden meer als problematisch dan als waardevol gezien. In eng financiële zin klopte dat ook wel: waar Indië de Nederlandse schatkist spekte, moest juist geld worden toegelegd op Suriname en de zes eilanden die als 'Curaçao en onderhoorigheden' bekendstonden.

Zo kon het gebeuren dat sinds de late negentiende eeuw regelmatig stemmen opgingen om de eilanden en mogelijk ook Suriname maar van de hand te doen. Die optie was - onze hedendaagse ethische bedenkingen daargelaten - op zich niet ondenkbaar. De laatste Nederlandse enclave in Afrika, Elmina, was in 1872 aan de Britten overgedaan. Nog in 1917 verkochten de Denen de Maagdeneilanden aan de Verenigde Staten. Er waren dus precedenten. Maar er werd geen serieus werk gemaakt van een mogelijke verkoop. Kopers dienden zich niet aan. Iets van eergevoel speelde mogelijk ook wel. Vanuit Venezuela werd vooral impliciet wel eens aanspraak gemaakt op de Benedenwindse Antillen, maar hierop werd altijd afwijzend gereageerd.

Was de omvang van de Europese bevolking in de Indonesische archipel rond 1800 nog vergelijkbaar geweest met die in de West, een eeuw later waren de contrasten groot. De pacificatie van NederlandsIndië ging gepaard met een spectaculaire toename van de Europese bevolking daar; in vrijwel alle opzichten raakte Nederland sterk verbonden met dit grote koloniale avontuur. Zo niet met Suriname en de Antillen, waar de uit Nederland afkomstige bevolking - voornamelijk bestuurders, onderwijskrachten, zendelingen en missionarissen - een bescheiden omvang behield, al ging zij lokaal wel een sterker stempel drukken. Dit algemene beeld veranderde slechts marginaal met de komst van de Shell op Curaçao, in de jaren twintig. Vanuit eilandelijk perspectief was de groeiende Nederlandse aanwezigheid weliswaar zichtbaar en voelbaar, vanuit Nederland bezien was getalsmatig alleen het migratiecircuit met Indië van belang.

De Tweede Wereldoorlog vormde voor Nederland de onverwachte genadeklap voor het kolonialisme in Indië. Hier werd een klassiek kolonialisme - grote economische en geopolitieke belangen gecombineerd met een zekere bestuurlijke zendingsdrift - ruw beëindigd door een al even klassieke dekolonisatie, gekenmerkt door bloedige strijd, slepende onderhandelingen en als gevolg daarvan langdurig vergiftigde postkoloniale relaties. In slechts zeven jaar tijd - gemarkeerd door de Japanse bezetting in 1942, de afkondiging van de onafhankelijkheid in 1945 en de formele soevereiniteitsoverdracht in 1949 - verloor Nederland zo Indië, volgens velen de kurk waarop de 
economie dreef en tevens het Nederlandse ticket tot de status van speler in de wereldpolitiek. Het verlies van Indië zou uiteindelijk in economische zin geen drama blijken. De geopolitieke gevolgen stemden weliswaar tot een nieuwe bescheidenheid, maar maakten Nederland nu ook weer niet tot een dwergstaatje.

In de marge van dat proces ontwikkelde Den Haag een dekolonisatiebeleid voor de West, de enige twee rijksdelen die in de oorlog niet waren bezet. Het oorlogskabinet had in zijn beraadslagingen over de naoorlogse hervorming van de koloniale verhoudingen vrijwel uitsluitend gesproken over het behoud van Indië - de Caraïbische koloniën kwamen alleen in bijzinnen aan bod, bijzinnen die echter wel op Haagse verplichtingen zouden uitlopen. En zo stelde koningin Wilhelmina in haar beroemde decemberrede, 1942, niet alleen aan Indië, maar ook aan Suriname en de Antillen een behoedzaam geformuleerd afscheid van de koloniale verhoudingen in het vooruitzicht.

Deze belofte van nieuwe verhoudingen wekte overzee hoge verwachtingen en na langgerekte onderhandelingen kon uiteindelijk, op 15 december 1954, het Statuut voor het Koninkrijk der Nederlanden worden geproclameerd, een regeling die boven de Nederlandse grondwet staat. Zij definieerde het Koninkrijk als een vrijwillig verband van drie intern autonome landen: Nederland, Suriname en de Nederlandse Antillen. Deze drie 'gelijkwaardige' landen zouden een aantal zaken in Koninkrijksverband regelen, waaronder buitenlands beleid, defensie, staatsburgerschap en het waarborgen van deugdelijk bestuur. Over deze zaken besliste de Koninkrijksregering: het Nederlandse kabinet uitgebreid met een gevolmachtigde minister voor elk van beide Caraïbische landen (en althans formeel uiteraard ook de koning). Het idee om deze Koninkrijksregering te laten controleren door een afzonderlijk Koninkrijksparlement werd gedurende de slepende onderhandelingen door alle partijen verlaten, om pragmatische redenen maar ook wel omdat aan Nederlandse zijde twijfels over de aangeboden gelijkwaardigheid groeiden. Gekozen werd voor een eenvoudiger variant, waarin de Caraïbische landen slechts bij bijzondere gelegenheden zouden bijdragen aan de debatten in het Nederlandse parlement. Een regeling die derhalve tot op heden een 'democratisch deficit' vertoont.

Het Statuut spreekt veelvuldig van 'gelijkwaardigheid' en 'wederzijdse bijstand', begrippen die fictief zijn, gezien de volstrekte asymmetrie in macht en schaal. Dat was in 1954 ook al duidelijk. Deze formuleringen waren dan ook gedurende de Tweede Wereldoorlog bedacht met geheel andere bedoelingen, namelijk in de hoop hiermee Indonesië te overtuigen om binnen het Koninkrijk te blijven. Men bedenke dat in 1940 Nederland ongeveer negen miljoen inwoners 
telde, Indonesië zeventig miljoen, Suriname 140.000 en de Antillen 108.00o. Waar Den Haag 'gelijkwaardigheid' had aangeboden aan een immens veel groter land, hielden de kleine eilanden nu Nederland weer aan die belofte. In het onderhandelingsproces dat uiteindelijk leidde tot het Statuut maakten de West-Indische politici behendig gebruik van de tegemoetkomingen die Den Haag eigenlijk alleen voor Indië had uitgewerkt. ${ }^{2}$

Tot omstreeks 1970 overheerste in Den Haag tevredenheid met het Statuut. De Curaçaose revolte van mei 1969, waarbij op verzoek van de Antilliaanse regering Nederlandse mariniers gewapenderhand moesten ingrijpen, was een keerpunt. Vanaf dat moment tot op heden werd het Haagse beleid voor de Caraïbische rijksdelen geleid door enerzijds wrevelige vaststellingen - geen positieve belangen, beperkt vertrouwen in een keer ten goede - anderzijds een groeiend besef van de nadelen en risico's die aan dit trans-Atlantische arrangement kleven.

Wat dat laatste betreft, ging het om een drietal overwegingen. Allereerst, en aanvankelijk de grootste zorg, het besef wel verantwoordelijk te zijn voor het waarborgen van deugdelijk bestuur overzee, maar met het oog op de Caraïbische autonomie weinig speelruimte te hebben om in een vroeg stadium te voorkomen dat problemen ontstaan. Daaraan was althans in eerste instantie, met mei 1969 nog vers

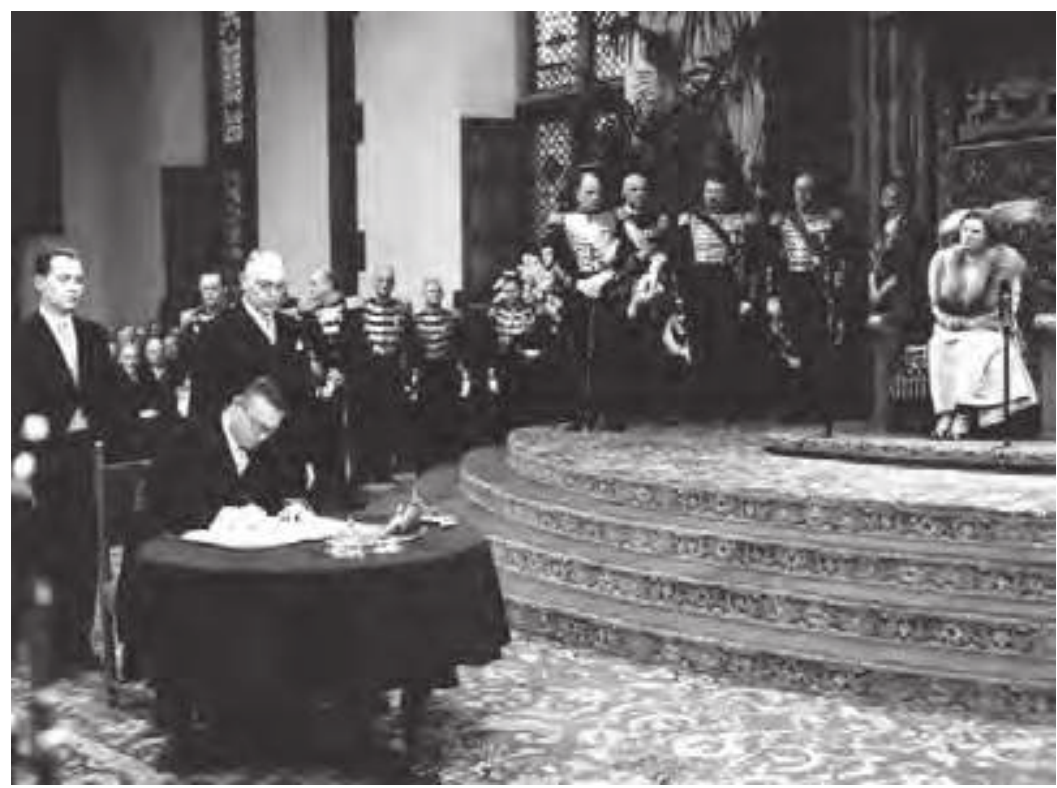

De Antilliaanse minister-president Efraïn Jonckheer ondertekent, toegekeken door koningin Juliana, het Statuut voor het Koninkrijk der Nederlanden in de Ridderzaal, Den Haag, 15 december 1954. 
in het geheugen, de beduchtheid gekoppeld voor een neokoloniaal imago wanneer dan tóch moest worden ingegrepen.

Een tweede overweging lag in de economische sfeer. De in en rond het Statuut geformuleerde verwachtingen over 'wederzijdse' bijstand teneinde de inkomensverschillen te verminderen, bleken een vrome hoop. De kleinschaligheid bleek een structureel probleem, nog afgezien van de kwaliteit van bestuur. Hoe dan ook, het idee van eindigheid van de ontwikkelingshulp aan Suriname en de Antillen bleek steeds duidelijker illusoir. De door Nederland verleende bijstand werd structureel, zonder uitzicht op beëindiging, althans zolang de soevereiniteit niet werd overgedragen. Wat de Antillen betreft, ontstond langzamerhand zelfs een beeld van 'hulpverslaving'. Dat was een gechargeerde voorstelling van zaken, zoals ook de vaak in Den Haag gedebiteerde stelling dat geen land ter wereld zoveel hulp per hoofd van de bevolking ontvangt als de Antillen onjuist en misleidend is. Op de Nederlandse begroting kosten de eilanden iets in de orde van een promille, geen reden tot zorg. Dat neemt niet weg dat de hulp de afhankelijkheid eerder heeft versterkt dan verminderd.

De derde overweging won in de loop der tijd aan gewicht: beduchtheid voor het open migratiekanaal. Rond 1970 woonden in Nederland zo'n 40.000 Antillianen en Surinamers. Inmiddels gaat het, wanneer de eerste en tweede generatie tezamen worden genomen, om bijna een half miljoen Nederlanders met een Surinaamse of Antilliaanse achtergrond. De toename van de Surinaamse gemeenschap, nu ruim 335.000 zielen groot, is langzamerhand afgevlakt; het open migratiekanaal is immers na de onafhankelijkheid afgesloten. Antillianen en Arubanen hebben echter als houders van het Nederlandse paspoort vrije toegang en vestigingsrechten in Nederland; het huidige aantal van bijna 135.000 zielen blijft nog groeien.

Nauwelijks positief te formuleren belangen, geen hoge verwachtingen, geen vanzelfsprekend engagement, veel zorgen: geen wonder dat Den Haag, hierin breed gesteund door vox populi in eigen land, sinds 1970 inzette op een beleid om definitief afscheid te nemen van de Caraïben. Politieke pressie werd daarbij niet geschuwd. En zo werd, in een zeer uitzonderlijke politieke conjunctuur, Suriname in 1975 inderdaad onafhankelijk. De pragmatischer Antillianen en Arubanen - politici én gewone burgers - bleven zich echter met goede argumenten op het standpunt stellen dat zij weinig te winnen hadden met onafhankelijkheid. De consequent volgehouden weigering het 'geschenk' van de soevereiniteit te aanvaarden noopte Nederland uiteindelijk tot een nieuwe, net als in 1954 en in 1975 vrijwel kamerbreed gesteunde, koerswijziging.

Rond 1990 aanvaardde Den Haag dat het de onafhankelijkheid niet 
kon opleggen aan de eilanden, niet met zoete woorden, niet met harde dwang. Hiermee conformeerde Nederland zich overigens slechts aan de geldende opvattingen in de Verenigde Naties over het zelfbeschikkingsrecht van voormalige koloniën. Daarmee verschoof het speelveld. Sindsdien draait het debat over het trans-Atlantische Koninkrijk rond de grenzen tussen Caraïbische autonomie en de ruimte voor het Koninkrijk - en dus in de eerste plaats Nederland - om in te grijpen waar de kwaliteit van bestuur te wensen overlaat. Het lijdt geen twijfel dat de overzeese autonomie in de afgelopen twee decennia is ingeperkt. Uiteindelijk, zo luidde de redenering, waren de $\mathrm{Ca}-$ raïbische Nederlanders meer gebaat bij versterking van het bestuur dan bij een teveel aan autonomie. Deze opvatting werd tot staand beleid onder het derde kabinet-Lubbers (1989-1994). De belangrijkste architect ervan, de toenmalige minister van Justitie en voor Nederlands-Antilliaanse en Arubaanse Zaken Ernst Hirsch Ballin, zou tot aan 10/10/10 een zwaar stempel drukken op de debatten over de vernieuwing van het Koninkrijk.

Inmiddels deed zich nog een tweede ontwikkeling voor. In 1983 had Aruba, na lange politieke strijd, overeenstemming bereikt over een status aparte, nog binnen het Koninkrijk maar buiten de Antillen. Den Haag had het Arubaanse separatisme slechts met tegenzin gehonoreerd en er bovendien een sanctie op gezet. Uiterlijk in 1996, tien jaar na het ingaan van de status aparte, zou Aruba de onafhankelijkheid moeten aanvaarden. Met deze inderdaad in het gewijzigde Statuut vastgelegde koppeling had Den Haag vergeefs geprobeerd de strijd om de afscheiding te breken. Maar ook de hoop hiermee paal en perk te stellen aan een verdere desintegratie van de Nederlandse Antillen werd niet bewaarheid. Aruba zou er uiteindelijk in slagen de koppeling ongedaan te maken en zo een apart land binnen het Koninkrijk te blijven. De overige eilanden, Sint Maarten voorop, zouden aan het zelfbeschikkingsrecht en het precedent van Aruba de argumenten ontlenen om eveneens afscheid te mogen nemen van het Antilliaanse land, maar met behoud van de Koninkrijksbanden.

Zo was vanaf 1990 de Haagse agenda van het Koninkrijk tweeledig. De perceptie was dat de overzeese bestuurders er onvoldoende in slaagden het bestuur op verantwoorde wijze te voeren, dat wil zeggen: deugdelijk volgens internationale normen die Nederland wél nakomt, of althans meent na te komen. Er was sprake van groeiende onrust over de kwaliteit van het bestuur, over het dreigende failliet van de Antilliaanse overheid, over de desintegratie van de Antillenvan-vijf, over de exodus naar Nederland. Allengs verhardde de toon van het debat en werd het wederzijdse vertrouwen zwaarder op de proef gesteld. 
In deze context lag rond de eeuwwisseling opnieuw de vraag ter tafel of het Statuut moest worden gewijzigd, dan wel het gebruik ervan. De laatste poging daartoe dateerde van de 'Toekomstconferentie' van 1993, toen de eerstverantwoordelijke minister Hirsch Ballin samen met Lubbers vergeefs had getracht de eilanden te bewegen tot een uitruil. Daarbij zou het land de Antillen van weleer uiteenvallen in drie, misschien zelfs meer entiteiten die elk een directere band met Nederland zouden krijgen. In deze constructie zou het Koninkrijk zijn versterkt ten koste van de eilandelijke autonomie. Deze ambitieuze onderneming mislukte omdat de Antilliaanse en Arubaanse politici hun autonomie met hand en tand verdedigden; tot op zekere hoogte werden zij daarin gesteund door hun eigen bevolkingen, die het behoud van eigenheid hoog waarderen. ${ }^{3}$ Dat wil echter niet zeggen dat het construct van de Antillen-van-vijf werkelijk leefde. Zoals Will Johnson, de ongekroonde koning van Saba, het eens uitdrukte: 'de Antillen is een historische vergissing'.

In het besef dat een wijziging van het Statuut nu eenmaal niet eenzijdig kan worden opgelegd, bewandelde Nederland sindsdien een pragmatische koers, waarbij de facto toch de Nederlandse greep op het Caraïbische bestuur werd versterkt. Deze benadering was kenmerkend voor het beleid van de twee paarse kabinetten-Kok (1994-2002) en ook voor de hierop volgende kabinetten-Balkenende (2002-2010). Niettemin bleef aan het 'Antillendossier' het imago kleven dat er veel werd gepolderd of zelfs voortgemodderd en groeide in Den Haag een kennelijke behoefte aan ferme ingrepen. Aan de overzijde werd dit met wantrouwen gadegeslagen, temeer vanuit de waarneming dat Haagse prioriteiten vaak eenzijdig werden vastgesteld. Inmiddels werd op de eilanden vanaf 2000 het onderlinge separatisme zo dominant dat Nederland dit niet langer kon negeren.

In deze context herdacht men in 2004 het vijftigjarig bestaan van het Statuut. Opnieuw werd gesproken over de noodzaak tot modernisering en versterking van de gemeenschappelijkheid en bestuurskracht, bovendien werd gepleit voor eilandelijk maatwerk. En zo werd uiteindelijk gekozen voor het beleid van gelijktijdige ontmanteling van de Nederlandse Antillen en verduidelijking dan wel versterking van de bevoegdheden van het Koninkrijk. Dit compromis, een althans ogenschijnlijk logisch slotstuk, moest tegemoetkomen aan ongeduld en soms tegengestelde verwachtingen aan beide zijden van de oceaan. 


\section{Geen eeuwig edict?}

Nog altijd geldt het Statuut voor het Koninkrijk der Nederlanden als de 'grondwet', de hoogste wettelijke regeling van het trans-Atlantische rijk. Dat dit Statuut gedurende ruim een halve eeuw inhoudelijk grotendeels ongewijzigd bleef, mag in het licht van de moeizame ontstaansgeschiedenis opmerkelijk heten. Dat geldt niet minder voor het feit dat ook in de zojuist afgesloten fase van opheffing van de Nederlandse Antillen de Statutaire kernwaarden zo'n belangrijke rol bleven spelen en het document inhoudelijk vrijwel ongewijzigd bleef.

Het Statuut, zo is vaak vastgesteld, is een merkwaardig document. Het spreekt van autonomie van afzonderlijke landen die op voet van vrijwilligheid en gelijkwaardigheid verkozen bijeen te blijven in een staatkundig verband. Het spreekt van de bereidheid elkaar bij te staan in tijden van nood. Het legt vast welke zaken gezamenlijk zullen worden geregeld en dat daarin een Koninkrijksregering het laatste woord heeft. Deze zogeheten Koninkrijksaangelegenheden zijn limitatief opgesomd en omvatten vooral een gezamenlijke verantwoordelijkheid voor bevoegdheden in de internationale sfeer (buitenlandse betrekkingen en defensie), het Nederlanderschap en deugdelijk bestuur. Het Statuut huldigt dus waarden als gelijkwaar-

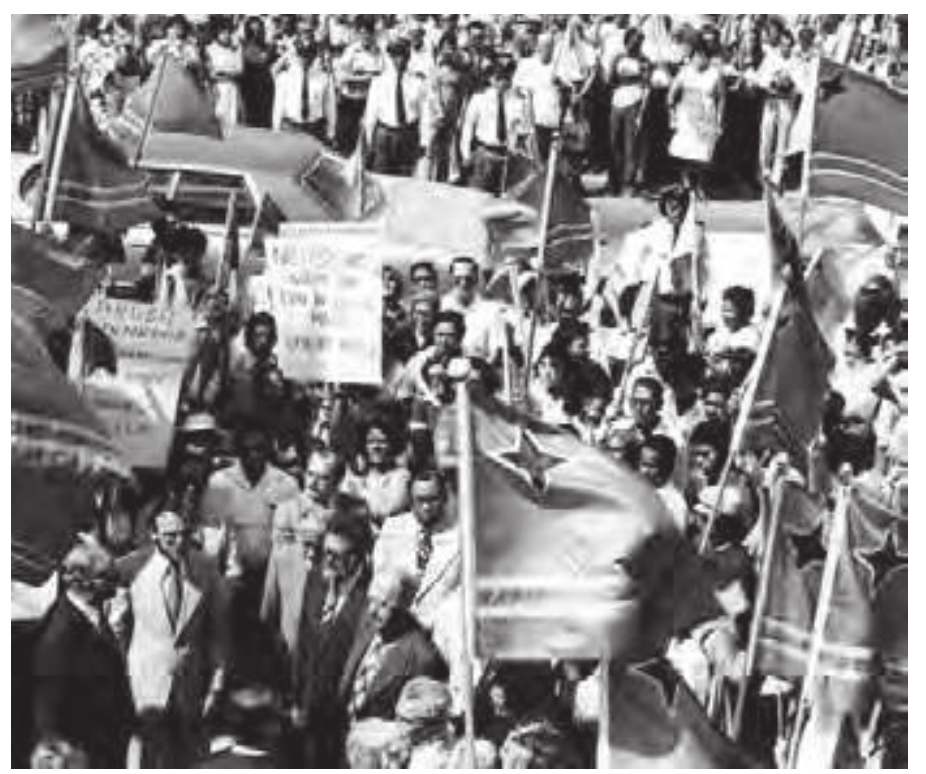

Het eerste hoofdstuk van het uiteenvallen van de Nederlandse Antillen: demonstratie op Aruba, april 1978, met onder, tweede van links, de voorvechter van de status aparte Betico Croes. 
digheid en wederzijdse bijstand, die echter op gespannen voet staan met de realiteit. Het wil een voorbeeld van democratie en goed bestuur zijn maar ontbeert een legitimerend Koninkrijksparlement.

Waarom bleef het Statuut dan zo lang overeind zonder noemenswaardige inhoudelijke aanpassingen? Dat kan, met alle respect voor de wetgevers van toen en voor degenen die sindsdien de werking en grenzen van de Statutaire orde verkenden, toch beter worden toegeschreven aan de rigiditeit van de wijzigingsprocedure dan aan de voortreffelijkheid van het document per se. Op het Statuut en op het functioneren ervan is in de afgelopen decennia veel kritiek geleverd, vooral van Nederlandse zijde. Dat het toch niet tot opheffing of ingrijpende aanpassing kwam, vloeide direct voort uit de in 1954, juist op Haags aandringen, gemaakte keuze om elke wijziging afhankelijk te stellen van de instemming van alle partners. Daarom kon Den Haag later de onafhankelijkheid niet eenzijdig opleggen aan de Caraïbische rijksdelen, maar evenmin de kernwaarden van het Statuut wijzigen. Elke verandering van lidmaatschap of inhoud dient op basis van consensus te worden verwezenlijkt. In die zin dwingt het Statuut tot het zoeken naar compromissen en bindt het Den Haag meer dan de werkelijke verhoudingen van schaal en macht zouden doen vermoeden.

Zo werd het Statuut en het leerstuk van de autonomie in de ogen van Haagse bestuurders steeds meer een anachronisme of ronduit een historische vergissing, voor de meerderheid van hun Caraïbische tegenspelers juist principieel een uitdrukking van het zelfbeschikkingsrecht, strategisch een verdedigingslinie. Illustratief zijn de tegenstrijdige beoordelingen van het Statuut zoals rond 2000 opgetekend voor de Epiloog van Knellende Koninkrijksbanden. Aan de ene kant zware kritiek van prominente Nederlandse politici als Frits Bolkestein ('Het was oliedom om de gelijkwaardigheid van de drie partners in 1954 in het Statuut te zetten'), Ernst Hirsch Ballin ('Het Statuut kent geen mechanisme om een impasse tussen de drie landen te doorbreken. Dat is hét grote probleem') of Joris Voorhoeve ('Het Statuut past de Nederlandse Antillen en Aruba als een dikke winterjas tegen de Hollandse kou, omdat zij in dat Statuut de Nederlandse bemoeienis kunnen afremmen. Het zit helemaal verkeerd in elkaar'). Aan de andere kant veel lof van toonaangevende Caraïbische bestuurders als Henny Eman ('een perfecte relatie'), 'Papy' Jesurun ('Het Statuut is juridisch een heel goed stuk, dat nog steeds goed werkt'), Maria Liberia-Peters ('Als de autonomie eenmaal weg is, is die voor altijd weg'), Don Martina ('De interpretatie van Nederland van het Statuut is verkeerd'), Miguel Pourier ('Als we van een boel zaken Koninkrijksaangelegenheden maken zijn we verder van huis') en Suzy Römer ('Ik vind het Statuut een uitstekend document'). ${ }^{5}$ 
In de toelichting op artikel 55 werd het Statuut destijds aangeduid als 'geen eeuwig edict'. Maar het bleef sindsdien, als gezegd, inhoudelijk onveranderd, ondanks de ingrijpende intensivering van de relaties binnen het Koninkrijk. Zo kreeg het stuk toch iets van eeuwigheid, een onveranderlijkheid die niet noodzakelijk logisch en functioneel is en inderdaad op toenemende weerstand stuitte, primair in Nederland. De oplossing werd niet gezocht in de keuze voor radicale alternatieven, maar in een versterking van het Koninkrijk en in een ruimer gebruik van de voorzieningen voor gezamenlijkheid die het Statuut toch al bood. Zo werd gekozen voor wat Gilbert Wawoe, destijds Antilliaans lid van de Raad van State van het Koninkrijk, ooit bepleitte als 'een warmere uitleg van het Statuut'. ${ }^{6}$

Het proces van ontmanteling van de Nederlandse Antillen is veelvuldig verdedigd in bewoordingen die inderdaad stroken met een 'warmere' uitleg. De verhitte reacties die het nieuwe beleid ook opriep, getuigen echter van het uiteenlopen van de beleving van de temperatuur in het Koninkrijk: wat voor de één een warme uitleg van het Statuut vormt, kan voor de ander een kille uitdrukking van Haagse dominantie zijn.

In de volgende paragrafen zal nader worden ingegaan op de ontwikkelingen die leidden tot een verhoogd gevoel van urgentie en vervolgens tot de keuze voor een beleid van opheffing van de Antillen en gelijktijdige versterking van het Koninkrijk. In de Epiloog van dit boek zal een ruimere vraag aan de orde komen, namelijk of het gekozen beleid werkelijk toereikend is en ook voor de verdere toekomst voldoende perspectief biedt. Hierop vooruitlopend moet nu al worden vastgesteld dat er, juist door de eis van consensus die inherent is aan de Statutaire orde, nauwelijks ruimte was voor het maken van radicale keuzes.

Theoretisch waren er immers twee radicale alternatieven. Ten eerste de optie van onafhankelijkheid, die echter vrijwel nooit serieus ter sprake kwam; de afgelopen twee decennia was het een vrijwel unanieme Haagse waarde om de zo mogelijk nog eenstemmiger Caraibische weigering deze mogelijkheid te bespreken zonder morren te aanvaarden. Maar het kan verkeren. Juist in de verhitte debatten die voorafgingen aan $10 / 10 / 10$ is de optie van onafhankelijkheid weer regelmatig op tafel gekomen, al dan niet retorisch.

Over de tweede optie, volledige integratie naar het model van de Franse overzeese provincies, werd vanaf de late jaren negentig wat vaker openlijk gesproken. Voorzichtig, gezien de Antilliaanse en Arubaanse gevoeligheden rond autonomie. Aarzelend ook, omdat de consequenties van deze optie ook voor Den Haag moeilijk te overzien waren en deels bovendien onaantrekkelijk leken, onder meer in 
financieel opzicht. Volledige integratie van de zes eilanden in een of enkele provincies is uiteindelijk geen serieus politiek thema geworden. Het kan echter niet worden uitgesloten dat de integratie van de 'BES-eilanden' (Bonaire, Sint Eustatius en Saba) als 'openbare lichamen' in het Nederlandse staatsbestel uiteindelijk zal worden beschouwd als een eerste aanzet tot volledige integratie, niet alleen van deze drie eilanden, maar ook van de drie Caraïbische landen.

\section{De knelpunten}

Het trans-Atlantische Koninkrijk kenmerkt zich in geografische zin door grote afstand en enorme schaalverschillen. Dit laatste wordt geillustreerd door het contrast tussen een bevolking die in Nederland ruim 16,5 miljoen burgers telt, op de zes eilanden niet veel meer dan 300.000. In demografische zin vormt de Antilliaanse gemeenschap in Nederland, in de orde van 135.000 zielen, grotendeels afkomstig uit Curaçao, een brug - samen met het veel kleinere aantal 'Europese Nederlanders' dat zich op de eilanden vestigde. Deze migraties versterkten overigens de asymmetrie. Hoewel in Nederland veel is geklaagd over de Antilliaanse migratie, is haar demografische en maatschappelijke betekenis hier gering, op de eilanden en vooral Curaçao juist dramatisch. Andersom is het vertrek van enige duizenden burgers naar de Antillen voor Nederland van weinig belang maar wordt dit anders beleefd op de eilanden.

Dat er knelpunten zijn in de Koninkrijksrelaties is duidelijk. Van een sterke belangengemeenschap is nauwelijks sprake. Voor zover over belangen wordt gesproken, hebben die vanuit Nederland veelal een negatieve toon: het verminderen van de problemen op de eilanden, in de onderlinge relaties en voortvloeiende uit de Antilliaanse migratie naar Nederland. Op de eilanden overheerst de overtuiging dat de Koninkrijksbanden cruciaal zijn, maar klaagt men veelvuldig over de last van bestuurlijke inmenging vanuit Nederland. De knelpunten worden, met andere woorden, heel verschillend gedefinieerd.

$\mathrm{Al}$ eerder werd kort ingegaan op oude Haagse zorgen, die zo ver gingen dat deze rond 1970 motieven voor een af te dwingen afscheid werden. In de afgelopen decennia kwamen daar nieuwe kwesties bij, verschoof het onderlinge gewicht ervan en groeide in sommige opzichten ook de behoefte aan gemeenschappelijke identificatie en bestrijding van de problemen. In deze context kwam de weg vrij voor een herziening van de relaties die inhoudelijk verderging dan ooit sinds 1954 .

In feite ging het om een keten van onderling samenhangende pro- 
blemen. Allereerst het brede terrein van de deugdelijkheid van bestuur, gekoppeld aan oude kwesties als de integriteit en slagvaardigheid van bestuur in kleinschalige samenlevingen en nieuwe zorgen over de invloed van (internationale) criminaliteit op de eilanden. Consistent uitgangspunt van het Haagse beleid in de afgelopen twee decennia was dat de kwaliteit van het bestuur op de eilanden onvoldoende was, dat versterking van de directe ondersteuning van de Caraïbische overheden daarom noodzakelijk was, en dat dit onder meer een verruiming van de bevoegdheden van het Koninkrijk impliceerde - en op grond van de eis tot waarborging (artikel 43, lid 2 Statuut) ook vereiste. Deze opvatting leidde al in de jaren negentig tot versterkte Haagse bemoeienis met het bestuur van de Caraïbische (ei)landen en tot directe interventie via een Algemene Maatregel van Rijksbestuur op Sint Maarten. ${ }^{7}$

Ook de Antilliaanse en Arubaanse regeringen ontplooiden initiatieven ter bevordering van de transparantie en kwaliteit van het bestuur. Dit beleid werd na de eeuwwisseling versterkt voortgezet, wat getuigde van de in elk geval in Den Haag levende overtuiging dat er nog een lange weg te gaan was. We zien dit uitgangspunt terugkeren in het Haagse beleid rond de ontmanteling van de Antillen, waaraan als harde voorwaarde een versterking van het Koninkrijk werd gekoppeld. Daarbij dient te worden benadrukt dat ook veel Antilliaanse bestuurders de noodzaak van versterking van het lokale bestuur benadrukten. Hun inzet was echter de aanpak van de problemen juist in eigen hand te houden.

Samenhangend met dit bestuurlijke vraagstuk, maar ook met het dossier van economische ontwikkeling, ging de financiële problematiek steeds sterker spelen. In de jaren negentig begon zich een financiële crisis af te tekenen van het land de Nederlandse Antillen. Het kabinet-Pourier reageerde hierop met een hard en dus pijnlijk saneringsbeleid, dat echter onvoldoende succesvol was - vanuit Antilliaans perspectief mede doordat de toegezegde Haagse ondersteuning tekortschoot. De snel oplopende tekorten en navenant stijgende schuldenlast bereikten een niveau dat ingrijpen uiteindelijk onvermijdelijk maakte. Dit zou Den Haag enerzijds noodzaken de schuld te saneren, waarmee uiteindelijk een Haagse bijdrage van 1,7 miljard euro was gemoeid. Anderzijds gaf deze interventie - die ook in de visie van de Antilliaanse overheid onvermijdelijk en dus gewenst was - Den Haag het doorslaggevende argument om een sterker en gedeeld financieel toezicht af te dwingen. En ook dit kreeg zijn beslag in de uitkomsten van de onderhandelingen rond de ontmanteling.

De crisis van de overheidsfinanciën hing nauw samen met de deels onbevredigende, deels onevenwichtige economische ontwikke- 
ling van de eilanden. De plicht tot 'wederzijdse bijstand' was sinds de jaren zestig in Haagse financiële bijstand vertaald, die tegen alle bedoelingen in al snel een structureel karakter kreeg en bovendien een voortdurende stijging liet zien. ${ }^{8}$ Waar het Nederlandse beleid hardnekkig werd verdedigd in termen van tijdelijke steun gericht op zelfredzaamheid, was de praktijk er een van toenemende hulpafhankelijkheid, althans in de publieke sector. Dit is slechts zeer ten dele een kwestie van falend beleid. Voor alle eilanden geldt dat hun economieën kwetsbaar zijn, mede door hun kleine schaal en beperkte economisch potentieel. De eisen die aan beide zijden van de oceaan worden gesteld aan het ontwikkelingsniveau sluiten daar niet altijd goed op aan.

Achter de ontnuchterende cijfers gingen overigens wel grote eilandelijke verschillen schuil. Aruba en Sint Maarten gaven de laatste decennia spectaculaire groeicijfers te zien; de wijze waarop deze groei tot stand kwam, met voor een belangrijk deel extern en niet altijd gecontroleerd aangetrokken kapitaal en arbeid, riep eigen problemen op die weer vragen uitlokten over de deugdelijkheid van bestuur. De Curaçaose economische ontwikkeling verliep trager en de structureel hoge werkloosheid op dat eiland zou zich onder meer vertalen in hoge emigratiecijfers. De publieke sector van de BES-eilanden leek alleen al door de extreme kleinschaligheid volstrekt afhankelijk van externe ondersteuning; de perceptie dat het land de Nederlandse Antillen hierin tekortschoot, voedde de voorkeur voor een directe band met Nederland.

Gezien de hardnekkige economische problematiek op het grootste eiland, Curaçao, verwondert het niet dat de Antilliaanse migratie vooral van dit eiland afkomstig is. De Antilliaanse bevolking in Nederland verdubbelde in de jaren tachtig van ruim 35.000 tot ruim 70.000 en verdubbelde sindsdien bijna opnieuw, tot de huidige 135.000. ${ }^{9} \mathrm{Zo}$ ontstond een keten van een Antilliaanse exodus en een integratieproblematiek in Nederland, die twee soms complementaire, soms strijdige reacties opriep. De ene reactie was de Haagse poging de migratie te bemoeilijken door juridische of andere formele belemmeringen op te werpen. De andere was gericht op het versterken van de eilandelijke sociaaleconomische structuur en in het bijzonder ook het onderwijs. Geen van beide benaderingen leverde merkbare effecten op. Dit zou na 2000, in het licht van de verharding van het Nederlandse debat over migratie en integratie, een schaduw werpen over de pogingen de Koninkrijksrelaties niet slechts sterker maar, de eerder aangehaalde beeldspraak volgend, ook 'warmer' te maken.

Inmiddels werd het eilandelijk separatisme een politieke realiteit die door Den Haag weliswaar als onwenselijk werd ervaren, maar 
langzamerhand ook als onvermijdelijk. Tussen het besluit om Aruba een als tijdelijk bedoelde status aparte te gunnen en het aanbod aan alle eilanden, op de Toekomstconferentie van 1993, van een eigen status binnen het Koninkrijk, lagen tien jaren waarin het draagvlak voor de Antillen-van-vijf erodeerde. Verrassend genoeg leek het tij daarna weer wat te keren, met een verrassende pro-Antillen uitslag van een referendum in 1993-1994 en kort hierop de verkiezing van een landelijke regering die het bijeenhouden van de vijf eilanden hoog in het vaandel hield. Een referendum op Sint Maarten in 2000 bezegelde echter het einde van deze laatste opleving. Een grote meerderheid sprak zijn voorkeur uit voor een autonome status binnen het Koninkrijk. Referenda in 2004 en 2005 wezen uit dat ook op de andere eilanden, met uitzondering van Sint Eustatius, het draagvlak voor de Antillen weer was verdwenen. Waar op de eilanden werd gesproken in termen van zelfbeschikkingsrecht, berustte Den Haag op pragmatische gronden. Het resultaat was gelijk: de keuze voor ontmanteling van de Nederlandse Antillen.

De politieke strijd van het eilandelijk separatisme werd gevoerd met bestuurlijke argumenten, maar ook met een beroep op eilandelijke culturele eigenheid. Het eerste, 'zakelijke' type argument - de opgelegde, 'koloniale' constructie van vijf of zes eilanden bestuurd vanuit Curaçao was inefficiënt en riep voortdurend obstructie op - legde in

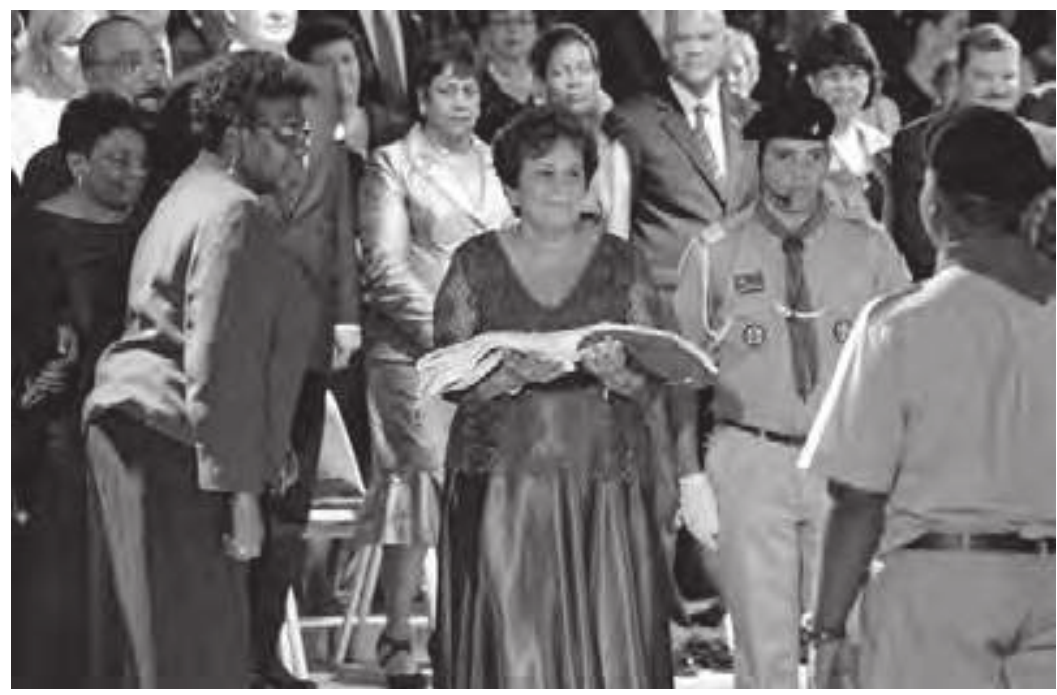

De laatste minister-president van de Nederlandse Antillen, Emily de Jongh-Elhage, neemt de vlag van de Nederlandse Antillen in ontvangst; rechts achter haar de laatste gouverneur van de Nederlandse Antillen, eerste gouverneur van Curaçao, Frits Goedgedrag; Curaçao, 9 oktober 2010. 
Den Haag wellicht meer gewicht in de schaal dan het tweede. Op het culturele argument van eilandelijke uniciteit kan ook wel worden afgedongen, al was het maar dat onderlinge en regionale migratiestromen de eilandelijke bevolkingen ook in de afgelopen decennia juist meer op elkaar hebben betrokken. Niettemin weegt de benadrukking van cultureel verschil zwaar op de eilanden. Dit kwam niet alleen tot uiting in het eilandelijk separatisme, maar ook en vooral in de reacties op het rond 2005 ingezette beleid van versterking van het Koninkrijk. In deze sfeer wegen de inderdaad aanmerkelijke culturele verschillen tussen de eilanden en Nederland zwaar. Het verzet tegen 'rekolonisatie' zou een niet te negeren politieke betekenis krijgen en op gezette tijden een reële bedreiging vormen voor de voortgang van het uitgestippelde beleid.

Met deze zes, onderling verbonden, knelpunten is de context geschilderd waarin de debatten over de herinrichting van het Koninkrijk zijn gevoerd. Vooralsnog voornamelijk op de achtergrond spelen nog twee andere kwesties, samenhangend met de regionale context. Enerzijds is daar de verhouding tot Europa. De discussie over een mogelijke herziening van de relatie van de eilanden tot de Europese Unie werd medio 2008 aangehouden, omdat deze kwestie kennelijk niet alleen technisch ingewikkeld is, maar vooral ook politiek gevoelige raakpunten heeft met de bredere discussie over de toekomst van de Antilliaanse autonomie. Toch is duidelijk dat deze vraag niet lang meer ontweken zal kunnen worden.

Anderzijds, en met meer zichtbare directe relevantie, zijn er problemen rond de relatie tot de omliggende Caraïbische landen. Het Koninkrijk is verantwoordelijk voor de territoriale integriteit van de eilanden, een opgave die vooral vragen oproept over de relatie tot Hugo Chávez' Venezuela. Hierover wordt tussen Den Haag en de Benedenwindse eilanden niet wezenlijk anders gedacht; het ontwerpen of bijstellen van beleid jegens Venezolaanse aanspraken speelt dus ook geen rol in de debatten over staatkundige vernieuwing. Op de eilanden wordt de regionale inbedding op een geheel andere manier zichtbaar, namelijk met de grote aantallen Caraïbische immigranten, vooral op Aruba en Sint Maarten. Den Haag heeft lang geaarzeld om over deze kwestie in debat te gaan met de Antilliaanse en Arubaanse overheden. Dat is mede opmerkelijk, omdat de ervaring leert dat een deel van deze migranten uiteindelijk wordt genaturaliseerd en daarmee houder wordt van een paspoort van het Koninkrijk der Nederlanden - uiteraard inclusief het recht zich te vestigen in het nieuwe 'moederland'. Het was voorspelbaar en is al aanwijsbaar dat deze kwestie in de recente debatten over de versterking van het Koninkrijk meer aandacht kreeg en vermoedelijk ook zal behouden. 


\section{Consensus en dispuut}

Met het bovenstaande is de context geschetst van het proces van staatkundige vernieuwing dat op 10/10/10 tot een voorlopig einde werd gebracht. In de volgende hoofdstukken worden de ontwikkelingen van het afgelopen decennium meer in detail besproken. Tot besluit hier een korte schets van het krachtenveld waarin draagvlak werd gevonden - of gecreëerd - voor veranderingen die misschien niet schokkend zijn, maar niettemin voorheen onhaalbaar waren. De logische volgende vraag is dan welke factoren bedreigend waren en wellicht zullen blijven voor deze nieuwe consensus.

De essentie is eenvoudig. Het besluit tot ontmanteling van de Nederlandse Antillen (een lang gekoesterde wens op de eilanden) en gelijktijdige versterking van het Koninkrijk en daarmee van de Haagse rol (een lang gekoesterde Nederlandse wens) kon slechts worden bereikt onder de dreiging van een acute financieel-economische crisis, die alleen door Nederland kon worden opgelost. Dat vergde een compromisbereidheid van de verantwoordelijke bestuurders in Nederland en in de Antillen, en een welwillende afzijdigheid van Aruba.

Hoe deze compromisbereidheid te verklaren? Laten we eerst de Nederlandse opstelling bekijken. De twee kabinetten-Kok (19942002) waren evenmin als het eerste kabinet-Balkenende (2002) geneigd tot ingrijpende hervormingen van de Koninkrijksrelaties. In de nadagen van het tweede en derde kabinet-Balkenende (2002-2007) werd echter gekozen voor een nieuwe, meer ambitieuze koers, die het vierde kabinet-Balkenende (2007-2010) zou voortzetten. Dit betekent dat een breed spectrum van politieke partijen (CDA, VVD en D66, vervolgens ook PVDA en ChristenUnie) als coalitielid bij dit beleid betrokken was, daarin gesteund door nog grotere parlementaire meerderheden. Persoonlijk engagement van enkele bewindslieden speelde daarbij ook een rol, zoals zal blijken. Doorslaggevend was echter de inschatting dat de combinatie van een acute financiële crisis en onstuitbaar separatisme de voorwaarden schiep om interventie in het Caraïbische bestuur op te eisen. Daarbij hielp het zeer dat Nederland nog in rustig economisch vaarwater verkeerde. Was de kredietcrisis enkele jaren eerder uitgebroken, dan had Den Haag zeker niet zo gemakkelijk kunnen en willen besluiten tot de omvangrijke schuldsanering.

Op het niveau van de landsregering van de Nederlandse Antillen werden de opeenvolgende coalities sinds 2000 , met een korte onderbreking in 2003-2004, gedomineerd door de Curaçaose PAR onder achtereenvolgens de premiers Miguel Pourier, Etienne Ys en Emily de Jongh-Elhage, een partij die dicht bij het CDA staat en in haar opstel- 
ling naar Nederland als pragmatisch kan worden gekarakteriseerd. De landsregering was steeds met handen en voeten gebonden aan de lang niet altijd gelijkluidende wensen van eilandelijke besturen, wat de onderhandelingen vaak ernstig compliceerde. Op eilandelijk niveau waren de coalities vaak minder compromisbereid, maar ook daar overheerste het verlangen tot afscheid van het Antilliaanse verband. Bovendien was allerwegen duidelijk dat de aangekondigde, omvangrijke Haagse schuldsanering onontbeerlijk was en niet gegeven zou worden als daar geen Antilliaanse concessies tegenover stonden.

Aruba ten slotte bezag, onder opeenvolgende kabinetten onder MEP-leider Nel Oduber (2001-2009), de ontwikkelingen met bezorgde distantie: distantie omdat de veranderingen formeel het eiland niet direct aangaan, bezorgd omdat de inperking van de autonomie van de nieuwe landen Curaçao en Sint Maarten mogelijk op termijn ook consequenties heeft voor Aruba. Omdat Arubaanse instemming met de noodzakelijke verandering van het Statuut vereist was, had zich hier een obstakel kunnen voordoen. Gezien de sterk op maximale autonomie gerichte opstelling van de MEP was dit niet denkbeeldig, maar juist in 2009 kwam de eveneens aan het CDA verwante AVP weer aan de macht, een partij die ook onder haar nieuwe leider en nu premier Mike Eman als meer compromisbereid te boek staat.

Zo was de politieke conjunctuur in alle betrokken landen en eilanden op alle kritieke momenten gunstig voor de voortgang van het drieledige project ontmanteling Nederlandse Antillen, schuldsanering en versterking van de Koninkrijksbevoegdheden. Gedurende de afgelopen jaren was dat allerminst vanzelfsprekend. Op verschillende momenten dreigde het proces stuk te lopen op politieke tegenstand op de eilanden, in het bijzonder op Curaçao en later ook Bonaire. Steen des aanstoots was onveranderlijk het gevoel dat Nederland zich te sterk manifesteerde, te veel taken van het autonome land de Nederlandse Antillen zou overnemen. Het verwijt van 'rekolonisatie' viel vaak. Het ligt niet voor de hand dat zulke verwijten in de komende jaren zullen verstommen, nu de Nederlandse invloed inderdaad merkbaar sterker is.

Gelijktijdig begon zich in Nederland na de eeuwwisseling een verschuiving in het politieke krachtenveld af te tekenen die op termijn mogelijk belangrijke consequenties voor het Antillenbeleid zal hebben. Het belangrijkst was een verharding van het migratie- en integratiedebat, wat onder meer leidde tot de steeds openlijker uitgesproken onvrede over problemen met Antilliaanse risicojongeren en pleidooien om deze migratie een halt toe te roepen. Zulke geluiden werden opmerkelijk breed vertolkt. Een volgende stap was een hernieuwd pleidooi voor hard ingrijpen dan wel, als nog beter voor- 
gesteld, een afgedwongen afscheid van de Caraïbische eilanden. Deze opstelling was karakteristiek voor nieuwe rechtse partijen, in het bijzonder de PVV, maar had ook invloed op de opstelling van andere partijen. Niet onbelangrijk was daarbij de wetenschap dat deze harde opstelling in parlementaire kringen wel betrekkelijk nieuw was, maar al decennialang resoneerde in de vox populi.

Zo deed zich de situatie voor dat de enorme bestuurlijke operatie die gepaard ging met de vernieuwing van het Koninkrijk, na regelmatig aan een zijden draadje te hebben gehangen, uiteindelijk werd veiliggesteld in een politieke context die aanmerkelijk verschilde van de uitgangssituatie rond 2000 of 2005 . Tijdens het proces waren de betrokken politici en bestuurders zich er voortdurend van bewust dat van uitstel afstel kon komen - omdat de oppositie in Nederland meende dat te veel was 'weggegeven', omdat de oppositie op de eilanden juist vond dat Nederland te veel had 'overgenomen'. Nu het staatkundig proces dan toch tot het gestelde einddoel is gebracht, blijft het een open vraag hoe de nieuwe verhoudingen in een mogelijk minder stabiele politieke context zullen functioneren. 


\section{De Koninkrijksrelaties:}

\section{instituties, spelers, dossiers}

Het proces van de opheffing van de Nederlandse Antillen en de gelijktijdige hervorming van de Koninkrijksrelaties was politiek omstreden en bestuurlijk gecompliceerd. In het derde en vierde hoofdstuk wordt het verloop ervan in detail besproken. Voor een goed begrip van dit proces is inzicht in de bredere institutionele en politieke context onontbeerlijk, evenals enige kennis van de lopende dossiers en activiteiten. Daarin voorziet dit hoofdstuk, uitdrukkelijk weer met een focus op de Nederlandse kant van zaken.

Allereerst komt de institutionele vormgeving van de Koninkrijksrelaties aan de orde. De bewindspersoon op het ministerie van Binnenlandse Zaken en Koninkrijksrelaties (BZK) was de eerstverantwoordelijke voor het Antillenbeleid - aldus zouden de opeenvolgende bekleders van dit ambt de schoorvoetende Haagse ommezwaai voorbereiden en uitvoeren. Tegelijk is het aannemelijk dat juist op BZK aanvankelijk reserves leefden rond de staatkundige vernieuwing. Mede hierdoor gingen andere institutionele spelers, in het bijzonder de Raad van State van het Koninkrijk, een opmerkelijk actieve rol spelen.

Vervolgens wordt de bredere politieke context besproken. De ingrijpende wijzigingen in het politieke landschap en het publieke debat in Nederland sinds de eeuwwisseling draaiden in belangrijke mate om kwesties van immigratie en integratie. Juist de partijen die zich rond deze dossiers als 'hard' profileerden, betoonden zich ook zeer kritisch tegenover de Antillen. Mede in reactie hierop was daar, in het bijzonder op Curaçao, eveneens sprake van een verharding van het debat. Deze voorheen ongekende politisering zou de uiteindelijk op 10/10/10 bereikte uitkomst voordien veelvuldig in gevaar brengen.

In de bestuurlijke praktijk van de Koninkrijksrelaties ging en gaat het niet alleen over de institutionele vormgeving van de verhoudingen en over de kwaliteit van bestuur, maar ook over financiële aangelegenheden, migratie en vraagstukken rond de internationale relaties 
van (de Caraïbische delen van) het Koninkrijk, zowel met de Europese Unie als met de directe omgeving van de Antilliaanse eilanden. Op deze dossiers wordt kort ingegaan, waarbij opnieuw de vraag wordt gesteld in hoeverre ze interfereerden met het proces van staatkundige vernieuwing.

Vaak is gewezen op het 'democratisch deficit' dat inherent is aan de Koninkrijksrelaties zoals die in het Statuut zijn neergelegd. In het afgelopen decennium zijn diverse voorstellen gedaan om dit deficit weg te nemen, voorstellen die uiteindelijk geen deel zouden uitmaken van het arrangement dat per 10/10/10 van kracht werd. Daarmee is een aantal vragen over de beperkingen van het Statuut blijven liggen, dat ongetwijfeld in de toekomst, in het kader van de zoektocht naar een visie voor het Koninkrijk, weer ter tafel zal komen. Bestudering van de debatten tot op heden wijst echter uit dat rond dit thema zelden werkelijke politieke urgentie is gevoeld.

\section{De institutionele vormgeving en werking van de Koninkrijksrelaties}

Sinds het Statuut van kracht werd, is de Rijksministerraad (RMR) het hoogste politieke orgaan van het Koninkrijk der Nederlanden. De gouverneurs fungeren enerzijds als Koninkrijksorgaan en vertegenwoordigen in die hoedanigheid de belangen van het Koninkrijk, anderzijds zijn zij als representant van de Kroon hoofd van de landsregering. Daarnaast zijn er nog enkele institutionele voorzieningen die althans formeel het Koninkrijk als geheel dienen, zoals de Hoge Raad en de Raad van State van het Koninkrijk.

Het besluit tot hervorming van de staatkundige structuur van het Koninkrijk was formeel een aangelegenheid van de toenmalige drie landen binnen het Koninkrijk, daarna pas kwamen de afzonderlijke eilandgebieden in beeld. Medewerking van het land Aruba, in en buiten de RMR, was krachtens het Statuut geboden - in de praktijk bleef dit land gedurende vrijwel het gehele traject bewust aan de zijlijn staan. De huidige minister-president Mike Eman (AVP) betreurt dit; hij ziet het als 'een gemiste kans': 'Nu lopen wij een beetje achter de feiten aan. Als we hadden meegedaan met de besprekingen over de rechtshandhaving, hadden we er ook voor onszelf een plekje in kunnen zoeken.' Zijn voorganger Nel Oduber (MEP) meent echter nog steeds dat zijn afwezigheid strategisch was. 'Ik wilde niet dat men later zou zeggen "Oduber, je hield je mond dicht, dus je was het ermee eens."'1

Over de rol van de gouverneurs in het hervormingsproces is uit de 
aard der zaak weinig bekend. Insiders benadrukken dat de gouverneurs te Willemstad (Jaime Saleh van 1990 tot 2002, Frits Goedgedrag van 2002 tot 2010) bij iedere stap nauw betrokken waren en dat hun advies zwaar woog. Het karakter van een functie met twee mogelijk niet altijd verenigbare taken (Koninkrijks- versus landsorgaan) bleef vragen oproepen. ${ }^{2}$ Zo werden eerdere voorstellen uit de nooit serieus besproken ambtelijke 'Proeve van een vernieuwd Statuut' (1993), om de gouverneur uitsluitend een taak te geven als hoofd van de landsregering, weer ter tafel gebracht. Minister Thom de Graaf stelde in 2004 voor om de taken van de gouverneur als Koninkrijksorgaan over te dragen aan een toezichthoudende 'Vertegenwoordiger van het Koninkrijk'. ${ }^{3}$ De Raad van State bepleitte juist een versterking van de positie van de gouverneur, althans in de transitieperiode. Oud-minister Johan Remkes daarentegen vroeg zich eind 2009 openlijk af of de functie niet overbodig was geworden. ${ }^{4}$ Uiteindelijk bleef alles echter functioneel bij het oude en zouden er op 10/10/10 drie gouverneurs zijn: Fredis Refunjol voor Aruba, Eugene Holiday voor Sint Maarten en opnieuw Frits Goedgedrag, nu voor het land Curaçao.

Kenmerkend voor de Koninkrijksrelaties, en conform het uitgangspunt van de landelijke autonomie, is dat de samenwerking in Koninkrijksverband een aangelegenheid is van (Nederlandse of Caraibische) organen die elkaar in politiek of ambtelijk overleg treffen. Op het hoogste en beslissende niveau is dat de Rijksministerraad, terwijl er op vele deelterreinen overleg wordt gevoerd tussen bewindslieden van de landen, ondersteund door hun ambtelijke staf. Op politiek niveau was er sinds 1970 het Contactplan, een halfjaarlijks overleg tussen parlementariërs van de betrokken landen. Dit overleg, in 2006 omgedoopt tot Parlementair Overleg Koninkrijksrelaties (РОК), kon agendastellend zijn in de richting van de betrokken regeringen, maar had geen wetgevende of andere beleidsmatige bevoegdheden. De Nederlandse leden van het POK maakten tevens deel uit van de Vaste Commissies van de Eerste en Tweede Kamer voor Antilliaanse en Arubaanse Zaken. Deze commissies gingen zich vanaf 2005 steeds uitdrukkelijker bezighouden met de voortgang van het staatkundig proces. Typerend voor de assertieve houding van de Senaat was de unanieme aanvaarding in februari 2006 van de motie Schuurman (cU) die, in weerwil van adviezen van de Raad van State, aandrong op een inhoudelijke wijziging van het Statuut. Zoals inmiddels bekend, bleef het Statuut desondanks inhoudelijk vrijwel gelijk. Willibrord van Beek (VVD), van 2005 tot 2011 de Nederlandse delegatieleider van het POK, kent dit overleg vooral een functie toe in het overbruggen van politiële en culturele verschillen, en omschrijft zijn eigen taak tijdens deze periode als 'procesbewaker. ${ }^{5}$ 
Aan Nederlandse zijde is sinds 1998 het ministerie van BZK het coördinerende departement. De directie Koninkrijksrelaties (KR) ressorteerde onder het directoraat-generaal van Constitutionele Zaken en Koninkrijksrelaties (czK), later Bestuur en Koninkrijksrelaties (DGBK). De directie kwam in de plaats van het Kabinet voor Antilliaanse en Arubaanse Zaken (KabNA), dat sinds 1972, aanvankelijk als Kabinet voor Surinaamse en Antilliaanse Zaken, de Koninkrijksrelaties had behartigd. De opheffing van KabNA was onvermijdelijk geacht: in brede kring was geoordeeld dat deze kleine 'zwerfkei' - die steeds werd toegewezen aan een andere vakminister en daarmee onder een wisselend departement kwam te vallen - naar Haagse normen tekortschoot in ambtelijke professionaliteit en bovendien te sterk betrokken was bij de Caraïbische landen, waardoor het daar een ongewenste politieke rol was gaan spelen. De behartiging van de Koninkrijksrelaties onderbrengen bij het tot BZK omgedoopte ministerie van Binnenlandse Zaken zou, zo was de redenering, de professionalisering van het Haagse beleid ten goede komen. ${ }^{6}$

In een brief aan minister-president Wim Kok beargumenteerde Joris Voorhoeve, minister voor Nederlands-Antilliaanse en Arubaanse Zaken in het eerste kabinet-Kok, aan het einde van zijn termijn waarom niet alleen de opheffing van KabNA en de overheveling van taken naar $\mathrm{BZ}(\mathrm{K})$ verstandig was, maar waarom bovendien, ge-

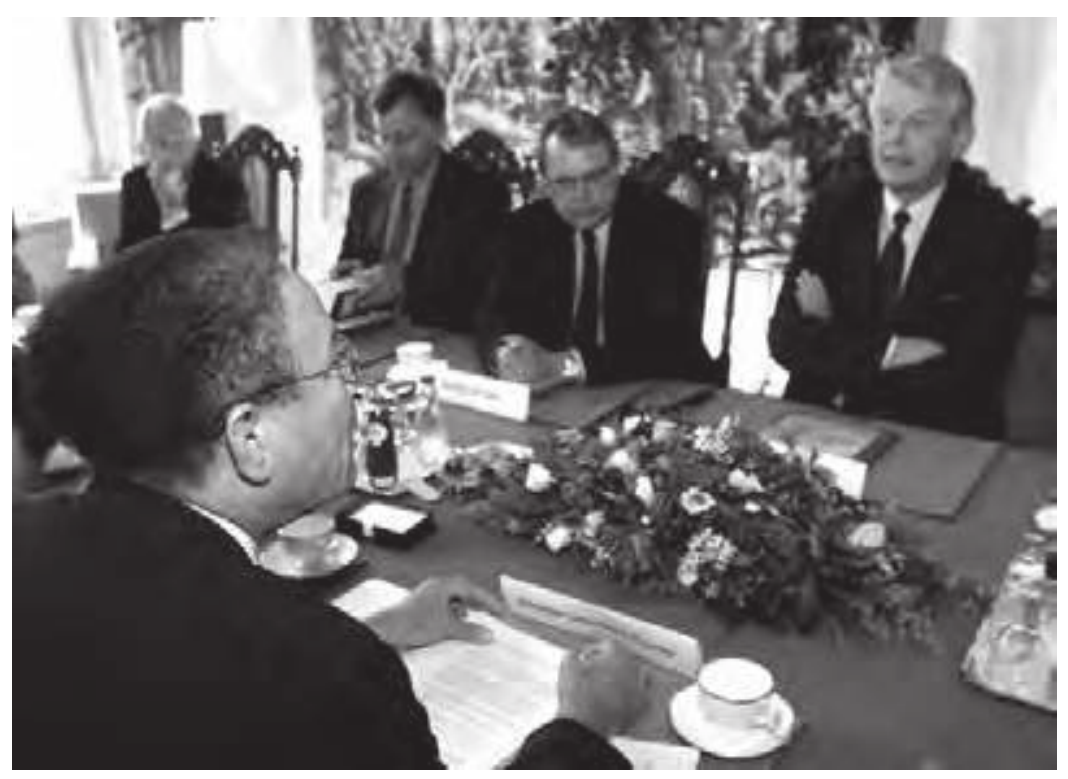

Miguel Pourier op bezoek bij (v.r.n.l.) zijn ambtgenoot Wim Kok en Klaas de Vries, vergezeld door diens DG Jan-Paul Dirkse, Den Haag, 29 augustus 2000. 
zien de complexiteit van het beleidsterrein, gekozen moest worden voor een aparte bewindspersoon, zij het dan niet op het niveau van een minister, maar van een staatssecretaris. Voorhoeve gaf ook een profielschets, denkelijk gebaseerd op zijn eigen ervaringen. 'Het is nl. geen taak waar de "gemiddelde Haagse politicus" - zo die bestaat-ervaring in heeft en geschikt voor is.' De bewindspersoon diende aan de volgende 'bijzondere vereisten' te voldoen: 'veel geduld en tact', 'algemene, politiek-bestuurlijke ervaring', uitstraling van 'natuurlijk gezag', 'niet te jong' en in het bezit van een 'groot incasseringsvermogen', omdat 'het risico van negatieve ontwikkelingen aanzienlijk is, terwijl de instrumenten om de Nederlandse waarborgfunctie ook echt waar te maken, zeer beperkt zijn'. Ten slotte strekte ervaring met ontwikkelingssamenwerking tot aanbeveling, alsook een korte cursus Papiaments, 'omdat daarmee wonderen kunnen worden verricht in het overbruggen van historisch bepaalde afstanden'. ${ }^{7}$ Niet veel van de sindsdien benoemde bewindslieden voldeden aan dit profiel.

Het ministerie van BZK moest, net als in het Nederlandse rijksbestuur, een coördinerende rol gaan spelen, maar daarnaast was het eerstverantwoordelijk voor het beleid. Uitdrukkelijk gold BZK als vertolker en behartiger van de Nederlandse belangen in de Koninkrijksrelaties, niet als orgaan van alle landen - critici meenden dat KabNA de neiging had gehad zich binnen het Nederlandse bestel als belangenbehartiger van de Caraïbische belangen op te stellen. Dit werd ongewenst geacht.

De Nederlandse overheid liet zich op de eilanden representeren door Vertegenwoordigingen met zetels in Willemstad, Oranjestad en Philipsburg, die enerzijds een rol hadden in de uitvoering van en communicatie over het Haagse beleid en de besteding van de Nederlandse ontwikkelingsgelden, anderzijds fungeerden als directe intelligence, en ook in die zin een rol hadden in de beleidsadvisering. De aansturing van deze kantoren lag primair in handen van BZK. De in 1997 gerealiseerde opwaardering van de Vertegenwoordigingen riep onvermijdelijk de vraag op of hiermee de betekenis van de gouverneur en diens Kabinet niet werd ondergraven. ${ }^{8}$ Zeker is dat op instigatie van Voorhoeves opvolgers op BZK werd geïnvesteerd in versterking en professionalisering. De personeelsformatie van de Vertegenwoordiging - thans nog één, in Willemstad, met filialen in Oranjestad en Philipsburg - is nu vele malen groter dan die van de twee (nu drie) Kabinetten van de gouverneur. Blijkens de archieven van de directie $\mathrm{KR}$ is de communicatie met de Vertegenwoordiging, als 'oog en oor van Nederland', intensief. Intern werd versterking van de rol van de Vertegenwoordigingen mede van belang geacht 'bij het harder inzet- 
ten op het Nederlands belang'. Betrokkenen beoordelen ook achteraf de upgrading van de 'VNW' onder achtereenvolgens Onno Koerten en Rob Vermaas positief. Een fel criticus van het Haagse beleid als Helmin Wiels daarentegen omschrijft de Vertegenwoordiging in Willemstad als 'het centrum van spionage voor Nederland'. ${ }^{9}$

Voor de BES-eilanden, waarmee de directe Haagse bemoeienis voorheen beperkt was, werd op 1 januari 2009 een Regionaal Service Centrum ingesteld - sinds 1 september 2010 'Rijksdienst Caribisch Nederland' (RCN) genoemd - onder leiding van Rijksvertegenwoordiger Henk Kamp. ${ }^{10}$ De figuur van Rijksvertegenwoordiger was een novum in de Koninkrijksrelaties, door staatssecretaris Ank BijleveldSchouten aangeduid als een soort Commissaris van de Koningin met buitengewone bevoegdheden, in haar woorden de 'waakhond' van het Koninkrijk. ${ }^{11}$ Bij de RCN waren aanmerkelijk meer ambtenaren aangesteld, grotendeels uit Nederland afkomstig, dan bij het Kabinet van de gouverneur. Daarmee werd de integratie van deze drie eilanden in Nederland al vóór 10/10/10 bestuurlijk voorbereid en letterlijk zichtbaar - met een groot hoofdkantoor op Bonaire en bijkantoren op Sint Eustatius en Saba. Ook hier liep de primaire band met Nederland via BZK. Eind 2009 werkten zo'n twintig 'kwartiermakers' van de diverse vakministeries (dus niet van de 'Koninkrijksministeries' $\mathrm{AZ}, \mathrm{BZ}$ en Defensie) op de drie eilanden. De Tweede Kamer maakte zich enige zorgen over wrevel op Bonaire over de sterke Nederlandse aanwezigheid. ${ }^{12}$

Het onderzoek in de archieven van de directie Koninkrijksrelaties riep verschillende vragen op over de rol en het functioneren van het ministerie van BZK, die vervolgens in een groot aantal, veelal vertrouwelijke, gesprekken met betrokken bewindspersonen, politici, ambtenaren en andere deskundigen aan de orde werden gesteld. Dit leidde tot twee opmerkelijke conclusies, de ene over de mate waarin BZK een wezenlijke bijdrage leverde aan de initiële politieke besluitvorming over de vernieuwing van het Koninkrijk, de andere over de relatie van het departement tot andere Haagse ministeries.

Over de rol van BZK in het transitieproces lijkt de conclusie tweeledig te moeten zijn. Zoals uit het volgende hoofdstuk zal blijken, duurde het tot 2004, onder het ministerschap van De Graaf, voordat Den Haag aarzelend het verzet tegen de opheffing van de Nederlandse Antillen begon te staken en gelijktijdig de draai ging maken naar een vernieuwing van de Koninkrijksrelaties. Analyse van de ambtelijke nota's aan de opeenvolgende bewindslieden wijst uit dat rond een dergelijke koerswijziging de advisering aanvankelijk overwegend afhoudend was. Tegelijk is duidelijk dat het verantwoordelijke directoraat-generaal, in het bijzonder de directie KR, zich na de 
politieke koerswending zonder merkbaar voorbehoud inzette om de nieuwe beleidslijn uit te voeren - daarbij veelvuldig, en naar zou blijken terecht, waarschuwend voor het vastleggen van onrealistische deadlines.

Het beeld dat zich opdringt is het volgende. $\mathrm{Na}$ de liquidatie van KabNA was op het ministerie van BZK ook inhoudelijk een nieuwe start gemaakt. Onder het tweede paarse kabinet was het staatssecretaris Gijs de Vries geweest die, voortbouwend op het beleid van zijn voorganger Joris Voorhoeve, aanstuurde op een beleid van verzakelijking, met 'zelfredzaamheid' van de Caraïbische landen als leidend motto. Dit beleid vond zijn neerslag in de nota Toekomst in Samenwerking (1999). Evenmin als Voorhoeve hechtte De Vries veel waarde aan discussies over staatkundige hervormingen. De prioriteit moest liggen bij goed bestuur, sanering van de overheidsfinanciën en economische ontwikkeling. De Haagse financiële bijstand aan de eilanden zou op middellange termijn moeten worden beëindigd.

De bemensing van de ambtelijke top bij BzK strookte goed bij deze benadering. De nieuwbenoemde directeur-generaal CZK Jan Paul Dirkse (1998-2003) was gedetacheerd door Buitenlandse Zaken en belichaamde in zijn optreden de wens om afstand te nemen van de vaak nauwe persoonlijke relaties met Caraïbische gesprekspartners uit het KabNA-tijdperk. Dat werd ook van hem verwacht. Hij herinnert zich dat bij de gesprekken rond zijn aanstelling Hans Dijkstal, op dat moment nog de gedoodverfde nieuwe minister op het ministerie, tevreden vaststelde dat Dirkse precies op het profiel paste: 'Ik zoek iemand die de Antillen niet beschouwt als een ver soort binnenland, maar als een dichtbij soort buitenland. ${ }^{13}$

Afstand nemen was het devies. Die benadering kreeg ook de volgende directeur KR Hanneke Schuiling (2000-2003) mee, voor wie het 'Antillendossier' eveneens nieuw was en die evenzeer de nadruk legde op verzakelijking. In deze nieuwe Haagse lijn werd de confrontatie niet uit de weg gegaan. Ruimte voor discussies over herstructurering van het land de Nederlandse Antillen werd niet gegeven. 'BZK wilde in die tijd niets', blikt De Graaf terug. Uiteraard deelt Gijs de Vries deze mening geenszins; hij benadrukt dat het de inzet van het tweede kabinet-Kok was om heldere afspraken te maken en dan ook consequent te zijn in het doen naleven daarvan. 'Je bent niet in de politiek om je populair te maken. ${ }^{14}$

Het kortstondige eerste kabinet-Balkenende, waarin Remkes het Antillendossier beheerde, ontwikkelde geen nieuw beleid. Aanvankelijk leek ook het tweede kabinet-Balkenende de onder 'paars' ingezette koers te zullen voortzetten. In 2004, het jaar waarin het vijftigjarig bestaan van het Statuut werd herdacht, begon zich ech- 
ter een beleidswijziging af te tekenen die uiteindelijk zou uitmonden in de akkoorden van eind 2006, die weer de grondslag legden voor 10/10/10. Niet minder dan drie bewindspersonen tekenden voor de voorzichtige wending in het Koninkrijksbeleid, achtereenvolgens Thom de Graaf, Alexander Pechtold en Atzo Nicolaï.

Door wie werden zij geadviseerd? Uit de archieven van BZK en gesprekken met betrokken ambtenaren blijkt dat er in 2003 intern wel werd nagedacht over mogelijke alternatieven, maar dat beslist niet werd aangestuurd op een koerswijziging zoals de uiteindelijke ontmanteling zou zijn. De ambtelijke adviezen aan De Graaf bleven afhoudend, wat gezien de politiek steeds gesanctioneerde opstelling van de ambtelijke top ook logisch was. ${ }^{15}$ In het parlement gingen inmiddels wel stemmen op om het sterke Sint Maartense separatisme serieus te nemen, zeker toen duidelijk werd dat dit op andere eilanden werd overgenomen. Het lijkt er echter op dat de eerste aanzet tot een fundamentele herbezinning noch uit het parlement, noch uit het ministerie kwam, maar van de zijde van de Raad van State, die vanaf 2003 een in zekere zin activistische rol ging spelen, waarover hieronder meer.

Mede onder invloed van de adviezen van de Raad van State (september 2003, december 2004) alsmede het rapport $\mathrm{Nu}$ kan het... nu moet het! van de Werkgroep Bestuurlijke en Financiële Verhoudingen (werkgroep-Jesurun, oktober 2004) zou De Graaf een nieuw beleid gaan inzetten. Hij brak daarmee niet alleen met de handelwijze van zijn voorgangers, maar ook met de strakke lijn die zijn hoogste ambtenaren in de voorgaande jaren hadden verdedigd. Medio december 2004 schreef hij de Kamer onder voorwaarden bereid te zijn met de opheffing van het land de Nederlandse Antillen. Inmiddels was Leon van Halder als nieuwe DG Bestuur en Koninkrijksrelaties (2003-2007) aangetreden - kennelijk kreeg en nam hij ruimte tot het verlaten van de sterk afhoudende, volgens critici verkrampte opstelling van BZK. De Graaf bevestigt dit in alle toonaarden; hij omschrijft Van Halder als een centrale figuur in de omwenteling. ${ }^{16}$ Onder leiding van Van Halder en de nieuw aangetreden directeur KR Gea van Craaikamp (2004-2009) ging de ambtelijke advisering allengs meer het karakter aannemen van een meedenken in de richting van door de Raad van State en de werkgroep-Jesurun voorgestelde, en vervolgens door het parlement verwelkomde, hervormingen.

Min of meer vanzelfsprekend bleef bij BZK de beklemtoning van Haagse belangen en mogelijke risico's overeind - in die zin bleef de stelregel dat het ministerie, en in het bijzonder KR, geen 'KabNAachtige' rol mocht spelen. Onvermijdelijk riep dat op de Antillen wel wrevel op, en ook wel eens het gevoel dat Haagse bewindslieden 
flexibeler waren dan hun ambtenaren. Zo karakteriseerde Ramonsito Booi, die namens Bonaire een groot deel van de onderhandelingen naar 10/10/10 leidde, Van Craaikamp achteraf als 'een van de taaiste', een 'nee-schudder'; Suzy Römer omschrijft haar als doortastend en een uitstekende onderhandelingspartner: 'Wij zijn bijna net zo bot. ${ }^{17}$ Ambtenaren van KR benadrukken echter dat Van Craaikamp, conform de nieuwe politieke lijn, allengs 'zachter op de inhoud' werd.

Terzijde zij opgemerkt dat de directie KR in bemensing vrijwel geheel 'wit' Nederlands bleef. Aan Antilliaanse zijde werd wel opgemerkt dat de directie onder DG Dirkse, die zou vrezen voor 'een vijfde colonne', 'verboden terrein' was voor Antillianen. Ook vicepresident van de Raad van State Herman Tjeenk Willink wees kritisch op het strikt Nederlandse karakter van de directie; PVDA-parlementariër John Leerdam, zelf van Antilliaanse afkomst, bestempelde dit als een belemmering voor het functioneren van de directie. Deze kritiek zou weinig waarneembaar effect hebben. ${ }^{18}$

Een nieuwe politieke situatie ontstond nadat in november 2006, inmiddels onder de verantwoordelijkheid van Nicolaï, met de vijf eilanden Slotakkoorden waren getekend waarin de contouren van het Koninkrijk-nieuwe-stijl waren vastgelegd. Het begin 2007 aangetreden vierde kabinet-Balkenende was gehouden tot uitvoering van deze afspraken en daarmee aangewezen op een goede samenwerking met de overzeese partners. Dit impliceerde ook een zekere flexibiliteit, terwijl gelijktijdig de allengs kritischer oppositie in Nederland ervan moest worden overtuigd dat niet te veel concessies werden gedaan. In deze nieuwe situatie lijkt het ambtelijk apparaat, onder leiding van de DG Bestuur en Koninkrijksrelaties Andrée van Es (2007-2009) en vervolgens Gert-Jan Buitendijk (2010-) en de nieuwe directeur KR Hans Gerritsen (2009-), vooral een sterk procesmatige taak te hebben gehad, waar de politieke advisering voornamelijk was gericht op de (on)wenselijkheid c.q. (on)haalbaarheid van specifieke concessies en deadlines. Over de 'onvoorstelbare' inzet van de directie Koninkrijkszaken in het hectische proces van de ontmanteling wordt nu in Den Haag vrijwel unaniem met grote waardering gesproken. ${ }^{19}$

De tweede conclusie rond de rol van het ministerie van BZK betreft de relatie tot de overige Haagse departementen. Deze was niet onomstreden. Als coördinerend ministerie had BZK de soms ondankbare taak om de regie te voeren over het gehele Antillenbeleid en in het bijzonder ook het voortouw te nemen bij de in 2004 ingezette hervormingsagenda. Uit gesprekken met betrokken ambtenaren klinkt door dat andere departementen niet altijd tevreden waren over de manier waarop BZK deze rol vervulde. Dat is op zich niet verwonderlijk; competentiekwesties tussen ministeries zijn inherent aan 
het functioneren van de Rijksoverheid. Bovendien zijn er geen sterke aanwijzingen dat dergelijke fricties op enig moment de koers of de voortgang van het hervormingsproces wezenlijk hebben beïnvloed.

De ministeries van Buitenlandse Zaken en Defensie zijn departementen die per definitie zelf Koninkrijksaangelegenheden behartigen. Traditioneel hebben zij dan geen sterke neiging hun beleid intensief met BZK af te stemmen. Het ministerie van Algemene Zaken (AZ) volgde en voerde het transitieproces met een tweeledige inzet, niet alleen namens en voor Nederland, maar ook voor het Koninkrijk - Jan Peter Balkenende was als minister-president en voorzitter van de Rijksministerraad tevens voorzitter van de beslissende Rondetafelconferenties. Uit de archieven en gesprekken met ingewijden blijkt dat BZK en AZ vrijwel altijd op dezelfde lijn zaten. Tevens werd duidelijk dat de secretaris-generaal op AZ, Richard van Zwol, achter de schermen een zeer prominente rol speelde.

Op inhoudelijk vlak was Justitie de belangrijkste departementale partner. Dit geldt in het bijzonder in de periode 2007-2010, toen onder het vierde kabinet-Balkenende de opheffing van de Antillen en de hervorming van het Koninkrijk hun beslag moesten krijgen. Het was duidelijk dat dit een majeure wetgevende inspanning zou vergen en dat Justitie daarbij dus een belangrijke rol zou moeten spelen. Daarbij kwam nog dat juist Ernst Hirsch Ballin in 2007 opnieuw aantrad als minister van dit departement. Van 1989 tot 1994 was hij zowel minister van Justitie als voor Nederlands-Antilliaanse en Arubaanse Zaken geweest en hij kan worden beschouwd als architect van het in 1990 ingezette beleid van een sterker engagement met de Caraïben.

Het verbaast niet dat Hirsch Ballin bij het constituerend beraad van het vierde kabinet-Balkenende een sterke rol bepleitte voor zijn ministerie. Onder leiding van staatssecretaris Bijleveld bleef BZK echter, zo werd besloten, primair verantwoordelijk voor de voortgang van het gehele staatkundige vernieuwingsproces. ${ }^{20}$ Justitie werd belast met de aanpassing van het Statuut, de totstandkoming van Rijkswetgeving ter uitvoering daarvan rond de rechtspleging en de rechtshandhaving en wijzigingen in de overkoepelende bestuursstructuur. Hiertoe werd een task force onder leiding van de Maastrichtse hoogleraar Luc Verhey ingesteld. ${ }^{21}$ Allengs werd duidelijk dat Hirsch Ballin minder sterk betrokken was dan hij, zo lijkt het, aanvankelijk had gewild.

In het constituerend beraad werden bovendien nog enige taken toebedeeld aan de minister van BZK, Guusje ter Horst, die de verantwoordelijkheid kreeg voor de samenwerking in politiezaken in Koninkrijksverband, inclusief de voorbereiding van nieuwe Rijkswetgeving op dit terrein. Minister Wouter Bos van Financiën was me- 
deverantwoordelijk voor de uitwerking van de financiële afspraken. Alle Nederlandse ministers zouden direct bij de voorbereiding van de statuswijziging van de drie kleinste eilanden betrokken worden - in de nieuwe staatkundige situatie zouden ze immers op deze eilanden verantwoordelijk worden op hun eigen vakgebied. ${ }^{22}$

Het verbaast niet dat er kritiek kwam op deze toedeling van verantwoordelijkheden, mede van voormalige bewindslieden, in het bijzonder Pechtold en Remkes. ${ }^{23}$ Gaande het proces zou, misschien onvermijdelijk, op Justitie het gevoel ontstaan dat het beleid van Bijleveld wat te veel op de voortgang van het proces was gericht, waardoor onnodige en onverstandige concessies zouden zijn gedaan op enkele voor Justitie cruciale punten. ${ }^{24}$ Ironisch is dat BZK, in 1998 begonnen met de uitdrukkelijke opdracht en intentie om anders dan KabNA veel afstand tot de Caraïbische landen te nemen - waarbij het in de eerste jaren door critici aan beide zijden van de oceaan nogal eens met termen als 'bot' of 'schofferend' werd gediskwalificeerd - nu juist de reputatie kreeg 'zachter' te zijn dan de andere, 'zakelijker' departementen.

Uiteindelijk werd het Nederlandse beleid uiteraard vastgesteld in het kabinetsberaad, grotendeels voorbereid door AZ en BZK. Voor het hieraan voorafgaande overleg tussen de diverse departementen werden verschillende nieuwe organen ingesteld. In dit verband was de eind 1998 opgerichte Interdepartementale Commissie Koninkrijksrelaties (ICKR), op het niveau van de DG's van de betrokken departementen, het hoogste orgaan. Daaronder ressorteerden diverse interdepartementale gremia, terwijl vooral ook BZK een reeks ad hoc task forces instelde. Volgens betrokken ambtenaren verloor de ICKR vanaf 2007 aan belang ten gunste van overlegstructuren op lager ambtelijk niveau, in het bijzonder de Interdepartementale Werkgroep (IWG). ${ }^{25}$

Het overleg in Koninkrijksverband is in normale tijden primair een kwestie van de Rijksministerraad, het Nederlandse kabinet aangevuld met gevolmachtigde ministers van de Caraïbische landen. Vaak zijn kritische kanttekeningen geplaatst bij de RMR; Klaas de Vries, tussen 2000 en 2002 minister van BZK, beaamde dit achteraf volmondig en gaf eufemistisch aan 'dat deze raad geen orgaan is dat nadenkt over de gemeenschappelijke toekomst' - mede hierom is met enige regelmaat gesproken over mogelijkheden tot opheffing van het 'democratisch deficit', waarover later meer. ${ }^{26}$

Gaande het proces van herziening van de relaties werd een aantal tijdelijke gremia onder de RMR ingesteld. Zo kwam er mede op advies van gevolmachtigde minister van de Nederlandse Antillen Paul Comenencia in december 2007 een ministeriële onderraad, de Raad 
voor Koninkrijksrelaties (RKR), bestaande uit de meest betrokken Nederlandse bewindslieden en de beide 'gevmins'. Hieraan werd het Ambtelijk Portaal Koninkrijksrelaties (APK) toegevoegd, onder voorzitterschap van de secretaris-generaal van het ministerie van BZK. ${ }^{27}$

Cruciale besluitvorming kreeg haar beslag in het kader van een langgerekte reeks Rondetafelconferenties: op 26 november 2005 de zogenoemde start-RTC, gevolgd door de toetsings-RTC op 15 december 2008 en uiteindelijk de slot-RTC op 9 september 2010. Deze RTC's werden voorgezeten door Balkenende in zijn kwaliteit van voorzitter van de Rijksministerraad; de vertegenwoordigde partijen waren niet slechts de drie landen van het Koninkrijk, maar ook de vijf eilanden van de Nederlandse Antillen apart. Kort voor de start-RTC werd de ambtelijke Voorbereidingscommissie RTC (V-RTC) ingesteld met een presidium (later in het proces aangevuld tot het 'presidium +'), drie gezamenlijke werkgroepen en twee toetsingscommissies: een voor de wetgeving en een voor de overheidsapparaten. Op 12 februari 2007 zag bovendien de Politieke Stuurgroep Staatkundige Veranderingen het licht, een overlegorgaan voor de bewindspersonen van Nederland, de Nederlandse Antillen, Curaçao en Sint Maarten; ook aan deze stuurgroep werden weer een Ambtelijke Regiegroep alsmede diverse projectgroepen (onder meer rond financiën en rechtshandhaving) gekoppeld. Naast dit brede overleg in Koninkrijksverband waren er nog enkele specifieke gremia van politiek overleg, zoals het tripartiet overleg tussen de ministers van Justitie.

\section{De rol van de Raad van State van het Koninkrijk}

Voor de eeuwwisseling was de bemoeienis van de Raad van State - een Nederlands orgaan dat, uitgebreid met een vertegenwoordiger voor elk van de Caraïbische landen, tevens als Koninkrijksorgaan fungeert-met het Nederlandse beleid voor de Antillen en met de Koninkrijksrelaties in algemene zin, betrekkelijk marginaal geweest. Dit veranderde hierna sterk, te beginnen met de voorlichting van 2003 over de relatie van de eilanden tot de Europese Unie, gevolgd door het ongevraagde advies uitgebracht ter gelegenheid van het vijftigjarig jubileum van het Statuut in 2004, de voorlichting van 2006 over de voorgenomen hervorming van de staatkundige verhoudingen binnen het Koninkrijk en ten slotte de twee voorlichtingen van 2008 over de versnelling van het gehele transitieproces en over mogelijkheden voor een gefaseerde herstructurering van de BES-eilanden. ${ }^{28}$

De voorlichting van 2003 over een mogelijke herziening van de verhouding van de Antillen en Aruba tot de Europese Unie kwam tot 
stand op initiatief van het eerste kabinet-Balkenende, met instemming van de Antilliaanse en Arubaanse regeringen. ${ }^{29}$ De Raad greep de gelegenheid aan om te wijzen op het contrast tussen 'de steeds verdergaande integratie van Nederland in een gemeenschappelijke Europese rechtsorde en een voortgezette relatie van de NAA met Nederland in het Koninkrijksverband waarin termen als autonomie en zelfredzaamheid nog steeds de toon van de onderlinge discussie bepalen'. Bovendien laakte hij het gebrek aan gemeenschappelijkheid binnen het Koninkrijk: 'Geconstateerd moet echter worden dat dit Koninkrijksverband, ook institutioneel, tot nu toe nauwelijks een gemeenschappelijke invulling heeft gekregen.'

De Nederlandse Antillen en Aruba hebben bij de EU de status van Landen en Gebieden Overzee (LGO), een vorm van associatie. Een mogelijke keuze voor de status van Ultraperifeer Gebied (UPG) impliceert een nauwere relatie met de Unie die, in de visie van de Raad, logisch onderdeel was van de noodzakelijke versterking van de relaties binnen het trans-Atlantische Koninkrijk. Handhaving van de status-quo betekende continuering van een 'onevenwichtig beeld'. Volgens de Raad was de keuze dan ook helder: zowel het ene, ongedeelde staatsburgerschap, zoals vastgelegd in het Statuut, als het handhaven van een 'Europese norm' voor het niveau van de maatschappelijke voorzieningen, waaronder de rechtshandhaving, was in feite alleen haalbaar bij verdere integratie, in Nederland, en dus ook in de EU. Voor de Raad was een snelle beslissing noodzakelijk, maar de praktijk bleek weerbarstiger, onder meer doordat tegenstanders op de eilanden de keuze voor een UPG-status als een onomkeerbare stap naar inperking van de autonomie zagen. Zeer ten onrechte, meent het toenmalige Antilliaanse lid van de Raad van State Gilbert Wawoe nog altijd: 'De UPG past de eilanden als een handschoen!'30

Inmiddels had de Raad met deze voorlichting een denkwijze verwoord die ver afstond van de politieke prioriteiten van de voorgaande jaren en van de geldende opvattingen binnen BZK. De opvattingen van de Raad werden uitvoeriger en nog sterker verwoord in '50 jaar Raad van State voor het Koninkrijk' (2004) dat, zeer ongebruikelijk, een ongevraagd advies was. ${ }^{31}$ De Raad had zich de vraag gesteld 'wat het Statuut in de nabije toekomst kan betekenen voor de burgers van het Koninkrijk' en zich daarbij gericht op een breed scala van vragen, van problemen in de sfeer van internationale criminaliteit tot sociaaleconomische ontwikkeling, kwaliteit van het bestuur en de rechten van de mens. Opnieuw adviseerde de Raad om een beter gebruik te maken van de 'mogelijkheden tot gezamenlijk optreden' die het Statuut bood.

Weer werd een filosofie verwoord die sterk afweek van de nadruk 
op eilandelijke 'zelfredzaamheid' die in Haagse kringen nog werd aangehangen. Over de betekenis van de grondrechten binnen het Koninkrijk wierp de Raad de retorische vraag op 'hoe lang het nog acceptabel is dat binnen het ene Koninkrijk met het ene staatsburgerschap, grote verschillen blijven bestaan tussen de wettelijke en internationaalrechtelijke waarborgen van de sociale grondrechten'. Bestrijding van deze verschillen achtte de Raad 'de onvermijdelijke consequentie van het ene staatsburgerschap, dat essentiële element van de nieuwe rechtsorde die het Statuut in 1954 vestigde'.

Het advies behelsde dus een pleidooi voor intensivering van de Koninkrijksrelaties; instemmend verwees de Raad naar het twee maanden eerder gepresenteerde rapport van de werkgroep-Jesurun, Nu kan het... nu moet het!. Daarmee kwam dit ongevraagde advies ook op een politiek gevoelig moment: de brede strekking van het rapport-Jesurun werd nu door de Raad ondersteund. Tegen zijn aanvankelijke bedoelingen, of althans publieke uitspraken, in maakte het tweede kabinet-Balkenende daarop de draai naar medewerking aan de ontmanteling van de Nederlandse Antillen bij een gelijktijdige versterking van het Koninkrijk. Het ligt voor de hand, en wordt door verschillende direct betrokkenen ook bevestigd, dat eerdere informele contacten met de Raad over de inhoud van het advies een rol hebben gespeeld bij de koerswijziging van het kabinet.

In drie latere voorlichtingen, respectievelijk over de hervorming van de staatkundige verhoudingen (2006), over de versnelling van het transitieproces (2008) en over een gefaseerde herstructurering van de BES-eilanden (2008), bleef de Raad de opdracht van gezamenlijkheid benadrukken. ${ }^{32}$ In eerstgenoemde voorlichting betoogde de Raad dat 'bij een goed gebruik van de in het Statuut gegeven bevoegdheden volstaan kan worden met een relatief beperkt aantal wijzigingen van het Statuut'. ${ }^{33}$ Meermalen legde hij een verband tussen de kleinschaligheid van de nieuwe landen en de beperkte bestuurskracht, waaruit de noodzaak van samenwerking op hoger en in het bijzonder Koninkrijksniveau voortvloeide. Zo bepleitte de Raad (naar zou blijken vergeefs) het voortbestaan van één Openbaar Ministerie voor alle Caraïbische delen van het Koninkrijk, met inbegrip van Aruba, geleid door één procureur-generaal, alsmede voor een overkoepelende Nederlands-Caraïbische politieorganisatie.

Van beslissende betekenis zou het advies zijn om Bonaire, Sint Eustatius en Saba in te richten als 'openbare lichamen' - 'in een relatie niet met het Koninkrijk, maar direct met Nederland' - in de zin van artikel 134 van de Grondwet. Uitdrukkelijk werd daarbij ruimte gelaten dit zodanig te regelen dat er ruimte zou zijn voor 'bijzondere bepalingen'. Veel van de algemene overwegingen van deze voorlich- 
ting weerspiegelden de terugkerende zorg van de Raad dat de Koninkrijksrelaties slechts als een bestuurlijk probleem werden opgevat, waarbij de culturele en sociale betrekkingen tussen de landen van het Koninkrijk onderbelicht bleven en waar zelfs kon worden gesproken over afzonderlijke toelatingsregelingen binnen het Koninkrijk. Opnieuw waarschuwde de Raad tegen een te grote nadruk op discussies over de toekomst van het Statuut en over staatkundige herinrichting, die dan ten koste zouden gaan van zorg voor de kwaliteit van publieke taken als onderwijs, milieu en rechtshandhaving. Dit weerhield hem er niet van de instelling van een Koninkrijkssecretariaat onder de verantwoordelijkheid van de voorzitter van de Rijksministerraad voor te stellen - ook in het advies van 2004 was al gepleit voor de instelling van een 'Koninkrijksdienst'. Laatstgenoemd advies dat, zoals gezegd, elementen bevatte van het rapport-Jesurun, zou uiteindelijk niet worden overgenomen, ook al reageerde het kabinet per brief van de minister voor Bestuurlijke Vernieuwing en Koninkrijksrelaties overwegend instemmend op deze voorlichting. ${ }^{34}$

In de in augustus 2008, op gezamenlijk verzoek van de Nederlandse en Nederlands-Antilliaanse regeringen uitgebrachte twee voorlichtingen - de ene over de 'mogelijkheden tot versnelling van het transitieproces naar de nieuwe staatkundige verhoudingen', de andere over 'mogelijkheden voor gefaseerde herstructurering van de BES-eilanden' - stelde de Raad, met beide regeringen, vast dat het transitieproces langer dan wenselijk duurde. Hij verklaarde dit uit de bestuurlijke complexiteit daarvan, maar ook uit de delicate dynamiek. Opnieuw benadrukte de Raad de noodzaak het wederzijdse vertrouwen te vergroten en bovendien institutionele voorzieningen te treffen, zonder te vervallen in excessieve juridisering.

De hierboven besproken stukken vormen de kern van de bijdrage van de Raad van State van het Koninkrijk aan de herstructurering van het Koninkrijk. Dit laat onverlet dat hij tientallen andere adviezen uitbracht, die echter meer dienen te worden gerangschikt onder de reguliere, toetsende activiteiten van de Raad. Een uitzondering vormde de doorslaggevende kritiek van de Raad op het Haagse voorstel om de Nederlandse minister van Justitie als lid van de Rijksministerraad een aanwijzingsbevoegdheid te geven aan de procureur-generaal van de Caraïbische landen met het oog op de opsporing en vervolging van strafbare feiten. Pikant was overigens dat de Raad rond de wetgeving over de BES-eilanden uiteindelijk advies moest uitbrengen over arrangementen die hij in een eerder stadium zelf had aanbevolen. ${ }^{35}$

Hoe moet de invloed van de Raad van State (van het Koninkrijk) nu worden beoordeeld? Hoewel de Raad een invloedrijk gremium vormt in het Nederlandse staatsbestel is de reikwijdte van deze in- 
vloed moeilijk vast te stellen - en nog minder de wijze waarop vanuit de Raad, naast de formele, gevraagde en ongevraagde adviezen, de politieke besluitvorming informeel wordt gevoed. Dit geldt ook voor de rol die dit orgaan speelde in de staatkundige hervorming van het Koninkrijk.

Zeker is wel dat de Raad juist in dit dossier meerdere malen wezenlijke invloed heeft uitgeoefend, niet in het minst in de cruciale jaren 2003 en 2004, toen het tweede kabinet-Balkenende uiteindelijk instemde met een fundamentele herziening van de Koninkrijksrelaties. Dat geldt niet alleen voor de staatsrechtelijke adviezen, zoals de vaststelling dat een herstructurering en verdieping van het Koninkrijk heel goed mogelijk zou zijn zonder wijziging van het Statuut, of het latere voorstel om van de BES-eilanden geen overzeese gemeenten te maken, maar te kiezen voor de vrijere optie van openbare lichamen. Het geldt uitdrukkelijk ook voor het voortdurend benadrukken van lotsverbondenheid binnen het Koninkrijk - waaruit naar het oordeel van de Raad de opgave voortvloeide om de discussie over herstructurering altijd primair te beoordelen vanuit het oogpunt van de gelijkwaardigheid van alle burgers van het Koninkrijk. In het formeel niet-verwante migratiedossier leidde dezelfde opstelling, zoals hieronder zal blijken, zelfs tot principiële afwijzing van in Nederland betrekkelijk breed gedragen voorstellen rond het beperken van de werking van het ene, ongedeelde Nederlanderschap.

Hier dringen zich enkele vragen op. Allereerst hoe de in historisch perspectief opmerkelijk actieve rol van de Raad in het afgelopen decennium verklaard kan worden. Het ligt voor de hand deze mede in verband te brengen met het lidmaatschap van de Raad van enkele voorheen nauw betrokken Nederlandse bewindslieden, in het bijzonder Hirsch Ballin (Staatsraad van 2000 tot 2006). Dit verklaart echter nog niet het merkbaar sterke engagement van een old hand als Rein Jan Hoekstra, raadslid sinds 1994, van de in 1997 aangetreden vicepresident, of van de achter de schermen zeer actieve Gilbert Wawoe (1994-2007), Caraïbisch lid van de Raad van State van het Koninkrijk. Zo was het vicepresident Tjeenk Willink die veelvuldig publiekelijk zou pleiten voor een verdieping van de Koninkrijksrelaties en die Haagse bestuurders opriep deze niet slechts vanuit Nederlands perspectief te bekijken. Typerend is zijn kritiek op het niveau en de aard van het debat in Koninkrijksverband: 'De communicatie staat in de sleutel van, vaak letterlijk, "afrekenen" in plaats van die van wederzijds belang. ${ }^{36}$

Het ligt voor de hand te veronderstellen dat hieraan ook andere dan persoonlijke factoren ten grondslag liggen. Enerzijds was er de urgentie van de maatschappelijke en staatkundige problematiek zoals 
die zich rond 2000 steeds duidelijker ging aftekenen. Anderzijds lijkt binnen de Raad de overtuiging te hebben postgevat dat de gedachtevorming in de volksvertegenwoordigingen, kabinetten, ministeries en politieke partijen aan beide zijden van de oceaan stagneerde. Dit zou - uit veel achtergrondgesprekken rijst althans dit beeld op - de Raad tot de conclusie hebben gebracht dat een eigen initiatief geboden was, zoals in het ongevraagde advies rond vijftig jaar Statuut uitdrukkelijk het geval was. En zo wierp de Raad zich achter de schermen met succes op als pleitbezorger van een vernieuwing en verdieping van de Koninkrijksrelaties. Haagse critici meenden dat de Raad van State daarmee wel eens de neiging had om, sprekend over de gezamenlijkheid binnen het Koninkrijk, de Caraïbische belangen wat meer onder de aandacht te brengen dan de Nederlandse.

Onverdeeld positief wordt de activistische rol van de Raad overigens niet beoordeeld. De Graaf kwalificeert zijn optreden als 'hinderlijk, ik zat er niet op te wachten'. In zijn visie wilde de Raad eenvoudigweg te veel verantwoordelijkheid leggen bij Nederland. Een verkeerd signaal, meent De Graaf. Zijn toenmalige DG Leon van Halder daarentegen ervoer de opstelling van de Raad als 'zeer behulpzaam'. $^{37}$

\section{Het politieke speelveld}

De onderhandelingen die uiteindelijk zouden leiden tot de opheffing van de Nederlandse Antillen en de hervorming van het Koninkrijk vonden plaats tussen drie landen en vijf eilanden. Verschuivingen in de politieke verhoudingen binnen elk van deze eenheden konden directe implicaties hebben voor de voortgang van het proces. Achteraf kunnen we vaststellen dat dit inderdaad verschillende malen tot impasses leidde, maar uiteindelijk de verwezenlijking van het in 2004 gestarte proces niet dwarsboomde. Dat had echter ook heel anders kunnen lopen, vooral door toedoen van de oppositie in Curaçao en in Nederland.

Het nieuwe beleid voor de Koninkrijksrelaties kon in de Nederlandse politiek in principe op een breed draagvlak rekenen. De Haagse koerswijziging werd een feit onder het tweede en derde kabinet-Balkenende, waarmee CDA, VVD en D66 zich hieraan verbonden. In het vierde kabinet-Balkenende onderschreven ook de PVDA en de ChristenUnie als regeringspartijen dit beleid. Van de andere partijen waren alleen de PVV en in mindere mate de SP zeer kritisch. In de laatste fase van het onderhandelingstraject werd het parlementaire verzet echter sterker: volgens de oppositie deed Nederland te veel concessies 
ten opzichte van de afspraken zoals vastgelegd in de Slotverklaring van 2006 - reden waarom de VVD haar steun dreigde in te trekken. Dit werd temeer prangend nadat het vierde kabinet-Balkenende in februari 2010 demissionair werd. De oppositie meende dat de voor de transitie nog te behandelen wetgeving 'controversieel' was, dat wil zeggen: te politiek beladen om aan een demissionair kabinet over te laten. Bovendien hadden beide Kamers grote kritiek op het korte tijdsbestek waarin nog een groot aantal wetten moest worden behandeld.

In deze onzekere politieke context moest staatssecretaris Bijleveld het proces gaande houden en hiervoor de steun van het Nederlandse parlement zien te behouden. Inmiddels was er sprake van een diepe financiële crisis, waarin de in betere tijden aangeboden sanering van de Antilliaanse overheidsfinanciën zeer kritisch commentaar ontlokte. sP-Kamerlid Ronald van Raak, met altijd al veel kritiek over de Antillen en het Antillenbeleid, rekende in de Kamer voor dat dit per Nederlander een uitgave van ongeveer honderd euro betekende, per Antilliaan een overname van een schuld van zes- tot zevenduizend euro. ${ }^{38}$ Daarmee zat hij, mede omdat hij uitging van een bedrag van 1,5 miljard euro, nog aan de lage kant. Uiteindelijk ging het om 1,7 miljard euro, per bewoner van de vijf Antilliaanse eilanden eerder 8500 euro.

Bovendien tekende zich een versterking van het rechtse blok af - waarin de PVV uitgesproken negatief was over zowel de Antillen

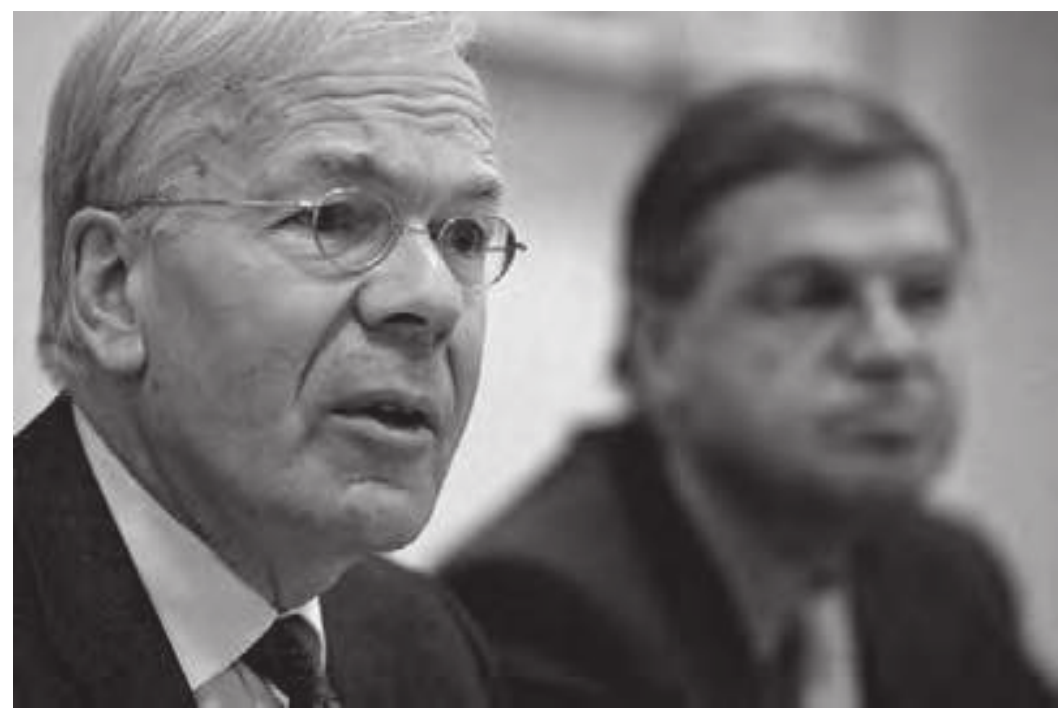

Vicepresident Herman Tjeenk Willink presenteert het jaarverslag van de Raad van State, rechts op de achtergrond Ernst Hirsch Ballin, op dat moment lid van de Raad, 26 april 2006. 
zelf als over het als te toegevend ervaren Haagse beleid, terwijl de VVD zich weliswaar verbonden had aan de in de Slotverklaring vastgelegde uitgangspunten, maar afwijzend stond tegenover sindsdien gedane concessies, vooral op het justitiële dossier. Ook de oppositionele SP bleef zich buitengewoon kritisch betonen. Tot op het laatst hing 10/10/10 daarom ook in Den Haag aan een zijden draadje. Cruciaal was de uiteindelijke instemming, op hoofdpunten, van de VVD. Afgezien van mogelijke partijpolitieke overwegingen zal het ook voor die partij een rol hebben gespeeld dat zich geen duidelijk alternatief aftekende. En dat hing weer samen met de stemming aan de overzijde.

Op soms dramatische wijze tekende de verharding van de standpunten zich af in het genoemde POK. Was in het verleden de kritiek op zijn voorganger, het Contactplan, vooral geweest dat dit overleg te vrijblijvend en over en weer eerder vriendelijk en vermijdend dan kritisch was, met het aantreden van de PVV in het POK veranderde dit radicaal, culminerend in het afgelasten van dit parlementair overleg in januari 2008 op de Antillen, nadat PVV'er Hero Brinkman weigerde excuses aan te bieden voor zijn begin december 2007 ingediende motie waarin hij de Antillen had omschreven als een 'grotendeels corrupt boevennest [...] dat verkocht moet worden via Marktplaats.nl'. ${ }^{39}$ De Staten van de Nederlandse Antillen ontzegden hem de toegang tot het parlementsgebouw, waarop de Nederlandse delegatie besloot niet meer deel te nemen aan het overleg. Weliswaar werd het POK in juni 2008 hervat - overigens zou Brinkman daarbij vlak voor het einde van het overleg door zijn eigen delegatiegenoten worden geschorst-maar deze conflicten waren een teken aan de wand, ook voor de onderhandelende partijen: de marges werden kleiner. $\mathrm{Na}$ januari 2009 vond geen apart tripartiet POK plaats; ook niet in 2010, een jaar van veelvuldig tripartiet overleg aan de vooravond van de ontmanteling van de Antillen.

Waar in voorgaande decennia het 'Koninkrijksdossier' in Nederland zelden aanleiding had gegeven tot grote partijpolitieke verschillen begon dit nu kennelijk te veranderen. ${ }^{40}$ Maar wellicht belangrijker is dat, gelijktijdig met en deels in weerwil van het proces van staatkundige vernieuwing, ook buiten de politiek sprake was van een kritischer beoordeling van de relaties, en vooral van de gang van zaken op de eilanden. De Nederlandse pers was daarbij een graadmeter, evenals door critici met graagte aangehaalde peilingen waaruit steevast (en overigens niet anders dan in het verdere verleden) bleek dat voor veel Nederlanders een afscheid van de Antillen en Aruba een goed idee was.

Niettemin, en waarschijnlijk tot geluk van de Antillen, bleef het 
'Koninkrijksdossier' in Nederland van bescheiden politiek gewicht. Op de eilanden daarentegen, en vooral op Curaçao, zou het hervormingsproces als een splijtzwam fungeren. Tussen 2000 en 2010 kende het land de Nederlandse Antillen niet minder dan zeven regeringscoalities. Voor het onderhandelingsproces hadden deze vele wisselingen uiteindelijk geen ernstige consequenties. Met uitzondering van de twee kortstondige kabinetten onder leiding van FOL-premiers Ben Komproe en Mirna Louisa-Godett (juli 2003-juni 2004)-een periode waarin de Antilliaans-Nederlandse relaties uitermate moeizaam waren - werden de Antilliaanse regeringen geleid door de PARpremiers Miguel Pourier, Etienne Ys en Emily de Jongh-Elhage. Niet alleen gold de Curaçaose PAR als verwant met het CDA, bovendien was er volgens vrijwel alle betrokkenen sprake van een uitstekende dynamiek tussen Bijleveld en De Jongh-Elhage. De kabinetsleden voor de andere eilanden legden eveneens hoge prioriteit bij het hervormingsproces. Op nationaal niveau lag het risico voor de voortgang dus niet, maar gelijktijdig wisten de landelijke coalitieregeringen zich voortdurend gebonden aan steeds wisselende en in hun standpunten vaak tegenstrijdige eilandelijke besturen. Dit maakte het voor de landsregering vaak bijzonder moeilijk om consistent en doortastend te opereren.

Zeer ingewikkeld was de politieke constellatie op Curaçao, waar in dezelfde periode eveneens zeven coalities de eilandsregering voerden. In de periodes dat lands- en eilandsregering beide door de PAR werden gedomineerd, kwam dit de voortgang van het onderhandelingsproces ten goede. Dit was echter niet altijd het geval. Gaande het proces vonden drie verkiezingen plaats voor de eilandsraad: in 2003, 2007 en 2010; steeds was de relatie tot Nederland een zwaar omstreden punt. In 2003 verloor de PAR op eilandsniveau haar dominante positie en werd zij oppositiepartij. Hiermee raakte tussen medio 2004 en 2007 de balans tussen de landsregering en de regering van het grootste eiland ernstig verstoord, waardoor ook het mandaat van de landsregering omstreden werd. In de cruciale periode 2007-2010 was de PAR echter weer in beide regeringen dominant, wat de voortgang van de onderhandelingen sterk bevorderde. Een Curaçaos referendum in 2009 over de staatkundige afspraken met Nederland bleek echter een dubbeltje op zijn kant, met 48 procent tegenstemmers.

Hoewel de PAR bij de eilandelijke verkiezingen van 2010 met acht van de 21 zetels de grootste partij werd, zou zij uit de eerste regering van het nieuwe land Curaçao worden gehouden door een coalitie onder leiding van Gerrit Schotte van de nieuwe partij Movementu Futuro Kòrsou (MFK). Deze eerste Curaçaose landsregering werd samengesteld uit MFK, PS en MAN, partijen die allemaal buitengewoon 
kritisch zijn over de uitkomst van het onderhandelingsproces, waarin Nederland een onaanvaardbare inperking van de Curaçaose autonomie zou hebben afgedwongen - veelvuldig viel het verwijt van 'rekolonisatie'.

Verkiezingen en bestuurswisselingen op de andere eilanden waren uiteindelijk niet van invloed op het onderhandelingsproces. Wat partijen op Sint Maarten ook verdeelde, het verlangen naar een landsstatus en de bereidheid hiertoe concessies te doen werd breed gedeeld. De eilandelijke politiek op Saba en Sint Eustatius interfereerde evenmin met het landelijke proces.

Alleen op Bonaire was vanaf mei 2009 sprake van onverwachte politieke complicaties. Een referendum in 2004 had ruime steun opgeleverd voor de optie van een directe band met Nederland, een keuze die in 2005 door de eilandsraad was bekrachtigd. Kort daarop besloot de Tweede Kamer zelfs het eiland een voortrekkersrol toe te kennen in het staatkundige veranderingsproces. Nadat in 2006 de eilandsraad unaniem de keuze voor de status van openbaar lichaam had bekrachtigd, veroorzaakte een dissident in de eilandsregering medio 2009 echter de val van de raad, de vorming van een nieuwe coalitie en de organisatie van een referendum waarin de bevolking zich, zo was de hoop, alsnog zou uitspreken tegen de bereikte vorm van integratie van Bonaire in Nederland. Hierop volgde een harde Nederlandse reactie, een ingreep van de gouverneur - die het geplande referendum vernietigde wegens strijd met onder meer het belang van het Koninkrijk - en alsnog een referendum op 17 december 2010, waarin een overgrote meerderheid zich inderdaad uitsprak tegen de nieuwe status van Bonaire, maar bij een zeer lage opkomst en bovendien ruim twee maanden na $10 / 10 / 10{ }^{41}$

Hiermee kreeg deze Bonairiaanse oppositie het karakter van de spreekwoordelijke mosterd na de maaltijd, evenals verklaringen van de regering-Schotte dat Curaçao de onderhandelingen over de op 10/10/10 bereikte status wilde heropenen. Dit neemt niet weg dat deze oppositie tegen wat geldt als een te sterke Nederlandse bemoeienis met de eilanden de komende jaren naar verwachting niet zal wegebben; deze kwestie komt in het slothoofdstuk van dit boek aan de orde. Hier past echter allereerst de conclusie dat de politieke context waarin de verschillende partijen consensus moesten zien te vinden uiterst precair en bovendien sterk tegenstrijdig was.

Niet alleen liep de politieke steun voor de uiteindelijk gekozen uitkomst meermalen gevaar, daarnaast was ook de aard van de eilandelijke oppositie volstrekt tegengesteld aan die in Nederland. Waar de Antilliaanse kritiek steeds draaide rond verwijten van 'rekolonisatie' was de kritiek in Nederland juist gericht tegen wat gold als een te toe- 
gevende houding jegens de eilanden. Dat waren onverenigbare standpunten. De conclusie moet dan ook luiden dat de hoofdrolspelers in het onderhandelingsproces niet anders konden dan een midden zoeken tussen beide extremen en daarbij grote haast maken, gezien de (achteraf uitgekomen) inschatting dat een volgende verkiezingsronde heel goed partijen aan de macht zou kunnen brengen die het vinden van consensus vrijwel onmogelijk zou maken. In die zin streden Bijleveld en De Jongh-Elhage tussen 2007 en 2010 wellicht minder tegen elkaar dan tegen de oppositie in eigen land en vooral tegen de politieke klok.

Mede doordat de Koninkrijksrelaties in de Haagse politiek tot voor kort zelden omstreden waren, is de ruimte voor een bewindspersoon om een eigen stempel te drukken vrij groot geweest. Het ligt daarom voor de hand de vraag te stellen naar de betekenis van de persoonlijke opvattingen en stijl van de opeenvolgende bewindslieden. ${ }^{42}$ Zeer duidelijk werd het belang van de persoonlijke factor met het aantreden, in 1989, van Ernst Hirsch Ballin, die direct een volkomen nieuwe agenda ging uitvoeren (versterking van het Koninkrijk en opsplitsing van de Nederlandse Antillen in plaats van blijven aandringen op een spoedige en gezamenlijke soevereiniteitsoverdracht), die uiteindelijk twee decennia later in hoge mate zou worden verwezenlijkt. Dit beleid werd vrijwel kamerbreed gesteund.

Bij zijn aantreden in 1994 hield Joris Voorhoeve weliswaar vast aan de conclusie dat een soevereiniteitsoverdracht onrealistisch was, mogelijk ook onwenselijk, maar uit het mislukken van de Toekomstconferentie in 1993 trok hij de pragmatische conclusie dat het inzetten op staatkundige vernieuwing geen prioriteit had. Ook hier volgde het parlement zonder veel bedenkingen. Dit beleid werd, nu vanuit het ministerie van BZK, in 1998 voortgezet door Gijs de Vries, de eerste staatssecretaris voor de Koninkrijksrelaties - conform het genoemde advies van Voorhoeve was inderdaad, om competentiekwesties te voorkomen, dit keer niet gekozen voor een minister (zonder portefeuille).

In zijn beleidsnota Toekomst in samenwerking betitelde De Vries 'het bevorderen van een zo groot mogelijke zelfredzaamheid van de Koninkrijkspartners' als 'de centrale doelstelling' van het kabinet. Dit streven was op zich niet nieuw, wel de sterke nadruk op de voorwaarden waaraan de Caraïbische landen moesten voldoen voordat Den Haag bereid zou zijn een 'nieuw samenwerkingsbeleid' te voe- 
ren, alsmede de strenge toonzetting van de nota en het daarop gebaseerde beleid. De basiseisen waren een solide financieel-economisch beleid en deugdelijk bestuur, de sleutelbegrippen 'modernisering' en 'effectiviteit'. In 2000, geconfronteerd met de breed gedragen wens van Sint Maarten om een landsstatus binnen het Koninkrijk te verkrijgen, weigerde de staatssecretaris hierop in te gaan, terwijl hij ook het dossier staatkundige vernieuwing gesloten wenste te houden. Dit kabinetsbeleid kon rekenen op brede steun van het Nederlandse parlement.

Direct betrokken ambtenaren herinneren zich het optreden van Gijs de Vries tegenover zijn Caraïbische partners als correct maar afstandelijk. Het bewaren van distantie werd vanuit de ambtelijke top uitdrukkelijk bevorderd, op alle niveaus: zoals gezegd, diende een breuk te worden gemaakt met de KabNA-periode, waarin de relaties te amicaal zouden zijn geweest en Nederland te weinig 'de poot had stijf gehouden'. De Vries drukte het in het parlement veel diplomatieker uit. Hij karakteriseerde zichzelf als 'iemand die nogal wat achterstallig onderhoud in de relatie aantrof'. Op de Antillen kreeg hij, niet verwonderlijk, de reputatie van een afstandelijk bestuurder. Het optreden van De Vries en zijn ambtelijke staf werd door sommigen als confronterend ervaren - kennelijk werd, kunnen wij vaststellen, inderdaad een stijlbreuk met de KabNA-periode geforceerd. Desgevraagd typeert Gijs de Vries zijn eigen opstelling als het tegenbeeld van het beleid van minister voor Nederlands-Antilliaanse Zaken Jan de Koning (CDA, 1982-1989). De Koning, meent De Vries, ging de eilanden rond als een 'twintigste-eeuwse bisschop van Myra'. Om te vervolgen: 'Aan zijn goede bedoelingen twijfel ik geen moment, maar zijn beleid kwam neer op neokoloniaal paternalisme.' De Vries wilde juist, breed gesteund in de Haagse politiek, een beleid voeren waarin de verantwoordelijkheid van de Antilliaanse bestuurders voor het eigen bestuur centraal stond, ook waar dit weerstanden opriep. ${ }^{43}$

Thom de Graaf, onder wiens ministerschap het beleid ging draaien richting ontmanteling, karakteriseert de betrekkingen tussen De Vries en zijn staf met de eilanden als 'buitengewoon koel'. Zijns inziens was er 'geen sprankje van vernieuwing mogelijk'. Het verbaast niet dat zowel zijn politieke voorgangers als de toenmalige DG JanPaul Dirkse daar volstrekt anders over oordelen en de inderdaad onmiskenbare tegenstellingen in deze jaren verbinden aan de observatie dat de Antilliaanse bestuurders nu voor het eerst werden geconfronteerd met een consistente en weinig toegevende Haagse houding. ${ }^{44}$

De herinnering aan de bewindsperiode van Gijs de Vries is op de eilanden verbonden gebleven met een diepgaande crisis in 2001 tussen hem en de toenmalige PAR-premier Miguel Pourier. Op Haags 
aandringen had Pouriers regering ongekend diep gesneden in de ook toen al onevenwichtige landsbegroting, ten koste van grootscheepse ontslagen bij overheidsdiensten. De Nederlandse regering had een ruimhartig flankerend beleid toegezegd, mits het Antilliaanse kabinet aan een lange reeks van met het IMF overeengekomen voorwaarden zou voldoen. Op het moment dat Pourier meende dat inderdaad aan vrijwel alle voorwaarden was voldaan, en bovendien de verkiezingen voor de deur stonden, vroeg hij Den Haag om de toegezegde middelen voor flankerend beleid. Tot Pouriers verbijstering weigerde De Vries, met het argument dat nog niet aan alle voorwaarden was voldaan. Deze Haagse opstelling zou de Antilliaanse geschiedenis ingaan als 'het verraad van Gijs de Vries'. De PAR verloor de verkiezingen, Pourier verliet de politiek, op de eilanden werd breed het sentiment gedeeld dat de keurige Pourier door Nederland, en in het bijzonder door de heersende 'rekenmeesterscultuur' op het ministerie, was belazerd - en dat Den Haag dus niet te vertrouwen was.

Een onderzoek naar het waarheidsgehalte van de opvatting dat Pourier zou zijn 'verraden' door Gijs de Vries valt buiten het bestek van dit boek - nog afgezien van het feit dat vrijwel niemand de persoonlijke integriteit van De Vries in twijfel trekt. Hoe dan ook moet worden benadrukt dat de toenmalige direct verantwoordelijken een volstrekt andere lezing hebben van deze episode en in het bijzonder van het vermeende 'verraad'. Klaas de Vries wijst erop dat het tweede paarse kabinet-Kok uitdrukkelijk wilde breken met wat werd gezien als het cultiveren van een afhankelijkheid van Nederland en het onvoldoende stimuleren van het dragen van eigen verantwoordelijkheid. Paars wilde, in zijn woorden, 'af van de door het CDA ingegeven traditie van liefdadigheid en pappen en nathouden'. Verzakelijking was de kern, en hij karakteriseert het beleid van Gijs de Vries en zijn DG Jan-Paul Dirkse in dit perspectief als consistent, professioneel en helder. Wel stelt de oud-minister 'dat de leidende politici op de Antillen dit als een cultuurshock ervoeren'. ${ }^{45}$

Gijs de Vries zelf bevestigt weliswaar het bestaan van 'de op Curaçao met zorg gekoesterde beelden over "het verraad" van De Vries', maar ontkent ten zeerste het waarheidsgehalte van deze perceptie. Pourier, zo stelt hij, kan uiteraard wel hebben gemeend dat 'aan vrijwel alle voorwaarden' was voldaan, maar dit was niet werkelijk het geval volgens de adviezen die hij van financiële deskundigen ontving. In De Vries' visie was er geen sprake van verraad, maar van een onvermijdelijk besluit omdat het kabinet-Pourier uiteindelijk onvoldoende bezuinigde: 'De Antillen zagen de afspraken wel als "inspanningsverplichting" en deden ook wel hun best, maar niet als "resultaatverplichting". Daar kwam nog een conflict bij over het migratiedossier, 
waarbij minister Roger van Boxtel vergeefs naar Curaçao afreisde om een akkoord over een verplichte inburgeringscursus voor jonge Antillianen te ondertekenen - waarover later meer. Nederland werd daarmee, in de woorden van Van Boxtel, 'in zijn hemd gezet'. Hierdoor verdampte het draagvlak in het kabinet-Kok voor een tegemoetkomende opstelling. De Vries stelt dat de Antilliaanse politiek zich onbegrijpelijk verkeek op de verhardende Haagse werkelijkheid, hoezeer hij daar ook voor waarschuwde en zelf concessies deed: 'It takes two to tango. ${ }^{46}$

Of het nu een mythe, een hele of een halve waarheid was, de perceptie dat er een 'verraad van Gijs de Vries' was geweest, lijkt zich enkele jaren nadien ook te hebben genesteld in het collectieve geheugen van het ministerie van BZK - waar inmiddels weer anderen werkten. De Vries' opvolgers zouden veel energie investeren om een basaal Antilliaans wantrouwen weg te nemen dat zou zijn voortgekomen uit deze episode en daarmee expliciet - bij monde van Pechtold zelfs met excuses - afstand nemen van deze erfenis. Het valt op dat in vele gesprekken met betrokkenen aan Nederlandse zijde wordt gememoreerd dat de relatie tussen Den Haag en de eilanden aan het einde van de bewindsperiode van Gijs de Vries 'dramatisch' was. Daarom werd sindsdien voortdurend benadrukt dat Den Haag een betrouwbare partner was - dat was de Nederlandse verantwoordelijkheid in Bijlevelds mantra 'afspraak is afspraak. ${ }^{47}$

Met het aantreden van Johan Remkes als minister van Binnenlandse Zaken en Koninkrijksrelaties werd voor de derde achtereenvolgende keer een VVD'er belast met het 'Antillendossier'. De figuur van een aparte staatssecretaris werd nu weer verlaten; Remkes deed de Koninkrijksrelaties 'erbij', als vanouds. Zijn drie opvolgers tussen 2003 en 2007 waren ministers zonder portefeuille. In 2007 zou worden teruggekeerd naar een aparte staatssecretaris, eind 2010 trad weer een minister van BZK aan die de Koninkrijksrelaties 'erbij' deed.

De Koninkrijksrelaties waren voor Remkes dus geen hoofdzaak van zijn portefeuille, bovendien was het eerste kabinet-Balkenende slechts kortstondig. De beleidslijn bleef onveranderd-'Een zakelijke en resultaatgerichte benadering staat hierbij voorop, met respect voor de verantwoordelijkheid van de Landen afzonderlijk. ${ }^{{ }^{48}} \mathrm{De}$ minister zou, zo was de bedoeling, slechts enkele keren per jaar op werkbezoek gaan, terwijl het ambtelijk overleg juist toenam, om succes te garanderen op de 'spaarzame momenten dat er politiek overleg is'. ${ }^{49}$ In de praktijk bezocht Remkes pas als demissionair minister de eilanden; dat hij zijn al voor de val van het kabinet geplande reis toch aflegde, betrok hem meer bij de problematiek en werd op de eilanden gewaardeerd, al bleef men daar hunkeren naar een bewindspersoon 
met 'meer begrip voor de Antilliaanse zaak' - waarbij in Haagse optiek de CDA-politicus Jan de Koning, uit de jaren tachtig, nog altijd als toegevend ijkpunt gold. ${ }^{50}$ De toenmalig gevolmachtigd minister Carel de Haseth herinnert zich dat Remkes op deze reis 'op zijn minst een luisterend oor had en open stond voor argumenten van Antilliaanse zijde. ${ }^{51}$

Tijdens een diner in Den Haag met Sarah Wescott-Williams, de politiek leider van Sint Maarten, zou Remkes hebben laten doorschemeren de optie van een status aparte niet geheel uit te sluiten. Ook zou hij mede op basis van contacten met de Raad van State hebben gesproken over de instelling van een commissie die moest adviseren over de structuur van de Antillen. Gedocumenteerd is dit niet, maar Remkes zelf bevestigt dat hij met Wescott heeft gesproken over de mogelijkheid dat 'de schurende landslaag' zou verdwijnen, mits een groot aantal garanties zou worden ingebouwd: 'Zij kan dit inderdaad als een opening hebben begrepen. ${ }^{52}$ Aan de vooravond van 10/10/10 zou Remkes als woordvoerder van de VVD het onderhandelingsproces volgen - hoewel hij akkoord ging met de hoofdlijnen zou hij zich zeer kritisch betonen over wat hij zag als te verregaande Haagse concessies. Hoe kritisch toen ook, zijn carrière als 'Antillenkenner' bevestigt het beeld dat betrokkenheid een politicus al snel tot geëngageerd 'Antillenvriend' maakt.

Remkes' opvolger Thom de Graaf had enige ervaring met de Antillen, onder meer in de Vaste Tweede Kamercommissie. Bij de formatie van het tweede kabinet-Balkenende had hij een dubbele portefeuille op BZK geëist, zowel Bestuurlijke Vernieuwing als Koninkrijksrelaties; Remkes liet dit laatste deel, althans volgens De Graaf, slechts node schieten..$^{53}$ De Graafs primaire doelstelling in het kabinet was het verwezenlijken van enkele door D66 reeds lang gekoesterde wensen - het stranden van zijn beleid inzake deze 'kroonjuwelen' zou in maart 2005 tot zijn voortijdige aftreden leiden. De Koninkrijksrelaties hadden volgens de meeste betrokkenen wel zijn aandacht, maar niet zijn hoogste prioriteit. Inzake dit dossier had het tweede kabinet-Balkenende geen beleidswijziging aangekondigd. Toch zou De Graaf de eerste draai maken. Uiteraard hing dit samen met de eigen en uiteindelijk niet meer te negeren dynamiek op de eilanden, waar het separatisme groeide en de legitimiteit van de landsregering navenant afnam.

In september 2003, dezelfde maand waarin de Raad van State een verdieping van de Koninkrijksrelaties bepleitte, gaf De Graaf aan te streven naar een herstructurering onder het motto minimale bevoegdheden voor het land de Nederlandse Antillen, maximale bevoegdheden voor de eilanden, cruciale bevoegdheden voor het Koninkrijk. 'Maatwerk per eiland is voor mij een leidend criterium bij 
de verbetering van de bestuurlijke structuur. ${ }^{54}$ Een maand later stelde De Graaf de Werkgroep Bestuurlijke en Financiële Verhoudingen (werkgroep-Jesurun) in.

Betrokken ambtenaren geven aan dat deze minister niet geïnteresseerd was in een abstracte evaluatie van het Statuut, maar wel in concrete vernieuwing, waarmee de werkgroep-Jesurun de ruimte kreeg om buiten de geijkte kaders te denken; De Graaf was, zo herinneren ambtenaren zich, bereid 'gecontroleerde risico's te nemen'. Binnen het ministerie, en in het bijzonder de directie KR, werd op dat moment nog verdeeld geoordeeld over de wenselijkheid van een beleidswijziging. Die kwam dan ook stapsgewijs, maar zeker. Begin januari 2005 verklaarde De Graaf publiekelijk: 'Ik wil één ding de komende jaren bereiken: dat er aan het einde van mijn periode onomkeerbare stappen gezet zijn naar een nieuwe structuur binnen het Koninkrijk.' Impliciet leek hij ook afstand te nemen van de verzakelijking die onder zijn voorgangers richtinggevend was geweest: 'Allerlei pogingen in de jaren tachtig en begin jaren negentig om hervormingen door te voeren, zijn mislukt. Dat is ook begrijpelijk, gezien de manier waarop emoties over en weer en juridische haarkloverij de boventoon voerden. Je kunt vanuit Den Haag niet denken dat je zomaar even kan ingrijpen en een aantal Caraïbische eilanden kan besturen. ${ }^{55}$

Inmiddels was ook het parlement om; daar was de minister in oktober 2004 al door een brede meerderheid tot grotere haast aangespoord. ${ }^{56}$ Op de voorlichting van de Raad van State over het Statuut van december 2004 reageerde de minister niet meer; uiteindelijk zou het zelfs een jaar duren voordat deze voorlichting door zijn opvolger alsnog met commentaar aan het parlement werd gestuurd. Nauw betrokken bestuurders op de eilanden beoordelen De Graaf overwegend positief. 'De Graaf begon te luisteren', stelt Booi, Statiaan Roy Hooker noemt hem een 'man met ideeën'. Op Curaçao en Sint Maarten wordt De Graaf gewaardeerd omdat hij, al was het nog aarzelend en ook wat afstandelijk, de ruimte ging geven voor verkenning van de ontmanteling. Ys karakteriseert hem daarom zelfs als 'de held van het verhaal'. Zelf karakteriseert De Graaf zich als een 'bestuurlijke procesdenker' - maar evengoed is hij verguld met de koosnaam die hij op de Antillen al snel kreeg, 'minister Thom. ${ }^{57}$

De Graafs opvolger was Alexander Pechtold, die welgeteld vijftien maanden minister voor Bestuurlijke Vernieuwing en Koninkrijksrelaties zou zijn, tot het moment dat D66 zich terugtrok uit het tweede kabinet-Balkenende. Voordien had Pechtold geen merkbare belangstelling voor of affiniteit met de Antillen getoond. Hij onderscheidde zich volgens zijn toenmalige ambtelijke omgeving echter van zijn voorgangers door in plaats van een zakelijke opstelling een meer per- 
soonlijk engagement alsook een gevoel van urgentie uit te stralen. Zo reisde hij twee weken na zijn benoeming al naar de Antillen en Aruba af, de eerste van vele reizen. Met deze opstelling oogstte hij direct brede parlementaire lof. Tijdens de begrotingsbehandeling van de Koninkrijksrelaties in de Eerste Kamer werd Pechtold gecomplimenteerd om zijn 'daadkracht', 'betrokkenheid' en 'proactieve houding'. De minister werd zelfs gewaarschuwd voor te veel optimisme. $.^{58} \mathrm{Amb}-$ telijk waren er wel zorgen, zo wordt achteraf herinnerd, dat Pechtold al te ontspannen met zijn onderhandelingspartners omging en werd juist benadrukt hoe belangrijk het was dat hij ook publiekelijk de problemen en meningsverschillen benoemde. Dat was het oude dilemma van het midden vinden tussen verzakelijking en empathie. ${ }^{59}$

De minister koos zelf voor een losse en soms onconventionele aanpak die hem dichter bij de Antilliaanse burger en ook zijn onderhandelingspartners moest brengen. Zo trad hij frequent op in radioprogramma's en trachtte hij te breken met in zijn ogen onnodige formaliteiten. Enkele malen bracht Pechtolds informele taalgebruik hem in een lastig parket. Zijn oproep 'aan de keukentafel' verder te praten om de problemen werkelijk onder ogen te zien werd verkeerd begrepen, niet als een uitnodiging tot vertrouwelijkheid maar als een provocatie, een gebrek aan respect voor decorum. Uiteindelijk leverde Pechtolds in de gebruikelijke Koninkrijksverhoudingen enigszins flamboyante optreden hem, naar eigen zeggen, het vertrouwen op van zijn gesprekspartners en de ruimte om 'de doorbraak te forceren' - terwijl intussen zijn ambtenaren het noeste werk deden. ${ }^{60}$

Pechtolds frisse aanpak bracht een welkom nieuw elan, maar kon niet verhelen dat er nog stevige verschillen tussen de onderhandelingspartners in stonden. Den Haag was intussen zover dat het onder voorwaarden kon instemmen met de opheffing van het land de Nederlandse Antillen en een omvangrijke schuldsanering - op zich een doorbraak. Maar over de voorwaarden bestonden nog diepe meningsverschillen. Hierop stelde Pechtold namens het kabinet de nota 'Partners in het Koninkrijk' op, die aan de nieuwe Antilliaanse premier De Jongh-Elhage bij haar kennismakingsbezoek aan Den Haag als ononderhandelbaar werd overhandigd. Bij deze gelegenheid, zo kan worden vastgesteld, presenteerde Pechtold zich weer meer conform de lijn dat het Nederlandse kabinet zich waar nodig hard moest opstellen. Terugblikkend is er onder Nederlandse betrokkenen wel enige scepsis over zijn losse optreden, maar wordt hij ook gezien als een katalysator van het proces. Dat laatste wordt tevens op de Antillen zo beoordeeld, al wordt Pechtolds aanvankelijke optreden, de take it or leave it-presentatie van het document 'Partners in het Koninkrijk', hem nog altijd niet in dank afgenomen. ${ }^{61}$ 
Met het vertrek van D66 verdween de interesse in bestuurlijke vernieuwing uit het nu tot Balkenende III omgedoopte rompkabinet. Opnieuw werd de bewindsman een VVD'er, en met Atzo Nicolaï werd nogmaals een minister benoemd die vrijwel onbekend was met het dossier - dit laatste aanvankelijk tot weinig enthousiasme op de eilanden. ${ }^{62}$ Aangezien de bestuurlijke vernieuwing de facto uit zijn portefeuille was verdwenen, had Nicolaï wel ruim de tijd en uitgebreid mandaat voor het Antillendossier in de kleine acht maanden dat hij bewindsman was - waarvan de laatste drie maanden als demissionair minister. Het is opmerkelijk dat het parlement hem ondanks zijn demissionaire status zo'n ruim mandaat gunde; blijk van de toen nog brede Haagse consensus over richting en tempo van het proces.

Nicolaï ging, volgens de Nederlandse vertegenwoordiger in Willemstad Rob Vermaas, van start met 'een heel hoog ambitieniveau'. ${ }^{63}$ Met succes, kan worden vastgesteld. Hij doorbrak de impasse rond het op de Antillen als een dictaat ervaren 'Partners in het Koninkrijk' en smaakte het genoegen om tegen het einde van zijn bewindsperiode met alle eilanden Slotakkoorden te kunnen tekenen die de basis zouden vormen waarop tussen 2007 en 2010, tijdens het vierde kabinet-Balkenende, de ontmanteling van de Antillen en de herstructurering van de Koninkrijksrelaties werden verwezenlijkt. Betrokkenen beoordelen het optreden van Nicolai veelal als diplomatiek behendig: enerzijds trok hij met veel charme het proces weer vlot, onder meer door 'Partners in het Koninkrijk' te ontdoen van het dwingende take it or leave it-devies. Anderzijds hield hij tijdens soms harde onderhandelingen voet bij stuk op voor Nederland essentiële punten.

Wezenlijk was de interpretatie die Nicolaï en KR zouden geven aan de voorlichting van de Raad van State uit september 2006 over de toekomstige status van Bonaire, Sint Eustatius en Saba. De Raad had, naast de optie van integratie in het Nederlandse staatsbestel als 'openbare lichamen', ruimte gelaten voor een vrije associatie. ${ }^{64}$ Die laatste mogelijkheid werd door Nicolaï direct verworpen. Volgens betrokkenen werd deze keuze mede ingegeven door de grote haast die de minister had om de onderhandelingen zo spoedig mogelijk af te ronden, zeker nog tijdens zijn mandaat. Zo gaf hij als voorzitter van de Miniconferentie van oktober 2006 vrijwel geen ruimte aan de verlangens van de BES-eilanden om op een aantal terreinen meer zeggenschap te behouden.

Ook Nicolaï kijkt met veel plezier terug op zijn ambtsperiode. Het ingewikkelde traject dat uiteindelijk uitmondde in de beslissende Slotverklaring van november 2006 ervoer hij zelfs als 'het leukste wat ik in mijn professionele leven heb gedaan!' Hij wijst erop dat de overzichtelijkheid van het beleidsterrein maakt dat een bewindsper- 
soon werkelijk het verschil kan maken. Partijsignatuur is hier in zijn visie van minder belang, bestuurlijke en ook diplomatieke ervaring temeer. Juist om dat laatste wordt hij door zijn eigen ambtenaren, maar ook door zijn Antilliaanse tegenspelers, geprezen: duidelijk op de inhoud, charmant, zij het ook wat gereserveerder in de omgang. Nicolaï wordt als 'strenger' dan Pechtold gezien, volgens een enkeling zelfs als 'keihard'; Römer ervoer zijn helderheid juist als een verademing. Zelf wijst Nicolaï op de soms moeilijk te hanteren 'paradox van de Antilliaanse verwachtingen: men wil duidelijkheid, zakelijkheid, gezag, maar óók soepelheid'. ${ }^{65}$ Overigens lijkt bij Nicolaï zijn politieke kleur wél van enig belang te zijn geweest. Enerzijds kon hij goede zaken doen met zijn liberale partijgenoot Gerrit Zalm op Financiën, die hem dat succes graag gunde. Anderzijds was het juist voor een VVD'er wat gemakkelijker de rechtse partijen zover te krijgen dat zij, al was het morrend, het migratiedossier 'voorlopig' van tafel haalden.

Bij het aantreden van het vierde kabinet-Balkenende waren de principiële beslissingen al genomen en vastgelegd in de Slotverklaring van 2006. Waar er kan worden getwist of de doorbraak nu moet worden toegeschreven aan De Graaf, Pechtold of Nicolaï ging het nu 'slechts' om de uitwerking, die uiteindelijk veel gecompliceerder en tijdrovender zou blijken dan tevoren verwacht, althans door de politici - ambtelijk was hierop voortdurend gewezen. Bij de kabinetsformatie waren de Koninkrijksrelaties voor het eerst sinds Gijs de Vries weer aan een staatssecretaris toegewezen, Ank Bijleveld-Schouten. Hiermee was voor het eerst sinds Hirsch Ballin weer een CDA'er belast met deze portefeuille. De drie meest betrokken bewindslieden, de staatssecretaris van BZK, de minister van Justitie en de minister-president, waren partijgenoten. Dit neemt niet weg dat er wel enige, ten minste institutionele competentiekwesties bestonden tussen Bijleveld op BZK en de vanouds zeer intens betrokken Hirsch Ballin op Justitie. Op het laatste ministerie werd regelmatig de zorg uitgesproken dat de staatssecretaris, door haar sterke nadruk op de voortgang van het proces, te veel inhoudelijke concessies deed.

Dat Bijleveld 'slechts' staatssecretaris was, kan aanvankelijk een nadeel zijn geweest. De Graaf herinnert eraan dat een minister immers altijd het kabinetsberaad bijwoont, een staatssecretaris slechts zelden. Hij memoreert bovendien dat Antilliaanse bestuurders in de tijd van Gijs ('kleine') de Vries nogal eens hun gelijk probeerden te halen bij minister Klaas ('grote') de Vries. 'En dan trad daar die kleine vrouw aan, na al die lange mannen die wél minister waren... ${ }^{66}$

Vriend en vijand zijn het echter eens dat Bijleveld er met grote persoonlijke inzet goed in slaagde de voortgang van het onderhandelingsproces te bewaken. Belangrijk was dat zij in staat was het groot- 
ste deel van haar tijd als staatssecretaris aan dit dossier te besteden en de eerste jaren eens per zes weken een week op de eilanden door te brengen. Zelf karakteriseert Bijleveld haar optreden als 'streng op de inhoud, soepel op het proces'. Haar mantra 'afspraak is afspraak' had uitdrukkelijk die dubbele lading, als volgt samen te vatten: 'Houden jullie je aan de afspraken, dan doe ik het ook; voor een herhaling van het "verraad van Gijs de Vries" hoeft niemand bang te zijn.' Achteraf wordt Bijlevelds optreden vrijwel unaniem door nauw betrokken Haagse spelers, inclusief VVD'ers als Van Beek, Kamp en Remkes, als zeer doeltreffend beoordeeld en haar bewindsperiode daarmee als succesvol. Op de eilanden wordt haar aanpak -inclusief een sporadische 'strategische driftaanval' - al even hoog gewaardeerd, althans door de voorstanders van de bereikte akkoorden. ${ }^{67}$

De synergie met De Jongh-Elhage was daarbij van groot belang, een female touch waarop beiden zich onnadrukkelijk lieten voorstaan. Maar ook Balkenende, die volgens direct betrokkenen een uitstekende persoonlijke relatie had met zowel Bijleveld als De Jongh-Elhage (die hem omschrijft als 'een fantastische man'), speelde in dit krachtenveld een actieve rol, met merkbaar meer interesse en inzet dan zijn voorganger Wim Kok (en juist vergelijkbaar met diens voorganger Ruud Lubbers) ${ }^{68}$ De minister-president en zijn ministerie van $\mathrm{AZ}$ legden eveneens sterke nadruk op de voortgang van het proces - Hirsch Ballin en Justitie lijken toch enigszins terzijde van deze trojka te hebben gestaan. Dat Hirsch Ballin vanaf februari 2010 in het demissionaire kabinet ook als minister van BZK optrad, deed daar niet wezenlijk meer aan af.

Resumerend valt op dat vanaf De Graaf alle bewindslieden zelf uitgesproken tevreden terugkijken op hun ambtsperiode en dat zij door de meeste betrokkenen - uitgesproken critici van de uitkomsten van de ontmanteling daargelaten - positief worden gewaardeerd. Dat is niet verwonderlijk. De Graaf, Pechtold, Nicolaï en Bijleveld hadden elk betrekkelijk veel politieke ruimte om een stempel te drukken en hebben inderdaad elk een aantal belangrijke stappen gezet in het proces, dat uiteindelijk vooral als een bestuurlijk huzarenstukje wordt gezien. Zo heeft het succes vele ouders; dat zou anders zijn geweest als 10/10/10 nooit was gehaald.

\section{Permanente dossiers: financiën en deugdelijk bestuur}

Vanuit Haags bestuurlijk perspectief domineerden de afgelopen decennia drie dossiers de Koninkrijksrelaties: financiën en ontwikkeling; deugdelijkheid van bestuur; en de migratie en integratie van de 
Antilliaanse gemeenschap in Nederland. Het eerste dossier stond al sinds de jaren zestig van de vorige eeuw prominent op de agenda, het tweede en derde gingen vanaf de jaren negentig een belangrijke rol spelen. Op alle terreinen werden de afgelopen decennia ambitieuze beleidsdoelstellingen geformuleerd die in de praktijk niet of slechts onvolledig werden gehaald - vandaar de in Haagse kringen vaak gebezigde uitdrukking 'hoofdpijndossier' wanneer het gaat over de Koninkrijksrelaties.

Dit boek beoogt geen uitputtende beschrijving te geven van de ontwikkeling van de Koninkrijksrelaties in het afgelopen decennium. Een summiere omschrijving van de hoofdlijnen van deze drie permanente dossiers volstaat daarom hier. Daarbij gaat het vooral om de vraag in hoeverre ontwikkelingen op elk van deze drie terreinen van invloed waren op het proces van ontmanteling van de Nederlandse Antillen en de staatkundige herstructurering van het Koninkrijk.

Versterking van de economische structuur van de Caraïbische (ei)landen en bevordering van de autonome ontwikkeling was decennialang het hoofddoel van de Nederlandse ontwikkelingshulp, later liever omschreven als het Nederlandse samenwerkingsbeleid. In weerwil van deze ambitie steeg de nominale en reële Haagse bijdrage aan de eilanden vanaf het midden van de twintigste eeuw tot 2000 vrijwel continu. ${ }^{69}$ In het hierop volgende decennium veranderde dit niet. Rond 2000 was het sleutelbegrip 'zelfredzaamheid'. In 2000 stond op de begroting voor Koninkrijksrelaties - het leeuwendeel, maar zeker niet het totaal van de met deze relaties gemoeide kosten, gezien de elders gemaakte kosten ${ }^{70}$ - een bedrag van 128 miljoen euro. Dat was iets lager dan eind jaren negentig het geval was geweest. Daarna liep de begroting echter gestaag op. Tussen 2000 en 2008 was er sprake van een stijgende lijn met een gemiddelde van ruim 150 miljoen euro, jaarlijks ongeveer 500 euro per hoofd van de bevolking van de eilanden. In 2009 prijkte bijna 350 miljoen euro op de begroting, in 2010324 miljoen. ${ }^{71}$

De fenomenale stijging van beide laatste jaren vloeide voort uit het besluit om de Antilliaanse overheidsfinanciën te saneren, waartoe Den Haag uiteindelijk ongeveer 1,7 miljard euro beschikbaar stelde. Duidelijk is echter dat ook zonder deze exceptionele bijdragen het beeld niet afweek van voorgaande decennia. Hoeveel er ook was gehamerd op de eigen verantwoordelijkheid van de Caraïbische (ei)landen, op 'zelfredzaamheid' en op de eindigheid van de ontwikkelingshulp, de werkelijkheid was opnieuw weerbarstiger gebleken. Daar had ook de nieuwe aanpak van BZK, neergelegd in Gijs de Vries' beleidsnotitie Toekomst in samenwerking (1999), weinig aan kunnen veranderen. 
Bestudering van de toelichtingen op de Rijksbegrotingen en Financiële jaarverslagen levert geen grote verrassingen op. De ontwikkeling van het beleid wordt in de volgende twee hoofdstukken uitvoerig gedocumenteerd. Kort gezegd, lag aanvankelijk alle nadruk op 'vernieuwing van het samenwerkingsbeleid' en werd staatkundige herstructurering slechts bestempeld als een proces binnen de Nederlandse Antillen, gericht op verbetering van de kwaliteit van het bestuur. Dit ging pas veranderen in de begrotingen voor 2006 en latere jaren. Geheel conform de realiteit werd sindsdien meermalen opgemerkt 'dat het spanningsveld tussen autonomie van de koninkrijkspartners en de noodzaak samen te werken om beleidsdoelstellingen te realiseren, weerbarstig is'. ${ }^{72}$

Er werden meer noten gekraakt. In 2002 werd gesproken over een nieuwe Haagse koers, gericht op 'zakelijkere verhoudingen, afrekenen op resultaat, meetbare prestaties, zicht op de belangen en de meerwaarde van het Koninkrijk, meer aandacht voor rechtshandhaving en goed bestuur'. Instemmend werd het parlementaire geluid aangehaald 'dat de tijd van pappen en nathouden voorbij is'; de 'beroering' overzee ten spijt zou er voortaan meer 'expliciete aandacht voor de belangen van het Koninkrijk' zijn. ${ }^{73}$

Veelvuldig werden ook migratie- en integratieproblemen aan de orde gesteld. Hierbij werd eveneens een koppeling gemaakt met de ontwikkelingsproblematiek, soms in onverbloemde termen. 'Naarmate de situatie op Aruba en de Nederlandse Antillen verbetert, zal dit ook positieve gevolgen hebben voor de Nederlandse burgers. Er zal dan immers minder "export van problemen" naar Nederland plaatsvinden. ${ }^{74}$

Het oordeel over het financiële en sociaaleconomische beleid van de Caraïbische partners was vaak uitgesproken negatief, ook toen het proces van staatkundige hervorming al was ingezet. 'De verslechtering van de overheidsfinanciën in combinatie met een niet daadkrachtig sociaal-economisch beleid in de Nederlandse Antillen geeft aanleiding tot grote zorg. Drastische ingrepen zijn onontkoombaar.' Aruba bleef niet buiten schot: 'Ook de Arubaanse overheidsfinanciën ontwikkelen zich ongunstig.' Beide regeringen werd verweten 'onvoldoende politiek commitment [te tonen] om de noodzakelijke maatregelen te nemen ter verlaging van de begrotingstekorten'. ${ }^{75}$ Den Haag, zo was de boodschap, wilde ondersteunen met raad en advies, onder meer in de commissie-Havermans (herverdeling taken en financiën tussen land en eilanden) en -Wijers (besteding ontwikkelingshulp), en door ruimhartig financieel bij te dragen, maar uiteindelijk moesten de Caraïbische landen het zelf doen.

Ook over de bestuurscultuur werd regelmatig hard geoordeeld. 
Zo heette het in de begroting voor 2007: 'Nederland hecht aan het inhoud geven aan de waarden van het Koninkrijk - niet als doel op zich, maar om de bevolking van alle delen van het Koninkrijk garanties te bieden voor belangrijke elementen van goed bestuur. Deze situatie vraagt op de Nederlandse Antillen om fundamentele herbezinning op de wijze van invulling van de primaire bestuurstaken. Voor grote groepen in de samenleving ontbreekt perspectief. Met alleen symptoombestrijding zal de neerwaartse spiraal niet kunnen worden doorbroken. Dit vraagt om veranderingen in de bestuurscultuur en in de rolopvatting van de overheid. [...] Nadrukkelijk is het niet de bedoeling om de eigen bestuursverantwoordelijkheid over te nemen, hoewel deze in Nederlandse ogen te kort schiet.' Ook met Aruba zou 'een gesprek worden gevoerd over de verschillen in opvatting over de gewenste autonomie en de bestuurskracht'; de 'spanning tussen autonomie en een werkbare borging van rechtszekerheid en deugdelijk bestuur' was 'een wederkerend thema'. ${ }^{76}$

Het leeuwendeel van de begrote middelen was bestemd voor wat werd omschreven als de 'bevordering van de autonomie van de Koninkrijkspartners'. Daartoe werden behalve 'harde' sociaaleconomische investeringen ook versterking van bestuur, rechtszekerheid en onderwijs gerekend. Vanaf de begroting voor 2002 werd een aparte bestemming 'waarborgfunctie' opgenomen, waaruit institutionele investeringen ten behoeve van de versterking van goed bestuur werden gefinancierd. Het aandeel van deze begrotingspost liep op van ruim tien procent in 2002 tot 25 procent in $2008 .{ }^{77}$ In financieel opzicht bleef de waarborgfunctie, waarover in de debatten over de herstructurering zoveel werd gesproken, dus van secundair belang, maar intussen werd onder de noemer 'bevordering van de autonomie' ook geïnvesteerd in versterking van het bestuur.

De schuld van de Antilliaanse overheden werd in 2008 geraamd op 3,4 miljard Antilliaanse guldens, waarbij nog doorlopende rentelasten zouden komen. Nederland was bereid hiervan, onder beding van indringend financieel toezicht, zeventig procent over te nemen, waarvoor tot een maximum van 2,2 miljard euro werd gereserveerd en uiteindelijk een totale som van 1,7 miljard euro beschikbaar gesteld zou worden - waarbij overigens kritische parlementariërs als Remkes tot op het laatst, en met enig recht, klaagden dat de staatssecretaris geen duidelijk integraal kostenoverzicht wist aan te bieden. ${ }^{78}$

Aan de vooravond van de Rondetafelconferentie (RTC) van 15 december 2008 werd, met het instellen van financieel toezicht, de schuldsanering voor het land de Nederlandse Antillen, Curaçao en Sint Maarten daadwerkelijk in gang gezet. ${ }^{79}$ Deze sanering betekende dat de nieuwe landen Curaçao en Sint Maarten weliswaar van start 
gingen met een overheidsschuld, maar de schuld was veel kleiner dan voorheen en zou gemakkelijk op de kapitaalmarkt te financieren zijn. Overigens was het tijdelijk financieel toezicht op de BES-eilanden al een jaar eerder, op 1 december 2007, in werking getreden - waarop Nederland de eerste saneringsmiddelen had overgemaakt aan deze eilanden. ${ }^{80}$

Nederland heeft blijkens de aan de vooravond van 10/10/10 gepresenteerde begroting het uitgangspunt dat de landen op eigen benen moeten staan niet verlaten: het budget voor 'samenwerkingsmiddelen' ten behoeve van de Caraïbische landen is met ingang van 2013 ook voor Curaçao en Sint Maarten geschrapt, zoals dat al per 2010 voor Aruba was gebeurd. 'De eilandelijke overheden', zo schreven de bewindslieden Hirsch Ballin en Bijleveld, 'krijgen een gezonde financiële basis en kunnen efficiënter opereren nu de dubbele bestuurslaag van het land de Nederlandse Antillen is verdwenen. Dit zorgt voor betere publieke dienstverlening en goede rechtsbescherming.' Hiermee werd een bezuiniging van ruim zeventig miljoen euro ingeboekt, waar tegenover echter extra kosten voor de BES-eilanden blijven staan. Op de meerjarenbegroting staat voor 2013 nog altijd zo'n negentig miljoen euro als Nederlandse bijdrage aan de rechterlijke macht, de Kustwacht, de gouverneurskabinetten, alsmede een reservering van tien miljoen euro voor technische bijstand of eventueel hoger toezicht. ${ }^{81}$

In maart 2010 liet Bijleveld de Tweede Kamer weten dat de Nederlandse overheid op jaarbasis ongeveer honderd miljoen euro zou gaan bijdragen aan de BES-eilanden. De grootste uitgaven zouden worden gedaan door de ministeries van Sociale Zaken en Werkgelegenheid, gevolgd door Onderwijs, Cultuur en Wetenschappen en Volksgezondheid, Welzijn en Sport, pas daarna kwam BZK. Deze verdeling is typerend voor de nieuwe verhoudingen, waarin de rol van BZK ten aanzien van de BES-eilanden sterk aan belang heeft ingeboet. Hoeveel van deze uitgaven door lokale belastingen zullen worden gecompenseerd, was nog onduidelijk; ambtelijk werd uitgegaan van veertig miljoen euro. Opmerkelijk is hoe laconiek in Den Haag werd gereageerd op deze berekening, die toch neerkomt op een jaarlijkse subsidie van meer dan drieduizend euro per BES-inwoner, terwijl het de bedoeling is dat de landen Aruba, Curaçao en Sint Maarten onafhankelijk worden van financiële steun uit Nederland. Kennelijk was dat inmiddels ingecalculeerd. ${ }^{82}$

Het besef van de kosten zal een ontnuchterend effect hebben gehad op velen die speelden met de gedachte van volledige integratie van alle eilanden. Niettemin kan worden geconcludeerd dat gedurende het hele proces van herstructurering van de Koninkrijksrelaties over- 
wegingen van financiële aard slechts zelden centraal stonden - het zal niet vaak voorkomen dat Financiën bedragen in de orde van anderhalf tot twee miljard euro zo gemakkelijk beschikbaar stelt. Het vraagstuk van duurzame sociaaleconomische ontwikkeling speelde, afgezien van het 'schuldendossier', slechts op de achtergrond van het proces van ontmanteling en herstructurering een rol. Het contrast met de rond 2000 nog dominante nadruk op zelfredzaamheid is treffend - ook al bleef de hoop overeind dat er ditmaal wél een doorbraak was geforceerd, getuige de toelichting bij de begroting voor 2011 en verder, en de eensgezindheid tussen bewindslieden en parlement dat er na deze schuldsanering geen sprake meer kon zijn van het opbouwen van nieuwe schulden aan Antilliaanse kant. ${ }^{83}$ Gebaseerd op de ervaringen van de voorgaande vier decennia lijkt die hoop niet gespeend van enige wishful thinking. ${ }^{84}$

Investeringen in onderwijs en cultuur ten slotte zijn ook in het afgelopen decennium geen hoofdzaak geweest in het Nederlandse beleid. Dit vloeit primair voort uit de overweging dat de inrichting en het functioneren van het Antilliaanse en Arubaanse onderwijs nu eenmaal een interne aangelegenheid is. Niettemin is ook in Nederland vaak vastgesteld dat verbetering van het onderwijs niet alleen een gunstig effect zou kunnen hebben op de sociaaleconomische situatie op de eilanden, maar ook op de migratie- en integratieproblematiek in Nederland - zowel omdat de migratie dan wellicht zou

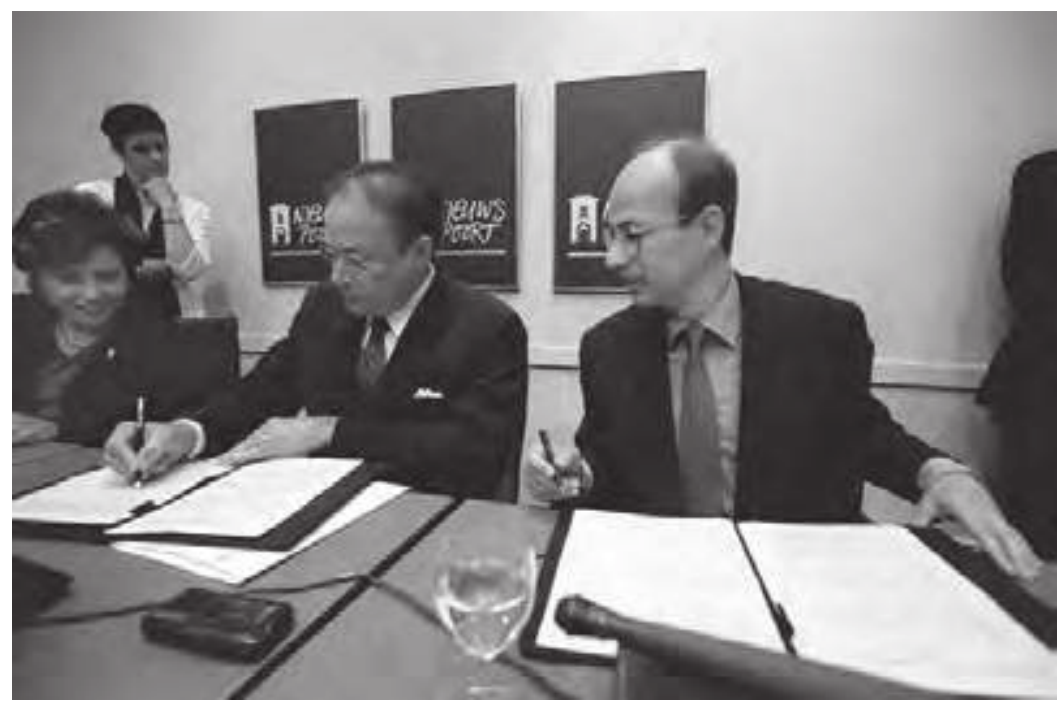

Miguel Pourier en Gijs de Vries in Nieuwpoort, Den Haag, 30 augustus 2000; links Suzy Römer. 
afnemen als omdat hoger opgeleide Antilliaanse en Arubaanse migranten betere kansen op een succesvolle integratie in Nederland zouden hebben. Uit dien hoofde werd een bescheiden deel van de $\mathrm{Ne}-$ derlandse financiële bijstand bestemd voor onderwijs; kwesties rond dit dossier hebben echter geen merkbare relatie gehad tot het debat over staatkundige vernieuwing.

Dit laatste geldt a fortiori voor de ontwikkeling van een gezamenlijk cultuurbeleid. Vastgesteld kan slechts worden dat er nog steeds nauwelijks sprake is van een weloverwogen beleid gericht op culturele samenwerking binnen het Koninkrijk. De vraag of en hoe in het vernieuwde Koninkrijksbestel meer ruimte moet worden gegeven aan gezamenlijkheid in de sfeer van taal en cultuur heeft vrijwel geen rol gespeeld in het politieke debat. Het ligt voor de hand dat deze vragen in de discussie over een toekomstvisie voor het Koninkrijk wel een plaats zullen krijgen.

Het is in zekere zin opmerkelijk dat in de debatten van het afgelopen decennium het financiële dossier niet eens zoveel aandacht trok - veel minder dan de deugdelijkheid van bestuur en de Antilliaanse migratie naar Nederland. Het lijkt erop dat de meeste politici zich het afgelopen decennium geen illusies maakten over de noodzaak van financiële ondersteuning en zich meer bekommerden over de vraag of die hulp wel goed werd besteed en de besteding goed gecontroleerd. De discussie daarover valt buiten het bestek van dit boek.

\section{Permanente dossiers: migratie}

In 1980 woonden 36.000 Antillianen en Arubanen in Nederland, in 199071.000 , in 2000110.000 en anno 2010 138.00o. Nederlandse onvrede over deze immigratie en zorgen over de bijkomende integratieproblematiek van Antillianen in Nederland bleven het afgelopen decennium prominent op de agenda van de Koninkrijksrelaties staan. Uiteindelijk zou het 'migratiedossier' echter door de opeenvolgende bewindslieden op BZK met succes buiten de debatten over staatkundige vernieuwing worden gehouden - geen geringe bestuurlijke prestatie. ${ }^{85}$

Waar de bescheiden aantallen Antilliaanse immigranten in de jaren zeventig en tachtig veelal behoorden tot de bovenlaag, zich vaak tijdelijk vestigden voor een opleiding en gemakkelijk in Nederland integreerden, veranderde dit patroon medio jaren negentig. De Antilliaanse immigratie nam sterk toe en veranderde van karakter. Het ging nu vaak om laag- of ongeschoolde jonge Curaçaoënaars die de 
oversteek maakten om de uitzichtloze situatie te ontvluchten op hun geboorte-eiland, dat gebukt ging onder jarenlange negatieve economische groei, achteruitgang van de onderwijskwaliteit en hoge (jeugd)werkloosheid. Dit ging gepaard met hoge voortijdige schoolverlating, toenemend drugsgebruik en (gewelddadige) criminaliteit. Deze problemen werden meegebracht naar Nederland, waar 'kansarm' vaak 'kansloos' bleek. 'Draaideurmigratie' van deze Antilliaanse jongeren compliceerde de zaken verder. ${ }^{86}$

Vanaf 2000, dus juist rond de tijd dat vanuit de Antillen de ontmanteling werd geagendeerd, zou de integratieproblematiek verergeren. Vooral in een beperkt aantal Nederlandse 'Antillengemeenten' werden de problemen als bijzonder ernstig ervaren. Het Haagse parlement sprak dan ook regelmatig over mogelijke oplossingen, zoals een voogdijregeling voor minderjarige Antilliaanse migranten, het uitwisselen van persoonsgegevens, het verplicht stellen van inburgeringscursussen op de Antillen voor vertrek, een remigratiebeleid en restricties op de onbeperkte toelating, bijvoorbeeld door een visumregeling. De diverse voorstellen die in de loop der jaren de revue zouden passeren, waren geen van alle succesvol; de ook in het parlement sterk omstreden pogingen om Caraïbische Nederlanders de vrije vestiging te ontzeggen sneuvelden op principiële tegenwerpingen.

Op de Antillen en Aruba leefden intussen eensgezinde zorgen over eenzijdige Nederlandse pogingen om de problematiek op te lossen via toelatingsrestricties. Opeenvolgende Antilliaanse en Arubaanse kabinetten waren van mening dat de problematiek vroeg om een gezamenlijke aanpak, op basis van het Statutaire principe van gelijkwaardigheid binnen het Koninkrijk, waarbij niet getornd kon worden aan het ene, ongedeelde Nederlanderschap. Iedere vorm van een migratiebeperking werd verontwaardigd verworpen.

Onder het tweede kabinet-Kok waren op het ministerie van BZK zowel staatssecretaris De Vries als minister voor Grote Steden- en Integratiebeleid Van Boxtel betrokken bij het migratievraagstuk. In antwoord op de noodkreet van de zeven Antillengemeenten - Amsterdam, Den Haag, Den Helder, Dordrecht, Groningen, Rotterdam en Nijmegen ${ }^{87}$ - presenteerden Van Boxtel en De Vries in november 1998 de nota Migratie Antilliaanse Jongeren. In het kabinetsoverleg over de conceptversie was de optie van een toelatingsregeling of visumplicht besproken maar uiteindelijk door een meerderheid verworpen op principiële en praktische gronden. Het dreigement van een visumplicht werd wel als politiek drukmiddel achter de hand gehouden. ${ }^{88}$

In de jaren na verschijning van de nota Migratie Antilliaanse Jongeren bleef de immigratie van kansarme Antilliaanse jongeren gestaag 
toenemen, alsmede de overlast in de Antillengemeenten. Van Boxtel maakte met de bestuurders van deze gemeenten afspraken over financiële steun voor de aanpak van de problematiek. Begin 2000 tekenden de kabinetten-Kok en -Pourier een Intentieverklaring over de koppeling van de Nederlandse en Antilliaanse bevolkingsadministratiebestanden, een voogdijregeling en een verplichte inburgeringscursus voor laaggeschoolde Antillianen; Pourier zegde toe zijn best te doen om zijn bewindslieden en de Staten van de noodzaak hiervan te overtuigen. Op de Antillen werd dit echter gezien als zeer veel, wellicht te veel, in Nederland als mogelijk onvoldoende-hardop werd nagedacht over het alternatief van een verwijderingsregeling voor deviante Antillianen.

Vervolgens tekende zich een polarisatie van standpunten af. Toen begin mei 2000 de Antilliaanse Staten zich unaniem uitspraken tegen de verplichting om vóór vertrek naar Nederland een inburgeringsprogramma te volgen - terwijl het Nederlandse kabinet een verwijderingsregeling overwoog en het opschorten van steun aan sociaaleconomische programma's - ontstond een patstelling. Van Boxtel riep de Antilliaanse regering op om zich aan de eerdere afspraken te houden. Ook Gijs de Vries was teleurgesteld over de tegenwerking vanuit het Antilliaanse parlement en noemde de inburgeringscursus 'verdorie niet eens zo'n verregaande maatregel'. ${ }^{89}$ Maar de Antilliaanse regering gaf geen krimp. Prioriteit voor de Antillen was educatie van de Antillianen die in de Antillen bleven; inburgering was in Antilliaanse visie toch vooral een Nederlands belang. Hiermee was de geloofwaardigheid van de gezamenlijke Antilliaans-Nederlandse aanpak, die tot dan toe in de Tweede Kamer en in de media was verdedigd, stevig aangetast.

Medio 2000 vertolkte het ministerie van Justitie het standpunt dat een toelatingsregeling juridisch niet of nauwelijks mogelijk was, gezien onder meer de in het Statuut en de Grondwet gestelde randvoorwaarden-kennelijk waren de werkzaamheden aan een dergelijke regeling binnenskamers niet gestopt, hoewel een kabinetsmeerderheid zich ertegen had uitgesproken - terwijl men bovendien twijfelde aan de effectiviteit en proportionaliteit van een dergelijke regeling, met alle gevolgen van dien voor de politieke verhoudingen tussen de Antillen en Nederland. Een verwijderingsregeling was het maximaal haalbare. $\mathrm{Na}$ enige aarzeling werd nu ook door BZK de uitwerking van een toelatingsregeling opgeschort. ${ }^{90}$

Als uitvloeisel van de nota Migratie Antilliaanse Jongeren kwamen Van Boxtel en De Vries op 8 juni 2000 met het kabinet-Pourier wel het 'Urgentieprogramma voor Jeugd en Jongeren' overeen, gericht op investeringen op de Antillen, vooral op Curaçao, in preventie, 
tweedekansonderwijs en resocialisatie, om zo de noodzaak tot emigratie weg te nemen. Aan Antilliaanse zijde bleven de bezwaren tegen een verplichte inburgeringscursus overeind. In Den Haag was men zich bewust van de juridische belemmeringen, en evenzeer van het risico dat met een harde opstelling het kabinet-Pourier, waarmee overigens goed kon worden samengewerkt, in problemen zou worden gebracht.

Binnen het kabinet-Kok werd verschillend gedacht over de vraag hoe hard Nederland zich moest opstellen, in het bijzonder of het verlenen van extra financiële steun in het kader van een door het IMF begeleid saneringstraject afhankelijk mocht worden gesteld van volledige Antilliaanse medewerking aan de Haagse wensen betreffende inburgering - laat staan van een daadwerkelijke vermindering van de immigratie of aanvaarding van een, mogelijk niet eens realistische, visumplicht. ${ }^{91}$ De relaties werden er niet beter op toen Van Boxtel in december 2000 op uitnodiging van Pourier naar Willemstad vloog om een akkoord te tekenen over een verplichte inburgeringscursus voor jonge Antillianen, maar daar aangekomen moest slikken dat Pourier door zijn bewindslieden, onder wie minister van Economische Zaken Suzy Römer en minister van Justitie Rutsel Martha, beiden van de PNP, maar ook door coalitiegenoot MAN, in de steek werd gelaten. Er werd niets getekend. Pourier was 'ziedend' op zijn coalitiegenoten, Van Boxtel keerde onverrichter zake en woedend (het Nederlandse kabinet 'is in zijn hemd gezet') terug. Een visumplicht werd weer op de Haagse agenda gezet. ${ }^{92}$

Een week later werd in Den Haag alsnog een protocol over de invoering van een verplichte inburgeringscursus voor Antilliaanse jongeren die naar Nederland wilden reizen getekend door Van Boxtel en gevolmachtigd minister Carel de Haseth. De Tweede Kamer reageerde 'voorzichtig positief'. Van Boxtel sprak van een eerste stap, 'die vertrouwen geeft en echt winst is' ${ }^{93}$ Verder zou het echter niet gaan. Begin april 2001 strandde dit project definitief. Omdat de Antilliaanse regering niet kon of wilde garanderen dat de jongeren (tot 25 jaar) de cursus ook daadwerkelijk volgden voorafgaand aan hun vertrek naar Nederland, ontbrak volgens Den Haag een controlemechanisme in het 'voortraject Inburgering'. Behalve dat de verplichte deelname niet was verzekerd, waren bovendien de sancties eenzijdig afgezwakt. Het eerdere reisverbod bij ontduiking van de inburgeringsplicht (onder meer zou het paspoort worden afgenomen) was nu door de Antilliaanse regering beperkt tot een boete. Alleen de PAR had de regel van 'controle bij vertrek' gesteund. Dit droeg ongetwijfeld bij aan de verkiezingsnederlaag van de partij begin 2002. Antillianen zouden uiteindelijk niet verplicht worden om in te burgeren. De Raad van 
State zou later vaststellen dat Nederlandse staatsburgers niet tot inburgering kunnen worden verplicht. In plaats van een plicht werd daarom op 1 januari 2007 de 'Regeling vrijwillige inburgering' in het leven geroepen - met magere resultaten. ${ }^{94}$

Het parlement gaf niet op - tot op heden overigens. In de Vaste Commissie NAAZ bepleitten VVD en CDA een toelatingsregeling nu het voortraject Inburgering was mislukt. ${ }^{95}$ Op 11 juni 2001 berichtte Van Boxtel de Tweede Kamer mede namens De Vries dat niet zou worden besloten tot een algehele toelatingsregeling voor Antillianen. Theoretisch was zo'n regeling weliswaar mogelijk, maar overweging van de politieke, juridische en uitvoeringsaspecten had geleid tot de conclusie dat 'Het instellen van een toelatingsregeling voor Antillianen geen reële optie [is]'. Evenmin werd een verwijderingsregeling uitvoerbaar of opportuun geacht. ${ }^{96}$ De Kamer bepleitte vergeefs een hardere opstelling. Het oppositionele CDA verweet de regering bij monde van Cees van der Knaap een tekort aan 'standvastigheid': 'Met vele miljoenen belastinggeld moet Nederland de brokken zien te ruimen die de Antilliaanse regering, samen met de Nederlandse, heeft veroorzaakt door een te slappe houding. ${ }^{97}$ Dit type verwijt zou de volgende jaren nog vaak klinken, vrijwel steeds vanuit parlementaire meerderheden.

Hoe verder? In december 2001 overhandigde een door het kabinetKok geïnstalleerde adviescommissie 'Antilliaans Medeburgerschap' onder voorzitterschap van de voormalige Antilliaanse minister van Onderwijs Jacques Veeris haar eindrapport Nèt Loke Falta ('Ontbrekende schakels') aan Van Boxtel en staatssecretaris van Justitie Ella Kalsbeek. De commissie schetste een beeld van grote sociale nood onder een deel van de Antillianen in Nederland, van marginalisering die leidde tot criminaliteit. Zij bepleitte vooral preventie, te weten op het terrein van inburgering en integratie, en een sterkere Antilliaanse betrokkenheid bij de oplossing van de problemen. Het kabinet onderschreef de noodzaak van een zo snel mogelijke opvang van Antilliaanse nieuwkomers na aankomst in Nederland, alsmede diverse andere aanbevelingen, en benadrukte dat 'een samenhangend beleid' wenselijk was, met aandacht voor preventieve en waar nodig repressieve elementen. ${ }^{98}$ Kort daarop viel het kabinet-Kok en traden het eerste en vervolgens het tweede kabinet-Balkenende aan, die beide een hardere lijn zouden trachten te voeren.

Het kortstondige eerste kabinet-Balkenende kwam niet toe aan beleid inzake de Antillen. In december 2002 stelde de inmiddels al demissionaire minister van BZK Remkes, in reactie op een pleidooi voor het instellen van een toelatingsregeling door LPF'er Frits Palm, nota bene voormalig KabNA-directeur, dat hij het niet met hem eens 
kon zijn, 'niet omdat ik er principieel tegen ben, maar omdat een dergelijke regeling niet effectief is'. ${ }^{99}$

In het tweede kabinet-Balkenende lag de primaire verantwoordelijkheid voor de integratie van Antilliaanse jongeren bij minister voor Vreemdelingenzaken en Integratie (V\&I) Rita Verdonk (VVD). ${ }^{100}$ Maar doordat de portefeuille van de minister voor Bestuurlijke Vernieuwing en Koninkrijksrelaties ook het grotestedenbeleid omvatte, bleven de opeenvolgende bewindslieden op dit departement tevens bij de problematiek betrokken. Dat het beleid voor de Antilliaanse jongeren in feite bij twee ministers was ondergebracht, werd in de Kamer als 'onbevredigend' aangeduid. ${ }^{101}$ Minister De Graaf zou de Kamer desgevraagd meermalen aangeven dat een toelatings- of verwijderingsregeling juridisch niet onmogelijk was, maar wel te veel uitvoeringsproblemen met zich zou brengen. Na het vertrek van D66 uit de regering zou het 'rompkabinet' van CDA en VVD toch weer een toelatingsregeling voorbereiden, vergeefs - onder Balkenende IV zou dit wetsvoorstel worden ingetrokken, mede na twee negatieve adviezen van de Raad van State.

Het steeds maar weer aandringen op een toelatingsbeperking heeft een lange geschiedenis die zelfs teruggaat tot de jaren vijftig van de vorige eeuw. Voorheen was steevast geconcludeerd dat zulke regelingen weliswaar juridisch aanvechtbaar maar niet geheel ondenkbaar waren, politiek echter ongewenst. ${ }^{102}$ Het is tekenend voor het veranderde maatschappelijke en politieke klimaat dat vanaf 2000 het argument van politieke ongewenstheid steeds minder gewicht had. Grote delen van het parlement, alsook een deel van de Antillengemeenten onder leiding van de Rotterdamse burgemeester Ivo Opstelten, waren de 'politieke correctheid' voorbij. ${ }^{103}$ Beslissend bleven echter argumenten in de sfeer van juridische toelaatbaarheid, uitvoerbaarheid en proportionaliteit, die althans tot $10 / 10 / 10$ restricties op het vrije personenverkeer binnen het Koninkrijk in de weg stonden. Daarnaast werd het een zorg voor de Haagse bewindslieden voor Koninkrijkszaken om het migratiedebat buiten het proces van de staatkundige hervormingen te houden.

Regeringspartij CDA nam in oktober 2003, met de motie Sterk, tegen de wens van het kabinet, het initiatief tot een harder toelatingsbeleid. De motie werd door De Graaf afgeraden en zou worden verworpen - een meerderheid, waaronder regeringspartijen VVD en D66, wenste eerst de aangekondigde beleidsnotitie van minister Verdonk af te wachten. ${ }^{104}$ Die Notitie Antilliaanse jongeren zou de Kamer in definitieve versie pas een jaar later, in oktober 2004, bereiken en bevatte geen maatregelen ter restrictie van de migratie. ${ }^{105}$

De notitie bepleitte een structurele en duurzame manier van ken- 
nisbundeling en -uitwisseling tussen steden onderling en tussen Rijk en steden over Antilliaanse probleemjongeren - via een Verwijsindex Risicojongeren (VIR) - en een beleid dat preventie en repressie combineerde. Ook werd een nieuw inburgeringssysteem voorgesteld dat onderscheid zou maken tussen Nederlanders geboren binnen en buiten de Europese Unie. Laatstgenoemden moesten niet alleen inburgeren, maar ook een verplicht examen afleggen. Als zij dit niet haalden, zou een boete van de gemeente volgen.

Dit laatste punt, dat al bekend was uit conceptversies, lokte heftig Antilliaans protest uit. De Staten vonden dit onderscheid onacceptabel, vreesden hierdoor binnen het Koninkrijk tot tweederangsburgers te worden gedegradeerd, en besloten in een unanieme motie de Tweede Kamer te benaderen met het dringende verzoek zich tegen de notitie uit te spreken. ${ }^{106}$ Eerder al had premier Ys een brief aan Verdonk gestuurd waarin hij zijn boosheid uitte over de 'discriminerende' Nederlandse plannen voor een nieuw inburgeringsstelsel. ${ }^{107}$

Ys sprak op 3 september 2004 met Verdonk. Over een toelatingsof verwijderbeleid voor criminele Antilliaanse jongeren had zij zich inmiddels positief uitgelaten, een dag eerder, tijdens een debat over integratieproblematiek in de Tweede Kamer. Verdonk had de Kamerfracties daarbij beloofd een toelatings- of verwijderregeling voor Antillianen te zullen ontwerpen, waarmee zij een door CDA-fractievoorzitter Maxime Verhagen ingediende coalitiebrede motie (medeondertekend door VVD en D66) overbodig had gemaakt. ${ }^{108}$

Mede onder druk van De Graaf zou Verdonk medio september beide regelingen echter (voorlopig) aan de kant zetten. Zij kondigde geen maatregelen aan voor een scherper toelatings- of verwijderbeleid voor Antilliaanse criminele jongeren. Wel zou zij nogmaals de juridische haalbaarheid van beide regelingen laten onderzoeken, door een gemengde commissie. ${ }^{109}$ De bewindslieden ontkenden dat er sprake was van onderlinge onenigheid. De Graaf zou zich blijven verzetten tegen een inperking van de toelating - waarmee hij ook ruimte behield voor een open debat met zijn Antilliaanse gesprekspartners over de staatkundige herstructurering en schuldsanering, een zorg die Verdonk niet had. Juist op dat moment werd ook het eindrapport van de werkgroep-Jesurun verwacht. Gesteund door het kabinet, verzette De Graaf zich tegen de door VvD'er Jozias van Aartsen bepleite koppeling van de besprekingen over staatkundige herstructurering en schuldsanering aan de migratieproblematiek. ${ }^{110}$

De door Verdonk ingestelde gemengde commissie kreeg expliciet opdracht om migratieregulerende maatregelen te bestuderen, tegen de zin van De Graaf. ${ }^{111}$ Voorspelbaar was dat de Antilliaanse regering direct afstand nam, opmerkelijk echter dat minister-president Bal- 
kenende zich vervolgens in november 2004 toch uitsprak voor een restrictief migratiebeleid: 'Soms heb je een toelatingsregeling nodig, ook ter bescherming van degenen die het betreft." ${ }^{112}$ Weer was de Antilliaanse, en overigens ook Arubaanse, reactie scherp afwijzend. Dat zou zo blijven. Gedurende de resterende termijn van het tweede en vervolgens derde kabinet-Balkenende, dus tot februari 2007, zou Verdonk namens de Nederlandse regering blijven aansturen op een toelatings- en verwijderregeling, hierin gesteund door een brede centrumrechtse meerderheid. Het zou uiteindelijk niets opleveren.

Politiek lag deze wetgeving buitengewoon moeilijk omdat de felle Antilliaanse tegenstand het debat over de staatkundige vernieuwing dreigde te doorkruisen, hoezeer achtereenvolgens De Graaf, Pechtold en Nicolaï dat ook trachtten te voorkomen. ${ }^{113}$ De parlementaire meerderheid wenste juist die koppeling, met het argument dat Nederland, nu werd gesproken over verregaande concessies (opheffing Antillen, schuldsanering), op goede gronden ook inwilliging van een eigen verlangen kon en mocht opeisen. Dit was de teneur van de door de linkse oppositie afgewezen, maar centrumrechts en ook door de Antillengemeenten breed gesteunde moties van CDA-parlementariër Mirjam Sterk en verschillende interventies van de VVD. ${ }^{114}$

Het zag ernaar uit dat het kabinet na een jarenlange discussie nu tot eenzijdige maatregelen zou besluiten. Voor Verdonk was de tijd van 'pappen en nathouden' voorbij. Zij hekelde jonge Antillianen die zonder kans op werk of opleiding naar Nederland kwamen-'Die denken dat op Schiphol de scooter voor hun klaar staat' - en wees erop dat de Antillengemeenten maatregelen wilden. Pechtold ondersteunde dit expliciet. ${ }^{115}$ De ministerraad verleende op 13 mei 2005 goedkeuring aan een voorstel voor een toelatingsregeling voor Antilliaanse en Arubaanse jongeren - zij moesten uitzicht op werk of een opleiding hebben voordat zij naar Nederland mochten afreizen - buiten de Rijksministerraad om, opnieuw een steen des aanstoots. ${ }^{116}$

Het optreden van Pechtold op dit dossier werd door de Antilliaanse premier Ys, maar ook door de linkse oppositie, als op zijn best onhandig gekwalificeerd. Partijgenoten Van Boxtel en De Graaf hadden zich immers altijd tegenstander betoond van een toelatingsbeperking, wegens strijdigheid met het recht op gelijke behandeling. Bovendien hadden zij de Antilliaanse regering niet voor het hoofd willen stoten. Nu voelden de Antillen zich voorspelbaar gebruuskeerd - temeer omdat Pechtold tijdens zijn overzeese bezoek in mei 2005, op de hoogte van genoemd kabinetsbesluit rond een toelatingsregeling voor Antilliaanse jongeren, verzuimd had hierover iets te zeggen, zodat zijn Antilliaanse gesprekspartners dit nieuws via de pers moesten vernemen. ${ }^{117}$ 
In het parlement kreeg de jongerenregeling brede steun van CDA, VVD, D66, LPF en SGP. Opmerkelijk genoeg werd tijdens het overleg geen koppeling gelegd met het staatkundig proces. ${ }^{118}$ Een direct hierop volgend 'bliksemoffensief' van Ys leverde weinig op. Verdonk hield vol dat ze de regeling ook zonder de Antillen kon doorzetten, Pechtold gaf geen krimp. Dit zette de verhoudingen in het Koninkrijk op scherp en versterkte op de Antillen anti-Nederlandse gevoelens. ${ }^{119}$ Overleg in de Rijksministerraad later die maand - dit had Ys' bezoek wel teweeggebracht-leverde geen nieuwe gezichtspunten op, behalve dat het Nederlandse kabinet in navolging van de Tweede Kamer bereid zou zijn de noodzaak voor een toelatingsregeling te heroverwegen als de sociale vormingsplicht op de Antillen, die kort daarop van kracht zou worden, aantoonbaar werkte. Pechtold zou deze uitweg later dat jaar gaan benadrukken, ook met het oog op de komende RTC, en daarmee impliciet afstand nemen van zijn collega Verdonk. ${ }^{120}$

De harde inzet van centrumrechts zou op dit dossier vergeefs blijken, misschien ook wel omdat de onderhandelende Pechtold zich overzee nu van een zachtere kant wilde laten zien. Uiteindelijk werd noch in het Hoofdlijnenakkoord van oktober 2005, noch in de beslissende Slotverklaring van november 2006 een koppeling gelegd met het migratiedossier - in weerwil van een door de Tweede Kamer, tegen het advies van Pechtold in, aangenomen motie Luchtenveld (VVD) die juist aandrong op zo'n verbinding. Pechtold zou uiteindelijk deze motie 'niet uitvoerbaar achten'. De blijvende ontkoppeling was een overwinning voor het Caraïbische standpunt en goed voor de voortgang van het staatkundig proces, maar volgens een belangrijk deel van het Nederlandse parlement een onnodig gemiste kans. Ruud Luchtenveld waarschuwde de minister: 'Maar wij nemen dit straks wel mee bij de beoordeling van het onderhandelingsresultaat over de staatkundige toekomst van de Antillen. ${ }^{121}$

Minister Verdonk vond haar Waterloo op dit dossier uiteindelijk niet in het Nederlandse parlement, maar in Haagse juridische colleges. Op 19 april 2006 - kort voordat het tweede kabinet-Balkenende ten val zou komen - had de Nederlandse Raad voor de rechtspraak Verdonks wetsvoorstel al bekritiseerd. ${ }^{122}$ Vervolgens zou de Raad van State tot tweemaal toe haar conceptwetgeving rond 'inburgering' en Antilliaanse 'risicojongeren' als onvoldoende kwalificeren - waarmee hiervan ten slotte zou worden afgezien. ${ }^{123}$ In 2006-2007 adviseerde de Raad tevens negatief over door het tweede en derde kabinetBalkenende voorgelegde wetsvoorstellen inzake de terugzending van Antilliaanse en Arubaanse risicojongeren. De Raad maakte het principiële bezwaar dat afbreuk werd gedaan aan het ongedeelde Nederlandse burgerschap, terwijl bovendien onderscheid zou wor- 
den gemaakt 'tussen Antillianen enerzijds en niet-Nederlandse EUburgers en vreemdelingen uit niet-EU-staten in vergelijkbare posities anderzijds'. Het wetsvoorstel werd derhalve niet gerechtvaardigd en bovendien (dit werd uitvoerig toegelicht) ondoelmatig geacht. ${ }^{124}$

Met deze opstelling had de Raad van State een in het Nederlandse parlement betrekkelijk breed gesteunde, maar in de Antillen en Aruba verafschuwde potentiële beperking van de werking van het ongedeelde burgerschap van het Koninkrijk gedwarsboomd. Dit betekende overigens niet dat dit onderwerp hiermee van tafel verdween.

De ongebruikelijk scherpe kritiek van de Raad van State weerhield het demissionaire derde kabinet-Balkenende er niet van om het aangepaste concept van de terugzendregeling naar de Kamer te sturen. ${ }^{125}$

84 Koningin Beatrix kreeg tijdens haar skivakantie het controversiële wetsvoorstel voorgelegd - ingediend dus door een demissionaire minister van een partij die, zo was inmiddels bekend, niet in het kabinet zou terugkeren.

Op 22 februari 2007 trad het vierde kabinet-Balkenende aan, een coalitie van CDA, PVDA en ChristenUnie. Gesteund door een parlementaire meerderheid, inclusief het CDA, maar zeer tegen de wil van VVD, PVV en SGP, trok dit kabinet vrijwel direct het wetsvoorstel 'Aanvullende maatregelen inzake onder meer de terugzending van Antilliaanse en Arubaanse risicojongeren' weer in. ${ }^{126}$ Op de Antillen werd verheugd gereageerd op deze beslissing. Premier De Jongh-Elhage zei zelfs altijd wel te hebben gedacht dat het wetsvoorstel het uiteindelijk niet zou halen. De Antilliaanse oppositie bleef Nederland wantrouwen. Voormalig gevolmachtigde minister Maurice Adriaens (FOL): 'Daarom moeten we in de staatkundige discussie goed nadenken voordat we ons onder toezicht van Nederland stellen. ${ }^{127}$

Vanzelfsprekend zou de rechtse oppositie (VVD, PVV) in de parlementaire debatten over de staatkundige herstructurering blijven trachten de gewenste koppeling tussen de beide dossiers te verwezenlijken. VVD-leider Mark Rutte stelde in augustus 2007, op bezoek in Curaçao, opnieuw dat zijn partij alleen met de Nederlandse sanering van de Antilliaanse staatsschuld zou instemmen als de destijds door Verdonk voorgestelde terugkeer- en uitzettingsregeling voor Antilliaanse jongeren alsnog werd aangenomen. De Tweede Kamerfractie van de VVD zou inderdaad tot op het laatst buitengewoon kritisch, en vaak afwijzend, blijven over het kabinetsbeleid inzake de Koninkrijksrelaties. ${ }^{128}$

Achteraf kan worden vastgesteld dat het vierde kabinet-Balkenende, en in het bijzonder staatssecretaris Bijleveld, met succes heeft weten te voorkomen dat het migratiedossier interfereerde met de voortgang van het staatkundig proces. Bijleveld slaagde erin het mi- 
gratiedossier zo veel mogelijk buiten de debatten over de herstructurering van het Koninkrijk te houden. In zekere zin ontzegde zij zichzelf daarmee richting de Antillen een onderhandelingstroef - tot ergernis van VVD, PVV en ook SP. Dat na 10/10/10, en in het bijzonder met het aantreden van het kabinet-Rutte, het migratiedossier gesloten zou blijven, was echter van meet af aan onwaarschijnlijk. Dit geldt temeer, omdat de mogelijkheid van een toelatings- en/of uitzettingsregeling niet definitief is verworpen, maar ook omdat nog steeds enkele gerelateerde maatregelen ter discussie staan: een Rijkswet personenverkeer, een Verwijsindex Antillianen (VIA) en het naturalisatiebeleid op de eilanden.

De Rijkswet personenverkeer kent inmiddels al een vrij turbulente geschiedenis. ${ }^{129} \mathrm{Om}$ de problemen rond de integratie van Antillianen in Nederland aan te pakken, presenteerden begin 2008 de ministers Hirsch Ballin van Justitie en Ella Vogelaar voor Wonen, Wijken en Integratie (WWI) een nieuwe 'Antillianenaanpak'. Onderdeel van het beleid was een Rijkswet personenverkeer (RPV), van toepassing op zowel Nederlanders als vreemdelingen - zoals ook aangekondigd in het Coalitieakkoord van het vierde kabinet-Balkenende. Wat betreft Caraïbische en Europese Nederlanders was het vrije verkeer en verblijf van personen binnen het Koninkrijk het uitgangspunt van de Rijkswet. De enige mogelijke uitzondering hierop was de zogeheten ongewenstverklaring: personen konden ongewenst verklaard worden als ze een bedreiging vormden voor de openbare orde, openbare veiligheid of volksgezondheid (conform EU-regels). Deze 'ongewenstverklaring' bleek aan Antilliaanse zijde erg gevoelig te liggen, ook al benadrukte Hirsch Ballin steeds weer dat zij 'non-discriminatoir' zou zijn en zou gelden op basis van wederkerigheid. ${ }^{130}$

Opnieuw zou de politieke gevoeligheid het zwaarst wegen. Al zou het bij een ongewenstverklaring slechts om kleine aantallen gaan, op de Antillen en Aruba bleef dit wetsvoorstel zeer moeilijk liggen. De RPV zou uiteindelijk niet meer door het kabinet-Balkenende IV worden afgehandeld. Om het proces van staatkundige herstructurering niet onnodig te vertragen, werd ervoor gekozen om de beslissing over deze wet over te laten aan een nieuwe regering. ${ }^{131}$ Zeer tegen de wens van VVD, PVV en SP nam het parlement wel de Wet Toelating en Uitzetting BES aan, een overgangsregeling voor de periode dat er nog geen Rijkswet personenverkeer zou zijn. Deze wet diende vooral de ongelimiteerde vestiging van Europese Nederlanders en inwoners van Aruba, Curaçao en Sint Maarten op de BES-eilanden te voorkomen. Ook de voorstemmers en Hirsch Ballin gaven aan dat zij liever een RPV hadden gezien; voor hen stond nu echter de voortgang van het staatkundig proces voorop. ${ }^{132}$ 
Nog meer emoties zouden de plannen voor een Verwijsindex Antillianen (VIA) oproepen. Op verzoek van de Antillengemeenten had Verdonk in het derde kabinet-Balkenende al plannen ontwikkeld voor het opzetten van een databank over Antilliaanse risicojongeren - noodzakelijk geacht omdat de onderlinge afstemming van de Antilliaanse en Nederlandse bevolkingsboekhoudingen weinig opleverde. Dit beleid werd voortgezet onder het volgende kabinet en kon rekenen op brede parlementaire steun en instemming van zowel het College Bescherming Persoonsgegevens (СВP) als de Raad van State. Toch zou na verhitte discussies ook deze VIA uiteindelijk worden afgeblazen. De afwijzing door de Antillen en door Antilliaanse organisaties in Nederland, aangevoerd door het Overlegorgaan Caraïbische Nederlanders (OCaN), was zeer heftig ('rassendatabank'). Maar ook de onder de Europese Raad ressorterende Europese Commissie tegen Racisme en Intolerantie (ECRI) oordeelde negatief over een mogelijke verwijsindex. ${ }^{133}$

Aan de vooravond van de RTC van 15 december 2008 werd op BZK vastgesteld dat de 'uiterst emotionele' discussie over de VIA aan Antilliaanse zijde een bedreiging vormde voor de voortgang van het staatkundig proces, zozeer dat Bijleveld werd geadviseerd het kabinet, en in het bijzonder de inmiddels als minister voor WWI aangetreden Vogelaar (PVDA) en minister voor Jeugd en Gezin André Rouvoet (CU), te overtuigen de Verwijsindex ('een bom onder de RTC') van tafel te halen. Vogelaar ging inderdaad om. Op 10 november, op de eerste dag van een werkbezoek aan de Antillen, verklaarde zij - tot grote Antilliaanse opluchting, maar ook wel verrassing - af te zien van de VIA. In

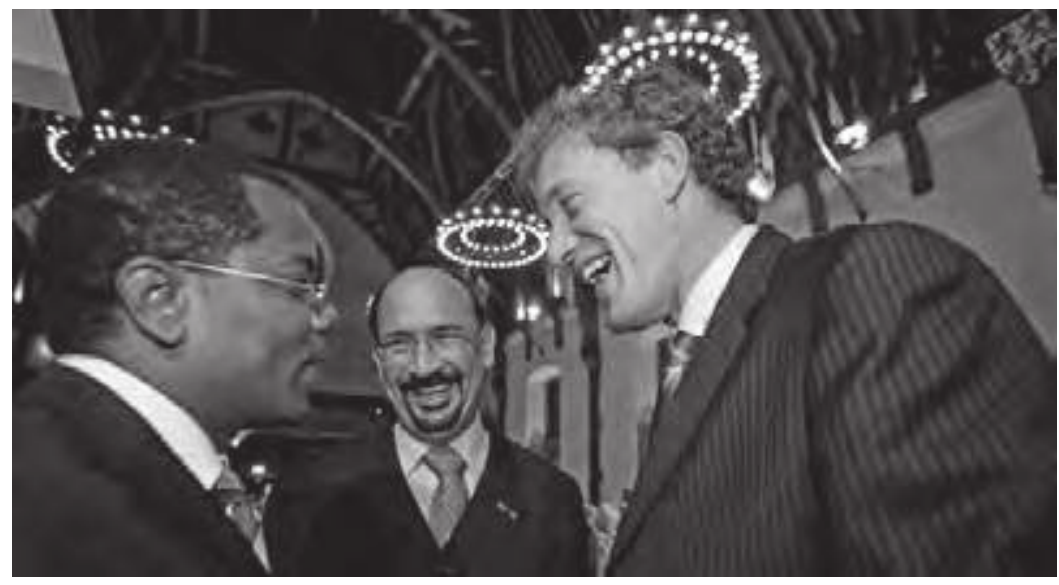

Viering vijftig jaar Statuut in de Ridderzaal, Den Haag, 15 december 2004; v.l.n.r. Etienne Ys, Nel Oduber, Thom de Graaf. 
het Nederlandse parlement werd haar dit optreden niet in dank afgenomen, maar Vogelaar wist zich tevoren wel gesteund door Bijleveld en Rouvoet. De PVDA bleek overigens al kort voor dit werkbezoek te hebben besloten haar te vragen af te treden, wat zij bij terugkomst ook zou doen. ${ }^{134}$

Hierna tendeerde het kabinet, inclusief de PVDA, toch naar doorzetten van de VIA. De brief waarin Vogelaar de Tweede Kamer had geschreven af te zien van deze Verwijsindex werd ingetrokken. Weer volgde een ronde interne Haagse besprekingen, waarbij het parlement vroeg om duidelijke maatregelen; het kabinet meende echter weinig bewegingsruimte te hebben, gezien de heftige Antilliaanse bezwaren tegen het intrekken van de brief van Vogelaar. ${ }^{135}$ Uiteindelijk werd afgezien van de VIA en besloten de algemene Verwijsindex voor Risicojongeren waaraan Rouvoet op dat moment werkte, uit te breiden naar alle Antillengemeenten. Antilliaanse jongeren zouden worden ondergebracht in de VIR - in plaats van de onder de VIA beoogde etnische registratie zouden er nu specifieke maatregelen voor Antilliaanse probleemjongeren komen. ${ }^{136}$ Wat bij dit alles zeer opvalt, is dat de Antilliaanse regering dreigde de voortgang van het staatkundige proces te blokkeren ingeval van aanvaarding van de VIA en dat het Nederlandse kabinet hiervoor zeer gevoelig was en opnieuw inbond - alsof de voortgang van het proces primair een Nederlands belang was. Het is niet verwonderlijk dat critici dit als de omgekeerde wereld ervoeren.

Een laatste omstreden onderdeel van het migratiedossier betrof de naturalisatie van immigranten in de Antillen. Bij de totstandkoming van het Statuut in 1954 was de principiële keuze gemaakt voor één ongedeeld staatsburgerschap van het Koninkrijk, het Nederlanderschap. Bijgevolg kunnen inwoners van de Antillen en Aruba zonder belemmeringen door het Koninkrijk reizen. Het vreemdelingenbeleid wordt echter niet op Rijksniveau geregeld: de toelating en uitzetting zijn en blijven, met het oog op de verschillen tussen de landen, autonome aangelegenheden. Voor het recht van toegang gelden de landen van het Koninkrijk als afzonderlijke gebieden, zodat de Antillen zelf mogen bepalen hoe hun toelatingsbeleid werkt - overigens ook voor Europese Nederlanders, zoals blijkt uit de huidige, uit 1962 stammende Landsverordening Toelating en Uitzetting (LTU).

Met ingang van 10/10/10 zijn in plaats van het land de Nederlandse Antillen nu Curaçao en Sint Maarten, in casu de ministers van Justitie van deze landen, verantwoordelijk voor het vreemdelingenbeleid en de handhaving daarvan. Hiertoe wordt nauw met Nederland samengewerkt. Met een goed functionerende vreemdelingenketen binnen het hele Koninkrijk is immers ook de reputatie van 
het Koninkrijk gemoeid. Dit is dan ook een van de prioriteiten van het Haagse ministerie van Veiligheid en Justitie wat betreft Bonaire, Saba en Sint Eustatius, waar Nederland sinds de transitie voor deze zaken verantwoordelijk is. ${ }^{137}$

Naturalisatie en het verlenen van Nederlandse paspoorten is een Koninkrijksaangelegenheid. Sinds oktober 2007 moeten buitenlanders die op de eilanden de Nederlandse nationaliteit willen verkrijgen, slagen voor een naturalisatietoets. Zij konden in eerste instantie kiezen of ze het examen in het Nederlands, Papiaments of Engels deden, maar het vierde kabinet-Balkenende wilde op termijn het Nederlands als verplichte taaleis invoeren. ${ }^{138}$

In Den Haag is er in de discussie over de staatkundige herinrichting van het Koninkrijk over het algemeen maar weinig aandacht geweest voor de problematiek van illegale vreemdelingen uit de omringende landen in de Nederlandse Antillen. Het parlement maakte zich echter wel zorgen over de kwaliteit van het vreemdelingentoezicht op de eilanden, ook op Aruba. ${ }^{139}$ Mede hierom startte het land de Nederlandse Antillen in november 2009 met de registratie en afhandeling van ongedocumenteerden, conform het zogenoemde Brooks Tower Protocol van 2 maart 2007, bedoeld om het aantal illegale vreemdelingen in kaart te brengen en terug te dringen. Illegalen kregen de ruimte om via een tijdelijke vergunning in het reguliere traject voor toelating te stappen. Volgens de Antilliaanse minister van Justitie Magali Jacoba maakten aldus circa 90.00o migranten kans op de toekenning van een tijdelijke verblijfsstatus, een aantal dat overigens later sterk naar beneden werd gecorrigeerd. ${ }^{140}$

Dit akkoord gaf aanleiding tot bezorgde Kamervragen - gevreesd werd voor een grote golf vreemdelingen richting Nederland. Bijleveld antwoordde dat onbekend was hoeveel illegale vreemdelingen in aanmerking zouden kunnen komen voor een tijdelijke vergunning, maar dat de kans op doorreis naar Nederland 'gering' was. ${ }^{141}$ Voor zowel de CDA- als de VVD-fractie moest het risico van effecten voor Nederland als gevolg van Brooks Tower tot nul worden gereduceerd. Brinkman sprak verontwaardigd van een 'generaal pardon' voor de 90.00o illegalen op de Antillen en formuleerde nogmaals de door de PVV voorgestane oplossing: 'het weren van Antillianen in Nederland'. Hij diende een motie in die ertoe moest leiden 'de Antillen te dwingen, deze pardonregeling op termijn niet in te voeren en anders desnoods deze geregistreerde illegalen nimmer een paspoort te verstrekken of anderszins op termijn te overwegen, de grenzen te sluiten voor Antillianen'. De fracties van de VVD, PVV en het lid Verdonk stemden op 8 december voor deze motie, de overige ertegen, zodat zij werd verworpen. ${ }^{142}$ 
Bijleveld trachtte de Kamerleden gerust te stellen dat op grond van de Brooks Tower-regeling illegale vreemdelingen alleen een tijdelijke vergunning konden krijgen voor het eiland waarvan zij konden aantonen er de afgelopen jaren te hebben verbleven, en stelde heel nadrukkelijk: 'Op grond van deze vergunning is toegang tot Nederland formeel niet mogelijk.' Wel deelde zij Remkes' zorgen over handhaving van de regeling. De Kamer nam vervolgens unaniem een motie aan ten behoeve van 'intensivering van de bestrijding van illegaal verblijf en de uitzetting van illegalen' in de Antillen. ${ }^{143}$

Formeel althans blijven de grenzen scherp getrokken. Het verblijfsrecht op Curaçao en Sint Maarten strekt zich niet uit tot de openbare lichamen Bonaire, Saba en Sint Eustatius; het verblijfsrecht in de BES-eilanden strekt zich evenmin uit tot deze landen of tot het Europese deel van Nederland, of omgekeerd. Het is duidelijk dat het parlement, en niet alleen PVV of VVD, het migratiedossier van groot belang achtte - de wens de migratie uit de Antillen te minimaliseren wordt kamerbreed gedeeld, slechts de toonvoering en beoogde methoden verschillen. ${ }^{144}$

\section{Permanente dossiers: de internationale dimensie}

Voormalig minister van Buitenlandse Zaken Jozias van Aartsen merkte ooit op het wel mooi te vinden minister te zijn van een Koninkrijk dat toch ook een beetje Latijns-Amerikaans is. Dat zal voor sommigen van zijn opvolgers ook gelden, maar neemt niet weg dat het feit dat het Koninkrijk zich uitstrekt tot de Caraïben toch ook, en misschien wel vooral, lastige uitdagingen oproept, ook voor BZ. Die uitdagingen lagen de afgelopen decennia vooral in de sfeer van de internationale misdaad (drugshandel, money laundering, mensenhandel) en meer recent ook het milieubeleid. ${ }^{145}$ Het afgelopen decennium werd ook een oudere, maar sinds de jaren zeventig slechts latent aanwezige risicofactor weer manifest, te weten de relatie tot Venezuela. Het Venezuela, welteverstaan, van de links-radicale president Hugo Chávez, die zich meermalen kritisch uitliet over de Nederlandse 'koloniale' aanwezigheid op de eilanden vlak voor zijn kust, maar vooral over de steun van het Koninkrijk aan de al dan niet vermeende Amerikaanse agressie tegen zijn land.

Dat het Venezuela van Chávez en de Verenigde Staten veelvuldig als kemphanen tegenover elkaar hebben gestaan is duidelijk. Het Koninkrijk raakte hierbij nauwer betrokken als gevolg van een eerdere beslissing, in 1998 voorgenomen en twee jaar later verdragsmatig vastgelegd, om op Aruba en Curaçao Amerikaanse Forward Ope- 
rating Locations (FOLs) te accepteren, waarvandaan Amerikaanse vliegtuigen verkenningsvluchten over Colombia zouden uitoefenen in het kader van de internationale drugsbestrijding. Het kader heette 'Plan Colombia', Bogotá stemde ermee in en Caracas speelde er geen rol in. Maar du moment dat Chávez in 1999 aan de macht kwam, was het onvermijdelijk dat de FOLs een sterkere politieke lading kregen. Een scenario dat overigens door een minderheid in het Nederlandse parlement destijds ook wel als risico was aangemerkt, maar dat noch in Nederland, noch in de Antillen of Aruba als doorslaggevend tegenargument was beschouwd. En dus hebben Aruba en vooral Curaçao, tot grote ergernis van Chávez' Venezuela, nu actieve FOLs. ${ }^{146}$

Het afgelopen decennium was voortdurend sprake van spanningen tussen de Verenigde Staten en Venezuela, waarbij incidenteel ook het Koninkrijk werd betrokken, juist rond die FOLs. Onder meer uit via WikiLeaks uitgelekte documenten blijkt wel hoezeer Den Haag door Washington wordt gewaardeerd als bondgenoot in de regio en hoezeer Nederland, overigens net als Aruba en de Nederlandse Antillen, deze rol ook wil spelen. ${ }^{147}$ Dat neemt niet weg dat het vanuit het trans-Atlantische Koninkrijk bezien een hoge prioriteit heeft om spanningen met Venezuela zo veel mogelijk te vermijden. Dit is meermalen expliciet bevestigd; de BZ-notitie 'Het buitenlands beleid van het Koninkrijk in de Cariben' (2009) benoemt weliswaar de politieke verschillen, maar vervolgt dat dit 'het handhaven en waar mogelijk uitbouwen van de vanouds goede betrekkingen van het Koninkrijk met [Venezuela] niet in de weg [staat]. ${ }^{148}$

Terugkijkend kunnen wij concluderen dat dit meestal ook wel lukte, een enkele 'hete' episode van wederzijdse aantijgingen daargelaten, zoals toen minister van Defensie Henk Kamp - die zich enkele jaren later als Rijksvertegenwoordiger op Bonaire zou vestigen - in 2006 Chávez een 'onverdraagzame populist' noemde en waarschuwde voor diens veronderstelde agressieve neigingen. ${ }^{149}$ Een klein jaar eerder had Chávez drie linkse Curaçaose oppositieleiders - Anthony Godett (FOL), Charles Cooper (MAN), Errol Cova (PLPK) - in een militair vliegtuig naar Venezuela laten overkomen. In een toespraak had Cova daar de 'Bolivariaanse revolutie' geprezen als antidotum voor het 'diepe en intelligente Nederlandse kolonialisme'. ${ }^{150}$ Het bleef echter bij geïsoleerde incidenten. Belangrijker voor het centrale thema van dit boek is de vaststelling dat overwegingen van diplomatieke of geopolitieke aard vrijwel nooit expliciet, en slechts zelden impliciet, in de onderhandelingen over de staatkundige vernieuwing aan bod kwamen.

In zekere zin is dat opmerkelijk. De opheffing van de Nederlandse Antillen impliceerde immers dat een van de drie eilanden voor de Ve- 
nezolaanse kust niet langer (deel van) een autonoom land binnen het Koninkrijk is, maar deel van Nederland werd - en dat Nederland dus op enkele tientallen kilometers van de Venezolaanse kust kwam te liggen. Dat dit in de onderhandelingen geen grote rol heeft gespeeld, weerspiegelt slechts, zo lijkt de conclusie te moeten luiden, dat geen van de betrokken landen, Venezuela inbegrepen, verwachtte dat dit de geopolitieke situatie merkbaar zou veranderen. Deze inschatting lijkt alleszins gerechtvaardigd. Het verbaast dan ook niet dat, zoals ingewijden verzekeren, er in dit proces 'weinig licht' was tussen $\mathrm{BZ}$ en de Antillen en Aruba; de belangen liepen parallel.

Uiteindelijk voornamelijk in de marge van de debatten over de staatkundige relaties binnen het Koninkrijk stond ook de vraag op de agenda hoe de Caraïbische (ei)landen zich in de toekomst konden verhouden tot de EU. Aanvankelijk domineerde in Den Haag, zowel bij het kabinet als in de Raad van State, de opvatting dat deze kwestie niet kon worden losgekoppeld van de vraag hoe de nieuwe relaties binnen het Koninkrijk eruit zouden zien. Al snel bleek dit thema echter politiek zeer omstreden en bestuurlijk buitengewoon gecompliceerd. Dit leidde ertoe dat besluitvorming werd uitgesteld. Bijgevolg ligt ook na 10/10/10 het 'dossier EU' nog geheel open.

De Antillen en Aruba zijn, zoals gezegd, LGO van de EU, sinds respectievelijk 1964 en 1986. Deze bijzondere associatieregeling voorziet in preferentiële markttoegang en financiële steun. De 'Landen en Gebieden Overzee' onderhouden een speciale band met een lidstaat-naast Nederlandse zijn er Deense, Engelse en Franse LGO - maar vormen zelf geen onderdeel van het Uniegebied. Europees recht geldt er dus niet, behalve regelgeving expliciet voor de LGO en de burgerschapsrechten. Ingezetenen van de Antillen en Aruba zijn op grond van hun Nederlandse nationaliteit ook burgers van de EU.

De op 10/10/10 geëffectueerde staatkundige veranderingen in het Koninkrijk zouden uiteindelijk geen wijziging brengen in de relatie van de Antillen met de EU: de vijf eilandgebieden verwierven automatisch elk afzonderlijk de LGO-status. De integratie van de BESeilanden in het Nederlandse staatsbestel betekende dus niet dat zij vanzelf ook onderdeel werden van de Unie. De afspraak is om vijf jaar na $10 / 10 / 10$ te bezien of het wenselijk is de bestaande relatie te verruilen voor een ander verband met de EU. Hoewel daarvoor althans in theorie verschillende opties bestaan, is over de status van een Ultraperifeer Gebied in de achterliggende jaren het meest gesproken.

UPG - oorspronkelijk bedoeld voor de Franse départements d'outremer (DOMs), later kwamen daar ook Spaanse en Portugese UPG bij, respectievelijk de Canarische eilanden en de Azoren - zijn in beginsel volledig geïntegreerd in EU-verband. Tijdelijke bijzondere maat- 
regelen om aan de speciale behoeften van deze gebieden tegemoet te komen (onder meer grote afstand tot de EU, insulair karakter, kleine oppervlakte, moeilijk reliëf en klimaat, economische afhankelijkheid van enkele producten) mogen geen afbreuk doen aan de communautaire rechtsorde en de werking van de interne markt. UPG zijn verplicht het-vele tienduizenden pagina's omvattende-pakket van EU-regelgeving, het acquis communautaire, te implementeren. Vrijwel het gehele EU-recht is er dus van toepassing. Ze kennen een volledig vrij verkeer van goederen, diensten, kapitaal en personen met de EU, alsook vrije vestiging. De UPG komen in aanmerking voor de reguliere EU-fondsen en programma's, waarvan de structuurfondsen de belangrijkste zijn.

De keuze waarvoor de Antillen dus nog steeds staan, is of zij wel of niet samen met Nederland willen deelnemen aan de voortschrijdende Europese integratie. Deze vraag was al in de aanloop naar het vijftigjarig Statuut in 2004 regelmatig onderwerp van discussie. Het eerste en tweede kabinet-Balkenende stuurden, aanvankelijk zonder overleg met en dus tot irritatie van de Caraïbische partners, aan op transitie naar een UPG-status. ${ }^{151}$ De Raad van State poneerde in 2003 in zijn voorlichting Verdieping of geleidelijk uiteengaan dat, als de Antillen en Aruba een voortgaande desintegratie van het Koninkrijksverband wilden voorkomen, zij moesten kiezen, en wel met urgentie, voor nauwere aansluiting bij de EU, als UPG. Een wijziging van de Statutaire rechtsorde was hiervoor niet nodig, 'als tenminste de bereidheid bestaat het Statuut niet te zien als rem, maar als gemeenschappelijke mogelijkheid'. ${ }^{152}$

Een op initiatief van De Graaf door de Rijksministerraad ingestelde 'Commissie ter bestudering van mogelijke toekomstige relaties van de Nederlandse Antillen en Aruba met de Europese Unie', onder leiding van de voormalige Nederlandse diplomaat Ronald van Beuge, zou echter tot andere conclusies komen. ${ }^{153}$ In haar eindrapport, Banden met Brussel, stelde de commissie-Van Beuge in de toenemende Europese integratie geen bedreiging te zien voor het voortbestaan van het Koninkrijk. Bovendien zou volgens de commissie een UPG-status de Antillen en Aruba in economisch opzicht niets opleveren - waarbij aangetekend werd dat het hierbij uiteindelijk ging om een politieke keuze. Zij bepleitte een 'LGO-plus', een scenario waarin de Antillen, Aruba en het Koninkrijk ernaar zouden 'streven de mogelijkheden van de LGO-relatie beter te benutten'. ${ }^{154}$

Banden met Brussel zou de basis gaan vormen voor de verdere discussie binnen het Koninkrijk. De Arubaanse reactie op het rapport verraste niet: MEP-premier Oduber, tevoren reeds een verklaard tegenstander van UPG en beducht voor iedere mogelijke aantasting van 
de autonomie, zag zich door het rapport gesterkt. ${ }^{155}$ De Antilliaanse regering nam nog geen definitief standpunt in. Wat de individuele eilandgebieden in hun relatie met de EU wilden, was nog onduidelijk. ${ }^{156}$

De Nederlandse regering hield haar opties voor een eventuele statuswijziging op Europees niveau uitdrukkelijk open, maar een kabinetsstandpunt bleef uit. De Graaf verklaarde het rapport-Van Beuge te willen verbinden met de uitkomsten van de werkgroep-Jesurun rond de bestuurlijke en financiële verhoudingen. De eilanden moesten zelf een heldere keuze maken. ${ }^{157}$ De Graafs opvolger Pechtold zou zich evenmin uitspreken in de LGO/UPG-discussie en de keuze aan de eilanden laten. ${ }^{158}$ Minister Bot van Buitenlandse Zaken stelde zich minder terughoudend op en toonde zich voorstander van een UPG-status voor de Antillen. Hij benadrukte dat niet de angst voor het verlies aan eigenheid, maar de winst van gedeelde saamhorigheid leidraad moest zijn bij het bepalen van de toekomst en wees op de risico's van gokken op een steviger LGO-status - daarvoor was in Brussel geen politiek draagvlak. ${ }^{159}$

Dat de keuze dus bleef openstaan, stond de voortgang van de staatsrechtelijke veranderingen binnen het Koninkrijk niet in de weg. In zijn voorlichting van 18 september 2006 zou de Raad van State, zoals gezegd, adviseren Bonaire, Saba en Sint Eustatius in te richten als openbare lichamen - 'in een relatie niet met het Koninkrijk, maar direct met Nederland' - wat overigens niet betekende dat de eilanden ook vanzelf in de Eu zouden integreren. Tegelijk achtte de Raad behoud van hun LGO-status na een overgangsperiode onwenselijk. Hoewel de Europeesrechtelijke status van Aruba, Curaçao en Sint Maarten niet per se dezelfde hoefde te zijn als die van 'de met Nederland geassocieerde eilanden', konden uiteenlopende keuzes volgens de Raad complicaties met zich brengen. ${ }^{160}$

De discussie raakte opnieuw actueel met de bestuurlijke afspraken die kort daarop, op 11 oktober 2006, met de BES-eilanden werden gemaakt, en op 2 november 2006 met de landsregering, Curaçao en Sint Maarten. $\mathrm{Nu}$ duidelijk was wat op hoofdlijnen de staatkundige positie van de eilandgebieden zou zijn - de BES zouden inderdaad in het Nederlandse staatsbestel worden opgenomen als openbare lichamen - zou ook een studie verricht worden 'naar de mogelijkheden voor het verkrijgen van de status van ultraperifeer gebied en de implicaties daarvan'. Bonaire had intussen te kennen gegeven onderdeel van de EU te willen worden; Saba en Sint Eustatius neigden naar hetzelfde standpunt. Hoewel een dergelijke studie niet was opgenomen in de Slotverklaring met de twee landen in spe, zou Nicolaï op verzoek van de Tweede Kamer besluiten dit onderzoek te verbreden tot Curaçao, Sint Maarten - en Aruba. ${ }^{161}$ 
In de zomer van 2007 startten aldus, met instemming van de vijf eilanden en Aruba, twee onderzoeken naar respectievelijk de juridische en de economische implicaties van de UPG-status. Op 19 juni 2008 bood staatssecretaris Bijleveld de Tweede Kamer de uitkomsten daarvan aan. Het juridische onderzoek had uitgewezen dat de UPGstatus alleen kon worden verkregen als de andere Europese lidstaten daarmee instemden - dat was voor de BES dus niet anders dan voor Curaçao, Sint Maarten en Aruba. Zolang een dergelijk besluit niet genomen was, zouden ze alle LGO blijven, ongeacht de voorgenomen staatkundige veranderingen, die op zichzelf geen UPG-status vereisten. Over de vraag of die status uiteindelijk wel wenselijk was, gaven de onderzoeken geen eenduidige conclusie. Een overduidelijk economisch voordeel werd niet gezien. Wel zouden de juridische en economische gevolgen ingrijpend zijn. Bij een UPG-status voor Curaçao, Sint Maarten en Aruba zou bovendien het Statuut gewijzigd moeten worden. Dit laatste was niet vereist als de BES-eilanden UPG werden. ${ }^{162}$

Op basis van deze uitkomsten was Bijleveld een dag eerder, op 18 juni, met de BES overeengekomen de LGO-status voorlopig te zullen handhaven en de relatie met de EU onderdeel te laten zijn van een evaluatie vijf jaar na toetreding van de eilanden tot het Nederlandse staatsbestel. Bovendien wilde het kabinet voorrang verlenen aan het transitieproces; op korte termijn voorbereidingen treffen voor een UPG-status zou hierin vertraging opleveren. Rond Aruba, Curaçao en Sint Maarten was het kabinet van mening dat zij in de eerste plaats zelf een standpunt moesten innemen over hun gewenste relatie met de EU. ${ }^{163}$ Aruba en Curaçao zouden Bijleveld vervolgens per brief laten weten voorlopig de LGO-status te willen behouden. Sint Maarten sprak zich nog niet uit. ${ }^{164}$

Zo werd in oktober 2008 duidelijk dat de Antilliaanse eilanden en Aruba in ieder geval voorlopig LGO zouden blijven. Tijdens Algemeen Overleg op 9 oktober stemde de Tweede Kamer in met het kabinetsstandpunt dat vijf jaar na dato de verhouding tussen de EU en de BESeilanden opnieuw bekeken zou worden. Ook Curaçao, Aruba en Sint Maarten zouden zich op termijn op deze vraag moeten oriënteren. In de tussentijd bleek voor behoud van de LGO-status een breed draagvlak te bestaan, waarmee een mogelijk obstakel in het staatkundig veranderingstraject was weggenomen: een pas op de plaats in de EUdiscussie, om voortgang te kunnen behouden in het staatkundige proces en de moeilijke onderhandelingen daarover niet te belasten. ${ }^{165}$

Bij dit alles valt overigens op dat slechts zelden, in parlementaire debatten of in beleidsnotities, gesproken is over samenwerking en het uitwisselen van ervaringen met de twee andere Europese landen die nog staatkundig aanwezig zijn in de Caraïben, Frankrijk en het 
Verenigd Koninkrijk. Evenmin is veel aandacht besteed aan samenwerking tussen de Britse overseas territories en de Franse départements en collectivités. Het debat over de herstructurering had in die zin een gesloten karakter. ${ }^{166}$

\section{Het democratisch deficit en de roep om een visie op het Koninkrijk}

In de afgelopen decennia is aan Nederlandse zijde vaak geklaagd dat het Statuut Nederland te weinig middelen zou geven om goed bestuur in het hele Koninkrijk af te dwingen - nog afgezien van de regelmatig opduikende klacht dat het Statuut Nederland niet in staat stelt afscheid te nemen van de voormalige koloniën. De reden hiervoor is uiteraard dat wijziging van dit hoogste rechtsdocument van het Koninkrijk slechts mogelijk is als alle partijen dit willen. Nederlandse parlementariërs hebben geregeld aangedrongen op verandering van deze situatie, wat zou neerkomen op een versterking van de positie van Den Haag. Andersom is vaak gewezen op het democratisch deficit van het Koninkrijk: er is geen Koninkrijksparlement en uiteindelijk zijn de (weinige) Koninkrijksorganen niet meer dan Nederlandse organen, aangevuld met een of enkele Caraïbische leden die nooit beslissende invloed kunnen uitoefenen. Critici van dit tekort zijn aan beide zijden van de oceaan te vinden; reparatie van het deficit zou juist de Antilliaanse en Arubaanse positie versterken.

Uiteindelijk zou, ondanks pogingen daartoe, noch het een noch het ander veranderen. Jaren van stevige onderhandelingen over een nieuwe vormgeving van het Koninkrijk leidden wel tot nieuwe verhoudingen, maar evenmin als bij de onafhankelijkheid van Suriname (1975) en de status aparte van Aruba (1986) tot een fundamentele herziening van het Statuut. De wijziging die 10/10/10 effectueerde, was opnieuw voornamelijk technisch: Curaçao en Sint Maarten werden zelfstandige landen binnen het Koninkrijk, Bonaire, Saba en Sint Eustatius openbare lichamen binnen het Nederlandse staatsbestel. Voor de BES-eilanden werd de Nederlandse Grondwet van toepassing, zij het met inachtneming van relevante verschillen in omstandigheden tussen het Nederlandse en het Caraïbische deel van het Koninkrijk. ${ }^{167}$

Ook het 'Koninkrijk 2.0' is dus gebouwd op de pijlers van autonomie in eigen aangelegenheden, gemeenschappelijke zorg voor een beperkt aantal Koninkrijksaangelegenheden en het verlenen van onderlinge hulp en bijstand op basis van gelijkwaardigheid. Vrijwel alle van de bijna zestig aanpassingen in het Statuut zijn van technische of 
redactionele aard. Daar staan slechts twee inhoudelijke wijzigingen naast: de aankondiging van een nieuwe vorm van geschillenbeslechting tussen de landen of tussen een of meer landen en het Koninkrijk en een voorziening waarbij het Koninkrijk via een Algemene Maatregel van Rijksbestuur landen kan dwingen uitvoering te geven aan internationale verdragen. ${ }^{168}$

Dit onderhandelingsresultaat kan worden beschouwd als een overwinning voor de Antilliaanse en Arubaanse partijen: aan het principe van autonomie werd niet getornd, Den Haag c.q. het Koninkrijk kreeg slechts beperkt extra middelen. Het Nederlandse parlement betoonde zich dan ook veelvuldig ontevreden en wees er bijvoorbeeld op dat het Koninkrijk als geheel kan worden aangesproken op een gebrek aan behoorlijk bestuur in een land, terwijl eenzijdig ingrijpen vanuit Nederland slechts in uitzonderingsgevallen mogelijk is, gezien de waarborgfunctie (artikel 43 lid 2 Statuut). Dit wringt. Het Statutaire instrumentarium van een Algemene Maatregel van Rijksbestuur - het zogeheten hoger toezicht - is een zwaar, laatste redmiddel en daarmee ongeschikt om op specifieke dossiers proportioneel te kunnen optreden; lichtere correctiemechanismen ontbreken in het Statuut. En dus heeft het Koninkrijk voor het uitoefenen van de waarborgtaak in feite de keuze tussen 'een nagelschaartje en een moker', in de woorden van senator Frank van Kappen (VVD). ${ }^{169}$

Daarom ook werd vaak geoordeeld dat het Statuut best een 'afstofoperatie' zou kunnen gebruiken; verder dan een snel weer gearchiveerde 'Proeve van een vernieuwd Statuut' kwam het echter niet. ${ }^{170}$ Uiteindelijk zegde De Graaf, voortbordurend op eerdere opmerkingen van Remkes, de instelling van een evaluatiecommissie toe die verschillende punten uit de Statutaire rechtsorde ter discussie zou stellen. De aanloop naar het vijftigjarig jubileum - in december 2004-werd aangegrepen als een goede gelegenheid om te onderzoeken waar de bestuurlijke verhoudingen aanpassing behoefden. De toegezegde commissie, zo moet nu worden vastgesteld, is echter nooit ingesteld. ${ }^{171}$

Inmiddels bleef het parlement aandringen op een inhoudelijke wijziging van het Statuut, onder meer in de unaniem gesteunde motie Schuurman in de Senaat (februari 2006) en de zeer breed gesteunde motie Remkes c.s. in de Tweede Kamer (oktober 2008). Laatstgenoemde motie werd ondertekend door twee voormalige, inmiddels oppositionele bewindslieden (Remkes en Pechtold), alsmede door Ronald van Raak (SP) en Kees van der Staaij (SGP). Remkes kwalificeerde het Statuut bij deze gelegenheid als een 'wurgcontract'. Tot teleurstelling van de parlementariërs werden de moties niet uitgevoerd. ${ }^{172}$ 
De verklaring is duidelijk, het ingezette proces ging vóór, politieke haalbaarheid was de norm. Bijleveld ontraadde de motie Remkes c.s. dan ook ernstig: 'Als wij dit onnodig complex maken, kunnen wij ons niet houden aan "afspraak is afspraak". [...] Wij moeten de Statuutwijzigingen nu beperken tot datgene wat strikt noodzakelijk is om de staatkundige kant te doen. Dat wil niet zeggen dat ik niet over het Statuut in brede zin wil praten, maar dit is gewoon niet het goede moment om dat te doen.' Met andere woorden, het proces had voorrang, wat het parlement, met inbegrip van Bijlevelds eigen CDA, ook vroeg. Collega Hirsch Ballin kwalificeerde in de Senaat het Statuut nog eens als een 'zeer rigide regeling' - maar als lid van de Raad van State had hij al vaak aangegeven dat er ook binnen de Statutaire rechtsorde veel mogelijk was. ${ }^{173}$

Die laatste zienswijze werd in voorlichtingen van de Raad en in publieke optredens van vicepresident Tjeenk Willink meermalen verwoord. Ook het Comité 2004, onder voorzitterschap van Pieter van Vollenhoven en oud-gouverneur Jaime Saleh, bepleitte een sterker gevoel van 'gemeenschappelijkheid' en een beter gebruik van het Statuut - op BZK werd opgemerkt dat de hand van het lid Hirsch Ballin hierin herkenbaar was. De Graaf liet zich publiekelijk positief uit over het Comité, maar zijn waarschuwing voor 'het kunstmatig in stand houden van een gevoelen dat er feitelijk niet is' suggereerde een zekere distantie, die hij achteraf ronduit bevestigt. ${ }^{174}$ Zeker is dat BZK weigerde het Comité financieel te steunen en dat er, blijkens gesprekken met ingewijden, op het ministerie enig ongemak leefde omtrent de actieve rol van Van Vollenhoven, lid van het Koninklijk Huis immers. Ook onder De Graafs opvolgers werd het Comité door BZK welwillend bejegend maar niet actief gesteund. ${ }^{175}$

Uiteindelijk was er weinig ruimte voor bredere verkenningen van de betekenis van 'gemeenschappelijkheid' in het Koninkrijk. Ook de min of meer gelijke pleidooien van de Raad van State, de werkgroepJesurun en het Comité 2004 voor de instelling van een gemeenschappelijk secretariaat voor Koninkrijksaangelegenheden werden niet gehonoreerd. Zo ontbeerde, in de woorden van Tjeenk Willink, het Koninkrijk zelfs een 'gemeenschappelijk adres' ${ }^{176}$ Opvallend bij dit alles is overigens de hoge mate van overlap en eensgezindheid tussen de betrokken leden van de Raad van State, het Comité 2004 en de zogenoemde 'Koninkrijkstafel' van sociëteit De Witte, op het Haagse Plein.

En dan was er nog dat genoemde 'democratisch deficit'. Gerepareerd is dat tekort, zoals gezegd, nooit: alle partijen hadden uiteindelijk andere prioriteiten. Het probleem blijft duidelijk. Het Nederlandse parlement is geen Koninkrijksparlement, maar wel Koninkrijkswetgever. Er is geen parlement voor het hele Koninkrijk, 
met afgevaardigden van de volksvertegenwoordigingen van alle Koninkrijkslanden. Er bestaat bovendien geen vertrouwensregel tussen de Koninkrijksregering en de respectievelijke parlementen. Slechts het Nederlandse parlement, en niet de Staten overzee, kan de Koninkrijksregering aanspreken - en overigens is zelfs niet algemeen aanvaard dat de Koninkrijksregering verantwoording zou moeten afleggen aan de Staten-Generaal. De Antilliaanse en Arubaanse Staten hebben in ieder geval nauwelijks inbreng in de totstandkoming van Koninkrijkswetgeving - hoewel dit bij de zogeheten consensusrijkswetgeving in het recente staatkundige proces anders was - en er is minimale parlementaire controle op besluitvorming in de Rijksministerraad. Dit alles wordt wel aangeduid als een fundamentele weeffout in het Statuut. Destijds werd deze keuze echter bewust gemaakt, door alle partijen, met het oog op de kleine schaal van de Antillen en Suriname. ${ }^{177}$

Met ingewikkelde overlegprocedures is geprobeerd de betrokkenheid van de overzeese parlementen bij de totstandkoming van Rijkswetgeving toch te waarborgen. Het Statuut biedt de Antilliaanse en Arubaanse Staten de mogelijkheid om bijzondere gedelegeerden af te vaardigen voor de behandeling van een Rijkswet in de Staten-

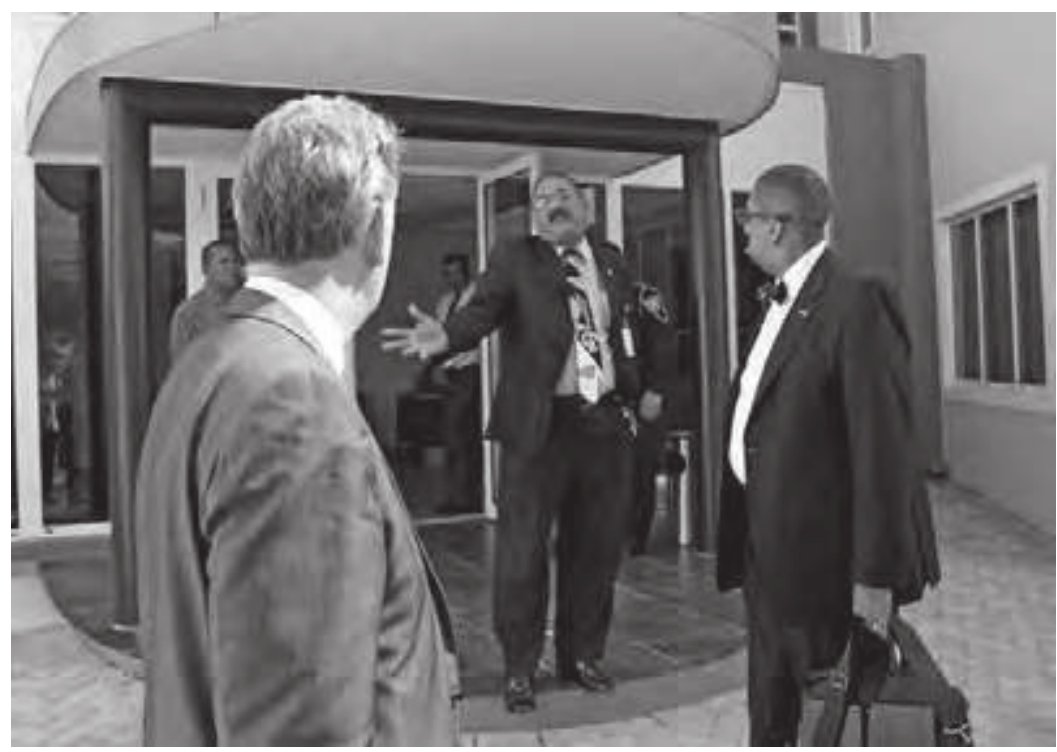

Het failliet van het Parlementair Overleg Koninkrijksrelaties (РОK) tekent zich af, Oranjestad, 4 januari 2009. De Arubaanse chef protocol Eric Brete zou hier PVv'er Hero Brinkman hebben toegevoegd: 'Aruba is niet corrupt, ik moet me inhouden om je niet kapot te slaan!' V.I.n.r. Brinkman, Brete en John Leerdam (PvdA). 
Generaal-wat in de praktijk overigens hoogstzelden gebeurt. ${ }^{178}$ Deze volksvertegenwoordigers mogen in de Tweede Kamer het woord voeren, moties indienen en amendementen voorstellen, maar hebben geen stemrecht. Kortom, ze hebben geen echte inbreng. Hetzelfde geldt in grote lijnen voor de gevolmachtigde ministers: zij kunnen in het Haagse parlement de behandeling van Koninkrijkswetten bijwonen en daarbij de zienswijze van hun landsregering naar voren brengen of een amendement indienen. Maar ze hebben evenmin stemrecht en in de Rijksministerraad telt hun stem, afgezet tegen het Nederlandse kabinet, niet zwaar. De 'gevmins' werken onder de verantwoordelijkheid van hun eigen regering en zijn geen verantwoording schuldig aan de Staten-Generaal. ${ }^{179}$

Het vaste parlementaire overleg in de vorm van het Contactplan, later het POK, wordt als gezegd niet gezien als een oplossing voor het democratisch deficit. Daarvoor blijkt de (Rijks)ministerraad zich telkens toch te weinig aangesproken te voelen door de acties en aanbevelingen van de volksvertegenwoordigers in hun 'Slotverklaringen' - nog afgezien van de polarisering binnen het POK aan de vooravond van 10/10/10. Toch wordt wel waarde gehecht aan de parlementaire contacten. Zonder deze gedachtewisselingen zou er immers nog minder controle en medezeggenschap zijn. Contactplan en later POK fungeerden ten minste als klankbord rond de besluitvorming van de Rijksministerraad.

Het lijkt een proces van kleine stapjes te zijn geweest. De ministeriële betrokkenheid bij het Contactplan nam de laatste vijf jaar toe. ${ }^{180}$ In 2005 trad De Graaf als eerste bewindsman ooit op in het Contactplan. Voorzitter van de Nederlandse delegatie Jan Rijpstra (VVD) bepleitte bij die gelegenheid dat de tweejaarlijkse bijeenkomsten 'de status [moeten] krijgen van een - noem het maar - Koninkrijksparlement', een richting die ook zijn opvolger en partijgenoot Willibrord van Beek voorstond. ${ }^{181}$ Sindsdien streefde het Contactplan, en later het POK, inderdaad steeds sterker naar politiek gewicht. De keerzijde hiervan werd pijnlijk duidelijk in de genoemde conflicten rond het PVV-lid Brinkman. Desgevraagd zijn er uiteindelijk maar weinig betrokkenen die, terugblikkend, veel belang hechten aan de rol van het POK in het ontmantelingsproces; evenmin wordt verwacht dat het POK in de toekomst wel van groot belang zal worden. Vrijwel niemand legt hier prioriteit en de facto lijkt dit platform voor parlementair overleg een stille dood te zijn gestorven. ${ }^{182}$

Er zijn ook andere pogingen ondernomen om de parlementaire controle op de Koninkrijksregering te versterken. Eind 1997 werd uit het Contactplan een gemengde werkgroep 'Democratisch Deficit Koninkrijk' in het leven geroepen, bestaande uit het Antilliaanse 
Statenlid Don Martina (voorzitter), Tweede Kamerlid Gerrit Jan van Oven en Duke Croes, lid van de Staten van Aruba. In zijn eindrapportage, in 2000, stelde deze werkgroep-Martina dat de problematiek erg complex was en dat er geen kant-en-klare oplossingen aan te dragen waren. Van belang was om de rol van de Antilliaanse en Arubaanse Staten bij de totstandkoming van Rijkswetten te versterken; daartoe bood het Statuut ruimte en waren dankzij de moderne techniek (zoals video conferencing) de mogelijkheden groot. ${ }^{183}$

De werkgroep bepleitte voorts de instelling van een Interparlementaire Commissie (IPC), bestaande uit parlementariërs uit de drie landen. Deze zou regelmatig bij elkaar moeten komen om zich te beraden over de besluitvorming van de Rijksministerraad en desgewenst met een vertegenwoordiging daarvan van gedachten kunnen wisselen. De IPC zou functioneren op basis van informele afspraken tussen de Rijksministerraad en de drie parlementen. Binnen het Contactplan werd echter geen overeenstemming bereikt over de omvang en samenstelling van zo'n commissie - en alternatieven had men niet kunnen ontdekken. Staatssecretaris van Binnenlandse Zaken en Koninkrijksrelaties Gijs de Vries reageerde terughoudend op het eindadvies van de werkgroep. ${ }^{184}$ De Antilliaanse en Arubaanse regeringen reageerden in het geheel niet op de aanbevelingen.

Het democratisch deficit bleef een terugkerend agendapunt voor het Contactplan, dat in 2000 een aantal aanbevelingen formuleerde. Zo moesten de Staten de gelegenheid krijgen mondeling overleg te plegen met de Kamercommissies over voorstellen van Rijkswet, voorafgaand aan de schriftelijke behandeling. Ook moest overwogen worden het recht van initiatief aan de Staten toe te kennen en te bekijken of een aantal van de bijzondere gedelegeerden stemrecht kon krijgen in de Tweede en Eerste Kamer bij de behandeling van voorstellen van Rijkswet die hun land raakten. Door een dergelijke uitbreiding van bevoegdheden van de Staten en van bijzondere gedelegeerden zou zich in de praktijk een parlement van het Koninkrijk kunnen ontwikkelen, zonder dat hiervoor een apart orgaan ingesteld hoefde te worden - aldus het Contactplan. ${ }^{185}$

In 2005 - inmiddels waren het advies van de Raad van State ter gelegenheid van vijftig jaar Statuut en het rapport Nu kan het... nu moet het! van de werkgroep-Jesurun verschenen, waarin ook aandacht was besteed aan het democratisch deficit-besloot het Contactplan de rapportage van de werkgroep Democratisch Deficit Koninkrijk uit 2000 weer te agenderen. Consensus over concrete aanbevelingen was er echter niet. De instelling van een Koninkrijksparlement werd gezien als een mogelijkheid om de democratische legitimatie te verbeteren, maar andere opties werden niet uitgesloten. Het omdopen van 
het Contactplan tot 'Parlementair Overleg Koninkrijksrelaties' (рок) was een klein symbolisch gebaar. ${ }^{186}$

In juni 2006, tijdens het eerste POK, ontvouwde Tjeenk Willink opnieuw de ideeën van de Raad van State over meer institutionele en inhoudelijke gemeenschappelijkheid. Hij suggereerde bij deze gelegenheid ook kiesrecht voor de Tweede Kamer voor alle Caraïbische Nederlanders, waardoor het Haagse parlement écht van het hele Koninkrijk zou worden. De staatsrechtelijke mogelijkheid hiertoe werd kort daarna door de Raad bevestigd. ${ }^{187}$

Toch kwam het hier niet van; sterker, in juni 2007 uitten de POKdelegaties hun bezorgdheid dat in de nieuwe verhoudingen het democratisch deficit zou groeien omdat dan in toenemende mate beslissingen op Koninkrijksniveau genomen zouden worden - en een groter aantal Rijkswetten betekent nu eenmaal een toename van het democratisch deficit. Ter voorbereiding van het POK van januari 2008 ging Bijleveld, mede op aandringen van de Vaste Kamercommissie NAAZ, daarom in op de opties voor versterking van de democratische legitimatie met het oog op de nieuwe staatkundige inrichting van het Koninkrijk. Zij meende dat het actieve POK eigenlijk de destijds voorgestelde IPC overbodig had gemaakt. Over het verlenen van kiesrecht voor de Tweede Kamer aan alle Nederlanders in de Antillen en Aruba was zij sceptisch, deels om praktische redenen (zetelverdeling), deels uit principe (competentiekwesties tussen de verschillende organen). Naar haar overtuiging moest gewoon beter gebruikgemaakt worden van de mogelijkheden die het Statuut al bood. ${ }^{188}$

In juni 2008 sprak het POK opnieuw uitvoerig over het democratisch deficit - ironisch is dat het overleg zelf inmiddels sterk was gepolariseerd en dat het door de eigen delegaties kennelijk niet werd gezien als een instrument dat dit tekort afdoende bestreed. De delegaties besloten slechts dat een commissie van drie deskundigen uit Nederland, de Antillen en Aruba zich moest buigen over de problematiek. Begin 2009 ging deze Commissie Democratisch Deficit van start onder leiding van Mavis Brooks-Salmon, plaatsvervangend gevolmachtigde minister van de Nederlandse Antillen. ${ }^{189}$

In haar eindrapport Kiezen voor het Koninkrijk; Democratische legitimiteit van besluitvorming en controle op Koninkrijksniveau (2009) bepleitte de commissie, in navolging van de Raad van State, de werkgroep-Jesurun en diverse eerdere auteurs, uitbreiding van het actieve stemrecht voor Tweede Kamerverkiezingen naar de inwoners van Aruba, Curaçao en Sint Maarten - de inwoners van de 'openbare lichamen' zouden dit recht per definitie ook krijgen. ${ }^{190}$ Ook werd voorgesteld de Statenleden van Aruba, Curaçao en Sint Maarten mee te laten stemmen voor de Eerste Kamer. Verder zouden de Caraïbische 
landen van het Koninkrijk een vertegenwoordiger moeten benoemen bij de Eerste en Tweede Kamer. De oprichting van een Koninkrijksparlement achtte de commissie 'disproportioneel en daarom niet verantwoord'. Een dergelijk orgaan zou 'vooral topzwaar' worden. ${ }^{191}$

Volgens de commissie diende de verantwoording door de Koninkrijksregering beter te worden georganiseerd door elk jaar een 'Koninkrijksdebat' in de Tweede Kamer te organiseren - met deelname door de Rijksministerraad, ten minste twee Antilliaanse en twee Arubaanse parlementariërs en de gevolmachtigde ministers - over de 'Staat van het Koninkrijk' (naar analogie van de Staat van de (Europese) Unie), een strategisch beleidsdocument met daarin de hoofdlijnen van het te voeren beleid, jaarlijks te publiceren door de RMR. Het POK zou volgens Kiezen voor het Koninkrijk de vorm moeten krijgen van een jaarlijks tweedaags overleg ter voorbereiding op dit Koninkrijksdebat. ${ }^{192}$

Bijleveld reageerde weinig enthousiast. In afwachting van het oordeel van het POK en de drie parlementen beperkte zij zich tot enkele algemene opmerkingen; een reactie van de Koninkrijksregering was 'niet opportuun'. De staatssecretaris stond net als ruim twee jaar eerder afwijzend tegenover de bepleite uitbreiding van het actieve kiesrecht. ${ }^{193}$ Antilliaanse en Arubaanse politici reageerden eveneens terughoudend of afwijzend op de voorstellen, mede omdat de commissie niet had aangeraden een Koninkrijksparlement in te stellen; de Staten wijdden niet eens een debat aan het rapport. Ook in het Haagse parlement was er scepsis en zeker geen draagvlak voor uitbreiding van het kiesrecht. ${ }^{194}$ En zo lijkt ook deze poging het democratisch deficit te repareren een stille dood te zijn gestorven.

Geen Koninkrijksparlement, zelfs geen Koninkrijkssecretariaat, zoals bepleit door de Raad van State en de werkgroep-Jesurun - en dus ontbeert het Koninkrijk nog altijd een 'adres', een 'huis' dat meer gezamenlijkheid vertegenwoordigt en uitstraalt dan de Rijksministerraad. Voormalig minister van BZK Klaas de Vries (PVDA) merkte tijdens het POK van 2006 op dat alleen de koningin werkelijk het Koninkrijk vertegenwoordigt. 'Naast haar vind je geen verantwoordelijke instantie, tenzij je heel lang zoekt en bij Binnenlandse Zaken langsgaat. Daar vind je dan een afdeling die zich met het Koninkrijk bezighoudt. ${ }^{195}$

En inderdaad, als er één verbindend symbool is in de Koninkrijksrelaties, dan is dat wel de monarchie. Zo wordt dat zeker ervaren op de eilanden, die vaak meer Oranjegezind lijken dan Nederland zelf. Bezoeken van leden van de koninklijke familie zijn grote gebeurtenissen op de eilanden, die kennelijk ook de Oranjes veel plezier doen en hen de gelegenheid geven hun engagement met de eilanden te 
tonen - geheel overeenkomstig de door de Raad van State bepleite verdieping van de Koninkrijksrelaties. ${ }^{196}$ Dat was in het afgelopen decennium niet anders. Koningin Beatrix bezocht de eilanden enkele malen, het laatst in november 2006. ${ }^{197} \mathrm{Zij}$ was niet aanwezig bij de plechtigheden en feesten rond 10/10/10. Daarbij waren kroonprins Willem-Alexander en prinses Máxima wel aanwezig; eerder bezochten zij de eilanden in 2002, dus kort na hun huwelijk - de eerste reis, in mei, werd afgebroken na de moord op Pim Fortuyn en hervat in augustus 2002.

Dit ene symbool wordt echter als onvoldoende ervaren; bovendien blijft kennelijk een behoefte bestaan aan een bredere visie op het Koninkrijk. En zo hield het ministerie van BZK de afgelopen jaren, aan de vooravond van 10/10/10, een aantal 'Koninkrijkssymposia'. Deze werden in de toelichting op de Rijksbegroting voor 2010 aangekondigd met een reeks vragen over wat het Koninkrijk betekent en betekenen kan voor de kwaliteit van het bestuur maar ook, meer concreet, voor burgers aan beide zijden van de oceaan. De symposia dienden bij te dragen aan het formuleren van een nieuwe 'visie op de toekomst van het Koninkrijk'. ${ }^{198}$ De Nederlandse toekomstvisie is in de zomer van 2011 aan het parlement aangeboden. Wat de betekenis hiervan zal zijn en welke rol deze visie zal spelen bij de voor 2015 geplande evaluatie van de nieuwe Koninkrijksconstellatie is onduidelijk. Zeker is wel dat wat sinds 1954 ook veranderd mag zijn in het trans-Atlantische Koninkrijk, het Statuut ondanks alle kritiek nog altijd overeind staat. ${ }^{199}$

\section{(On)denkbare modellen}

In Nederland is het Haagse Antillenbeleid de afgelopen decennia vaak betiteld als 'pappen en nathouden', een diskwalificatie die na de eeuwwisseling in krachtiger bewoordingen werd overgenomen door nieuwe rechtse partijen als de LPF en PVV. Ook binnen de partijen die de afgelopen decennia regeringsverantwoordelijkheid droegen, en dus het Antillenbeleid mede vormgaven, zijn voortdurend klachten te horen geweest over vermeende Haagse slapheid en stagnatie in het wel smalend als 'hoofdpijndossier' aangeduide Koninkrijksbeleid. Zeker is dat de Haagse opstelling sinds de eeuwwisseling getuigt van een breed gevoelde behoefte om sterker te sturen, maar dat Den Haag in het onderhandelingsproces dat leidde tot 10/10/10 regelmatig concessies deed die niet altijd strookten met de eigen ferm geformuleerde uitgangspunten. In het Nederlandse parlement werden krachtige verwijten in de sfeer van 'zwakke knieën' verwoord, zozeer 
dat het tot het laatste moment spannend was of hele pakket van ontbinding van het land en aanpassing van de Koninkrijksrelaties inderdaad door het Nederlandse parlement zou worden goedgekeurd.

Het is nuttig om enkele kanttekeningen te plaatsen bij dit beeld van stagnerend beleid en verregaande Nederlandse concessies. Allereerst moet eraan worden herinnerd dat vanuit Antilliaans perspectief het verlangen naar ontmanteling van het land de Nederlandse Antillen en de keuze voor een alternatieve eilandelijke status als land binnen het Koninkrijk of als deel van Nederland geenszins moet worden beschouwd als een gunst die van Nederland werd gevraagd, maar slechts als gebruikmaking van het recht op zelfbeschikking. Vanuit die optiek is de koppeling van de ontmanteling van de landsregering aan een versterking van de rol van het Koninkrijk dan wel Nederland nooit vanzelfsprekend geweest. In 1993 had dit al geleid tot verwerping van de door Den Haag voorgestelde uitruil, die overzee als uitholling van de Statutaire autonomie werd opgevat. In deze zin deden ook de Antilliaanse lands- en eilandsbestuurders nu meer concessies dan zij voorheen ooit hadden gewenst of gedacht.

Daarnaast is er het simpele feit dat wijzigingen van het Statuut nu eenmaal, krachtens artikel 55, instemming van alle betrokken landen behoeven. Een eenzijdige wijziging van de staatkundige relaties is dus uitgesloten, althans voor zover die binnen het Koninkrijk plaatsvindt. De enige manier waarop Nederland eenzijdig zou kunnen ingrijpen in de onderlinge relaties of in het Antilliaanse (of Arubaanse) bestuur zou zijn door in de Rijksministerraad een Algemene Maatregel van Rijksbestuur voor te stellen en deze desnoods tegen de zin van de Caraïbische partners door te zetten. Zo'n maatregel is in de afgelopen decennia enkele malen genomen, al dan niet met Caraïbische steun; per definitie zijn zulke ingrepen echter ad hoc en van tijdelijke aard.

Dat het Statuut nu met instemming van alle partijen is aangepast, is in dit perspectief opmerkelijk. Sinds 1954 werd dit hoogste rechtsdocument van het Koninkrijk, zoals gezegd weliswaar driemaal eerder gewijzigd, maar daarbij ging het uitsluitend om een verandering van het lidmaatschap van het Koninkrijk: de soevereiniteitsoverdracht aan Suriname in 1975, de status aparte van Aruba in 1986 en het in 1994 schrappen van de aan de status aparte gekoppelde onafhankelijkheid van Aruba. De in 2010 overeengekomen wijziging is daarmee de eerste waaraan ook wetgeving van inhoudelijke aard is gekoppeld. Hiermee zou tevens een oude wens van de Antillen en Aruba in vervulling gaan: de Rijkswetgever heeft nu, op Arubaans initiatief, in het Statuut de opdracht gekregen een regeling in het leven te roepen voor de beslechting van geschillen met het Koninkrijk c.q. Nederland bij de interpretatie van het Statuut. Voor deze reparatie van wat de 
Arubaanse jurist en voormalig gevolmachtigde minister Mito Croes aanduidt als 'het legaliteitsdeficit' van het Statuut bestaat inmiddels brede en expliciete steun aan beide zijden van de oceaan. Aan de uitwerking van de geschillenregeling, waarbij mogelijk de Raad van State of de Hoge Raad de beroepsinstantie zou worden, wordt thans gewerkt. $^{200}$

Een radicalere wijziging dan wel beëindiging van het Statuut was ook ditmaal niet aan de orde. Het ene extreem, de soevereiniteitsoverdracht aan Aruba, het land de Nederlandse Antillen of aan de afzonderlijke eilanden, is gezien de resolute weigering op de eilanden door opeenvolgende Nederlandse kabinetten nooit als een serieuze optie beschouwd. Het afgelopen decennium bepleitten de LPF en later de PVV een breuk met de eilanden, desnoods eenzijdig opgelegd; hiervoor is in de Nederlandse publieke opinie, getuige regelmatig opinieonderzoek, vermoedelijk vrij brede steun te vinden. Het dominante, decennialang vrijwel unaniem in regeringskringen en in alle andere politieke partijen onderschreven standpunt luidt echter dat het eenzijdig opleggen van de onafhankelijkheid onconstitutioneel, immoreel en met het oog op de geopolitieke context onrealistisch is, en bovendien in strijd met het internationaal recht. Mede in dit licht is het opmerkelijk dat aanvankelijk vanuit de directie Koninkrijksrelaties van het ministerie van BZK onafhankelijkheid weer als einddoel werd aangemerkt. ${ }^{201}$

Het andere extreem, volledige integratie van de (eilanden van de) Nederlandse Antillen en mogelijk ook van Aruba als provincie(s) in het Koninkrijk, is het afgelopen decennium serieuzer dan ooit tevoren besproken. In referenda op de vijf Antilliaanse eilanden werd deze optie voorgelegd en kreeg zij wat meer steun dan voorheen. ${ }^{202}$ Het bleef echter een minderheidskeuze die het land de Nederlandse Antillen noch de eilanden Curaçao en Sint Maarten serieus wensten te bespreken - Aruba, waar deze optie evenmin populair is, was slechts toeschouwer en behoefde zich niet uit te spreken. Als uitkomst van het onderhandelingsproces zouden Bonaire, Sint Eustatius en Saba als 'openbare bestuurslichamen' min of meer ingepast worden in $\mathrm{Ne}$ derland. Volkomen in het Nederlandse staatsbestel geïntegreerde gemeenten werden zij echter niet en een overkoepelende Antilliaanse provincie kwam er evenmin.

Waar de optie van het, in de woorden van Brinkman, 'op Marktplaats zetten' van de Antillen zonder omwegen werd verdedigd als het behartigen van het Nederlandse belang, werd de provincieoptie meer besproken in termen van gemeenschappelijke belangen. Voorstanders aan beide zijden van de oceaan verwachtten hiervan een verbetering van de kwaliteit van het bestuur door de directe Nederlandse betrok- 
kenheid en als gevolg daarvan betere levensomstandigheden en perspectieven voor de eilandelijke burgerij. Waar de provincieoptie werd verdedigd, gebeurde dit met een spectrum van welwillende, paternalistische tot bestraffende argumenten, die hoe dan ook bij Antilliaanse bestuurders weinig enthousiasme oogstten. De disciplinerende opvatting werd in 2002 door Pim Fortuyn (LPF) geopperd: de keuze was óf onafhankelijkheid, óf provincie. Deze zienswijze kreeg onder meer bijval van CDA-woordvoerder Van der Knaap, zeer tot ergernis van de Antilliaanse minister-president Ys. ${ }^{203}$

In Nederland brachten deskundigen en woordvoerders van diverse partijen het provinciemodel regelmatig onder de aandacht, echter zonder veel politieke steun buiten de LPF en SP. Over het financiële aspect bleef het daarbij opmerkelijk stil. Pas na enkele jaren van vrijblijvende opmerkingen in het parlement benoemde senator Egbert Schuurman (CU) ronduit dat de provincieoptie erg duur zou zijn. ${ }^{204}$ Bewindslieden, te beginnen met Gijs de Vries, wezen deze optie consequent af. De argumenten waren deels van principiële aard (verzet op de eilanden, afbreuk aan zelfstandigheid en aan de traditie van autonomie), deels van economische aard (verslechtering concurrentiepositie, hoge kosten). ${ }^{205}$ Diverse ambtelijke notities namen de optie min of meer routineus mee, waarbij echter steevast werd gewezen op de te verwachten complicaties en hoge kosten, terwijl ernstige bedenkingen werden geplaatst bij de effectiviteit van het Frans-Caraibische provinciemodel. Tekenend is dat oriënterende parlementaire of ambtelijke missies veelal meer geïnteresseerd waren in de Britse aanpak: in de overseas territories was geen sprake van ruime financiële steun, maar wel van sterke en directe Britse controle op het lokale bestuur. ${ }^{206}$

Het provinciemodel zou, kortom, bij gebrek aan draagvlak aan beide zijden van de oceaan in bestuurlijke kringen nooit serieus worden overwogen, althans niet voor de grotere eilanden. Als een mogelijk perspectief voor de lange termijn bleef het hooguit op de achtergrond rondzweven. Ook de optie om de openbare lichamen Bonaire, Sint Eustatius en Saba onder de paraplu van een Nederlandse provincie te plaatsen-gesuggereerd door commissaris van de Koningin in Noord-Holland Harry Borghouts (GL), werd door de betrokken eilanden afgewezen en in Den Haag niet verder onderzocht. ${ }^{207}$

Zo zagen opeenvolgende Nederlandse bewindslieden zich sinds 2000 geconfronteerd met een ongewenst maar als onvermijdelijk beschouwd proces van desintegratie van de Nederlandse Antillen; met de onmogelijkheid en ook wel onwenselijkheid om eenzijdig radicale oplossingen (onafhankelijkheid, provinciemodel) op te leggen; met de als urgent ervaren noodzaak de kwaliteit van het Caraïbische be- 
stuur (rechtshandhaving, financiën) te verbeteren; met de noodzaak consensus te vinden met de (eilanden van de) Nederlandse Antillen over nieuwe verhoudingen; en dit op zo'n wijze dat Aruba zou willen meewerken aan de hiertoe benodigde wijziging van het Statuut. Dat dit tot een ingewikkeld onderhandelingsproces zou leiden, was van meet af aan duidelijk. Een onverwachte extra complicatie werd de verharding van de standpunten in de Nederlandse politiek tegenover de grootscheepse Antilliaanse immigratie en daardoor ook tegenover Curaçao - het zoeken naar consensus met en vooral het doen van concessies aan de Caraïbische partners werd daarmee meer beladen dan voorheen het geval was geweest. Dit leidde weer tot fellere, ook politiek vertaalde oppositie op de eilanden en vooral op Curaçao tegen wat werd gezien als 'rekolonisatie'. 



\title{
3. Naar de keuze voor ontmanteling
}

\author{
en maatwerk
}

Op de magische datum van 10/10/10 werden de Nederlandse Antillen ontmanteld. De afzonderlijke eilanden kregen 'maatwerk'. De bevoegdheden en taken van het Koninkrijk en, voor de drie kleinste eilanden, van Nederland werden versterkt. Daarmee werd, met instemming van alle partijen, alsnog een richting ingeslagen die tijdens de Toekomstconferentie van 1993 op grote Antilliaanse tegenstand was gestuit.

Aan beide zijden van de oceaan was sindsdien dan ook veel veranderd. Het separatisme binnen de Antillen-van-vijf was vanaf de eeuwwisseling toegenomen onder steeds zorgelijker financiële omstandigheden. In Nederlandse optiek diende bovendien de kwaliteit van het Antilliaanse bestuur en van de rechtshandhavingsketen sterk te worden verbeterd. Deze combinatie van factoren leidde ertoe dat op Curaçao en Sint Maarten de bereidheid groeide om concessies te doen aan Den Haag, om zo de felbegeerde status van land te bereiken. Bonaire en Saba gingen aansturen op directere banden met Nederland; Sint Eustatius, dat als enige van de vijf eilanden een voorkeur had voor behoud van het land de Nederlandse Antillen, volgde noodgedwongen.

Dat de Nederlandse regering hierin zou meegaan, was niet vanzelfsprekend. In 1993 was het derde kabinet-Lubbers op het punt van een mogelijke ontmanteling van de Antillen verdergegaan dan al zijn voorgangers. 'Maatwerk' was het devies geweest van Lubbers, als voorzitter van de Rijksministerraad, en van de eerstverantwoordelijke Nederlandse minister Hirsch Ballin. Hun voorstel op de Toekomstconferentie was geweest dat Curaçao en Aruba de status van land zouden krijgen, respectievelijk behouden; de overige vier eilanden zouden 'Koninkrijkseilanden' worden, met rechtstreekse banden met Nederland, zij het dat ook Sint Maarten en Bonaire uiteindelijk land konden worden. In ruil daarvoor zouden de Koninkrijksaangelegenheden worden verruimd met rechtspleging en de zorg voor het 
bestuur van de Koninkrijkseilanden. Maar, zoals gezegd, liep deze poging tot een 'uitruil' vast op verzet van de Antilliaanse bestuurders, die vreesden voor verlies van autonomie. ${ }^{1}$

Na deze mislukte Toekomstconferentie sprak de Antilliaanse bevolking zich in referenda in 1993-1994, verrassend, in grote meerderheid uit voor handhaving van het landsverband. ${ }^{2}$ Den Haag zou zich vervolgens op het standpunt stellen dat discussies over staatkundige vernieuwing geen prioriteit verdienden; deze hielden slechts af van het vinden van een oplossing voor de als ernstig aangemerkte financiële en bestuurlijke problemen op de eilanden. Het eerste kabinetKok (PVDA, VVD, D66) zou nog met een Modellennota komen - met daarin alternatieven voor het Statuut - maar deze zou niet openbaar worden gemaakt. Onder het tweede kabinet-Kok ging de aandacht zich vervolgens meer pragmatisch richten op het versterken van de economische basis van de eilanden, het saneren van de overheidsfinanciën, het bevorderen van de deugdelijkheid van bestuur en het beteugelen van de immigratie van Antillianen in Nederland. ${ }^{3}$

Ook het kortstondige eerste kabinet-Balkenende (CDA-VVD-LPF) was de overtuiging toegedaan dat staatkundige wijzigingen geen prioriteit hadden. Het regeerakkoord stelde uitdrukkelijk dat een 'status aparte voor afzonderlijke eilanden dient te worden voorkomen' en in de troonrede verklaarde de regering zeer te hechten aan het voortbestaan van 'het huidige staatkundige verband van de Nederlandse Antillen'. Wel werd gepleit voor 'hechtere integratie' binnen het Koninkrijk. ${ }^{4}$

Daarna zou Den Haag echter schoorvoetend gaan bijdraaien. Het in mei 2003 aangetreden tweede kabinet-Balkenende (CDA-VVD-D66) handhaafde weliswaar in zijn regeerakkoord 'behoud van de landsverantwoordelijkheid' als uitgangspunt. Maar enkele maanden later al verklaarde de eerstverantwoordelijke minister Thom de Graaf (D66) te streven naar minimalisering van de bevoegdheden van de landsregering, maximalisering van de eilandelijke bevoegdheden en het leggen van cruciale bevoegdheden op het niveau van het Koninkrijk. In dit verband paste ook het streven naar een directere relatie tussen Nederland en de afzonderlijke eilanden. De panelen begonnen te schuiven. ${ }^{5}$

De hoofdlijnen van het proces dat in dit hoofdstuk wordt beschreven, zijn kort samen te vatten. De centrifugale krachten binnen het land de Nederlandse Antillen werden zo sterk dat Den Haag uiteindelijk, schoorvoetend, zijn verzet staakte en pragmatisch ging meewerken aan de ontmanteling. Aan beide zijden leidden de financieel-economische en bestuurlijke problemen tot een sense of urgency en compromisbereidheid. Niettemin leefden er principiële verschillen van opvatting over de betekenis van het zelfbeschikkingsrecht, 
wat leidde tot een moeizaam bestuurlijk proces waarin Den Haag de neiging had de bevoegdheden van Nederland c.q. het Koninkrijk sterk te verankeren, terwijl de eilanden, in het bijzonder Curaçao en Sint Maarten, zich verzetten tegen enige inperking van de Statutaire autonomie.

Startsein voor het hele proces was het referendum in Sint Maarten in 2000, voorlopig eindpunt 10/10/10. In deze tien jaar was voortdurend sprake van zogenoemde cruciale beslissingen en historische akkoorden. Hoewel er reden is te spreken van begripsinflatie, hing de voortgang van het proces inderdaad voortdurend aan een zijden draadje. Dat was zo in de periode die in dit hoofdstuk aan de orde is (2000-2006) en het zou in de volgende periode (2006-2010) niet anders zijn. Wat in dit proces opvalt, is dat ondanks verschillen van mening en ook wantrouwen, de partijen in toenemende mate tot elkaar veroordeeld waren om het proces tot een goed einde te brengen.

De Haagse opstelling kon mede verschuiven in de richting van concessies (ontmanteling, financiële bijstand) omdat de politieke gevoeligheid van dit dossier nog betrekkelijk gering was, met uitzondering van het migratievraagstuk, dat uiteindelijk buiten de onderhandelingen werd gelaten. De Antilliaanse opstelling was minder voorspelbaar door regelmatige bestuurswisselingen op land- en eilandniveau; dit geldt vooral voor Curaçao. Aruba, ten slotte, zou het gehele proces grotendeels vanaf de zijlijn aanschouwen, welwillend zolang de hervormingen geen inbreuk zouden maken op de eigen autonomie.

De compositie van dit hoofdstuk volgt de chronologie van het proces. Achtereenvolgens komen aan de orde het referendum van Sint Maarten (2000), de werkgroep-Jesurun (2004), de Intentieverklaring met Bonaire, Sint Eustatius en Saba (oktober 2005), het Hoofdlijnenakkoord (oktober 2005), de Slotverklaring van de start-RTC (november 2005), de Slotverklaring van de Miniconferentie met Bonaire, Sint Eustatius en Saba (oktober 2006) en de Slotverklaring van het bestuurlijk overleg met Curaçao en Sint Maarten (november 2006). Met beide laatste akkoorden werden de contouren vastgelegd van de belangrijkste afspraken - over onder meer rechtshandhaving, financieel beheer en schuldsanering - die in de volgende periode zouden worden uitgewerkt.

\section{Startschot: het referendum op Sint Maarten}

Het referendum van 23 juni 2000 over de toekomstige status van Sint Maarten binnen het Koninkrijk wees uit dat niet minder dan 69 procent van de stemmers koos voor de status van een autonoom 
land binnen het Koninkrijk. Dit luidde dan ook de ommekeer in; de eilandsraad van Sint Maarten en vervolgens ook de landsregering in Willemstad zouden voortaan de opheffing van het landsverband als gewenst, onvermijdelijk en bovendien - op grond van het zelfbeschikkingsbeginsel - als een onvervreemdbaar recht poneren.

Formeel stelde Nederland belang noch interesse in het referendum. De ruime steun voor de optie van een autonoom land, op 6 juli 2000 unaniem bekrachtigd door de eilandsraad, werd betiteld als een interne Antilliaanse aangelegenheid. De bewindslieden op BZK - ministers Bram Peper (1998-2000) en Klaas de Vries (20002002), staatssecretaris Gijs de Vries (1998-2002), alsook een ruime meerderheid in het parlement, gaven meermalen, ook al vóór het referendum, onomwonden aan geen enkel heil te zien in zelfs maar een discussie over een status aparte voor Sint Maarten. De staatssecretaris noemde dit voor een eiland met 40.000 inwoners een 'gevaarlijke illusie', de minister verklaarde meermalen 'niet goed in te zien hoe schaalverkleining van het bestuur een bijdrage aan de verbetering van de kwaliteit van het bestuur kan leveren'. ${ }^{6}$ Klaas de Vries zou tijdens een presentatie aan de Tweede Kamer door de Sint Maartense onderhandelaar Eugene Holiday, later de eerste gouverneur van het nieuwe land, hem hebben toegevoegd: 'Sint Maarten is niet eens een gehucht en dat wil land worden!'7 Desgevraagd weerspreekt De Vries het gebruik van het woord 'gehucht' ('Ik zal eerder hebben gesproken over "een betrekkelijk klein dorp" of iets in die geest'). Maar hij bevestigt dat hij het verlenen van een landsstatus aan Sint Maarten een 'misverstand' vond en overigens nog steeds vindt. ${ }^{8}$

Den Haag mocht dan andere prioriteiten hebben en een uiteenvallen van de Antillen-van-vijf onwenselijk vinden, met de eerdere erkenning van het eilandelijke zelfbeschikkingsrecht-waarvan Aruba in 1986 gebruik had gemaakt door voor een status aparte te kiezen - had het zelf de ruimte helpen creëren waarvan nu ook andere eilanden gebruik wensten te maken. ${ }^{9}$ Het kabinet hield daarbij vast aan de steeds ingenomen lijn: erkenning van het recht van een individueel eiland om eenzijdig uit het Koninkrijk te treden, maar een wijziging van de verhoudingen binnen het Koninkrijk vereiste de instemming van alle betrokken landen. Bovendien stelde Nederland dat het als partner in het Koninkrijk voorwaarden kon verbinden aan de invulling van een nieuwe status van de (ei)landen, voor zover die binnen het Koninkrijk gestalte zou krijgen. Opeenvolgende Nederlandse kabinetten hebben zich dit recht door de jaren heen consequent voorbehouden. ${ }^{10}$

Hoewel een Kamermeerderheid het kabinet opriep actief mee te denken over staatkundige hervormingen, prefereerde het tweede 
kabinet-Kok zich zo weinig mogelijk te uiten over wat het primair zag als een interne Antilliaanse zaak. ${ }^{11}$ Gijs de Vries lichtte in de Eerste Kamer toe dat Sint Maarten negen maanden na het referendum nog altijd niet duidelijk had gemaakt wat een status aparte kon inhouden. Daarom was het voor de Nederlandse regering nog 'niet opportuun om een inhoudelijke stelling in te nemen, zeker niet omdat binnen de Antillen is afgesproken dat ook de landsregering een belangrijke rol in de discussie zal spelen'. Wat hem betreft bleef verbetering van de financiën en van de economie de hoofdzaak. Het parlement drong wel aan op een actievere opstelling, maar was het niet oneens met de opvatting van de staatssecretaris dat oplossing van de economische problemen hogere prioriteit had. ${ }^{12}$

Het zou tot eind 2004 duren voor Den Haag expliciet aangaf onder voorwaarden bereid te zijn mee te werken aan de opheffing van de Nederlandse Antillen en aan het bereiken van een landsstatus voor Sint Maarten, en dan ook voor Curaçao. Het recht hieraan voorwaarden te verbinden zou echter nooit worden opgegeven; op dit principiële punt zouden de Antillen en Nederland tot ver in het proces tegengestelde posities blijven innemen.

Een kroniek van de tussenliggende periode illustreert enerzijds dat de Nederlandse regering de opheffing van het Antilliaanse landsverband slechts schoorvoetend aanvaardde, maar dat vervolgens de Haagse betrokkenheid bij dit proces van beslissende betekenis was. Anderzijds zal duidelijk worden dat de eilanden de impuls gaven aan het hele proces, maar dat de formulering van criteria en modellen in belangrijke mate in Den Haag werd voorbereid.

Zoals gezegd, het referendum op Sint Maarten zette het hele proces in beweging. Op de wens, na de glasheldere referendumuitslag, van de op Sint Maarten regerende DP om april 2002 aan te houden als streefdatum voor de 'status aparte', reageerde Den Haag formeel dat de kwaliteit van het bestuur en van de rechtshandhaving niet gediend was met een versnippering van het landsverband. ${ }^{13}$ Op de Antillen werd deze afwijzende houding ervaren als 'niet gepast'. Het kabinetPourier was weliswaar afwachtend, maar gaf aan dat het Sint Maarten niets in de weg zou leggen. ${ }^{14}$ Ook van de andere eilanden kreeg het eiland steeds duidelijker steun. Pouriers opvolger Ys zou van meet af aan de Sint Maartense wens om uit de Antillen te treden publiekelijk ondersteunen: uit het oogpunt van respect moest worden geluisterd naar de wens van de bevolking. Bij Ys' aantreden in juni 2002 verwachtte hij zelfs onomwonden dat 'Deze regering de laatste [zal] zijn van de staatsrechtelijke eenheid "De Nederlandse Antillen"'. ${ }^{15}$ Ook Aruba ondersteunde meermalen het streven van Sint Maarten - en 
liet intussen weten dat de eigen status aparte onaantastbaar was. ${ }^{16}$

In de Rijksbegroting voor 2002 sprak het tweede kabinet-Kok zich zeer terughoudend uit: Nederland zou de regering van de Antillen ondersteunen bij het identificeren van staatkundige hervormingen die de nadelen van de dubbele bestuurslaag konden ondervangen en die op korte termijn hun beslag konden krijgen. Tijdens de begrotingsbehandeling bestreed staatssecretaris De Vries de indruk dat hij zich op het terrein van de staatkundige structuur afwachtend zou opstellen. Hij beoogde de Antilliaanse regering te helpen bij het doorbreken van de patstelling rond de dubbele bestuurslaag door verdergaande bestuurlijke en financiële decentralisering - daarmee kon zijns inziens al veel van de onderlinge irritatie verholpen worden. ${ }^{17}$

Twee maanden eerder, in augustus 2001, had de Antilliaanse minister van Binnenlandse Zaken Magda Rafaël in de nota 'Naar een nieuw verband' een gefaseerd hervormingstraject voorgesteld; na twee fasen van decentralisering en reorganisatie zou de eigenlijke ontbinding van de landsregering kunnen plaatsvinden. ${ }^{18}$ Voor Sint Maarten, zo zou blijken, was deze nota onaanvaardbaar omdat zij de status aparte niet snel binnen bereik bracht. ${ }^{19}$ Nederland gaf uiteindelijk geen inhoudelijk standpunt, omdat een visie over de financiele en economische gevolgen van een landsstatus voor Sint Maarten ontbrak. ${ }^{20}$ Wel bleef staatssecretaris De Vries bereid tot ondersteuning van het voornemen tot hervorming van het Antilliaanse staatsverband, waarbij hij doelde op het ondervangen van de nadelen van de dubbele bestuurslaag via decentralisering. Op werkbezoek in juni 2001 moest hij overigens vaststellen dat de wensen van de eilanden onderling sterk uiteenliepen: Sint Maarten wenste een snelle status aparte, Curaçao nam nog geen standpunt in, de opinies op de kleinere eilanden weken van elkaar af. ${ }^{21}$

$\mathrm{Nu}$ 'Naar een nieuw verband' van tafel was, stelde de Antilliaanse regering op 5 december 2001 een commissie in onder voorzitterschap van de Curaçaose adviseur Raymond Begina, die binnen zes maanden scenario's moest aandragen voor een nieuwe staatkundige status voor de eilanden en hun onderlinge relaties binnen het Koninkrijk. Uitgangspunt was inderdaad een status aparte voor Sint Maarten. Den Haag, dat overigens niet op de hoogte was gesteld van de instelling van deze commissie, zette intussen in op financiële decentralisering, een sterke wens van Sint Maarten. Via een beperkte wijziging van de Eilandenregeling Nederlandse Antillen (ERNA) moest het eiland de bevoegdheid krijgen geld te lenen. Den Haag zag dit als een eerste stap op weg naar versterking van de kwaliteit van het eilandelijk bestuur en financieel beheer, en ten slotte naar hervorming van het Antilliaanse staatsverband - als dit laatste dan nog noodzakelijk 
mocht blijken. Hoewel alle benodigde arrangementen voor een geldleningsbevoegdheid voor Sint Maarten werden voorbereid, zou dit dossier nooit tot uitvoering komen; het werd door de tijd ingehaald. ${ }^{22}$

De commissie-Begina presenteerde in maart 2002 haar 'Houtskoolschets modaliteiten staatkundige veranderingen', waarin een 'Nieuwe Unie' (NU) werd beschreven tussen de vijf eilanden en Nederland (Aruba figureerde niet in de voorstellen). ${ }^{23}$ Deze Unie was nog geen uitgewerkt staatkundig model maar een denkrichting die inhield dat de vijf eilanden volledige autonomie konden krijgen en op vrijwillige basis op bepaalde terreinen zouden samenwerken. De eilanden zouden zelf de mate van afzonderlijke autonomie bepalen op basis van de eigen bestuurscapaciteiten. Het Statuut zou de basis blijven voor het Koninkrijk en waar nodig worden gewijzigd. Volgens de schets kreeg de Nieuwe Unie geen centrale regering en geen centraal parlement; wel één centraal overlegorgaan, de Samenwerkingsraad van de Unie, bestaande uit de regeringsleiders van de leden. Deze raad zou Unietaken krijgen (bijvoorbeeld Hof van Justitie) en een Commissariaat, dat zorg zou dragen voor het beheer en de uitvoering van de onderlinge afspraken.

Het model kwam neer op het uiteenvallen van de Antillen-vanvijf, waarvoor in de plaats een uiterst licht samenwerkingsverband zou komen. Nog onduidelijk was welke taken dat verband zou gaan vervullen en hoe het zou kunnen functioneren. Wat dat laatste betreft stelde een BZK-notitie dat 'de ervaringen met de samenwerking tussen de Antillen en Aruba een niet erg hoopvol beeld [geven]'. Inhoudelijke vragen van schaalverkleining en bestuurlijke draagkracht van de eilanden, garanties voor deugdelijk bestuur, onderlinge verhoudingen en functioneren in Koninkrijksverband waren niet aan de orde gesteld. ${ }^{24}$

De 'Houtskoolschets' was bedoeld als een tussenstap in de eindrapportage van de werkgroep, voorzien voor april/mei 2002. Zij zou echter niet tot een diepgaande discussie leiden: na de Statenverkiezingen van 18 januari 2002 ging alle aandacht uit naar het (moeizame) verloop van de kabinetsformatie. Gezien de te maken afspraken in het regeerakkoord - aanvankelijk leek de kans op een FOL-kabinet groot - was het onduidelijk wat de positie van de commissie zou zijn na die formatie. Zij zou uiteindelijk een stille dood sterven. ${ }^{25}$

De publieke weigering van het tweede paarse kabinet om een discussie over ontmanteling van de Nederlandse Antillen aan te gaan liet onverlet dat het ministerie van BZK zich hierop intern wel bezon. Typerend is de uitvoerige ambtelijke nota aan de beide bewindslieden die eind mei 2002 als voorzet diende voor een discussie over de te vol- 
gen lijn. ${ }^{26}$ De urgentie nam toe. In juni zou het nieuwe kabinet-Ys in zijn regeerakkoord het voornemen neerleggen van een status aparte voor Sint Maarten, met daaraan gekoppeld de aanstaande opheffing van de landsregering - Ys wenste over deze status en de verdere consequenties uiterlijk in december 2003 een RTC te houden tussen het land, de eilandgebieden, Aruba en Nederland.

Uitgangspunt van het ambtelijk advies was dat het volgende Nederlandse kabinet, gezien de situatie op onder meer Sint Maarten, zou worden geconfronteerd met de wens voor onderhandelingen over een wijziging van het Statuut. In Haagse optiek moest in dat geval het waarborgen van goed bestuur en een adequaat niveau van de rechtshandhaving de hoogste prioriteit hebben. Op deze terreinen speelden immers 'steeds klemmender problemen'. Ook werd de staatkundige discussie beïnvloed door de toenemende verzakelijking van de verhoudingen tussen Nederland, de Antillen en Aruba in het algemeen, met op onderdelen een negatieve beeldvorming. 'De solidariteit neemt af [...]. Ook voor Nederland komt meer nadruk te liggen op behartiging van de eigen belangen en de naleving van de internationale verplichtingen.'

Volgens de notitie stonden de Haagse prioriteiten bij een Statuut-

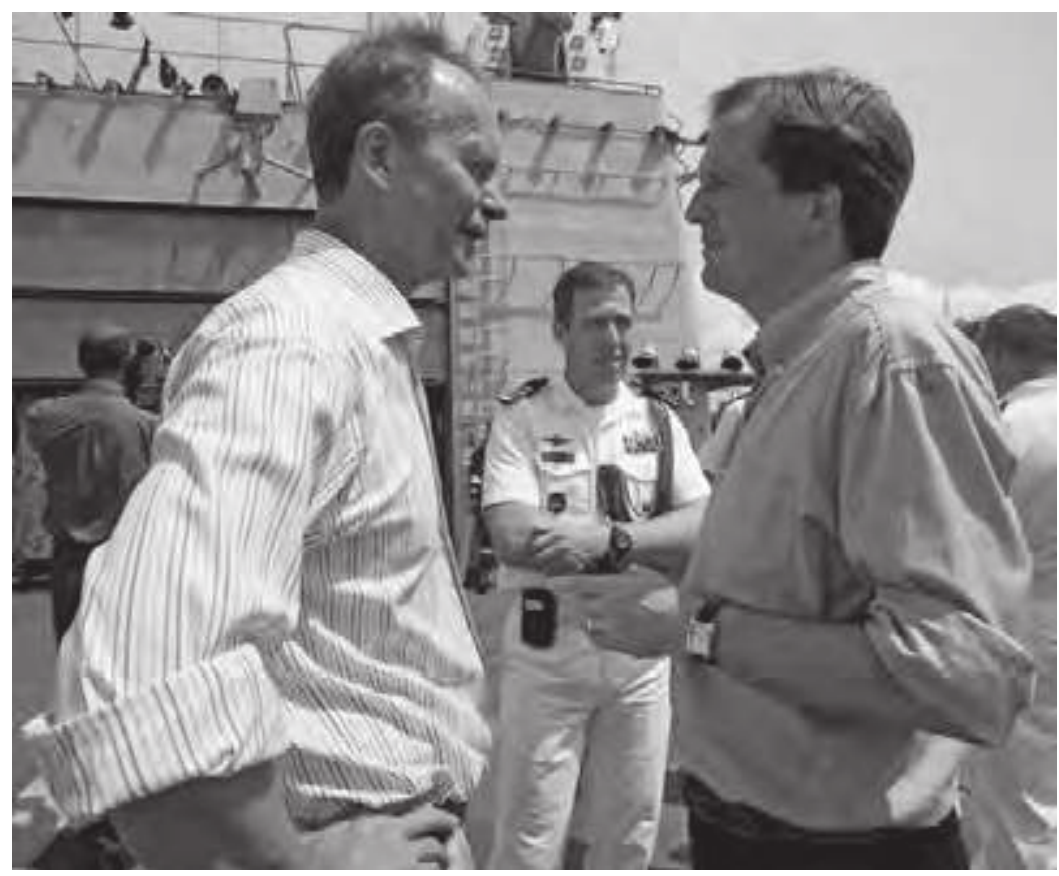

Henk Kamp (I.) en Alexander Pechtold (r.) tijdens de Caraïbische vlootdagen op de H.M. Tjerk Hiddes, Willemstad, 22 oktober 2005. 
wijziging ('vergroting van de invloed op essentiële functies van de overheid' en 'handhaving van een (functionerend) landsbestuur') vrijwel haaks op de Antilliaanse, die slechts gericht zouden zijn op beëindiging van het Antilliaanse staatsverband. Gewaarschuwd werd voor een slechte uitkomst van een onderhandelingsproces over een nieuw Statuut, namelijk dat 'de relaties binnen het Koninkrijk belangrijk onoverzichtelijker worden dan thans het geval is; de schaal van het bestuur verder wordt verkleind; wezenlijke vergroting van Nederlandse invloed niet wordt gerealiseerd in de verhouding met Curaçao'.

De Haagse ijkpunten in een eventueel onderhandelingsproces werden strak geformuleerd: goed bestuur en rechtsstaat, solide openbare financiën, goede wetgeving, goede en onafhankelijke rechtspraak (één rechterlijke organisatie en één rechterlijke macht voor alle entiteiten gezamenlijk), effectieve aanpak van de internationale misdaad en op Koninkrijksniveau bestrijden van corruptie, toezicht en handhaving, een zo eenvoudig mogelijke, praktisch hanteerbare structuur voor het Koninkrijk, nagenoeg gelijk blijvende kosten voor Nederland. Voornaamste punt was dat niet ingestemd kon worden met schaalverkleining van het bestuur op essentiële punten. Als het land zou ophouden te bestaan, moesten specifieke taken - met name wat betreft rechtshandhaving en deugdelijk bestuur - naar het Koninkrijksniveau worden getild.

Opmerkelijk is dat expliciet werd geadviseerd om, indien nodig, een harde lijn te volgen. Het instellen van hoger toezicht op basis van artikel 51 Statuut, bij Algemene Maatregel van Rijksbestuur, kon als hefboom fungeren om te komen tot een inhoudelijk bevredigende Statuutherziening. Maar dan diende Den Haag wel bereid te zijn de volledige consequenties van dit optreden te aanvaarden, op politiek niveau (verwijten van 'rekolonisatie' ten spijt), maar ook wat betreft de inzet van extra mensen en middelen. Het eindadvies luidde dat in de discussie de 'inhoudelijke benadering' voorop moest blijven staan en dat de Antillen duidelijk moest worden gemaakt dat 'voor opheffing van het Land een hoge prijs moet worden betaald wat betreft de autonomie'. Met de Antillen in de rol van 'vragende partij' zou Den Haag de eigen inhoudelijke prioriteiten optimaal kunnen laten gelden, waarbij ook 'sturing langs financiële middelen' nuttig kon zijn.

Een bijlage bij deze nota bood een verkenning van verschillende mogelijke staatkundige modellen. ${ }^{27}$ Met voorbijgaan aan eerdere Antilliaanse of Nederlandse voorstellen (Gemenebestmodel zoals voorgesteld door Hirsch Ballin, 1990; 'licht' landsmodel zoals ontwikkeld door kabinet-Pourier, 1995; Uniemodel zoals uitgewerkt door commissie-Begina, 2002) werd de optie 'bestuur op maat' als meest 
kansrijk gezien. Deze sloot aan op de aan het einde van de Toekomstconferentie van 1993 geformuleerde ideeën: een autonome landsstatus voor Curaçao conform Aruba, een 'uitgeklede' landsstatus voor Sint Maarten en Bonaire, en voor Saba en Sint Eustatius de status van Koninkrijkseilanden, ofwel een soort overzeese Nederlandse gemeenten.

Een andere bijlage besprak het provincie- en gemeentemodel in afwijzende bewoordingen. Deze optie was, gezien het zelfbeschikkingsrecht, alleen denkbaar op verzoek van de eilanden zelf en dan nog, werd verondersteld, zou de dekolonisatiecommissie van de VN 'met argusogen' bekijken 'of Nederland zich niet schuldig had gemaakt aan verdeel-en-heerspolitiek'. Vanuit Nederlands perspectief had een provincie- of gemeentestatus veel nadelen; zij zou bovendien voor de Antillen, gezien het verlies van autonomie, vrijwel zeker onaanvaardbaar zijn. Vergelijking met de Frans-Caraïbische DoMs - die bestuurd worden als een integraal onderdeel van de Franse staat: voor la France métropolitaine en de DoMs geldt één wet, één natie en één parlement-leverde ten slotte de conclusie op dat de ontwikkeling van deze provincies niet gunstiger was dan die van de Nederlandse Antillen, terwijl het Franse centrale bestuursapparaat de voornaamste 'probleemeigenaar' was geworden, een onaantrekkelijk perspectief voor Den Haag.

We mogen veronderstellen dat deze ambtelijke benadering niet alleen werd bekrachtigd door de beide bewindslieden van BZK, Klaas de Vries en Gijs de Vries, maar dat zij ook strookte met de politieke lijn van het eerste kabinet-Balkenende, dat in juli 2002 zou aantreden. Zijn Strategisch Akkoord sprak namelijk, als gezegd, van 'hechtere integratie in Koninkrijksverband' en liet geen ruimte voor opheffing van het Antilliaanse landsverband. Het onder 'paars' gestarte beleid van verzakelijking werd eveneens voortgezet, zij het dat het zwaartepunt zou verschuiven van ontwikkelingssamenwerking naar rechtshandhaving, drugsbestrijding en kwaliteit van bestuur.

In deze geest werd in september 2002, in een ambtelijke notitie met de titel 'Verscheidenheid kan niet zonder eenheid', aan de nieuwe bewindspersoon Johan Remkes voorgesteld om meer regie te gaan voeren op de Nederlandse belangen rond bestuur en rechtshandhaving in de Antillen en Aruba. Deze aangelegenheden moesten nu meer als een gezamenlijke verantwoordelijkheid (Koninkrijksaangelegenheid) worden gezien en georganiseerd. In de staatkundige discussie diende Nederland alleen mee te werken aan oplossingen die zouden bijdragen aan het beleidsdoel van good governance. Nederland zou aangeven welke gebieden meer invulling dienden te krijgen op Koninkrijksniveau. ${ }^{28}$ 
Een terugblik op het beleid onder de beide paarse kabinetten leidde in deze notitie tot de conclusie dat de sterke focus op economische ontwikkeling niet de gewenste zelfredzaamheid had gebracht en dat er te weinig aandacht was geweest voor de vraag wat de partners in het Koninkrijk deelden. De gezamenlijke belangen en verantwoordelijkheden, was nu de opvatting, lagen niet in financiële steunverlening maar op het terrein van goed bestuur, rechtshandhaving en beheersing van de migratieproblematiek. Op verzoek van Remkes kreeg de eerdere notitie over staatkundige modellen, aangevuld met de twee 'extreme' modellen van een provincie of onafhankelijkheid, de status van informele gespreksnotitie, nuttig als achtergrond voor overleg met de overzeese partners. Remkes zelf memoreert dat hij alleen interesse had in onafhankelijkheid als radicaal alternatief, niet in een provincieoptie. ${ }^{29}$

In de troonrede van 2002 herhaalde de koningin namens het kabinet dat het Statuut de basis diende te bieden voor een hechtere integratie in Koninkrijksverband. Daarbij stelde zij dat 'uit het oogpunt van evenwichtige verhoudingen' de regering 'zeer [hecht] aan het huidige staatkundige verband van de Nederlandse Antillen'. Typerend voor de harde lijn inzake de immigratie van - vooral veel jonge en kansarme - Antillianen was de zinsnede 'Zolang de criminaliteit zo verontrustend hoog is, zal de regering in overleg met de Koninkrijkspartners haar financiële bijdrage aan de samenwerking met voorrang aanwenden voor versterking van de rechtshandhaving. ${ }^{30}$

Daags na Prinsjesdag bleek uit overleg tussen Ys en de Nederlandse vertegenwoordiger op de Antillen Onno Koerten dat eerstgenoemde ongelukkig was met de toonzetting van het nieuwe kabinet en zich stoorde aan het voornemen 'de regie nadrukkelijker naar zich toe te trekken, met name op het gebied van de rechtshandhaving'. Ys waarschuwde voor het over en weer escaleren van publieke uitspraken. Ambtelijk werd opgemerkt dat men zich op de Antillen nog niet goed realiseerde dat een nieuwe lijn was ingezet en dat men te hoge verwachtingen koesterde over Haagse meegaandheid. ${ }^{31}$

Tot de onderwerpen van het kennismakingsgesprek, medio oktober in Den Haag, tussen Jan Peter Balkenende en Johan Remkes enerzijds, Etienne Ys en zijn gevolmachtigde minister Carel de Haseth anderzijds, behoorden de staatkundige verhoudingen, de financieel-economische relatie tussen Nederland en de Antillen en de relatie van de Antillen tot de Europese Unie. Het Nederlandse standpunt was dat concrete resultaten dienden te worden geboekt in de samenwerking, die overigens centraal bleef staan. Ys bepleitte in de staatkundige discussie rechtstreeks overleg tussen Den Haag en de eilandgebieden, niet alleen omdat de eilanden hierin sturend 
optraden (zodat de landsregering de besluitvorming slechts beperkt kon beïnvloeden), ook gezien het ontbreken van een gemeenschappelijk Antilliaans standpunt. Dergelijk overleg zou de centrifugale dynamiek - waar Ys, zo lijkt het, ambivalent tegenover stond - mogelijk afzwakken. Op Nederlands aandringen werd besloten tot een quick scan van de oorzaken van de financieel-economische impasse. Op staatkundig vlak bleven concrete afspraken uit. De Nederlandse regering ging niet direct in op Ys' suggestie tot instelling van een commissie van wijze mannen die deze discussie zou kunnen kanaliseren - althans, het zou nog ruim een jaar duren voordat de Werkgroep Bestuurlijke en Financiële Verhoudingen, onder Edsel 'Papy' Jesurun, het licht zou zien. ${ }^{32}$

Twee dagen na deze bijeenkomst viel het eerste kabinet-Balkenende. In het overleg dat demissionair minister Remkes in december met de Tweede Kamer voerde, bleek dat zijn scepsis over een status aparte voor Sint Maarten breed werd gedeeld - ook door de fractievoorzitter van GroenLinks, Paul Rosenmöller, die een jaar later als lid van de werkgroep-Jesurun overigens tot geheel andere gedachten zou komen. ${ }^{33}$ Deze lijn bleef Remkes vasthouden, ook toen de Sint Maartense DP zich dreigde terug te trekken uit de Antilliaanse regering, uit onvrede over het gebrek aan vooruitgang. ${ }^{34}$

Als demissionair bewindspersoon legde Remkes in februari 2003 alsnog zijn door de val van het kabinet uitgestelde kennismakingsbezoek aan de Antillen en Aruba af. In zijn Kamerverslag prees hij na afloop 'de openhartige wijze waarop de gesprekken gevoerd konden worden'. Zelf had hij, in de uitvoerige besprekingen over de staatkundige verhoudingen, de 'meerwaarde' van het Koninkrijk benadrukt en de mogelijkheid om de Rijksministerraad vaker te benutten als overlegforum. Remkes had aangegeven bereid te zijn een gezamenlijke commissie in te stellen die het functioneren van het Statuut zou gaan onderzoeken; zo'n commissie, waarop de Tweede Kamer had aangedrongen, zou ook voorstellen kunnen doen voor het oplossen van de problemen tussen het land en de eilandgebieden.

Zelf zag Remkes 'niet in [...] op welke wijze verdere versnippering van de Nederlandse Antillen een bijdrage kan leveren aan verbetering van de kwaliteit van het bestuur'. Hij bleef zich dan ook zorgen maken over 'deze tendens tot vergruizing'. Waar Sint Maarten meende dat het zelfbeschikkingsbeginsel zonder meer het recht tot verkrijging van de status aparte impliceerde, had Remkes benadrukt dat hiertoe de instemming van de drie landen van het Koninkrijk noodzakelijk was. En deze lag niet direct voor de hand. Omdat Den Haag 'de oplossing van inhoudelijke problemen' nastreefde, wees hij een landsstatus van Sint Maarten binnen het Koninkrijk althans publie- 
kelijk af - al had hij in vertrouwelijke gesprekken de deur wel op een klein kiertje gezet. ${ }^{35}$

Kort hierop constateerden vertegenwoordigers van de Vaste Commissies voor NAAZ uit de Eerste en Tweede Kamer tijdens een kennismakingsbezoek aan de Antillen dat er nog steeds geen sprake was van een gezamenlijk standpunt van de eilanden over de uitslag van het referendum op Sint Maarten. Sarah Wescott-Williams, leider van de dominante DP, bepleitte nogmaals de status aparte en beklaagde zich over de stagnatie op landsniveau. De parlementariërs zegden slechts toe hierover met Remkes te zullen spreken. Nog altijd was er geen brede Haagse steun voor het Sint Maartense streven. ${ }^{36}$

In het regeerakkoord van het in mei 2003 aangetreden tweede kabinet-Balkenende werd gesproken over 'aanpassing van de huidige structuur' van de Koninkrijksrelaties, maar 'behoud van de landsverantwoordelijkheid voor overstijgende aangelegenheden blijft de inzet'. In de regeringsverklaring werden deze beleidsvoornemens bevestigd. De Graaf, de nieuwe bewindspersoon voor Bestuurlijke Vernieuwing en Koninkrijksrelaties bij het ministerie van BZK, verklaarde in het parlement: 'Ik geloof niet dat ik behoefte heb aan nieuwe, grote nota's over de Koninkrijksverhoudingen. Ik heb wel behoefte aan ambities. ${ }^{37}$

Kort voor het aantreden van dit kabinet hadden Antilliaanse verkiezingen een grote overwinning opgeleverd voor de Curaçaose partij Frente Obrero Liberashon 30 di Mei (FOL). Omdat op dat moment nog een strafrechtelijk onderzoek liep naar partijleider Anthony Godett - die uiteindelijk werd veroordeeld - werd afgezien van zijn benoeming tot minister-president; in zijn plaats droeg de Antilliaanse ministerraad zijn zus Mirna Louisa-Godett voor. Deze gang van zaken leidde in Nederland tot veel onrust en deed afbreuk aan het vertrouwen in het Antilliaanse bestuur. Opeenvolgende Nederlandse kabinetten konden, zo lijkt het, gemakkelijker tot zaken komen met kabinetten onder een premier van de sociaalchristelijke PAR.

In deze delicate context brachten eind augustus 2003, kort na het aantreden van het kabinet-Louisa-Godett, de Nederlandse fractievoorzitters een werkbezoek aan de Antillen. Op Sint Maarten werd het de parlementariërs al snel duidelijk dat 'de Antillen niet bestaan', in de woorden van VVD-leider Van Aartsen. De Graaf moest zo snel mogelijk ingrijpen, luidde de conclusie. De enorme schuldenlast van de overheid, schrijnende armoede, oprukkende drugseconomie en onwerkbare bestuurlijke verhoudingen duldden geen uitstel meer. Bovendien werkte Sint Maarten nauwelijks samen met de landsregering. De tijd van doormodderen was absoluut voorbij, vond CDA'er Maxime Verhagen. Hoewel de fractievoorzitters zich dus minder 
voorzichtig uitspraken dan de leden van de Vaste Kamercommissies eerder dat jaar hadden gedaan, zagen ook zij niets in een status aparte. 'Het is een staatkundige oplossing voor iets wat geen staatkundig probleem is', meende PVDA-leider Wouter Bos. Met hem pleitten Verhagen en Van Aartsen voor meer op maat gesneden samenwerking en enige decentralisatie. ${ }^{38}$

De Graaf had tijdens zijn eigen kennismakingsbezoek in juni 2003 al een soortgelijke boodschap gekregen over het failliet van het Antilliaanse landsverband. Dat Sint Maarten een slechte relatie had met het omstreden kabinet-Louisa-Godett was ook hem duidelijk. De Graaf had op de eilanden aangegeven constructief te willen meedenken over de ontwikkeling van een bestuursstructuur die recht zou doen aan de positie van de eilanden en de wensen en behoeften van de bevolkingen. Dat kon in zijn ogen ook betekenen dat de relaties van de eilanden met het landsbestuur en met Nederland 'gedifferentieerd vorm krijgen'. Een status aparte voor een of meer eilanden wenste hij echter te voorkomen. ${ }^{39}$

De Graaf zou tijdens zijn bezoek aankondigen twee gemengde werkgroepen te willen instellen: de ene moest de relatie van de landen van het Koninkrijk met de Europese Unie onderzoeken, de andere zou zich buigen over de bestuurlijke en financiële decentralisatie binnen de Antillen. Onder het voorgaande kabinet was, op verzoek van het parlement, al besloten dat een gemengde commissie gewenste aanpassingen in het Statuut zou gaan onderzoeken, maar gezien de urgentie van de bestuurlijke en financiële problemen tussen het land en de eilanden wilde De Graaf hier niet op wachten - hij had kort na zijn aantreden al aangegeven geen behoefte te hebben aan grand designs. ${ }^{40}$ De twee werkgroepen zouden op korte termijn van start moeten gaan en losstaan van de Statuutcommissie, die naar verwachting een zaak van langere adem zou worden. De Graafs uitgangspunt bleef dat 'het land de Nederlandse Antillen, zij het mogelijk met andere taken en bevoegdheden, zal blijven bestaan'. ${ }^{41}$

Het kabinet-Louisa-Godett bleek instabiel, wat in Den Haag de behoefte aan snel handelen deed groeien. Onder het motto 'betrokkenheid, maar ook duidelijkheid' schreef De Graaf de Tweede Kamer te streven naar een nieuwe staatkundige vormgeving van de Antillen, juist ter verbetering van de "bestuurlijke structuur, de openbare financiën, de armoede en de rechtshandhaving'. Al waren de Antilliaanse regering en de eilandsbesturen hiervoor in de eerste plaats verantwoordelijk, Nederland 'kan en mag zich niet afzijdig houden'. Kern van De Graafs beleid was dat het land de Nederlandse Antillen nog maar over minimale bevoegdheden zou beschikken, de eilanden naar de maat van de mogelijkheden maximale bevoegdheden zouden 
krijgen om de eigen problemen op te lossen en dat cruciale bevoegdheden moesten worden ingevuld op het niveau van het Koninkrijk. 'Maatwerk per eiland is voor mij een leidend criterium bij de verbetering van de bestuurlijke structuur. ${ }^{, 42}$

Deze mantra van 'minimaal, maximaal, cruciaal' zou De Graaf de komende maanden nog vele malen herhalen. In zijn visie behoorden tot de landsverantwoordelijkheden het houden van toezicht op het eilandelijk bestuur, het onderhouden van de externe betrekkingen binnen het Caraïbisch gebied en het waarborgen van de rechtshandhaving. Cruciale taken van het Koninkrijk lagen op het gebied van de openbare orde en veiligheid. De Graaf voelde zich langzamerhand gedwongen - gezien de als weinig coöperatief ervaren houding van het Antilliaanse kabinet, en mede op aandringen van Sint Maarten - om meer zaken rechtstreeks met de eilanden te gaan doen, langs de landsregering heen. ${ }^{43}$

De Graafs beleid kon rekenen op brede steun in de Tweede Kamer. Evenmin als zijn voorgangers zag hij heil in de suggestie om de provincieoptie zelfs maar te onderzoeken, zo verklaarde hij in reactie op een vraag van SP-woordvoerder Harry van Bommel. De optie om Sint Maarten of Curaçao tot gemeenten van een Antilliaanse provincie van Nederland te maken wees hij ronduit af; ook voor de kleinere eilanden die graag een rechtstreekse relatie met Nederland wilden, verwachtte hij meer van het leveren van maatwerk per eiland dan van het in het leven roepen van gemeenten. De provincieoptie zou bovendien de regionale integratie bemoeilijken en de eigen identiteit in gevaar brengen; in de pers waarschuwde De Graaf voor 'rekolonisatie' die ook internationaal niet zou worden begrepen. ${ }^{44}$

\section{Een nieuw bestuursmodel: de werkgroep-Jesurun}

Alle scepsis ten spijt werd het De Graaf steeds duidelijker dat hij niet kon afwachten. In december 2003 verklaarde hij zelf stappen te willen zetten; hij achtte het 'niet meer reëel' om 'de eilanden kunstmatig bij elkaar te houden'. Maar dit betekende niet dat de minister zelf een 'blauwdruk' voor een status aparte op tafel wilde leggen. ${ }^{45}$

Conform zijn eerdere aankondiging had De Graaf eind augustus 2003 de Antilliaanse regering verzocht leden aan te wijzen voor de gezamenlijk in te stellen Werkgroep Bestuurlijke en Financiële Verhoudingen (BFV) en voor de Europese Unie-werkgroep. Vooral voor de eerste drong hij aan op haast; hij wenste rapportage in de eerste helft van 2004. ${ }^{46}$

Het kabinet-Godett voelde deze urgentie minder en gaf aan meer 
tijd nodig te hebben voor het voordragen van leden. Voor De Graaf was uitstel echter onaanvaardbaar. Desnoods zou hij het land passeren om alleen met de eilanden te gaan overleggen. Op de achtergrond speelde de brede Haagse perceptie mee dat het kabinet-Godett erop aanstuurde dat Nederland de ernstige budgettaire crisis - de Antilliaanse staatsschuld bedroeg twee miljard euro, tachtig procent van het BNP - zou helpen oplossen zonder daar veel harde eisen tegenover te stellen. Een stevige Nederlandse opstelling werd onvermijdelijk geacht. In de komende maanden zouden de relaties gespannen blijven. ${ }^{47}$

Tijdens politiek overleg op 30 september in Den Haag over de instelling en taak van de werkgroep BFV vielen er geen definitieve besluiten, hangende nader overleg tussen de Nederlandse Vertegenwoordiging (VNW) en ambtenaren van vicepremier, tevens minister van Constitutionele en Binnenlandse Zaken Errol Cova (PLKP). Door Den Haag voorgestelde formuleringen werden wel op enkele punten aangepast. Zo werd de doelstelling 'voortzetting van het verband van de Nederlandse Antillen vormt een randvoorwaarde voor het advies' vervangen door de zinsnede dat 'het Land een werkbaar staatkundig verband blijft' - een formulering die overigens aan Antilliaanse zijde nog tot interpretatieproblemen zou leiden. Typerend was dat, eveneens op Antilliaans verzoek, woorden als 'problemen' en 'knelpunten' werden vervangen door 'gewenste veranderingen'. ${ }^{48}$

In de Tweede Kamer verklaarde De Graaf begin oktober dat de 'sleutel voor de verbetering van de bestuurlijke en financiële verhoudingen op de Antillen ligt bij de eilandgebieden', zodat 'maatwerk' per eiland het uitgangspunt zou zijn. Hij omschreef de voornemens als een 'unieke kans' om met alle partijen maatwerk te ontwikkelen ter verbetering van de bestuurlijke structuren. ${ }^{49}$ Overigens zouden de Nederlandse leden van het parlementaire Contactplan kort daarop aangeven al een stuk verder te zijn dan zij een halfjaar eerder, tijdens hun kennismakingsbezoek, waren geweest - maar ook verder dan De Graaf zelf inmiddels was: CDA, D66, PVDA en VVD concludeerden dat de tijd rijp was voor één-op-éénrelaties van de Antilliaanse eilanden met Nederland - de PVDA wilde zelfs nog enkele stappen verder gaan, met een totale herziening van de Koninkrijksstructuur. Kennelijk hadden de Antillenwoordvoerders goed geluisterd naar hun fractieleiders. ${ }^{50}$

Medio oktober stemden de Antilliaanse regering en gedeputeerden van de vijf eilandgebieden, ondanks enkele kanttekeningen bij de taakomschrijving, onderling in met de instelling van de werkgroep BFV; elk eiland zou een lid leveren. ${ }^{51}$ Tijdens het daaropvolgend bezoek van De Graaf aan de Antillen werden verdere afspraken gemaakt en kon, op 29 oktober 2003, een protocol worden ondertekend over de instelling en taakomschrijving van de werkgroep. Deze zou aan- 
bevelingen doen over zowel staatkundige hervormingen, begrepen als verregaande decentralisering met een sterke nadruk op eisen van deugdelijkheid van bestuur, als over een saneringsbeleid om de overheidsschulden terug te dringen. ${ }^{52}$ Toch sprak de minister zich achteraf zeer kritisch uit over de Antilliaanse opstelling tijdens zijn bezoek. Hij meende dat '[m]en vooral met zichzelf bezig [is] en van de politieke besluitvorming in de relaties tussen de landen een politiek theater [maakt]. ${ }^{53}$ De Graaf bespeurde op landsniveau onvoldoende steun voor zijn aanpak om gelijktijdig zowel de staatkundig-bestuurlijke structuren als de financieel-economische problemen aan te pakken.

De werkgroep BFV kreeg een breed mandaat mee. Weliswaar was de onmiddellijke taak om binnen de grenzen van het Statuut met voorstellen te komen, maar men hoefde zich in de advisering niet te beperken tot de Statutaire kaders. Veranderingen die daarbinnen onmogelijk waren, zouden aan de orde kunnen komen in de later in te stellen commissie ter evaluatie van het Statuut. De Graaf stond hiermee een pragmatische aanpak voor: eerst draagvlak verwerven voor de richting van de oplossingen en pas daarna een eventuele bezinning op een Statuutwijziging. Duidelijk is dat de bewindsman - evenals zijn voorgangers en opvolgers, en gesteund door de Raad van State - aan dat laatste geen hoge prioriteit hechtte. Uitgangspunt van het protocol was dat binnen 'het werkbare staatkundig verband' van het land de Nederlandse Antillen maximale decentralisering zou worden nagestreefd. ${ }^{54}$

De werkgroep BFV zou bestaan uit vertegenwoordigers van het land, de eilandgebieden en Nederland. Aan Nederlandse zijde verliep de selectie soepel: Rosenmöller, voormalig fractieleider van GroenLinks en voorzitter van de Vaste Kamercommissie NAAZ, was al twee maanden eerder benaderd. Vervolgens werden oud-voorzitter van de werkgeversorganisatie VNO/NCW Hans Blankert (CDA) en burgemeester Geert Dales (VVD) van Leeuwarden bereid gevonden. Al waren ook andere kandidaten overwogen, de keuze voor dit drietal riep kennelijk weinig vragen op. ${ }^{55}$ Met de keuze van de Antilliaanse leden had De Graaf geen bemoeienis, zoals dat andersom evenmin het geval was. Uiteindelijk zou de werkgroep bestaan uit negen leden: naast de drie voor Nederland, vijf voor de eilanden en één namens het land, die tevens als voorzitter zou optreden; hiertoe werd voormalig gevolmachtigde minister van de Nederlandse Antillen Edsel Jesurun (PNP) benoemd. Er was voorzien in een stevig ambtelijk secretariaat, waarin de plaatsvervangend directeur Koninkrijksrelaties Marcel Cramwinckel van zijn minister en DG uitdrukkelijk ruimte kreeg om creatief mee te denken. ${ }^{56}$

Hoewel 'Papy' Jesurun voor alle partijen onomstreden was, was de 
benoeming van een voorzitter uiterst moeizaam verlopen - tekenend voor de stekelige relatie tussen het kabinet-Godett en de Nederlandse regering. Aanvankelijk circuleerde de naam van voormalig gouverneur Jaime Saleh, een keuze die voor Nederland zeker aanvaardbaar zou zijn geweest. Zonder vooroverleg maakte de Antilliaanse regering echter via de pers bekend oud-politicus Winston Lourens (P PK) voor te dragen, een procedure en een keuze die aan Nederlandse zijde ergernis en protest opriepen.Pas eind februari 2004 zou de benoeming van Jesurun rondkomen. In de tussenliggende maanden waren de irritaties hoog opgelopen. De Graaf verloor publiekelijk zijn geduld: 'Ik ga niet langer wachten tot het landsbestuur daarover met zichzelf in het reine is gekomen', aldus de minister, die voor deze ferme lijn brede steun in het Nederlandse parlement kreeg. ${ }^{57}$

Overwogen was nog als voorzitter Rosenmöller ('vriend van de Antillen') of zelfs een 'neutrale' Vlaming te benoemen, maar ook had De Graaf gesuggereerd een eigen werkgroep met de eilanden op te zetten, zonder deelname van de Antilliaanse landsregering. De kandidatuur van Jesurun zou pas volgen na een tussentijdse crisis van het kabinet-Godett, dat in een gewijzigde samenstelling voortging en per brief expliciet aangaf een koers van meer samenwerking met Nederland te willen gaan varen. ${ }^{58}$ Dit beleid zou, in Haagse optiek, voortvarend ingezet worden door Cova's opvolger als minister van Constitutionele en Binnenlandse Zaken, Richard Gibson (DP Sint Maarten, later National Alliance). ${ }^{59}$

Niet alleen in de impasse van de voorgaande maanden rond de beoogde voorzitter, ook rond de taakstelling van de werkgroep was Cova in Haagse ogen de dwarsligger geweest, die hiermee behalve Den Haag ook de afzonderlijke eilanden dupeerde. ${ }^{60}$ De Graaf betreurde de vertraging temeer omdat hij, mede op advies van zijn ambtenaren, steeds sterkere zorgen kreeg over de sociaaleconomische en financiële problemen op de eilanden. ${ }^{61}$ Tijdens een door Cova op 15 november 2003 te Sint Maarten bijeengeroepen Topoverleg Staatkundige Structuur ontstond tumult over het eind oktober geaccordeerde protocol. De delegaties van Bonaire, Curaçao en Sint Maarten bleken het oneens met het uitgangspunt dat het 'Land een werkbaar staatkundig verband blijft', waarna Cova het protocol weer in bespreking met Den Haag wilde brengen. Intussen nam het geduld met en vertrouwen in Cova sterk af, zowel in Den Haag als op de eilanden. ${ }^{62}$

Cova's interventie werd bij BZK geïnterpreteerd als een poging om tot een brede modellendiscussie te komen, iets wat in afwachting van de nog in te stellen commissie ter evaluatie van het Statuut voorkomen moest worden, ook gezien de urgentie van de op de Antillen heersende problemen. ${ }^{63}$ In het parlement verwierp De Graaf 
enigszins geïrriteerd het verwijt dat de schuld voor de Antilliaanse problemen in Nederland lag. ${ }^{64}$ Om uit de impasse te komen lichtte De Graaf Cova persoonlijk in over zijn besluit om met de eilandgebieden te gaan overleggen over het formeren van een nieuwe werkgroep waarvoor de landsregering wel zou worden uitgenodigd, maar waarin zij geen coördinerende rol meer zou hebben. Het eerder gesloten protocol zou dan worden losgelaten. De Graaf nam hiermee bewust het risico waarvoor zijn ambtenaren hadden gewaarschuwd, namelijk obstructie door de landsregering; kennelijk was aan Haagse zijde de zorg of zelfs overtuiging groot dat er met Cova - en in bredere zin met het kabinet-Louisa-Godett - geen zaken konden worden gedaan. ${ }^{65}$

Sint Maarten en ook andere eilandgebieden gaven inmiddels aan VNW te kennen geen vertrouwen meer te hebben in de beoogde werkgroep, omdat het land het succes daarvan zou proberen te saboteren. De Graaf kreeg zelfs het verwijt te veel toe te geven aan de landsregering. ${ }^{66}$ Cova van zijn kant had eind 2003 advies gevraagd aan de dekolonisatiecommissie van de Verenigde Naties, uit onvrede met wat hij ervoer als onredelijke Haagse pressie. ${ }^{67}$ Deze commissie zou overigens in het hele proces geen rol spelen. In antwoord op vragen uit Saba heeft zij zich meermalen op het standpunt gesteld geen bevoegdheid te hebben rond het land de Antillen of de individuele eilanden, omdat zij niet behoren tot de huidige zogeheten non-selfgoverning territories - zeventien in totaal - waarop de commissie toezicht houdt. Het ging hier dus volgens de VN van meet af aan om een interne aangelegenheid van het Koninkrijk.

Inmiddels lag vast dat als de werkgroep BFV toch van start zou gaan, deze zich primair zou bezighouden met versterking van het eilandelijk bestuur, conform het voornemen om maximale bevoegdheden bij de eilandgebieden te leggen. De Graaf gaf in overleg met de Vaste Kamercommissies aan onafhankelijkheid voor de eilanden niet als een optie te zien, ook al omdat 'Amerika daar zeker vragen bij [zou] stellen'. Het model van een nieuwe provincie van Nederland of vijf nieuwe gemeenten achtte hij net als zijn voorgangers eveneens 'betrekkelijk ondenkbaar'. Maximale decentralisatie bleef dus het uitgangspunt. De Graaf dacht daarbij aan verschillende graden van eilandelijke autonomie. Overigens kreeg hij steun voor zijn beleid, al gaven sommige partijen aan weinig vertrouwen te hebben in de Antilliaanse politiek en werd her en der gedreigd met direct Haags ingrijpen. Alleen de LPF bepleitte onmiddellijke en grondige herijking van het beleid. ${ }^{68}$

De Graaf zou Cova ten slotte in januari 2004 laten weten dat de gewraakte passage 'werkbaar staatkundig Antilliaans verband' niet uitsloot dat de werkgroep ingrijpende wijzigingen in dat staatsverband 
zou bespreken. ${ }^{69}$ Tijdens het later die maand op Bonaire en Curaçao gehouden parlementaire Contactplan stelde de Nederlandse delegatie wederom het failliet vast van het land de Nederlandse Antillen. Zij adviseerde De Graaf niet meer met de landsregering maar direct met de eilandsbesturen van Bonaire, Sint Eustatius, Sint Maarten en Saba te spreken en aan overleg met het bestuur in Willemstad voorlopig geen prioriteit te geven. ${ }^{70}$

Kort na dit dieptepunt kwam dan de genoemde crisis en wijziging in de samenstelling van het kabinet-Louisa-Godett, in februari 2004. Mede daardoor kon op 5 maart, na zes maanden vertraging, de werkgroep onder voorzitterschap van Jesurun eindelijk van start gaan. Deze zou uiterlijk 1 oktober 'zwaarwegende' voorstellen doen op het gebied van de financiële en bestuurlijke verhoudingen binnen het Koninkrijk en over de manier waarop de bevoegdheidsverdeling tussen land, eilandgebieden en het Koninkrijk moest worden aangepast om de voornaamste problemen in de Antillen op te lossen. Inmiddels werd overigens aan Haagse zijde, in afwachting van het rapport van de werkgroep, gewerkt aan de formulering van een eigen beleidsvisie. Ingewijden menen dat de opstelling van de Raad van State en ook de activiteiten van het genoemde Comité 2004 op het ministerie een zeker gevoel van urgentie teweegbrachten. ${ }^{71}$

In februari 2004 werd op BZK met De Graaf de notitie 'Koninkrijk op maat' besproken, waarvan in de voorgaande maanden vele concepten waren gelanceerd en aangevuld. Kennelijk had de bewindsman aangegeven behoefte te hebben aan een scherpe analyse, ook om de ministerraad van de ernst van de problematiek te overtuigen. De notitie draaide vooral om de relatie met de Antillen, aan Aruba werd slechts beperkte aandacht geschonken. Aanleiding voor de notitie was 'de bestuurlijke en financieel-economische crisissituatie' van de Nederlandse Antillen, die ingrijpende verandering onvermijdelijk zou maken. Het is opvallend hoe hard de toon van deze uitsluitend voor intern gebruik bedoelde notitie was. De problemen lagen op het bestuurlijke en het financieel-economische vlak, maar ook in de sfeer van moeizame onderlinge relaties, de politieke cultuur op de eilanden en de sociale problematiek. ${ }^{72}$

De doelstelling in de relatie met de Antillen werd gedefinieerd als een 'Koninkrijk op maat'. Een herschikking van bevoegdheden tussen de bestuurslagen - volgens de mantra van maximale, minimale en cruciale bevoegdheden - moest soelaas bieden. Duurzame ontwikkeling diende het einddoel te zijn; een doel dat overigens, zo moet worden vastgesteld, ook voorgaande bewindslieden als prioriteit hadden aangemerkt. De notitie wees de optie van onafhankelijkheid op korte termijn dan wel een provincie- of gemeentemodel af. Het 
laatste was onuitvoerbaar, regressief en te kostbaar, en zou bovendien bij de meeste eilanden op grote weerstand stuiten. Het model 'status aparte' was evenmin een optie omdat dit zou leiden tot een onoverzichtelijke structuur en omdat daarmee te kleinschalige entiteiten zouden worden gecreëerd. ${ }^{73}$

De optie van onafhankelijkheid werd uitdrukkelijk als perspectief op de lange termijn bepleit. Dit is opmerkelijk, aangezien voor het actief nastreven ervan in het parlement in de afgelopen vijftien jaar geen steun was geweest. Terzijde werd wel opgemerkt dat zo'n beleid het risico impliceerde van een grote migratiestroom vanuit de Antillen en Aruba. Dit opmerkelijke pleidooi zou de eerstvolgende jaren geen merkbare rol spelen; het kwam wel overeen met de opstelling van nieuwe partijen als de LPF en PVV, en later ook met de hardere opstelling van delen van de VVD. ${ }^{74}$

De werkgroep Bestuurlijke en Financiële Verhoudingen ging medio maart 2004 aan de slag, beginnend met een rondgang van de voorzitter langs alle eilanden. Op 8 oktober van dat jaar presenteerde zij haar eindrapport, Nu kan het... nu moet het! In de tussenliggende periode had de werkgroep intensief overlegd met alle betrokken partijen, de eilandsraden self-assessments laten maken, het oordeel van stakeholders ingewonnen en enkele tussenrapportages besproken; zij was vijfmaal bijeengekomen. ${ }^{75}$ Het eindadvies bepleitte, zoals de titel al aangaf, betrekkelijk radicale oplossingen voor de urgente bestuurlijke en economische problemen. De werkgroep was gaandeweg ambitieuzer geworden en vrijer gaan denken - Rosenmöller bevestigt dat hij in korte tijd 'helemaal omging. ${ }^{76}$ Voor het eerst leek daar nu voldoende draagvlak voor te bestaan - een momentum dat dus moest worden benut. Voorzitter Jesurun had bij de presentatie van zijn werkgroep al aangegeven dat er 'de facto geen beperkingen' waren. Zowel Gibson als De Graaf had 'alle ruimte gegeven om met innovatieve voorstellen te komen'. Het was tijd voor verandering: 'Er is een vurige hoop om fundamentele veranderingen te introduceren in het Caraïbische deel van het Koninkrijk! Men is unaniem van mening dat er flinke vernieuwing nodig is. ${ }^{77}$

Uit de self-assessments kwam naar voren dat vooral Curaçao en Sint Maarten hiervan veel werk hadden gemaakt, maar ook de betrokkenheid van de andere bestuurscolleges was groot gebleken. Direct had zich het beeld afgetekend dat de drie kleine eilanden sterk wilden leunen op Nederland, terwijl de andere twee juist veel in eigen beheer wilden oplossen. Curaçao streefde naar snelle en maximale autonomie, Sint Maarten rekende met een langere overgangsperiode en zag meer ruimte voor het delegeren van taken aan de Koninkrijksregering. ${ }^{78}$ Gezaghebber Franklyn Richards van Sint Maarten had 
overigens een eigen stuk ingeleverd vanuit de bezorgdheid over het overdragen van te veel bevoegdheden in het licht van de beperkte bestuurskracht van het eiland. ${ }^{79}$ In een brief aan Jesurun sprak hij zelfs een voorkeur uit 'dat de rechtshandhaving in zijn algemeenheid tot Koninkrijksaangelegenheid wordt aangemerkt, dat wil zeggen niet slechts de rechtspleging maar tevens het Openbaar Ministerie en het politieapparaat'. ${ }^{80}$ Dit advies, ingegeven door zijn zorgen over de kwaliteit van de rechtsorde en rechtsstaat op het eiland, stond haaks op de latere inzet van leidende bestuurders van Sint Maarten.

Van de drie kleine eilanden bleef Sint Eustatius het bijeenhouden van de Antillen-van-vijf verkiezen, terwijl Saba een directe relatie met Nederland nastreefde. Opmerkelijk is dat Bonaire, volgens een ambtelijke notitie, de 'één op één relatie met Nederland' wenste te 'realiseren door middel van integratie in Nederland'. De werkgroep bepleitte juist 'maatwerk' met de 'status van Koninkrijkseiland', zoals op de Toekomstconferentie in 1993 ontworpen, oftewel een associatiemodel; zij achtte integratie niet haalbaar. ${ }^{81}$

Op basis van deze assessments kon de werkgroep slechts concluderen, dan wel bevestigd zien, dat het land de Nederlandse Antillen niet levensvatbaar was en dat de eilanden, al hadden zij verschillende wensen rond autonomie, alle hoe dan ook in het Koninkrijk wilden blijven. ${ }^{82}$ Dit beeld rees ook op uit de gesprekken met de stakeholders, over wie overigens wel de indruk rees dat velen "beter weten wat ze niet willen dan wat ze wel willen, de algemene houding is reactief in plaats van initiërend'. ${ }^{83}$

$\mathrm{Al}$ in de interim-rapportage van juli 2004, aangeboden aan de verantwoordelijke ministers Gibson en De Graaf, bepleitte de werkgroep-Jesurun onomwonden de afschaffing van de centrale landsregering. Met de openbaarmaking ervan zocht de werkgroep bewust naar draagvlak. ${ }^{84} \mathrm{Zij}$ noemde grondige bestuurlijke herstructurering noodzakelijk voor een effectieve aanpak van de al jarenlang aanhoudende economische malaise, gekarakteriseerd door een zorgwekkende schuldpositie en hoge begrotingstekorten. Volgens de werkgroep was 'het sterk insulaire karakter' van de Antillen nooit voldoende onderkend; het staatsverband had vijftig jaar standgehouden alleen omdat een realistisch alternatief, 'een geloofwaardig eindperspectief', had ontbroken. De dure dubbele bestuurslaag werkte "kostenverhogend en bureaucratiebevorderend' en gaf bestuurders ruimte tot 'het wegspelen van verantwoordelijkheden'. De toenemende drugscriminaliteit en het opkomende terrorisme vroegen om intensieve samenwerking binnen het Koninkrijk. Integriteit van het bestuur was een punt van aandacht, in de keten van rechtshandhaving schoten de middelen tekort. 
Als nog voorlopige uitgangspunten poneerde de werkgroep dat, ondanks spanningen binnen het Koninkrijk en de wens tot meer autonomie, alle eilanden deel van het Koninkrijk wilden blijven en dat het Nederlanderschap niet ter discussie stond. De dubbele bestuurslaag diende plaats te maken voor maatwerk per eiland in de bestuurlijke en financiële verhoudingen met Nederland, met het Koninkrijk en onderling. Deze nieuwe verhoudingen moesten onder meer garanties bieden voor goed (financieel) bestuur, onafhankelijke rechtspraak en naleving van de mensenrechten. De taken van het Koninkrijk dienden daarnaast te worden versterkt, waarbij Nederland en het Koninkrijk sterker van elkaar moesten worden onderscheiden. Structuurveranderingen dienden gepaard te gaan met ingrijpende verbeteringen in de bestuurskracht en in basisprocessen van het bestuur, zoals de begroting.

Hiermee was de toon gezet; alle elementen zouden terugkomen in het eindrapport. De werkgroep wijdde daarnaast nog enige aandacht aan het heikele punt van onderlinge spanningen, de culturele kloof tussen Nederland en de eilanden, en bepleitte een grotere nadruk op gezamenlijkheid en - een terugkerend pleidooi, zeker in het jubileumjaar van het Statuut - versterking van het 'wij-gevoel' in het Koninkrijk. ${ }^{85}$

Het eindrapport Nu kan het... nu moet het! zou niet minder duidelijke taal spreken. ${ }^{86}$ De werkgroep stelde vast dat de Antillen vijftig jaar na de totstandkoming van het Statuut een fictie waren gebleken. De landsregering was er niet in geslaagd de armoede en criminaliteit te bestrijden; zij zou bovendien zelf geldverslindend zijn. Deze realiteit gebood daarom de Antillen te ontmantelen, zodat een effectiever antwoord kon worden gegeven op maatschappelijke vraagstukken als armoedebestrijding, vergroting van de veiligheid, duurzame economische ontwikkeling en beheersing van de openbare financiën.

Uitwerking van het uitgangspunt van afschaffing van de dubbele bestuurslaag moest enerzijds leiden tot versterking van de autonomie van de afzonderlijke eilanden, die nog onvoldoende bestuurskracht hadden, anderzijds tot een versterking van de rol van het Koninkrijk, waarbij de gebruikelijke vereenzelviging van Nederland met het Koninkrijk moest worden doorbroken. De werkgroep adviseerde voor Curaçao en Sint Maarten een autonome status binnen het Koninkrijk; Saba, Sint Eustatius en Bonaire zouden 'Koninkrijkseiland' worden, met een directe bestuurlijke band met Den Haag. ${ }^{87}$ Onafhankelijkheid noch integratie was aan de orde geweest omdat hiervoor 'op dit moment' onvoldoende draagvlak bestond. ${ }^{88}$ Parallel aan het proces van staatkundige hervormingen moesten de overheidsfinanciën worden gesaneerd en moest de kwaliteit van het openbaar 
bestuur worden verbeterd. Het unanieme eindadvies mondde uit in vijf praktische hoofdlijnen.

Allereerst pleitte de werkgroep voor versterking van de waarborgfunctie van het Koninkrijk op fundamentele terreinen als openbare financiën en rechtspraak. Dit Koninkrijk 'Nieuwe Stijl', dus zonder het land de Nederlandse Antillen, impliceerde behalve een heroriëntatie op de rechten en plichten van de leden van het Koninkrijk enkele institutionele aanpassingen. Voorgesteld werd een onderraad van de Rijksministerraad in te stellen waarin de meest betrokken ministers van de landen beleid zouden uitstippelen en besluitvorming in de Koninkrijksregering voorbereiden. Daarnaast pleitte de werkgroep voor instelling van een gezamenlijke Koninkrijksdienst die onder het gezag van de Rijksministerraad een ondersteunende functie zou moeten vervullen in alle gemeenschappelijke zaken van de partners in het Koninkrijk. Verder was er het voorstel om het 'democratisch tekort van het Koninkrijk' op te lossen door de vorming van een nieuw Koninkrijksparlement, inclusief Antilliaanse en Arubaanse parlementariërs. De waarborgtaak van het Koninkrijk zou een nieuwe invulling krijgen door het gezamenlijk vaststellen van normen voor rechtsorde, goed bestuur en overheidsfinanciën. Volgens de werkgroep waren de eilandsbesturen nu niet in staat om de bestuurlijke corruptie, drugs en criminaliteit voldoende aan te pakken. ${ }^{89}$

Voor de tweede hoofdlijn, wijziging van de staatkundige structuur,

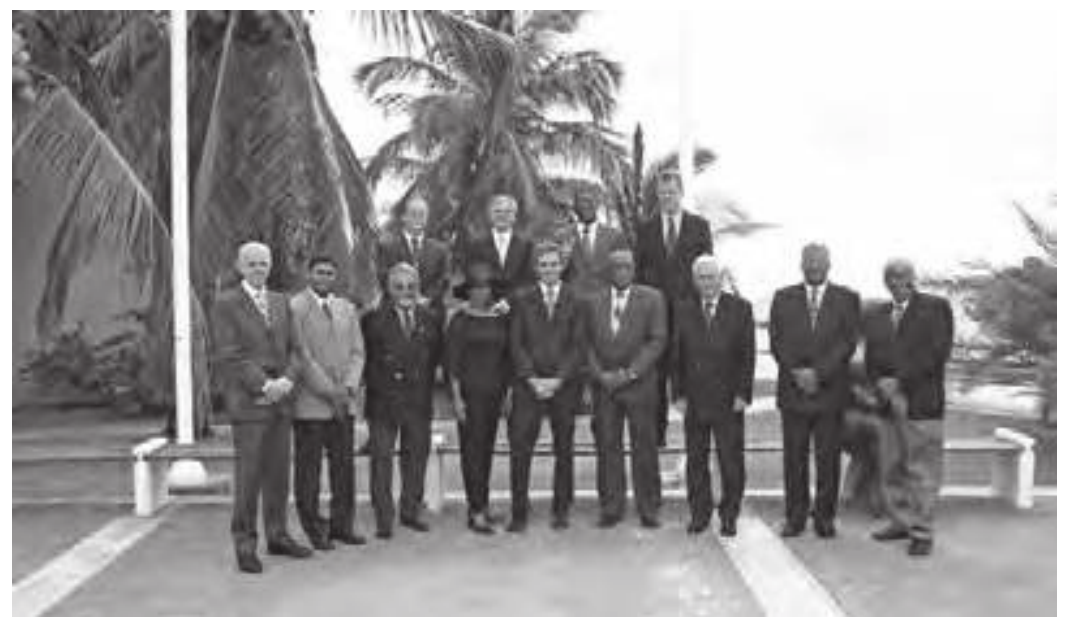

De werkgroep-Jesurun, Curaçao, 2004. Voorste rij v.l.n.r. Geert Dales, Anthony Nicolaas, Edsel 'Papy' Jesurun, Marilyn Alcalá-Wallé (adj.-secr.), Paul Rosenmöller, Ralph Berkel, Hans Blankert, Julian Larmonie, Vance James. Achterste rij v.I.n.r. Will Johnson, Marcel Cramwinckel (secr.), Raymond Begina (secr.), Bob van der Bijl (adj.-secr.). 
werd het reeds besproken maatwerk voorgesteld, waarbij gezocht zou worden naar vormen van zowel verplichte als vrijwillige samenwerking tussen de eilanden. ${ }^{90}$ De werkgroep deed vervolgens stevige aanbevelingen rond de verankering van de democratische rechtsorde, de derde hoofdlijn, uitgaande van het principe van eindverantwoordelijkheid van het Koninkrijk. Dat zou een beperkte aanwijzingsbevoegdheid krijgen voor het vervolgingsbeleid op het gebied van zware en georganiseerde criminaliteit en terrorisme; het vervolgingsbeleid in eerste aanleg zou een landsaangelegenheid blijven. Andere aanbevelingen op dit terrein omvatten regeling van de positie van de procureur-generaal bij Rijkswet; invoering van constitutioneel toetsingsrecht; instelling van normen op Koninkrijksniveau voor kwaliteit en kwantiteit van de rechtshandhavingsketen; oprichting van een onafhankelijke raad voor toezicht op het functioneren van de rechtshandhavingsketen; regeling van de rechtshandhaving bij Rijkswet voor de Koninkrijkseilanden; intensieve samenwerking tussen de veiligheidsdiensten van het Koninkrijk; en bevordering van de concordantie van wetgeving. ${ }^{91}$

Aanbevelingen rond de versterking van de bestuurskracht-de vierde lijn - bevatten voorts onder meer de bepaling dat de verdeling van de landstaken als gevolg van het opheffen van het land moest aansluiten bij de bestuurskracht van de afzonderlijke eilanden; dat het begrip 'deugdelijk bestuur' van artikel 43 Statuut moest worden genormeerd; en dat regelmatige inspecties door een in te stellen audit-commissie zouden worden gehouden. ${ }^{92}$

Over de financiële verhoudingen ten slotte werd niet alleen vastgesteld dat de overheidsfinanciën, na een lange periode van gebrek aan financiële discipline, in evenwicht dienden te worden gebracht en dat het toezicht hierop moest worden verbeterd, ook werd bepleit dat het Koninkrijk op basis van een gezamenlijk geformuleerd toezichtskader financieel toezicht zou houden op de landen en Koninkrijkseilanden. Het Solidariteitsfonds moest vervangen worden door directe begrotingssteun van Nederland aan de drie kleinere eilanden. Nederland zou moeten bijdragen aan sanering en herstructurering van de schulden van het land en van de eilandgebieden. Het rapport noemde hiertoe een aantal scenario's - in elk geval mocht Den Haag de schulden niet saneren zonder harde voorwaarden, waaronder ferm toezicht. ${ }^{93}$

$\mathrm{Al}$ met al bepleitte de werkgroep-Jesurun dus een aanmerkelijke versterking van het Koninkrijk, dat zelf 'deel van de oplossing' diende te worden. ${ }^{94}$ In de woorden van het rapport: 'Het is er de afgelopen 30 jaar niet van gekomen een heldere Koninkrijksvisie te ontwikkelen. Dit vindt zijn oorzaak in het feit dat Nederland in de jaren ' 70 en '80 sterk gericht was op onafhankelijkheid van de Nederlandse Antillen. 
In de jaren '9o is dit streven met het aantreden van minister Hirsch Ballin verlaten, maar hebben de Koninkrijksrelaties zich vooral gekenmerkt door incidenten waarbij emoties en legalisme het wonnen van zakelijkheid en wederzijds belang. Daarbij is het Statuut vaak gebruikt om te onderbouwen dat iets niet kan. Het wordt tijd deze periode van onproductief incidentalisme te vervangen door een productief partnership als onderdeel van een heldere visie op het Koninkrijk. ${ }^{95}$

Nu kan het... nu moet het! zou een katalysator blijken in het proces dat uiteindelijk zou leiden tot de ontmanteling van de Nederlandse Antillen en de gelijktijdige versterking van het Koninkrijk. Het rapport pakte de draad op die na de Toekomstconferentie van 1993 was blijven liggen. Uitvoering ervan zou betekenen dat de Antilliaanse partners versterking van de rol van het Koninkrijk accepteerden, ook waar dit de eigen autonomie begrensde. Intussen zou Nederland een aanzienlijke financiële injectie moeten geven - gaande de werkzaamheden van de werkgroep was de omvang van de schuldenlast steeds beter en daarmee schrikbarender in beeld gekomen. ${ }^{96}$

'Gezamenlijkheid' was het kernbegrip van $\mathrm{Nu}$ kan het... nu moet het!. De bereikte consensus liet onverlet dat er nog op veel punten nadere uitwerking vereist was. Bovendien waren enkele zaken die wel door de werkgroep waren besproken buiten het eindrapport gehouden. Waar het ging om een vergelijking met andere staatkundige modellen - in het bijzonder dat van de Britse overseas territories - betrof dit geen evidente conflictstof. Dat lag anders voor het onderwerp van mogelijke maatregelen ter beperking van de Antilliaanse migratie naar Nederland, met beperkt succes geagendeerd door het Nederlandse lid Dales. ${ }^{97}$

\section{Het Hoofdlijnenakkoord: groen licht voor staatkundige wijzigingen}

Op 8 oktober 2004 kregen Gibson en De Graaf met Nu kan het... nu moet het! een blauwdruk voor een nieuw bestuursmodel in handen. Het kwam op een historisch moment, vijftig jaar na de inwerkingtreding van het Statuut, een jubileum dat in december allerwegen werd herdacht en leidde tot vele gevraagde en ongevraagde adviezen over de toekomst van de Koninkrijksrelaties.

De werkgroep-Jesurun had bij alle betrokkenen een groot gevoel van urgentie vastgesteld en voorzag in een ambitieuze planning: nog in 2004 moest de politieke standpuntbepaling van alle partijen bekend zijn, zodat medio 2005 een RTC zou kunnen volgen.

Het rapport werd onder goed politiek gesternte ontvangen. Poli- 
tiek Den Haag reageerde enthousiast en zwaaide De Graaf veel lof toe - 'Ach, ik kon het moeilijk slecht doen na de impasse uit de periode-De Vries', stelt hij achteraf. ${ }^{98}$ De moeizame start van de werkgroep had direct samengehangen met de problemen in de relatie tussen het kabinet-Godett enerzijds, het Nederlandse kabinet en de eilandsregeringen anderzijds. De val in april 2004 van het door de FOL gedomineerde kabinet-Godett en het aantreden van PAR-premier Ys in juni hadden de context waarin Jesurun en zijn commissie werkten aanmerkelijk vergemakkelijkt. ${ }^{99}$ Daar kwam nog bij dat in het najaar ruime meerderheden van de bevolkingen van Bonaire en Saba zich in referenda uitspraken voor een directe band met Nederland. ${ }^{100}$ Van belang was ook dat De Graaf tussentijds had aangegeven bereid te zijn 'gecalculeerde risico's te nemen'. In de Memorie van Toelichting bij de Rijksbegroting voor Koninkrijksrelaties tekende hij aan, onder verwijzing naar het tussenrapport van de werkgroep-Jesurun, dat 'in 2005 zich nieuwe verhoudingen tussen de landen van het Koninkrijk [zullen] aftekenen'. ${ }^{101}$

Aruba, dat bij de totstandkoming van het rapport nauwelijks betrokken was geweest, had meermalen laten weten dat het uitvoering van de aanbevelingen van de werkgroep-Jesurun niet zou dwarsbomen, maar dat aan de eigen autonomie niet getornd kon worden. ${ }^{102}$ Het verwondert niet dat het rapport in kringen van de Curaçaose oppositie op felle kritiek stuitte - bij aankomst op Curaçao werd De Graaf onthaald op protestdemonstraties van de FOL, onder wie de net afgetreden premier Mirna Louisa-Godett, met leuzen als 'Welkom aan De Graaf, op bezoek bij zijn zwarte marionet Ys'. Commissievoorzitter Jesurun werd door opposanten verbaal keihard aangepakt omdat er te veel autonomie zou zijn 'weggegeven', een ervaring die hem niet in de koude kleren ging zitten. ${ }^{103}$ Verder oogstte Nu kan het... nu moet het! zowel in Nederland als op de Antillen brede instemming.

De vraag was nu hoe het momentum vast te houden. Aan Nederlandse zijde was de voorbereiding van een regeringsstandpunt al vóór de presentatie van het rapport van start gegaan, zowel binnen het ministerie van BZK als in interdepartementaal overleg. De Graaf stelde daar dat het rapport hem aansprak en vertaalde het motto ' $\mathrm{Nu}$ kan het, nu moet het' naar 'Als het kan, dan moet het'. ${ }^{104}$ Het vervolg zou echter een ingewikkeld proces blijken te zijn vol impasses en herhaald uitstel.

Vrijwel direct bleek dat aan Haagse kant het rapport naast brede politieke instemming ook vragen en kritiek opriep, vooral van ambtelijke zijde. In een interne ambtelijke nota van BZK werd geconcludeerd dat 'De tijd is niet rijp om tot besluitvorming te komen' en dat 'de bestuurskracht van de verschillende entiteiten te gering [is] 
om de voorstellen te omarmen'. De Interdepartementale Commissie Koninkrijksrelaties (ICKR), die een centrale rol speelde in de voorbereiding van een Nederlands kabinetsstandpunt over het rapport, stemde in met veel van de uitgangspunten en doelstellingen, maar kon zich niet vinden in de voorgestelde institutionele wijzigingen, te weten een nieuwe onderraad van de Rijksministerraad en een ambtelijke Koninkrijksdienst. Volgens betrokkenen werd het idee van een Koninkrijksdienst ook op BZK sceptisch ontvangen, mede omdat het ministerie hiermee eigen taken zou moeten afstaan. Als alternatief dacht De Graaf aan de instelling van een toezichthoudende 'gouverneur' met de titel Vertegenwoordiger van het Koninkrijk. ${ }^{105}$

Over de transitieperiode werd verschillend gedacht, maar aan $\mathrm{Ne}-$ derlandse zijde werd toch algemeen gerekend met een periode van tien jaar, veel langer dan de werkgroep-Jesurun en de Antilliaanse partners nodig achtten. Versterking van het financiële beheer werd in Den Haag als hogere prioriteit aangemerkt dan staatkundige wijzigingen. ${ }^{106}$

Waar van Antilliaanse zijde - uiteraard met uitzondering van de Curaçaose oppositie - intussen werd aangedrongen op haast, zou de steevast als voorzichtig getypeerde De Graaf steeds blijven hameren op zorgvuldigheid. Ys en Gibson spraken de hoop uit dat de Nederlandse regering zo snel mogelijk groen licht zou geven voor uitvoering van de hoofdpunten uit het advies. Ys streefde naar een akkoord op hoofdlijnen tussen Nederland en de eilanden nog in 2004 en dan een besluitvormende RTC medio 2005. Dit was ook een wens van het Nederlandse parlement, dat De Graaf aanmoedigde nu voortvarend te werk te gaan, onder meer via breed aanvaarde moties die de regering opriepen om nog in 2004 een politiek akkoord op hoofdlijnen te sluiten. ${ }^{107}$ Waar De Graaf publiekelijk en intern bleef manen tot zorgvuldigheid boven spoed, leidde dit in de Antilliaanse pers tot het beeld dat de minister geen haast leek te willen maken met de uitvoering van het advies. Rosenmöller vond dat 'alles politiek uiterlijk juli 2005 moet worden afgekaart', maar De Graaf liet zich niet vastleggen op een tijdstip. ${ }^{108}$

Gezien de complexiteit en de vele resterende vragen achtte de minister een regeringsstandpunt vóór 15 december niet haalbaar. Bovendien wilde De Graaf niet vooruitlopen op de bepaling van standpunten op de Antillen. Hij voorzag dat het gezamenlijke politieke akkoord, dat de werkgroep-Jesurun graag rond de vijftigste Statuutdag had gezien, niet eerder dan in het voorjaar van 2005 te verwachten was. ${ }^{109}$ Wel schreef hij nu, voor het eerst zo expliciet, dat het kabinet bereid was akkoord te gaan met de opheffing van de Nederlandse Antillen als land. 'Dat is voor het Nederlandse kabinet 
bespreekbaar, indien het Land en de eilandsbesturen dat onderschrijven en de eveneens door de werkgroep-Jesurun voorgestelde verplichte intereilandelijke samenwerking voldoende verankerd is in de verhoudingen tussen de eilanden in een krachtiger Koninkrijk.' Het bestuur en de kwaliteit van de rechtsorde en de financiën op de eilanden moesten dan gegarandeerd zijn en de rol van het Koninkrijk moest meer invulling hebben gekregen. ${ }^{110}$

De werkgroep-Jesurun had bepleit dat op een RTC, uiterlijk medio 2005, de eindbeslissingen zouden worden genomen over nieuwe bestuurlijke en financiële verhoudingen binnen het Koninkrijk. Uiteindelijk zou in november van dat jaar inderdaad een 'start-RTC' gehouden worden, maar daarmee werd slechts een proces in gang gezet dat pas op 9 september 2010 in de slot-RTC zou worden bekrachtigd - ruim vijf jaar later dus dan aanbevolen. In de tussenliggende tijd werd permanent en onder grote druk overlegd door de betrokken partijen. De grote kwestie was niet meer of de Antillen zouden worden ontmanteld, maar hoe en onder welke voorwaarden dit zou gebeuren. Uit de talloze interne Haagse discussies en de naar buiten gebrachte regeringsstandpunten blijkt de prioriteit van een sterk Koninkrijk met ruime bevoegdheden in kwesties van bestuur, financiën en rechtshandhaving. Uit de opstelling van de Antilliaanse landsregering en van de individuele eilanden spreekt de vrees - met verschillende intensiteit geuit - te veel van de voorheen geldende autonomie te moeten opgeven. Iets nadrukkelijker dan voorheen ging ook Aruba zich uitlaten over de voorgestelde staatkundige veranderingen, zij het steeds duidelijker vanuit het standpunt dat het alleen meewerkte als de eigen autonomie onverkort overeind zou blijven.

Het eerste traject, op weg naar de start-RTC, kende een aantal mijlpalen. Aan Haagse zijde was dat de vaststelling van een kabinetsstandpunt in december 2004. Aan Antilliaanse zijde waren er politieke Topoverleggen in januari en april 2005, referenda in april op Curaçao - waar de meerderheid koos voor een landsstatus, de doodsteek voor de Antillen - en op Sint Eustatius, waar de bevolking een grote voorkeur uitsprak voor het voortbestaan van het Antilliaanse landsverband; een voorkeur die vervolgens om pragmatische redenen werd verruild voor de keuze voor een directe relatie met Nederland. ${ }^{111} \mathrm{Ge}-$ zamenlijk overleg in Koninkrijksverband zou leiden tot een ambtelijk akkoord in september 2005 en een bestuurlijk 'Hoofdlijnenakkoord' in oktober, waarin de hoofdzaken voor de start-RTC werden vastgelegd.

Het tweede kabinet-Balkenende communiceerde op 17 december 2004 in een eerste reactie op het rapport-Jesurun de randvoorwaarden die het stelde aan het proces van staatkundige wijzigingen. Deze 
randvoorwaarden zouden richtinggevend blijven voor de gehele verdere Haagse opstelling in het proces; ze waren tot stand gekomen na intensief (inter)departementaal ambtelijk overleg en gerichte advisering aan de bewindslieden. Het overleg tussen de meest betrokken ministeries vond plaats binnen de ICKR, terwijl ook werd gesproken met de VNG, de Rekenkamer, de Raad van State en, om de ogen niet alleen op het 'Haagse' gericht te hebben, met gezaghebbende Antillianen in Nederland en Antillenkenners. De directie Koninkrijksrelaties van BZK zou het initiatief nemen bij het schrijven van het kabinetsstandpunt, dat na overleg met De Graaf weer in de ICKR zou worden besproken. ${ }^{112}$

Uitgangspunt was dat Nederland positief kon staan tegenover de hoofdlijnen van $\mathrm{Nu}$ kan het... nu moet het!, mits aan een reeks voorwaarden was voldaan. De ambtelijke opvatting luidde dat de werkgroep de knelpunten wel goed had vastgesteld, maar dat aangereikte oplossingen nog weinig waren uitgewerkt. Daarbij ging het vooral om de juridische en praktische uitvoerbaarheid en politieke verantwoordelijkheid. Hiertoe moest een duidelijk Antilliaans engagement worden verlangd, maar ook Aruba moest meer worden betrokken bij een beleid dat mogelijk ook voor dit land consequenties zou hebben.

Uit overleg van KR met onder meer AZ, BZ, Defensie, Financiën, Justitie en de Algemene Rekenkamer bleek een ruime sense of urgency en brede steun voor de door BZK voorziene aanpak, al was nog wel enige aarzeling te bespeuren over de voorgenomen ontmanteling. Leidraad was echter het gebrek aan vertrouwen dat de centrale regering in staat was de Antilliaanse problematiek effectief op te lossen. Strategisch was het zaak niet de vragende partij te worden. 'Het is aan de Landsregering en de eilandgebieden om commitment te tonen op de wijze waarop zij hun bestuur wensen vorm te geven.' Aruba moest vanaf het begin bij de onderhandelingen betrokken worden - uitdrukkelijk door de Antillen, niet door Nederland - ook omdat voor wijziging van het Statuut Arubaanse medewerking vereist was. ${ }^{113}$ Geadviseerd werd voorts om de dossiers over de immigratie van Antillianen (en een mogelijke beperking daarvan) en de relatie tot de Europese Unie niet te koppelen aan de discussie over de herstructurering van het Koninkrijk - deze koppeling was een wens geweest van ambtelijk Justitie. ${ }^{114}$

In tussentijds overleg met minister van Justitie Piet Hein Donner bevestigde De Graaf dat hij verwachtte dat het hele proces tien jaar zou kosten. De bewindslieden waren het eens dat verbetering van de rechtshandhaving dringend noodzakelijk was, maar ook dat duurzaam hoger toezicht door het Koninkrijk een onaantrekkelijke optie was. 'Op zijn minst', meende Donner, 'moet de schijn worden 
opgehouden dat de verantwoordelijkheid voor het oplossen van de problemen bij de Antilliaanse regering ligt. ${ }^{115}$ Kennelijk waren er twijfels over betrokkenheid en/of competentie aan Antilliaanse zijde.

Het ambtelijk voorwerk zou uitmonden in de notitie 'Naar een werkbaar Koninkrijk', die op 10 december door de ministerraad werd goedgekeurd. Een week later liet De Graaf de Kamer weten welke inhoudelijke uitgangspunten Nederland stelde aan het proces van staatkundige veranderingen. Pas als de uitvoering daarvan op gang kwam, kon het proces worden voorbereid. Als voorwaarden noemde De Graaf een 'werkbare en slagvaardige structuur', 'adequate invulling van het toezicht' door een 'krachtig Koninkrijk', 'waarborging van de integriteit van bestuur en rechtspleging' en 'robuuste' intereilandelijke samenwerkingsverbanden. Dit vergde institutionele versterking van het Koninkrijk en zo nodig verlegging van taken naar Koninkrijksniveau. Hiertoe behoorden in elk geval de rechtspraak, een aanwijzingsbevoegdheid op Koninkrijksniveau voor het vervolgingsbeleid op het gebied van de internationale criminaliteit, toezicht op het functioneren van de rechtshandhavingsketen en financieel toezicht op de landen en eilanden. De gebieden waarop tussen de landen en de Koninkrijkseilanden zou worden samengewerkt, zoals rechtshandhaving, onderwijs, volksgezondheid en rampenbestrijding, moesten expliciet worden vastgesteld, evenals de verantwoordelijkheden van de samenwerkende entiteiten. ${ }^{116}$ Met deze randvoorwaarden beoogde De Graaf een werkbare structuur voor het Koninkrijk mogelijk te maken die zou leiden tot slagvaardige besluitvorming, handhaving van de bestaande Koninkrijksaangelegenheden en een adequate invulling van het toezicht door het Koninkrijk.

Inmiddels stelde de Raad van State van het Koninkrijk, ter gelegenheid van het vijftigjarig bestaan van het Statuut in december 2004, zich in zijn spontane advies de vraag of - en zo ja, in hoeverre - het Statuut ruimte bood om de knelpunten in de Koninkrijksrelaties en de behartiging van de belangen van de burgers krachtdadig aan te pakken. De Raad bestreed de opvatting dat voor effectieve Koninkrijksrelaties een wijziging van het Statuut nodig was en gaf aan dat de bestaande voorzieningen veel beter konden worden benut. De aanpak van urgente problemen en intensivering van de samenwerking binnen het Koninkrijk hoefden niet afhankelijk te worden gesteld van een inhoudelijke Statuutherziening. De Raad benadrukte bovendien het ongedeelde Nederlanderschap binnen het Koninkrijk en adviseerde, zoals gezegd, bezinning op de relatie van de eilanden tot de EU. De regering zou pas een jaar later, maar overigens instemmend, reageren. ${ }^{117}$

Eveneens in het kader van het jubileum van het Statuut bood het 
Comité 2004 onder voorzitterschap van Pieter van Vollenhoven en voormalig gouverneur van de Nederlandse Antillen Jaime Saleh de Rijksministerraad de notitie Investeren in gezamenlijkheid aan. Daarin werd gepleit voor een nieuw maatschappelijk elan binnen het Koninkrijk. ${ }^{118} \mathrm{Al}$ werd het advies van de Raad van State pas een jaar later openbaar gemaakt en al kreeg de notitie van het Comité 2004 slechts bescheiden aandacht, beide documenten waren een aanmoediging om vaart te maken met de verdieping van het Koninkrijk.

Intussen bleek Nu kan het... nu moet het! op de eilanden toch ambivalenter te worden ontvangen dan het zich aanvankelijk had laten aanzien. Met name op Curaçao tekende zich een scherpe tegenstelling af. ${ }^{119}$ De FOL, de PLKP van Cova ('rekolonisatie') en de MAN keerden zich op essentiële onderdelen tegen het rapport. De PNP bleek intern verdeeld; één kamp vond dat de partij uit loyaliteit naar partijlid Jesurun positief moest reageren, anderen stelden dat de aanbevelingen een onaanvaardbare inbreuk op de autonomie betekenden. De PAR aarzelde aanvankelijk met een standpunt. Gremia als de Vereniging Bedrijfsleven Curaçao (VBC) en de Kamer van Koophandel omarmden het rapport. Steen des aanstoots bij alle tegenstanders was dat de voorgestelde nieuwe status Curaçao een uitgeklede autonomie zou geven, minder dan die van het land de Nederlandse Antillen of van Aruba. Dit bleek een zeer gevoelig punt, zodat op 17 januari 2005 de meerderheid van de Curaçaose eilandsraad het rapport verwierp. Ook Aruba liet weten de voorstellen, waarin het nauwelijks was gekend - Den Haag had zich op het formele standpunt gesteld dat het aan de Antilliaanse regering was om Aruba in het proces te betrekken - te ervaren als een indirecte aanval op de eigen autonomie. Aan Nederlandse zijde was er juist kritiek op de 'minimale opstelling' van Aruba op het gebied van rechtshandhaving en rechtspleging. ${ }^{120}$

Hier tekende zich een buitengewoon lastig krachtenveld af. Waar in Den Haag breed werd gedacht in termen van een ferm vasthouden aan versterking van de rol van het Koninkrijk, leek het draagvlak op de eilanden fragiel en afhankelijk van Haagse meegaandheid. Tegelijkertijd hadden de voorstanders op de Antillen haast, terwijl Den Haag gezien de complexiteit van het hele proces hamerde op zorgvuldigheid - die onvermijdelijk tijdrovend zou zijn.

Tijdens het eerste Antilliaanse Topoverleg op Sint Maarten, van 24 en 25 januari 2005, moesten de vijf eilandgebieden met een standpuntbepaling over het rapport-Jesurun komen. Curaçao was echter niet vertegenwoordigd, in afwachting van het referendum; het zou dan ook de Slotconclusies van het overleg niet ondertekenen. De Antilliaanse regering en aanwezige eilanden ondersteunden de hoofd- 
lijnen van Nu kan het... nu moet het!. Bonaire en Saba gaven aan de status van Koninkrijkseiland na te streven, Sint Maarten wenste land te worden. Het meest heikele punt in de discussies betrof het moment waarop Sint Maarten die status kon verkrijgen, een kwestie waarin de andere deelnemers zich niet wilden mengen. Duidelijk was dat er substantiële financiële ondersteuning van Den Haag werd verwacht. In de Slotconclusies werd aangedrongen op spoedig overleg met Nederland over het vervolgtraject. Getracht zou worden Curaçao weer bij het proces te betrekken. ${ }^{121}$

De Antilliaanse landsregering stemde op 2 februari unaniem in met deze Slotconclusies. ${ }^{122}$ De Graaf gaf te kennen erop te vertrouwen dat Curaçao alsnog zou aansluiten bij de gesprekken; hij mikte op een Hoofdlijnenakkoord in juni 2005. Jan Peter Balkenende, die overigens anders dan zijn voorganger Wim Kok (één bezoek in acht jaar tijd) de eilanden meermalen ook persoonlijk zou bezoeken, liet zich in dezelfde zin uit. ${ }^{123}$ Gibsons voorstel tot spoedig politiek overleg werd door De Graaf echter afgewezen, in afwachting van voorafgaand ambtelijk overleg ter inventarisering van de wensen voor een akkoord. ${ }^{124}$

In april bezochten Haagse ambtenaren de eilanden; zij meenden brede instemming met de Nederlandse benadering te ondervinden. De Graaf bleef aansturen op 'robuuste' intereilandelijke samenwerkingsverbanden en versterking van het Koninkrijk. ${ }^{125}$ Inmiddels ontstond ook aan Haagse zijde 'lichte vrees [dat] in het geval het traject-Jesurun niet wordt voortgezet er een soort doormodderscenario opdoemt'. ${ }^{126}$ Ook daarom was het ongelukkig dat De Graaf in het voorjaar van 2005 aftrad, overigens over een kwestie in het andere deel van zijn portefeuille, bestuurlijke vernieuwing. Zijn opvolger, partijgenoot Alexander Pechtold, trad op 30 maart 2005 aan; hij zou zich aanvankelijk wat terughoudender opstellen.

Het tweede Antilliaanse Topoverleg, op 26 en 27 april 2005 te Sint Maarten, mislukte goeddeels. Het lukte niet een concept voor een Hoofdlijnenakkoord op te stellen. De Curaçaose politici wilden niet over het rapport-Jesurun praten en dit keer weigerde Sint Eustatius de Slotconclusies te tekenen. Hiermee dreigde dit eiland nu de ontmanteling van het land de Antillen te blokkeren. De andere deelnemers noemden bij deze gelegenheid juist een datum voor de opheffing van het land, te weten 1 juli 2007. ${ }^{127}$ In dit kader werden ook afspraken gemaakt over voorbereidingen voor een RTC uiterlijk oktober 2005, maar Curaçao gaf aan in geen enkele werkgroep te zullen deelnemen die de aanbevelingen van het rapport-Jesurun ging uitwerken. De PAR van minister-president Ys, een partij die in het latere traject een hoofdrol zou spelen, had zich op het overleg van stemming onthouden. ${ }^{128}$ 
Ambtelijk werd nog niet heel zwaar getild aan de Curaçaose opstelling, maar richting de Kamer sprak Pechtold zijn teleurstelling uit over dit Topoverleg. 'Er is bovenal een ingewikkeld en gecompliceerd traject afgesproken waarbij Nederland aan de zijlijn staat terwijl Nederland uiteraard een bepalende factor is om gewenste bestuurlijke veranderingen te bewerkstelligen. ${ }^{129}$ In Haagse optiek was een gedegen voorbereiding van het proces op Koninkrijksniveau in de wielen gereden - een ontwikkeling die overigens mede samenhing met het ongeveer gelijktijdig bekend worden dat minister voor V\&I Rita Verdonk, tot grote Antilliaanse verontwaardiging, een toelatingsregeling voor Antilliaanse jongeren voorbereidde. ${ }^{130}$

Volgens de afspraken in het Topoverleg zou in de aanloop naar de RTC geen inhoudelijke rol zijn weggelegd voor Nederland of voor Aruba, maar Den Haag werd wel om financiële en personele steun gevraagd. Het vastleggen van het jaar 2007 voor het stopzetten van het Antilliaanse staatsverband achtte het Nederlandse kabinet volstrekt prematuur. Bovendien konden de landsregering en de vier eilanden niet bepalen wanneer het land zou worden opgeheven: hiertoe was een Statuutwijziging vereist, zodat hierover overeenstemming zou moeten worden bereikt met álle Koninkrijkspartners. ${ }^{131}$

In de volgende maanden was enerzijds sprake van een impasse en de dreiging van eenzijdig ingrijpen door Den Haag, anderzijds van een potentiële doorbraak omdat in het Nederlandse kabinet de bereidheid ontstond tot een omvangrijke schuldsanering. Nederland wilde zich verre houden van bilaterale staatkundige arrangementen met de afzonderlijke eilanden, omdat er nu eenmaal, in de woorden van Pechtold, binnen het Koninkrijk slechts 'twee smaakjes' waren: die van land of van Koninkrijkseiland. Ambtelijke adviezen en ministeriële verklaringen legden de nadruk op de nieuwe mantra van 'goed bestuur, rechtsorde en financiën' als voorwaarden voor een herziening van de staatkundige verhoudingen. ${ }^{132}$

Belangrijk struikelblok was dat Curaçao, blijkens publicaties in de Antilliaanse pers, steeds afstand hield van het rapport-Jesurun, dat door de FOL en PLKP als 'rekolonisatie' werd betiteld. Den Haag bleef daaraan juist onverkort vasthouden en wilde een akkoord sluiten met de landsregering. ${ }^{133} \mathrm{Op}$ de verklaring van Ys dat de opheffing van het land al van start zou kunnen gaan, werd echter afwijzend gereageerd. In dit kader adviseerde KR de minister een mogelijk Nederlands aanbod voor schuldsanering niet voortijdig als onderhandelingstroef uit handen te geven. Inmiddels begon men in ambtelijk Den Haag, naarmate duidelijker werd hoe 'ronduit deplorabel' de overheidsfinanciën van het land ervoor stonden, serieuzer te denken aan voorbereiding van hoger toezicht als alternatief voor een beleid dat werd omschre- 
ven als 'pappen en nathouden'. ${ }^{134}$ Achter de schermen, maar ook publiekelijk, werden een harde lijn en een grote sense of urgency uitgedragen. Daartoe behoorde ook dat eilandelijke verwachtingen rond een spoedige ontmanteling moesten worden getemperd. ${ }^{135}$

Ongewild werd Den Haag steeds meer getrokken in het Antilliaanse, en vooral Curaçaose politieke krachtenveld. Een dreigement van Ys om bij instelling van hoger toezicht direct te zullen aftreden, werd als loos afgedaan, maar wel geplaatst in een context waarin men zich hardop afvroeg hoe (on)aantrekkelijk een alternatieve coalitie met de FOL zou zijn. ${ }^{136}$ In de komende jaren zouden de ideologische verbondenheid en goede persoonlijke verstandhouding tussen CDAbewindslieden en landsregeringen van PAR-signatuur van steeds groter belang worden voor de voortgang van het proces.

In mei 2005 werd intussen duidelijk dat minister van Financiën Gerrit Zalm (VVD) - waarschijnlijk mede op advies van president van de Bank van de Nederlandse Antillen Ensley Tromp, die in Den Haag veel vertrouwen genoot - bereid was een forse bijdrage te leveren aan herfinanciering van de Antilliaanse staatsschuld, mits daar maatregelen tegenover stonden om een hernieuwde schuldopbouw in de toekomst uit te sluiten. Ook in deze context werd weer gedacht aan direct Haags bestuurlijk ingrijpen (hoger toezicht), zeker als het politieke overleg niet zou vorderen. Pechtold werd geadviseerd hierover al met de meest betrokken collega's te overleggen, ook al gold deze optie slechts als laatste redmiddel. ${ }^{137}$

Op 24juni stemde het kabinet-Balkenende in met de in een conceptHoofdlijnenakkoord vastgelegde voorwaarden waaronder Nederland bereid was de staatkundige veranderingen te steunen. Pechtold besprak dit concept een week later op de Antillen. De politieke context was inmiddels verder gecompliceerd door het 'migratiedossier' en de eenzijdige Haagse voorbereiding van een toelatingsstop voor Antilliaanse jongeren. Pechtold moest dus proberen zowel de sfeer te verbeteren als harde afspraken te maken. ${ }^{138}$

In zijn reisverslag gaf Pechtold niettemin aan dat het overleg in 'constructieve sfeer' had plaatsgevonden. Hij had de Nederlandse voorwaarden waaronder in 2007 nieuwe verhoudingen zouden kunnen ingaan, uiteengezet en daarbij gesproken van 'pijnlijke maatregelen', maar ook van sociaal flankerend beleid en herstructurering van de schulden. Een en ander moest nu worden vastgelegd in een Hoofdlijnenakkoord, waarna het traject 'in volle vaart' van start zou kunnen gaan. ${ }^{139}$

De prioriteit van de landsregering en zeker van de eilandsbesturen bleef echter liggen bij een staatkundige herstructurering en niet zozeer bij het bredere pakket van sociaaleconomische maatregelen dat 
Den Haag voorstond. In een ambtelijke notitie werd Pechtold niet alleen gedetailleerd geïnformeerd over de verschillende posities en zelfs de mogelijke politieke en ambtelijke gesprekspartners, maar ook over de te volgen strategie, een mengeling van hard op de inhoud en oog houden voor een goede sfeer. ${ }^{140}$

De presentatie van het voor de beoogde RTC geschreven Antilliaanse rapport Toekomst in zicht! bevestigde de Haagse zorgen. Hierin waren de staatkundige wensen van de eilanden geïnventariseerd, maar over de te treffen arrangementen en de Nederlandse standpunten werd vrijwel niets gezegd. Weer werd duidelijk hoezeer de uitgangspunten uiteenliepen. In Antilliaanse optiek hadden de eilanden op grond van het zelfbeschikkingsrecht de vrijheid een nieuwe status te kiezen zonder aan voorafgaande voorwaarden te voldoen. Den Haag bleef dit bestrijden: Nederland mocht als Koninkrijkspartner voorwaarden stellen omdat iedere vorm van lidmaatschap van het Koninkrijk nu eenmaal verplichtingen schept. ${ }^{141}$

Tijdens ambtelijk overleg in augustus werd van Haagse zijde onomwonden gesteld dat Toekomst in zicht! geen aanvaardbaar uitgangspunt bood voor een Hoofdlijnenakkoord. Het bleek lastig de impasse te doorbreken. De Nederlandse inzet om de financieel-economische problemen op te lossen vóórdat de staatkundige veranderingen zouden worden geëffectueerd, vond geen gehoor bij het land en de eilanden. Van hun kant wilden de Antillen juist zo spoedig mogelijk, nog voor de Statenverkiezingen in januari 2006, het principebesluit nemen dat het land zou worden opgeheven en dat de eilanden vóór juni 2007 hun nieuwe status daadwerkelijk zouden krijgen. ${ }^{142}$

De impasse leidde tot wederzijdse wrevel over stagnatie. Saba, dat al geruime tijd aandrong op bilaterale onderhandelingen met Den Haag, deed nogmaals zijn beklag bij de dekolonisatiecommissie van de VN. Bij monde van Will Johnson - die meermalen in felle bewoordingen kritiek had geleverd op wat hij zag als de lakse houding van Nederland ('should hang its head in shame') en de dominantie van Curaçao ('Saba is weary of advices brought out all the time by strictly pro Curaçao institutions') - liet Saba opnieuw weten dat Nederland de oren te veel naar Curaçao liet hangen. Deze acties hadden wel enig succes: Nederland liet weten informeel met de afzonderlijke eilanden te willen spreken. Het kabinet weersprak echter traineren: waar het al op 17 december 2004 een eerste reactie had gegeven op het rapportJesurun, was er medio 2005 nog steeds geen Antilliaans standpunt ontvangen. ${ }^{143}$

Daags voor een nieuw Antilliaans Topoverleg informeerde Pechtold de Kamer over de stand van zaken. Zijn eigen standpunten had hij enkele weken eerder in een vertrouwelijk 'non-paper' aan Ys voorgelegd. 
Hij had daarin benadrukt dat het komen tot een Hoofdlijnenakkoord over het schuldvraagstuk, de rechtszekerheid, de deugdelijkheid van bestuur en het revitaliseren van de economie cruciaal voor Nederland was. Voor het eerst verklaarde Nederland zich nu bereid tot sanering van de Antilliaanse staatsschuld, die op ruim 2,4 miljard euro werd geschat. ${ }^{144}$

Een wel zeer te elfder ure verzonden brief aan de Kamer ademde dezelfde geest, maar was nog wat harder gesteld. Daarin speelde wellicht mee dat de Antillen hadden aangegeven te willen praten op basis van het in Haagse ogen volstrekt ontoereikende Toekomst in zicht! ${ }^{145}$ Pechtold schreef op 24 augustus - aan de vooravond van nieuw Antilliaans Topoverleg - de Kamer in dramatische bewoordingen over de crisis van de Antilliaanse overheidsfinanciën en de noodzaak tot drastisch ingrijpen. Hij signaleerde stagnatie op vele fronten en het achterwege blijven van een werkelijke 'beleidsomslag' aan Antilliaanse zijde. Dit sterkte het kabinet in de opvatting dat 'geen bestuurlijke veranderingen kunnen worden doorgevoerd zonder eerst concrete maatregelen te nemen om de overheidsfinanciën en de economie aan te pakken, waarbij ook economische hervormingsmaatregelen nodig zijn'. Waar Pechtold in zijn 'non-paper' nog over 'parallelle' trajecten had gesproken, noemde hij staatkundige herstructurering nu 'het sluitstuk': 'Goed en transparant bestuur met degelijke overheidsfinanciën, een robuuste rechtshandhaving en een effectief sociaaleconomisch beleid zijn nodig voordat een begin kan worden gemaakt met het doorvoeren van staatkundige veranderingen. ${ }^{146}$

Het derde Antilliaanse Topoverleg, op 25 en 26 augustus 2005, gaf opnieuw een beeld van teleurstelling en wrevel over dreigend uitstel van de ontbinding van het land, diepe onderlinge verschillen en bovendien gemengde, en vanuit Curaçao ronduit afwijzende, reacties op het door de werkgroep-Jesurun aanbevolen versterkte toezicht van het Koninkrijk op de financiën, de rechtshandhaving en het openbaar bestuur. 'Het Koninkrijk valt in de praktijk samen met Nederland, zo groot is het democratisch deficit', verwoordde Cova de onvrede. Dit zou Pechtold tot een opmerkelijke potentiële concessie brengen: ' $\mathrm{Za}$ ken als financiën, rechtshandhaving en goed openbaar bestuur hoeven geen Koninkrijkstaken te zijn. Als er maar afspraken gemaakt worden over hoe je daarmee omgaat. ${ }^{147}$ Opmerkelijk is overigens dat een van de voorstellen van de werkgroep-Jesurun, en ook van de Raad van State, om te voorzien in het democratisch deficit, namelijk de instelling van een Koninkrijksdienst, nauwelijks meer besproken werd.

Tijdens het Topoverleg werd, met toestemming van Pechtold, diens eerdere 'non-paper' alsnog openbaar gemaakt. ${ }^{148}$ Daarmee werd dus 
ook de Haagse bereidheid tot aanzienlijke schuldsanering wereldkundig, alsmede een heel draaiboek met als uitkomst de ontmanteling van het Antilliaanse staatsverband. Gelijktijdig noemde de notitie weer de bekende voorwaarden, die aan Antilliaanse zijde voorspelbare kritiek opriepen. Het overleg leverde weinig op. Curaçao liet aantekenen eerst bilateraal met Nederland te willen onderhandelen. Het eilandsbestuur verklaarde onomwonden dat 'niemand, Pechtold, de Antilliaanse regering noch de andere eilanden, Curaçao mag belemmeren op zijn weg naar autonomie en daar al helemaal geen eisen aan mag stellen'. De Curaçaose opstelling wekte ergernis bij alle andere partijen. ${ }^{149}$

Uit de Slotconclusies bleek wel consensus over het vasthouden aan de data van 27 en 28 oktober 2005 voor een RTC. Dat was op zijn minst ambitieus. Pechtold had immers de Antillen aan de vooravond van het Topoverleg indirect onder zware druk gezet met genoemde Kamerbrief, waarin hij verdere medewerking aan de bestuurlijke hervormingen weigerde als er niet eerst sprake was van concrete maatregelen om de overheidsfinanciën en de economie aan te pakken. ${ }^{150}$ Deze harde toon, naar mag worden aangenomen mede ingegeven door zijn ambtelijke staf, kwam Pechtold op stevige kritiek te staan, niet alleen van Antilliaanse zijde. In zijn notitie 'Hoe het op de Antillen wel heeft gewerkt' verweet Ys Pechtold een onheus negeren van 'de mate van de Antilliaanse commitment in de aanpak van de problemen'; de Antillen hadden de afgelopen jaren al, in het kader van het IMF-traject, een financieel hervormingsproces ondergaan 'dat binnen het Koninkrijk z'n weerga niet kent'. Bovendien: 'Met deze brief en de toonzetting ervan wordt een gezond overleg tussen de Koninkrijkspartners en de eilandgebieden schier onmogelijk gemaakt. ${ }^{151}$

De Tweede Kamer uitte, mede op basis van Ys' notitie en vervolgens ook gesprekken van de Antilliaanse premier en zijn staf met betrokken parlementariërs, forse kritiek op Pechtolds aanpak. Een Kamermeerderheid van CDA, VVD, PVDA en SP billijkte de ergernis van Ys over Pechtolds 'uitglijder' (Van Bommel) en bekritiseerde de harde toon. ${ }^{152}$ Pechtold kon weinig anders dan deze toon matigen en in een gesprek met Ys de onenigheid bijleggen. Hij gaf nu weer aan, conform het eerdere non-paper, dat er 'langs parallelle trajecten' zowel over een nieuwe staatkundige structuur als over de financieeleconomische problematiek kon worden gesproken. ${ }^{153}$

Hiertoe vond op 17 september bestuurlijk overleg plaats, op $\mathrm{Cu}$ raçao, tussen Nederland, de landsregering en de vijf eilanden; Aruba was uitgenodigd als waarnemer. Hoewel Pechtold van ambtelijke zijde in niet mis te verstane bewoordingen was gewaarschuwd voor een te meegaande houding, koos hij in zijn openingsverklaring op 
17 september te Curaçao voor een meer verbindende en enthousiasmerende toonzetting. ${ }^{154}$ Hij sprak van het uitstippelen van een gezamenlijke routekaart naar een nieuwe toekomst voor de eilanden. De speech, op basis van een document 'Spreekpunten', verliep langs trefwoorden als 'start', 'finish', 'obstakels', 'gezamenlijke routekaart', 'onderweg goed naar elkaar luisteren', 'elkaar helpen met verzorgen van de blaren', 'stevig warmlopen', 'niet onvoorbereid op weg gaan want dan kans op lelijke blessure', 'voor de aanpak van schuldpositie en begrotingstekorten meer nodig dan een noodverbandje'. Onderling vertrouwen was het kernbegrip, terwijl Pechtold nu ook alle ruimte gaf voor het bespreken van maatwerk: dan 'loop ik even met een paar van $\mathrm{u}$ apart om ons daarna weer bij de rest van de groep te voegen'. Er zou geen uitgebreid verslag van de besprekingen komen. De resultaten moesten worden vastgelegd in een Gemeenschappelijke Verklaring, die zou fungeren als aanzet voor het te sluiten Hoofdlijnenakkoord en de RTC. ${ }^{155}$

Tijdens dit overleg schoof Nederland voor het eerst aan bij de besprekingen met de individuele eilanden over de opheffing van de Antillen. Er ontstonden verhitte discussies, maar uiteindelijk werd wel een 'agenda-akkoord' bereikt dat in oktober, na bilaterale overleggen, moest leiden tot een Hoofdlijnenakkoord dat weer moest uitmonden in de 'uiterlijk vóór het einde van 2005' te houden RTC. Conform Haagse wensen werd voorzien in een gefaseerde aanpak, waarbij nog niet was vastgelegd wanneer de Antillen formeel zouden ophouden te bestaan. Drie ambtelijke werkgroepen zouden zich richten op de vormgeving van de bilaterale banden met Nederland, de financiele startpositie van de eilanden en kwesties van rechtszekerheid en deugdelijkheid van bestuur. Ook zou de Rijksministerraad een voorbereidingscommissie (v-RTC) instellen, waartoe tevens Aruba zou worden uitgenodigd. Pechtold had zich, conform de ambtelijke adviezen, onthouden van toezeggingen over de hoogte van de toekomstige Nederlandse financiële bijdrage. ${ }^{156}$

Het volgende bestuurlijk overleg zou plaatsvinden op 21 oktober, met als doel het sluiten van een Hoofdlijnenakkoord. De Slotverklaring stelde vast dat 'de Regering van de Nederlandse Antillen en de eilandgebieden, met uitzondering van Sint Eustatius [dat immers per referendum voor voortzetting van de Antillen had gekozen], in dit proces streven naar realisatie van de nieuwe staatkundige verhoudingen op 1 juli 2007'. Pechtold had slechts verklaard rekening te zullen houden met dit streven; bij BZK bestond nog steeds grote twijfel over de haalbaarheid van een RTC in 2005 en temeer over de datum van 2007. In de Kamer verklaarde de minister dat er 'stevig op de inhoud' was onderhandeld en dat voor het vervolgtraject 'veel bestuurlijke 
lef' nodig zou zijn. ${ }^{157}$ Dit bleek al direct toen Ys verklaarde dat er dus 'geen koppeling tussen de parallelle trajecten bestaat', een stelling die Pechtold met klem tegensprak. ${ }^{158}$

Het volgende traject was nu de voorbereiding van het Hoofdlijnenakkoord. Steeds duidelijker werd dat het meeste ambtelijke voorwerk in Den Haag moest worden verricht. In de voorbereidingsfase zou Pechtold op alle eilanden gaan spreken over de wederzijdse verwachtingen en eisen. Het ambtelijke advies aan de minister over een concepttekst was helder: 'Hoe vager de inhoud, hoe groter de kans op een akkoord.' Ook moest Nederland de eilanden niet overvallen met volledig uitgewerkte ideeën. Strategisch was het verstandig de kleine eilanden als breekijzer in te zetten voor Sint Maarten en Curaçao. Het uiteindelijke Hoofdlijnenakkoord diende minimaal toetsingscriteria te bevatten voor de nieuwe statussen en een handvat te bieden voor een snelle aanpak op de terreinen van financiën, economie, rechtshandhaving en goed bestuur. ${ }^{159}$

Een door de Tweede Kamer aanvaarde motie van Wim van Fessem (CDA) c.s. om Bonaire een voortrekkersrol in het staatkundige veranderingsproces toe te bedelen strookte goed met de ambtelijke advie-

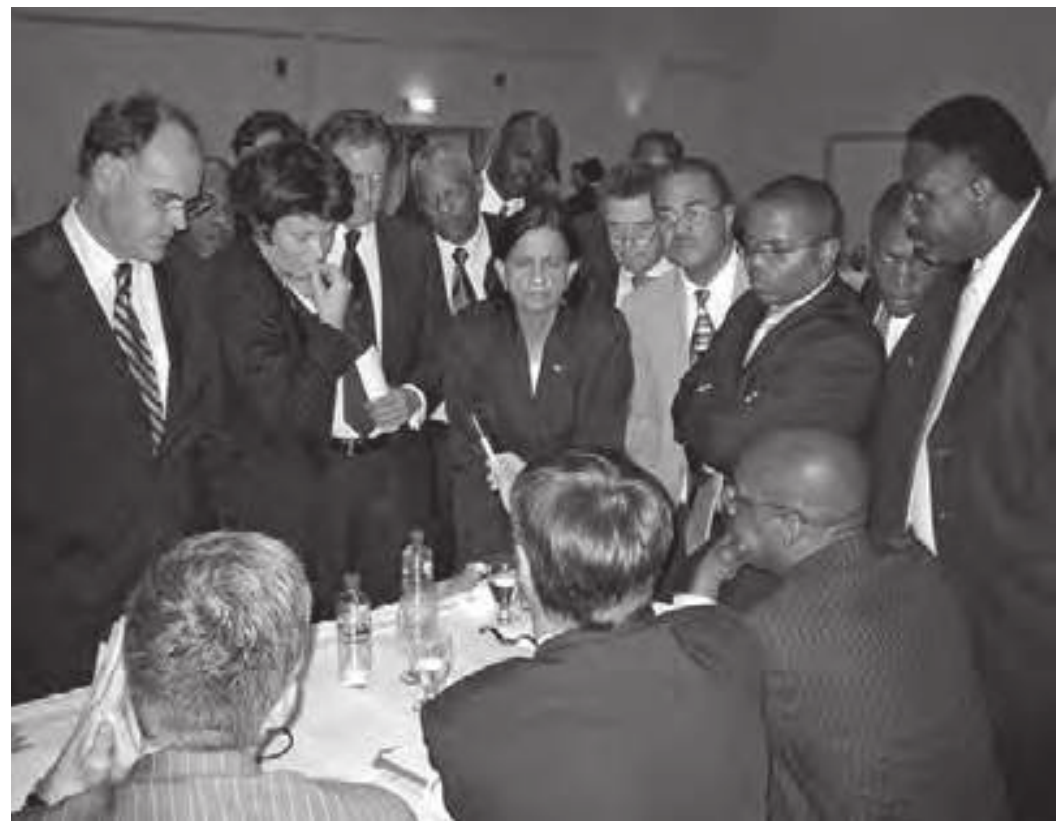

Overleg tijdens start-RTC, Curaçao, 26 november 2005; op de rug v.I.n.r. Richard van Zwol, Jan Peter Balkenende, Raymond Begina; tegenover hen v.I.n.r. Leon van Halder, Clive van Putten, Gita Salden, Alexander Pechtold, Julien Larmonie, Eugene Holiday, Sarah WescottWilliams, Freek van Beetz, Freddie Curiel, Etienne Ys, Roy Hooker, Sedney Ignacio. 
zen om de kleine eilanden als breekijzer te beschouwen. ${ }^{160}$ Bonaire had namelijk al een uitgewerkt plan opgesteld met het oog op de toekomstige staatkundige verhoudingen. Pechtold stemde dan ook graag toe. 'De bilaterale trajecten hebben wat mij betreft meer ruimte dan ik misschien eerder heb aangegeven.' En: 'Ik zie dat die bilaterale processen belangrijk zijn om het hoofdproces tussen de landen vlot te houden.' Illustratief voor het belang van directe, persoonlijke banden is in dit verband ook het volgende. Dankzij de bemiddeling van CDAprominent Hans Hillen had Ramonsito Booi, leider van de regerende Bonairiaanse UPB, Pechtold in het najaar van 2005 zover gekregen dat hij de minister tijdens diens vrije weekend op Texel mocht opzoeken. Het resultaat van hun gesprek was dat Bonaire ook door Pechtold steeds meer werd gezien als de ideale voortrekker van het ontmantelingsproces en dat hij meer ging inzetten op 'bilateraaltjes. ${ }^{161}$

In oktober 2005 gaf Pechtold aan de Tweede kamer te kennen dat de nieuwe statussen van Curaçao en Sint Maarten niet noodzakelijk onderling gelijk of gelijk aan die van Aruba zouden zijn. ${ }^{162}$ In de aanloop naar het Hoofdlijnenakkoord legde Nederland een concept-KB voor ter instelling van de voorbereidingscommissie RTC en van de drie ambtelijke werkgroepen. De afwijzende Antilliaanse reacties over het gezamenlijk ontwikkelen van normen waaraan de nieuwe entiteiten zouden moeten voldoen, illustreerden dat er nog steeds grote meningsverschillen waren. ${ }^{163}$

Op 21 oktober zou op Bonaire het overleg worden gevoerd dat moest leiden tot een daadwerkelijk Hoofdlijnenakkoord. Pechtold vertrok de $14^{\mathrm{e}}$ al naar de Antillen voor een reeks bilaterale besprekingen, met het in Den Haag opgestelde concept op zak. Op Sint Maarten werd uitvoerig gesproken over zaken als het eilandelijke aandeel in de staatsschuld, maar het lastigste thema was dat van de integriteit van bestuur, in het bijzonder van politici. ${ }^{164}$

Gemakkelijker waren de gesprekken met de drie kleinste eilanden. Op initiatief van Bonaire werd een Intentieverklaring overeengekomen tussen Nederland enerzijds en Bonaire, Sint Eustatius en Saba anderzijds. Deze Intentieverklaring zou een onderdeel vormen van het te sluiten Hoofdlijnenakkoord en gaf in een breed kader de toekomstige bilaterale verhoudingen weer. In de nieuwe relatie tussen Nederland en de drie kleine eilanden zou veel nadruk liggen op directe samenwerking, garanties voor integer bestuur, bewaking van de kwaliteit van de rechtsorde, zorg voor deugdelijke overheidsfinanciën en het nakomen van internationale verplichtingen. Van ambtelijke zijde was Pechtold er tevoren aan herinnerd dat ook op Bonaire, Sint Eustatius en Saba op deze terreinen nog veel moest gebeuren. ${ }^{165}$

Op Curaçao werd vervolgens in overleg met het eilandelijk bestuur 
en de landsregering het concept van het Hoofdlijnenakkoord nog wat aangepast. Daarbij werd echter niet tegemoetgekomen aan de principiële bezwaren die de eilandsraad, onder verwijzing naar het zelfbeschikkingsrecht, bleef aanvoeren tegen beperking van de autonomie. Pechtold legde daarnaast veel nadruk op het 'integriteitstraject'. ${ }^{166}$

De bewindsman ging het eigenlijke bestuurlijke overleg met de landsregering en alle vijf eilanden op 21 oktober in met het dringende ambtelijke advies om het maken van concrete afspraken over de omvang van de schuldsanering zo veel mogelijk naar achteren te schuiven. Dit was immers 'een van de weinige wortels die Nederland de Antillen kon voorhouden'. ${ }^{167}$ Het overleg liep uit op een marathonsessie van zestien uur, waarin de emoties regelmatig hoog opliepen. Een verslag van twee onderhandelaars voor de Antillen repte later over 'moeizaam onderhandelen', 'soms vinnige debatten', 'een crisissfeer' en 'vele schorsingen'. Hun anekdote dat tijdens een heftig dispuut met Pechtold Ys demonstratief opstond om 'zijn handen te gaan wassen' en langdurig wegbleef, wordt door beide voormalige bewindslieden bevestigd. ${ }^{168}$

Pas in de vroege ochtend van 22 oktober konden de partijen een Hoofdlijnenakkoord sluiten, waarvan ook de Intentieverklaring met Bonaire, Sint Eustatius en Saba deel uitmaakte. Het akkoord lag dicht bij Pechtolds oorspronkelijke inzet, die zich na afloop dan ook tevreden betoonde. Het land de Antillen zou verdwijnen. De overheidsfinanciën zouden worden doorgelicht en vervolgens geherstructureerd; er werd nog niet vastgelegd dat Nederland substantieel zou bijdragen aan een eventuele schuldsanering. Wel was afgesproken dat financieel toezicht en aanvullende maatregelen de garantie moesten bieden dat niet opnieuw onaanvaardbare schulden zouden worden gemaakt. Den Haag had zich niet vastgelegd op de wens van Curaçao en Sint Maarten om een autonome landsstatus te verkrijgen per 1 juli 2007. In de Intentieverklaring was een apart traject voor onderhandelingen met de drie kleinste eilanden vastgelegd, overigens zonder verdere deadlines. Het akkoord moest de basis vormen voor de start-RTC, dan ook inclusief Aruba, die inmiddels was uitgesteld tot 26 november 2005. ${ }^{169}$

Het Hoofdlijnenakkoord bestond uit zeven secties. De eerste sectie bevatte de gemeenschappelijke afspraken, waaronder de bepaling dat in het proces van staatkundige hervormingen normen en criteria zouden worden opgesteld die aansloten bij de waarborgfunctie van het Koninkrijk. Het staatkundige veranderingsproces zou bestaan uit een ontwerp- en een implementatiefase, die qua inhoud en tijd per eiland konden verschillen. Vastgelegd werd dat het land, Curaçao, Bonaire, Sint Maarten en Saba streefden naar realisatie van de nieu- 
we staatkundige verhoudingen per 1 juli 2007-een door Den Haag als onrealistisch beschouwde datum die dan ook niet als norm zou gelden. De eerste sectie omvatte verder afspraken over de financiële doorlichting en het opzetten van een 'Sociaal-Economisch Initiatief', bestaande uit een aanpak van de overheidsfinanciën, herstructurering van de economie, een investeringsimpuls en een sociaal vangnet - voor de laatste twee punten verklaarde Nederland zich bereid om niet nader gespecificeerde middelen beschikbaar te stellen.

De tweede sectie bevatte afspraken tussen Nederland en het land de Antillen, vooral dat lopende trajecten op het gebied van veiligheid, armoedebestrijding en integriteitswetgeving in de tussentijd onverkort zouden worden voortgezet, evenals de implementatie van terrorismeverdragen. De vijf volgende secties betroffen bilaterale afspraken tussen Nederland en de afzonderlijke eilandgebieden. De eilanden committeerden zich onder meer aan een financiële doorlichting, het vaststellen van de schuldenpositie en een traject van bestuurlijke integriteit. Een en ander zou in werkgroepen nader worden uitgewerkt.

Met de ondertekening van het Hoofdlijnenakkoord was na het bestuurlijk overleg van 17 september een tweede belangrijke stap gezet naar nieuwe verhoudingen binnen het Koninkrijk. Dat de Antillen hiermee hadden geaccepteerd een brede agenda - ook rond openbare financiën, economie, rechtshandhaving en goed bestuur - in het ontmantelingstraject te zullen voeren, was voor Nederland cruciaal.

\section{Van start-RTC tot 'Partners in het Koninkrijk'}

Zo was de weg vrijgekomen voor de RTC, waarmee het proces van staatkundige veranderingen in het Koninkrijk ook officieel van start kon gaan. Op 11 november 2005 stemde de Rijksministerraad in met de noodzakelijke Koninklijke Besluiten. De v-RTC werd ingesteld, alsmede drie werkgroepen: Directe/Nieuwe Banden met Nederland; Rechtszekerheid en Deugdelijkheid van Bestuur; en Algemene Financiële Positie. Het algemeen secretariaat lag bij het ministerie van AZ; de Nederlandse ambtelijke vertegenwoordiging in de werkgroepen werd gedomineerd door de directie KR van BZK. ${ }^{170}$

Op 26 november 2005 werd de start-RTC op Curaçao geopend door Balkenende, q.q. als voorzitter van de Rijksministerraad. De Antillen en Aruba werden vertegenwoordigd door hun premiers en enkele kabinetsleden. Van de eilandgebieden waren leden van de bestuurscolleges aanwezig, samen met door hen aangewezen woordvoerders. Nederland werd vertegenwoordigd door Pechtold. Er stond veel op 
het spel; niet onbegrijpelijk was op de Antillen verbolgen gereageerd op de beperkte tijd (vijf uren) die op een zaterdag voor de conferentie was uitgetrokken. ${ }^{171}$

Balkenende stelde in zijn openingsverklaring dat het ging om 'een historische stap' want het was het 'begin van een proces waarin wij opnieuw definiëren wat ons met elkaar verbindt'. Op basis van 'verscheidenheid en verbondenheid' zou worden gewerkt aan een gezamenlijke toekomst. De in de komende periode te maken afspraken moesten duurzaam zijn. Het ging om 'nieuwe verhoudingen, geschraagd door de rechtsstaat, goed bestuur en gezonde financiën'. Het was een gezamenlijke verantwoordelijkheid deze resultaten te bereiken. Duidelijk was geworden dat binnen het Koninkrijk in de loop van de jaren te veel was uitgegaan van 'one size fits all'. Dat had niet gewerkt. De centrale boodschap van deze RTC was daarom om de verscheidenheid te laten doorklinken in de bestuurlijke verhoudingen en in de manier van samenwerking, op zoek naar maatwerk. Dit ruimte geven aan de verscheidenheid kon alleen doordat er ook verbondenheid was, behalve door het Statuut ook door het Koninklijk Huis. Bovendien waren de landen en eilanden verbonden door gedeelde waarden, en door de steeds intensievere contacten over en weer - een verrijking, in persoonlijke zin, maar zeker ook voor de samenwerking binnen het Koninkrijk. Ten slotte benadrukte Balkenende dat de keuze voor het Koninkrijk niet alleen rechten met zich meebracht, maar ook verantwoordelijkheden en verplichtingen. ${ }^{172}$

Gedeputeerde Sedney Ignacio van Curaçao (FOL) stelde in zijn openingsverklaring dat het duidelijk was dat de Antilliaanse constructie zichzelf had overleefd en dat Curaçao van harte zou meewerken aan de verwezenlijking van de wensen van de diverse eilandgebieden, waarbij hij hoopte dat dezelfde medewerking ook zou worden gegeven aan het bereiken van de positie van autonoom land binnen het Koninkrijk voor Curaçao. Curaçao was niet meer in staat de last van de Antilliaanse constitutie te dragen en had ruimte nodig om zich te kunnen ontwikkelen. Ignacio verwees ook naar de eerdere loyale medewerking aan de verwezenlijking van de wensen van Aruba, zodat het eiland ervan uitging 'ten minste dezelfde positie [te] zullen verwerven als Aruba'. De grootste uitdaging was ervoor te zorgen dat de nieuwe staatkundige eenheden een eerlijke kans zouden krijgen en niet werden opgezadeld met een desastreuze erfenis en beladen met schulden.

Wescott-Williams benadrukte in haar (Engelstalige) openingsverklaring dat Sint Maarten al sinds de jaren negentig volhardend streefde naar een status aparte en hierbij veel tegenstand had ondervonden. Booi memoreerde dat Bonaire reeds twee keer een serieuze 
poging had gedaan om een directe relatie met Nederland te krijgen. Hij hoopte dat de derde keer scheepsrecht zou zijn. Bonaire, maar ook Saba en Sint Eustatius, rekenden op een goede afloop, mede gebaseerd op de Intentieverklaring.

Ys stelde in zijn openingsverklaring dat zijn regering zich van meet af aan met kracht had ingezet om invulling te geven aan de keuze van de eilanden, met als uitgangspunt 'Het zelfbeschikkingsrecht is heilig'. In het verleden was te veel naar staatkundige structuren gekeken met een Europese bril, nu moest vooral met een Antilliaanse bril gezocht worden naar een nieuwe staatsvorm, die flexibel genoeg zou zijn in deze tijd van globalisering. Einddoel was een nieuwe staatkundige structuur waarin de eilanden met een schone lei konden beginnen.

Pechtold benadrukte vervolgens dat het ging om tweerichtingsverkeer. 'Het enige eenrichtingsverkeer dat bestaat in het Koninkrijk, is het Koninkrijk uit.' Daarom moesten nu gezamenlijk normen en criteria worden opgesteld, in aansluiting op de waarborgfunctie van artikel 43 Statuut. Tweerichtingsverkeer betekende ook wederzijds respect. Tijdens de bestuurlijke overlegrondes had Pechtold aangegeven dat aan onderling vertrouwen moest worden gewerkt. 'Wij werken aan een Koninkrijk op maat', waarbij ook in de toekomst samenwerking tussen de eilanden, en met Aruba en Nederland, nodig zou zijn - zodat het Koninkrijk als geheel aan de eisen van rechtsstatelijkheid kon voldoen. In het belang van de burgers van het Koninkrijk moesten nu goede afspraken worden gemaakt over openbare financiën, rechtsorde en goed bestuur.

De Arubaanse premier Oduber sprak de wens uit dat de landen binnen het Koninkrijk meer en beter gebruik gingen maken van de Statutaire bepalingen rond onderlinge bijstand, overleg en samenwerking. Daar waar wrijving ontstond door verschillen van mening over bijvoorbeeld de rechtshandhaving, rechtspleging en de financiele huishouding lag er een rol voor het Koninkrijk. Aruba verlangde bovenal 'rust en stabiliteit. Wij willen dat onze normen en waarden worden gerespecteerd en dat onze staatkundige verworvenheden onberoerd worden gelaten.' Overigens achtte Oduber het tijd om ook het 'sociale deficit' binnen het Koninkrijk op te heffen; hij doelde daarmee op de welvaartsverschillen.

Roy Hooker (DP) stelde dat Sint Eustatius altijd als verbindende, inschikkelijke factor had opgetreden, eerst binnen de Bovenwindse eilanden, vervolgens binnen het land de Nederlandse Antillen - met als resultaat dat het eiland aanzienlijk verzwakt was geraakt. 'Statia' rekende erop dat het Koninkrijk in de behoeften van de zwaksten zou voorzien. Ook Saba rekende op een goede afloop. Een directe band met Nederland was, zo stelde Will Johnson (WIPM), een al sinds 1973 
gekoesterde wens. 'Nu kan het en nu moet het.' Zo niet, dan zou Saba zich genoodzaakt zien om zich opnieuw over het uitoefenen van het zelfbeschikkingsrecht te beraden. En dan sloot Johnson 'niet uit dat de bevolking ditmaal voor onafhankelijkheid zal kiezen' - een verrassend 'dreigement'.

Tijdens de conferentie domineerden drie thema's. De eilanden wensten van Nederland erkenning van de referendumuitslagen. Omdat dit echter de indruk kon wekken dat Nederland zich onvoorwaardelijk inspande om de door de eilanden gewenste staatkundige statussen te realiseren - 'dat gaat te ver' - werd gesproken van 'het respecteren van de uitslagen'. ${ }^{173}$ Daarnaast wensten nagenoeg alle eilanden de datum van 1 juli 2007 opgenomen te zien als de einddatum voor het proces van staatkundige veranderingen. Omdat Den Haag dit 'weinig realistisch' achtte, werd gesproken van 'een streefdatum'. ${ }^{174}$ Ten slotte was er veel discussie over de schuldenproblematiek. In de Slotverklaring zou uiteindelijk het 'gezamenlijk uitgangspunt' worden vastgelegd dat de nieuwe entiteiten een 'gezonde startpositie' zouden krijgen, waarbij de financiële huishouding op orde zou zijn en blijven. ${ }^{175}$

De extra stap die Nederland nu, na het Hoofdlijnenakkoord, wilde zetten, was enerzijds het bieden van een oplossing voor de schuldenproblematiek en anderzijds het overeenkomen van een financieel instrumentarium om de overheidsfinanciën blijvend op orde te brengen. Pechtold betoogde: 'Ik ben bereid geen veto uit te spreken over de wijze van sanering, mits er vanuit het land en de eilanden geen veto ligt op de daarbij te stellen voorwaarden.' De Antillen wensten een totale schuldsanering en hadden zelf meermalen aangegeven dat afspraken gemaakt moesten worden om een herhaling van de schuldopbouw in de toekomst te voorkomen. Niettemin bleven zij aanvankelijk afhoudend over de precieze voorwaarden waaronder de sanering in Haagse ogen moest plaatsvinden, in het bijzonder waar het financieel toezicht betrof. Begrijpelijkerwijs waren de Antilliaanse onderhandelaars niet van zins wel al in te stemmen met voorwaarden zonder dat Nederland had vastgelegd de schuldsanering te willen financieren. Na een schorsing kwamen Pechtold en Ys uiteindelijk met een concepttekst over de schuldpositie, met daarin onder meer de verzekering 'Nederland zal een oplossing bieden voor de schuldenproblematiek'. Ys was bereid zich vast te leggen op het voorkomen van nieuwe schulden als er eerst schoon schip werd gemaakt. ${ }^{176}$

Mooi is de anekdote over dat 'schoon schip maken'. Toen deze term viel tijdens de besprekingen vroeg Statia's gedeputeerde Hooker zich hardop af 'hoe schoon is "schoon"?' Hierop, zo herinneren betrokkenen zich, antwoordde Pechtold in de trend van 'helemaal schoon', wat 
werd opgevat als een toezegging dat alle schulden zouden worden overgenomen. Waarop Balkenende, al dan niet gespeeld, Pechtold zei dat dit in de ministerraad nog wel een stevig gesprek met zijn collega van Financiën zou opleveren. Deze anekdote wordt allerwegen herhaald; het blijft enigszins omstreden of Hooker met zijn aandringen een nieuwe toezegging verzilverde, of dat Pechtold en Balkenende, met medeweten van Zalm, slechts een spelletje speelden. Duidelijk is wel dat Balkenende en Zalm tevoren positieve signalen hadden afgegeven. ${ }^{177}$

De RTC was door alle partijen ervaren 'als een bijzonder moment'. ${ }^{178}$ Er hadden vooral stevige discussies plaatsgevonden over de schuldpositie van het land en van de eilandgebieden. De belangrijkste uitkomst was dat Nederland, om de nieuwe entiteiten een gezonde start te geven, een oplossing zou bieden voor de op 2,4 miljard euro geraamde schulden van de Antillen (waarvan uiteindelijk 1,7 miljard euro zou worden gesaneerd). Daarbij had hard onderhandelen van de delegatie van Sint Maarten, in het bijzonder Eugene Holiday en Dennis Richardson, ertoe geleid dat de betalingsachterstanden van het eiland - dat zelf geen leningen mocht aangaan - uiteindelijk op dezelfde wijze zouden worden meegenomen als de schulden van de lands- en Curaçaose overheid. Dit is een wapenfeit dat op Sint Maarten wordt herinnerd als blijk van de noodzaak de Antilliaanse regering te corrigeren, die toch de neiging zou hebben gehad vooral voor Curaçao op te komen. In algemene zin benadrukken onderhandelaars voor Sint Maarten ook hun gezamenlijke optreden, over de partijtegenstellingen heen. ${ }^{179}$

Op deze eerste concrete Nederlandse toezegging om de miljardenschuld weg te werken was achter de schermen ook aangedrongen door vicevoorzitter van de Raad van State Herman Tjeenk Willink. ${ }^{180}$ Ys toonde zich na afloop heel tevreden met deze belofte van Nederland en complimenteerde Balkenende met zijn leiding - achteraf was het korte tijdsbestek voor de RTC toch voldoende geweest. Balkenende en Pechtold spraken zich al even positief uit over het verloop en de resultaten. ${ }^{181}$

In de Slotverklaring van deze 'start-RTC' verbonden alle partijen zich aan alle eerdere akkoorden. ${ }^{182}$ Ook maakten zij afspraken over de wijze waarop invulling zou worden gegeven aan het verdere proces. Dit zou verlopen langs twee trajecten, een voor de ' $\mathrm{K}_{3}$ ' (een verwijzing naar 'kleine eilanden') en een voor Curaçao en Sint Maarten. Er was voorzien in een reeks vervolgconferenties. Gedurende 2006 zouden de eilanden in strak tempo zelf hun transitie moeten voorbereiden, waarbij hun voorstellen en de uitwerking daarvan zouden worden getoetst aan het Statuut en de Slotverklaring van de RTC. Op 
een in januari 2007 te houden Slotconferentie zouden dan de resultaten worden getoetst. Werden alle deadlines gehaald, dan zou het Koninkrijk op 1 juli 2007 worden uitgebreid met twee landen en drie eilanden met een directe band met Den Haag. Nederland bleef uitgesproken sceptisch over de haalbaarheid van die datum.

Pechtold benadrukte in de Kamer de voorwaardelijkheid van de Nederlandse toezeggingen, ook op financieel terrein: geen schuldsanering zonder een deugdelijk begrotingsbeleid en streng financieel toezicht teneinde herhaling te voorkomen. 'Rechtsorde en goed bestuur komen wat mij betreft in de volgende rondetafelconferenties aan de orde.' De randvoorwaarden die zijn voorganger De Graaf in december 2004 had vastgelegd, bleven richtinggevend. Over het heikele migratiedossier was niet gesproken. ${ }^{183}$

Achteraf zou de Haagse scepsis over de haalbaarheid van 1 juli 2007 terecht blijken. In 2006 vond geen vervolg-RTC plaats. Pas in november dat jaar zou met het sluiten van de 'Slotverklaring' weer een nieuwe dynamiek in het proces komen, mede door het aantreden van een nieuwe Nederlandse bewindspersoon, Nicolaï. In de tussenliggende tijd bleken de verwachtingen en eisen over en weer nog steeds ver uiteen te liggen. Dit werd ook al snel duidelijk in de drie ambtelijke werkgroepen, Rechtszekerheid en Deugdelijkheid van Bestuur (RDB), Algemene Financiële Positie (AFP) en Directe/Nieuwe Banden met Nederland (DNB). De interne Haagse rapportages getuigden van geringe voortgang; de oorzaak, zo meende men, lag zowel in politieke verschillen als in onvoldoende ambtelijke capaciteit op de eilanden. Daarnaast moesten sommige principiële keuzen nog gemaakt worden: moesten de $\mathrm{K}_{3}$ nu gemeenten worden of een andere status krijgen? ${ }^{184}$

Op verzoek van de Vaste Commissie NAAZ lichtte Pechtold begin 2006 toe dat er nog geen definitieve afspraken waren gemaakt over de status van de $\mathrm{K}_{3}$. Aan het begrip 'Koninkrijkseiland' was nooit concrete invulling gegeven, ook niet in 1993, op de Toekomstconferentie; de vraag was nu welke voorstellen de eilanden en de werkgroep DNB zouden doen. 'Speerpunt van mijn beleid is de zelfstandigheid van de Koninkrijkspartners te bevorderen', schreef de minister. Directe toepassing van de Gemeentewet lag daarom niet voor de hand. 'Deze wet is daarvoor teveel op de Nederlandse leest geschoeid en sluit niet aan bij de bijzondere omstandigheden van de eilanden., ${ }^{185}$

Uiteindelijk zouden de $\mathrm{K}_{3}$ de positie van 'openbare lichamen' krijgen, op basis van de genoemde voorlichting van de Raad van State van het Koninkrijk van 18 september 2006 (waarover later meer) - en overigens met voorbijgaan aan de uiteindelijke voorstellen van de werkgroep DNB. In de uitwerking van deze keuze zou primair worden gekeken naar het Nederlandse gemeentemodel, terwijl de optie 
van een associatief verband, verankerd in het Statuut, mogelijk eenvoudiger was geweest en zeker meer ruimte had gelaten voor aansluiting op de lokale regelgeving. Uitgerekend Hirsch Ballin had, in zijn periode als lid van de Raad van State, dit associatiemodel als het meest voor de hand liggend aanbevolen. De werkgroep DNB zou zich nog meermalen uitspreken voor een integratiemodel, maar beoogde daarbij niet direct dat de eilandgebieden ook onderdeel zouden worden van de Nederlandse rechtsorde. ${ }^{186}$

Pechtold lichtte de Vaste Commissie NAAZ voorts in dat Curaçao en Sint Maarten niet per se dezelfde status als Aruba zouden krijgen. De ontwikkelingen sinds 1986 (toenemende grensoverschrijdende criminaliteit, behoefte aan adequaat financieel toezicht op Koninkrijksniveau) rechtvaardigden het om een 'status aparte op maat' te overwegen. ${ }^{187}$ Uit het overleg met de commissie bleek onder parlementariërs de zorg te leven dat vooral op Curaçao de resultaten van de RTC als een 'blanco cheque' werden beschouwd. Van Fessem betwijfelde of de boodschap goed was aangekomen dat de taken en verantwoordelijkheden van de Koninkrijksregering zouden toenemen, conform het rapport-Jesurun. Andere sprekers sloten daarop aan. Er waren twijfels over een landsstatus voor Sint Maarten en over de datum van 1 juli 2007; ook legden de LPF en VVD het verband met een toelatingsregeling voor Antillianen in Nederland. Pechtold trachtte gerust te stellen. Hij was 'optimistisch' over de voortgang en verzekerde dat er geen blanco cheques waren uitgedeeld. De nadruk lag op harde afspraken en garanties op alle terreinen. Over de datum van 1 juli 2007 had hij zich consequent terughoudend opgesteld. ${ }^{188}$

Het 'historische akkoord' van de RTC kwam niettemin in Nederland onder vuur te liggen. Uitgerekend de gewoonlijk terughoudende Eerste Kamer bepleitte een hardere Haagse lijn. De senatoren gingen alleen akkoord met staatkundige hervormingen als er na schuldsanering voldoende waarborgen zouden zijn voor controle op het financiële beleid en deugdelijkheid van bestuur. Curatele werd niet uitgesloten. ${ }^{189}$

Op 14 februari 2006 diende Eerste Kamerlid Egbert Schuurman (cu) c.s. een motie in die onder meer stelde dat nieuwe staatkundige verhoudingen binnen het Koninkrijk moesten leiden tot een nieuwe definitie van de begrippen 'Koninkrijk' en 'relaties binnen dat Koninkrijk'. Deze nieuwe definitie zou ook een nadere invulling moeten geven aan cruciale Koninkrijkstaken zoals rechtshandhaving, effectief financieel toezicht en deugdelijk bestuur. De motie zag invulling van deze cruciale Koninkrijkstaken, als voorwaarde, onlosmakelijk verbonden met de beoogde schuldsanering en riep de regering op het proces van staatkundige hervormingen te eindigen met een nieuw 
Statuut; het kabinet werd dan ook verzocht een voorstel voor een nieuw Statuut te agenderen voor de volgende RTC. De motie werd kamerbreed aangenomen, met instemming van Pechtold, die de kritische Senaat als steun in de rug bij de onderhandelingen zag. Uitvoering van deze motie zou wel het risico in zich dragen van Arubaanse oppositie. ${ }^{190}$

De Tweede Kamer was eveneens kritisch. Met een uiteindelijk unaniem gesteunde motie van Klaas de Vries c.s., waarin werd gevraagd om duidelijkheid inzake het kabinetsstandpunt over de al in december 2004 uitgebrachte voorlichting van de Raad van State in verband met het vijftigjarige Statuut, had Pechtold geen moeite. Lastiger had de minister het in het debat over een vijftal andere moties, die opriepen tot een harde Haagse opstelling. Een meerderheid van CDA, VVD, LPF en SGP liet Pechtold weten dat er geen sprake kon zijn van Nederlandse toezeggingen over schuldsanering als van Antilliaanse zijde geen bereidheid bestond om financieel toezicht te accepteren en als sluitende garanties voor deugdelijk bestuur, effectief financieel beleid en een adequate handhaving van de rechtsorde zouden uitblijven. Bovendien wilde een Kamermeerderheid de schuldsanering koppelen aan instemming van de Antilliaanse regering met het plan van Verdonk om criminele Antilliaanse jongeren terug te sturen. Hoewel de door VVD'er Luchtenveld ingediende motie hierover door Pechtold ernstig werd ontraden - hij vreesde dat het onderhandelingsproces daarmee onmogelijk zou worden - werd zij aangenomen. Pechtold zou deze motie vervolgens als onuitvoerbaar terzijde schuiven. ${ }^{191}$

Op een uiteindelijk verworpen motie van De Vries en Gerard van As (LPF) die de regering verzocht om een 'eindvisie' reageerde Pechtold bezwerend: het werken met blauwdrukken was in het verleden niet succesvol gebleken. 'Wij weten dus waar wij naartoe willen: niet te veel verschillende kleuren binnen het Koninkrijk; duidelijkheid op een aantal gebieden waar nu nog geen Koninkrijkstaken liggen maar waar meer afstemming moet zijn; gezonde financiën; een goede rechtsorde en goed bestuur. ${ }^{, 192}$ Met andere, breed gedragen moties die steeds waarschuwden voor verdere concessies en voor 'blanco cheques' had Pechtold geen moeite. Hij prees de grote betrokkenheid van alle woordvoerders, maar vroeg er begrip voor dat hij enige onderhandelingsruimte moest behouden. 'Ik vind dit zo belangrijk omdat de ervaring uit [de Toekomstconferentie van] 1993, toen Nederland dit proces ook inging met de Antillen, leert dat het proces vastliep doordat Nederland te veel uitstraalde het eindbeeld voor ogen te hebben. De blauwdruk van Lubbers lag eigenlijk al klaar. Dat wordt in retrospectief gezien als een groot probleem. ${ }^{193}$

Inmiddels bleek dat in de drie ambtelijke werkgroepen veel ge- 
schilpunten bleven bestaan over de criteria waaraan de landen en eilanden in de nieuwe staatkundige situatie zouden moeten voldoen; de voortgang stagneerde. De coördinerende v-RTC concludeerde dat politiek overleg onmisbaar was om het proces weer vlot te trekken. ${ }^{194}$ Daarbij wist Pechtold zich gebonden door de kritische opstelling van het parlement, terwijl Curaçao en Sint Maarten zich ook waar het ging om quid pro quo rond de schuldsanering bleven beroepen op hun autonomie. In een persbericht kondigde Pechtold aan dat Nederland het initiatief voor politiek overleg zou nemen met de Antilliaanse regering en de vijf eilandgebieden, en dat pas daarna een definitieve datum voor de RTC zou worden voorgesteld. Dit eenzijdige besluit om de RTC, die inmiddels gepland stond voor 28 maart, uit te stellen, en in plaats daarvan bilaterale overleggen te gaan voeren, zorgde voor opschudding op de Antillen, ook al omdat het procedureel onjuist was. ${ }^{195}$

Mede in het licht van deze impasse werd de Raad van State verzocht advies uit te brengen over de toekomstige constitutionele inbedding van de $\mathrm{K}_{3}$ in het Koninkrijk; dit advies werd, zoals gezegd, in september 2006 uitgebracht. Ys gaf Pechtold intussen te kennen geen probleem te zien in nieuwe bilaterale overleggen om de impasse te doorbreken, maar wel bezwaar te hebben tegen uitstel van de RTC. Zelfs over de procedure werd geen overeenstemming bereikt. Pechtold wilde de mogelijkheid openlaten om na de bilaterale gesprekken eventueel nog een plenaire sessie te houden. Dit was voor Ys echter onaanvaardbaar: hij ontraadde de eilandgebieden ten sterkste om een bilateraal overleg met de Nederlandse delegatie te houden zonder een concrete datum voor plenair bestuurlijk overleg uiterlijk eind maart. ${ }^{196}$

Op 13 en 14 maart 2006 vond vervolgens een Topoverleg plaats tussen de landsregering en de vijf eilandgebieden over 'criteria ten aanzien van constituties, wetgeving en overheidsapparaten' van de nieuwe entiteiten. In de Slotconclusies onderschreven de delegaties het standpunt van de v-RTC dat politiek overleg een noodzakelijke stap was om te komen tot een succesvolle RTC. Zij bekritiseerden echter de eenzijdige en onreglementaire Nederlandse verdaging van de conferentie. De delegaties meenden dat de overeengekomen planning voor het vervolgtraject onverkort van kracht diende te blijven. Afronding van de ontwerpfase moest in ieder geval in juli 2006 plaatsvinden, zodat de overeengekomen einddatum van 1 juli 2007 kon worden gehaald. ${ }^{197}$

De Nederlandse Vertegenwoordiging in Willemstad berichtte dat de Slotconclusies mager waren en dus weinig vooruitgang beloofden. ${ }^{198}$ Pechtold berichtte de Kamer dat hij geen blauwdruk wilde 
opleggen, maar wel aanstuurde op concrete voortgang. ${ }^{199}$ De voorwaarden die Nederland al sinds december 2004 hanteerde, bleven bij de beoordeling van het proces onverkort van kracht. Voorts wilde Nederland verdere duidelijkheid scheppen over het raamwerk waarbinnen de staatkundige veranderingen konden plaatsvinden. De nieuwe structuur en verhoudingen moesten 'werkbaar en efficiënt' zijn. De nieuwe status zou pas ingaan nadat gebleken was dat de nieuwe constitutie, de wetgeving en het overheidsapparaat van de eilanden voldeden aan de tijdens de start-RTC vastgestelde criteria en er dus een reële overtuiging bestond dat zij de nieuwe verantwoordelijkheden ook konden waarmaken.

Er mocht bovendien, schreef Pechtold, geen 'versnippering' in de rechtshandhaving en rechtszekerheid plaatsvinden; er zou dus één Gemeenschappelijk Hof van Justitie en één OM zijn. De rechtshandhaving, veiligheid, criminaliteits- en terrorismebestrijding moesten op gelijkwaardige, samenhangende en consistente wijze verzekerd worden. De integriteit, professionaliteit en kwaliteit van de strafrechtketen moesten volstrekt gewaarborgd zijn. Een gemeenschappelijke rechtspleging, een gelijkwaardige rechtshandhaving en gelijke rechtsbescherming vergden een gelijke wetgeving. Op het gebied van deugdelijk bestuur stelde Pechtold dat de overheden op democratische wijze beleid zouden uitvoeren en ontwikkelen, dat er voldoende checks and balances moesten zijn, en dat het tevoren reeds in het Antilliaanse overheidsdocument Konfiansa vastgelegde integriteitsbeleid volledig gerealiseerd moest worden voordat de nieuwe status kon ingaan.

Op het gebied van de openbare financiën en economie somde Pechtold als randvoorwaarden op: onafhankelijk toezicht op de openbare financiën van de nieuwe entiteiten, te regelen bij Rijkswet; één gezamenlijke centrale bank en één gezamenlijke munt voor de nieuwe entiteiten; geen zelfstandige leningsbevoegdheid om nieuwe schuldenopbouw te voorkomen; financieel beheer naast goed bestuur en rechtshandhaving structureel op orde, anders geen Nederlandse bijdrage aan oplossing schuldenproblematiek; toetsdatum voor schuldsanering op 26 november; vaststelling economische hervormingsagenda.

Verder moest er een heldere regeling komen voor de instanties, procedures en verantwoordelijkheden rond het buitenland- en defensiebeleid van het Koninkrijk. Het subsidiariteitsbeginsel zou van toepassing zijn op de drie eilanden met directe/nieuwe banden (in eerste instantie zo veel mogelijk taken en bevoegdheden op eilandniveau uitvoeren, pas daarna kwam samenwerking tussen de eilanden in beeld). Als taken de bestuurskracht van de eilanden of een samen- 
werkingsverband te boven gingen, zou worden gekeken welke rol Nederland dan wel het Koninkrijk voor de eilanden kon spelen. Er zou sprake moeten zijn van robuuste intereilandelijke samenwerking, waar nodig verankerd op het niveau van het Koninkrijk.

Ten slotte stelde Pechtold dat op de agenda van de volgende RTC een voorstel zou komen om procesmatige afspraken te maken rond een vernieuwd Statuut, dat invulling zou moeten geven aan de cruciale terreinen rechtshandhaving, effectief financieel toezicht en deugdelijk bestuur. Bovendien zou op de volgende RTC het advies van de Raad van State inzake vijftig jaar Statuut worden geagendeerd - een en ander in navolging van de breed aanvaarde Kamermoties. ${ }^{200}$

De Haagse eisen waren dus helder en in vele opzichten hard. In overleg met de Vaste Commissie NAAZ sprak Pechtold weer van een cruciale fase. De RTC was met name uitgesteld omdat nog geen overeenstemming bestond over de toekomstige rol van het Koninkrijk, stelde Pechtold, en hij achtte dit geen eenzijdig Nederlands besluit. Opnieuw liet hij weten de op uitdrukkelijke wens van de eilanden vastgelegde datum van 1 juli 2007 slechts als streefdatum te hebben geaccepteerd. Eerst diende inhoudelijke consensus te worden bereikt, pas daarna kon een RTC worden gehouden. ${ }^{201}$

Vervolgens voerde de minister bilateraal overleg op de eilanden, 'toch vooral een poging van mijn kant om het proces door te laten gaan via een politieke by-pass'. ${ }^{202}$ Dit leidde tot wisselende ervaringen. De gesprekken met Saba, Sint Eustatius en Bonaire had Pechtold als uitermate constructief ervaren. Het overleg met Sint Maarten was echter halverwege geschorst, terwijl het Curaçaose bestuurscollege geen inhoudelijk gesprek had willen voeren.

Met de landsregering had Pechtold gesproken over het zien te voorkomen van een langdurige impasse in het staatkundig proces. Vastgesteld was dat data weliswaar van belang waren om druk op het proces te houden, maar dat overeenstemming over de inhoudelijke invulling van het Koninkrijk een 'conditio sine qua non' was. Afgesproken was om medio april met Sint Maarten en Curaçao ambtelijk de onderwerpen rechtsorde, financieel toezicht en goed bestuur nader in te vullen, in de vorm van 'vingeroefeningen' en scenario's. Op basis van deze verdiepingsslag zou Pechtold vervolgens met de nieuwe Antilliaanse premier Emily de Jongh-Elhage (PAR) en minister van Constitutionele en Binnenlandse Zaken Roland Duncan (NA) beoordelen of en wanneer een plenair bestuurlijk overleg wenselijk was. Daarna kon Balkenende, als voorzitter van de RTC, bepalen wanneer de volgende conferentie zou plaatsvinden.

In zijn laatste gesprek, met Oduber, had Pechtold het belang van de betrokkenheid van Aruba benadrukt en gewezen op de afspraken 
over samenwerking binnen het Koninkrijk in het Protocol van 21 oktober 1993, dat de voorwaarden bevatte waaraan Aruba moest voldoen om als land binnen het Koninkrijk te kunnen blijven. Oduber stelde dat Aruba destijds veel meer voorbereidingswerk had verricht en dat er op het eiland aanzienlijk meer steun was geweest voor de nieuwe status. De twee Antilliaanse bestuurslagen moesten zijns inziens wel verdwijnen, want er waren te veel verkiezingen en te vaak wisselende besturen. Oduber raadde aan om snel een nieuwe RTC te houden. Hij was ertegen om allerlei andere zaken op de agenda op te voeren, zoals de Tweede Kamer scheen te willen.

Pechtold rapporteerde aan de Tweede Kamer 'tevreden' te zijn over de duidelijkheid die de gesprekken met Saba, Sint Eustatius en Bonaire hadden gebracht, maar dat hij de houding van Sint Maarten en Curaçao 'betreurde', omdat het staatkundige proces zo onnodige vertraging opliep. Tijdens de overleggen was vooral gebleken hoe moeilijk de stap van 'proces' naar 'inhoud' was; voor Nederland gold daarbij dat alleen bij voortgang op de inhoudelijke onderwerpen er sprake kon zijn van voortgang in het staatkundige proces. Dat was scherp verwoord: tijdens de gesprekken had Pechtold helder gemaakt dat voor Nederland niet de beoogde data 'heilig' waren, maar de voortgang van de inhoudelijke besprekingen. ${ }^{203}$

Dit laatste bleef moeizaam. Van de drie ambtelijke werkgroepen liep, volgens Haagse berichtgeving, de werkgroep over de $\mathrm{K}_{3}$ het voorspoedigst. 'De drie kleine eilanden vinden veel best als men maar van Curaçao af is. Voor Nederland is het vooral zaak te voorkomen dat alle verantwoordelijkheid voor overheidstaken naar Nederland wordt geschoven. ${ }^{.04}$ De drie hanteerden als uitgangspunt 'een integratiemodel met specifieke afwijkingsmogelijkheden'. ${ }^{205}$

De verhoudingen tussen Nederland en de Antillen leken intussen te verslechteren. Het gebrek aan voortgang in de onderhandelingen werd nog verergerd doordat het Nederlandse parlement - tegen advies van Pechtold in, maar overigens gesteund door het kabinet - het proces was gaan koppelen aan het eenzijdig gestarte debat over de immigratie en integratie van Antillianen in Nederland. Het kabinet beoogde nog voor de zomer een door Verdonk voorbereide wet door de Tweede Kamer te loodsen ter beteugeling van de komst van Antilliaanse probleemjongeren. Ook zou deze wet het mogelijk moeten maken om door de rechter veroordeelde jongeren als bijkomende straf terug te sturen naar de Antillen. Een Kamermeerderheid - de coalitiepartijen plus LPF en SGP - was hiervoor; aan Antilliaanse zijde hadden deze voornemens geleid tot grote opschudding. ${ }^{206}$

Op 19 en 20 april 2006 vond informeel tripartiet ambtelijk overleg plaats tussen Nederland, Curaçao en Sint Maarten, georganiseerd en 
geleid door het presidium en het secretariaat van de V-RTC en bedoeld om de impasse te doorbreken. ${ }^{207}$ Over deze tripartiete besprekingen schreef Duncan aan Pechtold dat ze hem de 'hoop' hadden gegeven een 'heel eind op weg' te zijn richting consensus. De Haagse ambtelijke terugkoppeling was echter aanmerkelijk terughoudender: 'Conclusie van de informele gesprekken is dat het nog te vroeg is voor bestuurlijk overleg met de eilanden.' ${ }^{\text {,08 }}$

In deze lastige context bezocht Pechtold medio mei 2006 opnieuw de Antillen. In Haagse optiek was de datum van 1 juli 2007 nu volstrekt achterhaald. Het ambtelijk advies was duidelijk: de minister kon moeilijk anders dan zijn gesprekspartners vragen of en zo ja hoe zij dachten het proces op de rails te krijgen. ${ }^{209}$ Een bevredigend antwoord werd kennelijk niet gegeven. Daags na de reis vond in Den Haag een bijeenkomst plaats van een speciale stuurgroep Beleidsinzet Nederlandse Antillen. Vastgesteld werd dat het staatkundig proces dreigde te stokken en dat de sociale en economische situatie op de Antillen dan snel zou verslechteren. Nederland moest proberen een doorbraak te forceren door de landsregering en de eilandgebieden een aanbod te doen. ${ }^{210}$

Eveneens in voorbereiding op dit bewindsliedenoverleg informeerde Pechtold de minister-president en de ministers van Financiën, Economische Zaken, Justitie, Defensie en Buitenlandse Zaken over de situatie. Er was geen wezenlijke vooruitgang in de discussie over de criteria waaraan de nieuwe landen moesten voldoen. Deze discussie spitste zich nu toe op die criteria waarbij een rol voor het Koninkrijk was voorzien, met name op de terreinen van rechtszekerheid en openbare financiën. Over een groot aantal andere voorwaarden, zoals voor goed bestuur, was wel overeenstemming bereikt. Intussen, stelde Pechtold, verslechterde de financiële situatie van het land en van de eilandgebieden steeds verder, mede gevoed door onzekerheid over de staatkundige toekomst. Daarnaast achtte Pechtold de politieke situatie instabiel. De situatie was zo nijpend dat de bewindsman, conform de vertrouwelijke ambtelijke beleidsnota, pleitte 'voor het forceren van besluitvorming over de criteria en over afspraken over het op orde brengen van de openbare financiën'. Hiertoe was een concreet Nederlands aanbod nodig, ook waar het de schuldsanering betrof. 'Indien men instemt met het aanbod kan het staatkundige proces voortgang vinden. Indien men voor de zomer niet instemt komen dwingende (eenzijdige) maatregelen vanwege het Koninkrijk in beeld. ${ }^{211}$

De bijgevoegde notitie 'Aanbod staatkundig proces Nederlandse Antillen', die later geamendeerd openbaar zou worden onder de 'warmere' titel 'Partners in het Koninkrijk', was geclassificeerd als staats- 
geheim. Het 'aanbod' bevatte de minimumcriteria waaraan de nieuwe entiteiten moesten voldoen, een traject en ideeën over een 'plan B'. Op 31 mei werd de notitie door de ministerraad goedgekeurd en daags daarna, op 1 juni, zouden Balkenende en Pechtold deze aan De Jongh-Elhage overhandigen. Hiermee werd de nieuwe Antilliaanse premier, die op kennismakingsbezoek kwam, direct onder grote druk gezet. Het zou - als zij overtuigd was - aan haar zijn om de Antilliaanse regering en de eilandgebieden te overtuigen. Pechtold zou de criteria ook aan Oduber voorleggen.

Het 'Aanbod staatkundig proces Nederlandse Antillen' schetste allereerst de crisis en de impasse. Vervolgens formuleerde het document een aantal voor Nederland ononderhandelbare criteria waaraan door de eilandgebieden moest zijn voldaan voordat hun nieuwe status zou kunnen intreden. Het betrof afspraken over toezicht op de financiën, zorg van de landsregering voor de drie kleine eilanden in de transitieperiode, verbetering van de rechtshandhavingsketen en het bestuurlijke integriteitsbeleid, en over de regie op de voorbereiding van de RTC's. Daartegenover bood Den Haag de Antillen en de eilandgebieden voortgang in het staatkundig proces, zodat zij invulling konden geven aan de referendumuitslagen, en vermindering van de schuldenlast tot het niveau van de rentelastnorm. ${ }^{212}$

Als niet op korte termijn werd ingestemd met het 'Aanbod' waren eenzijdige maatregelen van het Koninkrijk rond de openbare financiën onontkoombaar-via niet-vrijblijvende samenwerking

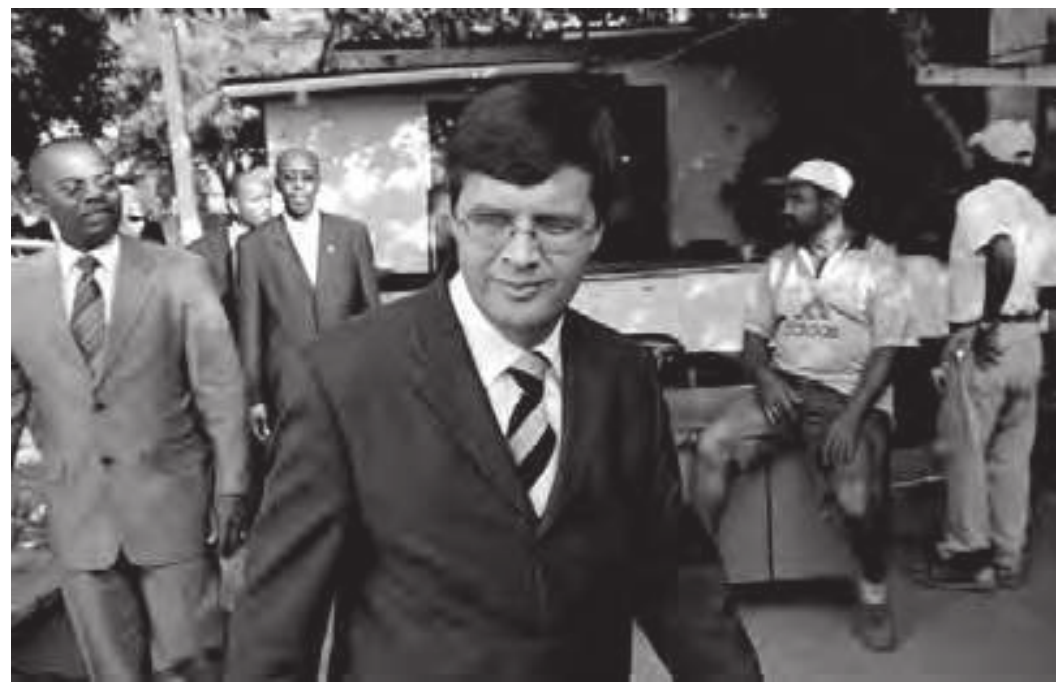

Jan Peter Balkenende op werkbezoek, Sint Maarten, 3 februari 2005. Links zijn ambtgenoot Etienne Ys. 
met de eilanden die instemden, of via eenzijdige maatregelen van het Koninkrijk op basis van de artikelen 43, 50 of 51 Statuut voor de eilanden die niet instemden. Als werd ingestemd met de criteria en afspraken, zouden deze tijdens een RTC kunnen worden vastgelegd. Het was wenselijk dat de criteria ook door Aruba werden geaccepteerd, maar de notitie stelde dat het onwaarschijnlijk was dat dit zonder meer zou gebeuren. Voor Aruba bestond immers geen urgentie om de staatkundige situatie te wijzigen en geen reden een deel van de autonomie op te geven. Het genoemde Samenwerkingsprotocol van 1993, voortgekomen uit bilaterale gesprekken met Aruba ten tijde van de Toekomstconferentie en mede opgesteld om de bepaling uit het Statuut te schrappen dat Aruba met ingang van 1 januari 1996 onafhankelijk zou worden, bood echter wel aanknopingspunten. ${ }^{213}$

Pechtold informeerde vervolgens een ongeruste Vaste Commissie NAAZ - die al een impasse signaleerde terwijl eigenlijk nog niet eens aan de inhoud was begonnen - dat er geen sprake zou zijn van verdere concessies. De plannen voor openbare financiën, rechtshandhaving en de economie waren, benadrukte hij, duidelijk: één bank, één Hof, één OM, één munt en één politieorganisatie. De drie kleine eilanden maakten op dit gebied al grote stappen, maar ook Curaçao en Sint Maarten werkten daadwerkelijk mee. Nederland was bereid genereus bij te dragen aan de schuldsanering. Een harde voorwaarde was dat er direct na de transitie sluitende begrotingen zouden zijn - een overgangsperiode van vier jaar, zoals Curaçao voorstelde, was onaanvaardbaar. ${ }^{214}$ Ook in interne notities werd de minister op het hart gebonden om bij zijn overleg met De Jongh-Elhage geen concessies te doen. ${ }^{215}$

Het document 'Partners in het Koninkrijk', gebaseerd op het hierboven beschreven 'Aanbod' werd in het Nederlandse bewindsliedenoverleg van 31 mei 2006 overgenomen als ononderhandelbaar document en daags erna aan De Jongh-Elhage overhandigd tijdens haar kennismakingsbezoek aan Nederland. Den Haag hanteerde bewust een overvaltactiek om een doorbraak te forceren. ${ }^{216}$ Afgesproken werd dat de Antilliaanse premier uiterlijk 20 juni een gezamenlijke reactie van land en eilandgebieden kenbaar zou maken. Als zij met het document zouden instemmen, was het mogelijk om nog voor het zomerreces een RTC te laten plaatsvinden. ${ }^{217}$ Maar in de Staten zouden met name de oppositiepartijen sterk gekant blijken tegen het Nederlandse voorstel: 'de koloniale tijd herleeft'. ${ }^{218}$

'Partners in het Koninkrijk' bevatte, in Haagse termen, de 'huisregels van het Koninkrijk'. Het waren punten die Nederland tijdens het hele proces al had ingebracht, zoals het op orde brengen van de financiën, een goed financieel beheer, een adequate rechtshandhavings- 
keten en deugdelijk bestuur. Pechtold: 'Het is dus niet zomaar een "non-paper" of "denkrichtingen" zoals de Antilliaanse pers dit noemt, maar fundamentele uitgangspunten met bovendien een voorstel over schuldsanering.' De 'huisregels' zouden in beginsel ook moeten gelden voor Aruba; voor wat betreft de rechtshandhaving was dit ook al met zoveel woorden in het document opgenomen. ${ }^{219}$

In 'Partners in het Koninkrijk' stelde Nederland zwart op wit bereid te zijn de schulden van de Antillen grotendeels over te nemen voordat de eilanden nieuwe verhoudingen met elkaar en met Nederland zouden aangaan. Hiervoor golden wel strenge voorwaarden, die volgens vrijwel alle Antilliaanse politici, inclusief de PAR, te vergaand waren. Voor het Caraïbische deel van het Koninkrijk (dus inclusief Aruba) moest er één rechterlijke organisatie komen, met als hoogste orgaan het Gemeenschappelijk Hof van Justitie, voorts één Openbaar Ministerie, met aan het hoofd één procureur-generaal, en één politiekorps. De verantwoordelijkheid voor het beheer van de rechterlijke organisatie zou worden gelegd in een gemeenschappelijk orgaan dat verantwoording zou afleggen aan de Rijksministerraad, waaraan ook het OM verantwoording moest afleggen. Curaçao en Sint Maarten zouden alleen onder strikte condities geld mogen lenen en pas na toestemming van de toezichthouder. 'Afhankelijk van het nakomen van de afspraken om de gezonde startpositie te bereiken' was Nederland bereid tot een aanmerkelijke verlichting van de schuldenlast van de vijf (ei)landen. Ook was het bereid, indien het land en de eilandgebieden de hoofdlijnen onderschreven, nog in juli 2006 een RTC te houden. De notitie gaf op elk van deze terreinen een uitvoerige uitwerking. Ten slotte werd aangestuurd op een slagvaardiger voorbereiding van de RTC's. ${ }^{220}$

Op een haastig ingelast Topoverleg van de vijf eilanden en de Antilliaanse regering verdedigde De Jongh-Elhage 'Partners in het Koninkrijk' als een uniek aanbod, ondanks de ook in haar eigen partij levende grote bezwaren. Er was zware kritiek, voornamelijk van Curaçao en Sint Maarten, neergelegd in een tegendocument, dat de Antilliaanse premier vervolgens aan Balkenende als voorzitter van de RTC zou aanbieden. De bezwaren richtten zich vooral tegen de voorwaarden voor schuldsanering en tegen een gezamenlijke procureur-generaal en OM. Ambtelijk werd gewaarschuwd voor een nieuwe onderhandelingsronde en gepleit voor standvastigheid. ${ }^{221}$

In het Nederlandse bewindsliedenoverleg werd inderdaad vastgesteld dat er geen reden was om van strategie te veranderen, zeker ook omdat er naast kritiek brede steun was op de Antillen. Wel had Aruba bij monde van premier Oduber en minister van Justitie Hendrik Croes zich zeer kritisch uitgelaten. Den Haag besloot de druk op 
te voeren, maar intussen ook te denken over een 'plan B', dat bestond uit het opstellen van een draaiboek voor versterkte regie als 'Partners in het Koninkrijk' niet tot instemming zou leiden. ${ }^{222}$ Deze lijn werd volgehouden. Inmiddels had De Jongh-Elhage de voormalige Antilliaanse premiers Suzy Römer en Etienne Ys als adviseurs aangesteld, voor inhoudelijke ondersteuning maar ook om het draagvlak op de eilanden te versterken - het duo zou in de Haagse wandelgangen al snel worden aangeduid als 'Room-Ys'.

Het geplande bilaterale overleg werd ten slotte van Haagse kant onverwachts slechts op ambtelijk niveau gevoerd; Pechtold moest verstek laten gaan in verband met een politieke crisis die de val van het kabinet en zijn vertrek inluidde. De ambtelijke inzet was al even helder: 'Partners in het Koninkrijk' was 'de bottomline'.

\section{De impasse voorbij: de Slotverklaring van 2 november 2006}

Op 29 juni 2006 viel het tweede kabinet-Balkenende. Minister van BZK Remkes nam de portefeuille van Pechtold tijdelijk over. De bestuurlijke lijn was dat de val van het Nederlandse kabinet geen gevolgen zou hebben voor de Nederlandse opstelling in het proces. Ingewijden herinneren zich dat wel werd nagedacht over een 'plan B', Haags ingrijpen als de impasse voortduurde.

Het rompkabinet-Balkenende III (CDA en VVD) trad op 7 juli aan; als minister voor Bestuurlijke Vernieuwing en Koninkrijksrelaties werd Atzo Nicolaï (VVD) benoemd. Medio augustus reisde hij voor zijn eerste werkbezoek naar de Caraïben. Er was aanvankelijk wat irritatie - De Jongh-Elhage had verondersteld dat Remkes de Koninkrijksrelaties in zijn portefeuille zou krijgen en hoorde het nieuws over Nicolaï van een journalist - en ook scepsis over wéér een nieuwe minister. Auteur Frank Martinus Arion noemde de benoeming 'schandelijk': 'De Antillen worden telkens van de een naar de ander geschopt; allemaal mensen die er niets van weten.'224

Het contact van Nicolaï en de Antilliaanse raad van ministers verliep echter goed. Nicolaï creëerde nieuwe ruimte door ontspannen te benadrukken dat 'Partners in het Koninkrijk' geen dictaat was, al stonden de hoofdlijnen niet ter discussie. ${ }^{225}$ Tijdens overleg met de fractievoorzitters uit de Staten gaf de minister aan binnen enkele maanden een politiek akkoord te willen bereiken. Wel stelde hij 1 juli 2007 erg ambitieus te vinden; de indruk was dat ook onder zijn gesprekspartners deze ingangsdatum inmiddels als niet heel realistisch gold. Vervolgens voerde Nicolaï gesprekken met de afzonderlijke eilanden. Weer bleek Curaçao het meest kritisch. ${ }^{226}$ 
Nicolaï had tijdens zijn kennismakingsbezoek voortdurend benadrukt dat staatkundige veranderingen vooral een middel waren om de grote sociaaleconomische problemen structureel te kunnen aanpakken. Daartoe was intensieve samenwerking op Koninkrijksniveau vereist. Na zijn bezoek was hij 'voorzichtig positief' over de mogelijkheden om binnen enkele maanden harde politieke afspraken te maken. De vraag bleef hoe ver Curaçao en Sint Maarten inmiddels waren. Inmiddels werd al gewerkt aan concrete overgangsscenario's voor de $\mathrm{K}_{3} .{ }^{227}$

Op 18 september 2006 bood de Raad van State van het Koninkrijk dan de al genoemde voorlichting aan over de hervorming van de staatkundige verhoudingen van de Antilliaanse eilanden. Het verzoek aan de Raad was geweest om vooral te kijken naar de constitutionele inbedding van de drie 'Koninkrijksgebieden', maar de voorlichting had een bredere strekking. ${ }^{228}$

De Raad gaf zoals gezegd in overweging de drie kleine eilanden een positie te verschaffen binnen het Nederlandse staatsbestel. Al werd het model van de Nederlandse gemeente hiertoe niet zonder meer bruikbaar geacht, het advies luidde wel om als hoofdregel de Nederlandse wetgeving van toepassing te verklaren. Gezien onder meer de bevolkingsomvang van de drie eilanden, de grote afstand tot Nederland en het insulaire karakter zouden echter van de Nederlandse wetgeving afwijkende voorzieningen moeten worden getroffen. De Raad adviseerde deze gebieden daarom op grond van artikel 134 van de Grondwet in te richten als 'openbare lichamen'. ${ }^{229}$ Deze keuze voor een aangepaste gemeentestatus werd mede ingegeven door de overweging dat dit, aldus de overweging in een ambtelijke nota, een 'panklaar concept' was. ${ }^{230}$

Hiertoe was een wijziging van de Grondwet naar het oordeel van de Raad niet direct noodzakelijk, hoewel op den duur wel wenselijk. Bonairianen, Sabanen en Statianen in het bezit van een Nederlands paspoort zouden stemrecht krijgen voor de verkiezingen van de Eerste en Tweede Kamer. De Nederlandse regering moest de provinciale bevoegdheden voor de drie eilanden op zich nemen. De Raad van State wees op het risico dat bestuurlijke energie werd gestoken in nieuwe structuren zonder dat de kwaliteit van publieke taken als onderwijs, milieuzorg en rechtshandhaving daadwerkelijk werd verbeterd. ${ }^{231}$

De Raad gaf in zijn voorlichting aan dat een positie binnen het Nederlandse staatsbestel niet betekende dat het Nederlandse voorzieningenniveau, met name de sociale zekerheid, zonder meer voor de eilanden zou gelden. In het geval dat enkele eilanden een relatief beter welvaartsniveau zouden kennen, was er immers het risico van migratie. Nicolaï, die de voorlichting instemmend ontving, onder- 
schreef ook deze waarschuwing, waarbij hij meende dat hetzelfde zou kunnen gelden voor het fiscale stelsel. 'Dit zou niet passen binnen de sociaal-economische omstandigheden van de Caribische regio. Voorkomen moet worden dat de eilanden economisch worden geïsoleerd in de regio of worden geconfronteerd met ongewenste migratie. ${ }^{232}$ De Raad adviseerde met klem om in de toekomst de rechtspraak in handen te laten van een Gemeenschappelijk Hof van Justitie voor alle Caraïbische delen van het Koninkrijk. De Raad waarschuwde voorts voor optimisme over de krappe deadline van juli 2007 voor het opheffen van de Antilliaanse landsregering.

Net als Nicolaï reageerde de Vaste Commissie NAAZ positief op de voorlichting van de Raad. Er was bovendien waardering voor de 'aangename voortvarendheid' (Van Fessem) van de minister. Voor het overige bleven er veel vragen bestaan en zeker ook zorgen over te veel Haagse concessies. Van de zijde van de VVD waren er weer vragen rond migratie. Nicolaï benadrukte nog eens dat schuldsanering alleen mogelijk zou zijn als de eilanden bereid waren hardere normen te accepteren voor het begrotingsbeleid en een strikter financieel toezicht daarop. Ook was daar weer de eis van één bank voor Curaçao en Sint Maarten en één gezamenlijk OM. Nicolaï gaf aan dat er weinig middelen waren om Aruba hiertoe te brengen, maar liet opnieuw doorschemeren dat er toch enige ruimte was. Het gesprek met de eilanden zou hij 'natuurlijk niet' beginnen met een dictaat van de regering of van de Tweede Kamer. 'Dan is het slikken of stikken, is er geen sprake van onderhandelen en is de kans op succes nihil. ${ }^{233}$

Tussen Nicolaï en het Antilliaanse kabinet leek zich inmiddels een consensus af te tekenen, ook over de voorlichting van de Raad van State, al waren er nog knelpunten, vooral in de sfeer van de institutionele vormgeving van de rechtshandhaving. Nicolaï achtte nu de tijd rijp voor het organiseren van een 'Miniconferentie' om beslissende stappen te zetten voor de $\mathrm{K}_{3}$. Problematisch bleef intussen de sterke oppositie op Curaçao en ook Sint Maarten, en de afzijdigheid van Aruba. ${ }^{234}$

In onderhandelingen met Bonaire, Sint Eustatius en Saba-nu niet langer als 'Koninkrijkseilanden' aangeduid - kozen alle partijen voor een inbedding conform de voorlichting van de Raad van State, al was die ambivalent over de wijze waarop de drie eilanden aansluiting zouden vinden bij Nederland, volledig geïntegreerd dan wel in een associatie. ${ }^{235}$ Tijdens een Miniconferentie in Den Haag op 11 oktober werd hierover een akkoord bereikt tussen Nederland en de $\mathrm{K}_{3}$. Doordat zij als 'openbare lichamen' deel zouden gaan uitmaken van het Nederlandse staatsbestel kregen zij een staatsrechtelijke positie binnen de Nederlandse staat en niet zozeer een directe band met 
Nederland, waarbij het associatiemodel - tot veler verbazing, ook achteraf-geruisloos van tafel verdween. Minister Nicolaï had deze uitkomst een week eerder al tijdens voorbereidend overleg op Bonaire bekendgemaakt. De inhoudelijke afweging was, in zijn ogen op goede gronden, al onder zijn voorganger gemaakt. Nu ging het erom het proces verder te brengen. ${ }^{236}$

Uit deze keuze vloeide de principiële vraag voort of de Grondwet hiermee ook onverkort van toepassing zou moeten worden op de eilanden, en dan in het bijzonder het gelijkheidsbeginsel vastgelegd in artikel 1. Daarnaast moest een reeks arrangementen nog nader worden uitgewerkt, waaronder de relatie tot de Eu. Zeker was dat sociale voorzieningen op het welvaartsniveau van de eilanden zouden komen te liggen, niet op het Nederlandse. ${ }^{237}$ Met deze keuze voor integratie in Nederland was uitdrukkelijk afgeweken van het advies van de werkgroep DNB. ${ }^{238}$ Deze uitkomst zou later op de eilanden kritiek oproepen, omdat het integratiemodel als te dwingend werd ervaren.

De afspraken met Bonaire, Saba en Sint Eustatius konden pas doorgevoerd worden nadat ook overeenstemming was bereikt met de Antilliaanse landsregering en vooral met Curaçao en Sint Maarten - het ging immers om een breder proces waarbij het land zou worden opgeheven. Met de $\mathrm{K}_{3}$ was daarom afgesproken dat de Slotverklaring van de Miniconferentie-onverkort-zou worden samengevoegd met een nog met Curaçao en Sint Maarten te bereiken bestuurlijk akkoord, hopelijk datzelfde jaar. Nicolaï beloofde wel dat als per 1 januari 2007 met Curaçao en Sint Maarten nog geen overeenstemming was bereikt, hij en de drie kleine eilanden zich zouden beraden op een snelle oplossing. Hij hoopte al met al op een omvattend akkoord nog voor het nieuwe Nederlandse kabinet zou aantreden - vervroegde Kamerverkiezingen waren gepland voor 22 november 2006.

Met deze Slotverklaring was het uiteenvallen van de Antillen weer een stap dichterbij gekomen. De reacties op de eilanden liepen uiteen van 'gemengde gevoelens' tot opluchting. Op Curaçao en Sint Maarten reageerden sommigen licht afgunstig, anderen met zorg over 'rekolonisatie', die mogelijk ook de grotere eilanden zou treffen. De drie eilandsraden stemden vrijwel unaniem in met de integratie. ${ }^{239}$

Ook in het Nederlandse parlement kreeg het akkoord met de $\mathrm{K}_{3}$ brede steun, al kwamen er wel kritische vragen over de uitwerking en over het ontbreken van een link met het migratiedossier (Stef Blok, VVD). Een enkele parlementariër als Klaas de Vries meende dat Sint Maarten, gezien de kleine schaal, beter aan de $\mathrm{K}_{3}$ zou zijn toegevoegd; hij betreurde hardop dat het Koninkrijk nu uit vier landen zou gaan bestaan, waar één land meer voor de hand had gelegen. Deze kritiek oogstte echter weinig bijval. Sprekers waren het eens dat de 
verschillen in wet- en regelgeving tussen de drie kleine eilanden en Nederland zo klein mogelijk moesten zijn. ${ }^{240}$

Van groter gewicht, voor alle partijen, was het vervolg van de onderhandelingen met de twee aanstaande landen. Vooral op Curaçao was er felle oppositie, binnen en buiten de eilandsraad. Opinieonderzoek bevestigde dat er brede zorgen bestonden over 'rekolonisatie', wat politici weer beducht maakte om de indruk te wekken te veel aan de Haagse leiband te lopen. Alleen de PAR en, wat voorzichtiger, de PNP, verdedigden de ingezette koers. ${ }^{241}$ Aan Haagse zijde begon de tijd te dringen: op 1 november zou het parlement met verkiezingsreces gaan, Nicolaï moest voordien zaken zien te doen.

De Curaçaose eilandsraad gaf zijn onderhandelaars stevige instructies mee voor het vervolgoverleg in Den Haag. Curaçao eiste, net als Sint Maarten, een eigen OM en een eigen politiekorps. Alle partijen meenden dat Nederland de volledige Antilliaanse schuld moest overnemen, terwijl de oppositionele partijen bovendien een koppeling aan Haags toezicht afwezen. Het overleg in Nederland bevestigde in eerste instantie dan ook een impasse op vrijwel alle terreinen, waaronder politie, OM en schuldsanering. Ambtelijk werd Nicolaï daarom geadviseerd met de meest betrokken Nederlandse bewindslieden - Hirsch Ballin, Remkes en Zalm - te bespreken waar nog onderhandelingsruimte was. Rond de rechtshandhaving werd daarbij opgemerkt dat de voorstellen van de Antilliaanse adviseurs Römer en Ys goede aanknopingspunten boden. Zalm had inmiddels al laten doorschemeren, ook aan zijn Antilliaanse collega, de voorwaarden voor schuldsanering wat te kunnen versoepelen, althans, zolang hij niet demissionair was. Met dit aanbod en in het besef van de tijdelijkheid ervan konden Curaçao en Sint Maarten mogelijk over de streep worden getrokken. ${ }^{242}$

Minister van BZK Remkes hield vooralsnog, conform 'Partners in het Koninkrijk', vast aan één politiekorps voor de vijf (of nog beter zes, inclusief Aruba) eilanden. Aangezien Curaçao en Sint Maarten echter elk een eigen politiekorps wilden behouden, hadden Ys en Römer een alternatief ontwikkeld waarbij beide nieuwe landen inderdaad een eigen korps zouden hebben, maar waarvoor wel een verplichte samenwerking was geregeld. Nicolaï werd ambtelijk geadviseerd Remkes aan te geven 'dat één politiekorps geen doel op zichzelf zou moeten zijn'. Met de aanstelling van een onafhankelijke toezichthouder zou ook Koninkrijkstoezicht worden gewaarborgd ter bewaking van de kwaliteit en integriteit van de politie. Tegemoetkomen aan de verlangens van Curaçao en Sint Maarten rond een eigen Openbaar Ministerie was evenzeer verdedigbaar zolang - conform het voorstel van Römer en Ys - aan het hoofd één gezamenlijke procureur-gene- 
raal stond. De vraag was wel of Hirsch Ballin hiermee akkoord kon gaan; ambtelijk leefden er bij Justitie bezwaren. Opmerkelijk genoeg stelde de ambtelijke nota ronduit dat de modellen van Ys en Römer voor de politie en het OM in de basis 'logischer (staatsrechtelijk en in de praktische werking) zijn, dan de Nederlandse voorstellen (rot maar waar)'. Hun alternatief ging, werd waarderend vastgesteld, niet uit van structuren maar vanuit de gedachte wat gewaarborgd moest zijn. $^{243}$

Informeel bilateraal overleg eind oktober van Nicolaï met Curaçao en Sint Maarten leidde tot overeenstemming over de voorwaarden voor sanering van de Antilliaanse staatsschuld, over toezicht op de overheidsfinanciën en over criteria voor deugdelijk bestuur. Over de kwesties rond het OM en de politiekorps(en) was de onenigheid blijven voortbestaan. Toch werd vastgesteld dat de tijd rijp was voor politiek overleg in Den Haag, teneinde besluiten vast te leggen die ook na de aanstaande Nederlandse verkiezingen overeind zouden blijven. Problematisch bleef de stemming op Curaçao. Waar De Jongh-Elhage de unieke kansen benadrukte, kampte zij met een brede oppositie die zich verzette tegen 'uitverkoop' aan Nederland. Een akkoord met het eiland was temeer urgent daar de Curaçaose Statenleden eventueel ook de uitvoering van de overeenkomsten met de andere eilanden zouden kunnen tegenhouden. ${ }^{244}$

Nicolaï informeerde de ministerraad dat het overleg met Sint Maarten en Curaçao hem 'voldoende vertrouwen' had gegeven dat op 1 november 2006 beslissende afspraken gemaakt konden worden. De belangrijkste overgebleven punten van overleg waren 'de organisatie van de rechtshandhaving en de schuldsanering. ${ }^{245}$ Ook de Vaste Commissie NAAZ werd geïnformeerd over de Nederlandse inzet voor het bestuurlijk overleg. Er was al overeenstemming over een Gemeenschappelijk Hof van Justitie, stelde Nicolaï. Nederland achtte het voorts van belang dat er één PG zou komen voor Curaçao, Sint Maarten en de drie kleine eilanden; deze moest ook dwingend medewerking van de politie kunnen vorderen. Om de kwaliteit en slagkracht van het OM te waarborgen, moest dit arrangement in een Rijkswet worden vastgelegd. Die zou ook moeten regelen dat de minister van Justitie van het Koninkrijk, via een eenvoudige, bij Rijkswet te regelen procedure, aanwijzingen kon geven aan de PG als dat noodzakelijk was voor de waarborgfunctie van het Koninkrijk.

Wat de politie betreft, moest er sprake zijn van intensieve en niet-vrijblijvende samenwerking tussen de korpsen op de eilanden, onder meer in het reeds bestaande Recherche Samenwerkingsteam (RST) - hiermee liet Nicolaï dus de eerdere eis van één gezamenlijk korps voor alle eilanden los. Omdat de aanpak van grensoverschrij- 
dende criminaliteit de belangen van de individuele landen oversteeg, stuurde Nederland wel aan op een gezamenlijk beleid in het Caraïbische deel van het Koninkrijk, vast te stellen door de Rijksministerraad op voorstel van de ministers van Justitie van de landen. Voordat de nieuwe structuur in werking zou treden, dienden de organisaties binnen de Caraïbische rechtshandhavingsketen, met name de politie, nog sterk verbeterd te worden. ${ }^{246}$

Op 1 en 2 november 2006 vond in Den Haag het bestuurlijk overleg plaats tussen Nederland, de Antillen en de bestuurscolleges van Curaçao en Sint Maarten. Een omvangrijke Curaçaose delegatie was naar Nederland afgereisd. ${ }^{247}$ Deze tweedaagse onderhandelingen vormden in feite een voortzetting van de start-RTC. Het eindresultaat was de 'Slotverklaring', een 'historisch akkoord' dat in de volgende jaren het ijkpunt zou vormen in alle onderhandelingen over de arrangementen rond de ontmanteling van de Nederlandse Antillen. Het was een moeizaam bereikt compromis. Curaçao en Sint Maarten zouden weliswaar autonome landen worden, maar tegelijkertijd werd op verschillende terreinen - overheidsfinanciën, justitie en politie - de Nederlandse bemoeienis groter. De Volkskrant vroeg zich hardop af of deze 'lappendeken aan arrangementen', en daarmee de door Curaçao en Sint Maarten gewenste autonomie, 'niet te veel een doel op zich is geworden, met voorbijgaan aan de vraag waarmee de bevolking van de eilanden het meest is gebaat'. ${ }^{248}$

De Slotverklaring, een dertien pagina's tellend document over de status van Curaçao en Sint Maarten na het uiteenvallen van de Antillen, legde de criteria vast waaraan de constitutie, organieke wetten en het overheidsapparaat van de nieuwe landen zouden moeten voldoen. ${ }^{249}$ De verklaring bevatte een aantal samenhangende principiële afspraken tussen Nederland, het land en de eilanden over verbetering van de overheidsfinanciën (schuldsanering, financieel beheer, financieel toezicht, ook in de transitieperiode, en financiële normen voor de overheid), de rechtspleging en -handhaving, deugdelijk bestuur en criminaliteitsbestrijding (Gemeenschappelijk Gerechtshof, de politie en het $\mathrm{OM}$ ).

Een van de belangrijkste afspraken betrof de schuldsanering. Nederland verklaarde zich bereid om de schulden en betalingsachterstanden van het land en de eilandgebieden per ultimo 31 december 2005 te saneren en hiertoe ruime middelen te verschaffen. Curaçao en Sint Maarten moesten op hun beurt financieel toezicht op hun begrotingen in de komende jaren toestaan, ook tijdens de transitieperiode (de financieel toezichthouder zou onder de verantwoordelijkheid van de Rijksministerraad aanwijzingen kunnen geven). Teneinde de 
overheidsfinanciën gezond te houden werden bindende afspraken gemaakt over financiële normen, een strikte begrotingsdiscipline en controle door een nieuwe overheidskredietbank waarvan de leden benoemd zouden worden door de Rijksministerraad. Ook zou er één centrale bank komen voor Curaçao en Sint Maarten. De kosten van deze gedeeltelijke sanering van de Antilliaanse schuldenlast zouden uiteindelijk 1,7 miljard euro bedragen.

Het Koninkrijk verkreeg daarnaast ruim toezicht op justitieel terrein. Nederland had na lange aarzeling - mede van de tussentijds op Justitie teruggekeerde bewindspersoon Hirsch Ballin - er wel mee ingestemd dat de twee nieuwe landen elk een eigen politiekorps en Openbaar Ministerie zouden krijgen, maar er zou één procureurgeneraal blijven, met verantwoordelijkheid voor alle vijf eilanden. Bovendien zou de Nederlandse minister van Justitie de bevoegdheid krijgen om namens de Rijksministerraad, dus als bewindspersoon voor het Koninkrijk, aanwijzingen te geven aan de procureur-generaal. Deze speciale aanwijzingsbevoegdheid maakte daarmee onlosmakelijk deel uit van de staatkundige vernieuwingen - onder zware druk van Hirsch Ballin en Nicolaï, zeer tegen de zin van de Antilliaanse onderhandelaars. ${ }^{250}$ Nederland (i.c. de minister van Justitie) zou ook verantwoordelijk blijven voor de bestrijding van grensoverschrijdende criminaliteit, corruptie en integriteitschendingen. De nieuwe landen zouden gaan samenwerken in een Gemeenschappelijk Hof van Justitie (Nederland, Curaçao en Sint Maarten). Er zouden stringente afspraken worden gemaakt over verbetering van de poli-

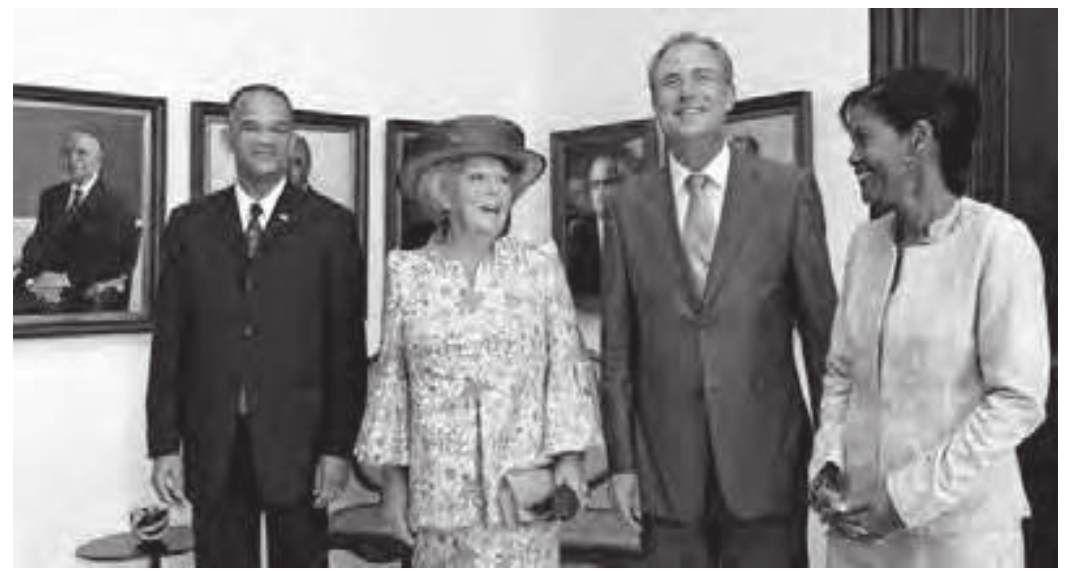

Koninklijk bezoek, Curaçao, 12 november 2006; v.l.n.r. gouverneur Frits Goedgedrag, koningin Beatrix, Atzo Nicolaï, Dulcie Goedgedrag-Terborg; op het portret links van Goedgedrag diens voorganger Jaime Saleh. 
tieorganisatie op Curaçao en Sint Maarten voordat de nieuwe structuur in werking zou treden.

De (nieuwe) landen kwamen overeen bepaalde landsaangelegenheden die cruciaal werden geacht te zullen regelen bij 'consensusrijkswet', zodat op deze terreinen, bijvoorbeeld de rechtspleging en politieorganisatie, gedurende het gehele proces consensus tussen de partijen behouden zou blijven. Nederland zou bovendien helpen met de aanpak van de grote problemen op Curaçao en Sint Maarten teneinde het toekomstperspectief van de jeugd op de eilanden te verbeteren. Afgesproken werd dat Nederland, het land de Nederlandse Antillen, Curaçao en Sint Maarten gezamenlijk vóór 1 februari 2007 een stappenplan zouden opstellen ter realisering van de afspraken over de nieuwe staatkundige verhoudingen. Voor zover nodig zou Aruba betrokken worden bij de totstandkoming van dit stappenplan, waaraan, rekening houdende met de afspraken in de start-RTC, een tijdschema zou worden toegevoegd. Vijf jaar na volledige inwerkingtreding van de nieuwe staatkundige structuur zou deze door Curaçao, Sint Maarten en Nederland gezamenlijk worden geëvalueerd en waar nodig aangepast. Eenzelfde evaluatie na vijf jaar was al voor de BES afgesproken.

De door de PAR als overwinning van de partij gevierde Slotverklaring oogstte op Curaçao sterk gemengde reacties, terwijl in Nederland en op de andere Antilliaanse eilanden de ontvangst positief was. Het bezoek van koningin Beatrix aan de eilanden van 6 tot 16 november, kort na het sluiten van het akkoord, gaf ruimte voor veel warme woorden over de Koninkrijksrelaties. Ingewijden van alle partijen verklaren overigens off the record dat het besef van het koninklijk bezoek er zeker toe bijdroeg dat de partijen elkaar net op tijd vonden. ${ }^{251}$ De Tweede Kamer stemde unaniem in met het akkoord, al verbond de VVD hieraan de uitdrukkelijke voorwaarden van streng Nederlands toezicht op de rechtshandhaving en het treffen van een bevredigende regeling voor de toegang tot Nederland en de terugzending van criminele Antilliaanse jongeren (de eerdere motie Luchtenveld). In algemene zin was de consensus dat er 'geen millimeter ruimte' werd gelaten om opnieuw met Curaçao over de Slotverklaring te onderhandelen. Ondanks de blijvende vragen bij een landsstatus voor Sint Maarten was er veel waardering voor het feit dat de status die Curaçao en Sint Maarten uiteindelijk zouden kunnen bereiken minder ruim was dan de status aparte van Aruba. De transitiedatum van 1 juli 2007 werd overigens noch door de minister, noch door de Kamer als realistisch ervaren. ${ }^{252}$

Ook op de Antillen werd positief gereageerd: de Staten en de eilandsraden van Bonaire, Saba, Sint Eustatius en Sint Maarten ratificeerden 
de akkoorden. Alleen op Curaçao bleef de tegenstand sterk, mede omdat het eiland een minder autonome status zou verwerven dan Aruba. Een meerderheid in de Curaçaose eilandsraad (coalitiepartijen MAN, MPK en NPA) van dertien tegen zeven (PAR en PNP) zou op 29 november 2006 de 'koloniale' Slotverklaring verwerpen - meermalen werd daarbij door de oppositie in grimmige bewoordingen verwezen naar het slavernijverleden. ${ }^{253}$ Pas op 6 juli 2007 zou een nieuw verkozen eilandsraad alsnog de Slotverklaring goedkeuren; in de tussenliggende periode verliep de uitwerking ervan dus onder een onzeker gesternte, waarin toch weer enige ruimte zou ontstaan voor verruiming van de als 'finaal' en ononderhandelbaar gepresenteerde afspraken. ${ }^{254}$

Een omstreden keuze met voorspelbare politieke en bestuurlijke risico's

Met de aanvaarding van de Slotverklaring van 2 november 2006 hadden alle partijen zich vastgelegd op de ontbinding van de Antillen en op een nieuwe, opmerkelijk gedifferentieerde Koninkrijksstructuur. Alle partijen hadden iets te winnen bij de uitvoering van de Slotverklaring. De landsregering was gelukkig dat zij het gordijn kon laten vallen voor de niet langer functionerende constructie van de Nederlandse Antillen. Curaçao en Sint Maarten verkregen de felbegeerde landsstatus binnen het Koninkrijk, de drie kleinere eilanden verruilden de vaak gehekelde afhankelijkheid van het land en de grotere eilanden voor een naar verwachting meer veelbelovende directe band met Nederland. Alle vijf eilanden werden verlost van de financiële crisis die het land op de drempel van bankroet had gebracht. Nederland moest weliswaar toestemmen in de ontmanteling en bovendien rekenen op aanzienlijke extra kosten, maar verkreeg uiteindelijk meer instrumenten voor het waarborgen van de deugdelijkheid van bestuur in de Koninkrijksrelaties. En Aruba stond veilig aan de zijlijn.

Net als het Hoofdlijnenakkoord van 2005 was de Slotverklaring getekend onder grote tijdsdruk. De eilanden hadden haast, ondanks Haagse scepsis was als streefdatum 1 juli 2007 gekozen. Er moest nog zeer veel gebeuren voordat het zover kon zijn. Er bestond dan wel overeenstemming over de hoofdpunten, maar het was duidelijk dat over de details van een aantal principiële zaken verschillend werd gedacht, terwijl bovendien de praktische uitwerking buitengewoon veeleisend beloofde te zijn. Daarbij was te voorzien dat, gezien de beperkte schaal en toerusting van het bestuurlijke apparaat op de eilanden, intensieve Haagse ondersteuning onvermijdelijk zou zijn. Dat dit zonder spanningen zou verlopen, was niet waarschijnlijk. 
Politiek leek de Slotverklaring breed te worden gesteund door de Antilliaanse Staten, de vijf eilandsbesturen en het Nederlandse parlement; Aruba was welwillend afzijdig. Op de eilanden bestond echter oppositie tegen wat werd gezien als een te zeer tegemoetkomende opstelling naar Nederland; dit zou kort daarna al leiden tot een onverwachte verwerping van de Slotverklaring door de Curaçaose eilandsraad. In Nederland leefden juist zorgen over het te veel 'weggeven' aan de Antillen. Dit beperkte de onderhandelingsruimte aan beide zijden aanzienlijk en verhoogde het risico van de complexe onderneming, temeer gezien het feit dat gaande het proces voorzien was in een nieuwe reeks referenda op de eilanden en politieke toetsingen aan beide zijden van de oceaan.

Nederlandse ambtenaren waarschuwden hun bewindslieden daarnaast voortdurend voor het risico dat, gezien de enorme complexiteit van het hele proces, politiek gemotiveerde haast ten koste zou gaan van bestuurlijke zorgvuldigheid. Ook werd rekening gehouden met onvoorziene extra kosten - maar nog niet met de financiële wereldcrisis die enkele jaren later zou uitbreken.

De in de Slotverklaring vastgelegde akkoorden hadden enerzijds nog veel open einden, anderzijds was hiermee een richting aangegeven waarvoor geen van de betrokken partijen een alternatief had: er was geen alternatief scenario, geen serieus 'plan B', de onderhandelende partijen waren tot elkaar veroordeeld. Dat zou veel vergen van de onderlinge chemie en zou leiden tot een steeds sterkere procesmatige benadering. Het betekende ook dat principiële oppositie zo veel mogelijk buiten dit proces werd gehouden, wat voorspelbare kritiek op zowel het proces zelf als de steeds weer gezochte en bereikte compromissen zou uitlokken. 



\section{Het proces: chronologie en resultaten}

Toen eind 2006 de Slotakkoorden waren gesloten, brak een transitieperiode aan: één land moest worden ontbonden, twee nieuwe landen moesten worden gesticht, drie eilanden zouden de status krijgen van openbare lichamen van Nederland. Dit complexe proces zou moeizaam verlopen. De spanningen liepen allengs op, aan beide zijden van de oceaan; sfeer, tempo en overtuiging kwamen onder druk te staan.

In oktober en november 2006 waren afspraken gemaakt over de nieuwe verhoudingen - na vaak lange en moeizame onderhandelingen en op basis van de nodige politieke inschikkelijkheid, over en weer. Het aanvankelijke optimisme over een snelle voltooiing zou echter algauw afbrokkelen. De ambitie om de nieuwe structuur op 1 juli 2007 in werking te laten treden, bleek niet realistisch. Volgende streefdata, 15 december 2008 en daarna 1 januari 2010, bleken evenmin haalbaar. 10 oktober 2010 werd de uiteindelijke ontknoping van het staatkundig vernieuwingsproces. Omdat het aanvankelijk brede politieke en publieke draagvlak aan beide zijden van de oceaan gaandeweg was verminderd, bleef het tot op het laatste moment onzeker of de onderhandelende partijen werkelijk de magische datum van 10/10/10 zouden halen. Het risico van een mislukking lag steeds op de loer.

Uiterst ingewikkeld bleek het tegelijkertijd opereren op verschillende maar onderling samenhangende trajecten. Daarbij moest het proces onder moeizame politieke gesternten volbracht worden. Regelmatige bestuurswisselingen op land- en eilandniveau dreigden meermalen het draagvlak voor eerdere afspraken uit te hollen en zo de ontwikkelingen te vertragen. De door Nederland gestelde randvoorwaarden voor het slagen van het proces - betere rechtshandhaving, efficiënter bestuur en financiële deugdelijkheid op de eilanden - zetten het proces onder druk, maar kwamen regelmatig ook zelf weer onder grote druk te staan.

Complicerend was ook dat er van meet af aan aanmerkelijke me- 
ningsverschillen bestonden tussen de Nederlandse en de Caraïbische delegaties over de betekenis van autonomie en zelfbeschikkingsrecht, dat sommige eilanden over de afspraken referenda hielden of voorbereidden, dat ambtelijke en politieke processen door elkaar heen liepen, en dat het onderlinge vertrouwen ook belemmerd werd door het ontbreken van werkelijk als gemeenschappelijk functionerende en aldus ook ervaren Koninkrijksorganen. Desondanks kon de vereiste Rijkswetgeving voor de nieuwe verhoudingen slechts worden vastgesteld bij volledige consensus tussen alle partijen.

Gaande het proces zouden de tegenstellingen binnen de Antilliaanse politiek scherpere vormen aannemen - eerst vooral op Curaçao, waar de oppositie klaagde over 'neokolonialisme' en 'rekolonisatie', later ook op Sint Maarten en Bonaire. Maar in de Nederlandse politiek veranderde de sfeer eveneens. Ondanks aanhoudend optimisme van de zijde van de bewindvoerders - al te vaak werd gesproken van een 'historische doorbraak' - nam in het parlement het enthousiasme voor de operatie gaandeweg af. De Slotverklaring had in november 2006 nog kunnen rekenen op kamerbrede steun, inclusief de toen net aangetreden PVV. In 2009 en 2010 bestond die brede steun niet meer. Vooral Sint Maarten werd een parlementair zorgenkindje - maar ook voor ondersteunende maatregelen zoals de schuldsanering kalfde de steun in de Kamer af. Ten slotte dreigde het vallen van het vierde kabinet-Balkenende (CDA, PVDA en CU), begin 2010, de beoogde afsluiting van het proces in dat jaar onmogelijk te maken.

Aruba stond nog steeds grotendeels buiten het proces - al moest dit land wel betrokken worden bij sommige Rijkswetgeving, zoals die voor het Gemeenschappelijk Hof van Justitie en de wijziging van het Statuut. Bovendien legde Balkenende IV in zijn coalitieakkoord het streven vast om met Aruba soortgelijke afspraken te maken als met Curaçao en Sint Maarten, onder meer over de rechtshandhaving en overheidsfinanciën. Aruba's grondhouding in dit alles was zowel afhoudend als constructief: zolang de eigen autonome positie niet werd aangetast, zou het alle medewerking verlenen aan de staatkundige veranderingen van de andere eilanden. Maar de vrees dat deze zouden leiden tot een verslechtering van de eigen status, maakte dat de regering van MEP-premier Nel Oduber vooral afstand hield. De aflossing van de wacht onder de meer op Nederland georiënteerde AVPpremier Mike Eman bracht hier uitkomst.

Zo bezien was het op zijn minst opmerkelijk dat op 10/10/10 alle benodigde wetgeving gereed was om de nieuwe Koninkrijksconstellatie in werking te laten treden: de basiswetgeving voor de drie nieuwe openbare lichamen van Nederland was rond, het land de Nederlandse Antillen was ontmanteld en Curaçao en Sint Maarten kregen groen 
licht om zelfstandige landen binnen het Koninkrijk te worden - zij het op verschillende terreinen nog onder Haags toezicht. Een grote stap, maar niet onomkeerbaar. Vijf jaar na dato zal een evaluatie van de nieuwe verhoudingen moeten aantonen of deze hybride structuur werkbaar is of wellicht wijziging behoeft. Intussen zegde het ministerie van BZK, op aandrang van het Nederlandse parlement, in 2009 toe een toekomstvisie op het Koninkrijk voor te bereiden. Want die, zo wordt breed gevoeld, ontbreekt nog altijd.

\section{De start van de transitiefase, zonder Curaçao}

Eind 2006, onder het rompkabinet-Balkenende III, waren de "historische akkoorden' gesloten. Met de 'K3' (kleine drie, de latere BES) was overeengekomen dat de door deze eilanden gewenste directe banden met Nederland zouden worden ingevuld via de status van openbaar lichaam van Nederland, en dus onder de Grondwet kwamen te vallen - de eilanden zouden aldus een bijzondere positie krijgen, maar uitdrukkelijk geen bijzondere gemeente worden. Vervolgens waren in de Slotverklaring van 2 november 2006 voor de 'G2' (grote twee, Curaçao en Sint Maarten) criteria vastgelegd op het gebied van rechtshandhaving, deugdelijk bestuur en overheidsfinanciën. Curaçao en Sint Maarten zouden hun landsstatus binnen het Koninkrijk krijgen zodra aan alle voorwaarden was voldaan. Voor de inrichting van beide trajecten $-\mathrm{K}_{3}$ enerzijds, G2 anderzijds-moesten vóór 1 februari 2007 stappenplannen worden opgesteld. Minister voor Bestuurlijke Vernieuwing en Koninkrijksrelaties Atzo Nicolaï zette vlak voor de kabinetswisseling, in februari 2007, zijn handtekening onder een 'Overgangsakkoord'. Maar Curaçao ontbrak onder de verdragspartijen.

Tot grote ontsteltenis van zowel de Antilliaanse coalitiepartijen als Den Haag wees de eilandsraad van Curaçao in de nacht van 29 november 2006, aangemoedigd door luidruchtige demonstranten buiten het raadsgebouw, de Slotverklaring af als een 'koloniaal construct'. Dit was temeer een onverwachte tegenslag omdat ook de MAN, die ten tijde van de onderhandelingen deel uitmaakte van het kabinet-De Jongh-Elhage, zich bij terugkomst van de delegatie op Curaçao tegen het akkoord uitsprak. De partij distantieerde zich nu, geconfronteerd met heftige lokale oppositie en uit onvrede met het triomfalisme van de PAR. Achteraf wordt over deze opstelling van de MAN verschillend geoordeeld. De voorstemmers betichten de MAN van woordbreuk; vanuit de partij zelf wordt echter met grote stelligheid tegengesproken dat haar vertegenwoordiger tijdens de onderhandelingen, Urvin 
Macaay, zich expliciet zou hebben uitgesproken vóór de Slotverklaring. Humphrey Senior, MAN-prominent en thans plaatsvervangend gevolmachtigde minister van Curaçao, betoogt dat Macaay zelf niet ondertekende en direct na de ondertekening vertrok met de vroegere MAN-leider, Don Martina. Zeker is wel dat de opstelling van de MAN ook intern voor verdeeldheid zorgde. Grand old man Don Martina betreurde het afwijzen zeer en trok zich terug als adviseur van het Curaçaose bestuurscollege. ${ }^{1}$

De Curaçaose afwijzing werd in Den Haag ervaren als een grote teleurstelling. Er werd echter 'geen millimeter ruimte' geboden om te heronderhandelen. Den Haag achtte het akkoord optimaal, volgens Nicolaï had het zelfs een 'veel betere constructie' opgeleverd dan de status aparte van Aruba. ${ }^{2}$ Dat Curaçao zichzelf nu buitenspel zette, noemde de bewindsman weliswaar 'onverantwoord' tegenover de bevolking, maar dit hoefde geen vertraging op te leveren voor de overige eilanden. In de Kamer bevestigde Nicolaï dat de maatregelen, ook op financieel gebied, voor de $\mathrm{K}_{3}$ en Sint Maarten volgens het afgesproken schema uitgevoerd zouden worden; desnoods kon het Antilliaanse staatsverband alleen nog uit Curaçao blijven bestaan. Deze take it or leave it-houding richting Curaçao kon rekenen op de steun van de voltallige Kamer. Intussen werd Nicolaï van ambtelijke

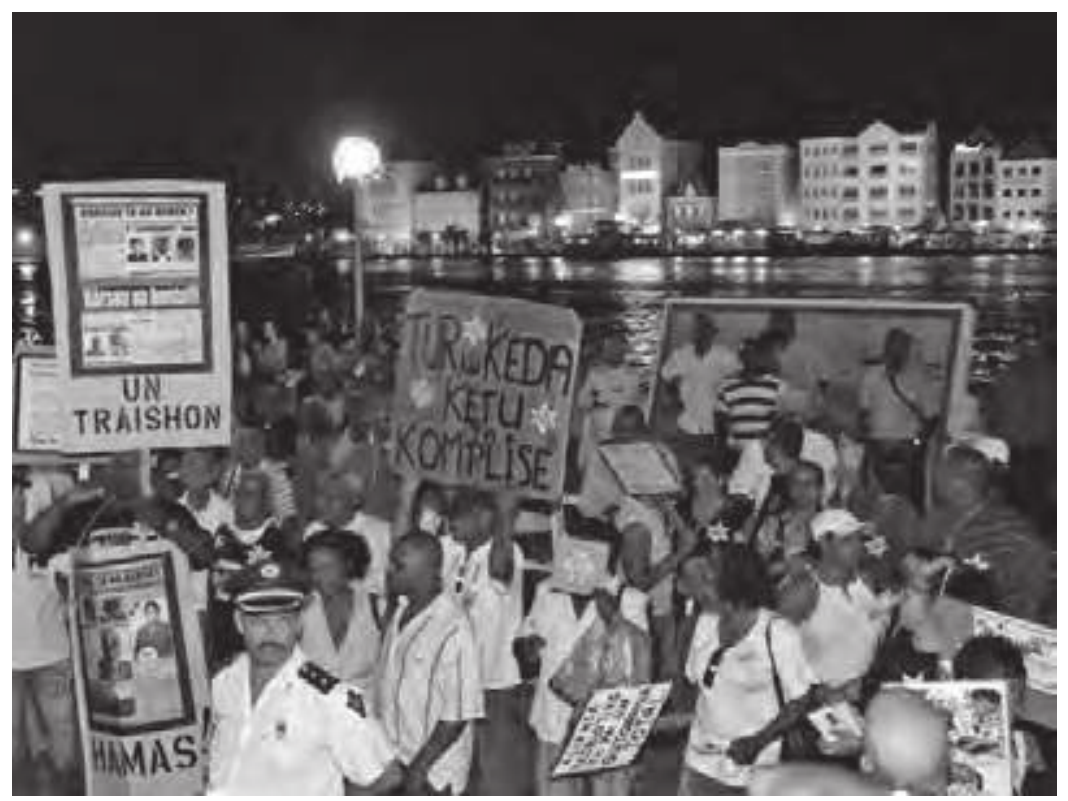

Betoging tegen 'rekolonisatie' door Nederland en het 'verraad' van de PAR tijdens de toetsings-RTC in Willemstad, 15 december 2008. 
zijde gewaarschuwd dat door de afwijzing van de Slotverklaring, en daarmee van de schuldsanering, Curaçao al op korte termijn in grote geldproblemen zou komen. Hoger toezicht op de financiële situatie zou dan 'onontkoombaar' worden. De situatie werd nog complexer door aanhoudende conflicten rond het migratiedossier. ${ }^{3}$

Dat de Slotverklaring in de Curaçaose politiek, en daarmee in de gehele eilandelijke samenleving, als een splijtzwam ging fungeren, werd duidelijk in de aanloop naar de eilandsraadverkiezingen van april 2007. Voorstanders van de afspraken met Nederland kwamen lijnrecht te staan tegenover de partijen die de voorwaarden voor de schuldsanering - onder meer financieel toezicht - opvatten als een vorm van rekolonisatie, terwijl ook de afspraken op het gebied van de rechtshandhaving veel weerstand opriepen. Op dit laatste terrein was de grote steen des aanstoots de in de Slotverklaring overeengekomen bevoegdheid van de Nederlandse minister van Justitie om op Koninkrijksniveau aanwijzingen te geven aan de, gezamenlijke, Antilliaanse procureur-generaal. ${ }^{4}$

Maar waar de oppositie opnieuw wilde onderhandelen om gunstiger voorwaarden te bedingen - wellicht in de naïeve hoop op een ruimhartiger Nederlandse opstelling onder een nieuw kabinet na de Tweede Kamerverkiezingen van 22 november 2006 - werd binnen de directie KR verwacht dat het nieuwe kabinet juist strenger zou zijn. Een ambtelijke nota noemde dan als mogelijke Nederlandse punten voor heronderhandeling het komen tot Rijkswetgeving in plaats van de overeengekomen consensusrijkswetgeving rond financiën en rechtshandhaving, het opnemen van een aanwijzingsbevoegdheid voor de minister van Justitie in het Statuut en het (gedeeltelijk) terugschroeven van de afspraken rond de schuldsanering. ${ }^{5}$

Het dwarsliggen van Curaçao bracht Nicolaï niet van zijn koers. Tijdens Topoverleg van de vijf eilanden en de Antilliaanse regering, op 11 en 12 januari 2007, werd besloten dat de vier eilanden het staatkundig traject zouden voortzetten zonder Curaçao. Vervolgens resulteerden gesprekken tussen de bewindsman, de eilandsbesturen en het land de Nederlandse Antillen in de afspraak om op 12 februari 2007 een RTC te organiseren. Aruba zou als waarnemer worden uitgenodigd, maar ook Curaçao - in de hoop dat dit land in spe zich dan later weer soepel bij het proces zou kunnen aansluiten.

Tijdens deze RTC moesten onder meer de stappenplannen bekrachtigd worden, de regie van het proces worden vastgelegd en de transitiedatum worden besproken. ${ }^{6}$ Interdepartementaal Haags overleg had intussen duidelijk gemaakt dat 2009 een 'logisch' transitiejaar bleef, ook omdat voor de kleine eilanden niet alle regelgeving als een 'big bang' zou worden ingevoerd: om de overgang niet te abrupt te 
maken, zou de Antilliaanse wetgeving aanvankelijk grotendeels blijven gelden in de nieuwe situatie, om pas langzamerhand plaats te maken voor Nederlandse. ${ }^{7}$

Het werd uiteindelijk geen RTC maar een bestuurlijk overleg, dat op 12 februari plaatsvond te Sint Maarten, tussen het land de Nederlandse Antillen, Sint Maarten, Bonaire, Saba en Sint Eustatius. Curaçao was aanwezig als waarnemer; Aruba onder Oduber had deelname 'niet opportuun' geacht. ${ }^{8}$ In zijn opening gaf Nicolaï het belang van de conferentie weer: de eerdere afspraken moesten nu worden geconcretiseerd om de onomkeerbaarheid van het proces te markeren - een hard signaal richting Curaçao.

De minister was ambtelijk geadviseerd in te stemmen met de voorliggende stappenplannen, hoewel de daarin voorgestelde transitie per 1 juli 2008 werd bestempeld als 'ONREALISTISCH'. Het tijdpad moest met minstens een jaar verschoven worden; bovendien mocht het niet gaan om 'een fatale datum', er kon alleen sprake zijn van een 'STREEFdatum'. Pas op een slot-RTC, waar zou worden getoetst of beide toekomstige landen werkelijk aan alle normen voldeden, zou de definitieve datum kunnen worden vastgesteld - in de tussentijd moest de inhoud het tempo bepalen. Vooropstond dat het proces vooral zorgvuldig en transparant moest verlopen. ${ }^{9}$

Het politiek overleg verliep constructief en werd dezelfde dag nog afgesloten met een door alle partijen ondertekend Overgangsakkoord: een uitwerking van de eerdere afspraken, op onderdelen aangevuld, inclusief stappenplannen. ${ }^{10}$ Een van de hoofdpunten betrof het loslaten van de in het Hoofdlijnenakkoord van oktober 2005 genoemde maar onhaalbaar gebleken transitiedatum van 1 juli 2007. Die werd nu anderhalf jaar uitgesteld, naar 15 december 2008, Koninkrijksdag - waarmee ook werd vastgehouden aan één moment van overgang voor alle eilanden. Aanvankelijk hadden de meeste eilanden de nieuwe status willen laten ingaan op hun respectievelijke feestdagen, verspreid over het kalenderjaar. Koninkrijksdag $2008 \mathrm{im}-$ pliceerde volgens Nicolaï nog steeds een 'ambitieus' tijdschema, dat vooral de politieke wil benadrukte om gezamenlijk, met volle inzet, de staatkundige veranderingen voor te bereiden. ${ }^{11}$

Deze gezamenlijke verantwoordelijkheid werd vormgegeven met de instelling van een Politieke Stuurgroep Staatkundige Veranderingen en een voorbereidende Ambtelijke Regiegroep. ${ }^{12}$ De stappenplannen dienden als uitgangspunt voor de inrichting van het traject. Het stappenplan voor Sint Maarten zou worden uitgevoerd binnen twee ambtelijke projectgroepen: 'Financiën' en 'Rechtspleging, Rechtshandhaving en Constitutionele Zaken' (PRRC). ${ }^{13}$ Voor de BES-eilanden - de betiteling ' $\mathrm{K}_{3}$ ' was van het toneel gewerkt nadat 
de Statiaanse adviseur Xavier Blackman erachter was gekomen dat een succesvolle Vlaamse meisjespopgroep onder dezelfde naam door het leven ging - werd een projectgroep 'Wet Openbare Lichamen Bonaire, Sint Eustatius en Saba' (WOLBES) in het leven geroepen. Daarnaast zou de v-RTC een rol houden bij het toetsen aan de vastgestelde criteria van de constituties van de nieuwe landen, de wet- en regelgeving en de implementatie daarvan.

Het andere hoofdpunt uit het Overgangsakkoord betrof de schuldsanering. Na de Nederlandse toezegging bij de start-RTC om een oplossing te bieden voor de schuldenproblematiek en de afspraken in de Slotverklaring over de voorwaarden, werd nu vastgelegd hoe het grootste deel van de geconsolideerde schuld van het land en de eilandgebieden - gefaseerd - gesaneerd zou worden en welke bedragen daarmee gemoeid waren. In totaal trok Nederland in het Overgangsakkoord bijna een half miljard euro uit - ook voor financiële ondersteuning van projecten met zichtbare gevolgen voor de bevolking op de korte termijn ('quick wins' in de sociale sfeer) ${ }^{14}{ }^{14}$ Ten opzichte van de Slotverklaring bood Nederland geen extra middelen aan voor de schuldsanering, die - het bedrag was mede afhankelijk van koersverschillen en zou pas in 2010 duidelijk worden - uiteindelijk 1,7 miljard euro zou omvatten. Wel werden verplichtingen versneld overgenomen en was er ruimte voor eenmalige begrotingssteun aan de vier eilanden.

Als Curaçao in een later stadium alsnog zou aanhaken, kon het eveneens profiteren van de beschikbare middelen. Intussen hoefde het eiland echter niet te rekenen op sanering van zijn meerderheidsaandeel (circa driekwart) in de staatsschuld. De Nederlandse inzet - een lijn die in december 2006 met minister van Financiën Gerrit Zalm was afgestemd - was dat Curaçao, zolang het de Slotverklaring niet onderschreef, niet mocht profiteren van de afspraken met het land de Nederlandse Antillen. ${ }^{15}$ Overigens zou pas formeel worden overgegaan tot sanering van de geconsolideerde schulden van het land en de eilandgebieden nadat het financieel toezicht bij wet geregeld was. Want, in de woorden van Nicolaii: 'Als de schuldenlast nu al wordt overgenomen, is Nederland zijn ultieme drukmiddel kwijt. ${ }^{16}$

Voor Sint Maarten, Saba, Sint Eustatius en Bonaire werd met het Overgangsakkoord - door Nicolaï bestempeld als 'een doorbraak in het Koninkrijk' - formeel gestart met de transitiefase. In de Curaçaose politiek begon het besef door te dringen dat wijziging van de Slotverklaring geen optie was en dat het land in spe weer aansluiting moest zien te vinden bij het proces. Nicolaï beklemtoonde dat de deur permanent openstond; de Slotverklaring lag vast, maar over de uitwerking ervan kon gesproken worden. ${ }^{17}$ 
Nog afgezien van de afzijdigheid van Curaçao hadden de onder Nicolaï vastgelegde afspraken veel open einden. Nicolaïs opvolgster, CDA-staatssecretaris Ank Bijleveld-Schouten, zou daaraan nog een onverwacht zware dobber hebben. Het op 22 februari 2007 aangetreden vierde kabinet-Balkenende bevestigde in zijn regeerakkoord de bestuurlijke herinrichting van de Nederlandse Antillen en de daarbij behorende verdieping van de samenwerking op het gebied van de 'rechtshandhaving, goed bestuur, sociale voorzieningen, onderwijs en Nederlandse taal, overheidsfinanciën'. Met Aruba streefde het kabinet, als gezegd, 'overeenkomstige afspraken' na. ${ }^{18}$ Bijleveld zette de beleidslijn van haar voorganger onverkort voort: de Slotverklaring bleef ononderhandelbaar. Daarover liet zij tijdens haar kennismakingsbezoek aan de eilanden, eind maart 2007, geen misverstand bestaan. ${ }^{19}$

Allerwegen werd met spanning uitgekeken naar de eilandsraadverkiezingen van 20 april op het sterk gepolariseerde Curaçao, met als inzet het al dan niet alsnog accorderen van de Slotverklaring. Terwijl op de Bovenwinden en Bonaire de regerende partijen hun positie behielden, vormde de verkiezingsuitslag op Curaçao een bedreiging voor het proces. Hoewel de PAR van premier De Jongh-Elhage, die de Slotverklaring onverkort was blijven steunen, als grootste uit de bus kwam, behaalde zij met haar coalitiegenoten geen meerderheid in de eilandsraad - die bleef voorbehouden aan de 'autonomiepartijen' die zich tegen de afspraken met Den Haag hadden gekeerd.

Hoewel de uiteindelijke formatie op Curaçao gunstig zou uitvallen voor de voortgang en dus ook Den Haag goed uitkwam - de PAR kreeg als grootste partij het initiatief en slaagde erin de flink teruggevallen FOL uit het 'antikamp' los te weken - was duidelijk dat de weerstand tegen de Slotverklaring niet genegeerd kon worden, ook niet door Den Haag. ${ }^{20}$ Op 4 mei ondertekenden PAR, FOL en PNP, samen goed voor een krappe meerderheid van 11 van de 21 zetels, een Intentieverklaring om een bestuurscollege te vormen met als streven de samenwerking met Nederland weer op de rails te zetten. Op 21 mei 2007 werd het bestuurscollege daadwerkelijk gevormd. ${ }^{21}$

De nieuwe eilandsraad stemde in de nacht van 6 op 7 juli alsnog in met de gehele Slotverklaring, met twaalf stemmen voor en zeven tegen. De aanvaarding verliep niet zonder slag of stoot. De zeventien uur durende vergadering werd verstoord door betogers en een bommelding, en moest ten slotte worden verplaatst. Bovendien waren er nog steeds inhoudelijke vragen en bedenkingen. In een tweede raadsbesluit kreeg het bestuurscollege instructie om zes 'pijnpunten' 
nader met de Koninkrijkspartners te bespreken - vooral rond de afspraken op het vlak van justitie, politie, financieel toezicht en de consensusrijkswetten. ${ }^{22}$

De Curaçaose oppositie was teleurgesteld en boos, bij de andere partijen was de opluchting groot. Curaçao, hoewel verscheurd, deed weer mee aan de ontmanteling. Bijleveld kon nu ook met dit eiland gaan praten over een Overgangsakkoord als volgende stap in de opheffing van de Antillen. Gedeputeerde van Staatkundige Structuur Zita Jesus-Leito zou al snel overeenkomstige afspraken vastleggen als eerder met de andere vier eilanden waren gemaakt: op 28 augustus sloot Curaçao zich met het 'Toetredingsakkoord' aan bij het Overgangsakkoord van 12 februari en de daaraan gehechte stappenplannen. Enkele dagen eerder, op 25 juni, was er een kortstondig gewelddadig protest geweest, gericht tegen Nederlanders; een blanke Curaçaoënaar werd het ziekenhuis in geslagen, De Telegraaf schreef verontwaardigd over 'blankenjacht'. Niettemin gold 15 december 2008 nu ook voor Curaçao als transitiedatum en kwamen aanzienlijke fondsen beschikbaar voor schuldsanering, alsmede enige sociaaleconomische initiatieven. Opmerkelijk is dat in het akkoord de rol van de in te stellen financieel toezichthouder beperkt werd tot een adviserende in plaats van een bepalende, zoals voor de $\mathrm{K}_{3}$ het geval was. Bovendien kreeg Curaçao garanties voor de schuldsanering, waarvoor in de Voorjaarsnota 2007 een bedrag van maximaal 2,2 miljard euro werd gereserveerd. ${ }^{23}$

Een soepele voortgang leek nu gegarandeerd. Curaçao onderschreef de werkplannen van de inmiddels gestarte ambtelijke projectgroepen. Bijleveld was verheugd en wees op de streefdatum van 15 december 2008 - ook al betekende dit dat de wetgeving dan al op 1 juli 2008 gereed moest zijn. ${ }^{24}$ Curaçao zou echter sterk verdeeld blijven, waarbij de oppositie steeds opnieuw Nederland verweet te trachten meer controle te krijgen over landszaken, vooral ook op financieel terrein. ${ }^{25}$ Inderdaad was duidelijk dat voor Den Haag schuldsanering zonder financieel toezicht uitgesloten was.

Hoe dan ook kon het proces nu worden voortgezet. Dat de eerste gestelde deadline van 1 juli 2007 niet haalbaar was gebleken, verbaast niet - het zou 'een Koninkrijksrecord' zijn geweest, alleen al de voorbereiding van de status aparte van Aruba had ongeveer drie jaar in beslag genomen. De nieuwe streefdatum was nog steeds erg ambitieus. Ambtelijk was geadviseerd eerder te denken aan ergens in 2009, waarbij ook was gewaarschuwd dat de betrokkenheid van Aruba 'hoewel op zich positief, tot verdere vertraging zal leiden'. ${ }^{26}$

Volgens de stappenplannen was Nederland verantwoordelijk voor de transitie van de BES-eilanden tot openbare lichamen, evenals 
voor de totstandkoming van de daarvoor benodigde (Rijks)regelgeving. Het land de Nederlandse Antillen was verantwoordelijk voor de ontmanteling van de landslaag, Sint Maarten en Curaçao voor de opbouw van de nieuwe landen. ${ }^{27}$ Van Haagse zijde werd voortdurend benadrukt dat deze trajecten nauw met elkaar samenhingen: ten slotte was er één gezamenlijk moment van overgang beoogd.

Voor alle partijen betekenden de hervormingen een enorme inspanning. Het gedurende het traject afgewerkte wetgevingsprogramma zou uiteindelijk 18 (consensus)rijkswetten, 25 Koninklijke Besluiten en AMVRB's, 10 onderlinge regelingen tussen diverse landen, en nog eens 45 ministeriële regelingen en besluiten voor de nieuwe situatie van Bonaire, Saba en Sint Eustatius omvatten. ${ }^{28}$ Complicerende factor was dat voor het land de Nederlandse Antillen en de (ei)landen Curaçao en Sint Maarten ook intern een tijdrovend wetgevingsproces speelde. Bovendien zou aan Antilliaanse zijde vaak discussie ontstaan over de vraag of wel de goede besluiten waren genomen, zodat Den Haag zich voortdurend geconfronteerd zag met wat in de wandelgangen betiteld zou worden als Antilliaans 'terugonderhandelen'. Dit had niet alleen tot gevolg dat het proces aanmerkelijke vertraging opliep, maar ook dat Nederland steeds weer consessies zou doen ten opzichte van eerdere, moeizaam bereikte compromissen.

Aan Haagse zijde is ook achteraf veel geklaagd over dit proces en de vermeende Haagse bereidheid tot het doen van concessies, hetzij 'uit desinteresse, uit neo-koloniale liefdadigheid, uit vermoeidheid of uit wanhoop', zoals professor Luc Verhey, als projectleider aangetrokken door het ministerie van Justitie, het achteraf verwoordde. ${ }^{29}$ Daarbij kwam nog dat in vergaderingen van de Politieke Stuurgroep vaak geschilpunten werden voorgelegd die men op ambtelijk niveau niet had weten op te lossen, en dat de Antilliaanse delegaties altijd uit een enorme groep mensen bestonden - een invloedrijke maar lang niet altijd eenstemmige 'achterban'. ${ }^{30}$ Daarbij ging het uiteraard om meer dan technische, bestuurlijke kwesties. Hirsch Ballin waarschuwde in dit verband: 'Achterdocht is een gif dat insluipt in het proces en het wordt gevoed door populistische sprekers aan beiden kanten van de oceaan. ${ }^{31}$ Daartegenover mag, zoals de Antilliaanse adviseur en voormalig gevolmachtigde minister Carel de Haseth met recht stelt in reactie op de woorden van Verhey, niet de indruk worden gewekt dat Antilliaanse tegenwerpingen altijd onredelijk of slecht beargumenteerd waren, of omgekeerd, dat 'Den Haag' altijd het gelijk aan zijn zijde had. ${ }^{32}$

Dat de Nederlandse onderhandelaars inderdaad meermalen verdere concessies deden in de belangrijkste dossiers - financiën, politie en het Openbaar Ministerie - ondergroef in het parlement de politieke 
houdbaarheid van de afspraken. De oppositie verhardde gaandeweg, met als uitgesproken tegenstanders PVV'er Brinkman en ook SPwoordvoerder Van Raak. Uiteindelijk zou ook de VVD haar steun aan het proces intrekken, omdat in de rechtshandhaving onaanvaardbare concessies waren gedaan. Daarnaast hield de VVD tot op het einde, tevergeefs, vast aan een koppeling tussen de schuldsanering en een regeling voor het personenverkeer binnen het Koninkrijk. ${ }^{33}$ Ook deze parlementaire oppositie zette Bijleveld en haar staf onder grote druk om de ontmanteling tijdens Balkenende IV volledig af te ronden.

Intussen vergde het complexe proces nu onvermijdelijk zijn tijd. Medio juni 2007 werd al geconstateerd dat rond de rechtshandhaving en financiën vertraging was opgetreden - een 'risico' voor de haalbaarheid van 15 december 2008. Bijleveld droeg tijdens haar eerste werkbezoek aan de eilanden de boodschap uit door te gaan 'op de afgesproken weg', maar 'wel wat zorgen' te hebben 'over de voortgang'. In Haagse ogen focusten de BES-eilanden, maar ook Sint Maarten, te sterk op de details. Bovendien maakte de Antilliaanse regering naar haar mening te weinig vaart met de ontmanteling van de landslaag. De bewindsvrouw wilde het proces 'een positieve duw' geven, ook door de besluitvorming zo snel mogelijk naar politiek niveau te tillen. ${ }^{34}$

Op de eerste politieke bijeenkomst, op 22 juni 2007 te Curaçao, moesten Haagse zorgen over de voortgang en het 'reële risico' dat 15 december 2008 in gevaar kwam in vele toonaarden worden geuit. Onderling vertrouwen was cruciaal, zo zou vanwege BZK worden benadrukt; Nederland was zonder meer bereid mee te werken aan het realiseren van de deadline, maar de kwaliteit van het resultaat stond voorop. Over de betrokkenheid van Aruba en Curaçao werd intern verondersteld dat het eerste eiland 'zelf een beetje buiten beeld wil blijven', Curaçao was 'feitelijk redelijk betrokken'. De externe communicatie over dit laatste diende echter terughoudend te zijn, omdat dit risicovol was voor de nieuwe eilandcoalitie, waarin de PAR en de PNP door de oppositie als arrogant werden afgeschilderd. ${ }^{35}$

De discussies over het financieel toezicht zoals vastgelegd in de Slotverklaring, als voorwaarde voor de toegezegde schuldsanering, leidden vrij snel tot besluitvorming met de 'BES-eilanden'-in de wandeling ook wel de 'Besjes' genoemd. Op 20 juni 2007, met de aanvaarding van de AMVRB Tijdelijk financieel toezicht BES, waren deze eilanden meteen al een flinke stap dichter bij hun nieuwe status - in de voorafgaande ambtelijke besprekingen was duidelijk geworden dat in dit onderhandelingstraject niet zozeer het toezicht het pièce de resistance was, maar veeleer het toekomstige voorzieningenniveau. ${ }^{36}$

Overeengekomen werd dat onder streng toezicht tijdens de transitieperiode de eilandelijke financiën op orde zouden worden ge- 
bracht en de begrotingen sluitend gemaakt. Een College financieel toezicht $(\mathrm{Cft})$, te benoemen door de Nederlandse ministerraad, zou beoordelen of de begrotingen voldeden aan de in het besluit vastgelegde toetsingscriteria en tevens toezicht houden op de uitvoering van de begrotingen en de verantwoording via de jaarrekening. De Rijksministerraad kon, indien nodig, een aanwijzing geven aan het betreffende eilandsbestuur; de sanering van schulden of betalingsachterstanden kon dan worden stopgezet. In afwijking van de afspraken van eind 2006 kregen de eilanden nu tot 2011 de tijd om een sluitende begroting te realiseren. Hoewel de AMVRB was gericht op de overgangsfase, zou ook daarna sprake blijven van toezicht, op ongeveer dezelfde wijze. Verder zou de financiële verhouding met de drie openbare lichamen worden geënt op de verhouding tussen het Rijk en de Nederlandse gemeenten, waarbij echter de complexe systematiek van het Gemeentefonds niet exact zou worden gevolgd. Ook kregen de drie eilanden, in afwijking van alle Nederlandse gemeenten, geen leenbevoegdheid. ${ }^{37}$

Hiermee kon Bijleveld, die sprak van een 'belangrijke mijlpaal', een succes op haar conto schrijven. ${ }^{38}$ Op 1 december 2007 trad het College financieel toezicht in werking, met als voorzitter Hans Weitenberg. ${ }^{39}$ Op 10 november 2007 maakte Nederland de eerste saneringsmiddelen over aan de BEs. ${ }^{40}$ De eerste opgave voor het $\mathrm{Cft}$ was het beoordelen en goedkeuren van de begrotingen voor 2008. Op 5 juni 2008 deelde Bijleveld de Tweede Kamer mee dat dit intussen gelukt was, wat zij 'een niet geringe prestatie' noemde. ${ }^{41}$ Deze relatief snelle afspraken op het financiële vlak namen niet weg dat in het 'BES-traject' nog de nodige spanningen zouden optreden, zoals gezegd vooral rond het op de eilanden te hanteren voorzieningenniveau, ook in het licht van het in de Nederlandse Grondwet vervatte gelijkheidsbeginsel (artikel 1). Daarnaast zouden in de overname van Nederlandse wetgeving - die geheel moest worden doorgelicht om te bezien of en zo ja, in welke mate die overzee zou gaan gelden - ethische kwesties als abortus, euthanasie en homohuwelijk de nodige aandacht eisen en spanningen oproepen.

Maar ook Sint Maarten, Curaçao en het land de Nederlandse Antillen moesten nu onder het toezicht van het $\mathrm{Cft}$ gaan vallen, zodat in de overgangsperiode kon worden toegewerkt naar evenwichtige begrotingen en schuldbeheersing. Dit proces verliep echter traag. Pas op 10 december 2008 - een jaar na het besluit voor de BES - zou het besluit Tijdelijk financieel toezicht Nederlandse Antillen, Curaçao en Sint Maarten in werking treden. ${ }^{42}$

Dat de aanpak van de schuldsanering, waarmee maximaal 2,2 miljard euro gemoeid zou zijn, met Curaçao en Sint Maarten aanmer- 
kelijk meer discussie opleverde dan met de BES kwam mede door politieke weerstand tegen de Nederlandse wens tot verbreding van het werkveld van de toezichthouder naar controle op corporate governance, dus overheidsnv's. Dit zou nog veel voeten in aarde hebben. Tijdens een Topoverleg op Sint Maarten in januari 2008 werd in principe overeenstemming bereikt over een AMVRB waarin de Nederlandse eis rond corporate governance-regels voor overheidsnv's niet onder het Cft viel. Curaçao en Sint Maarten kregen tot augustus van dat jaar om met eigen regelgeving op dit terrein te komen; toen die echter uitbleef, werden de corporate governance-afspraken toch opgenomen, in ruil voor een afzwakking van de bevoegdheden van de toezichthouder in de zin dat een afkeuring van de begroting via de Rijksministerraad zou moeten lopen - over enkele laatste artikelen moest nog besluitvorming volgen. ${ }^{43}$

De financiën waren niet het enige hete hangijzer. Medio 2007, in haar eerste voortgangsrapportage aan de Kamer, had Bijleveld moeten constateren dat vooral in het juridische traject de onderhandelingen moeizaam verliepen. ${ }^{44}$ Ambtelijk was gerapporteerd dat het onderhandelingsklimaat in de PRRC 'ernstig te wensen overlaat'; er zou sprake zijn van 'groot wantrouwen', 'alles [wordt] uitgebreid besproken, ook niet relevante onderwerpen'. Vooral de keuze voor één procureur-generaal voor alle eilanden (tegenover de Antilliaanse roep om twee PG's) en de in de Slotverklaring overeengekomen aanwijzingsbevoegdheid aan deze PG voor de Nederlandse minister van Justitie als lid van de Rijksministerraad stuitten op groot verzet; volgens de Caraïbische delegaties was dit laatste zelfs in strijd met het Statuut. Een ander heikel punt was (en bleef, naar zou blijken) de invulling van de nieuwe politieorganisatie, waarover de gedachtevorming nog lang niet bleek te zijn uitgekristalliseerd, hoewel de Slotverklaring al had vastgelegd dat Curaçao en Sint Maarten sterke verbeteringen bij de politie moesten doorvoeren, wilden ze land kunnen worden. ${ }^{45}$

De geconstateerde achterstand op het 'kritische tijdpad' werd volgens Bijleveld deels veroorzaakt doordat Curaçao enige tijd buiten spel had gestaan. Maar er waren ook positieve dingen te melden: op hoofdlijnen was overeenstemming bereikt over het Gemeenschappelijk Hof van Justitie en de opbouw van het land Sint Maarten verliep 'redelijk voortvarend'. De tot dan gevolgde strategie 'Nederland heeft geen haast, zorgvuldigheid gaat voor snelheid' zou worden voortgezet, zo heette het. In de praktijk zou echter blijken dat, naarmate de tijd vorderde, de druk op Den Haag zou toenemen om mee te werken aan een zo kort mogelijke transitieperiode, mede vanuit de zorg dat het ontmantelende land zijn verplichtingen niet meer (voldoende) 
zou nakomen. Dit zou leiden tot Nederlandse concessies, vooral op Justitiegebied, die Bijleveld op een allengs kritischer houding van de Tweede Kamer kwamen te staan. ${ }^{46}$

Volgens VVD-woordvoerder Remkes stond op grond van deze eerste voortgangsrapportage al vast dat 15 december 2008 niet haalbaar was. ${ }^{47}$ Bijleveld hield 'druk op het proces' maar moest ook in de tweede helft van 2007 achterstand constateren, die nu een 'daadwerkelijk risico' opleverde voor de overgang per 15 december 2008. Niet alleen verliep het ontmantelen van de landslaag in haar visie traag, in de financiële en juridische projectgroepen vergden veel onderwerpen 'onevenredig veel' vergadertijd. Het schorsen van een Politieke Stuurgroepvergadering begin oktober gold in Den Haag als het bewijs dat de onderhandelingen niet goed verliepen. Besloten werd - zij het van Nederlandse zijde schoorvoetend - de belangrijkste geschilpunten op de Justitiethema's voor te leggen aan externe deskundigen. ${ }^{48}$ De sombere conclusie bij BZK luidde dat sinds november 2006 in de ambtelijke onderhandelingen geen enkele inhoudelijke voortgang geboekt was, eerder vertraging; de indruk bestond dat de Antilliaanse ambtenaren steeds trachtten terug te komen op de politieke afspraken. ${ }^{49}$ Intussen trachtte De Jongh-Elhage, wellicht met de moed der wanhoop - 'Er moet ontzettend veel gebeuren. [...] Het is gewoon even teveel' - te sussen: er was geen sprake van een conflict en zij zag geen reden om de streefdatum te verplaatsen naar medio 2009, zoals geruchten wilden. ${ }^{50}$

Het traditionele werkbezoek van de Nederlandse fractievoorzitters van de Tweede Kamer aan alle eilanden, eind oktober, kwam dus op een gevoelig moment. ${ }^{51}$ Dit werd nog versterkt door de recente verschijning van het uiterst kritische WODC-rapport Georganiseerde criminaliteit en de rechtshandhaving op St. Maarten. Dit rapport zou het toch al wankele imago van het eiland op rechtshandhavingsgebied weinig goed doen. De WODC schetste een 'zeer zorgwekkend beeld' van de georganiseerde misdaad op Sint Maarten, dat door zijn ligging en infrastructuur, gecombineerd met een nog beperkte rechtshandhaving, een 'ideale gelegenheidsstructuur' bood voor het ontplooien van criminele activiteiten, zoals drugssmokkel, mensensmokkel en illegaal geldverkeer. Er waren zelfs vermoedens van financiering van terroristische activiteiten. Aangezien de controlesystemen en -mogelijkheden hiermee niet of nauwelijks in evenwicht waren, onderstreepte het rapport de noodzaak van een spoedige, integrale aanpak van de vele problemen die op het eiland speelden. ${ }^{52}$

De constatering dat Sint Maarten in de greep was van de georganiseerde criminaliteit bracht een Kamermeerderheid, en ook de meeste fractievoorzitters, tot de conclusie dat van een zelfstandig land geen 
sprake kon zijn, zeker niet al in 2008. Bijleveld wilde geen datum noemen en benadrukte dat het 'geen automatisme' was dat Sint Maarten een land zou worden. Eerst moest aan de aanbevelingen van het rapport drastisch inhoud worden gegeven en voldaan zijn aan de 'harde randvoorwaarden' uit de Slotverklaring, die zou blijven dienen als haar kompas: 'Wie niet klaar is, wordt geen land. ${ }^{53}$

Niet alleen op Sint Maarten, ook op de andere eilanden was de toon van de fractievoorzitters hard, vaak zelfs ronduit negatief. Antilliaanse politici zeurden en klaagden, vond CDA-fractieleider Pieter van Geel; volgens VVD-leider Mark Rutte was de schuldsanering de laatste kans voordat Nederland het bestuur zou overnemen en moest Sint Maarten een noodplan krijgen onder regie van de minister van BZK om de criminaliteit en corruptie te stoppen; Verdonk noemde de Slotverklaring 'geld over de balk smijten'. Intussen bekritiseerden parlementariërs de respectievelijk 'mensonterende' en 'levensbedreigende' situatie in de Curaçaose gevangenis en Isla-raffinaderij - het waren allemaal uitspraken die de toch al gespannen verhoudingen geen goed zouden doen en het wantrouwen tegenover Nederland alleen maar versterkten. ${ }^{54}$

De Haagse boodschap was duidelijk: de Antilliaanse politiek moest zich realiseren dat het draagvlak in Nederland voor de staatkundige hervormingen dramatisch kon afnemen. Aan de Slotverklaring en uitwerkingsakkoorden viel niet te tornen - een mededeling die volgens de Curaçaose oppositie bewees dat haar 'pijnpunten' helemaal niet zouden worden 'meegenomen' in de uitwerking van de afspraken. Beroering bracht vervolgens ook Bijlevelds uitspraak op 31 oktober in dagblad Spits: zij noemde de autonomie van Curaçao en Sint Maarten per 15 december 2008 vrijwel onhaalbaar omdat de eilanden volgens haar niet op tijd aan de Nederlandse voorwaarden konden voldoen. ${ }^{55}$

Maar niet alles zat tegen. De voorbereiding van de wetgeving over het Gemeenschappelijk Hof van Justitie, dat op termijn ook jurisdictie moest krijgen voor Bonaire, Sint Eustatius, Saba en Aruba, lag op schema. ${ }^{56}$ Een tweede belangrijk resultaat was overeenstemming over de betrokkenheid van Curaçao en Sint Maarten bij het tot stand komen van de consensusrijkswetgeving - dit voor het proces gekozen instrument van consensus, geïnspireerd op een voorlichting van de Raad van State uit september 2006, zou overigens door betrokken Justitieambtenaren worden gekwalificeerd als lastig en 'innerlijk tegenstrijdig', vanwege het bij deze wetgeving vrijwillig vastleggen van landsaangelegenheden op Koninkrijksniveau. ${ }^{57}$ In de politieke verklaring beloofde Nederland dat een consensusrijkswet of -AMVRB niet naar de Rijksministerraad zou gaan zonder voorafgaande instem- 
ming van Curaçao en Sint Maarten. Zo zouden, was de redenering, alle partijen gedurende het gehele proces van vrijwillig aangegane regelgeving ervan verzekerd blijven dat de eis van consensus serieus werd genomen.

Ook het waarborgen van consensus tijdens de parlementaire fase van het wetgevingsproces was lang omstreden geweest. Nederland wilde niet instemmen met de Antilliaanse wens dat een wetsvoorstel zou worden ingetrokken als de Tweede Kamer dit zodanig amendeerde dat Curaçao en/of Sint Maarten daar niet meer achter kon(den) staan - hierdoor kon de Nederlandse minister namelijk klem komen te zitten tussen het parlement, de Rijksministerraad en/of Curaçao en Sint Maarten. Als Nederlands 'wisselgeld' werd afgesproken dat op een door de Tweede Kamer geamendeerd voorstel schorsing van de behandeling zou worden gevraagd, waarna het zou worden besproken in de Rijksministerraad, die vervolgens zou vaststellen of er nog consensus bestond. ${ }^{58}$ Consensusrijkswetten zouden dus niet door het Nederlandse parlement gewijzigd kunnen worden zonder dat het betrokken eilandgebied daarvoor goedkeuring had gegeven.

Ondanks deze succesjes vormde het onderlinge klimaat een punt van zorg. Begin december 2007 werd aan Nederlandse zijde geconstateerd 'dat er een slechte sfeer is ontstaan op de Antillen. Er zijn veel klachten over Nederland en veel negatieve sentimenten'. Met name op Curaçao was de politieke verdeeldheid nog steeds groot. Tijdens de laatste Politieke Stuurgroep, op 12 november, was opnieuw fel gedemonstreerd; het Vrijwilligers Korps Curaçao had Bijleveld en haar Antilliaanse gesprekspartners moeten ontzetten. ${ }^{59}$ Het proces was met veel wantrouwen omgeven en de interne Haagse boodschap luidde dat hiermee terdege rekening moest worden gehouden. De vraag was nu wat de grootste pijnpunten waren voor de vertegenwoordigers van de eilanden en of de politici op de eilanden werkelijk bereid waren hervormingen door te voeren. ${ }^{60}$

Hoewel het begrotingsdebat van 5 en 6 december 2007 brede steun voor het kabinetsbeleid opleverde, had een Kamermeerderheid er evenmin als Bijleveld vertrouwen in dat de transitie op 15 december 2008 kon plaatsvinden. De staatssecretaris sprak van een moeizaam proces, Remkes kwalificeerde de voortgangsrapportage als 'onthutsend'. Het bezoek van de fractievoorzitters aan de eilanden had daaraan weinig positiefs bijgedragen. ${ }^{61}$

Er werd sterk gepleit voor uitstel; onder meer coalitiepartijen CDA en PVDA noemden de streefdatum 'een knellend harnas'; volgens de SP kwam het noemen van transitiedata slechts neer op het organiseren van teleurstellingen. Concrete nieuwe deadlines werden niet genoemd. Bijleveld zegde toe na gesprekken met de Antilliaanse 
partners, gepland voor het begin van 2008, te zullen bezien of de oorspronkelijke deadline nog haalbaar was. Inmiddels zinde zij op het reeds doorvoeren van verbeteringen op de BES-eilanden - namelijk op de in het Overgangsakkoord geprioriteerde beleidsterreinen van volksgezondheid, sociale zekerheid, onderwijs en jeugd, veiligheid, politie en financiën - en op het decentraliseren van landsbevoegdheden aan Curaçao en Sint Maarten. Op die manier konden toch onomkeerbare stappen in het proces worden gezet en kon Nederland ook zijn verantwoordelijkheid richting de BES-eilanden nemen. ${ }^{62}$

\section{Naar de toetsings-RTC, december 2008}

Verdere complicaties bleven niet uit; in januari 2008 bereikten de interparlementaire relaties een dieptepunt. Het reguliere overleg van de POK op de Antillen werd afgelast, een primeur, aangezien PVV'er Brinkman zijn excuses weigerde aan te bieden voor uitspraken waarin hij de Antillen als een corrupt boevennest had afgeschilderd en suggereerde de eilanden te koop aan te bieden op Marktplaats.nl. Op 5 december 2007 had Brinkman, vergeefs, een motie ingediend, waarin hij, 'overwegende dat de Nederlandse Antillen en Aruba een grotendeels corrupt boevennest zijn dat de Nederlandse belastingbetaler al vele miljarden euro's heeft gekost en nog gaat kosten' de regering verzocht 'initiatieven te nemen om te komen tot het verbreken van alle staatsrechtelijke banden met de Nederlandse Antillen en Aruba'. In deze gespannen sfeer vloog Bijleveld op 19 januari naar de eilanden om met de bestuurders verder te spreken over de uitwerking van de Slotverklaring. ${ }^{63} \mathrm{Al}$ sluimerde de 'kwestie-Brinkman', de inzet van de reis luidde dat gewoon moest worden doorgewerkt, waarbij echter gemeenschappelijk geconcludeerd diende te worden dat de deadline van 15 december 2008 onhaalbaar was. Dat kon zelfs een niet-jurist nu op zijn vingers natellen. ${ }^{64}$

$\mathrm{Na}$ lange en intensieve besprekingen stelde de Stuurgroep van 22 januari inderdaad vast dat ook de tweede streefdatum onrealistisch was: op alle trajecten en in alle werkgroepen was vertraging opgetreden. Ook de voorbereidingen voor de BEs kostten, gezien de complexiteit daarvan - uitwerking van een nog niet bestaande structuur, terwijl de eilanden voor de meeste Nederlandse ministeries onontgonnen terrein vormden - meer tijd dan was verondersteld. ${ }^{65}$ Voor de ontmanteling van het land ontbrak bovendien nog steeds een plan van aanpak met een tijdsplan.

Afgesproken werd dat de Ambtelijke Regiegroep voor het proces een 'realistische tijdsplanning' zou gaan maken, die ook rekening 
hield met de rol van de adviserende en volksvertegenwoordigende organen in het wetgevingsproces en de planning voor de BES-eilanden. Een tweede opdracht aan de Regiegroep luidde om te zoeken naar mogelijkheden voor versnelling van het proces, waarbij 'de zorgvuldigheid en kwaliteit voorop staat'. Eind maart zou de planning op tafel moeten liggen, waarna besluitvorming zou volgen in de eerstvolgende Politieke Stuurgroep, van april. Binnenskamers werd gesuggereerd dat, gezien de wetgevingstrajecten, planning op eerdere data dan eind 2010 onrealistisch was. ${ }^{66}$

Het overleg in januari was in meerdere opzichten beslissend. Niet alleen ging de transitiedatum van tafel, ook werd overeenstemming bereikt over de laatste drie artikelen van het Tijdelijk financieel toezichtsbesluit voor het land de Nederlandse Antillen, Curaçao en Sint Maarten. Er werden strikte afspraken gemaakt over regelgeving rond corporate governance: Curaçao en Sint Maarten verplichtten zich tot opstelling van een 'goed en transparant bestuur' en een strikter benoemingenbeleid bij overheidsbedrijven. ${ }^{67}$ Voorts werden afspraken gemaakt over lenen onder gunstige voorwaarden, waarbij niet zou worden geleend om lopende uitgaven te financieren en Nederland bovendien inzicht zou krijgen in mogelijke nieuwe leningen. Ten slotte werden beroepsmogelijkheden tegen besluiten van de Rijksministerraad inzake leningen vastgelegd.

Met dit akkoord was een groot Haags pijnpunt weggenomen; aan de schuldsanering waren nu regels voor goed bestuur gekoppeld. Bijleveld verwachtte in de tweede helft van 2008 daadwerkelijk te kunnen beginnen met de overname van de schulden van het land, Curaçao en Sint Maarten; het kwam er nu op aan deze correct in kaart te brengen. ${ }^{68}$

Hoewel de afspraken over het tijdelijk financieel toezicht nog ambtelijk moesten worden uitgewerkt en vervolgens zowel in Nederland als op de Antillen door de parlementen en eilandsraden worden goedgekeurd - en bovendien getoetst door de Raad van State op strijdigheid met het Statuut ${ }^{69}$ - leek deze hobbel nu niettemin genomen. De volgende horde was de in de Slotverklaring van 2006 op Haags aandringen vastgelegde mogelijkheid dat de Nederlandse minister van Justitie zou kunnen ingrijpen in de nieuwe landen, via een aanwijzingsbevoegdheid op Koninkrijksniveau aan de Antilliaanse procureur-generaal. Hernieuwde bespreking van dit voor de Antillen eigenlijk onverteerbare punt was verschoven naar een voor 16 februari geplande extra Stuurgroepvergadering te Willemstad, in aanwezigheid van minister-president Balkenende, waarbij het advies van twee aangezochte deskundigen, de Antilliaan L.A.J. de Lannoy en de Nederlander D.W. Steenhuis, zou worden besproken. 
In dit 'praktijkgerichte', unanieme advies gaven De Lannoy en Steenhuis concreet aan op welke wijze de gemeenschappelijke PG en de aanwijzingsbevoegdheid - waartegen geen principiële bezwaren werden geuit-konden worden uitgewerkt in een consensusrijkswet. ${ }^{70}$ Het advies bood volgens BZK een goede kans om op korte termijn verder te komen in dit dossier. Het ambtelijk advies luidde dan ook dat beide partijen wat water bij de wijn moesten doen. ${ }^{71}$

Ambtenaren van BZK en Justitie verwachtten niettemin vanuit de Antillen commotie over dit advies, nu het niet had gebracht waarop vooral Curaçao had gehoopt: een principiële afwijzing van de Nederlandse aanwijzingsbevoegdheid en mogelijk ook van de gemeenschappelijke procureur-generaal. Daarnaast zat een deel van de pijn in de afspraak deze aanwijzingsbevoegdheid neer te leggen in een - vrijwillig te onderschrijven - consensusrijkswet. De Haagse tactiek, zo werd vastgesteld, moest vasthoudend blijven. Nieuwe concessies waren niet aan de orde en verder tijdverlies moest worden voorkomen. ${ }^{72}$

Op 16 februari werd een hele dag intensief vergaderd naar aanleiding van het deskundigenadvies. Uiteindelijk werd vastgelegd dat, op voorwaarde van positieve toetsing door de Raad van State van het Koninkrijk, de Nederlandse minister van Justitie namens de Rijksministerraad aan de procureur-generaal aanwijzingen zou mogen geven als dat 'noodzakelijk is om de fundamentele menselijke rechten en vrijheden, rechtszekerheid en deugdelijkheid van bestuur te waarborgen'. Als er bezwaren waren tegen een aanwijzing, dan kon dit worden voorgelegd aan het Hof van Justitie of de Hoge Raad. De wet bepaalde verder dat in de nieuwe constellatie Curaçao en Sint Maarten ieder een eigen OM zouden krijgen en Bonaire, Sint Eustatius en Saba een gezamenlijk OM, met aan het hoofd één, in Willemstad zetelende, procureur-generaal voor alle vijf eilanden. Hiermee was dus definitief geen sprake van een gemeenschappelijk OM - een Nederlandse wens die medio 2006 nog prominent had geprijkt in het 'ononderhandelbare' aanbod van 'Partners in het Koninkrijk'. ${ }^{73}$

Direct na de vergadering was de Curaçaose onderhandelaars al verweten te snel het hoofd te hebben gebogen, en Nederland een te grote rol te hebben gegeven in de lokale rechtshandhaving in ruil voor 'een zak met geld'. De discussie was weer in alle hevigheid opgelaaid. Ook de verklaring van minister Hirsch Ballin dat Aruba van de afspraken werd uitgezonderd, leidde tot consternatie. ${ }^{74}$

Met deze afspraken hoopte Bijleveld juist de voortgang in het proces te houden 'omdat we anders te langzaam werken'. ${ }^{75}$ Deze boodschap was ook onderstreept door Balkenende tijdens zijn bezoek aan de eilanden, dat meer dan een beleefdheidsbezoek was geweest. 'Balkenende heeft een mantra', schreef NRC Handelsblad, 'Problemen 
benoemen, tempo maken en positivisme.' De premier drong aan op spoed in het gehele traject en markeerde de randvoorwaarden voor de nieuwe statussen nog eens duidelijk. In dit opzicht vergde vooral het op orde brengen van de rechtshandhaving op Sint Maarten extra aandacht, aldus Balkenende, samen met waarborgen voor goed bestuur en het op orde brengen van de financiën. Antilliaanse verwachtingen rond een nieuwe transitiedatum kort na 15 december 2008 wees hij van de hand, zonder zelf een nieuwe deadline te noemen. ${ }^{76}$

Het Antilliaanse kabinet en de Curaçaose delegatie waren zeer tevreden over de in januari geboekte voortgang, maar de afspraken verdeelden Curaçao opnieuw ten diepste. De publiekelijk getrokken conclusie van Balkenende dat de Curaçaose oppositie 'geen alternatief' zou hebben, had kwaad bloed gezet. De Nederlandse Vertegenwoordiging rapporteerde dat op het eiland geen wil te bespeuren viel om de kloof tussen voor- en tegenstanders te overbruggen. Ook Bijleveld vertelde in de Kamer dat de discussie op het eiland gepolitiseerd was. Zij had tevergeefs getracht de oppositie bij de gesprekken te betrekken en vroeg zich af of er wel de wil was elkaar, en Nederland, goed te verstaan. ${ }^{77}$

In de derde voortgangsnotitie, van 27 maart, bevestigde Bijleveld de Kamer dat 15 december 2008 definitief onhaalbaar was. Voor de

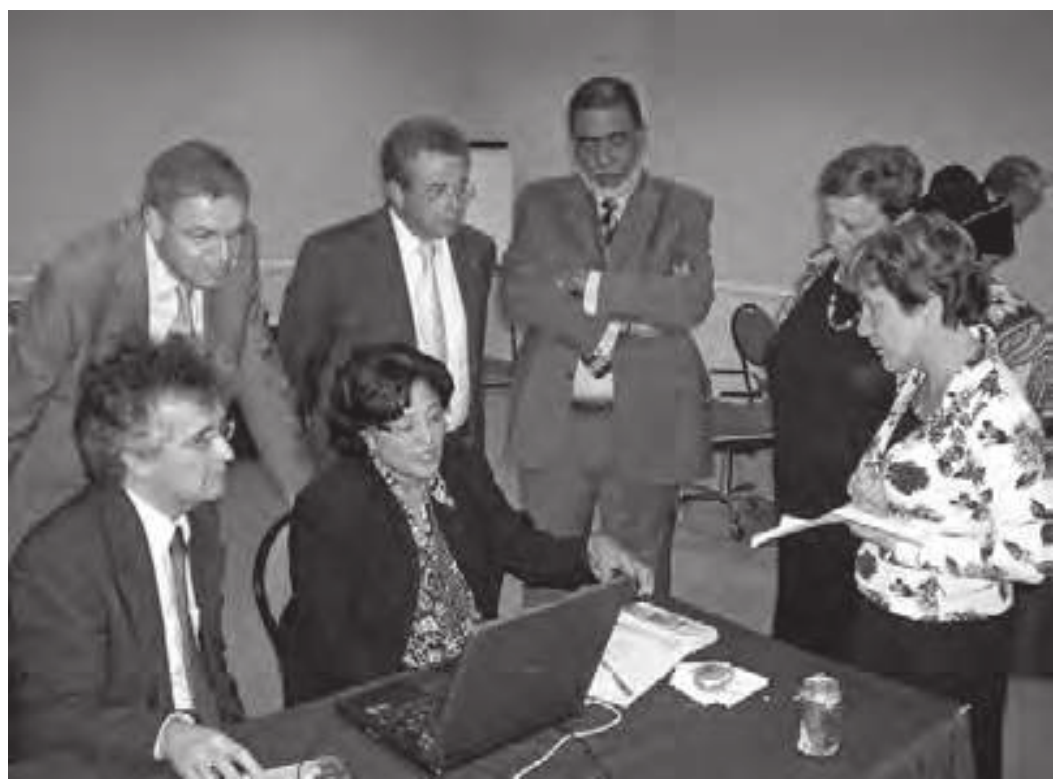

Overleg over een mogelijke aanwijzingsbevoegdheid op Koninkrijksniveau, Willemstad, 16 februari 2008; v.I.n.r. zittend Luc Verhey, Suzy Römer; v.I.n.r. staand Ernst Hirsch Ballin, Freek van Beetz, Norwin Carolus, Gea van Craaikamp, Ank Bijleveld-Schouten. 
BES-eilanden streefde Nederland er nu naar gefaseerd taken van de landsregering over te nemen, vooruitlopend op de formele statuswijziging - een besluit dat overzee op instemming kon rekenen. ${ }^{78}$ Nederland zou Curaçao en Sint Maarten blijven aanspreken op de voortgang en het belang van een goede uitvoering van de afspraken; als dat niet was geregeld, kon de nieuwe status niet ingaan. Bijleveld dacht officieus aan een transitie eind 2010. ${ }^{79}$

Waar dit uitstel voor het Nederlandse parlement geen nieuws was - bij de begrotingsbehandeling in december 2007 hadden de Kamerleden zich goed kunnen vinden in het aangekondigde, al verwachte, vooruitschuiven van de datum - voelde men zich op Curaçao en Sint Maarten door Bijlevelds aankondiging overvallen: zij zou de conclusie van de Ambtelijke Regiegroep hebben moeten afwachten. ${ }^{80}$ Meteen hierop reisde Bijleveld weer af naar de eilanden, met als boodschap dat een andere aanpak noodzakelijk was en dat 'terugonderhandelen' onaanvaardbaar was. Dit was haar van ambtelijke zijde stellig geadviseerd. Om toch een duidelijk politiek signaal af te geven zou Nederland kunnen verklaren toe te willen werken naar een toetsings-RTC in december 2008 - maar dan moesten wel alle consensusrijkswetten klaar zijn. ${ }^{81}$

Vooral op de BES-eilanden was uitstel van de streefdatum als teleurstellend ervaren; daar leefde nog sterk het beeld dat 15 december wel haalbaar was. Pogingen van Nederland om vooruitlopend op de nieuwe status al het een en ander in werking te stellen konden dan ook rekenen op instemming van de BES-bestuurders, die eraan hechtten dat Nederland vanaf 1 januari 2009 taken ging verrichten op de eilanden. ${ }^{82}$ In dit kader vroeg Bijleveld op 24 april 2008 de Raad van State van het Koninkrijk om een voorlichting over de mate waarin een gefaseerde herstructurering van de BES-eilanden mogelijk was. Daarbij werd van regeringszijde gedacht aan een gefaseerde invoering vanaf 15 december 2008, te beginnen met de overdracht van landstaken naar deze eilanden, vooruitlopend op de definitieve inwerkingtreding van de vernieuwingen. ${ }^{83}$

De Politieke Stuurgroep op Curaçao van 22 mei duurde ruim vijftien uur en leverde een nieuwe transitiedatum op. ${ }^{84}$ Een Haagse analyse had uitgewezen dat de vroegst haalbare datum 1 januari 2011 was, wat nog steeds als zeer krap werd ingeschat; 2012 en 2013 werden als meer aannemelijke opties genoemd. Bijleveld nam toch 1 januari 2011 over, al benadrukte zij dat het ging om een 'werkdatum' en niet, zoals Sint Maarten wenste, een 'nieuwe, onherroepelijke datum'. De definitieve datum zou pas op de slot-RTC worden vastgesteld, benadrukte zij. ${ }^{85}$

Uiteindelijk prijkte toch ' 1 januari 2010' als datum voor de voltooiing van het transitieproces in de besluitenlijst van de Stuurgroep. Het 
was politiek onhaalbaar gebleken deze datum uit de besluitenlijst te krijgen, al strookte hij niet met de planning van BZK of met de eerder met de Tweede Kamer gedeelde datum van eind 2010. De Raad van State zou door de Nederlandse en Antilliaanse regering gezamenlijk om advies gevraagd worden over mogelijkheden voor een versnelling van het proces, met inachtneming van de parlementaire betrokkenheid, zodat Curaçao en Sint Maarten toch al per januari 2010 autonome landen binnen het Koninkrijk konden worden.

Niet alleen werd een bekorting van het proces beoogd omdat de landslaag de facto steeds verder verbrokkelde, ook wilde het land het proces gereed hebben vóór de begin 2010 geplande Statenverkiezingen. In verband met dit laatste kreeg de Raad van de Antilliaanse regering tevens het verzoek te adviseren over de mogelijkheden om, als het proces toch niet voor januari 2010 kon worden afgerond, af te zien van de reguliere Statenverkiezingen - de opbouw van de nieuwe landen zou dan immers in volle gang zijn. Aan Antilliaanse zijde wilde men liefst geen landelijke verkiezingen meer hoeven uit te schrijven: die zouden het proces alleen maar doorkruisen en verdere vertraging opleveren. Hierbij zal ook de vrees hebben meegespeeld voor verlies van de bestaande meerderheid in de Staten. ${ }^{86}$

Voor de Haagse departementale voorbereiding van het transitieproces bleef intussen eind 2010 het richtsnoer. Bijleveld rapporteerde ook de Kamer aan te sturen 'op overgang december 2010'. ${ }^{87}$ In antwoord op Kamervragen stelde zij dat de oorzaken van de vertraging redelijk in beeld waren; cruciaal zou zijn 'de moed van bestuurders om besluiten te nemen'. ${ }^{88}$

Om voortgang in het proces te houden, werd besloten Koninkrijksdag 2008 wel betekenisvol te houden, door op die datum een 'onomkeerbare stap' te zetten naar een volgende fase van de transitie, met een 'toetsings-RTC' - dit was ook een wens van de Kamer. Als het volledige wetgevingspakket - de (consensus)rijkswetgeving, Staatsregelingen en organieke wetten van de nieuwe landen en de Statuutwijziging - in concept gereed zou zijn, kon dit worden getoetst aan de criteria zoals overeengekomen in de Slotverklaring en tijdens de start-RTC. Bijleveld waarschuwde dat vooral de consensusrijkswet Politie nog een heet hangijzer vormde. ${ }^{89}$

Ook voor het BES-traject, dat goed 'op streek' was, zou 15 december 2008 een betekenisvolle dag worden, zo werd afgesproken: de omschrijving van cruciale wetsvoorstellen voor de BES moest dan gereed zijn. Deze BES-wetgeving zou echter alleen ter kennisname aan de RTC worden aangeboden en niet getoetst aan de overeengekomen criteria, omdat dit immers geen Koninkrijksaangelegenheid meer zou zijn. ${ }^{90}$ 
Bijleveld stelde de bezorgde Kamer gerust dat de conferentie wat Sint Maarten en Curaçao betreft geen 'go/no-gomoment' zou opleveren: geen onomkeerbare stappen, wel een eerste toetsing. Na deze RTC, die de 'bouwtekening' van het nieuwe Koninkrijk zou vaststellen, kwam dan de uitvoeringsfase in beeld en zou het proces zich verplaatsen 'van de tekentafel [naar] de bouwplaats'. Pas aan het einde, als alle wetgeving af was, zou in een Slotconferentie worden getoetst of alles daadwerkelijk kon functioneren. Dan zou ook een definitieve transitiedatum worden vastgesteld. ${ }^{91}$

Het streven was nu om alle wet- en regelgeving in concept gereed te hebben voor de toetsings-RTC. Medio juni berichtte Bijleveld dat de consensusrijkswetten er inderdaad grotendeels waren, maar die voor de Politie nog niet - tijdens de Politieke Stuugroep van 9 juli op Curaçao hadden de partijen nog ernstig van mening verschild over de vormgeving en inrichting van een gemeenschappelijke politiedienst die de drie afzonderlijke korpsen van Curaçao, Sint Maarten en de BES-eilanden verbond. Nederland had er in de Slotverklaring, slechts na lange aarzeling, mee ingestemd dat de twee nieuwe landen elk een eigen politiekorps zouden krijgen, op voorwaarde van intensieve en verplichte samenwerking en een ingrijpende verbetering van de politieorganisatie.

Van Nederlandse zijde werd nu ingezet op een sterke Gemeenschappelijke Voorziening Politie (GVP) met een omvangrijk takenpakket, waaronder alle taken van het RST. Hiermee was aangesloten bij de voorstellen in het eerder in 2008 verschenen rapport $\mathrm{Nu}$ of nooit. ${ }^{92}$ Liefst was Nederland, mede naar aanleiding van dit rapport-dat constateerde dat de kwaliteit van de Antilliaanse politieonderdelen ver beneden de maat was en dat ingrijpende maatregelen nodig waren om tot een adequaat niveau te komen - alsnog overgegaan tot de vorming van één politiekorps voor alle eilanden van de Antillen, maar tornen aan de Slotverklaring was voor de Antillen onbespreekbaar.

De meningen van Nederland enerzijds en de Antillen, Curaçao en Sint Maarten anderzijds over de GVP en de inbedding van het RST lagen volgens BZK 'mijlenver uit elkaar'. De Antilliaanse mening was dat het RST moest zijn ingebed in de eigen, lokale politieorganisatie, bestaande uit leden van de politiekorpsen en aangestuurd door een teamchef; er was grote weerstand tegen de figuur van een korps (GVP) binnen het eigen lokale korps. In de Nederlandse visie maakte het RST juist deel uit van de GVP, die belast zou zijn met onder meer de bestrijding van de grensoverschrijdende en georganiseerde criminaliteit en overige specialistische politietaken. De Stuurgroep van 9 juli eindigde wat de toekomstige politiesamenwerking betreft onbe- 
slist en werd geschorst; in augustus zou verder worden gepraat over dit onderwerp. ${ }^{93}$

De besprekingen werden nu even opgeschort, maar de context werd er niet eenvoudiger op. Niet alleen op Curaçao was sprake van polarisatie, nu ook op de BES-eilanden; in het bijzonder op Bonaire zou de invulling van de BES-status discussie gaan oproepen. Intussen groeide ook de onrust en verontwaardiging over een mogelijke invoering van een Verwijsindex Antillianen (VIA) in Nederland. ${ }^{94}$

Op Curaçao en Sint Maarten werd in de eerste week van september met gemengde gevoelens gereageerd op Bijlevelds uitspraak dat het er niet meer naar uitzag dat op 15 december inderdaad een RTC kon worden gehouden. Voor de eilandelijke oppositie in Curaçao was Bijlevelds voortgangsrapportage van eind augustus het bewijs dat de coalitie ten onrechte steeds verzekerde dat het traject voorspoedig verliep. $^{95}$

De grootste problemen leken zich echter voor te doen op Sint Maarten; daar was de voortgang minimaal en liet de kwaliteit van het bestuur in Haagse ogen sterk te wensen over. In reactie op de aanhoudende parlementaire zorg over de vraag of het eiland binnenkort wel klaar was om de gewenste stap te zetten, herhaalde Bijleveld dat Sint Maarten in alle gevallen aan de criteria moest voldoen voordat het land kon worden - ook wat betreft de bestuurscultuur, die juist vanwege de kleine schaal extra inspanningen vergde. Naast het opbouwen van de algemene instituties van het land diende vooral te worden geïnvesteerd in versterking van de politie en de vreemdelingenketen. De staatssecretaris - die eerder vaak had geklaagd dat de ontmanteling te traag verliep - waarschuwde overigens ook voor een bestuursvacuüm wanneer de landslaag al ver in ontmanteling zou zijn, terwijl Sint Maarten nog niet de status van land had. ${ }^{96}$

Aan de Raad van State van het Koninkrijk waren, naar aanleiding van het besluit om de transitiedatum opnieuw uit te stellen, zoals gezegd twee vragen voorgelegd; ten eerste over mogelijkheden voor bekorting van het transitieproces, met inachtneming van de democratische besluitvorming, gericht op het halen van de streefdatum 1 januari 2010; ten tweede over het al dan niet laten doorgaan van de begin 2010 geplande verkiezingen voor de Antilliaanse Staten. In zijn voorlichting concludeerde de Raad dat het proces van staatkundige herstructurering uiterlijk 1 januari 2010 kon worden afgerond; de Antillen konden dan als land feitelijk ophouden te bestaan. Nieuwe Statenverkiezingen zouden in dat scenario overbodig zijn. De Raad noemde in de voorlichting decentralisatie een bruikbaar instrument voor een versnelde overgang van bevoegdheden naar Curaçao en Sint Maarten, maar niet goed bruikbaar voor de BES-eilanden, omdat de 
transitie daar in hoofdzaak bestond uit de overgang van bevoegdheden van het ene land naar het andere, en niet naar de eilanden zelf.

Gelet op het belang van voortvarendheid meende de Raad dat met de formele oprichting van de nieuwe landen niet gewacht hoefde te worden totdat alle voorwaarden waren vervuld om de bevoegdheden over te dragen. Curaçao en Sint Maarten zouden op 1 januari 2010 de landsstatus kunnen krijgen als de taken die ze op dat moment nog niet zelf konden uitvoeren op Koninkrijksniveau werden neergelegd, bijvoorbeeld door ze tijdelijk op te dragen aan de gouverneur als Koninkrijksorgaan, op basis van artikel 51 (of artikel 52) van het Statuut. Daarbij meende de Raad dat artikel 51 in deze omstandigheden moest worden gezien als 'taakwaarneming' - en niet, zoals gebruikelijk, 'taakverwaarlozing'. De Raad vond ten slotte dat de herstructurering van het Koninkrijk niet op alle onderdelen gelijk op hoefde te gaan. ${ }^{97}$

Dit advies bleek controversieel. Voor Nederland lag het gevoelig omdat de Raad voorstelde het land op te heffen per 1 januari 2010, zonder daaraan voorwaarden te verbinden. Dit was niet in lijn met het kabinetsbeleid: Bijleveld had altijd volgehouden dat aan alle voorwaarden moest zijn voldaan voordat Curaçao en Sint Maarten hun landsstatus konden krijgen. ${ }^{98}$ Bovendien stuitte het overnemen van de resterende bevoegdheden door de gouverneur ook overzee op bedenkingen. Op de eilanden stond taakwaarneming bekend als hoger toezicht en daar werd derhalve niets voor gevoeld. De Kamer omarmde evenmin het advies om bepaalde landstaken over te dragen aan de gouverneur als Koninkrijksorgaan. Voorlopig werd daarom besloten nog geen reactie op de voorlichting te formuleren - uiteindelijk zou hierover pas in juni 2009 in de Politieke Stuurgroep worden gesproken. ${ }^{99}$

Over het andere onderwerp, de door de Antilliaanse Staatsregeling voorgeschreven Statenverkiezingen voor begin 2010, oordeelde de Raad in dezelfde voorlichting dat die, als het proces inderdaad in de komende zestien maanden het beoogde resultaat had, in hoge mate een theoretisch vraagstuk zouden worden. Het land zou dan immers in januari 2010 de facto niet meer bestaan; tijdig voordien zouden al verkiezingen moeten zijn gehouden voor de beide nieuwe landen. De Raad van State vond het redelijk dat de zittingsduur van het bestaande parlement werd verlengd met een halfjaar. De werkelijkheid zou weerbarstiger blijken. De oppositie op de Antillen was het oneens met dit advies: uitstel van de verkiezingen zou indruisen tegen democratische principes. Ook de Antilliaanse Raad van Advies sprak zich in een scherp advies uit tegen uitstel van de verkiezingen. Aldus werd in het najaar van 2009 besloten deze alsnog uit te schrijven. ${ }^{100}$ 
Overigens bracht de Raad bij deze gelegenheid nog een tweede voorlichting uit, naar aanleiding van de in april gestelde vraag naar de mate waarin een gefaseerde herstructurering van de BES-eilanden mogelijk was. Dit advies nam de Nederlandse regering wel grotendeels over; uit de plannen van aanpak van de Nederlandse ministeries was gebleken dat er alle ruimte was om al voorafgaand aan de transitie de uitvoering op de BES te verbeteren. ${ }^{101}$

In zijn verkenning van de Statutaire opties voor een gefaseerde vergroting van de Nederlandse verantwoordelijkheden voor de BES, voorafgaand aan de formele transitie, concludeerde de Raad dat het Statuut verschillende mogelijkheden bevatte om de eindsituatie versneld dichterbij te brengen. Gezien de nog korte tijd tot de beoogde transitiedatum van 1 januari 2010 achtte de Raad een herschikking van verantwoordelijkheden en bevoegdheden urgent. Hij vond dat dit het beste kon worden bereikt via onderlinge regelingen op basis van artikel 38, eerste lid. Zo konden de BES-eilanden stapsgewijs openbare lichamen worden. ${ }^{102}$

Daarnaast gaf de Raad in overweging om voor de transitieperiode een gezaghebbende uitvoerder aan te wijzen, voor een 'krachtige regie ter plaatse', aan te stellen door de Rijksministerraad. Dit voorstel viel in Den Haag en op de eilanden in goede aarde: per 1 januari 2009 werd oud-minister van Defensie en oud-Tweede Kamerlid Henk Kamp (VVD) aangesteld als Rijksvertegenwoordiger, voor alle drie BES-eilanden. In Haagse ogen bestond aan een functionaris van een dergelijk kaliber sterke behoefte nu het proces concreter werd en dit steeds meer overleg vergde tussen de Nederlandse departementen en de eilanden. Daarbij zal zeker ook een rol hebben gespeeld dat de onderlinge afstemming tussen de betrokken Haagse departmenten te wensen overliet; een politiek zwaargewicht als Kamp kon, zo was de terechte verwachting, impasses voorkomen c.q. doorbreken. Parlementariërs voelden dit net zo: aanstelling van een Rijksvertegenwoordiger - als schakel tussen politiek en ambtelijk Den Haag en de BES-eilanden - zou bijdragen aan de snelheid die de Kamer zelf ook wilde bereiken in dit traject. Bovendien was het vanuit het perspectief van het Nederlandse kabinet uiteraard aantrekkelijk via Kamp de nu oppositionele VVD weer wat sterker bij het proces te betrekken. Zo zou de Rijksvertegenwoordiger vanuit het Regionaal Service Centrum (RSC) in Bonaire cruciaal werk verrichten, niet alleen aan de gefaseerde integratie van de BES-eilanden, maar indirect ook aan het hele transitieproces. ${ }^{103}$

Ten slotte meende de Raad in deze voorlichting dat een eerdere overdracht aan Nederland van bevoegdheden voor de BES-eilanden dan de overdracht van taken aan Curaçao en Sint Maarten niet op 
juridische bezwaren hoefde te stuiten - de herstructurering van het Koninkrijk hoefde niet op alle onderdelen gelijk op te gaan. Over het gewenste voorzieningenniveau op de BES-eilanden - de Slotverklaring van 11 oktober 2006 had tegen de zin van de BES het door de commissie-Havermans vastgestelde, maar nog te actualiseren, op Curaçao geënte voorzieningenniveau als uitgangspunt genomen ${ }^{104}-$ merkte de Raad op dat het voor de maatschappelijke acceptatie van het transitieproces van groot belang was dat gezamenlijk en op korte termijn een duidelijk perspectief werd geschetst. Daarbij achtte de Raad het 'raadzaam ervaringen op de Franse en (voormalig) Britse Caribische eilanden mee te wegen, evenals die op de Azoren, Madeira en de Canarische eilanden'. Hoewel het wenselijk was al te grote verschillen te voorkomen - in zijn voorlichting van 18 september 2006 had de Raad al gesteld dat geen onderscheid mocht worden gemaakt tussen de burgers van het Koninkrijk - was een zekere diversiteit in het voorzieningenniveau logisch en ook juridisch aanvaardbaar, aldus de Raad. ${ }^{105}$ Het was een onderwerp dat in het vervolgtraject nog een voortdurend punt van discussie zou blijken. De meningen liepen, bijvoorbeeld, uiteen over wat, bij eenzelfde staatsburgerschap, acceptabele verschillen in sociaaleconomische positie waren. Ook werd in Den Haag gevreesd voor een aanzuigende werking in het personenverkeer bij een aanmerkelijk hoger voorzieningenniveau op de BES dan op de omringende eilanden.

Bestuurlijk overleg met de BES-eilanden op 31 januari 2008 zou - na een juist op het voorzieningenniveau stukgelopen overleg in november 2007-succesvol verlopen. Overeenstemming werd bereikt over de invulling van een binnen het Koninkrijk acceptabel niveau van voorzieningen op geprioriteerde terreinen. Er zouden normen worden opgesteld voor de BES op de vier pijlers van onderwijs, volksgezondheid, sociale zekerheid en veiligheid. Deze verhoging van de normen zou stap voor stap kunnen worden ingevoerd, waarbij gewaakt diende te worden voor sociale en economische ontwrichting. ${ }^{106}$

Niettemin zou de overdracht van landstaken naar Nederland ten behoeve van de BES flinke vertraging oplopen. ${ }^{107}$ In september 2009 werd het eerste overdrachtsprotocol tussen een Antilliaans ministerie en een Nederlands vakdepartement ondertekend. Het ging om taken op Sint Eustatius en Saba die tot dan toe vielen onder het Antilliaanse ministerie van Volksgezondheid; ze kwamen nu in de portefeuille van vws. Ook was het de bedoeling geweest om al vanaf april 2009 taken gefaseerd over te dragen aan Curaçao en Sint Maarten - het land had dit op 24 november 2008 met de landen in spe afgesproken - maar ook de ontmanteling van de landslaag liep flinke vertraging op, vooral 
veroorzaakt door onduidelijkheid over de rechtsposities van de landsambtenaren. Pas begin 2010 werd begonnen met deze taakoverdrachten; alleen op onderwijsgebied was dit al gebeurd. ${ }^{108}$

Op 1 oktober 2008 zette de Politieke Stuurgroep dan toch 'grote stappen', aldus Bijleveld, door de weg vrij te maken voor een in december te houden toetsings-RTC: er werden akkoorden bereikt over de invulling van de toekomstige politieorganisatie, over de Memorie van Toelichting bij de consensusrijkswet Openbaar Ministerie, over de consensusrijkswet Financieel toezicht, de onderlinge regeling Detentiecapaciteit en over de Rijkswet voor de Raad voor de Rechtshandhaving. Dit waren de laatste punten waarover nog overeenstemming moest worden bereikt om de conferentie op Koninkrijksdag mogelijk te maken. ${ }^{109}$

De geschilpunten rond het politiedossier die na de Stuurgroep van 9 juli nog bestonden, leken nu beslecht, zodat de uitgangspunten van 'een kwalitatief hoogwaardige en integere politieorganisatie' in de nieuwe landen en op de BES nu 'in de steigers' stond. Partijen waren het eens geworden over het grootste struikelblok, dat voor Nederland cruciaal was: het opzetten van een GVP ter bestrijding van de georganiseerde en grensoverschrijdende criminaliteit en voor operationele ondersteuning. Kortom, voor de taken van het bestaande RST, waarbij ook Nederland betrokken was.

De kern van de overeenstemming was dat het RST zou verdwijnen, want opgenomen in de drie politiekorpsen. De nieuwe GVP, waarin de korpsen zouden samenwerken, zou worden aangestuurd door de ministers van Justitie van Curaçao, Sint Maarten en Nederland (namens de $\mathrm{BES}^{110}$ ). Van een overkoepelende structuur, zoals Nederland had gewenst, was geen sprake: de GVP zou slechts een coördinerende rol gaan spelen. Deze uitkomst was een overwinning voor de Antilliaanse onderhandelaars, die ernaar hadden gestreefd de bevoegdheden van de GVP beperkt te houden. ${ }^{111}$

De Consensusrijkswet Openbaar Ministerie was al op 22 mei goedgekeurd, maar nu werd de Memorie van Toelichting vastgesteld. Afgesproken werd de Raad van State uitdrukkelijk advies te vragen over de resterende discussiepunten, alsook voor de nu vastgelegde aanwijzingsbevoegdheid op Koninkrijksniveau. ${ }^{112}$ In de Onderlinge Regeling Detentiecapaciteit werd overeenstemming bereikt over samenwerking op dit gebied. De consensusrijkswet Raad voor de Rechtshandhaving regelde de instelling van een inspectieorgaan op de gehele rechtshandhavingsketen in Curaçao, Sint Maarten en de BES-eilanden: politie, OM, gevangeniswezen en justitiële zorg. Alleen het Gemeenschappelijk Hof viel hierbuiten. ${ }^{113}$ 
Last but not least was een akkoord bereikt over structureel financieel toezicht door het Cft op Curaçao en Sint Maarten vanaf het moment van verzelfstandiging; na vijf jaar zou worden geëvalueerd of het toezicht kon worden verminderd of zelfs beëindigd. Deze consensusrijkswet sloot aan bij de AMVRB voor het tijdelijk toezicht, die op 10 november 2008 zou worden vastgesteld. ${ }^{114}$ Bijleveld berichtte de Kamer hierover tevreden te zijn; in eerste instantie 'wilden de Antillianen de rol van het $\mathrm{Cft}$ te veel terugbrengen, namelijk tot onder het regime van de AMVB'. Dat was voor de staatssecretaris onaanvaardbaar geweest. Dat Nederland als lid van het $\mathrm{Cft}$ toezicht zou houden op overheidsbestedingen, financieel beheer en corporate governance van Curaçao en Sint Maarten was een Antilliaanse concessie geweest. ${ }^{115}$

Ondanks deze 'grote stappen' was er tijdens de begrotingsbehandeling in oktober sprake van scepsis. Over het tijdstip dat Sint Maarten een zelfstandig land kon worden, ontspon zich een ferme discussie. Remkes vond dat Sint Maarten niet de status van land kon krijgen op de gestelde transitiedatum, Van Raak was het met hem eens. Een door beide parlementariërs ingediende motie die de regering dwong 'tijdig aan de bestuurlijke partners kenbaar te maken dat de waarschijnlijkheid dat Sint Maarten volgens de nu voorziene planning een zelfstandig land kan worden, gering is' werd echter verworpen. ${ }^{116}$ Een Kamermeerderheid nam wel de motie Van Bochove c.s. aan, die de regering verzocht de landsstatus aan Sint Maarten te zullen onthouden totdat het eiland aan alle criteria voor rechtshandhaving en goed bestuur had voldaan. Dit verengde de onderhandelingsvrijheid van de staatssecretaris. ${ }^{117}$

PVV, VVD en SP stemden tegen de begroting voor 2009. Zowel de SP als de VVD vond onder meer dat de Antillen hun belastingen moesten verhogen, de PVV wilde geen cent meer naar de Antillen overmaken. ${ }^{118}$ Bijleveld hield publiekelijk vast aan haar optimisme. Op de RTC zou de bouwtekening worden vastgesteld, waarna de uitvoeringsfase van start kon gaan. Remkes en Van Bochove bezwoer zij dat Sint Maarten geen land kon worden zonder te hebben voldaan aan de criteria uit de Slotverklaring: 'voor mij geldt: afspraak is echt afspraak. ${ }^{119}$

Voor de laatste Politieke Stuurgroep voorafgaand aan de toetsingsRTC, op 25 en 26 november, reisde Bijleveld met een grote ambtelijke delegatie naar Sint Maarten. ${ }^{120}$ Op de agenda stonden de laatste twee uit de Slotverklaring voortvloeiende consensusrijkswetten: voor de politie en het financieel toezicht. De consensusrijkswetten Gemeenschappelijk Hof van Justitie, Openbaar Ministerie en Raad voor de Rechtshandhaving waren inmiddels definitief. Na opnieuw een marathonvergadering, tot diep in de nacht, met veel en lange schorsin- 
gen werden de laatste obstakels uit de weg geruimd. Op alle punten werd overeenstemming bereikt, ook over het voorstel van Rijkswet tot wijziging van het Statuut. ${ }^{121}$ Hiermee was de 'bouwtekening' voor het nieuwe Koninkrijk gereed en kon de RTC daadwerkelijk worden belegd. ${ }^{122}$

Het akkoord over het toezicht op de openbare financiën van de nieuwe landen behelsde afspraken over de totale omvang van de schuldsanering en de wijze waarop die zou worden uitgevoerd. Het $\mathrm{Cft}$ zou vanaf december 2008 minimaal vijf jaar lang toezicht gaan uitoefenen op de nieuwe landen, met als uitgangspunten begrotingsevenwicht en een limiet voor het aangaan van schulden. Na vijf jaar zou een evaluatie volgen. Aangezien de afspraken erop gericht waren dat de landen structureel zouden gaan voldoen aan de begrotingsnormen, was het de bedoeling dat het toezicht op termijn overbodig werd.

De omvang van de schuld en de betalingsachterstanden van het land, Curaçao en Sint Maarten werd vastgesteld op ruim anderhalf miljard euro. Nederland kon nog in 2008 beginnen met de sanering. Er zou een monetaire unie van Curaçao en Sint Maarten komen met een gezamenlijke centrale bank en een nieuwe munt, de aan de dollar gekoppelde Dutch Caribbean Florin. ${ }^{123}$ De BES zouden met ingang van 1 januari 2011 de Amerikaanse dollar als officiële munteenheid aannemen.

De inbedding van de GVP in de politiekorpsen bleek weer een heet hangijzer. Omdat het door Nederlanders bemenste en geleide RST zou overgaan in de GVP, vreesden de Antilliaanse onderhandelaars voor Nederlands overwicht. $\mathrm{Zij}$ verzetten zich met succes tegen de Nederlandse wens om het door de GVP ingezette personeel voor RSTtaken in een aparte eenheid onder te brengen, met het argument dat dit de GVP zou ondermijnen. Eerder was al besloten dat de GVP de bestrijding van de grensoverschrijdende criminaliteit van het RST zou overnemen. Nu werd ook vastgelegd dat de GVP zou worden ingebed in de lokale korpsen en dat de korpschefs het beheer zouden voeren; wel zou de dienst worden aangestuurd door een aparte, eigen directeur, die verantwoording zou afleggen aan de ministers van Justitie van de drie landen. ${ }^{124}$

Ter voorbereiding van de RTC was al eerder besloten een Toetsingsadviescommissie (TAC) in te stellen, met voor elke entiteit twee deskundigen, die aan de v-RTC advies moest uitbrengen over de Staatsregelingen van Curaçao en Sint Maarten en de organieke wetten van beide beoogde landen. Dit advies zou centraal staan op de toetsings-RTC. ${ }^{125}$ De TAC werd op 20 oktober 2008 daadwerkelijk ingesteld en zou exact een maand later concluderen dat zowel Curaçao 
als Sint Maarten 'in hoge mate' voldeed aan de criteria die aan de constituties en wetgeving waren gesteld. Resterende aandachtspunten waren de onafhankelijkheid van de Hoge Colleges van Staat, de overeenstemming met Rijkswetgeving, en de redactie en onderlinge consistentie van de ontwerpen van landsverordeningen. Voor Curaçao gold als extra aandachtspunt de ontbrekende integriteitswetgeving, voor Sint Maarten het bestuursrecht. Hierop adviseerde de v-RTC om op de RTC vast te stellen dat de voorliggende ontwerpwetgeving van beide beoogde landen in hoge mate voldeed aan de overeengekomen criteria, mits de Staatsregelingen en organieke wetten nog werden aangepast en aangevuld conform het advies. ${ }^{126}$

De RTC werd aan Nederlandse zijde voorbereid door de ministeries van $\mathrm{AZ}$ en $\mathrm{BZK}$, in samenwerking met de Vertegenwoordiging te Willemstad. Ondanks enige parlementaire tegenwind had Nederland onverkort vastgehouden aan de afspraak om op 15 december 2008 het hele wetgevingspakket te laten toetsen, vooral ook om de steun in de Tweede Kamer te behouden. Daarnaast wilde Nederland, opnieuw, een 'point of no return' bereiken in het proces, een belang dat het met de eilanden deelde. Vertraging was met het oog op de begin 2010 geplande Statenverkiezingen onaantrekkelijk, maar ook gezien een mogelijke kabinetswisseling in Nederland. ${ }^{127}$

In Haags interdepartementaal overleg voorafgaand aan de conferentie was gesteld dat het moeilijk in te schatten was of er op de RTC nog andere lastige kwesties zouden opdoemen. Wel werd rekening gehouden met de mogelijkheid dat Sint Maarten een einddatum zou willen vastleggen, naar verwachting 1 januari 2010. Nederland zou 15 december 2010 aanhouden. Een terughoudende opstelling bleef geboden, stelde het ambtelijk advies. ${ }^{128}$

$\mathrm{Nu}$ alle wetgeving in kannen en kruiken leek, werd de RTC door KR vooral opgevat als een 'feestelijke mijlpaal'. Ondanks enige zorg over in de Papiamentstalige media op Curaçao uitgesproken negatieve sentimenten en de vrees dat de RTC gepolitiseerd zou verlopen, voorzag KR geen onoverkomelijke meningsverschillen meer. ${ }^{129}$ Voorafgaand aan de conferentie had Balkenende in de Kamer, die hem op het hart had gedrukt geen onomkeerbare stappen te zetten, nog eens benadrukt dat het 'gelijk oversteken' zou zijn: Nederland zou alleen de anderhalf miljard euro schuldenlast overnemen als de eilanden alle daaraan verbonden afspraken over goed financieel beheer en een betere rechtshandhaving nakwamen. ${ }^{130}$ Juist over deze Nederlandse voorwaarden zouden de meningen op Curaçao echter nog sterk verdeeld blijken. De beoogde feestelijke sfeer rond de RTC werd bovendien bedorven door demonstraties van de Curaçaose oppositie. Sommigen schreeuwden, met stickers 'Nederlandse apartheid' 
of gele Jodensterren op de borst-een verwijzing naar de Haagse plannen voor de registratie van Antilliaanse risicojongeren in $\mathrm{Ne}-$ derland-leuzen over 'verraad', 'herkolonisering' en 'verkoop'. De conferentie zou na een bommelding onder zware politie-escorte zelfs worden verplaatst van het World Trade Centrum naar de zwaarbewaakte marinebasis Parrera. ${ }^{131}$

Ondanks dit tumult werd in de tevoren opgestelde openingsspeeches weer gesproken in termen als 'nieuwe keuzes, nieuw elan', 'vooruitkijken', 'we hebben lang op deze dag gewacht', 'het welzijn en de ambities van de bevolking'. Volgens voorzitter Balkenende was dit de goede toon om het proces met gezwinde spoed voort te zetten. Verwijzend naar de demonstraties erkende hij dat sprake was geweest van 'tegenstellingen, maar we zijn nooit tegenstanders geworden'. Niet de 'gescheidenheid, maar het gevoel van verbondenheid' had overheerst. Hij benadrukte dat de nieuwe staatkundige verhoudingen zich niet alleen zouden kenmerken door sterke onderlinge banden, maar ook door meer zelfstandigheid, voor Sint Maarten en Curaçao, maar ook voor de BES-eilanden. Alle partijen hadden nu hun inhoudelijke commitment getoond, 'geen carte blanche'. Aan de afgesproken criteria moest worden vastgehouden, anders 'stort ons bouwwerk ineen'. Balkenende riep op tot bestuurlijke en persoonlijke moed om ook op moeilijke thema's als de rechtshandhaving de feiten onder ogen te zien, in plaats van 'om de hete brij heen te blijven draaien'. ${ }^{132}$

Bijleveld sprak in haar openingsstatement van een 'sleutelmoment' en 'een doorslaggevende fase'. Zij benadrukte dat het hervormingsproces vanuit Nederland nooit gezien was als middel om de Nederlandse invloed overzee te vergroten, maar juist als 'een kans voor de nieuwe eilanden, om een start te maken in nieuwe saamhorigheid'. ${ }^{133}$ Voor De Jongh-Elhage - die door Helmin Wiels van de oppositionele PS werd uitgemaakt voor 'house nigger van de Nederlanders' ${ }^{134}$ - was het eveneens een 'ijkmoment' waarnaar lang was uitgezien. De wens van de bevolkingen van de vijf eilanden werd nu uitgevoerd. Zij benadrukte het behoud van de Statutaire autonomie als uitgangspunt voor de nieuwe staatkundige structuur. Ook bij het toezichtsregime, in ruil waarvoor Nederland een groot deel van de schulden ging overnemen, was terdege rekening gehouden met de autonome bevoegdheden. De Jongh-Elhage riep op deze unieke kans op een gezonde startpositie en een duurzame verbetering van het welzijn van de bevolkingen niet voorbij te laten gaan.

Ook Aruba sprak zich ditmaal uit. Premier Oduber memoreerde het streven van Aruba om zich los te maken uit het Antilliaanse verband. Het land had in 23 jaar van status aparte bewezen deze status te hebben verdiend. Aruba had het zelfbeschikkingsrecht van de ande- 
re eilanden van meet af aan erkend en wilde zich 'slechts heel marginaal' betrekken bij dit 'ontvlechtingsproces', omdat dit vooraleerst een zaak van de Antillen zelf was. Aruba wilde 'beslist geen spelbreker zijn', maar vroeg wel om 'een behandeling als een gelijkwaardige partner'; daarom meende het recht te hebben op de zetel van het Gemeenschappelijk Hof. Omdat alle samenwerkingsorganen op Curaçao zetelden kon anders moeilijk van gelijkwaardigheid gesproken worden, aldus Oduber. Ten aanzien van het Hof verwoordde Oduber nog een ander bezwaar: Aruba wilde de rechtspraak tot Koninkrijksaangelegenheid verheffen, terwijl het Hof een consensusrijkswet betrof. ${ }^{135}$

Nicolaas refereerde namens Bonaire kort aan het proces vanaf het referendum in 2004; er waren goede 'inhoudelijke en procesversterkende' afspraken gemaakt over een transitieperiode 'waarin de voor ons belangrijkste peilers, namelijk onderwijs, volksgezondheid, jeugd en gezin, veiligheid en sociale zekerheid reeds 1 januari 2009 door Nederland geleidelijk zullen worden overgenomen'. Jesus-Leito stelde dat veel was bereikt, 'een aanvaardbaar en evenwichtig pakket'. Er was stevig onderhandeld, logisch: 'Wij vechten voor het land Curaçao met de nodige bestuurlijke kracht' en geen 'krakkemikkig Curaçao'. Het 'emancipatieproces' moest nu niet alleen juridisch en materieel, maar ook psychologisch vorm en inhoud krijgen. 'Wat nu op tafel ligt, is een aanvaardbaar en evenwichtig pakket', meende zij. ${ }^{136}$

Wescott-Williams sprak haar waardering uit dat sinds 2004 ook Nederland deelnam aan het proces, 'in de realisatie dat de door Sint Maarten geïnitieerde staatkundige veranderingen onomkeerbaar waren'. Zij wees op de volharding van Sint Maarten in het bereiken van zijn doel, in het besef dat het een proces was 'van geven en nemen'. Alles was op alles gezet om de status van land te bereiken, 'al het overige is secundair'. Voor Sint Maarten was het niet langer de vraag of het land kon worden; vastgehouden werd 'aan onze streefdatum van 2010', 'the drop dead date for Sint Maarten'. Julian Woodley (Sint Eustatius) betitelde Bijleveld tot 'vrouw van het jaar' voor alles wat zij gedaan had voor de BES. Saba's delegatieleider Chris Johnson benadrukte de continuïteit in de langdurige relatie met het Koninkrijk: 'here is where we belong'. Hoewel Johnson refereerde aan 'tough negotiations' en zijn vaders gang naar de VN was de kameraadschap tussen de BES-eilanden en Nederland in de afgelopen drie jaren juist gegroeid. ${ }^{137}$

$\mathrm{Na}$ drie jaar onderhandelen werd nu de tussenstand opgemaakt. De 'bouwtekening' voor het nieuwe Koninkrijk - het toetsingspakket omvatte vijf consensusrijkswetten, de Staatsregelingen van Curaçao en Sint Maarten en hun organieke wetten - werd tegen het licht gehouden. ${ }^{138}$ De toets of aan alle randvoorwaarden en eisen voor de 
staatkundige vernieuwing was voldaan, was nog niet aan de orde; toetsing van de overheidsapparaten zou pas tijdens een volgende RTC plaatsvinden. Het rapport van de TAC van 20 november was het grootste inhoudelijke agendapunt.

Kort voor de conferentie waren de politici het nog eens geworden over twee openstaande beslispunten. Het eerste betrof een passage over het zelfbeschikkingsrecht in de Staatsregeling van Curaçao. De Curaçaose wens om in de preambule van de Staatsregeling het zelfbeschikkingsrecht te bestempelen als 'een absoluut recht van het Curaçaose volk' werd op Nederlands aandringen - gezien het Haagse medebeslissingsrecht bij een andere status binnen het Koninkrijk - aangepast. Het tweede gesprekspunt betrof de Sint Maartense wens om de constitutionele toetsing bij het Gemeenschappelijk Hof van Justitie neer te leggen. Het leek Hirsch Ballin (in het verlengde van TAC-advies) geen goede gedachte om een dergelijk politiek gevoelige taak aan het Hof toe te bedelen. Partijen werden het slechts eens over een tekst waarin werd vastgesteld dat nog overeenstemming moest worden bereikt over een andere onafhankelijke instantie die zou worden belast met de door Sint Maarten voorgestane wijze van toetsing. ${ }^{139}$

De conclusies werden vervolgens in snel tempo afgedaan. Een heikel punt als de aanwijzingsbevoegdheid stond niet op de agenda, want daarover moest de Raad van State zich nog uitspreken. Een ander knelpunt, de bij het financieel toezicht vastgelegde criteria voor good governance in Curaçaose en Sint Maartense overheidsbedrijven, had de agenda evenmin gehaald, omdat deze kwestie nog niet behandeld was in de Curaçaose eilandsraad.

De conferentie werd tegen de avond afgesloten met een akkoord op alle agendapunten. Daarmee was het overleg uiteindelijk - conform de intentie - niets anders geweest dan een juridische toetsing; vrijwel alle punten waren van tevoren uitonderhandeld. Sommigen deden de RTC dan ook af als een 'ceremonieel circus'. ${ }^{140}$ Vastgesteld werd dat de voorstellen voor de Staatsregelingen en organieke wetten van Curaçao en Sint Maarten voldeden aan de criteria, met inachtneming van een aantal aanpassingen (genoemd in een rapportage van de v-RTC van 12 december), waarover eerder overeenstemming was bereikt. ${ }^{141}$ De wetgeving voor de BES-eilanden was ter kennisgeving aangenomen - het instemmingsrecht van deze eilanden met hun nieuwe status was geborgd via aanvaarding van de wijzigingen in het Statuut. ${ }^{142}$

In de RTC-besluitenlijst werd geconstateerd dat het voorstel van consensusrijkswet Openbare Ministeries en het voorstel Gemeenschappelijk Hof van Justitie in de Rijksministerraad inmiddels waren behandeld en voor advies aangeboden aan de Raad van State van 
het Koninkrijk. Alleen over de zetelplaats van het Hof bestond nog geen overeenstemming met Aruba. Verder constateerde de RTC bestuurlijke overeenstemming over de voorstellen van consensusrijkswet Politie, Raad voor de Rechtshandhaving en Financieel Toezicht: na behandeling in de Rijksministerraad zouden ook deze aangeboden worden aan de Raad van State. ${ }^{143}$ Een definitieve transitiedatum werd niet vastgesteld; Balkenende had zich daarop nog niet willen vastleggen. Op de eilanden werd gehoopt op het voorjaar van 2010. ${ }^{144}$

Het Jaarverslag Koninkrijksrelaties 2008 constateerde dat het een succesvol jaar was geweest voor de Koninkrijksrelaties: op alle aspecten van het staatkundig proces was voortgang geboekt. Tijdens de RTC was een 'wezenlijke' stap gezet in de totstandkoming van de ambities voor nieuwe verhoudingen. De ontwerpfase was nu afgesloten. Bijleveld weersprak in antwoord op Kamervragen dat de 'relaties meer gespannen dan ooit zijn'. Zij achtte het logisch dat de uitwerking van het proces discussie opleverde. ${ }^{145}$

\section{Koortsachtige onderhandelingen}

De opbouw van de nieuwe landen kon nu daadwerkelijk beginnen. In de uitvoeringsfase lag de nadruk op de parlementaire goedkeuring van de wetsontwerpen, aan beide zijden van de oceaan, en op de implementatie van de afspraken. In 2009 zou de schuldsanering voor Curaçao en Sint Maarten starten, en werd een begin gemaakt met het overhevelen van de eerste landstaken naar de nieuwe landen en Nederland. ${ }^{146}$

Intussen had de Raad van State advies uitgebracht over de verschillende consensusrijkswetten. Eén advies zou grote consequenties hebben voor het verdere traject. De Raad oordeelde op 11 maart 2009 zeer kritisch over de in het voorstel van 'Consensus Rijkswet Openbare Ministeries van Curaçao, van Sint Maarten en van Bonaire, Sint Eustatius en Saba' opgenomen aanwijzingsbevoegdheid voor de $\mathrm{Ne}$ derlandse minister van Justitie als lid van de Rijksministerraad. De Raad noemde deze maatregel van 'zeer ingrijpende aard', omdat deze 'een vergaande breuk [kan] betekenen op het opsporings- en vervolgingsbeleid van de landen'. Hij vond deze aanwijzingsbevoegdheid bovendien niet nodig omdat artikel 43, tweede lid, samen met artikel 51 Statuut, al voldoende mogelijkheden bood om in het kader van de waarborgfunctie op te treden ter bescherming van rechtsstatelijke beginselen. De Raad adviseerde daarom de bevoegdheid-destijds met name door toedoen van Hirsch Ballin en Nicolaï in de Slotverklaring van 2006 opgenomen - te schrappen. ${ }^{147}$ 
Dit advies werd op Curaçao en Sint Maarten uiteraard met instemming ontvangen. Eind maart werd tijdens de Politieke Stuurgroepvergadering op Curaçao, mede door de opstelling van Balkenende, die Bijleveld bijviel, inderdaad besloten de aanwijzingsbevoegdheid op Koninkrijksniveau te laten vervallen. ${ }^{148}$ De democratische rechtsstaat, zo werd in aansluiting op de Raad geconcludeerd, kon ook op andere wijze gewaarborgd worden. De consensusrijkswet Openbare Ministeries zou aangepast worden: in plaats van de aanwijzingsbevoegdheid kwamen partijen een nieuw overlegmechanisme overeen. In een jaarlijks overleg zouden de ministers van Justitie van de landen (waarbij Nederland de BES zou vertegenwoordigen) en de procureurgeneraal afspraken maken over het opsporings- en vervolgingsbeleid voor de georganiseerde en zware criminaliteit en dit beleid op elkaar afstemmen. Daarnaast kon elke minister van Justitie het Gemeenschappelijk Hof vragen om een bevel tot vervolging te mogen geven aan de procureur-generaal. ${ }^{149}$

Hiermee was een zeer heet hangijzer van tafel. Bijleveld reageerde tevreden, ook al wist zij dat haar collega Hirsch Ballin het schrappen van de Nederlandse aanwijzingsbevoegdheid betreurde. Zij betoogde dat Nederland structureel meer invloed op de bestrijding en opsporing van de georganiseerde en zware criminaliteit op de Antillen

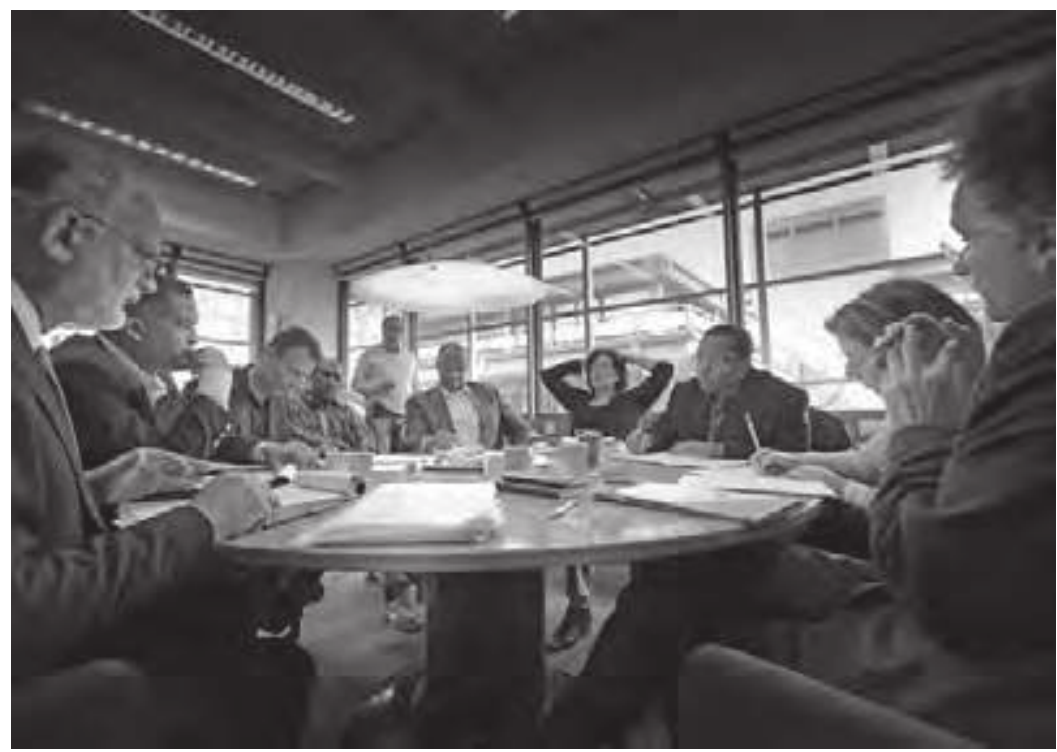

Overleg rond de slot-RTC, ministerie van BZK, Den Haag, 7 september 2010; v.I.n.r. Frank Willemsen, Gilbert de Windt, Hans Gerritsen, Richard Gibson, Freddie Curiel, Eugene Holiday, Suzy Römer, Etienne Ys, Anneke van Dijk, Luc Verhey. 
had gekregen en sprak van een 'evenwichtige regeling' die een goede rechtshandhaving in het Koninkrijk ondersteunde. De positie van de procureur-generaal was versterkt, waarmee de ruimte voor lokale politici om het functioneren van het Openbaar Ministerie en de rechters te beïnvloeden verder zou worden teruggedrongen. Niet onbelangrijk, bovendien, was dat met dit besluit de kans op een positieve uitslag van het inmiddels aangekondigde Curaçaose referendum, over de resultaten van de laatste RTC, aanmerkelijk groter was geworden. Aan de uitslag had premier De Jongh-Elhage haar politieke lot verbonden en ingewijden stellen dat zij Bijleveld veelvuldig had gewezen op de noodzaak van Haagse concessies op dit punt. ${ }^{150}$

Onvermijdelijk werd dit deel van het akkoord gezien als een grote concessie van Nederland, dat al die tijd had vastgehouden aan een aanwijzingsbevoegdheid op Koninkrijksniveau. Hierop werd ook de eerdere unanimiteit in de Nederlandse politiek definitief doorbroken: de VVD en de PVV onderschreven de uitwerking van de afspraken in de Slotverklaring niet langer. Voor de VVD was het schrappen van de bepaling onverteerbaar; de partij had de aanwijzingsbevoegdheid altijd gesteld als een absolute voorwaarde voor de schuldsanering. Op 31 maart 2009 zou de Tweede Kamerfractie haar steun aan het proces intrekken. ${ }^{151}$

De parlementaire frustratie kwam mede voort uit de inschatting dat het mogelijk niet zou lukken een meer subtiel systeem van checks and balances te ontwikkelen dan het aloude ultimum remedium van artikel 43 lid 2 Statuut. De liberale senator - en voormalig commandant van de Nederlandse strijdmacht in het Caraïbisch gebied - Van Kappen verwoordde in een later stadium deze frustratie in maritieme beeldspraak. Hij stelde dat artikel 43 een wel erg 'grof instrument [is] om bij te sturen. Bij het navigeren in een nauw vaarwater, en daar bevinden wij ons in, zijn grove koerscorrecties bij het afwijken van de juiste koers uit den boze; ze leiden vaak tot ernstige zeeschade. ${ }^{152}$

Maar ook op de eilanden verscherpten de politieke tegenstellingen. Het op Curaçao aangekondigde referendum over de resultaten van de toetsings-RTC beloofde een nek-aan-nekrace te worden tussen voor- en tegenstanders van de afspraken met Nederland. Balkenende had al gewaarschuwd het geaccordeerde wetgevingspakket te beschouwen als het eindresultaat; bij een afwijzing was er geen ruimte voor nieuwe onderhandelingen. De premier dreigde, gesteund door een Kamermeerderheid (waar sprake was van toenemende twijfel en ook wel cynisme rond de haalbaarheid en wenselijkheid van het hele proces) - de schulden niet te saneren als de optie 'nee' een meerderheid behaalde. Ook Bijleveld hoopte op een duidelijk 'ja' en benadruk- 
te dat het ging om een eenmalige, unieke kans. ${ }^{153}$

Op 15 mei 2009 bleek inderdaad een meerderheid van het electoraat in te stemmen met de ja-optie en dus het onderhandelingspakket, maar Curaçao bleek dramatisch verdeeld: tegenover een nipte meerderheid van 52 procent stond een contingent van 48 procent nee-stemmers. De argumentatie contra het pakket draaide erom dat de autonomie werd afgepakt en dat de 'rekolonisatie' door Nederland geen structurele verbetering van de situatie op het eiland zou brengen. Uiteraard riep de diepe verdeeldheid ook in Den Haag vragen en twijfels op; toch overheerste daar de opluchting. Formeel was nu de weg vrij om 'in volle vaart' het proces langs de afgesproken weg voort te zetten. ${ }^{154}$

In de Antilliaanse politiek en media werd gesproken over 1 januari 2010 als transitiedatum, maar aan de opbouw van de landen was in Haagse ogen onvoldoende urgentie gegeven. Curaçao en Sint Maarten hadden hun aangepaste en nog ontbrekende wetgeving uiterlijk 11 februari 2009 zullen aanleveren, ter toetsing door de TAC en het presidium van de V-RTC, maar een belangrijk deel was medio juni 2009 nog niet ontvangen. ${ }^{155}$ Deze zorgen zouden tot het einde van het jaar aanhouden. De Nederlandse inzet voor de Stuurgroep van 9 december 2009 luidde dat de ontmanteling zo moeizaam verliep dat het risico bestond dat in oktober 2010 het land goeddeels nog zou bestaan. Dan tekenden zich twee scenario's af: ofwel per oktober 2010 de ontmanteling en taakoverdracht met een 'big bang', ofwel opnieuw een vertraging in het staatkundig proces. ${ }^{156}$

Niet verwonderlijk werd eind mei 2009 op BZK vastgesteld dat de derde deadline, 1 januari 2010, net zomin haalbaar was gebleken als de eerdere streefdata 1 juli 2007 en 15 december 2008. Deze boodschap zou Bijleveld tijdens een videoconferentie op 2 juni 2009 met De Jongh-Elhage en Ys moeten overbrengen. De praktische voortgang in Curaçao en Sint Maarten was ontoereikend en de noodzakelijke Rijkswetgeving kon nog niet in werking treden. Een nieuwe complicerende factor was de politieke situatie op Sint Maarten, waar op 8 juni een nieuw bestuurscollege zou aantreden met als politiek leider William Marlin (NA). Wescott-Williams' DP had eind 2008 haar meerderheid verloren nadat de voor fraude veroordeelde gedeputeerde Louie Laveist was opgestapt. ${ }^{157}$ Ook leken nieuwe Statenverkiezingen vrijwel onontkoombaar, nu de noodzakelijke wetgeving op zijn vroegst (pas) medio 2010 gereed kon zijn - als alles meezat en de Staatsregelingen in één keer de benodigde tweederde meerderheden zouden behalen in de eilandsraden. ${ }^{158}$

In de Stuurgroep van 24 juni 2009 werd nog geen nieuwe deadline vastgesteld, maar wel dat de nieuwe statussen in de tweede helft 
van 2010 zouden ingaan, in ieder geval 'niet later dan eind oktober 2010'. ${ }^{159}$ Het was de eerste keer dat over een definitieve opheffingsdatum werd gesproken, en niet langer over een streefdatum. Hiermee lag vast dat Curaçao en Sint Maarten vóór eind oktober 2010 zelfstandige landen zouden worden. Met het besluit dat beide eilanden tegelijk hun nieuwe status van land zouden verwerven, stapte de Stuurgroep bovendien heen over de Haagse parlementaire scepsis rond de vraag of Sint Maarten wel op tijd zover zou zijn. ${ }^{160}$

Wel werd een besluit genomen over de kwestie hoe om te gaan met het risico dat Sint Maarten, en mogelijk ook Curaçao, niet klaar zou zijn. Een gemengde ambtelijke commissie zou dan voorzieningen bedenken om de landen vanaf de transitiedatum alsnog aan de criteria te kunnen houden. Deze instrumenten konden fungeren op Koninkrijksniveau, conform de voorlichting van de Raad van State van 29 augustus 2008, dan wel in Koninkrijksverband als onderlinge, bindende afspraken tussen de betrokken entiteiten. Ter voorbereiding van de Stuurgroep op 30 september zou over dit alternatieve scenario een advies worden opgesteld. ${ }^{161}$

Rond de toetsing van de nieuwe overheidsinstituties tekende zich intussen een impasse af, zodat Bijleveld werd geadviseerd om in deze aanstaande Stuurgroep Sint Maarten en Curaçao uitdrukkelijk op hun eigen verantwoordelijkheid te wijzen. In Haagse optiek hielden de beide aspirant-landen het proces gegijzeld, ook waar het de toetsing van de overheidsapparaten betrof; zo zou de voor de onderhandelingen benodigde informatie niet worden aangeleverd. Er was dus een sterk politiek signaal richting de potentiële nieuwe landen nodig, temeer door de harde opstelling van de Tweede Kamer. Onomwonden werd Bijleveld gewaarschuwd niet toe te geven en duidelijk te maken dat het alternatief slechts zou zijn dat de besluitvorming naar Koninkrijksniveau zou worden getild. ${ }^{162}$

De Jongh-Elhage en Bijleveld bleven niettemin uitgaan van een goede uitkomst. Naar verluidt werd min of meer spontaan, op voorstel van de Antilliaanse premier, de beleidsmatig uitermate onhandige, maar symbolisch mooie - en volgens De Jongh-Elhage 'romantische'-datum van 10/10/10 geprikt. En zo kon gouverneur Goedgedrag bij de opening van het parlementaire jaar, op 8 september 2009, 'Tien Tien Tien!' als transitiedatum noemen. Hierop liet ook het bestuurscollege van Curaçao weten deze datum als 'definitieve transitiedatum' te willen beschouwen. ${ }^{163}$

In de Politieke Stuurgroep van 30 september 2009 ging de kogel definitief door de kerk: op 10 oktober 2010 zou de nieuwe staatkundige situatie in werking treden en zouden de Antillen worden opgeheven. ${ }^{164}$ In de overeenkomst werden ook de voorwaarden opgenomen 
voor de daadwerkelijke doorgang van de transitie per 10/10/10, waaronder aanvaarding door de Staten van de Nederlandse Antillen en Aruba van de Rijkswet tot wijziging van het Statuut. Als Curaçao en/ of Sint Maarten op 10/10/10 nog niet aan alle criteria voldeden om land te worden, zou, op advies van de gemengde commissie, een alternatief scenario worden ontwikkeld, een 'plan B'. ${ }^{165}$

Dit plan B behelsde dat op de transitiedatum de zogeheten AMVRB 'Samenwerkingsregeling waarborging plannen van aanpak landstaken Curaçao en Sint Maarten' in werking zou treden, met een werkingsduur van twee jaar en de mogelijkheid van eenmalige verlenging met twee jaar, ter waarborging van de taken die de nieuwe landen nog niet zelf aankonden. De landen in spe zouden voor de terreinen waarop ze nog niet aan alle criteria voldeden een plan van aanpak opstellen, zodat het Koninkrijk deze taken tijdelijk kon overnemen. De plannen van aanpak zouden worden vastgesteld op de slotRTC - die inmiddels gepland was op 15 september 2010-waarna een voortgangscommissie zou toezien op de uitvoering ervan. Deze voortgangscommissie zou aanbevelingen kunnen doen aan de verantwoordelijke minister en regelmatig rapporteren aan een ministerieel overleg, bestaande uit de premier van het betreffende land en de Nederlandse bewindspersoon voor Koninkrijksrelaties. In dit bilaterale overleg zouden dan de knopen worden doorgehakt. Mocht dit overleg niet tot overeenstemming kunnen komen, dan zou de Rijksministerraad voorzien in een oplossing - dit orgaan zou dus het laatste woord krijgen. ${ }^{166}$

Met andere woorden: door via genoemde AMVRB 'adequate voorzieningen' te treffen, konden Curaçao en Sint Maarten, tegen de Slotverklaring en alle daaropvolgende afspraken in, al land worden vóórdat ze alles op orde hadden. Op 10/10/10 zouden de nieuwe landen er komen, ongeacht de vraag hoever ze daarmee waren. Hiermee leek Bijleveld, althans tegenover het eigen parlement, het tegengestelde te doen van haar tot dan volgehouden adagium van 'afspraak is afspraak'. Bovendien had Nederland er altijd aan vastgehouden dat pas op een slot-RTC de definitieve ingangsdatum bepaald zou worden. Het zou Bijleveld dan ook nog veel moeite kosten de Kamer enigszins te overtuigen van de juistheid van dit besluit. ${ }^{167}$

$\mathrm{Na}$ afloop van de Stuurgroepvergadering betoonde De JonghElhage zich blij met de definitieve deadline. Bijleveld zei, zuiniger, met de datum van 10/10/10 te kunnen leven, al moest er nog veel worden gedaan. Op de Haagse departementen die verantwoordelijk zouden worden voor de BES-eilanden werd 10/10/10 ervaren als een slecht gekozen datum, want midden in een maand, midden in een jaar en bovendien een zondag; 1/1/11 - ook een mooie datum - was 
een logischer en wenselijker moment geweest. Voor de invoering van de nieuwe munt en het nieuwe fiscale stelsel, en de daarmee samenhangende sociale en zorgverzekeringen, was een gebroken kalenderjaar problematisch en kostbaar. Bovendien verkortte het naar voren schuiven van de transitiedatum de toch al krappe tijd die de departementen hadden om de uitvoering op orde te brengen. ${ }^{168}$

Daarnaast was er het vraagpunt hoe om te gaan met de financiële dekking. Vanaf 1/1/11 was structureel 88 miljoen euro gereserveerd op de aanvullende post van de Rijksbegroting ter dekking van de uitgaven van de eilanden én de extra uitgaven van de Rijksoverheid. Bij een naar 10/10/10 vervroegde transitiedatum was echter al eerder budget nodig. Bijleveld zou later dat jaar in een brief aan de ministerraad voorstellen om op 10/10/10 zo veel mogelijk BES-wetgeving in te voeren en een uitzondering te maken voor (onderdelen van) wetgeving die tot te veel extra (administratieve) lasten voor burgers, bedrijven en overheid zou leiden. $\mathrm{Zij}$ constateerde nu dat praktische problemen zouden optreden als alle nieuwe wetgeving voor de BESeilanden werd ingevoerd per 10/10/10. ${ }^{169}$

De parlementaire steun voor de verzelfstandiging van Curaçao en Sint Maarten nam intussen verder af. Bijlevelds verdediging van 10/10/10 stuitte op onbegrip en twijfel in de Kamercommissie, zeker voor Sint Maarten. SP-woordvoerder Van Raak betoogde tijdens een werkvakantie met eigen ogen te hebben gezien dat beide eilanden in 2010 nog niet klaar zouden zijn om land te worden ('onverantwoord'). $\mathrm{Nu}$ ook de SP het hervormingsproces niet langer steunde-eerder hadden de PVV ('geen cent meer aan de Antillen uitgeven') en de VVD (na het schrappen van de aanwijzingsbevoegdheid) zich al teruggetrokken - moest Bijleveld steeds meer druk uitoefenen op de Kamer om nu in te stemmen met de opheffing van het land per 10/10/10. ${ }^{170}$

Bijleveld verdedigde de datum als 'essentieel' en 'het onder ogen zien van een realiteit'. Immers, de referenda op Curaçao en Sint Maarten en ook de Slotverklaring lagen intussen al jaren terug. Als reden voor de koerswijziging - plan B-noemde zij de voortschrijdende ontmanteling van de landslaag: het was onverantwoord geworden de eilanden nog langer dan strikt noodzakelijk binnen het Antilliaanse staatsverband te houden. Sceptische Kamerleden dachten echter eerder aan '10/10/20 of 10/10/30' (Van Gent, GL); Brinkman sprak van '12/12/12'. Ook de PVDA- en CDA-woordvoerders uitten weinig vertrouwen in de datum. ${ }^{171}$

Bijlevelds pogingen om de door plan B overvallen Kamerleden gerust te stellen, wierpen geen vrucht af, al betoogde zij dat ook met de AMVRB 'maximale waarborgen' bestonden op de meest essentiële terreinen om de landen op 10/10/10 goed van start te kunnen laten 
gaan. Sint Maarten en Curaçao moesten immers nog steeds voldoen aan de criteria: vóór de creatie van de landen zou getoetst worden op een slot-RTC. Alleen de taken die ze op de transitiedatum nog niet aankonden, zouden via de AMVRB onder de tijdelijke verantwoordelijkheid van de Koninkrijksregering geplaatst worden, aan de hand van een door het betrokken land zelf opgesteld plan van aanpak. Over de AMVRB bestond nu overeenstemming met de eilandgebieden, die zich hiermee dus onderwierpen aan mogelijk ingrijpen door de Rijksministerraad. Bovendien, zo benadrukte Bijleveld, bleef artikel 51 - hoger toezicht - altijd achter de hand. ${ }^{172}$

De Kamerleden waren niet onder de indruk. In plaats van de afgesproken route - heldere toetsingscriteria formuleren, toetsen en conclusies trekken - werd nu een 'vaag vehikel van een voortgangscommissie' (Remkes) gekozen. Dat was de 'wereld op zijn kop' (Van Raak). Bovendien waren goed bestuur en rechtshandhaving belangrijke normen bij het oordeel over een landsstatus; daarover was in oktober 2008 al kamerbreed een motie aangenomen, met nota bene Bijlevelds eigen CDA als eerste ondertekenaar: de eilanden konden geen land worden zolang ze de rechtshandhaving en rechtspleging niet op orde hadden. Remkes liet er geen misverstand over bestaan: 'Ik ben het absoluut oneens met dat wonderlijke Plan B van de staatssecretaris. We worden steeds verder het moeras in getrokken. Dat wordt zwemmen in stroop. ${ }^{, 173}$ Het lukte Bijleveld niet de scepsis weg te nemen. Afgesproken werd slechts dat zij later dat jaar opnieuw mocht proberen de fracties ervan te overtuigen dat Curaçao en Sint Maarten op 10/10/10 land konden worden, zelfs als zij dan niet voldeden aan de altijd als 'keihard' gepresenteerde criteria. ${ }^{174}$

Ook tijdens de begrotingsbehandeling op 2 december 2009 toonde de Tweede Kamer zich zeer kritisch over de staatkundige hervorming - de behandeling duurde tot halfdrie 's nachts. ${ }^{175}$ Onder aanvoering van de VVD-fractie werd Bijleveld niet alleen stevig aangevallen op de ambitieuze transitiedatum (Remkes: 'tegen die tijd is de boel nog niet op orde, zeker niet op Sint Maarten'), maar ook op de afwezigheid van substantiële garanties voor een volwaardige rechtshandhaving op de eilanden (het schrappen van de aanwijzingsbevoegdheid stak de VVD 'als een graat in de keel') en op de keuze voor het als ongeloofwaardig ervaren plan B. ${ }^{176}$ Heftige kritiek was er ook op de kwaliteit van de consensuswetgeving, vooral rond de politie ('het resultaat is drie veel te kleinschalige korpsen, opgeleukt door een gemeenschappelijke voorziening die niets om het lijf heeft ${ }^{{ }^{177}}$ ).

Verder werden zeer kritische opmerkingen gemaakt over de ruimte voor de Statutaire waarborgfunctie en over het referendum dat Bonaire nu alsnog wenste te organiseren. Er gingen stemmen op om het 
hervormingsproces te stoppen tot het referendum achter de rug zou zijn. ${ }^{178}$ De houding van de eilanden inzake abortus, euthanasie en vooral het homohuwelijk riep veel kritiek op; Bijleveld ontraadde zonder succes een motie die het homohuwelijk op de BES mogelijk moest maken. ${ }^{179}$ Ook enkele andere moties werden door de staatssecretaris vergeefs ontraden. ${ }^{180}$ Opmerkelijk genoeg stemde toch, ondanks alle tegensputteringen, medio december 2009, met uitzondering van de PVV, de gehele Tweede Kamer in met de Koninkrijksbegroting voor 2010. ${ }^{181}$

De herstructurering van het politiewezen bleef een heikel punt. Sinds de besluitvorming in oktober 2008, waarbij een structuur van (sub)werkgroepen was ingesteld, was er in de optiek van BZK geen vooruitgang meer geboekt. Hierop reageerde Bijleveld assertief, door de Stuurgroep ervan te overtuigen om de samenwerking met het RST op de eilanden te verlengen tot twee jaar na de transitie; pas daarna zouden, in principe, de taken van het RST door de nieuwe landen kunnen worden overgenomen. Verder werd besloten dat een in te stellen 'kleine commissie' van vijf leden (één vertegenwoordiger per entiteit) met een voorstel zou komen voor de inrichting van de GVP, conform de taken zoals vermeld in de concept-Politieconsensusrijkswet. Dit inrichtingsplan moest dan aan de Stuurgroep van december 2009 kunnen worden voorgelegd. ${ }^{182}$ Mede gelet op het - afbrokkelende-draagvlak in de Tweede Kamer voor de Politiewet, was het de Nederlandse inzet om de GVP te versterken en zo de samenwerking tussen de korpsen en de kwaliteit van de politie te waarborgen. Dit mede, in Haagse optiek, contra 'de Antilliaanse inzet dat de GVP wordt weggezet als een uitzendbureau'. ${ }^{183}$

De Politieke Stuurgroep van 9 december 2009 begon uren later dan afgesproken, zoals wel vaker door meningsverschillen tussen de landsregering en de eilandelijke onderhandelaars, in dit geval vooral die van Sint Maarten - dit tot uitgesproken woede van de Nederlandse minister van BZK Ter Horst, die De Jongh-Elhage toevoegde nog nooit zoiets belachelijks en inefficiënts te hebben meegemaakt. In de uiteindelijk tot diep in de nacht durende vergadering werden tentatieve afspraken gemaakt over de inrichting van de GVP. ${ }^{184}$ Over de basis daarvoor bereikten Ter Horst en Bijleveld een akkoord met de Antillen, Curaçao en Sint Maarten. De nieuwe korpsen van Curaçao, Sint Maarten en het BES-korps zouden in de GVP gaan samenwerken bij het bestrijden van de georganiseerde en grensoverschrijdende criminaliteit. Ze zouden elk een speciale eenheid voor de bestrijding van deze criminaliteit krijgen; de drie units zouden nauw gaan samenwerken. Deze voorziening was ook bedoeld voor operationele ondersteuning. Uiterlijk op 31 januari 2010 - vóór de behandeling van de 
Rijkswet Politie in de Tweede Kamer en de Stuurgroep van februari 2010 - zou een volledig uitgewerkt voorstel voor een inrichtingsplan en takenpakket, voorzien van een financiële paragraaf, en gerelateerd aan de inrichtingsplannen van de korpsen, op tafel liggen. Medio februari 2010 kon dan besluitvorming plaatsvinden over de precieze invulling van de GVP. Als de toetsing van de politieorganisatie daartoe aanleiding mocht geven, zouden de inrichtingsplannen van de politiekorpsen van Curaçao, Sint Maarten en de BES direct worden uitgewerkt in plannen van aanpak zoals bedoeld in de AMVRB 'Samenwerkingsregeling waarborging plannen van aanpak landstaken Curaçao en Sint Maarten'. ${ }^{185}$

Gekoppeld aan de eerdere afspraak om de samenwerking binnen het RST na de transitie met twee jaar te verlengen, was het politiedossier nu weer vlot getrokken. In navolging hiervan zou de Politieke Stuurgroep op 11 februari 2010 spreken over de relatie tussen de korpsen van Curaçao, Sint Maarten en de BES tot de GVP, de adviezen van de kleine commissie en de inrichtingsplannen van de drie korpsen. Er was nog geen overeenstemming over de inbedding van de GVP in de drie politiekorpsen. Met het oog op de behandeling van de consensusrijkswet was deze besluitvorming uiterlijk 1 maart vereist. ${ }^{186}$

Tijdens deze - uitzonderlijk vlot verlopen - Politieke Stuurgroep werd ook gesproken over andere dossiers. In de AMVRB en het plan van aanpak was bepaald op welke wijze omgegaan zou worden met de overheidstaken die door Curaçao en/of Sint Maarten op het transitiemoment nog niet overgenomen konden worden. Hiermee meende Bijleveld te voldoen aan de voorwaarden voor behandeling van de consensusrijkswetten, zoals gesteld door de Vaste Commissie NAAZ ${ }^{187}$ Tijdens de vergadering bleek Sint Maarten nu de meeste problemen te hebben met de toetsingscriteria voor de nieuwe landen. Bijleveld sprak zich uit voor een harde toetsing: 'We moeten kunnen zien of de instituties [inderdaad] kunnen functioneren als men een land wil worden. De nadruk ligt hierbij op rechtshandhaving, financiën en deugdelijkheid van bestuur. ${ }^{188}$

Op de slot-RTC in september 2010 moest worden afgesproken of Curaçao en Sint Maarten werkelijk klaar waren om land te worden of dat bepaalde taken nog in samenwerking met Nederland of op Koninkrijksniveau moesten worden uitgevoerd. Het was nu wel zeer waarschijnlijk dat in ieder geval de politie op Sint Maarten de toetsing niet zou doorstaan en dus voor twee jaar onder de met Nederland afgesproken AMVRB zou vallen. Maar overigens was, volgens Bijleveld, 10/10/10 nog steeds haalbaar, 'zolang iedereen maar meewerkt'. ${ }^{189}$ 
Intussen was het ook overzee weer gaan rommelen, nu uit onverwachte hoek. Nadat lange tijd de belangrijkste problemen zich op Curaçao en Sint Maarten hadden afgespeeld, wierp vanaf medio 2009 Bonaire zich op als struikelblok. Na een bestuurscrisis op het eiland kwam er een wisseling van de (tienjarige) wacht. Het nieuwe bestuurscollege zou de afspraken met Nederland ter discussie gaan stellen.

Op 29 mei trad eilandsraadlid Anthony Nicolaas uit de christendemocratische Union Patriotiko Bonaireano (UPB) van de grote voorvechter van aansluiting bij Nederland, Ramonsito Booi. De UPB verloor hierdoor haar meerderheid. Na tien jaar de oppositierol te hebben vervuld, trad vervolgens op 8 juni de Aliansa Demokratika Bonairiana (ADB) van Jopie Abraham aan in een nieuw bestuurscollege, met steun van het nu onafhankelijke eilandsraadlid Nicolaas. ${ }^{190}$ Het nieuwe bestuur zou gaan inzetten op meer autonomie en op het houden van een staatkundig referendum, waarbij de bevolking ook de optie van 'vrije associatie' voorgelegd zou krijgen. Volgens het nieuwe college was het nooit de bedoeling geweest dat de optie van 'directe banden' met Nederland - waarvoor in 200459 procent van de Bonairiaanse kiezers zich had uitgesproken - werd uitgelegd als dat het eiland deel zou worden van Nederland als een openbaar lichaam; het hebben van een rechtstreekse band was iets heel anders dan ergens deel van worden. De ADB had overigens destijds wel de Slotverklaring geaccordeerd; uitgerekend Nicolaas, toen nog van de UPB, had deze ondertekend. ${ }^{191}$

Waar het zijn van openbaar lichaam door de ADB gelijkgesteld werd met integratie, was de precieze betekenis van de nu geponeerde 'vrije associatie' - in het internationale recht een (vrij uitzonderlijk) samenwerkingsverband tussen twee soevereine landen, zoals Puerto Rico met de Verenigde Staten - niet helemaal duidelijk. Deze keuze werd door het bestuurscollege niet nader ingevuld; voor het begrip 'vrije associatie' werd slechts verwezen naar de voorlichting van de Raad van State uit 2006. Bonaire wenste in een directe bestuurlijke relatie met Nederland toch zo veel mogelijk autonomie te verwerven. Het college wenste dat Bonaire geen deel van Nederland zou worden, maar wel gelijke rechten zou krijgen op gebieden als onderwijs, volksgezondheid en sociale zekerheid. Het nieuwe bestuur meende dat integratie, met alle bijbehorende toezicht en controle, ten onterechte als uitgangspunt voor de band met Nederland was genomen, waarbij bovendien nog eens, ondanks die integratie, geen sprake was van gelijke rechten en voorzieningen met het Europese deel van Nederland. Dit werd opgevat als discriminatie.

Op 15 september 2009 accepteerde de Bonairiaanse eilandsraad, 
met vijf stemmen voor (inclusief Nicolaas) en vier tegen, een motie om binnen vier maanden een referendum te organiseren over de invulling van het staatkundig proces, in ieder geval vóór de Statenverkiezingen van eind januari 2010. In een brief van 24 september aan het Haagse ministerie van Justitie werd Nederland vervolgens verzocht om de verdere politieke en ambtelijke behandeling van de Statuutwijziging aan te houden tot na het referendum. Het bestuurscollege had 'principiële en fundamentele bezwaren' tegen de voorstellen. Ook ging Nederland volgens het bestuurscollege te voortvarend te werk, met onvoldoende oog voor de lokale omstandigheden. Het college stelde de keuze voor een openbaar lichaam ter discussie en noemde vrije associatie als alternatief. Zo dreigde, tot verontwaardiging van Bijleveld, uitgerekend Bonaire - dat aanvankelijk juist een voortrekkersrol had gespeeld - het proces nu te vertragen. ${ }^{192}$

Dat Bonaire onverwachts op een referendum ging aansturen, zou noch aan de transitiedatum, noch aan de nieuwe staatkundige structuur, uiteindelijk iets veranderen. Maar de kwestie zou de gemoederen wel over en weer acht maanden lang zeer bezighouden. Een ruime Kamermeerderheid-CDA, PVDA, SP, VVD en PVV-steunde Bijleveld in haar besluit om naar aanleiding van de motie de schuldsanering aan Bonaire te stoppen en niet terug te zullen komen op eerdere afspraken. Hoewel oppositiepartijen VVD, SP en PVV eigenlijk pas na het geplande referendum de behandeling van de BES-wetgeving wilden voortzetten, werd met steun van onder meer coalitiepartijen CDA en PVDA besloten dat dit traject verder kon gaan, om nog meer vertraging te voorkomen. Het voorstel tot Rijkswet wijziging Statuut moest op 15 september afgerond zijn, wilde 10/10/10 gehaald worden. Daarbij werd ook gewaarschuwd voor mogelijke verharding in de Nederlandse politiek en onderlinge polarisatie. ${ }^{193}$

In Haagse ogen stond het Bonaire vrij een referendum te houden, maar de vraagstelling moest wel duidelijk zijn, met voor de bevolking heldere consequenties. In Haagse optiek waren er slechts twee keuzes: uitwerking van de afspraken in een openbaar lichaam dan wel zelfstandigheid buiten het Koninkrijk. 'Meer smaken in het Koninkrijk kennen wij niet en willen wij ook niet', aldus Bijleveld: 'Ik heb al klip-en-klaar gezegd dat het enige alternatief dan onafhankelijkheid is.' Niet alleen bood de Grondwet geen mogelijkheden voor associatie, ook moest een consistent beleid gevoerd worden: afspraak was afspraak, dat gold op alle trajecten. Bovendien mochten Saba en Sint Eustatius niet 'gegijzeld worden' in het proces. Bijleveld stelde beide eilanden gerust dat de voorbereiding van hun status de planning zou blijven volgen. Bonaire, zo benadrukte zij, kon op ieder moment weer instappen in het traject. ${ }^{194}$ 
Maar zo ver was Bonaire niet. Het verwijt van de bestuurders dat Bijleveld zich met het opschorten van de schuldsanering mengde in de lokale politiek, wierp de bewindsvrouw verre van zich. Zij bleef benadrukken dat voor Bonaire een wat ander arrangement dan voor de 'ES-eilanden' bespreekbaar was. Bovendien wees zij erop dat na vijf jaar ervaring met de nieuwe status sowieso een evaluatie zou plaatsvinden, waarbij dan ook bekeken kon worden in hoeverre Bonaire nog meer taken op zich kon nemen. De WOLBES was niet per definitie het staatsrechtelijke eindmodel, benadrukte de bewindsvrouw; misschien zou te zijner tijd de status van (bijzondere) gemeente beter blijken te passen. De parlementaire stemming werd goed vertolkt door Van Bochove: 'Op de Antillen is terugonderhandelen tot kunst verheven. Anders dan Jopie Abraham nu wil doen geloven, heeft hij wel degelijk zijn handtekening onder de Slotverklaring van 2006 gezet. Van mij mag Bonaire elke dag een referendum houden. Als Bonaire niet meer over integratie wil spreken, moet men wel alle consequenties van die keuze aanvaarden.' Dat was de keuze voor onafhankelijkheid. ${ }^{195}$

In november 2009 was nog geen definitief besluit genomen over de datum van het referendum; duidelijk was wel dat dit nu niet meer ging lukken vóór de Statenverkiezingen van januari 2010. Nicolaas en Abraham verklaarden niet met Nederland over de taakverdeling na 10/10/10 te willen spreken zolang nog geen referendum was gehouden. Met Saba en Sint Eustatius was hierover in een bestuurlijk overleg op 3 november al een akkoord gesloten, dat erop neerkwam dat beide eilanden zo veel mogelijk taken zelf zouden behartigen, met als uitgangspunten dat aanvankelijk de Antilliaanse wetgeving nog van kracht zou blijven - waarmee ook de bestaande taakverdeling met het land werd gehandhaafd - en dat het beginsel van subsidiariteit tevens van toepassing zou zijn op de toekomstige taakverdeling tussen het Rijk en de openbare lichamen. ${ }^{196}$

Kennelijk was BZK er niet gerust op. Bijlevelds rechterhand, directeur KR Hans Gerritsen onderstreepte de Nederlandse lijn nog eens in een ingezonden stuk in het Antilliaans Dagblad. Een Bonairiaanse afwijzing van het akkoord met Nederland zou als consequentie hebben dat ook voor de andere vier eilanden een streep door 10/10/10 zou gaan. Bij een 'nee' in het referendum werd het staatkundig proces volgens de KR-directeur met twee jaar vertraagd - een uitstel dat, gezien de wijzigende politieke verhoudingen in Nederland, zelfs tot afstel kon leiden. Hij waarschuwde in dit - voor een ambtenaar - ongebruikelijk politieke stuk bovendien dat in Nederland geen draagvlak bestond voor het idee van een vrije associatie. ${ }^{197}$

Het referendum van 15 januari ging uiteindelijk niet door; er was kritiek op de onduidelijke vraagstelling en omschrijving van het begrip 
'vrije associatie'. Op 29 januari 2010 - de Statenverkiezingen waren achter de rug - besloot de eilandsraad dat het referendum op 26 maart zou plaatsvinden. De bevolking kon dan kiezen voor associatie met, of integratie in Nederland. De verordening werd aangenomen met vijf stemmen voor en vier (van de oppositionele UPB) tegen. De Tweede Kamer reageerde positief op het feit dat nu een datum was vastgesteld, drong aan op een objectieve vraagstelling en benadrukte dat de uitslag geen aanleiding kon vormen voor heronderhandelen - het enige alternatief voor de afspraken was onafhankelijkheid. ${ }^{198}$

Op 2 februari schortte gezaghebber Glenn Thodé echter de referendumverordening op en droeg deze bij gouverneur Goedgedrag voor ter nietigverklaring. Naar Thodés mening kon de verordening de toets aan het internationele recht niet doorstaan en was ze in strijd met het algemeen belang van het Koninkrijk. Hij doelde daarbij onder meer op het gebrek aan consensus in de eilandsraad over de verordening, de onduidelijke vraagstelling en de uitsluiting van het stemrecht van Europese Nederlanders die korter dan drie jaar op het eiland woonden, en van jongeren van 16 en 17 jaar. Dit alles zou in strijd zijn met eerder VN-advies. ${ }^{199}$

Goedgedrag vernietigde de verordening inderdaad op grond van strijd met het internationaal recht, het algemeen belang van het Koninkrijk en het non-discriminatiebeginsel. Na dit besluit zou het streven naar een nieuw referendum tijdelijk worden gestaakt. De bestuurscoalitie ging niet in kroonberoep (bij de Raad van State) tegen de beslissing van de gouverneur. Ook werd geen nieuwe referendumverordening bij de eilandsraad neergelegd. ${ }^{200}$

De nietigverklaring zou de nodige discussie opleveren over de rol van de gezaghebber, de gouverneur en Nederland rond het referendum. Volgens critici had de gezaghebber in strijd met de wet gehandeld en voldeed de referendumverordening wel degelijk aan de vN-eisen. Ook waren er aantijgingen dat Bijleveld Goedgedrag zou hebben beïnvloed bij zijn beslissing om de referendumverordening nietig te verklaren. ${ }^{201}$ Alle fracties in de Staten behalve de PAR en UPB ondersteunden een motie om de beslissing van Goedgedrag aan de VN voor te leggen. ${ }^{202}$ De Raad van State verwierp intussen - 'absolute onzin' - de beschuldiging van Abraham en Nicolaas dat hij vooringenomen was geweest in de referendumkwestie. ${ }^{203}$

Ook een Bonairiaans bezoek aan Den Haag - de delegatie woonde onder meer de behandeling van de BES-wetten in de Kamer bij-zou weinig opleveren. Bijleveld stond alleen open voor overleg over de taakverdeling tussen eiland en Rijk, niet over het referendum; dat was een interne zaak van het eiland. De delegatie slaagde er evenmin in de Vaste Commissie NAAZ voor haar standpunt te winnen. 
Zelfs bij Van Raak en Brinkman - beiden voorstander van het referendum - ving Abraham bot. De Antilliaanse pers kwalificeerde het bezoek als 'mislukt'. ${ }^{204}$

Tijdens de plenaire behandeling van de BES-wetten - die op 8 maart door een overgrote Kamermeerderheid goedgekeurd zouden worden, waarover later meer - kwam de referendumkwestie tussen de bedrijven door aan de orde. Bijleveld bevestigde, gesteund door alle fracties, dat Bonaire op elk moment-dus ook na toetreding tot het Nederlandse staatsbestel - het recht had referenda te organiseren over de status van openbaar lichaam of onafhankelijkheid. Nederland wenste nu echter het traject te voltooien zoals dat was ingezet; als Bonaire iets anders wilde, dan maar buiten het Koninkrijk. Tot na het referendum zou de geldkraan dichtblijven. De door CU-woordvoerder Ortega-Martijn en CDA'er Van Bochove ingediende motie die de regering verzocht rekening te houden met de uitslag van het referendum werd aanvaard. ${ }^{205}$

Het politiek overleg met Bonaire kwam diezelfde maand, maart 2010, weer op gang, mede door tussenkomst van Rijksvertegenwoordiger Kamp. Inmiddels was, op 25 maart, een nieuw bestuurscollege aangetreden, waarin Abraham en Nicolaas gedeputeerden werden. Er was goede hoop dat afspraken gemaakt konden worden over de taakverdeling tussen het eiland en het Rijk. Volgens Bijleveld besefte Bonaire dat het verder moest. ${ }^{206}$

Inderdaad werd op 22 april, na afloop van een bestuurlijk overleg op Bonaire, een bestuurlijk akkoord gesloten waarin onder meer de verdeling van taken en bevoegdheden tussen Bonaire en het Rijk na 10/10/10 werd geregeld. Vastgelegd werd dat Bonaire na de ontmanteling een openbaar lichaam van Nederland zou worden, met als uitgangspunten subsidiariteit, de bepalingen van de WOLBES en de eerdere afspraken over de taakverdeling, alsmede de in behandeling zijnde BES-wetgeving. Het akkoord noemde expliciet het behoud van het zelfbeschikkingsrecht, alsook een inspraakprocedure voor Bonaire rond voor het eiland relevante Nederlandse wetgeving - dit om te voorkomen dat Nederlandse parlementariërs wetgeving aan het eiland konden opleggen. Daarnaast kon Bonaire een vertegenwoordiging in Nederland hebben ter behartiging van zijn belangen en werden afspraken gemaakt over uitkeringen en infrastructuur. $\mathrm{Na}$ de transitie zou het mogelijk zijn nog wijzigingen aan te brengen in de taakverdeling.

Bonaire was weer aan boord - Booi bood in de Tweede Kamer excuses aan voor de vertraging die het proces door toedoen van zijn antipode Abraham had opgelopen, een geste die hem door zijn tegenstanders niet in dank werd afgenomen. Hoe dan ook werden nu 
de voorbereidingen voor de overgang naar openbaar lichaam hervat, evenals de aflossing van de betalingsachterstanden en de investeringen in sociaaleconomische initiatieven. ${ }^{207}$

Op 31 mei 2010 besloot de eilandsraad van Bonaire vervolgens unaniem om uiterlijk 1 oktober 2010 een referendum te houden over het onderhandelingsresultaat tussen het nieuwe bestuurscollege en Nederland, met een herziene vraagstelling en andere regels voor de kiesgerechtigden. Booi stemde nu in, met de bedoeling de tegenstanders van het akkoord de wind uit de zeilen te nemen. Inmiddels was de BES-wetgeving aangenomen en was ook de wijziging van het Statuut behandeld door de Tweede Kamer. De status van openbaar lichaam an sich stond niet meer ter discussie. Het ging dan ook niet om een staatkundig referendum, maar om een evaluatie, waarbij de bevolking kon aangeven of zij instemde met de inhoud van het op 22 april gesloten akkoord. De uitslag zou vooral een peiling zijn om tijdens het latere evaluatieproces over 'democratisch verantwoorde argumenten' te beschikken. Als datum werd 3 september 2010 geprikt, zes dagen voor de slot-RTC. ${ }^{208}$

Dit besluit om wel in een heel laat stadium van het proces nog een referendum te houden verbijsterde Den Haag: was dit mosterd na de maaltijd of juist een bom onder de transitiedatum? Een Kamermeerderheid vond dat Bijleveld opnieuw de investeringen in Bonaire en de sanering van de schulden van het eiland moest opschorten. ${ }^{209}$ Op 13 augustus besloot de eilandsraad het referendum uit te stellen. Het 'zelfbeschikkingsreferendum' werd ten slotte toch gehouden op 17 december 2010, dus na 10/10/10. De bevolking van het openbaar lichaam Bonaire sprak zich uit over de vraag: 'Ik ben het ermee eens dat Bonaire een openbaar lichaam in de zin van artikel 134 van de Nederlandse Grondwet is geworden.' De overgrote meerderheid (88 procent) stemde 'nee', maar de opkomst was met 34,18 procent lager dan de vereiste 51 procent, zodat de uitslag geen vervolg kreeg. ${ }^{210}$

\section{Het laatste jaar}

Aan het einde van 2009 had Bijleveld in een voortgangsrapportage gewaarschuwd dat de belangrijkste risico's in het vernieuwingsproces lagen bij de opbouw van het land Sint Maarten: 'het [is] onwaarschijnlijk dat Sint Maarten op de transitiedatum alle vereiste instellingen om als land te kunnen functioneren gereed heeft'. Het geven van ondersteuning vanuit Nederland bleek een 'moeizaam proces'. Naar verwachting konden de andere onderdelen van het proces wel op tijd worden afgerond. ${ }^{211}$ 
De laatste tien maanden richtten zich, behalve op het gereedmaken van de lokale instituties en het overdragen van landstaken en -bevoegdheden, vooral op het afronden van dikke stapels wetgeving. Vele zaken konden nog leiden tot uitstel - de aangekondigde Statenverkiezingen, het Bonairiaanse referendum, de behandeling van de wetgeving in het parlement. En dit alles terwijl op Curaçao en Bonaire de tweespalt groeide en ook in de Tweede Kamer de twijfels toenamen: werd het proces niet ondergeschikt gemaakt aan een louter symbolische datum, ten koste van de inhoud? Aan het einde van het jaar zou Balkenende er bij zijn collega-premiers op aandringen haast te maken, want de situatie was niet meer zoals in 2006. ${ }^{212}$

Het zou tot op het allerlaatste moment spannend blijven of '10/10/10' zou doorgaan - ook door gebeurtenissen aan Nederlandse zijde. De onverwachte val van Balkenende IV, in februari over de Uruzgan-crisis, dreigde even een punt te zetten achter het jarenlange werk. De Kamer zou echter beslissende medewerking blijven verlenen aan het proces door het als een 'lopende zaak' te behandelen, mede uit de overtuiging dat het 'nu of nooit' was.

Ten slotte zou het proces ook gered worden door Bijlevelds 'plan B', dat zij in april 2009 aan een ongeruste Kamer had toegezegd maar daarna met moeite aan de parlementariërs had weten te verkopen. Dit zou het voor Curaçao en Sint Maarten mogelijk maken om - tegen de Slotverklaring van 2006 in - eerst de landsstatus te verwerven en daarna pas te voldoen aan alle criteria. Het was de enige manier om eruit te komen, stelde Bijleveld, want de landslaag werkte steeds slechter. Hiermee was de druk van de ketel en zouden de partijen erin slagen om op 9 september 2010 de definitieve handtekeningen te zetten onder de opheffing van het land de Nederlandse Antillen. ${ }^{213}$

Maar zover was het nog lang niet. Leden van de Vaste Commissie NAAZ waren het kerstreces 2009 ingegaan met een 'gigantisch pakket' aan wetsvoorstellen, Memories van Toelichting, commentaren van de Raad van State en - inmiddels ook al - opeenvolgende nota's van wijziging. Twee dagen -15 en en 18 januari 2010 - waren ervoor uitgetrokken om het eerste pakket BES-wetten, de zes belangrijkste, kritisch tegen het licht te houden. Ook al was gekozen voor een geleidelijke aanpak en zou de eerste jaren zo veel mogelijk de Antilliaanse regelgeving behouden blijven, het was een omvangrijk pakket dat volgens veel parlementariërs zeker geen schoonheidsprijs verdiende. ${ }^{214}$

Centraal in de discussie stond de invoering op de eilanden van drie 'ethische' kwesties, het homohuwelijk, abortus en euthanasie, en van het kiesrecht voor niet-Nederlanders op de BES voor de eilandsraadverkiezingen. Tegen de eerste thema's heersten aan Antilliaanse zijde principiële bezwaren, tegen het kiesrecht aan Nederlandse zijde, want 
daarmee zouden niet-Nederlanders ook een (indirecte) stem krijgen in de Eerste Kamer, wat tegen de Grondwet indruiste. Een amendement van Remkes riep op de invoering van het actieve kiesrecht voor niet-Nederlanders op de BES voor de eilandsraadverkiezingen te schrappen. ${ }^{215}$ Vooral PVV en SP vonden de behandeling te vroeg - er was 'nog bijna niets klaar', het referendum op Bonaire was ook nog niet gehouden - en verweten de regering een 'salami-tactiek' door de wetgeving steeds in losse stukjes naar de Kamer te sturen. Verschillende partijen hadden bovendien voorafgaand aan het Statuut eerst de Grondwet willen wijzigen, met het oog op de nieuwe status van de BES-eilanden. Het functioneren van het financieel toezicht kon de meeste goedkeuring wegdragen. ${ }^{216}$

Bijleveld waarschuwde voor een ontwrichtende werking van onverkorte invoering van de 'ethische' wetgeving op de eilanden en ontraadde de wijzigingsvoorstellen van Remkes, ondersteund door Van Gent, om kort na de transitie een einde te maken aan de strafbaarheid van abortus (na één jaar) en euthanasie (na twee jaar), evenals een door VVD, GroenLinks en PVV ingediend amendement om het homohuwelijk (na twee jaar) mogelijk te maken. Liever wilde de staatssecretaris bij de evaluatie, na vijf jaar, bekijken of regelingen op deze terreinen aan de orde waren; bovendien voorzag zij uitvoerings-

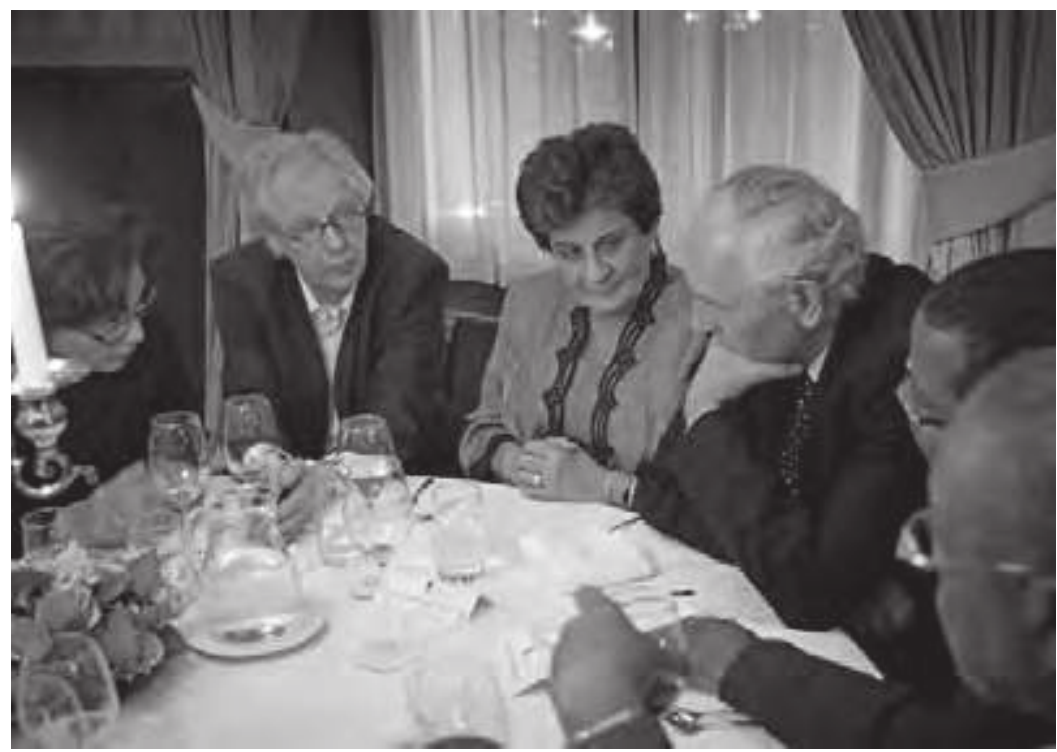

Tijdens het diner wordt overeenstemming over de politievoorziening gezocht en gevonden, Den Haag, 7 september 2010; v.l.n.r. Suzy Römer, Bas Jan van Bochove, Emily de JonghElhage, Johan Remkes, Etienne Ys. 
problemen. De amendementen werden niettemin door de Tweede Kamer aangenomen. ${ }^{217}$

Ook zegde Bijleveld, onder druk van de Kamer, een voorstel tot Grondwetswijziging toe-zijzelf had de integratie in het staatsbestel van Nederland voorlopig voldoende gevonden. De bewindsvrouw verklaarde bereid te zijn om deskundigen te laten kijken naar het Statuut in relatie tot artikel 1 Grondwet, specifiek naar de vraag in hoeverre voor de eilanden specifieke maatregelen konden worden getroffen in relatie tot het gelijkheidsbeginsel. ${ }^{218}$

$\mathrm{Na}$ afloop van de besprekingen waren de parlementariërs nog niet gerust; ze wilden vóór de afrondende plenaire behandeling van het eerste pakket naar de BES reizen om zich ervan te verzekeren dat daar de boel op orde was. Dit paste echter niet in Bijlevelds strakke schema; op 9 februari drong zij per brief aan op een snelle plenaire afhandeling, in de eerste week van maart, opdat de beoogde datum niet in gevaar kwam. Ook het pakket consensusrijkswetgeving moest snel behandeld worden, nog vóór aantreding van een nieuw Antilliaans kabinet, eind maart: 'Indien u toch kiest voor behandeling van dit wetsvoorstel [wijziging Statuut] in april, betekent dit in feite dat de beoogde transitiedatum van 10 oktober 2010 zeer onrealistisch is. $\mathrm{U}$ zult begrijpen dat ik dat zeer onwenselijk vind.' Hierop werd geprikkeld gereageerd; Remkes noemde het een 'kul-argument', Van Raak sprak van 'een fuik': 'een muurtje links, een muurtje rechts en een muurtje achter ons en zo kom je op 10-10-10 uit'. ${ }^{219}$

De parlementariërs zouden niettemin thuis blijven, ook door de val, kort daarop (20 februari), van het vierde kabinet-Balkenende. Hiermee leek 10/10/10 definitief onhaalbaar en de kans groot dat het laatste Antilliaanse kabinet, De Jongh Elhage II, langer zou aanblijven dan de voorziene datum. ${ }^{220}$ Wel was aan Nederlandse zijde opgelucht gereageerd op de PAR-winst in de Statenverkiezingen van 22 januari. Ondanks de onverminderd grote Curaçaose verdeeldheid kon de coalitie van PAR, PNP, NA, UPB, WIPM en DP-Statia (met uitzondering van weggevaagde coalitiepartner FOL) verder.

Het lot van het proces lag nu in handen van de Tweede Kamer. Het risico dat onder een demissionair kabinet het hele wetgevingsdossier, zeker de consensusrijkswetten en de Statuutwijziging, het stempel 'controversieel' kregen, was groot. In dat geval kon het proces pas na aantreding van een nieuwe regering worden voortgezet. Veelbetekenend was dat het demissionaire kabinet de opdracht had meegekregen alles te doen wat in het belang van het Koninkrijk (dus niet slechts Nederland was). Daarin lag een ruim mandaat besloten.

In wat volgens een ingewijde haar spannendste vergadering van de gehele kabinetsperiode werd, besloot de Kamercommissie op 2 
maart, tegen veler verwachting in, met een ruime meerderheid alle BES-wetgeving tot een lopende zaak te verklaren - alleen SP en PVV stemden tegen. Of ook de VVD-fractie aan boord kon worden gehouden, bleef tot op het laatste moment spannend. De Jongh-Elhage had voorafgaand bij diverse politici sterk ervoor gepleit het proces nu niet te stoppen. Achter de schermen had ook de Raad van State een rol gespeeld om de dreigende impasse te doorbreken. ${ }^{221}$

Hiermee kon de voor 4 maart geplande plenaire behandeling van de BES-wetten doorgaan. Het debat zou ongeveer langs dezelfde lijnen verlopen als het wetgevingsoverleg van januari. Opnieuw richtte de aandacht zich vooral op de ethische wetgeving. Ondanks Bijlevelds bezwaren hield een ruime meerderheid vast aan de amendementen van Van Gent en Remkes inzake ethische wetgeving en kiesrecht op de BES. Tegen Bijlevelds opzet in was er brede steun voor Remkes' amendement om niet-Nederlanders op de BES geen actief kiesrecht te geven. ${ }^{222}$

De VVD-woordvoerder zette daarnaast veel vraagtekens bij de GVP: niet meer dan 'een veredeld inhuur- en uitzendbureau', de directeur een 'generaal zonder leger'. Tijdens de laatste begrotingsbehandeling was al Remkes' motie aangenomen over een wettelijke verankering van een RST nieuwe stijl. ${ }^{223}$ Een 'belangrijke hinderpaal' voor de VVD was bovendien het nog ontbreken van een regeling voor het personenverkeer binnen het Koninkrijk, inclusief de toelating en uitzetting van criminele Antilliaanse jongeren - het enige (en niet formeel vastgelegde) voorbehoud dat de VVD-fractie in 2006 had gemaakt bij de Slotverklaring. Last but not least herinnerde Remkes eraan dat ook de gewenste fundamentelere heroverweging van het Statuut was uitgebleven. ${ }^{224}$

Een ruime meerderheid zou zich bij de stemming, op 9 maart, achter de wetten scharen - ondanks bezwaren stemde de SP vóór, ook omdat nog altijd onzeker was of het referendum op Bonaire wel zou doorgaan. Alleen de PVV en het lid Verdonk waren tegen alle BESwetgeving.

De wetten werden echter niet helemaal vastgesteld zoals Bijleveld ze voor ogen had gehad. De drie belangrijkste wijzigingen vormden de versnelde erkenning van het homohuwelijk, het recht op euthanasie en op abortus op de BES - waarmee het parlement Bijlevelds eerdere afspraak met de eilanden dat dit pas na een aantal jaren zou gebeuren, had overruled. Alleen CU en SGP hadden tegen alle drie amendementen gestemd; CDA tegen die over abortus en euthanasie. Bijleveld stelde na afloop dat de termijnen kort waren maar wel haalbaar. Onder Nederlandse en Antilliaanse tegenstanders vielen echter woorden als 'ontwrichting' en 'neokolonialisme'. Abraham noemde 
de amendementen 'sfeerverziekend'; de eilandsraad van Sint Eustatius nam vervolgens een motie aan tegen de 'anti-sociale' wetten en dreigde naar de VN te stappen. ${ }^{225}$

Naast de amendementen werden zeven moties ingediend, waarvan er vijf werden aangenomen; ook het door Bijleveld ernstig ontraden voorstel van GroenLinks en VVD om in onderling overleg met de Antilliaanse en Arubaanse autoriteiten de effecten van het plaatselijke homo-emancipatiebeleid te onderzoeken en, indien nodig, aan te jagen. De twee moties van de PVV, waarvan één het proces wilde stoppen tot na de nieuwe verkiezingen, werden afgewezen. ${ }^{226}$

Hiermee was een grote stap gezet. BZK lag nu wat betreft de BES volledig op schema. Zowel de wetgeving als de door de kwartiermakers geboekte voortgang op de eilanden zelf-alle departementen waren er inmiddels helemaal thuis, al had dit vanaf de start van het interdepartementale overleg wel zo'n anderhalf jaar grote druk van KR gevergd - zou leiden tot het tijdig 'klaar staan' van BZK, aldus een voortgangsrapportage op 10 maart. ${ }^{27}$ Het tweede pakket BES-wetgeving zou later in maart volgen.

$\mathrm{Nu}$ moesten onder het demissionaire kabinet ook de (consensus)rijkswetten door de Kamer worden gesleept. Ze tot een 'lopende zaak' verklaren had, weinig verrassend, meer voeten in aarde dan bij de BESwetgeving. VVD, SP en PVV deden herhaalde pogingen ze van de Kameragenda afgevoerd te krijgen; wegens faliekante tegenstand tegen het hele proces (PVV); angst dat de ontmanteling erdoorheen gejaagd werd (SP); of ontevredenheid over, vooral, de Statuutwijziging en de consensusrijkswet politie (VVD). ${ }^{228}$ Maar na een plenair debat op 11 maart, met veel harde woorden over en weer, zou de Kamer, tegen de verwachting in, besluiten om ook de behandeling van de consensusrijkswetten te laten doorgaan. Een meerderheid van CDA, PVDA, GroenLinks, ChristenUnie, D66, Partij voor de Dieren en SGP (92 stemmen) zette het licht op groen om het proces af te ronden, zij het met voor de CU één uitzondering: de Rijkswet personenverkeer. Hiermee werd een grote minderheid (58 stemmen) overruled. De scepsis over de haalbaarheid van het proces was onverminderd groot. Remkes was nog steeds overtuigd dat het niet zou lukken voor 'de heilige datum', 'daar durf ik een goede fles wijn onder te verwedden'. ${ }^{229}$

In totaal ging het voor Curaçao en Sint Maarten om tien wetsvoorstellen, die in vier dagen, van 9-15 april, zouden worden behandeld. Een grote delegatie reisde vanuit de Antillen - waar De Jongh-Elhage II op 26 maart was beëdigd - naar Den Haag om aan de behandeling deel te nemen en de interne consensus waar nodig te waarborgen. In tegenstelling tot de Nederlandse media zou de Antilliaanse pers uitgebreid en prominent-onder meer met integrale 
televisieuitzendingen - berichten over het overleg. ${ }^{230}$ Dat het spannend zou worden, was duidelijk: voorafgaand aan het debat waren al amendementen aangekondigd over onder meer de Politiewet (schrappen van de GVP) en het financieel toezicht (meebeslissingsrecht voor de parlementen over de stopzetting ervan na vijf jaar).

Tussen de start van het wetgevingsoverleg op vrijdag de $9^{\mathrm{e}}$ in de Vaste Commissie NAAZ en de voortzetting ervan op maandag de $12^{\mathrm{e}}$ lag een weekend waarin ambtenaren van BZK en van Justitie gestaag zouden doorwerken om de schriftelijke beantwoording van de meeste vragen voor te bereiden - aan het 33 pagina's tellende document gaven op de zondagmiddag ook de delegaties van de Antilliaanse landsregering en eilandsbesturen hun zegen. ${ }^{231}$ Ondanks grote bezwaren van Antilliaanse zijde dienden de Nederlandse parlementariers in totaal zeven moties in en achttien amendementen. Onder meer de Sint Maartense gedeputeerde van staatkundige structuur Marlin drong aan op het behoud van de wetgeving zoals die er lag, ook al was het eiland nog niet helemaal gereed, want 'afspraak is afspraak'. ${ }^{232}$

De Rijksministerraad besloot in een ingelaste zitting op 13 april de meeste amendementen aan het oordeel van de Kamer over te laten; een aantal werd echter ernstig ontraden, onder verwijzing naar het gevaar van procesvertraging. Dit schoot bij verschillende Kamerleden, vooral Remkes, in het verkeerde keelgat: 10/10/10 was geen heilige datum, de inhoud moest prevaleren. ${ }^{233}$

De grote critici van het proces - VVD, PVV en SP - bezigden in het negen uur durende debat een scherpe toon. Volgens Van Raak was de verkeerde volgorde aangehouden: eerst een zak geld op tafel, daarna pas onderhandelingen; men 'laat zich gijzelen door 10/10/10'. Hij weigerde die 'fuik' ingedreven te worden nu er nog zoveel onduidelijkheid was, Bonaire nog een referendum wilde houden en pas later een discussie over het Statuut (een 'onding'), Grondwet en waarborgfunctie zou volgen - al deze zaken had de regering niet aangepakt om 10/10/10 maar te kunnen halen. Remkes verweet het kabinet te grote concessies op kernpunten en miste bovendien 'het complete financiële plaatje'.

De Politiewet zou het meeste stof doen opwaaien. Van meet af aan was duidelijk dat een amendement over de GVP, op 12 april ingediend door Remkes, Van Bochove en Leerdam, met steun van SP en PVV, het proces in gevaar kon brengen. Remkes c.s. eiste het RST in stand te houden, juridisch verankerd in de GVP, omdat niet geloofd werd dat de GVP al na twee jaar, zoals was overeengekomen, gereed zou zijn om de taken van het RST over te nemen in de bestrijding van de georganiseerde en zware criminaliteit. Voor Curaçao en Sint Maarten was behoud van het - onder Nederlands gezag staande - RST echter 
'ontoelaatbaar'; het zou de zelfstandigheid van de Antilliaanse korpsen belemmeren; kern van de bereikte consensus was juist de GVP geweest. ${ }^{234}$

Voorafgaand aan het plenaire debat was onder aanvoering van een nerveuze De Jongh-Elhage dagenlang heel stevig gelobbyd in een poging de partijen ervan te overtuigen het gewraakte amendement in te trekken dan wel te wijzigen. Antilliaanse en Nederlandse politici, adviseurs en ambtenaren waren in koortsachtig overleg doende alternatieve teksten uit te werken. Tot op het laatste moment zou het voorstel voor grote spanning zorgen. Pas vijf uur voor de stemming reikten Remkes, Van Bochove en Leerdam een tussenoplossing aan, die dus al intensief was voorbesproken met alle betrokken onderhandelaars. Het RST zou nog zeker vier jaar actief blijven (twee jaar langer dan de oorspronkelijke overgangsperiode van twee jaar), met de mogelijkheid deze termijn, na een gezamenlijke evaluatie door Curaçao, Sint Maarten en Nederland, telkens met twee jaar te verlengen. Dit gaf aan Nederlandse kant althans voldoende zekerheid dat het RST niet eerder zou worden ontbonden dan dat de GVP in staat zou zijn naar behoren te functioneren. Kon de GVP na vier jaar nog niet de taken van het RST overnemen, dan bleef alles bij het oude, of zou worden gekeken naar alternatieven. Zonodig kwam er twee jaar later opnieuw een evaluatie. Na twee negatieve toetsingen zou de Rijksministerraad een voorziening kunnen treffen. ${ }^{235}$ Hiermee was de kou uit de lucht - zoals voorzien stemden de Antilliaanse en eilandelijke delegaties nu in, evenals de VVD-fractie. De GVP was niet helemaal uit de Politiewet gehaald en kon beginactiviteiten ontplooien, maar het RST behield zijn eigen plaats en taken.

Ook bij de Wet Financieel toezicht werden nog vraagtekens gezet. Van Bochove diende een amendement in om de intrekking van deze Rijkswet te regelen per consensusrijkswet - volgens Bijleveld een te zwaar middel - in plaats van bij KB, opdat de parlementariërs van alle landen bij dit belangrijke besluit zouden worden betrokken. ${ }^{236}$ Aanvaard werd een motie van PVDA, CDA en GroenLinks om het toezicht op de financiën van Curaçao en Sint Maarten na de eerste vijf jaar met wederzijdse instemming steeds maximaal drie jaar te kunnen verlengen als dat nodig was, zonodig in een 'light versie'. Het toezicht zou in ieder geval van kracht blijven totdat structureel voldaan was aan de eisen.

Rond het besluit om over te gaan tot het maken van plannen van aanpak voor de landen in spe was de twee jaar eerder vrijwel kamerbreed aanvaarde motie Van Bochove - geen landsstatus zonder eerst te voldoen aan de voorwaarden - nog niet vergeten. ${ }^{237}$ Hoewel men nu wel inzag dat de voorgestelde AMVRB waarschijnlijk de minst 
slechte oplossing was voor een lastig probleem, meende Leerdam, hierin ondersteund door Van Bochove, Remkes en Van Gent, dat die regeling dan wel zo lang als nodig was in werking moest blijven - en niet slechts maximaal vier jaar. Per motie werd geëist dat de AMVRB waarborging plannen van aanpak landstaken onbeperkt zou kunnen worden verlengd en dat de Kamer iedere keer vooraf gekend zou worden in de besluitvorming over eventuele verlenging. Remkes, Van Raak en Brinkman vroegen ten slotte naar een fundamentele herziening van het Statuut. De overige wetten, zoals die voor het Openbaar Ministerie, stuitten bij geen van de aanwezigen op grote bezwaren. ${ }^{238}$

De meeste Antilliaanse gedelegeerden benutten hun spreektijd door zich positief uit te spreken over het proces en de wetgeving. Dissonant was oppositieleidster Eunice Eisden (MAN), die de Curaçaose verdeeldheid ten tonele bracht door erop te hameren dat zij de 48 procent van de Curaçaose bevolking vertegenwoordigde die zich tegen het proces had uitgesproken. Haars inziens 'verkrachtte' de Tweede Kamer het Statuut en was het ontmantelingsproces een 'teruggang' in de emancipatie en het zelfbestuur van Curaçao, dat op slimme wijze geherkoloniseerd werd door Nederland ('een BES-plus'). Consternatie wekte ook Statia's woordvoerder Reginald Zaandam, met zijn oproep tot een referendum op Sint Eustatius voorafgaand aan 10/10/10 - al wilde hij het proces daarmee niet vertragen. Met hun grote aantal moties en amendementen - waarvan het merendeel overigens werd afgewezen - kregen de Arubaanse gedelegeerden het verwijt het proces nu tegen te werken, terwijl Aruba in de achterliggende jaren grotendeels afwezig was geweest. Steen des aanstoots voor de MEP was het in het nieuwe Statuut voorgestelde artikel 27 lid 3, dat een instrument bood om landen, indien nodig, te dwingen tot implementatie van door hen aanvaarde internationale verdragen, opdat het Koninkrijk internationaal als een eenheid kon functioneren. ${ }^{239}$

De ontknoping van vier dagen taai onderhandelen volgde op donderdag de $15^{\mathrm{e}}{ }^{240}$ Voorafgaand aan de stemming sprak De JonghElhage het parlement toe, een unieke gebeurtenis die volgens een door de Antilliaanse overheid uitgegeven kroniek 'diepe indruk maakte op de Kamerleden en de volle publieke tribunes'. Uiteraard riep de laatste Antilliaanse premier de Tweede Kamer op in te stemmen met de voorliggende wetgeving. Zeer strategisch prees zij de wijze waarop het herziene amendement Remkes c.s. over de Politiewet tot stand was gekomen als 'een blijk van saamhorigheid, een voorbeeld van hoe we samen kunnen werken aan de toekomst'. Ook pleitte zij voor het vinden van een 'oplossing' voor het democratisch deficit. ${ }^{241}$

Tijdens de eindstemming - in aanwezigheid van de oud-ministers 
van Koninkrijkszaken Pechtold en Nicolaï-gaf de Kamer inderdaad met een ruime meerderheid zijn zegen aan alle tien (consensus)rijkswetten, inclusief het voorstel tot wijziging van het Statuut. PVV en SP stemden tegen alle wetten; Van Raak benadrukte nogmaals dat men 'er niet klaar voor is'. Tegen de Statuutwijziging stemden ook VVD en het lid Verdonk - samen met de PVV en SP een grote minderheid. Het gewijzigde amendement op de consensusrijkswet Politie werd met een ruime meerderheid aangenomen. Dit gold ook-ondanks afraden van Bijleveld - voor de motie Leerdam over een mogelijk onbeperkte werkingsduur van de plannen van aanpak; in het bijzonder deze motie zou nog gevolgen hebben voor het verdere traject. ${ }^{242}$

Veel amendementen en moties haalden het niet, waaronder die van de PVV om het proces stop te zetten (9 stemmen voor, 120 tegen; op verzoek van Geert Wilders was hoofdelijk gestemd). ${ }^{243}$ Wel steunde de Kamer de motie van Glenn Sulvaran (PAR) om het Papiaments, Nederlands, Engels en Fries als Koninkrijkstalen in het Statuut op te nemen. De motie van Van Bochove over een visie op de toekomst van het Koninkrijk werd met algemene stemmen aangenomen. Leerdams voorstel om een secretariaat voor het Koninkrijk op te richten - eerder voorgesteld door de werkgroep-Jesurun, de Raad van State en het Comité 2004-werd ook ondersteund, evenals een amendement van Van Bochove, dat het in het hele Koninkrijk mogelijk moest maken om belastingzaken tot de Hoge Raad uit te vechten. Zeer bijzonder was dat de Tweede Kamer ook een amendement over het in het leven roepen van een instantie voor de beslechting van geschillen inzake het Statuut aanvaardde dat was ingediend door Arubaanse Statenleden.

$\mathrm{Bij}$ de directie KR stond de champagne klaar om het historische moment te vieren - tegen veler verwachting in was het zelfs onder een demissionair kabinet gelukt. 10/10/10 leek nu zeker haalbaar, ook al benadrukte Bijleveld, als altijd, dat hiermee het werk nog niet gedaan was. De Jong-Elhage sprak haar dank uit voor de goede samenwerking met het Nederlandse kabinet, wat geleid had tot deze 'voor de Antillen zo belangrijke dag, een historisch moment'. Wel merkte zij op dat er een oplossing moest komen voor het democratisch deficit binnen het Koninkrijk. ${ }^{244}$

Behalve dat er nog enige BES-wetgeving door de Tweede Kamer moest, was nu de Eerste Kamer aan zet. ${ }^{245}$ Tijdens de Senaatsbehandeling van het eerste pakket BES-wetten, op 11 mei, stuitten twee punten op bezwaren: het ontbreken van een Grondwettelijke verankering van de nieuwe status van de BES-eilanden en de drie door de Tweede Kamer aangenomen ethische amendementen. Vooral het CDA was er erg van geschrokken dat deze voorstellen ('een soort overval') in de wet waren opgenomen. SGP en CU stemden zelfs tegen de 
wet waarin de amendementen waren opgenomen. Om het proces niet in gevaar te brengen, zou het CDA dit niet doen. De Senaat keurde ten slotte de BES-wetten in meerderheid goed, in het vertrouwen dat Bijleveld 'prudent' zou omgaan met de invoering van homohuwelijk, abortus en euthanasie op de eilanden. Hiermee konden Bonaire, Sint Eustatius en Saba ten slotte 'bon bini/welcome' bij Nederland worden geheten - duidelijk was al dat het daarbij om meer ging dan 'lusten' alleen. ${ }^{246}$

Bijleveld sprak nu opnieuw haar overtuiging uit dat 10/10/10 gehaald ging worden - al verwachtte zij op 6 juli, tijdens het Senaatsdebat over de (consensus)rijkswetten, meer discussie over de Grondwettelijke kant van de hervormingen. Zorgelijk bleef ook de opbouw van Curaçao en Sint Maarten. Bijleveld maande de beide aspirant-landen voortvarend aan de slag te gaan, met als prioriteit het gereedmaken van hun Staatsregelingen - deze dienden in de eilandsraden met een tweederde meerderheid te worden aanvaard en vervolgens te worden goedgekeurd door de Koninkrijksregering. ${ }^{247}$

Er waren dus nog hordes, maar het einde kwam in zicht. Vooruitlopend op definitief groen licht prikte de Stuurgroep op 20 april alvast 9 september als datum voor de slot-RTC - dan moesten Sint Maarten en Curaçao daadwerkelijk kunnen aantonen klaar te zijn om hun verantwoordelijkheden te nemen. Daarvóór zouden nog twee Stuurgroepsessies plaatsvinden: op 21 juni via een videoconferentie en op 1 juli plenair in Willemstad. Daarbij draaide alles om de vraag in hoeverre de landen op 10/10/10 in staat zouden zijn zelfstandig hun taken uit te voeren. Voor de terreinen waarop dit niet het geval was, zouden ze plannen van aanpak moeten maken. Hoe dan ook verwachtte de Tweede Kamer een serieuze toetsing van het functioneren van de overheidsapparaten. ${ }^{248}$

Op de RTC van december 2008 was afgesproken dat het presidium van de v-RTC het toetsen zou regisseren. ${ }^{249}$ Een speciaal aangestelde commissie van drie deskundigen zou de toetsing in 2010 uitvoeren; ${ }^{250}$ het aangevulde presidium van de v-RTC, die de slot-RTC voorbereidde, bracht op basis van haar conclusies in juni advies uit. Voor Curaçao bleek het op twee gebieden niet realistisch te veronderstellen dat het land op 10/10/10 zou beschikken over functionerende instanties: de gevangenis en de inrichting van het nieuwe politiekorps. Voor Sint Maarten was - het kwam niet als een verrassing - de uitkomst ingrijpender: op ten minste vijf, maar mogelijk acht, cruciale beleidsterreinen zat het volgens de commissie niet goed. In ieder geval waren plannen van aanpak nodig voor de bevolkingsadministratie, het korps politie, de landsrecherche, de gevangenis en de nieuwe toelatingsorganisatie. Of ook juridische en wetgevingszaken, de Dienst 
Ruimtelijke Ordening en Beheer, en de Dienst Buitenlandse Betrekkingen onder toezicht van de Koninkrijksregering zouden komen, moest nog worden besloten tijdens de slot-RTC. Dan zou worden bekeken of Sint Maarten op deze terreinen intussen voldoende vorderingen had gemaakt. De toetsingscommissie noemde het over de volle breedte ontbreken van voldoende gekwalificeerd kader een risico voor de inrichting van het land Sint Maarten. Bovendien had het nog te veel gekeken naar het bestaande model van de Antillen, dat voor het eiland te uitgebreid was. Centrale regie was noodzakelijk.

De Stuurgroep van 21 juni stelde de plannen van aanpak ten slotte vast, waarmee volgens Bijleveld 'weer een belangrijke stap is gezet op weg naar $9 / 9$ en 10/10'. De uitvoering van de plannen zou plaatsvinden door de ministers van de betrokken landen, met toezicht door een voortgangscommissie en de mogelijkheid tot ingrijpen op Koninkrijksniveau. Opvallend was het gebrek aan verzet; de Curaçaose onderhandelaars noch die van Sint Maarten repten van een juk van Nederland of 'blamage'. Dat de landen in spe de plannen zelf hadden gemaakt, en deze ook zelf zouden gaan uitvoeren, zal zeker tot de consensus hebben bijgedragen. Bovendien, zo stelde Marlin, was het logisch dat Sint Maarten een achterstand had in te halen. Het ging immers vooral om terreinen die in handen waren geweest van de centrale Antilliaanse overheid; als zou blijken dat Sint Maarten de plannen niet in twee jaar kon afronden, was dat alleen maar een teken dat de verwaarlozing door het land de Antillen substantieel was geweest. Van Raaks omschrijving van Sint Maarten als een halfleeg land - dat zijns inziens beter had gekozen voor een BES-plus-optie-wierp Marlin echter verre van zich. ${ }^{251}$

Intussen was het Nederlandse politieke landschap ingrijpend veranderd na de verkiezingen van 9 juni. De VVD en PVV boekten grote winst, zodat de ruime Kamerminderheid die zich altijd tegen het proces had uitgesproken nu een meerderheid was geworden. Het formatieproces zou echter gecompliceerd blijken - en niet eerder dan op 14 oktober eindigen in een rechts kabinet van VVD en CDA, met gedoogsteun van de PVV, steunend op een minieme meerderheid van 76 zetels in de Kamer. ${ }^{252}$

Aan Antilliaanse zijde werd gevreesd dat de VVD nu een hard punt zou maken van een migratieregeling binnen het Koninkrijk. Inderdaad zou het proces op dit punt nog bijna stranden. Het werd gered met het verwerpen van de motie van VVD'er Paul de Krom - opvolger van de tot commissaris van de Koningin in Noord-Holland benoemde Remkes - die het proces had willen uitstellen als er geen strengere toelatings- en uitzettingsregeling kwam voor kansarme Antillianen en Arubanen. Was de motie aanvaard, dan was behandeling van de 
voor het proces cruciale Wet Toelating en Uitzetting BES (WTU BES) - die de toelating tot Caraïbisch Nederland regelt - aangehouden tot de Rijkswet personenverkeer op tafel lag; en dat had betekend dat 10/10/10 definitief uit het zicht was verdwenen. De Rijkswet personenverkeer was immers als controversieel bestempeld en moest worden overgelaten aan een nieuwe regering.

Hoewel het ontbreken van een overkoepelende Rijkswet voor het regelen van de migratie binnen het Koninkrijk breed werd betreurd-partijen waren onder meer bezorgd dat de 'Caribische achterdeur van het Koninkrijk' niet waterdicht zou zijn-kreeg de VVD-motie na een pittig debat alleen steun van de PVV en SP; weliswaar goed voor zeventig zetels, maar de andere tachtig Kamerleden stemden tegen. PVDA en CDA gaven, evenals de Raad van State, wel voorkeur aan een Rijkswet personenverkeer, maar namen genoegen met de tussenoplossing van de WTU. Hirsch Ballin had zich krachtig verzet tegen de motie - 'chantage' volgens Van Raak - want nu het proces zo ver was gevorderd, was het 'slechtst denkbare scenario [...] de transitie uit te stellen'. ${ }^{253}$

$\mathrm{Nu}$ alle essentiële wetten door de Tweede Kamer waren aanvaard - de nog resterende BES-wetten waren van fiscale aard en hoefden niet per se voor 10/10/10 te zijn aangenomen, het nieuwe fiscale regime werd namelijk pas op 1/1/11 van kracht ${ }^{254}$ - was de Eerste Kamer aan bod. Nadat deze op 11 mei het eerste pakket BES-wetgeving had aanvaard, zouden op 28 juni nog drie BES-wetten volgen en op 6 juli de consensusrijkswetten en Statuutwijziging. Druk op de transitiedatum bleef echter onverminderd groot; de Curaçaose Staatsregeling bleek op 19 juni niet de vereiste tweederde meerderheid te behalen in de eilandsraad, waarop de Senaat dreigde op de rem te trappen. Aanvaarding van de Staatsregeling werd nu gekoppeld aan de Statuutwijziging en overwogen werd om het voor 6 juli geagendeerde debat uit te stellen tot medio september. Daarmee zou de voor 9 september geplande slot-RTC in het water vallen. ${ }^{255}$

Bovendien meende de Senaat dat voorafgaand aan behandeling van de wetgeving, de in de Tweede Kamer aanvaarde motie Leerdam volledig moest zijn opgenomen in de wet. Nu voor Curaçao en Sint Maarten de omgekeerde volgorde werd gehanteerd - eerst land worden, daarna pas voldoen aan de voorwaarden - wilde de Eerste Kamer de garantie dat die voorwaarden uiteindelijk ook echt werden gehaald. Vooral voor Sint Maarten werd niet geloofd dat een maximale termijn van vier jaar lang genoeg zou zijn. ${ }^{256}$

10/10/10 was opnieuw in gevaar. Wilde het schema nog haalbaar zijn, dan betekende dit het versneld nemen van een aantal extra stappen: ontbinding van de Curaçaose eilandsraad, nieuwe verkiezin- 
gen, aantreden van de nieuwe raad en goedkeuring van de conceptStaatsregeling. Het risico dat alle beslismomenten doorschoven was groot. ${ }^{257}$ Aangezien het bij de plannen van aanpak om consensusrijkswetgeving ging, moesten alle partijen het bovendien over een verlenging eens zijn. Aan de onderhandelingstafel bleek het vooral voor de - Curaçaose - oppositie een zware dobber te zijn dat het toezicht eventueel oneindig kon duren. Het Stuurgroepbesluit van 1 juli, om de plannen na de eerste vier jaar voor onbeperkte tijd te kunnen laten verlengen, met een rol van de Staten-Generaal in de beoordeling hiervan, had dan ook het nodige lobbywerk gevergd. Met de aldus aangepaste AMVRB waren volgens Bijleveld de garanties 'echt keihard' en was 'zorgvuldigheid zowel op weg naar de nieuwe status van Curaçao en Sint Maarten als in de startfase van de nieuwe landen gegarandeerd'. ${ }^{258}$

De aangepaste tekst van de AMVRB werd op 2 juli in de Rijksministerraad goedgekeurd; Bijleveld wist de Senaat hiermee op het nippertje over de streep te trekken en uitstel van het debat over de consensusrijkswetgeving te voorkomen. ${ }^{259}$ Ook was zij erin geslaagd twijfels over de Staatsregeling weg te nemen, met de verzekering dat die voorafgaand aan de slot-RTC zou worden behandeld in de eilandsraad en door de Koninkrijksregering zou worden goedgekeurd, anders kon Curaçao geen land worden.

Het cruciale debat over de (consensus)rijkswetgeving en Statuutwijziging ging nu op 6 juli - de laatste dag voor het zomerreces - definitief door. Of de Senaat dan ook ging stemmen, was bij aanvang nog onzeker. In aanwezigheid van overzeese vertegenwoordigers werd het een bij vlagen pittig debat, met als voornaamste punten de afgeketste Staatsregeling van Curaçao, de nog niet in stemming gebrachte Staatsregeling van Sint Maarten, het uitblijven van de Rijkswet personenverkeer, het nog te houden referendum op Bonaire, de complexiteit van het wetgevingsproces voor de BES en vraagtekens bij de 'caribisering' van het Gemeenschappelijk Hof, het OM en de politie. Ook hier kreeg het proces geen schoonheidsprijs. PVDA-woordvoerder Linthorst was niet de enige die meermalen het gevoel had gekregen in een 'fuik' te zijn beland.

Het voornaamste pijnpunt lag echter in de wijziging van het Statuut; PVDA, maar vooral ook VVD, betreurden het dat dit (een 'legalistisch wurgcontract') nu werd gewijzigd voordat de Grondwet aan de nieuwe staatkundige verhoudingen was aangepast. Ook dat het niet was gemoderniseerd en dat het proces niet was aangegrepen om volwassen relaties op te bouwen binnen het Koninkrijk werd betreurd. ${ }^{260}$

Hoewel de mogelijk onbeperkte werkingsduur van de plannen van 
aanpak inmiddels geregeld was, bleven partijen in dit opzicht kritisch: met 'plan B' leek de nieuwe status gaandeweg een voorwaarde te zijn geworden om de criteria te realiseren in plaats van andersom. Bijleveld verdedigde deze ommezwaai door te stellen dat zonder het vastleggen van een datum het proces tot in lengte van dagen had kunnen doorgaan; de Antilliaanse medeverantwoordelijkheid voor het slagen van de plannen was bovendien winst. Marlin benadrukte opnieuw dat Sint Maarten de plannen van aanpak zeer serieus zou nemen en dat ze niet werden ervaren 'als struikelblok, maar als noodzaak om beter te kunnen functioneren als land'. ${ }^{261}$

Naast teleurstelling over het uitblijven van een Rijkswet personenverkeer (VVD-senator Van Kappen maakte volgens de Antilliaanse Statenvoorzitter Pedro Atacho van een mug een olifant ${ }^{262}$ ) zouden de pijlen zich verder vooral richten op de waarborgfunctie van het Koninkrijk. De bereidheid om daadwerkelijk in te grijpen was voor alle partijen cruciaal, maar daarvoor lag in de Statutaire gereedschapskist, in de woorden van Van Kappen, slechts 'een moker'. Een meer verfijnd instrument, 'een tangetje of een schroevendraaier', was niet voorhanden om bij te sturen. Bijleveld meende dat nu niet alleen betere randvoorwaarden waren gecreëerd, maar dat de regering ook zeker, 'aan het einde van de escalatieladder', artikel 51 Statuut als ultimum remedium ter beschikking stond en dit ook zou durven toepassen - ten aanzien van Aruba had zij al laten zien er niet voor terug te schrikken de consensusrijkswet Hof van Justitie via artikel 43 aan Aruba op te leggen. Een enigszins bittere Oduber zou ook achteraf stellen: 'Aruba wilde de zetel van het Gemeenschappelijk Hof, maar dat heeft Nederland overruled.' Zijns inziens was het argument van Hirsch Ballin 'juridische kolder' dat 'als Aruba de zetel van het Hof krijgt, dit invloed zou hebben op de rechtszekerheid'. ${ }^{263}$

De Senaat zou vrijwel unaniem, zonder stemming, de (consensus)rijkswetgeving goedkeuren. (Wellicht hielp het dat het Nederlands elftal later die avond aantrad voor de halve finale van het wK voetbal-en dat vele Antilliaanse delegatieleden demonstratief oranje kleding of accessoires droegen om zo het Koninkrijksgevoel uit te dragen.) De wijziging van het Statuut werd unaniem aangenomen, in een aparte stemming. De SP-fractie stemde alleen tegen de Rijkswet Financieel toezicht. Dat de partijen ondanks alle aanvankelijke kritiek het proces ten slotte steunden, zal ook te maken hebben gehad met het gebrek aan een goed alternatief. Bovendien was van regeringszijde toegezegd dat gebruik van de waarborgfunctie niet zou worden geschuwd en dat ook nieuwe instrumenten zouden worden ontwikkeld ter bijsturing. De winst van die dag, aldus Van Kappen, was 'dat het een kwestie is van doormodderen, maar op een iets beter niveau'. ${ }^{264}$ 
Met de afronding van alle wetgeving was weer een belangrijke mijlpaal bereikt. Bijleveld sprak opnieuw van een historisch moment; ook De Jongh-Elhage was tevreden met het resultaat en wees op het 'allergrootste belang' dat de nieuwe eilandsraad van Curaçao de Staatsregeling zou aannemen, anders 'valt alles in het water. ${ }^{265}$ Premier Mike Eman van Aruba - in oktober 2009 aangetreden - hoopte op een sterkere samenwerking binnen het Koninkrijk en een nieuwe invulling van de Koninkrijksbanden. De nieuwe Arubaanse regering wilde zich aansluiten bij de wetgeving rond het $\mathrm{OM}$, de politie en de rechtshandhaving in het algemeen - een traject dat zou worden opgepakt na de transitie. ${ }^{266}$

Om de deadline van 10/10/10 nog te kunnen halen, was intussen als datum voor de Curaçaose eilandsraadverkiezingen 27 augustus gekozen. Ze zouden winst opleveren voor de PAR, die van zeven naar acht zetels ging. De oppositionele Movementu Futuro Kòrsou (MFK) van Gerrit Schotte werd echter, vanuit het niets, met vijf zetels de tweede partij en zou erin slagen de PAR-PNP-FOL-coalitie naar de oppositiebanken te dwingen. Partijen die vier jaar lang de onderhandelingen hadden gevoerd, stonden nu plotseling buitenspel - een voor betrokkenen wrange politieke omwenteling, waarmee de eilanden overigens niet onbekend waren: al in 1954 had M.F. da Costa Gomez' Nationale Volkspartij (tegenwoordig PNP) de onderhandelingen over autonomie gevoerd, maar ondertekende DP-leider Efraïn Jonckheer uiteindelijk het Statuut. Ook de door de MEP bevochten Arubaanse status aparte werd ten slotte verwezenlijkt door een AVP-regering. Op Sint Maarten had DP-leider Sarah Wescott-Williams op driekwart van het hervormingsproces het stokje moeten doorgeven aan National Alliance-voorman William Marlin. Voor het aanvaarden van de Sint Maartense Staatsregeling had dit verder geen consequenties gehad: op 22 juli was deze door een unanieme eilandsraad aanvaard - een belangrijk signaal van vertrouwen richting het immer wijfelende Den Haag. ${ }^{267}$

Op zaterdag 4 september vormde de MFK samen met Wiels' PS (vier zetels) en de MAN (twee zetels) een nieuwe coalitie, die dezelfde nacht nog de Staatsregeling aanvaardde, met vijftien stemmen voor (MFK, PAR, PNP en FOL) en zes (PS en MAN) tegen. Hiermee gaf het eiland op het nippertje groen licht voor de slot-RTC - was het later dan 6 september geworden, dan was die geannuleerd. De nieuwe Curaçaose bestuurders spraken wel af om zo snel mogelijk tot een andere Staatsregeling te komen, inclusief een referendum over de voorgestelde veranderingen. Men had nu slechts vóór gestemd om het proces niet te verstoren. ${ }^{268}$

Tegelijkertijd riep de eilandsraad op tot meer autonomie: in de 
consensusrijkswetten moest een eenzijdige beëindigingsbepaling, een 'opzegrecht', worden opgenomen en in het Statuut een procedure om na 10/10/10 te kunnen beginnen met het realiseren van de onafhankelijkheid van Curaçao (conform de in de jaren tachtig toegevoegde artikelen voor Aruba). Dit was het mandaat waarmee de Curaçaose delegatie, onder leiding van de kersverse minister-president Schotte - die vliegensvlug was 'bijgepraat' over het gehele proces door Rob Vermaas, hoofd van de Vertegenwoordiging - naar de RTC in Den Haag zou afreizen. ${ }^{269}$ Als de Slotverklaring van de RTC niet tegemoetkwam aan deze wensen zou Curaçao niet tekenen. Beide voorstellen stuitten op veel weerstand van de nu oppositionele PAR - er zou in Den Haag hoe dan ook nog worden onderhandeld.

Zo hadden de 'historische dagen' elkaar in de nazomer van 2010 snel opgevolgd. Na de Senaat hadden ook de Antilliaanse en Arubaanse Staten het voorstel tot Statuutwijziging aanvaard, respectievelijk op 22 augustus en 4 september, zij het niet zonder hordes. ${ }^{270}$ In Aruba had de behandeling zelfs drie dagen van onstuimige debatten gevergd, inclusief twee lezingen en een valse bommelding. Heet hangijzer was het nieuwe artikel 27, lid 3 inzake de mogelijkheid over te gaan tot Koninkrijksingrijpen als de landen - en dus ook Aruba - internationale verdragen niet snel genoeg implementeerden. Volgens de oppositie was het artikel overbodig en tastte het de autonomie van Aruba aan. ${ }^{271}$

Op 1 september werd het pakket (consensus)rijkswetten officieel gepubliceerd in het Staatsblad, evenals 'de Samenwerkingsregeling waarborging plannen van aanpak landstaken Curaçao en Sint Maarten', waarmee ze een feit waren. De daadwerkelijke inwerkingtreding van de wetten zou plaatsvinden op het moment van wijziging van het Statuut op 10/10/10. Nu resteerden nog het laatste Tweede Kamerdebat over die wijziging, de slot-RTC van 9 september en de transitiedatum zelf, en met dit alles de hoop dat dit echt de eindstreep zou zijn.

De tijd drong; in de nacht van 6 op 7 september werden in de allerlaatste Politieke Stuurgroep besluiten genomen over 48 punten die nog geregeld moesten worden voor de slot-RTC; het merendeel betrof de laatste technische detailafspraken rond politie, hof en vreemdelingenketen. De Curaçaose wens om procedures op te nemen met als doel uit de consensusrijkswetten en uit het Statuut te kunnen stappen, werd na lang onderhandelen omgebogen naar een neutralere afspraak: na 10/10/10 zou jaarlijks een Koninkrijksconferentie worden gehouden (overigens geen nieuwe aanbeveling, want al naar voren gebracht door onder meer de commissie Democratisch Deficit), waarbij ook de verhouding tussen het Koninkrijk en de landen aan de orde 
zou kunnen komen, alsmede de verdere ontwikkeling van een visie op het Koninkrijk en actuele bestuurlijke ontwikkelingen. Dat officieel werd vastgelegd dat Curaçao te allen tijde gebruik kon maken van het zelfbeschikkingsrecht om voor onafhankelijkheid te kiezen, had Bijleveld richting de Antilliaanse delegatie nog de nodige overredingskracht gekost. Het nieuwe Curaçaose kabinet besloot, aldus zijn plaatsvervangend gevolmachtigde minister Humphrey Senior, uiteindelijk toch te tekenen, om chaos te voorkomen en het verdwijnen van de Antilliaanse regeringslaag mogelijk te maken. ${ }^{272}$

Rond de noodzaak tot ondersteuning van Sint Maarten werd besloten dat het land niet méér dan de vijf overeengekomen plannen van aanpak zou krijgen - een niet geheel geruste Bijleveld had hier water bij de wijn moeten doen. De Stuurgroep stelde formeel vast dat de overheidsapparaten van de beoogde landen aan de criteria voldeden, dan wel dat de plannen van aanpak voldoende vertrouwen wekten dat die daartoe zouden leiden. Ten slotte werd besloten dat het gewijzigde Statuut in werking zou treden met ingang van 10 oktober 2010. $\mathrm{Na}$ afloop benadrukte Osepa dat het er niet om ging nu onafhankelijk te worden. 'Dat is nonsens. [...] het kan tien, twintig, dertig, honderd jaar zijn, als Curaçao ooit wil opteren voor een andere rechtsorde hebben we vandaag een mogelijkheid gecreëerd. ${ }^{273}$

De weg was nu vrij voor het 'ultieme' debat, waarin de Kamer aan de vooravond van de slot-RTC voor de laatste keer ja of nee kon zeggen tegen het doorgaan van 10/10/10-Bijleveld had de Kamer in april toegezegd aan het einde van het proces een finaal oordeel te mogen vellen over de inwerkingtreding van de Statuutwijziging. Zij verwachtte nog een pittige bespreking. De kans dat een meerderheid nee zou zeggen, was niet geheel uitgesloten: op steun van de PVV hoefde in ieder geval niet te worden gerekend, de SP had al aangekondigd het кв tot inwerkingtreding te willen tegenhouden, de ChristenUnie had twijfels, wat de VVD ging doen, was evenmin zeker. ${ }^{274}$

De behandeling zou echter overschaduwd worden doordat vlak ervoor de nieuwe bestuurscolleges van de landen in spe controversiële besluiten namen, op Curaçao om de pensioenen van politici fors te verhogen en op Sint Maarten om de casinoregels te versoepelen. De besluiten werden vrij snel teruggedraaid door ingrijpen op Rijksniveau; hoe dan ook was de ophef groot. Voor Sint Maarten kwam dit nog eens boven op de brandbrief waarin het $\mathrm{Cft}$ eind juli aan de Rijksministerraad het vertrouwen had opgezegd in de begrotingsdiscipline van het bestuurscollege. ${ }^{275}$

De Kamer keurde het ultieme $\mathrm{KB}$ voor de inwerkingtreding niet kritiekloos goed; toch kon de afronding van het ontmantelingsproces uiteindelijk rekenen op een ruime meerderheid. 111 leden stemden 
voor, 39 tegen (PVV en SP, met de gebruikelijke argumenten). Het was een bredere steun dan verwacht. Hiermee stond definitief vast dat de nieuwe structuur per 10/10/10 zou ingaan; alle eerder aangenomen wetgeving werd op die datum van kracht. Wel koppelde de Kamer aan deze instemming de voorwaarde van een toelatings- en terugkeerregeling voor Antillianen en Arubanen op basis van 'wederkerigheid' in de nog tot stand te komen Rijkswet personenverkeer. Aanname van de motie van André Bosman (VVD) met deze strekking bleek voor de VVD-fractie voldoende om te stemmen tegen de oproep van PVV'er Eric Lucassen, die een punt achter het proces had willen zetten.

Met het diezelfde dag, 8 september, bereikte akkoord over het in het aangevulde presidium van de V-RTC voorbereide slotdocument was nu alles klaar: Curaçao en Sint Maarten waren gereed om zelfstandige landen te worden binnen het Koninkrijk, de plannen van aanpak waren bekrachtigd, alle wetgeving voor de transitie was rond en het land de Nederlandse Antillen ontmanteld. De binnen KR besproken alternatieve scenario's - uitstel van de slot-RTC naar de laatste week van september, of splitsing in twee conferenties, één over de Staatsregelingen en één over de plannen van aanpak - hoefden niet uit de kast te worden gehaald. ${ }^{276}$

In de Haagse Ridderzaal, de plek waar koningin Juliana in 1954 het eerste Koninkrijksstatuut bekrachtigde, vond op donderdag 9 september het langverwachte tekenmoment van het proces plaats. Voor

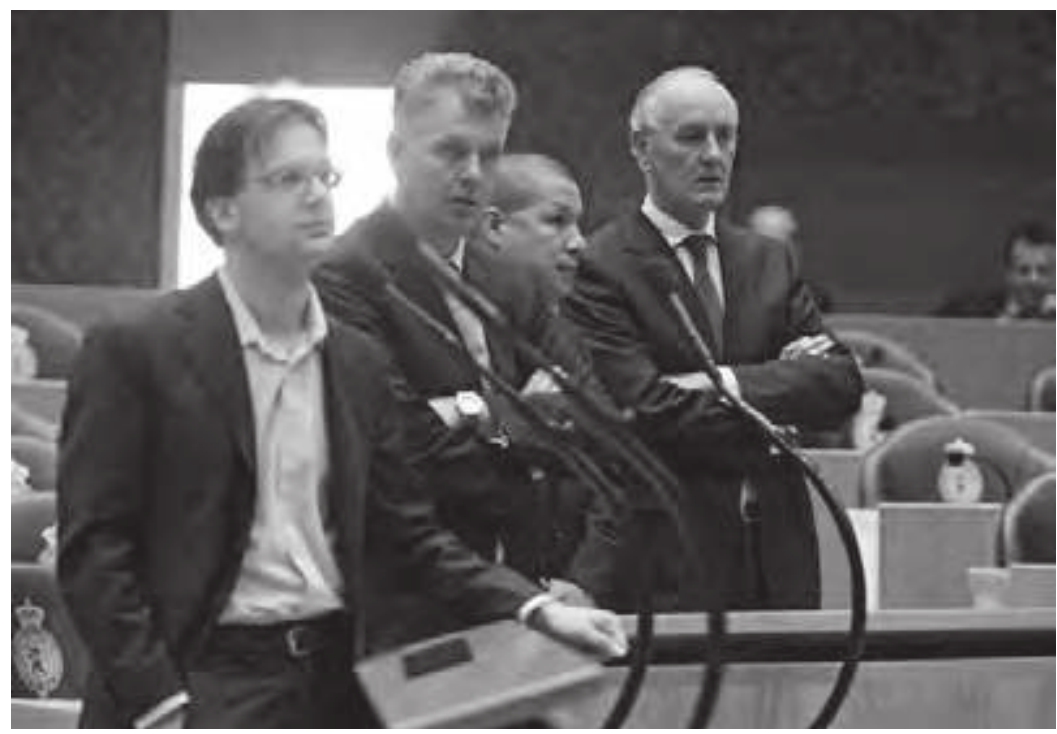

Antillendebat in de Tweede Kamer, 8 september 2010; v.l.n.r. Ronald van Raak, Hero Brinkman, Andy Bikker, Johan Remkes. 
de laatste keer kwamen de drie landen van het Koninkrijk en de vijf eilanden van de Nederlandse Antillen bijeen. ${ }^{277}$ Het was uiteindelijk niet meer dan een formaliteit. Verrassingen waren uitgesloten; de een dag eerder overeengekomen Slotverklaring bood geen mogelijkheid meer tot onderhandelen. Koningin Beatrix had de Statuutwijziging intussen ondertekend; deze hoefde alleen nog maar te worden gecontrasigneerd door de andere Koninkrijkspartners. ${ }^{278}$

Ruim een uur voor de geplande eindtijd werd de kroon op het werk gezet. Balkenende - voor de derde keer tijdens het proces RTC-voorzitter $^{279}$ - noemde het (Suriname vergetend) 'de meest ingrijpende wijziging sinds de ondertekening van het Statuut in 1954', waarmee 'recht werd gedaan' aan de 'gevoelens van meer autonomie' onder de bevolking van de eilanden. 10/10/10 was 'geen eindpunt, maar het beginpunt van nieuwe mogelijkheden', aldus de scheidende ministerpresident. Bijleveld was tevreden over 'de goede weg die we gegaan zijn; zij benadrukte het bijeenblijven van alle partijen, in een 'vermoeiend proces van vier jaar'; het was 'geweldig' dit te mogen afmaken als demissionair kabinet. ${ }^{280}$

De meeste Antilliaanse politici waren verheugd en keken vooruit. De Jongh-Elhage noemde de ontmanteling een 'heel bijzonder, onvergelijkelijk proces', dat daadwerkelijk inhoud gaf aan de geest van het Statuut: een goede samenwerking op basis van gelijkwaardigheid, met de wil elkaar, waar nodig, bij te staan. Osepa tekende voor $\mathrm{Cu}$ raçao en sprak woorden van dank aan zijn politieke voorgangers, die tijdens de ceremonie echter genoegen moesten nemen met een plaats op de tweede rij. Booi, nu oppositielid, was tevreden dat het werk af was. Voor Bonaire had Abraham getekend, zij het met gemengde gevoelens nu nog geen referendum was gehouden. 'Onderdeel' worden van Nederland was zijns inziens niet de beoogde uitkomst; hij riep Nederland op tot geduld en begrip voor het eigen karakter en de cultuur van de eilanden. Gedeputeerde Woodley van Sint Eustatius hoopte op een betere toekomst voor zijn eiland, dat eigenlijk de voorkeur had gegeven aan het voortbestaan van de Antillen-van-vijf. De Sint Maartense delegatie onder leiding van Marlin - ook DP-leider Wescott-Williams zat overigens op de eerste rij-overhandigde alle aanwezigen een ingebonden kopie van de Staatsregeling. Hij was tevreden; Nederland kreeg met de plannen van aanpak geen al te grote vinger in de pap. Eman memoreerde hoe Eman sr. in 1948 de aanzet had gegeven tot de Arubaanse status aparte en pleitte voor een strategisch partnerschap in het Koninkrijk. Chris Johnson van Saba citeerde ten slotte - als enige sprak hij de aanwezigen in het Engels toe-de woorden van zijn vader Will, bijna tien jaar geleden: 'Wij doen de deur dicht en het licht uit. ${ }^{\text {,281 }}$ 
Vooral de - veelal euforische-Antilliaanse pers besteedde aandacht aan 'de ingrijpendste wijziging' binnen het Koninkrijk sinds ruim een halve eeuw. In de Nederlandse media leidde die echter tot weinig ophef. Op het achtuurjournaal van diezelfde avond kreeg de RTC geen vermelding - wel was er, een wellicht tekenend toeval, een rapportage over gewelddadige criminaliteit onder Antilliaanse jongeren. ${ }^{282}$ Koningin Beatrix ontving de dag erna de leiders van de delegaties op Paleis Huis ten Bosch - het leverde voornamelijk in de Antilliaanse media foto's op. ${ }^{283}$

10/10/10 was nu in zicht. Op Sint Maarten vond kort daarvoor nog een wisseling van de wacht plaats, met de installatie op 5 oktober van de nieuwe eilandsraad - de NA van Marlin had gewonnen, maar de United People's Party van Theo Heyliger en de DP slaagden erin een coalitie te vormen. Volgens het op 20 september ondertekende regeerakkoord gingen zij samen de eerste regering van Sint Maarten vormen, waarbij front woman Wescott-Williams, hoewel van de kleinere DP, de eer kreeg om de geschiedenis in te gaan als eerste premier van het land Sint Maarten, anders dan De Jongh-Elhage op Curaçao.

Op 9 oktober 2010 vond de laatste Statenvergadering van de Nederlandse Antillen plaats - ruim zeventig jaar na de eerste vergadering op 5 april 1938 - in aanwezigheid van prinses Máxima en kroonprins Willem-Alexander. Een dag later, 10/10/10, was het ultieme moment daar: de artikelen I en II van de Rijkswet wijziging Statuut in verband met de opheffing van de Nederlandse Antillen traden om twaalf uur 's nachts op Aruba, Curaçao, Sint Maarten, Bonaire, Sint Eustatius en Saba in werking. Hiermee waren de Nederlandse Antillen voltooid verleden tijd.

\section{Afspraken en concessies}

De eerstkomende vijf jaar na 10/10/10 zal er legislatieve rust heersen op het Koninkrijksfront. Daarna zal de werking van de nieuwe staatkundige structuur voor de BES-eilanden, Curaçao en Sint Maarten worden geëvalueerd. Tijdens de onderhandelingen heeft namelijk altijd vooropgestaan dat de verworven statussen niet het eindmodel hoeven te zijn. Bovendien behielden alle (ei)landen het recht om te allen tijde voor volkenrechtelijke onafhankelijkheid te kiezen; binnen het Koninkrijk zijn de opties voor een andere status echter klein.

De strakke Haagse houding tegenover de eilanden die zich in de achterliggende jaren (tijdelijk) buitenspel zetten-eerst Curaçao, later ook Sint Maarten en Bonaire - had vruchten afgeworpen; de Nederlandse bewindslieden hielden het proces vier jaar lang, on- 
danks alle tegenwind, op de rails. Dat zou niet mogelijk zijn geweest zonder de uiteindelijk toch goede samenwerking met de Antilliaanse landsregeringen onder PAR-premiers Ys en later De Jongh-Elhage. Dat daarbij wederzijds stevige concessies zijn gedaan en dat er ook werd 'terugonderhandeld', was welhaast onvermijdelijk. Voor politiek Den Haag - dat gaandeweg ook in een vragende positie terechtkwam-waren de concessies wezenlijk, ook omdat ze betrekking hadden op cruciale onderwerpen als de migratie en de rechtshandhaving. Tot op heden zien critici het uitblijven van een migratieregeling binnen het Koninkrijk als een gemiste kans in het proces. De Jongh-Elhage zou echter van meet af aan duidelijk maken dat het op de agenda zetten van het migratiedossier het gehele proces overboord zou gooien.

Dat voor het Caraïbische deel van het Koninkrijk drie gescheiden politiekorpsen werden gecreëerd, in plaats van het door Den Haag gewenste ene korps voor alle eilanden, was direct al een stevige Haagse concessie. Op het laatste nippertje zou een Kameramendement op de Politiewet ervoor zorgen dat wel kon worden vastgehouden aan het in Den Haag zo sterk gewenste RST bij de aanpak van zware criminaliteit. Zo werd afschaffing van het RST onder druk van de Kamer teruggedraaid - een belangrijke concessie voor de twee landen in spe en een knap staaltje Nederlands 'terugonderhandelen'.

Ook op het punt van het creëren van drie Openbaar Ministeries in plaats van één gezamenlijk OM had Nederland moeten toegeven. In ruil wist Den Haag wel te bedingen dat dan één gezamenlijke procureur-generaal zou leidinggeven aan de drie OM's - een punt waarop aan Antilliaanse zijde was ingeschikt, waar was gestreden voor een PG per land. Bovendien had Den Haag, aanvankelijk, de bevoegdheid weten te bedingen om op Koninkrijksniveau de PG aanwijzingen te geven. Dat deze eis - het verzet aan Antilliaans zijde was fel - in een later stadium zou sneuvelen, kwam mede door de adviezen van de Raad van State. Bijleveld zou zich vervolgens tevreden moeten stellen met een intensievere samenwerking tussen de Justitieministers.

Het Gemeenschappelijk Hof van Justitie voor Curaçao, Aruba, Sint Maarten, Bonaire, Sint Eustatius en Saba was een van de weinige consensusrijkswetten waarbij ook Aruba betrokken was-maar onder meer een zakelijk geschil tussen de MEP-regering en het Nederlandse kabinet stond een meer betrokken Arubaanse houding tijdens het grootste deel van het proces in de weg. Den Haag zou zelfs artikel 43 Statuut uit de kast halen om Aruba in het gareel te dwingen en Willemstad voor de eerstkomende jaren als standplaats van het Hof te accepteren. ${ }^{284}$

De plannen van aanpak op het gebied van de consensusrijkswetge- 
ving, ten slotte, waren een toezegging van Nederlandse kant: dat de landen nog niet aan de voorwaarden voor hun nieuwe status hoefden te voldoen om daadwerkelijk land te kunnen worden, week belangrijk af van de in 2006 overeengekomen Slotverklaring. Dat Curaçao en Sint Maarten de eerstkomende jaren nog op een aantal overheidsterreinen onder Koninkrijkstoezicht staan, is dan ook een minder bittere pil voor de landen dan op het eerste gezicht misschien lijkt. De Senaat zou op dit punt tegen het einde van het proces nog een beslissende rol spelen door te eisen dat de plannen oneindig kunnen worden verlengd.

Per 10 oktober zijn de BES-eilanden bij Nederland gaan horen en is de Grondwet daar in principe in zijn geheel van toepassing, inclusief het in artikel 1 vervatte gelijkheidsbeginsel. Als de situatie op de eilanden duidelijk anders is dan in Nederland kunnen wel specifieke maatregelen worden genomen die afwijken van de Nederlandse, maar het onderscheid moet objectief gerechtvaardigd zijn. Bij Nederland horen, bleek ook direct - pijnlijk - uit de door de Tweede Kamer afgedwongen amendementen rond de 'ethische' wetgeving: anders dan de door Bijleveld afgesproken overgangsperiode van vijf jaar zal de Nederlandse wetgeving op het gebied van abortus, euthanasie en homohuwelijk één c.q. twee jaar na de transitiedatum op de BES van kracht worden. Ook hier heeft de Kamer een beslissende stem gehad.

De regering zou zich onder druk van de Kamer over de Grondwet gaan buigen - op 18 maart 2011 besloot het kabinet een wijziging voor te bereiden, onder meer om leden van de eilandsraden van de BES actief kiesrecht voor de Eerste Kamer te verlenen. In de nieuwe Grondwet zal de status van de BES-eilanden als openbare lichamen geregeld worden en zullen de meeste grondwettelijke bepalingen over gemeenten van overeenkomstige toepassing verklaard worden. Oorspronkelijk had de regering de nieuwe situatie, tot aan de evaluatie in 2015, willen afdekken met de nu gekozen - beperkte - wijziging van het Statuut.

De schuldsanering ten bedrage van 1,7 miljard euro, ten slotte? Daar werd in het hectische laatste jaar weinig meer over gesproken, een done deal. Evenmin overigens over de vraag hoe realistisch de verwachting is dat de nieuwe landen, mede gezien hun kleine schaal, na die schuldsanering financieel wel op eigen benen zullen weten te staan. 


\section{Epiloog}

Zo werd de transitie op de symbolische datum van 10/10/10 dan toch, op het nippertje, gehaald. Bij vele officiële gelegenheden werd positief teruggeblikt. De onderhandelende partijen waren trots dat het moeilijke proces tot een goed einde was gebracht en dat deze deadline uiteindelijk wel haalbaar was gebleken. Maar inmiddels hadden overal verkiezingen plaatsgevonden. De PAR van Emily de Jongh-Elhage op Curaçao en de UPB van Ramonsito Booi op Bonaire waren in de oppositie terechtgekomen. Onder de nieuw aangetreden bestuurders leefde niet hetzelfde enthousiasme over de uitkomst van het in 2000 begonnen proces van ontmanteling van de Nederlandse Antillen en herstructurering van het Koninkrijk. En nog steeds ligt de vraag op tafel hoe de toekomst van de trans-Atlantische relaties eruitziet.

\section{Recapitulatie}

Het proces was begonnen met de strijd van Sint Maarten voor de status van land binnen het Koninkrijk, in navolging van Aruba. De Curaçaose dominantie, dan wel de perceptie zo sterk afhankelijk te zijn van het 'hoofdeiland', was na Aruba ook andere eilanden ondraaglijk geworden. De moeizame constructie van de Nederlandse Antillen, voorheen treffend bekend als 'Curaçao en onderhoorigheden', bleek niet meer te redden. Het probleem was niet nieuw en ging aan de separashon van Aruba vooraf. Ook in koloniale tijden was er al veel twijfel geweest over de praktische haalbaarheid van dit koloniale construct. De optie om de kleinste eilanden 'in onmiddellijke betrekking tot het moederland' te plaatsen was al geopperd door minister van Koloniën J.C. Baud (1840-1848), toch zeker geen bestuurder van grote toegeeflijkheid jegens de koloniale onderdanen in Oost en West. In 1920 bepleitten prominente bewoners van de Bovenwinden vergeefs 'rechtstreeks bestuur onder het moederland'. In 1845 stelde de Ko- 
loniale Raad te Willemstad onomwonden dat het samenvoegen van de Boven- en Benedenwindse eilanden een historische vergissing was geweest. ${ }^{1}$

Indertijd was daarvoor in Den Haag geen steun te vinden, maar de tijden waren veranderd. Aruba had de status aparte verkregen in 1986 en daarmee was een precedent geschapen. Het referendum op Sint Maarten, waar de overgrote meerderheid stemde voor een eigen land binnen het Koninkrijk, luidde het einde van de Nederlandse Antillen in. Het duurde niet lang voor de Antilliaanse landsregering dit streven steunde, Curaçao eveneens een landsstatus ging ambiëren en de drie kleinste eilanden kozen voor een directe band met Nederland - Bonaire en Saba uit overtuiging, Sint Eustatius alleen omdat de geprefereerde voortzetting van de Antillen-van-vijf niet meer haalbaar was. Formeel was de uitkomst op 10/10/10, de opheffing van het land de Nederlandse Antillen, een succes voor alle Antilliaanse partijen, met uitzondering van Statia.

Al snel was het onderhandelingsdoel van de opeenvolgende Antilliaanse lands- en eilandsregeringen verbreed met het streven naar een sanering van de overheidsfinanciën, zodat de nieuwe landen met een redelijk schone lei van start zouden kunnen gaan. Dit streven werd niet volledig gehonoreerd, maar Den Haag kwam wel substan-

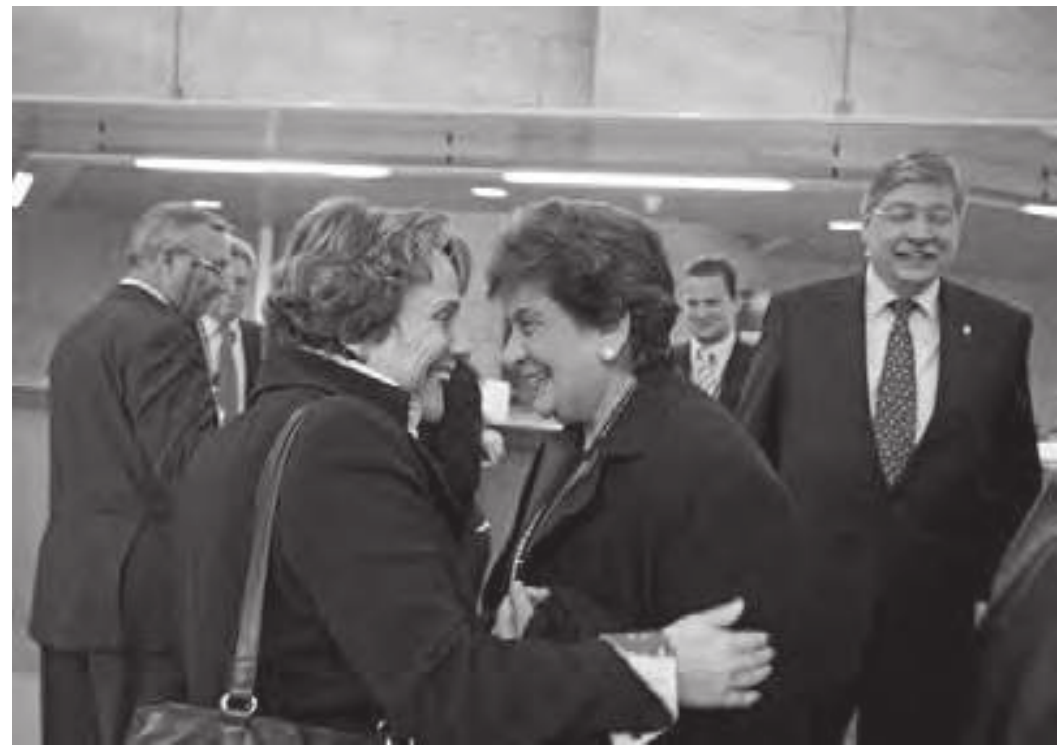

Vreugde direct na de definitieve parlementaire instemming, Den Haag, 8 september 2010; in het midden Ank Bijleveld-Schouten en Emily de Jongh-Elhage; I. Marcel van der Plank, r. Willibrord van Beek. 
tieel over de brug. De Nederlandse overheid gaf uiteindelijk 1,7 miljard euro uit aan de sanering van zeventig procent van de Antilliaanse overheidsschulden. Volledige sanering werd ook op de Antillen niet nagestreefd, om een zekere autonomie in het eigen financieel-economisch beleid te kunnen behouden.

Bezien vanuit het standpunt van 2000 had Nederland twee ingrijpende concessies gedaan. Decennialang was het (verder) uiteenvallen van de Nederlandse Antillen afgewezen; nu had Den Haag met man en macht meegewerkt aan het verwezenlijken van de ontmanteling. Rond 2000 was 'zelfredzaamheid', ook op financieel-economisch terrein, het strenge devies aan de Caraïbische landen van het Koninkrijk geweest. $\mathrm{Nu}$ was juist substantieel bijgedragen aan het op orde brengen van de overheidsfinanciën van het voormalige land de $\mathrm{Ne}-$ derlandse Antillen en de eilandgebieden.

Deze Haagse concessies werden niet zonder voorwaarden gedaan. Sinds Den Haag rond 1990 de illusie had opgegeven de Caraïbische (ei)landen naar de onafhankelijkheid te loodsen, hadden opeenvolgende Nederlandse kabinetten ingezet op verbetering van de kwaliteit van het overzeese bestuur. In Haagse optiek impliceerde dit een versterking van de rol van het Koninkrijk en daarmee de facto van Nederlandse bemoeienis met het Caraïbische bestuur. Dit beleid had regelmatig tot confrontatie met de overzeese partners geleid, die wars waren van iedere aantasting van de Statutaire autonomie. Den Haag had echter voet bij stuk gehouden en gaandeweg inderdaad de eigen rol verstevigd. De onderhandelingen in de aanloop naar 10/10/10 gaven de Nederlandse regering de ruimte om deze positie te bestendigen en op verschillende terreinen te intensiveren. Het (voorlopige) eindresultaat zou betwist blijven. Aan Nederlandse zijde was er kritiek dat de akkoorden het toezicht vanwege het Koninkrijk nog onvoldoende garandeerden, aan Antilliaanse zijde juist dat de autonomie ontoelaatbaar was aangetast.

Potentieel had ook een tweede Haagse beleidslijn een rol kunnen spelen in de onderhandelingen, namelijk de wens de Caraïbische migratie naar Nederland te reguleren. Voor alle Antilliaanse eilanden was dit verlangen onaanvaardbaar, maar de Tweede Kamer nam in de periode 2000-2010 verschillende moties aan die aandrongen op restricties op de vrije toelating en vestiging van Antillianen. Opeenvolgende Nederlandse kabinetten kozen ervoor deze onderhandelingstroef niet uit te spelen, mogelijk omdat zij een andere mening waren toegedaan dan het parlement, zeker ook om het toch al moeizame proces zo min mogelijk te verstoren en de ultieme deadline van 10/10/10 niet verder in gevaar te brengen. Uiteraard riep dit in het Nederlandse parlement onvrede op. 
Wanneer nu de balans wordt opgemaakt, blijken uiteindelijk vooral twee kwesties omstreden te zijn gebleven: enerzijds het migratiedossier, anderzijds de vraag of de eilanden nu werkelijk datgene hebben gekregen waarnaar zij streefden. Veel meer op de achtergrond, zo bleek tijdens een rondgang langs een groot aantal hoofdrolspelers, een halfjaar na 10/10/10, spelen vragen over de toekomst en democratische vormgeving van het Koninkrijk en de relatie tot de Europese Unie nog een rol. In vele opzichten blijven de meningen verdeeld; maar waar de Toekomstconferentie van 1993 stukliep op diepe meningsverschillen tussen Nederland enerzijds en de Nederlandse Antillen anderzijds, zijn de scheidslijnen nu aanmerkelijk complexer.

254

\section{Het migratiedossier}

Als er een kwestie is waarover bestuurders op alle zes eilanden het onderling - en naar wij mogen aannemen met hun electoraat - roerend eens zijn, dan is dat het migratiedossier. Niet alleen menen vrijwel alle betrokken Caraïbische politici en ambtenaren dat deze kwestie volstrekt terecht buiten de onderhandelingen is gehouden, zij wijzen ook elke suggestie van de hand dat hierover nu wel zaken gedaan kunnen worden. Daarbij vallen, vooral op Curaçao, bezwerende termen als 'non issue', 'belachelijk' en 'domme discussie'. Er worden niet alleen juridische argumenten gebezigd, ook wordt in vaak emotionele bewoordingen herinnerd aan het gedeelde Nederlanderschap. Betrokken onderhandelaars benadrukken daarnaast dat Den Haag het dossier wel moest laten vallen, omdat anders het proces zou zijn getorpedeerd. ${ }^{2}$

Dit ligt aan Nederlandse zijde volstrekt anders. Daar is geen sprake van consensus. Zowel in de aanloop naar 10/10/10 als sindsdien hebben enkele kleine partijen ( $\mathrm{CU}, \mathrm{GL}$ ) zich consequent verzet tegen restricties op de vrije vestiging van Antillianen in Nederland, terwijl een groter deel van het politieke spectrum beperkende maatregelen eist dan wel wenst te onderzoeken. Lopende het onderhandelingsproces heerste in deze laatste groep, waartoe ook de regeringspartij CDA behoorde, al grote onvrede dat de migratie als troefkaart van tafel was gehaald. Deze spanning klinkt duidelijk door in de terugblikken van nauw betrokken bewindslieden en deskundigen aan Nederlandse zijde. Vrij algemeen wordt gesteld dat het laten vallen van een migratieregeling vrijwel onvermijdelijk was met het oog op de voortgang van de onderhandelingen en in het bijzonder ook om de PAR niet in verlegenheid te brengen. De voormalige D66 bewindspersonen Thom de Graaf ('Je moet pragmatisch omgaan met alle emoties die dit op- 
roept') en Alexander Pechtold ('Het migratiedossier was helemaal niet uit te spelen!') bezien dit laconiek. In het bijzonder VvD'ers ervaren deze uitkomst echter als een groot minpunt, temeer daar er na het bereiken van de mijlpaal 10/10/10 weinig ruimte meer is om hierover opnieuw in onderhandeling te gaan - de stok achter de deur ontbreekt nu. Johan Remkes, gewezen minister van BZK en later de leidende figuur op dit dossier in de oppositionele VVD, betreurt dan ook dat Nederland het migratiedossier niet harder uitspeelde. In zijn visie bood de nog onder medeverantwoordelijkheid van de VVD getekende Slotverklaring van 2006 daartoe voldoende ruimte. Zijn fractie had bij die verklaring immers het voorbehoud gemaakt dat gelijktijdig met de ontmanteling het personenverkeer binnen het Koninkrijk diende te worden geregeld, inclusief de toelating en uitzetting van criminele Antilliaanse jongeren; ook een meerderheid in de Tweede Kamer had hierop aangedrongen. Het vierde kabinetBalkenende hield het echter op 'volgtijdelijkheid', dus eerst de ontmanteling, daarna pas een migratieregeling. Daarmee was deze troef weggegeven. PAR-prominent en voormalig gevolmachtigde minister van de Nederlandse Antillen Carel de Haseth wijst er overigens op dat de Slotverklaring zelf met geen woord rept over migratie; de 'troef' bestond in zijn visie niet, althans niet als voorbehoud waaraan Antilliaanse onderhandelaars zich gebonden achtten. ${ }^{3}$

Het aantreden van het kabinet-Rutte betekende mede een overwinning voor twee partijen met een hard standpunt inzake immigratie in algemene zin, en een uitgesproken voorkeur voor beperking van de Antilliaanse migratie in het bijzonder. Het regeerakkoord merkt hierover op dat het kabinet zal komen met een 'voorstel voor een Rijkswet personenverkeer die berust op het uitgangspunt van wederkerigheid en tevens de mogelijkheid omvat wederzijds eisen te stellen aan de toelating en het verblijf tot en de terugkeer naar landen van het Koninkrijk (Curaçao, Aruba, St. Maarten en Nederland)'. Het door VVD, CDA en PVV getekende gedoogakkoord herhaalt dit voornemen. ${ }^{4}$

Dit betekent dat de komende tijd het migratiedossier omstreden zal blijven. De voorgenomen Haagse wetgeving zal aan de overzijde van de oceaan - en uiteraard bij Antilliaanse organisaties in Nederland-grote weerstand blijven oproepen. De juridische haalbaarheid en de praktische uitvoerbaarheid van een migratiebeperking zijn, zoals de Raad van State meermalen aangaf, twijfelachtig. Het lijkt er echter niet op dat dit politiek Den Haag tot de conclusie zal brengen het hele dossier dan maar te sluiten. Het kabinet-Rutte heeft in zijn regeringsverklaring aangekondigd om, indien 'nieuw nationaal beleid' op juridische grenzen zou stuiten, 'zich binnen de Europese Unie 
of in ander verband [te zullen] inzetten voor wijziging van de betreffende verdragen, richtlijnen of afspraken'. ${ }^{5}$ Dat klinkt dreigend, maar is wellicht niet zeer realistisch.

Opmerkelijk is hoe dan ook dat er inzake de Antilliaanse migratie geen concrete stappen zijn gezet. Zelfs een als hardliner in migratiezaken bekendstaande VVD'er als Henk Kamp, nu minister van Sociale Zaken en Werkgelegenheid in het kabinet-Rutte, kwalificeert de juridische ruimte voor een beperking van de Antilliaanse migratie als 'beperkt', en minister Gerd Leers voor Immigratie en Asiel (CDA) gaf al aan geen haast te maken met dit dossier 'om de lieve vrede te bewaren met het Caribisch deel'. ${ }^{6}$ Het Haagse parlement blijft echter aandringen, terwijl aan Caraïbische zijde iedere verwijzing naar mogelijke restricties juist buitengewoon gevoelig blijft. Het ligt daarom voor de hand dat de spanningen rond het migratiedossier de komende jaren niet zullen afnemen en dat ze een gezamenlijke verkenning van een verdieping van de Koninkrijksrelaties zullen bemoeilijken.

\section{De versterking van het Koninkrijk en de betekenis van autonomie}

Bij de opening van de Toekomstconferentie in 1993 draaide de toenmalige minister-president Ruud Lubbers er niet omheen. 'Wij maken allen deel uit van het Koninkrijk. Om 't zomaar eens te zeggen: de Koningin is van en voor ieder van ons. Eén Koninkrijk dus, waarvan wij ieder één vertrek bewonen. Dat schept wel verplichtingen. Allereerst om ons eigen huis, onze eigen kamer op orde te houden. Pas dán, óók samenwerking. Geen hulp, maar samenwerking [...]. Deugdelijk bestuur vraagt om een integer, hard en streng bestuur. Met mooie beloftes komen we d'r nooit. Ik stel voor dat we met elkaar het achterstallig onderhoud gaan aanpakken; met dat deugdelijk bestuur ieder van ons, op de eerste plaats op de eigen plek en van daar uit, natuurlijk ook gezamenlijk. [...] Het gaat hier eigenlijk niet om onderhandelen, het gaat om samen handelen."

De mogelijk invulling van dat 'met elkaar' was voorbereid door de architect van het nieuwe Nederlandse beleid, de toenmalige minister van Justitie en voor Nederlands-Antilliaanse en Arubaanse Zaken Ernst Hirsch Ballin. De Toekomstconferentie mislukte, vooral omdat er aan Antilliaanse zijde sterke weerstand was tegen wat werd ervaren als een onaanvaardbare aantasting van de Caraïbische autonomie. In dat licht lijkt het ironisch dat de verschillende akkoorden die 10/10/10 mogelijk maakten direct aansluiten op de beleidsagenda die bijna twintig jaar tevoren in Den Haag was uitgezet - en overigens 
pikant dat Hirsch Ballin er opnieuw sterk bij betrokken was, ditmaal alleen als minister van Justitie, terwijl zijn meest uitgesproken tegenstander uit 1993, Suzy Römer, nu topadviseur van de Antilliaanse regering was. Zoals eerstgenoemde opmerkte: men kan spreken van zeventien verloren jaren, maar evengoed vaststellen dat deze lange periode kennelijk nodig was om de geesten rijp te maken. ${ }^{8}$

De paradox is eenvoudig te verklaren: aan Antilliaanse kant was de compromisbereidheid ditmaal veel groter en Nederland had meer te bieden. De 'doorstart' van de Nederlandse Antillen tussen 1993 en 2000 was inmiddels volgens vrijwel alle partijen - het land en de eilanden met uitzondering van Sint Eustatius - een mislukking geworden; de wil gezamenlijk verder te gaan ontbrak zowel onder de politici als onder de bevolking. Voorts was er in 1993 nog geen sprake van een diepe financiële crisis, of althans nog niet van een breed besef daarvan; nu had alleen Den Haag de sleutel in handen om deze acute problematiek op te lossen en wist het deze onderhandelingstroef te spelen. Ten slotte lijkt het erop dat aan Antilliaanse zijde, althans door de onderhandelende partijen, de eigen autonomie minder angstvallig werd verdedigd. Voortschrijdend inzicht wellicht, mede ingegeven door het besef van de complexiteit van de uitdagingen en mogelijk ook wel gebaseerd op de inmiddels opgedane ervaringen met Haagse bestuurders.

Zo kon worden gewerkt aan een landsstatus voor Curaçao en Sint Maarten die wezenlijk anders, en volgens critici op beide eilanden ook minder aantrekkelijk was dan de autonome status die de Nederlandse Antillen hadden gehad en die Aruba in 1986 had bereikt. Wat was er minder? In de consensusrijkswetgeving is vastgelegd dat het Koninkrijk c.q. Nederland nu een directe invloed kan uitoefenen op de kwaliteit van bestuur en de rechtshandhaving van de nieuwe landen. Daar komt nog bij dat er plannen van aanpak zijn overeengekomen - twee voor Curaçao (voor de politie en de gevangenis) en vijf voor Sint Maarten (voor de bevolkingsadministratie, politie, landsrecherche, gevangenis en de nieuwe toelatingsorganisatie) - die op deze specifieke terreinen een nog veel sterkere rol van het Koninkrijk, c.q. Den Haag impliceren. Uitgangspunt is dat dit overgangsbepalingen zijn, bedoeld voor enkele jaren, maar de vraag is hoe realistisch dit zal zijn.

Aan Curaçaose kant wordt het resultaat van de onderhandelingen zeer verschillend beoordeeld. Vrijwel alle partijen zijn tevreden met het feit dat het eiland 'eindelijk' af is van de last van de kleinere eilanden, waarover vaak werd geklaagd als bultu di buriku, ezelslast. De onderhandelaars voor het land de Nederlandse Antillen en voor Curaçao zelf, overwegend van de PAR en in mindere mate de PNP, kijken zeer tevreden terug op het proces en de resultaten, waarin 
Nederland steeds meer begrip zou hebben gekregen voor de Antilliaanse standpunten. Papy Jesurun, die met het rapport $\mathrm{Nu}$ kan het ... nu moet het! in zekere zin de weg vrijmaakte, noemt 10/10/10 'het logische gevolg' op het rapport van zijn commissie. De Jongh-Elhage spreekt onomwonden van een pakket 'zonder minpunten', een 'gouden theeblad' waarmee zij 'heel happy' is. Haar adviseur Römer, vanouds zeer kritisch over Haagse bemoeienis, betreurt de concessies die werden gedaan op het gebied van politie en rechtshandhaving, maar karakteriseert de uitkomst van de onderhandelingen toch als 'voor 85 procent heel goed': 'Je kunt je nu op je eigen land gaan concentreren.' Ys, de andere topadviseur van de Antilliaanse c.q. Curaçaose regering - vandaar hun gezamenlijke epitheton 'Room-Ys' - is al evenzeer tevreden; er werden wat concessies gedaan ('Gaandeweg pas je je ambities aan'), maar op wezenlijke punten gaf Den Haag meer toe. ${ }^{9}$

De oppositie van weleer, die juist de eerste regering van het land Curaçao zou vormen en in die hoedanigheid ook de finale documenten van de ontmanteling ondertekende, blijft zeer kritisch over de onderhandelingsresultaten. Helmin Wiels, leider van de pro-onafhankelijkheidspartij Pueblo Soberano, kwalificeert de structurele Haagse betrokkenheid bij het Curaçaose bestuur als ondemocratisch: Curaçao is 'als een ezel aan een lang touw'; Haagse curatele vormt in zijn visie een permanente bedreiging. Naar zijn mening heeft Neder-

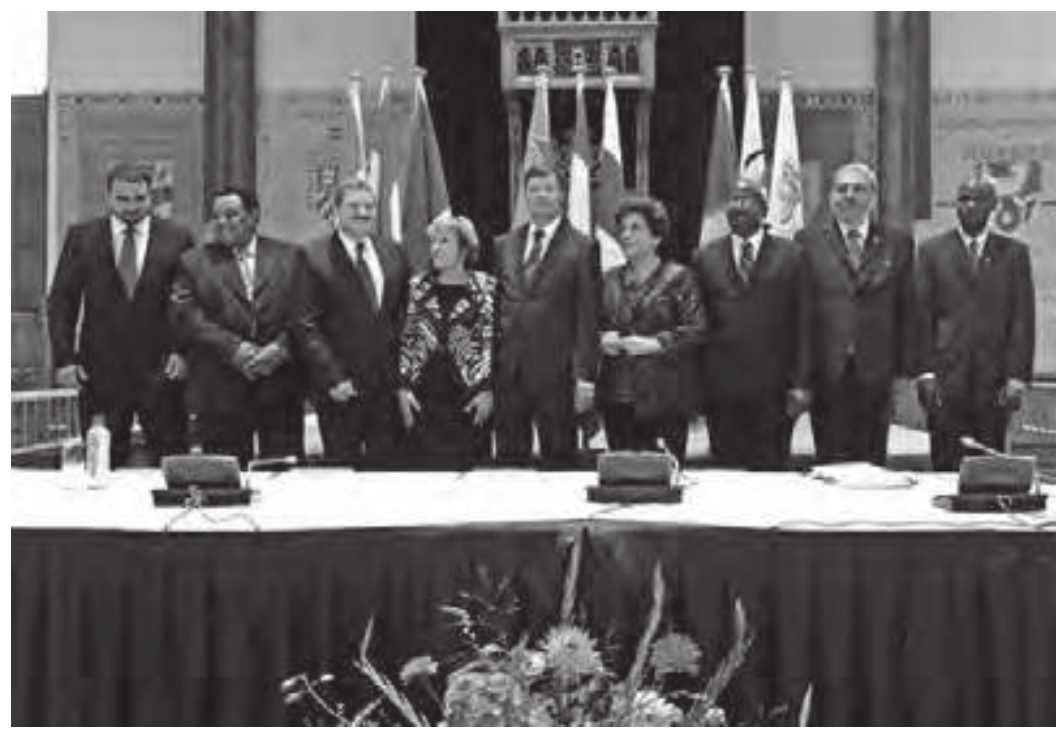

Ondertekeningsceremonie Slotverklaring slot-RTC, 9 september 2010; v.l.n.r. Chris Johnson, Julian Woodley, Mike Eman, Ank Bijleveld-Schouten, Jan Peter Balkenende, Emily de JonghElhage, William Marlin, Jopie Abraham, Sheldry Osepa. 
land de Antillen voor 1,7 miljard euro gekocht; 'ze hebben ons in hun zak voor een koopje' en het resultaat is onderschikking, 'een deficit van de democratie'. ${ }^{10}$

MAN-prominent en thans plaatsvervangend gevolmachtigde minister van Curaçao Humphrey Senior hekelt eveneens het eindresultaat, dat in zijn ogen een onaanvaardbaar verlies aan autonomie impliceert, en dus veroordeelt hij ook de Haagse opstelling. 'Nederland was hier van het begin af aan op uit', meent hij, en maakte misbruik van de schuldenproblematiek van de toenmalige Nederlandse Antillen door 'te zwaaien met een buidel geld tegenover een zwakke onderhandelingspartner'. Hij beschouwt de Haagse opstelling als een schending van de VN-principes over dekolonisatie en bezigt daarbij termen als 'machtsmisbruik', 'politiek onethisch' en 'een terugkeer naar koloniale verhoudingen' die bij de dekolonisatiecommissie van de VN zou moeten zijn aangemeld. Opmerkelijk is dat ook de prominente ambtelijke adviseur van Curaçao Julien Larmonie meent dat te veel concessies werden gedaan in de sfeer van Haagse betrokkenheid bij de rechtshandhaving. ${ }^{11}$

Interessant is dat Curaçaose betrokkenen in dit verband vaak verwijzen naar het Protocol dat Aruba in 1993 met Nederland overeenkwam als onderdeel van de onderhandelingen om de onafhankelijkheid per 1 januari 1996 af te wenden. ${ }^{12}$ Verdedigers van de concessies die het land de Nederlandse Antillen c.q. het aspirant-land Curaçao deed, wijzen er graag op dat met dit Protocol ook de reikwijdte van de autonome landsstatus van Aruba wezenlijk werd beperkt. Curaçaose critici als Charles Cooper van de MAN werpen echter tegen dat dit Protocol de facto nauwelijks is gebruikt. Ter ondersteuning van deze interpretatie moet worden gezegd dat in Arubaanse ogen het Protocol in de praktijk weinig betekenis heeft gehad. Dit oordeel wordt gedeeld door de huidige premier Mike Eman (AVP) en zijn voorganger Nel Oduber, van de nu oppositionele MEP. Laatstgenoemde placht zijn Curaçaose collega's voor de voeten te werpen 'jullie hebben een eend gevraagd maar een konijn gekregen'. Wat minder bloemrijk maar even stellig menen ook Eman en de invloedrijke jurist en politiek adviseur van de AVP Mito Croes dat de autonomie die $\mathrm{Cu}$ raçao en Sint Maarten hebben verworven beperkter is dan die van Aruba. Overigens wijst Croes op andere beperkingen van de 'deal' die Aruba met de status aparte kreeg: deze was gekoppeld aan de onafhankelijkheid na tien jaar en ging niet gepaard met schuldsanering. ${ }^{13}$

Een andere kwestie betreft de verwachtingen die worden gehecht aan het functioneren van beide nieuwe landen. Over Curaçao is de toonzetting aan beide zijden van de oceaan betrekkelijk (Nederland) tot uitgesproken (Curaçao) positief. Aan Curaçaose zijde is de rede- 
nering uiteraard dat met het opheffen van de dubbele bestuurslaag niet alleen de complexiteit is verminderd, maar dat bovendien juist op dit eiland ruime bestuurlijke expertise en ervaring aanwezig is. Daar staat wel tegenover dat er kritiek is op de mate van zorgvuldigheid waarmee aan de vooravond van 10/10/10 de Nieuwe Bestuurlijke Organisatie (NBO) in grote haast en deels slechts op papier werd ingericht. ${ }^{14}$

Een stap verder gaat de vraag of Curaçao, ook na het elimineren van de dubbele bestuurslaag, werkelijk in staat zal zijn op eigen benen te staan als autonoom land binnen het Koninkrijk. Uiteraard was dit het uitgangspunt van de Antilliaanse onderhandelaars en de meesten beantwoorden ook nu deze vraag bevestigend. De rondgang langs betrokkenen in Nederland wees echter uit dat niet iedereen van deze bestuurlijke zelfredzaamheid overtuigd is. Er wordt, veelal off the record, gewezen op de politieke polarisering en het functioneren van het kabinet-Schotte als een risicofactor voor het nieuwe land $\mathrm{Cu}$ raçao. De mogelijkheid dat het Nederlandse medetoezicht via de consensusrijkswetten en plannen van aanpak voor langere tijd zwaar zal moeten blijven gelden, wordt regelmatig genoemd. Binnen de huidige coalitieregering bestaat juist het gevoel dat sterke Haagse bemoeienis zal leiden tot voortdurende en oplopende spanningen - Senior typeert het Koninkrijk zelfs als 'een rommelende en rokende vulkaan'. ${ }^{15}$

En hoe wordt op de andere eilanden teruggeblikt? Allereerst moet worden vastgesteld dat daar, en overigens ook in Nederland, vrij breed wordt gevoeld dat het onderscheid tussen Antilliaanse en $\mathrm{Cu}$ raçaose onderhandelaars gering was. Dit leidt her en der wel tot enige kritiek, maar de meesten lijken dit te hebben ervaren als onvermijdelijk en ook niet als zeer bezwaarlijk. Roy Hooker, onderhandelaar voor Sint Eustatius, stelt nuchter vast: 'De Antilliaanse regering was toch vooral Curaçao' - dat was inderdaad precies de kern van het eilandelijk separatisme. ${ }^{16}$ De landsregering moest de ontmanteling faciliteren, zo lijkt alom de grondhouding te zijn geweest, en voor de rest moest ieder eiland voor zichzelf opkomen. Aan Nederlandse zijde wordt wel opgemerkt dat daarmee Curaçao als vanzelfsprekend 'de beste deals' vroeg, en ook vaak kreeg.

Opmerkelijk is de kennelijk breed gedeelde twijfel over de levensvatbaarheid van Sint Maarten als autonoom land in het Koninkrijk. Aan Nederlandse zijde bestonden hierover van meet af aan grote twijfels - typerend is dat Remkes en ook De Graaf aanvankelijk het idee van een landsstatus voor dit (halve) eiland categorisch afwezen. Remkes is nog steeds sceptisch over de kans dat het land Sint Maarten zich zal kunnen waarmaken 'waar het gaat om fatsoenlijk bestuur en sociaal beleid'. Maar deze ambivalentie klinkt ook door bij de vier 
volgende bewindslieden, Thom de Graaf, Alexander Pechtold, Atzo Nicolaï en Ank Bijleveld. Ook zij menen dat de landsstatus van Sint Maarten nooit echt voor de hand heeft gelegen; Bijleveld had aanvankelijk liever op een 'BESS-constructie' aangestuurd, met Sint Maarten als vierde bijzondere gemeente. In alle gevallen wordt de keuze voor een landsstatus verdedigd met een beroep op enerzijds de noodzaak een oplossing te vinden voor het vastlopen van het Antilliaanse landsbestuur, anderzijds op de waarborgen die rond de nieuwe status van Sint Maarten werden getroffen. 'Het is een gok, maar alternatieven waren er gewoon niet', vat Pechtold het dilemma samen. ${ }^{17}$

Een van zijn voorgangers, minister van BZK (2000-2002) Klaas de Vries, bestrijdt dit nog altijd. Hij meent, onder verwijzing naar de kleine schaal, de problematiek van bestuurlijke integriteit en het feit dat voor het binationale eiland in de toekomst een Europese status kan worden ontwikkeld, dat de landsstatus van Sint Maarten een 'misverstand' was en dus 'beter niet had kunnen worden verleend'. ${ }^{18}$ Die opvatting werd, zoals duidelijk zal zijn geworden, tien jaar geleden nog vrijwel kamerbreed gedeeld.

Enkele maanden na de start van het land Sint Maarten op 10/10/10 begonnen ook Haagse parlementariërs, geconfronteerd met aanhoudende problemen rond de eilandelijke financiën en geruchten over bestuurlijke malversaties, zich al hardop af te vragen of directer Koninkrijksoptreden geboden was. Daarop reageerden de meeste voormalige Haagse betrokkenen nog afwijzend. De toenmalige voorzitter van de Vaste Kamercommissie NAAZ, Willibrord van Beek (VVD), had en heeft grote twijfels over de levensvatbaarheid van het land Sint Maarten, maar wijst ingrijpen af met het argument dat het nieuwe land en de akkoorden van 10/10/10 een kans moeten krijgen. Ook vreest hij dat Den Haag anders nog meer betrokken raakt-'Dat moet je echt niet willen', concludeert Van Beek stellig. ${ }^{19}$ Enigszins ontluisterend is het dat zelfs verschillende Curaçaose onderhandelaars achteraf hun twijfel uitspreken over het realiteitsgehalte van een apart land Sint Maarten. Soortgelijke geluiden worden ook op de BES-eilanden gehoord, waar onder meer Booi aangaf al vaker tijdens de onderhandelingen te hebben gezinspeeld op een viertal 'BESSeilanden'. ${ }^{20}$

Uiteraard wordt deze inschatting geenszins gedeeld door de meest betrokken bestuurders op het eiland zelf. ${ }^{21}$ Maar ook hun optimisme kan niet verhullen dat in Den Haag en vanuit door Nederlanders bevolkte ambtelijke organisaties op het eiland zelf met argusogen wordt gevolgd welk gebruik Sint Maarten van de nieuwe vrijheden maakt. Zo dringt zich het beeld op dat het eiland dan wel de stoot gaf tot de ontmanteling van de Nederlandse Antillen, maar zelf voorlopig en 
mogelijk voor langere tijd slechts beperkt zal kunnen functioneren als een autonoom land - en het beeld van Curaçao als de lachende derde. Theo Heyliger, lid en volgens sommigen achter de schermen sterke man van het eerste kabinet van het land Sint Maarten, schroomde onlangs niet om het strakke Haagse toezicht te karakteriseren als 'modern day slavery'. Hij - zelf telg uit een familie die eeuwen her tot de slavenhoudende elite van de Bovenwinden behoorde - maakt dan ook deel uit van de minderheid die streeft naar volledige onafhankelijkheid van zijn eiland, waar overigens bijna de helft van de geregistreerde stemgerechtigden niet is geboren. ${ }^{22}$

Blijft de vraag of Nederland achteraf tevreden is over het tot stand komen van de twee nieuwe landen. Ook hier weer gemengde gevoelens. Vrij algemeen wordt aanvaard dat het uiteenvallen van de Antillen onvermijdelijk was geworden en dat een verder uitstel hiervan bestuurlijk onverstandig zou zijn geweest. De kosten van de sanering van de Antilliaanse overheidsfinanciën roepen weinig kritiek meer op - een done deal. De belangrijkste twijfels draaien toch weer om de vraag of op andere gebieden niet te veel concessies zijn gedaan, altijd uitgaande van de twijfels of deze kleinschalige eilanden in hun riskante geopolitieke omgeving wel voldoende bestuurskracht kunnen opbrengen. ${ }^{23}$ Had Sint Maarten wel de landsstatus moeten krijgen? En zelfs Curaçao? Was het verstandig toch akkoord te gaan met afzonderlijke Openbare Ministeries en politiemachten? Had de migratiekaart harder kunnen en moeten worden gespeeld? Heeft Den Haag nu voldoende waarborgen in handen om deugdelijk bestuur desnoods af te dwingen? Is de kans voorbijgegaan om het Statuut inhoudelijk op werkelijk nieuwe leest te schoeien, zoals onder meer de VVD graag had gezien?

\section{Het experiment van Caraïbisch Nederland}

Tijdens de Toekomstconferentie van 1993 presenteerde Hirsch Ballin, in de vergeefse hoop de tegenstellingen te overbruggen, een 'synthesedocument', dat evenwel door de Antillen verontwaardigd van de hand zou worden gewezen. Interessant is wat in dit document aan Bonaire, Sint Eustatius en Saba in het vooruitzicht werd gesteld: '[Zij] zullen een in het Statuut door het Koninkrijk gegarandeerde positie behouden. [...] Bestuurlijk krijgen deze eilanden een rechtstreekse band met Nederland, wat overigens niet hoeft te betekenen dat alle Nederlandse wetgeving daar zonder meer van kracht wordt. ${ }^{24}$

Het is inmiddels duidelijk dat de aanvankelijk wederzijds gedragen optie van een rechtstreekse band of een associatie met Nederland 
uiteindelijk werd verdrongen door een model van integratie in Nederland in de vorm van openbare lichamen. In dit model is inderdaad de ruimte opengehouden dat niet alle Nederlandse wetgeving op de BES-eilanden direct van kracht wordt. Niettemin ging het uiteindelijke onderhandelingsresultaat verder in de richting van integratie, in tegenstelling tot associatie, dan het electoraat op de BES-eilanden had kunnen bevroeden toen het in 2004 of 2005 deelnam aan de eilandelijke referenda. ${ }^{25}$

Hoewel op elk van de drie eilanden een bestuurlijke meerderheid te vinden was voor de uitkomst van openbaar lichaam is de uitkomst omstreden, zeker op Bonaire, dat ook in de aanloop naar 10/10/10 al diep verdeeld was. De rondgang bij betrokkenen en ook de uitlatingen op en rond de laatste RTC, in september 2010, getuigen van een breed spectrum van gevoelens, van tevredenheid via enige twijfel tot spijt of boosheid. Het verbaast niet dat de verdeeldheid op Bonaire, bij monde van de eeuwige kemphanen Jopie Abraham en Ramonsito Booi, groot is gebleven. Laatstgenoemde, de grote pleitbezorger voor een directe band met Nederland 'We gaan niet meer via de paus [Curaçao], we gaan direct naar God [Nederland] ${ }^{26}$ - blikt overwegend tevreden terug op het proces en de resultaten. Wel heeft hij kritiek op onderdelen van de nieuwe regelingen. Booi vreest dat het voorzieningenniveau lager komt te liggen dan verwacht; ook is hij ontevreden dat Nederland in een laat stadium en tegen de afspraken in wetgeving over ethische kwesties - homohuwelijk, abortus, euthanasie - doordrukte. Niettemin is hij 'heel tevreden' over de kern van wat is overeengekomen: 'Nu kan ik de politiek met een gerust hart vaarwel zeggen.' Booi verwacht niet dat de evaluatie na vijf jaar tot een wezenlijke herziening zal leiden: 'Bonaire heeft over twintig en zelfs honderd jaar nog steeds deze status.'27

Abraham daarentegen blijft van mening dat Bonaire onnodig veel zeggenschap heeft afgestaan aan Nederland, terwijl daar bovendien teleurstellend weinig voor is teruggekregen. De BES-regeling is volgens hem 'een groot democratisch deficit: Bonaire is gewoon geannexeerd, ons eiland is verkwanseld!'. Nederland erkent de eigen Bonairiaanse waarden niet, veel van de Haagse financiële steun vloeit in Abrahams optiek terug naar de Nederlandse schatkist. Hij bekritiseert ook de andere eilanden, die niets voor Bonaire deden: 'Het was een Haags verdeel en heers, ieder voor zich.' Elders concludeerde hij: 'De positie van de BES-eilanden is in het gehele proces volkomen van ondergeschikt belang geweest.' Abraham zet tot op heden zijn oppositie onverdroten voort en waarschuwt voor heftige reacties ('makamba-haat') als reactie op wat hij omschrijft als onbetrouwbaar Nederlands optreden. Daarbij verwijst hij instemmend naar wat uit- 
gerekend de Nederlandse Rijksvertegenwoordiger Hans Gerritsen noteerde: 'Bonairianen, Statianen en Sabanen hebben de nieuwe staatkundige structuur niet in het hart gesloten. Veelgehoord zijn klachten over het verlies van de eigen cultuur, identiteit en cultuur. ${ }^{28}$

Op Saba en Sint Eustatius wordt eveneens ambivalent geoordeeld, al lijkt net als op Bonaire het algemene gevoel te zijn dat er de komende jaren nu eerst een periode van bestuurlijke rust zal aanbreken. Als bijzonder pijnlijk is wel ervaren dat het zo duidelijk Den Haag is dat uiteindelijk bepaalt welke in Nederland geldende bepalingen wel en welke niet van toepassing worden verklaard op de eilanden: niet een aantal voorzieningen in de sfeer van uitkeringen en salariëring, wel de wetgeving inzake abortus, euthanasie en het homohuwelijk. Roy Hooker (Statia) toont zich weliswaar 'niet honderd procent happy' met de uitkomst, maar hij is toch blij met de resultaten in de sfeer van onderwijs en financiën, in het bijzonder de sterke verhoging van de Nederlandse bijstand. Will Johnson (Saba) is veel kritischer, hij hekelt de 'koloniale' bestuurlijke regelgeving, de 'beledigende' inmenging in ethische wetgeving en de sterke verhoging van de belastingdruk. Beider kritiek richt zich ook op de wijze waarop de integratie in de praktijk uitpakt, waarbij de als sterk dirigistisch ervaren opstelling van Rijksvertegenwoordiger Henk Kamp wordt gehekeld. In meer algemene zin vrezen beiden een situatie waarin Bonaire de vroegere positie van Curaçao overneemt als dominante 'grotere broer'. ${ }^{29}$

Onder de voormalige Antilliaanse c.q. Curaçaose onderhandelaars is wel enig begrip voor de reserves op de drie kleinste eilanden en beduchtheid over heftige reacties. De Jongh-Elhage memoreert hoe zij

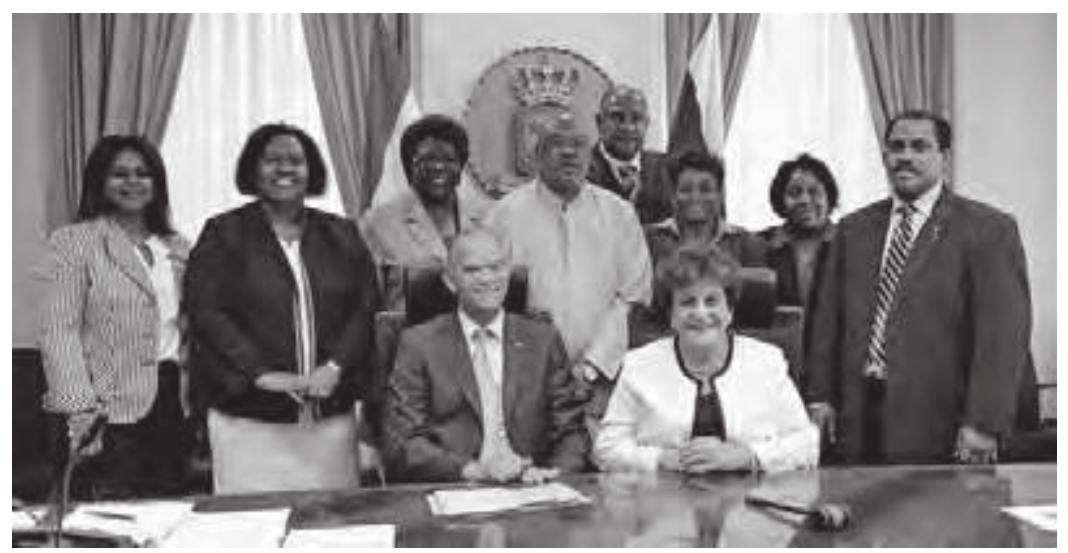

Het laatste kabinet van de Nederlandse Antillen: zittend Frits Goedgedrag en Emily de Jongh-Elhage; staand v.I.n.r. Judric Pietersz (secr.), Ersilia de Lannooy, Omayra Leeflang, Ronald Duncan, Magali Jacoba, Shamara Nicholson, Papito Thomas, Erny Simmons. 
Booi waarschuwde: 'Hiermee wordt je veel Nederlandser dan je wilt.' Ys vermoedt dat alle partijen erachter zullen komen 'dat te veel $\mathrm{Ne}$ derland ook niet goed is'. Adviseur Raymond Begina voorspelt zelfs een 'revolte', omdat Den Haag te uitdrukkelijk aanwezig zou zijn. Ook de Arubaanse adviseur Mito Croes meent dat Nederland op de BES-eilanden 'te hard van stapel is gelopen'. ${ }^{30}$

Aan Nederlandse zijde wordt wel voorzichtig de vraag gesteld of het wellicht beter zou zijn geweest wat meer terughoudendheid te betrachten bij het 'uitrollen' van het integratiemodel naar de 'BES'. De Raad van State stelde in zijn adviezen over de wetsvoorstellen vragen bij 'de mate van detaillering', waar 'maatwerk' geboden was. Hirsch Ballin bevestigt dat de stap van directe banden met naar integratie in Nederland afweek van de lijn die door de Raad van State - mede door hem - in de voorgaande fase was aanbevolen, maar in het onderhandelingsproces wellicht wat snel werd verlaten. ${ }^{31}$

Op Curaçao spreekt oud-gouverneur Jaime Saleh, eveneens staatsrechtjurist, dezelfde twijfels uit over wat hij beschouwt als een te weinig rekening houden met de lokale omstandigheden van de eilanden en het doordrukken van Nederlandse waarden en normen zonder rekening te houden met de gevoelens van de bevolking op de eilanden, zoals inzake abortus, euthanasie en homohuwelijk. Anderzijds ging de door sommigen voorgestane optie van vrije associatie hem een stap te ver omdat deze status volkenrechtelijk veel verder zou gaan dan de autonome status (status aparte) van Aruba, Curaçao en Sint Maarten. Over het doordrukken van de ethische wetgeving wordt zeer verschillend gedacht; Bijleveld vindt dit nog altijd ongelukkig, terwijl de liberalen Kamp, Nicolaï en Remkes het alleszins gerechtvaardigd achten. Er worden ook wel vragen gesteld bij de glanzende outillage van de Nederlandse bestuursgebouwen, die schril afsteekt bij de lokale voorzieningen. ${ }^{32}$

Niets wijst er intussen op dat Den Haag bereid zou zijn, of gedwongen zou kunnen worden, het nu gekozen model alweer aan te passen of zelfs maar ter discussie te stellen. Bijleveld verwacht 'dat de BES over tien jaar tevreden zullen terugkijken', ook al hebben ze op korte termijn misschien onderschat hoe sterk de Rijksdienst Caribisch Nederland zich zou doen gelden. Kamp verwacht dat het model goed zal werken 'mits de lokale bestuurders hun eigen taken goed uitvoeren en niet de confrontatie met Nederland zoeken'. ${ }^{33}$ 


\section{Schaken en domino}

De formule 'minder land = meer Nederland' hing van meet af aan boven de onderhandelingen. Het wegnemen van de bestuurlijke laag van het land de Nederlandse Antillen impliceerde dat het Koninkrijk, en daarmee Nederland, veel directer betrokken zou worden bij het bestuurlijke reilen en zeilen op elk van de eilanden. En daarmee ging het toch weer, als vanouds, om het oude spel van het vaststellen van de grenzen van de autonomie. Een spel waar voor de Antilliaanse spelers de belangen overigens onvergelijkbaar veel groter zijn. Waar in Den Haag het 'Antillen-dossier' slechts beperkt politiek gewicht heeft, wordt het optreden van Haagse politici en ieder bericht in de Nederlandse pers op de eilanden met argusogen gevolgd.

Hoe werd het spel gespeeld? De vaak aangehaalde metafoor van de Curaçaose schrijver Boelie van Leeuwen blijft hier treffend. Waar Haagse onderhandelaars de stukken klaarzetten voor een partijtje schaak, zo mocht Van Leeuwen graag zeggen, komen hun Caraïbische tegenspelers met dominostenen voor de dag. Er wordt een volstrekt verschillend spel gespeeld waar Nederlanders maar moeilijk grip op krijgen.

Het valt op dat vele betrokkenen aan Nederlandse zijde deze bevinding onderschrijven, met enige bewondering dan wel met duidelijke irritatie. Daarbij wordt vaak ook gewezen op de enorm grote onderhandelingsdelegaties, die door de veronderstelde delegatieleiders lang niet altijd in het gareel werden gehouden. De toenmalige DG Leon van Halder kwalificeert de Antilliaanse onderhandelaars als 'meesters op het onderhandelen op punten en komma's' - maar anderen oordelen minder welwillend. Zo schrijft Luc Verhey, destijds projectleider voor het hele wetgevingstraject bij Justitie, thans lid van de Raad van State, terugblikkend over de 'incremental approach' aan Antilliaanse zijde. Een 'deal' is nooit een vaststaande afspraak, maar 'uiteindelijk slechts een tussenstation op weg naar het einddoel. Eerder bereikte compromissen worden daarom steeds met een nooit aflatende volharding opnieuw ter discussie gesteld. In het jargon is deze werkwijze "terugonderhandelen" gaan heten. Nederland weet met deze tactiek vaak geen raad. Of het nu is uit desinteresse, uit neo-koloniale liefdadigheid, uit vermoeidheid of uit wanhoop, Nederland heeft in bijna elke fase concessies gedaan ten opzichte van het eerder bereikte compromis. ${ }^{34}$

Aan Haagse zijde zijn de verwijzingen naar Antilliaans 'terugonderhandelen' inderdaad legio. Van Beek spreekt van een 'volstrekt andere onderhandelingscultuur', Kamp van 'ongekend grote verschillen in bestuurlijke cultuur' - waarbij van Halders voorganger Jan-Paul 
Dirkse als keerzijde een 'soms op misplaatste postkoloniale schuldgevoelens gestoelde toegevendheid' van Haagse bewindslieden signaleert. Daarbij zal het ongetwijfeld een rol hebben gespeeld dat aan Nederlandse zijde het accent sterk lag op de ambtelijke inbreng, terwijl op de Nederlandse Antillen en de afzonderlijke eilanden het sterk politieke karakter van de onderhandelingen zijn weerslag had op de (zeer ruime) samenstelling van de delegaties - twee belevingsniveaus die slecht op elkaar pasten, zo constateerde de Raad van State. ${ }^{35}$

Interessant is hoe de opeenvolgende bewindslieden dit ervoeren. Remkes bevestigt het beeld van voortdurend terugonderhandelen, waardoor er van Haagse zijde voortdurend de neiging bestond te veel water bij de wijn te doen. Pechtold herkende de politieke cultuur uit zijn eerdere ervaring met de lokale politiek: 'Er is veel ketelmuziek, vooral voor de eigen publieke tribune. Toch kun je alles met Antilliaanse bestuurders bespreken, mits je maar respect uitstraalt en bereid bent je tegenspeler publiekelijk wat te laten scoren.' Nicolaï ziet het Antilliaanse 'terugonderhandelen' als een ongewenst maar ook wel 'briljant inspelen op onze zwakheden'; hij benadrukt juist dat het niveau van politiek bedrijven op de Antillen 'opmerkelijk hoog' ligt - er wordt tactisch slim en hard gespeeld, de uitkomst is onvoorspelbaar, hangt uiteindelijk primair af van de onderlinge verstandhouding. Hirsch Ballin kwalificeert de Antilliaanse onderhandelingskunst eveneens in deze zin; toch waardeert hij ook 'de knipoog als je stevig onderhandelt zonder echt tegenover elkaar te komen staan'. Bijleveld, ten slotte, benadrukt dat haar mantra 'afspraak is afspraak' mede een antwoord beoogde te zijn op dat 'achteruitonderhandelen'. Ook zij stelt dat, zeker in tijden van hoogoplopende spanningen, het zaak was publiekelijk alle respect te betonen aan de Antilliaanse 'tegenspelers'. ${ }^{36}$

Verhey gaat in zijn kritiek overigens verder. Hij meent dat het hele proces getuigde van 'grote onvolwassenheid', waarbij de Caraïbische onderhandelaars maar niet loskwamen van een angstvallige verdediging van de autonomie en tegelijkertijd een afhankelijke opstelling, gericht op financiële steun 'zonder een ruimhartig commitment aan tastbare tegenprestaties'. Daartegenover onderscheidde Den Haag, nog altijd in Verheys woorden, zich door 'inconsistentie, een gebrek aan inlevingsvermogen en afwezigheid van werkelijke belangstelling', te beginnen met het niet controleren of afspraken ook werkelijk werden nageleefd. ${ }^{37}$

Zo hard wordt het door de betrokken Nederlandse bewindspersonen niet geformuleerd, althans niet openlijk. Zonder uitzondering beamen zij dat zij concessies deden om het proces maar in gang te houden, maar daarbij toch altijd een zekere ondergrens bewaakt te 
hebben: er werd niet te veel 'weggegeven'. Bijleveld omschrijft haar opstelling als 'Strak op de inhoud, soepel op het proces', waarbij de mantra 'afspraak is afspraak' uitdrukkelijk voor alle partijen moest gelden. In deze context fungeerden deadlines, zelfs waar die mogelijk niet geheel realistisch leken, om maar het tempo in het proces te houden - en het 'terugonderhandelen' tegen te gaan. ${ }^{38}$

Het behoeft geen betoog dat hierover aan Caraïbische zijde geheel anders wordt geoordeeld. Het eigen optreden wordt daar impliciet positief gewaardeerd door de onderhandelaars zelf, die de door Den Haag als hinderlijk ervaren incremental approach juist zien als strategisch sterke vasthoudendheid. Er is veel kritiek op de bewindslieden Gijs de Vries en Remkes, die als rigide werden ervaren; ambivalentie over het optreden van meer 'meedenkende', maar toch nog als streng ervaren bewindslieden als De Graaf, Pechtold en Hirsch Ballin; en vooral veel waardering voor Bijleveld en Jan Peter Balkenende.

Vergelijkbaar is de waardering op de eilanden van de betrokken Haagse ambtenaren: negatief over de ambtelijke top in de eerste jaren, over de opvolgers steeds positiever omdat die het proces faciliteerden. Opmerkelijk is daarbij de breed gedeelde, en mogelijk niet onjuiste perceptie dat aan Nederlandse zijde vaak een spelletje good cop/bad cop werd gespeeld, waarbij vooral directeur Koninkrijksrelaties Gea van Craaikamp vaak (al dan niet met overtuiging) de ondankbare rol van houwdegen speelde, terwijl Bijleveld en ook DG Van Halder een tegemoetkomender houding innamen. In de slotfase was Van Craaikamp van het toneel verdwenen; haar opvolger Hans Gerritsen gaf leiding aan de directie - die inmiddels geheel gericht was op het halen van de deadlines en dan ook door de Antilliaanse betrokkenen positief wordt gewaardeerd. ${ }^{39}$

De lokale oppositie daarentegen meent dat er niet hard genoeg is onderhandeld, dat te veel Nederlandse eisen zijn ingewilligd en dat dus kennelijk het door Nederland zo gehekelde 'terugonderhandelen' helemaal niet zoveel heeft opgeleverd. Daarom spreekt Abraham op Bonaire bitter over het 'inpalmen' door Den Haag en mort Wiels dat Curaçao zich heeft laten inpakken. Hij legt daarbij als een van de zeer weinigen ook een verband met het feit dat alle onderhandelingen altijd in het Nederlands werden gevoerd, voor vrijwel alle Antillianen de tweede taal. Dat leidde, meent Wiels, tot tactische fouten aan Antilliaanse zijde. 'Nederland heeft een van de belangrijkste mind games gespeeld: de taal.' Ook de nauw betrokken adviseurs Larmonie en Römer menen dat Nederland zich eerder te hard dan te meegaand opstelde. $^{40}$

Opvallend is dat aan beide zijden de stellige perceptie leeft dat zich in het vierde kabinet-Balkenende een tegenstelling aftekende tussen 
de staatssecretaris op BZK en de minister van Justitie. Waar Bijleveld zich steeds uitdrukkelijker procesgericht opstelde, zou Hirsch Ballin langer hebben vastgehouden aan de inhoud, namelijk strengere regelgeving en waarborgen. Uiteindelijk prevaleerde de pragmatische benadering van Bijleveld, mede dankzij de 'onvoorwaardelijke steun' die zij kreeg van minister-president Balkenende. Deze observatie wordt door vele betrokkenen gedeeld. Ook Hirsch Ballin onderschrijft deze interpretatie, waarbij hij aantekent dat hiermee wel enige risico's voor de toekomst zijn genomen, maar dat hij met het oog op de eenheid van het regeringsbeleid - anders dan in 1993 het geval was, toen het Haagse front zich splitste - consequent het beleid van Bijleveld ondersteunde. ${ }^{41}$

Het verwondert niet dat ook achteraf bij de betrokkenen op het ministerie van Justitie en zeker ook bij de toenmalige Haagse politieke oppositie de kritiek op de procesmatige aanpak is gebleven. Aan die zijde heerst de overtuiging dat Nederland hardere eisen had kunnen en moeten stellen, en dat vanuit BZK alles te sterk ging draaien om het halen van de deadline. Die kritiek wordt vooral in kringen van de VVD gedeeld. Remkes is hierover duidelijk: de onder zijn partijgenoot Nicolaï getekende Slotverklaring was uitstekend en kon dus ook kamerbreed worden ondersteund; in de hierop volgende vier jaar werden, de bezwaren van de nu oppositionele VVD ten spijt, onnodig veel concessies gedaan. Deze zienswijze wordt gedeeld door Remkes' voorganger Klaas de Vries, die het proces ook als parlementariër volgde. Ook deze sociaaldemocraat hekelt het 'gebrek aan doortastendheid' aan Nederlandse kant, wat het proces in zijn visie te langdurig maakte en leidde tot onnodige concessies in de sfeer van garanties voor deugdelijk bestuur en rechtshandhaving. ${ }^{42}$

Bijleveld en Balkenende denken daar uiteraard anders over. En inderdaad, wat het alternatief was geweest als de deadline niet was gehaald, is volstrekt onduidelijk, zeker gezien de polarisatie die zich aan beide zijden van de oceaan is gaan aftekenen. Maar het moet gezegd, er speelde ook een ijzeren politieke logica. Was 10/10/10 niet gehaald, dan was het staatssecretariaat van Bijleveld achteraf als mislukt gekwalificeerd; nu kon zij met recht claimen haar belangrijkste beleidsdoel voor de poorten van de hel te hebben weggesleept.

In die zin lijkt er zelfs bij veel critici wel sprake te zijn geweest van een zekere opluchting dat het proces kon worden afgesloten en op 10/10/10 een nieuwe start werd gemaakt. Gaandeweg waren aan alle kanten de emoties hoog opgelopen en was ook wel gewanhoopt over de goede afloop - Bijleveld somt de diepe twijfels direct op: toen de Curaçaose eilandsraad alsnog de Slotverklaring verwierp, toen Bonaire onverwachts ging dwarsliggen, toen Sint Maarten nieuwe conces- 
sies eiste, toen het vierde kabinet-Balkenende demissionair werd... ${ }^{43}$

Steeds weer leek, ondanks al die als 'historisch' aangeprezen akkoorden, het proces vast te lopen, steeds weer verslechterde dan de sfeer en steeds weer moest dan het uiterste worden gedaan om opnieuw on speaking terms te komen. Dat dit lukte, wordt door velen mede toegeschreven aan een inderdaad opmerkelijke karakteristiek van het vierjarige eindspel: de dominantie van vrouwen die, naar eigen zeggen, wat gemakkelijker over hun eigen schaduw heen konden springen dan de heren die voorheen de onderhandelingen bepaalden. 'Je kunt niet alles willen, je moet geven en nemen. Mannen blijven vaak ergens in hangen', meent Zita Jesus-Leito, de Curaçaose gedeputeerde en vertrouwelinge van De Jongh-Elhage. Sarah WescottWilliams sluit zich daarbij aan. Ook adviseur en voormalig voorzitter van de voorbereidende RTC Raymond Begina, die het hele proces aan Antilliaanse zijde een decennium lang meemaakte, bevestigt deze visie. Natuurlijk was De Jongh-Elhage uitstekend in haar public relations richting Nederland, een knap charmeoffensief. Maar er konden ook goed zaken en dus ook concessies worden gedaan. 'Op Curaçao hebben de dames de leiding, zij stralen commitment uit. Mannen hebben een grote bek maar vrouwen regelen de zaken.' Begina's nadruk op het cruciale belang van 'relatiemanagement' komt dicht bij Nicolaïs benadrukking van het belang van goede onderlinge relaties. ${ }^{44}$

Op de achtergrond van deze politieke processen speelden voortdurend ook electorale zorgen. Hier lijkt een duidelijk patroon zichtbaar.

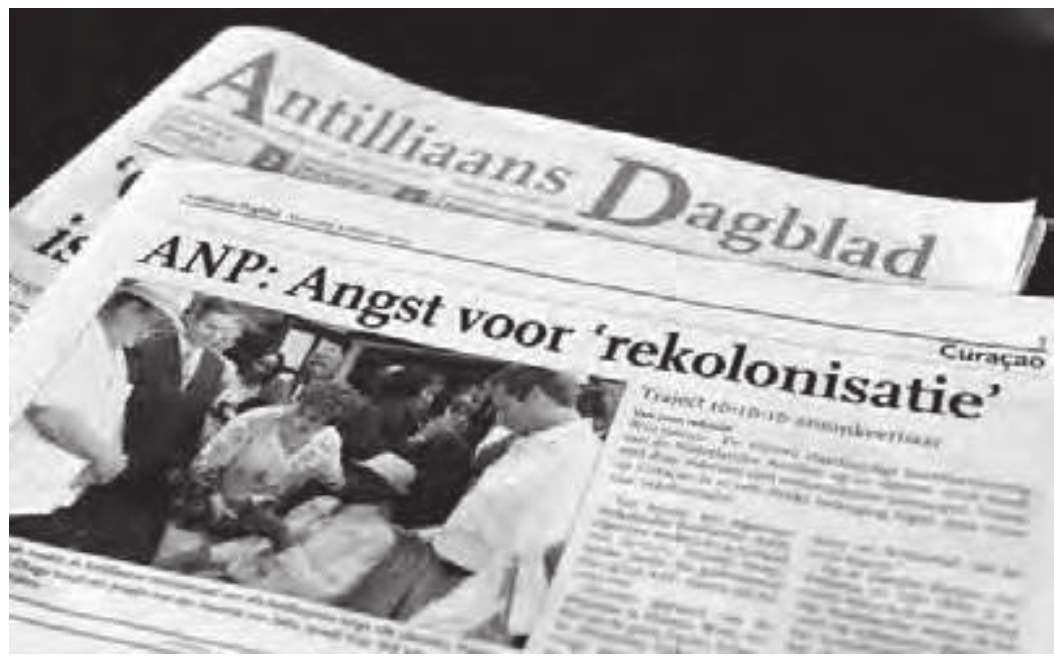

Op 4 oktober 2010, nog geen week voor de magische datum 10/10/10, kopt het Antilliaans Dagblad dat op de eilanden zorgen leven over 'rekolonisatie'. 
Aan Haagse zijde leidde het bewustzijn van groeiende maatschappelijke en ook politiek gearticuleerde weerstand tegen (Antilliaanse) migratie en ondersteuning van de Antillen niet zozeer tot een hardere bestuurlijke opstelling, maar juist tot het streven het proces zo snel mogelijk af te ronden - en dus tot compromisbereidheid. Groeiende weerstand op de eilanden tegen wat werd gezien als een te veel toegeven aan Haagse eisen bracht de Antilliaanse onderhandelaars, vooral die op Curaçao, er juist toe om concessies van Den Haag te vragen. Die werden meer dan eens ingewilligd om maar de val te voorkomen van de Antilliaanse partners, in het bijzonder de PAR. En zo werden ooit 'harde' onderhandelingspunten als de aanwijzingsbevoegdheid van de Nederlandse minister van Justitie op Koninkrijksniveau of een migratieregeling door Den Haag zelf van tafel gehaald.

Dus werd Den Haag toegevender tegenover Curaçao, en ook wel Sint Maarten, om het proces maar niet in gevaar te brengen. Dat het kabinet-Rutte na 10/10/10 omzichtig afstand hield van de nieuwe landen en vragen uit het parlement over de mogelijke noodzaak van ingrijpen afwimpelde, getuigt wellicht van eenzelfde pragmatische inslag. Maar daar waar de lokale oppositie niet sterk werd gearticuleerd of waar er al geen weg terug meer was, bleef Nederland op de eigen koers. En zo kon het gebeuren dat de BES-eilanden zich uiteindelijk juist geconfronteerd zagen met een invulling van hun nieuwe status die veel meer Nederlandse betrokkenheid impliceerde dan zij hadden verwacht of verkozen.

Hetgeen allemaal niet wegneemt dat veel van de Haagse terugblikken 'een algemene geest van trots en tevredenheid dat het gelukt is' (Van Beek) ademen die vooral te verklaren lijkt uit de opluchting dat er eindelijk knopen zijn doorgehakt en een nieuwe start kon worden gemaakt. Bijleveld formuleert het zakelijk, 'De uitkomst was maximaal qua inhoud.' Pechtold zegt het bloemrijker; hij 'kan geen superlatieven genoeg vinden om het hele proces te betitelen, zoals dat tot een einde is gebracht: een rimpelloze, majeure staatkundige hervorming'. Kamp zegt het juist zuinig: het is goed dat het proces tot dit einde is gebracht, maar 'voor alle eilanden is nu de grens wel bereikt, wat Nederland betreft'. ${ }^{45}$

Bij dit alles wordt soms wellicht wat gemakkelijk over het hoofd gezien dat de kunst van het 'terugonderhandelen' Den Haag niet helemaal vreemd is. Van Antilliaanse zijde wordt bijvoorbeeld wel gewezen op het steeds maar weer opdiepen van het migratiedossier. Maar ook dat het parlement, tegen het advies van Bijleveld in, te elfder ure ethische wetgeving voor de BES oplegde, werd op de eilanden als een onaangename verrassing ervaren: dat was toch niet afgesproken? En dat de Tweede Kamer, alweer bij het sluiten van de markt, het al bijna 
uit beeld verdwenen RST alsnog weer op het schild verhief was een grote tegenvaller voor Curaçao en Sint Maarten - wellicht vermoedde het parlement niet ten onrechte dat dit ingrijpen ook Bijleveld wel goed uitkwam.

\section{Een nieuwe visie op het gedeelde Koninkrijk?}

Het trans-Atlantische Koninkrijk der Nederlanden is in meerdere opzichten een gedeeld Koninkrijk. Het is gedeeld in de zin van opgedeeld, tussen een Europees en een Caraïbisch deel, constitutioneel nu nog verder opgedeeld binnen de Caraïben. Het is verdeeld, omdat er sprake is van grote materiële en immateriële verschillen tussen de delen van het Rijk - wat weer leidt tot veelvuldige polarisatie, 'de tragiek van het Koninkrijk'. ${ }^{46}$ Maar het is ook gedeeld in de zin van gemeenschappelijk, te beginnen met het Nederlandse staatsburgerschap zoals dat in het Statuut verankerd ligt, maar ook in de sfeer van een gedeeld verleden en sterke persoonlijke relaties over en weer.

De laatste jaren werd onder meer vanuit het Nederlandse parlement weer gevraagd om een nieuwe visie op het Koninkrijk. Uitdrukkelijk is ook Aruba onder minister-president Mike Eman daarbij betrokken, zelfs als 'trekker'; de Arubaanse regering presenteerde eind 2010 al een visiedocument. Aan Nederlandse zijde heeft staatssecretaris Bijleveld enkele 'Koninkrijkssymposia' georganiseerd om de discussie op gang te brengen. Al snel bleek, in de woorden van haar DG Andrée van Es, 'dat het lastig is om gezamenlijke waarden te benoemen, die de eilandgebieden en landen delen'. Zelf kijkt Bijleveld ook met enige scepsis terug op de Koninkrijkssymposia. ${ }^{47}$

De huidige minister van BZK Piet Hein Donner - die uiteraard in zijn vorige ambtsperiodes als minister van Justitie (2002-2006) en Sociale Zaken en Werkgelegenheid (2007-2010) ook bij de Koninkrijksrelaties betrokken was - lijkt een zekere reserve tentoon te spreiden als het om vergezichten gaat. 'We kunnen', zo merkte hij op naar aanleiding van de af en toe stekelige stemming binnen het Koninkrijk na 10/10/10, 'nog even doorgaan met elkaar op luide toon verwijten maken, maar het beperkt de opties en brengt het moment van definitief uiteen gaan sneller dichtbij.' 'De liefde moet van twee kanten komen', benadrukt Donner; als de onderlinge verhoudingen niet verbeteren wordt ontbinding van het Koninkrijk 'onvermijdelijk'. Gelijktijdig geeft hij aan dat elk van de eilanden eerst maar eens zelf een antwoord moet vinden op de vraag 'Wat willen met het Koninkrijk?'. ${ }^{48}$

De roep om een nieuwe visie reflecteert de ambitie om de juridisch bestaande gemeenschappelijkheid ook in andere opzichten beter 
vorm te geven - want vrij algemeen overheerst de indruk dat er op dit moment nauwelijks sprake is van een gevoel van verbondenheid tussen de burgers aan beide zijden van de Atlantische oceaan. Het is de vraag wat het langdurige proces dat uiteindelijk leidde tot 10/10/10 heeft gedaan voor het creëren van meer gemeenschappelijkheid. Daarover wordt verschillend gedacht. Lopende de onderhandelingen was steeds weer sprake van fundamentele verschillen van inzicht en stijl. Tegenstellingen kwamen onverbloemd op tafel; er vielen harde woorden en er wordt achteraf nog altijd scherp geoordeeld over 'de ander'. Maar toch overheerst onder de partijen die tot op het laatst betrokken waren bij de onderhandelingen het tevreden gevoel dat gezamenlijk is gezocht naar aanvaardbare compromissen en dat het onderlinge begrip allengs groeide. Harde kritiek komt, niet verwonderlijk, vooral van partijen die toen het erop aankwam buiten spel stonden. Dat is vanuit een oogpunt van cohesie zorgelijk. De tweedeling in de Curaçaose politiek en in zekere zin ook samenleving rond de relatie tot Nederland is een onverhoopte en bittere vrucht van het proces van ontmanteling. Ook op de BES-eilanden leidde de integratie tot interne spanningen en een zekere animositeit richting Nederland.

Dit maakt de ontwikkeling van een positieve visie op het Koninkrijk temeer urgent. Maar die visie ligt er nog niet. Daar was het hele proces van ontmanteling van de Nederlandse Antillen en hervorming van het Koninkrijk ook niet op gericht. Voor zover er een Nederlandse visie achter dit hele proces te ontwaren is, lijkt die voornamelijk een geest van pragmatisme te hebben geademd: versterking van het Koninkrijk als consequentie van het bestendigen van de Koninkrijksrelaties, de onvermijdelijk geworden opdeling van de Antillen aangrijpen ter verbetering van de kwaliteit van bestuur. Aan Antilliaanse zijde lagen aan het separatisme, naast pragmatische overwegingen, wel immateriële factoren ten grondslag, namelijk een insulair gericht nationalisme. Dit betekende dus in de Caraïben zelf, net als de eerdere status aparte van Aruba, een vermindering van onderling gevoelde en gewaardeerde gemeenschappelijkheid.

Hoe nu de gemeenschappelijkheid binnen het Koninkrijk te versterken? Er is veel gesproken en geschreven over de mogelijkheid dit te doen door het zogenaamde democratisch deficit van het Koninkrijk weg te nemen of te verzachten. In het tweede hoofdstuk is al aangegeven dat dit een moeizaam proces is; de vraag is bovendien of staatsrechtelijke ingrepen uiteindelijk erg relevant zijn voor het bevorderen van gemeenschappelijkheid. De onmiddellijk volgende vraag is wat dan wel zou kunnen werken, wat een wervende toekomstvisie kan zijn en of er aantrekkelijke alternatieven zijn voor de nu ingeslagen weg. 
Allereerst het democratisch deficit. Het probleem is duidelijk: er is onvoldoende constitutionele legitimatie van de hoogste organen van het Koninkrijk. Het meest in het oog springt uiteraard dat de Koninkrijksregering niet wordt gecontroleerd door een corresponderend Koninkrijksparlement. De afgelopen decennia zijn allerlei voorstellen gedaan om dit democratisch deficit te verminderen, maar dit heeft niets opgeleverd. De kern van de zaak is toch dat de verschillen in schaal en macht zo enorm groot zijn. Dat voor majeure constitutionele veranderingen in Den Haag geen politieke steun bestaat, verbaast niet. Daar wordt nuchter gesteld dat de schaalverschillen nu eenmaal bepalend zijn. De Graaf, inmiddels als senator weer betrokken bij de Koninkrijksrelaties, typeert het zoeken naar een oplossen van het democratisch deficit en naar een gezamenlijke toekomstvisie als een ritueel, een 'zoeken naar de Heilige Graal'. Nicolaï wijst erop dat dit 'deficit' onder de nieuwe verhoudingen, op grond van een democratisch verlopen proces, zelfs groter is geworden, gezien de versterking van de rol van Nederland (voor de BES-eilanden), dan wel de Rijksministerraad. ${ }^{49}$

Het verbaast niet dat onder de Curaçaose politici die geloven in onafhankelijkheid van hun eiland de discussie over het democratisch deficit als zinloos wordt afgedaan. Senior vat het bondig samen: 'Het democratisch deficit is niet opgelost en kan ook niet worden opgelost, behalve door onafhankelijkheid.' Opmerkelijk is dat uit een rondgang op de eilanden blijkt dat, een uitzondering als De Jongh-Elhage daargelaten, veruit de meeste Caraïbische bestuurders weinig geloof en geen prioriteit hechten aan het 'repareren' van het democratisch deficit. Booi vindt het 'je reinste onzin, want je probeert twee dingen die totaal niet in evenwicht zijn in evenwicht te brengen'. Terugblikkend herinneren Antillianen van de andere eilanden eraan dat voor hen het werkelijke 'deficit' lag in de relatie met Curaçao, niet met Nederland. ${ }^{50}$

Daar staan de principiële bezwaren van nauw betrokken Curaçaose prominenten als Jesus-Leito en Römer tegenover. ${ }^{51}$ Het ligt niet voor de hand dat hun voorstellen voor 'reparatie' van het deficit veel steun zullen vinden. Meer kansrijk lijken pragmatische voorstellen om de implicaties van het democratisch deficit althans te verkleinen. Zo wordt nog gewerkt aan een transparante geschillenregeling, waarbij mogelijk de Hoge Raad of de Raad van State van het Koninkrijk als arbiter zou kunnen optreden. En nog altijd is er het voorstel van de werkgroep-Jesurun, het Comité 2004 en de Raad van State om te komen tot een secretariaat van het Koninkrijk. Hierover wordt op de eilanden overwegend positief geoordeeld, waarbij vaak wordt verwezen naar de in het proces als meer neutraal ervaren rol van het ministerie van Algemene Zaken onder Balkenende. Een apart Koninkrijkssecre- 
tariaat onder Az zou, zo is de redenering, de Koninkrijksregering versterken en daarmee meer gemeenschappelijkheid kunnen brengen.

In Nederland is er steeds sprake geweest van vrij ruime parlementaire steun voor zo'n Koninkrijkssecretariaat, zonder dat dit tot concrete stappen leidde. De motie Leerdam, die de regering verzocht om 'nog in 2010 in nauwe afstemming met de overzeese partners een besluit te nemen over het al dan niet in het leven roepen van een secretariaat van het Koninkrijk' is zonder vervolg gebleven. ${ }^{52}$ Het heeft er, zoals eerder aangegeven, alle schijn van dat opeenvolgende kabinetten, en zeker ook de ambtelijke diensten, hier weinig voor voelden. Dat is niet verwonderlijk, gezien het streven naar efficiency en transparantie in de departementale taakverdeling. Het ministerie van BZK behartigt expliciet de Nederlandse belangen in de Koninkrijksrelaties, AZ is notoir wars van uitbreiding van zijn strak gedefinieerde kerntaken. Onderbrenging van een Koninkrijkssecretariaat bij een van de 'Koninkrijksministeries' (Buitenlandse Zaken of Defensie) zou hoogstwaarschijnlijk ook aan Antilliaanse kant op weerstand stuiten, gegeven de nooit afwezige argwaan dat Den Haag toch nog streeft naar afstoting van de eilanden. Blijft toch over de optie van een Koninkrijkssecretariaat onder de hoede van AZ of eventueel, minder sterk verankerd, onder de Raad van State.

Met of zonder een Koninkrijkssecretariaat zal het de komende jaren een opgave blijven om niet slechts de uitvoering van de akkoorden achter 10/10/10 te bewaken, maar ook te trachten een langetermijnvisie voor het Koninkrijk gestalte te geven. Minister van BZK Donner nam deze erfenis over van zijn voorgangster Bijleveld, naar het schijnt met enige, begrijpelijke, scepsis. Niettemin bood Donner medio 2011 de Tweede Kamer een notitie 'De toekomst van het Koninkrijk' aan. Voorafgaand aan een summiere bespreking van deze notitie is een wat bredere en niet door politieke overwegingen beperkte verkenning van belang.

Wat zijn de elementen voor de ontwikkeling van een breed gedragen visie op het Koninkrijk? In de rondgang langs hoofdrolspelers viel het op hoe vaak het gesprek, als hiernaar werd gevraagd, stokte of in algemeenheden verzandde. Dat is niet verwonderlijk. De kern van de Koninkrijksrelaties is niet dat de verschillende delen ervan vandaag bij elkaar zijn op grond van een bewuste afweging van wederzijdse belangen en een onderling sterk ervaren verbondenheid, maar omdat er nu eenmaal constitutionele banden zijn die Nederland eeuwen geleden ongevraagd creëerde en nu niet kan slaken. De meest intensieve koppeling tussen de delen van het Koninkrijk is de onderlinge migratie; maar precies die menselijke brug wordt in Nederland eerder als een last dan als een lust ervaren. 
Gevraagd naar de kern van de gezamenlijkheid voor de toekomst benadrukken Antillianen in de regel allereerst de geschiedenis 'die ons nu eenmaal met elkaar verbindt', vervolgens vaak de belangen die Nederland zou hebben bij het bestendigen en verder ontwikkelen van de Koninkrijksrelaties. Graag wordt daarbij dan het argument gebruikt dat de Antillen kunnen fungeren als hub voor het Nederlandse bedrijfsleven - 'zoiets wil iedereen hebben', meent De Jongh-Elhage. Dit argument is de afgelopen decennia van Antilliaanse zijde voortdurend naar voren gebracht - overigens ook door de minderheid van politici die actief streven naar onafhankelijkheid, zoals Wiels. ${ }^{53}$

De werkelijkheid is echter dat grote Nederlandse bedrijven als Shell of ABN-AMRO zich al lang hebben teruggetrokken en dat, voor zover het Nederlandse bedrijfsleven al interesse heeft in landen in de Caraibische regio of onmiddellijke omgeving, er nauwelijks meer behoefte is aan 'eigen' gateways: de moderne technologie en de globalisering van markten hebben de voorheen inderdaad belangrijke voordelen van fysieke nabijheid geminimaliseerd. De Arubaanse minister-president Eman wijst erop dat zijn partij al jaren pleit voor een strategisch partnership tot wederzijds voordeel - 'Het Koninkrijk kan niet alleen op basis van piëteit voortbestaan, placht mijn broer [en voormalige premier] Henny Eman te zeggen. ${ }^{54}$ Maar ook dan blijft het een vraag of het concrete Nederlandse voordeel van de relatie werkelijk opweegt tegen de kosten.

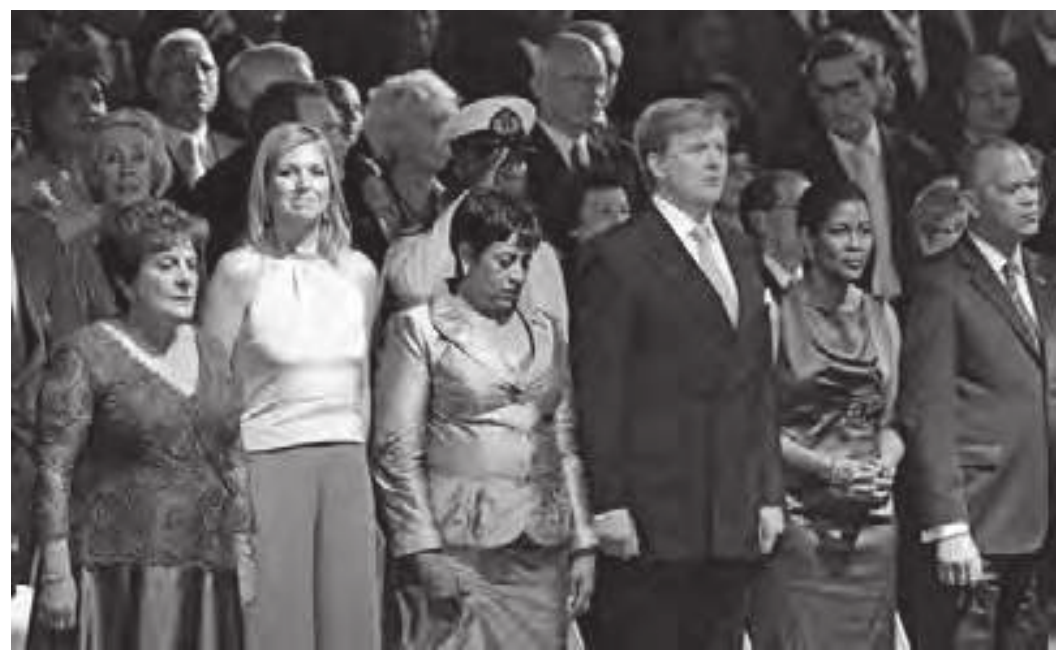

Ceremonie bij het strijken van de vlag van de Nederlandse Antillen, Willemstad, 9 oktober 2010; v.l.n.r. Emily de Jongh-Elhage, prinses Máxima, Liza Dindial, kroonprins Willem-Alexander, Dulcie Goedgedrag-Terborg, Frits Goedgedrag. 
Geopolitieke voordelen dan? Frankrijk ziet die zeker, vandaar het handhaven en investeren in zijn départements d'outre-mer verspreid over de hele wereld. ${ }^{55}$ Het Verenigd Koninkrijk en Nederland redeneren echter pragmatischer, wellicht minder fantasierijk. Het feit dat het Koninkrijk der Nederlanden zich uitstrekt tot de Caraïben en dat Nederland daar sinds 10/10/10 zelfs eigen pseudogemeenten heeft, impliceert een breder internationaal profiel dan wat een Europees land zonder zulke resten van een koloniaal imperium kan hebben. Dat betekent dat de (Koninkrijks)regering in deze regio wat intensiever te maken heeft met regionale grootmachten als de Verenigde Staten, Venezuela, Colombia, Frankrijk en het Verenigd Koninkrijk dan anders het geval zou zijn geweest. Dat laat 'Nederland' wat zichtbaarder zijn in de internationale arena, geeft ruimte voor nauwe samenwerking met en daardoor waardering door de Verenigde Staten, en maakt de Koninkrijksbanden belangrijk voor de ministeries van $\mathrm{AZ}$, BZ en Defensie. Die afweging klinkt dan ook weer door in de beoordeling van de internationaal georiënteerde Nicolaï - maar dat alles in een regio waar Nederland geen grote economische of strategische belangen heeft. Beleidsnotities van het ministerie van Buitenlandse Zaken kunnen dit laatste niet verhullen, en proberen dat ook niet. ${ }^{56}$

Evenmin wordt de migratie als een breed gedeeld belang gedefinieerd. Van Caraïbische zijde wordt consequent het recht op vrije toegang tot en vestiging in Nederland verdedigd, al dan niet op basis van wederkerigheid. ${ }^{57}$ Maar nergens wordt de visie verdedigd dat het Antilliaanse recht op vrije migratie naar de overzijde van de oceaan ook een Nederlands belang is. En omgekeerd wordt in Den Haag, hoezeer de meningen ook verschillen over migratierestricties en integratiekwesties, het ontstaan van een Antilliaanse gemeenschap in Nederland zelden betiteld als een Nederlands belang.

De bestendiging van het trans-Atlantische Koninkrijk wordt, kortom, aan Nederlandse zijde zelden beschouwd als een kwestie van eigenbelang, ook al wordt op de eilanden door velen, van uiteenlopende politieke signatuur, het tegendeel verdedigd, namelijk de stelling dat ook Nederland profiteert van de Koninkrijksbanden. In dit verband stelt Kamp onomwonden: 'Spreken van "rekolonisatie" is onzin. Het is een voorrecht voor de eilanden om bij Nederland te mogen horen!' Dat is zeer waarschijnlijk ook de mening van de meeste Nederlanders, afgaande op opiniepeilingen van de afgelopen decennia. ${ }^{58}$

Zeker is dat nog altijd vrijwel alle bestuurders op de zes eilanden, hierin ondersteund door het overgrote deel van de bevolking, het voortbestaan van het Koninkrijk ('a gift from God', aldus De JonghElhage) als een kwestie van groot belang zien voor de Antillen. In die zin is het afgelopen decennium niets veranderd en blijven de eilanden 
passen in een breder Caraïbisch beeld: non-soevereiniteit wordt om pragmatische redenen omhelsd, hoeveel ambivalentie en zelfs rancune er ook mogen bestaan over de koloniale geschiedenis, de slavernij en de hedendaagse afhankelijkheid. Als er al over onafhankelijkheid wordt gesproken, bijvoorbeeld door Jesus-Leito voor Curaçao of Wescott-Williams voor Sint Maarten, dan ligt die in een verre toekomst. ${ }^{59}$

Alleen voorstanders van volledige onafhankelijkheid op kortere termijn als Wiels en andere prominenten uit de huidige Curaçaose coalitie en recentelijk ook de Sabaan Will Johnson, achten de voordelen van non-soevereiniteit van minder belang en/of zijn bereid hiervan af te zien; zij blijven echter, althans vooralsnog, een kleine minderheid vormen onder de politici en hun achterbannen. Plaatsvervangend gevolmachtigde minister Senior gelooft in een volledig onafhankelijk Curaçao, maar hij ziet de grootste en eerste uitdaging in het overhalen van zijn eigen bevolking, niet van Den Haag-al meent hij ook dat van Den Haag, 'net als destijds tegenover Indonesië', niet veel te verwachten valt. Wat nodig is om de Curaçaose bevolking over de streep te trekken, betoogt hij, is het doorbreken van het 'Stockholm-syndroom', het bestrijden van 'de psychologische afhankelijkheid ingeslepen door ruim driehonderd jaar kolonialisme en slavernij, en het ontzenuwen van de mythen rondom de gevaren van onafhankelijkheid, zoals de mythe van onze economische afhankelijkheid van Nederland'. ${ }^{60}$

Waar sprake is van gemeenschappelijke belangen wordt het, zoals de geschiedenis van de Europese Unie laat zien, ook gemakkelijker de eenheid mede te funderen op een vertoog over gemeenschappelijke waarden. Het Koninkrijk der Nederlanden is echter, zo moet de conclusie luiden, niet zozeer gestoeld op een gemeenschappelijkheid van belangen, maar op een historisch proces van kolonisatie, waarbij de vaak als logisch of zelfs onvermijdelijk beschouwde uitkomst van een soevereiniteitsoverdracht aan de voormalige koloniën is uitgebleven. Deze gezamenlijke geschiedenis is er, dat is onmiskenbaar; de ironie wil dat de gekoloniseerden van weleer aan die geschiedenis gelijktijdig postkoloniale woede kunnen verbinden en een argument ontlenen om de onafhankelijkheid beslist af te wijzen en Nederlandse ondersteuning op te eisen.

En zo lijkt het grootste zakelijke belang aan Nederlandse zijde voornamelijk gelegen te zijn in het behartigen van de belangen van de BES-eilanden, die immers gewoon 'Nederland' zijn geworden, en het bestrijden van problemen die voortvloeien uit een eerder gedoogde dan gezochte relatie met de andere eilanden. Het gaat hier om het minimaliseren van wat de Britten, in hun relatie tot hun overseas territories, omschrijven als de contingent liabilities: problemen in de sfeer 
van deugdelijk bestuur, drugshandel en money laundering - nu eenmaal endemisch in deze regio, gelegen op het kruispunt van internationale narcoroutes ${ }^{61}-$ die ook hun weerslag hebben op de reputatie van het 'moederland'.

De toonaangevende Haagse bestuurders uit de periode voorafgaand aan de ontmanteling benadrukken dat de staatkundige veranderingen de onderliggende bestuurlijke en maatschappelijke problemen geenszins hebben opgelost. Gijs de Vries spreekt in dit verband van de veronachtzaamde 'morele dimensie', door hem omschreven als het wegkijken door de lokale elites van de armoede onder de eigen bevolking, belangenverstrengeling, de informele macht van enkele oude families en bedrijven, en zelfs 'schandelijk profiteurgedrag van sommige politici'. Klaas de Vries en ook toenmalig DG Dirkse waarschuwen in dezelfde zin. Dirkse ervoer 'een volstrekt gebrek aan compassie van de eilandelijke elites met de armen - daarvoor verwachtte men altijd oplossingen van Den Haag. ${ }^{62}$

Het is duidelijk dat hierover verschillend wordt geoordeeld, aan beide zijden van de oceaan; en voor zover men in Den Haag deze kritische observaties al deelt lopen de meningen toch uiteen over de vraag of in de nieuwe structuren wel voldoende bestuurlijke controle is ingebouwd. Overigens omvatten de contingent liabilities, anders dan in het Britse geval, voor Nederland tevens een substantiële migratieproblematiek en, gezien de spanningen rond Venezuela, zorgen over territoriale integriteit en veiligheid van de eilanden.

Natuurlijk verbindt de transnationale Antilliaanse gemeenschap inmiddels althans een deel van de burgers van het Koninkrijk, en ongetwijfeld blijft het koningshuis een verbindende factor. Maar uiteindelijk lijkt de kern van het gemeenschappelijke in het Koninkrijk toch voornamelijk te liggen in de aanvaarding dat er nu eenmaal een gemeenschappelijke geschiedenis is en dat daaruit hedendaagse betrekkingen voortvloeien die ook de sterkste partner - en de initiator van de relatie - binden, al is het belang van die banden wederzijds niet zo duidelijk. Dat lijkt uiteindelijk niet meer dan een kwestie van statelijk fatsoen, al is het evident dat menigeen in Nederland zich hierin niet herkent, waarmee de houdbaarheid van die acceptatie onder druk blijft staan.

Het gaat hierbij uitdrukkelijk niet alleen om de PVV en mogelijk de SP. Binnen het CDA, vanouds nauw gelieerd met de Curaçaose PAR, de Arubaanse AVP en de Bonairiaanse UPB, zal het engagement met de eilanden wel blijven; maar deze Nederlandse steunpilaar is zelf sterk verzwakt. Het engagement van de PVDA met de eilanden is minder uitgesproken. VVD'ers als Van Beek ('dat is toch de logische ontwikkeling') en Remkes wensen de toekomstige onafhankelijkheid 
weer te agenderen, althans voor de grotere (ei)landen, die dan een 'Gemenebestrelatie' met Nederland zouden kunnen onderhouden, een optie die tot 1990 in de Haagse politiek breed werd nagestreefd. Ook D66-leider Pechtold spreekt 'het gevoel' uit dat de Antillen 'halverwege deze eeuw' in de regio zullen integreren en het Koninkrijk dan verlaten. ${ }^{63}$

Zover is het nog niet en de haalbaarheid van deze scenario's is omstreden. Maar is er ook ruimte om het Koninkrijk sterker te funderen op gedeelde waarden, nu zo vaak is opgemerkt, ook door nauw betrokkenen bij de ontmanteling, dat een gevoel van gemeenschappelijkheid ver te zoeken is? ${ }^{64}$ De gedeelde geschiedenis weegt alleen aan de Caraïbische kant echt zwaar. De taalverschillen zijn groot, de culturen van het dagelijkse leven lopen sterk uiteen. Politieke controverses worden vaak uitvergroot door culturele verschillen, en andersom dient het beroep op cultuurverschil vaak om zakelijke discussies uit de weg te gaan. Dat geldt temeer wanneer daarbij ook wordt verwezen naar de slavernij of naar neokolonialisme, een strategie die onder meer door Bijleveld met grote stelligheid is verworpen. Toch blijven ook bij het hele proces nauw betrokken Antillianen als Römer moeite houden met wat zij ervaren als het aannemen van 'een superieure houding' door Haagse bestuurders: 'Denken dat de Nederlandse normen en waarden de juiste zijn, zonder enig relativisme. ${ }^{65}$

Niettemin lijkt er, gegeven de onvermijdelijke duurzaamheid van de Koninkrijksrelaties, geen andere keuze te zijn dan te trachten de verschillen te overbruggen, en op basis van overeenstemming over fundamentele waarden het beste te maken van het samen-zijn en -blijven. Van een fundamenteel verschil in waarden is geen sprake, een vaststelling die in het vele verbale geweld wel eens verloren gaat. Op bestuurlijk niveau gaat het er verder voornamelijk om dat afspraken worden nagekomen en dat het principe gehuldigd blijft dat binnen zekere marges lokale verschillen aanvaardbaar zijn. Waar het gaat om het nastreven van gelijkwaardigheid binnen het Koninkrijk zal het blijven wringen dat de ontwikkelingskansen voor burgers op de Antilliaanse eilanden vaak zoveel slechter zijn dan in Nederland-zeker daar dit leidt tot een migratiestroom die in Nederland voornamelijk wordt gezien als last, maar op de eilanden ook wordt ervaren als een aderlating, althans waar het jonge, talentvolle Antillianen betreft die na hun studies niet meer terugkeren.

Waar het gaat om het creëren van een gevoel van gemeenschappelijkheid kunnen uiteraard, zoals van Caraïbische zijde zo vaak wordt betoogd, onderwijs en de media een positieve rol spelen; toch is het, gezien de schaalverschillen, een illusie dat er ooit sprake zal zijn van een evenwicht in wederzijdse kennis. Voorlopig is hier nog veel ach- 
terstallig onderhoud, temeer urgent aangezien door de vorming van een Antilliaanse gemeenschap in Nederland het 'vaderlandse' van onze geschiedenis allengs sterker trans-Atlantisch moet worden begrepen. Ook in dit perspectief is het onbegrijpelijk dat er in de afgelopen decennia geen sprake is geweest van consistent en ambitieus beleid in de sfeer van culturele en wetenschappelijke samenwerking binnen het Koninkrijk. Juist daar, zo zou men denken, zou het mogelijk zijn de gemeenschappelijkheid binnen het bijna vier eeuwen oude trans-Atlantische, 'gedeelde' Koninkrijk te onderzoeken en te beleven, zonder overigens de onderlinge verschillen te verbloemen.

In het hele proces dat op 10/10/10 tot een voorlopig einde werd gebracht, speelden zulke vragen hooguit op de achtergrond een rol, in het bijzonder in de buitengewoon invloedrijke adviezen en voorlichtingen van de Raad van State - die recentelijk dan ook weer is gevraagd om te adviseren over een visie op het Koninkrijk. ${ }^{66}$ Het beleid rond de opheffing van de Nederlandse Antillen en de herstructurering van het Koninkrijk was dan ook primair pragmatisch, niet zozeer visionair. Dat weerspiegelt het gebrek aan werkelijke alternatieven. Regionale integratie is nog altijd een wijkende horizon; er is geen enkele aanleiding te denken dat deze zich de komende jaren wel zal materialiseren en evenmin dat de andere niet-soevereine delen van de Caraïben de keuze voor onafhankelijkheid zullen maken. Eerder, en waarschijnlijk, zal de rol van de Europese Unie in de regio belangrijker worden en op termijn een zekere uniformering van bestuurlijke arrangementen kunnen meebrengen; maar dat zal dan uitsluitend de met volle overtuiging niet-soevereine Britse, Franse en Nederlandse Caraïben raken. ${ }^{67}$

Zo blijven uiteindelijk de radicale alternatieven nog altijd dezelfde: een staatkundig afscheid of juist een volledige integratie en daarmee bestuurlijke onderschikking van de resterende delen van de Nederlandse Antillen van weleer. Het eerste lijkt ver weg, ook al wordt deze optie in Den Haag herontdekt en ook wel door sommige politici op de eilanden bepleit. Het tweede alternatief tekent zich nu af op Bonaire, Saba en Sint Eustatius. De vraag is of de materiële voordelen van dit arrangement beantwoorden aan de verwachtingen van de bewoners van deze eilanden en opwegen tegen de - veelal als last ervaren - zoveel sterker aanwezige Nederlandse bemoeienis. Als dit zo is, zou dat mogelijk ook de bewoners van Curaçao en Sint Maarten op andere ideeën over integratie kunnen brengen. Maar ook dan is het geenszins zeker dat dit tot fundamentele veranderingen in de Koninkrijksrelaties zou kunnen leiden. Het is immers goed denkbaar, wellicht zelfs te voorspellen, dat de ervaringen en vooral kosten van de 'BES-operatie' Den Haag afkerig zullen maken om dit experiment 
op grotere schaal te herhalen.

De tijd zal het leren. In de tussentijd zal het zoeken en leven naar een nieuwe visie voor het Koninkrijk, vooral met het oog op de blijvende asymmetrie in de relaties, een moeizaam proces blijven. In dit perspectief ademt de recente notitie 'De toekomst van het Koninkrijk' een niet onbegrijpelijke voorzichtigheid. ${ }^{68}$ De visie is uitdrukkelijk slechts van het Nederlandse kabinet, het wachten is op visies van de andere landen, althans van Curaçao en Sint Maarten. Er wordt veel gezegd over de noodzaak van een sterk besef van gemeenschappelijkheid; anders heeft het Koninkrijk geen toekomst. 'De verwevenheid binnen het Koninkrijk is [door 10/10/10] exponentieel toegenomen', en gelijktijdig is de buffer van het land de Nederlandse Antillen weggevallen. Dat impliceert dat de partners (nog) meer bij elkaar betrokken zullen zijn, ten goede of ten kwade (het risico van 'groeiende irritatie, frustratie en afkeer'). Den Haag, zo schrijft Donner, zet in op 'meer en hechtere samenwerking', niet op een rol van 'politieagent'. De Nederlandse belangen worden, gezien het bovenstaande niet verwonderlijk, toch voornamelijk gedefinieerd in de sfeer van wat hier eerder werd omschreven als het 'beste maken' van het niet ter discussie gestelde feit dat Nederland en het Koninkrijk nu eenmaal ook in de Caraïben liggen, en het aanvaarden van de hieruit voortvloeiende uitdagingen. De Nederlandse visie behelst vooral dat hiertoe sterkere samenwerking vereist is, meer onderling vertrouwen en engagement. Het vervolg op 10/10/10, zo eindigt de notitie, zou 'zonder wil, bereidheid en inspanningen van de samenstellende delen' goed kunnen uitlopen op 'het einde van het Koninkrijk'.

Dat laatste is te lezen als een verklaring van goede wil, gekoppeld aan een schot voor de boeg. Wat de Nederlandse inzet betreft, 'er het beste van maken' is al een opgave in zichzelf; de hervormingen van 10/10/10 bieden althans de voorwaarden om die pragmatische doelstelling dichterbij te brengen. Het is een open vraag of Den Haag zich de komende jaren zal kunnen bekwamen in 'de kunst van het loslaten' of zich gedwongen zal voelen de teugels strakker aan te halen, vanuit de aanhoudende zorg over de kwaliteit van het Antilliaanse bestuur en de al decennia uitgesproken overtuiging 'dat het Koninkrijk nu eenmaal geen vrijblijvend arrangement is'. ${ }^{69}$ Waarmee nog eens is onderstreept dat ook na 10/10/10 de afhankelijkheidsrelatie niet is verbroken - maar daar was de 'operatie ontmanteling' ook niet op gericht. En zo blijft het trans-Atlantische Koninkrijk 'gedeeld': geografisch en bestuurlijk opgedeeld, onderling verdeeld, maar ook gedeeld, in de zin van lotsverbonden. 


\section{Noten}

Woord vooraf 283

1 Zie voor de Caraïben onder meer Baldacchino \& Milne 2009, Clegg \& PantojasGarcía 2009; en voor de Antillen Van Beetz \& Martha-Alberto 2010, Broek 2005, Bröring, Kochenov, Hoogers \& Jans 2008, Römer 2006, Croes 2005, 2006 en 2007, Grieken \& Köper 2007, Hillebrink 2008, Hirsch Ballin 2006, Jansen van Galen 2004, Justitiële Verkenningen 2009, De Jong \& Kruijt 2005, De Jong \& Boersema 2005, Nauta 2011, Oostindie 2005, 2009, Rogier \& Hoogers 2005, Van Romondt et al. 2005, Roos \& Verhey 2010, Rosheuvel 2005, Sluis 2004 en 2010, Societas Iuridica 2004, Staatkundige veranderingen 2011.

\section{Ruimte voor nieuwe keuzes}

1 De terugblik in dit eerste hoofdstuk is voornamelijk gebaseerd op Oostindie \& Klinkers 2001, de eerste paragraaf deels direct ontleend aan Oostindie 2005.

2 Klinkers 1999:137-9.

3 Oostindie \& Verton 1998.

4 Gesprekken A. Pechtold, 27 t/m 30 maart 2006. Enkele punten uit het gesprek met Saba: conceptverslagen (Digidoc; Dossier Beleid Koninkrijksstructuur Projectgroep Koninkrijk op Maat, kenmerk 2004-0000002743; Subdossier Verslag, kenmerk 2006-0000017307).

5 Oostindie \& Klinkers 2001, III:425-8.

6 Oostindie \& Klinkers 2001, III:428.

7 In het geval van Sint Maarten overigens niet gebaseerd op art. 43 lid 2 Statuut. Zie Oostindie \& Klinkers 2001, III:265-7.

8 Oostindie \& Klinkers 2001, II:184-5 en III:294.

9 Oostindie \& Klinkers 2001, III:335.

\section{De Koninkrijksrelaties: instituties, spelers, dossiers}

1 Interviews M. Eman en N.O. Oduber, 29 maart 2011.

2 Vaststelling begrotingsstaat Raad van State, Algemene Rekenkamer, Nationale Ombudsman, Kanselarij der Nederlandse Orden, kabinet Gouverneur 
Nederlandse Antillen en kabinet Gouverneur Aruba (IIB) voor 2010. MvT (TK, 2009-2010, 32 123, nr. 2), ondertekend door minister van BZK G. ter Horst. 3 In plaats van het voorstel uit het rapport-Jesurun (2004:8) - instelling van een toezichtraad van het Koninkrijk, als onderraad van de RMR, en een Koninkrijksdienst - zou het Nederlandse kabinet een 'Vertegenwoordiger van het Koninkrijk' voorstellen om de belangen van het Koninkrijk te waarborgen en de financiële toezichtfunctie te laten uitvoeren. Zie ook verslagen ICKR 17 november en 9 december 2004 (Digidoc; Dossier ICKR 2004 t/m 2005, kenmerk 2004-0000002728; Subdossier 2004-11-17 ICKR vergadering \& Subdossier 2005-03-03 ICKR vergadering, kenmerk 2005-0000005132). Bespreking Proeve in Oostindie \& Klinkers 2001, III:214-20.

4 Voorlichting over mogelijkheden tot versnelling van het transitieproces naar de nieuwe staatkundige verhoudingen tussen Nederland, de Nederlandse Antillen, Curaçao en Sint Maarten, 29 augustus 2008 (zaaknr. Wo4.08.0213/I/AK). Zie ook NRC Handelsblad, 10 september 2008, Antilliaans Dagblad, 4 november 2009. J.W. Remkes in TK, 2009-2010, 32178, nr. 6, 9 april 2010 en The Daily Herald, 11 december 2009.

5 De motie E. Schuurman c.s. (medeondertekend door J.J. van Heukelum, W. Lemstra, I.Y. Tan, L.H.G. Platvoet, M. Linthorst, E. Hessing, F. de Graaf, A.G. Schouw, R. van Raak, H. ten Hoeve; EK, 2005-2006, 30300 IV, B) van 14 februari 2006 riep de regering op om op de agenda van de volgende RTC een voorstel voor een nieuw Statuut te plaatsen. Vgl. ook nota aan A. Pechtold, 16 februari 2006, kenmerk 2006-0000051618; nota aan A. Pechtold, 17 februari 2006, kenmerk 2006-0000053630 (Digidoc, Dossier beleid Koninkrijksstructuur Projectgroep Koninkrijk op Maat, kenmerk 2004-0000002743; Subdossier Motie Schuurman, kenmerk 2006-0ooooo8915). Interview W.I.I. van Beek, 27 mei 2011.

6 Oostindie \& Klinkers 2001, III:366-78; interview J.P. Dirkse, 7 september 2011.

7 Brief J.J.C. Voorhoeve aan W. Kok, 7 mei 1998 (Papieren Archief KR; Dossier Minister zonder portefeuille, inv. nr. 1998502036, doos 30).

8 Oostindie \& Klinkers 2001, III:378-82.

9 Papieren archief KR; Dossier Werkbezoek van het prinselijk paar aan de Nederlandse Antillen en Aruba van 11 t/m 21 augustus 2002, inv. nr. 2002054763, doos 256. Interviews J.P. Dirkse, 7 september 2011, K.G. de Vries, 30 augustus 2011, H.M. Wiels, 25 maart 2011.

10 Het instellingsbesluit Regionaal Service Centrum BES-eilanden werd bekendgemaakt in de Staatscourant van 26 november 2008, nr. 964. Zie ook www.rijksdienstcn.com, Amigoe, 1 september 2010.

11 Antilliaans Dagblad, 12 mei 2010. Vgl. HTK, 23 oktober 2008, pp. 1039, 1099

[Behandeling wetsvoorstel vaststelling begrotingsstaat Koninkrijksrelaties (IV) 2009]. Verslag AO van 23 oktober 2008, vastgesteld 1 december 2008 (TK, 2008-2009, 31 568, nr. 5). Antilliaans Dagblad, 12 mei 2010.

12 Verslag houdende een lijst van vragen en antwoorden, 23 november 2009 (TK, 2009-2010, 32123 IV, nr. 3) [Vaststelling begrotingsstaat Koninkrijksrelaties (IV) 2010]. Amigoe, 19 mei 2010, Antilliaans Dagblad, 20 mei 2010.

13 Interview J.P. Dirkse, 7 september 2011.

14 Interviews Th.C. de Graaf, 30 juni 2011, G.M. de Vries, 7 september 2011.

15 Interview J.P. Dirkse, 7 september 2011.

16 Interview Th.C. de Graaf, 30 juni 2011.

17 RNW, 8 oktober 2010. Interviews R.T. Booi, 28 maart 2011, S.F.C. Römer, 21 maart 2011. 
18 Inleiding H.D. Tjeenk Willink, 13 juni 2006, tijdens Contactplanbijeenkomst van 12 t/m 16 juni 2006 te Den Haag (Kamerstukken I/II, 2005-2006, 30 461, D en nr. 4). J. Leerdam bijv. in de Volkskrant, 6 april 2006. Interview F.P. van Beetz, 25 augustus 2011.

19 Interviews W.I.I. van Beek, 27 mei 2011, A.Th.B. Bijleveld-Schouten, 20 mei 2011.

20 De bestuurlijke herinrichting van de Nederlandse Antillen in het algemeen en de omvorming van de drie kleine eilanden tot openbaar lichaam in het bijzonder. Zie ook Verhey 2010:16 over de taakverdeling. Ambtelijk vertaalde dit zich in een spilpositie in het proces voor de directie KR. Vgl. verslag houdende een lijst van vragen en antwoorden, 15 december 2008 (TK, 2008-2009, 31792 IV, nr. 3), met overzicht van de omvang van de voor het transitieproces uitgetrokken wetgevingscapaciteit bij de verschillende ministeries.

21 Op 17 maart 2010 werd hij opgevolgd door Alfred Roos, tot dan lid van het ministeriële projectteam DWA (Directie Wetgeving Antillen).

22 De Tweede Kamer werd over de taakverdeling geïnformeerd bij brief van

A.Th.B. Bijleveld-Schouten van 30 maart 2007 (TK, 2006-2007, 30800 IV, nr. 24). Vgl. Verhey 2010:16. Hoewel Ter Horst eerstverantwoordelijke was voor de politie, werd de CRW Politie bij Justitie voorbereid en was Hirsch Ballin eerste ondertekenaar.

23 A. Pechtold, HTK nr. 45, 1 maart 2007, p. 2685; J.P. Balkenende, p. 2729. Motie nr. 27, 30891. Verslag AO Koninkrijksrelaties (IV) voor 2007, 26 april 2007 (TK, 2006-2007, 30800 IV, nr. 26).

24 Te weten, het laten vallen van de aanwijzingsbevoegdheid van de minister van Justitie op Koninkrijksniveau, het creëren van een Gemeenschappelijke Voorziening Politie (GVP) in plaats van het Recherche Samenwerkingsteam (RST) - de besluiten op dit laatste terrein werden overigens later geamendeerd door de Tweede Kamer - en het buiten het proces houden van de Rijkswet personenverkeer, zie hfdst. 4.

25 Verslag ICKR, 23 september 1998 (Papieren archief KR; Dossier ICKR vergaderstukken 1999, inv. nr. 1999055543, doos 120). Nota aan DGKB, 27 augustus 2004, kenmerk 2004-0000007197 (Digidoc; Dossier ICKR 2004-2005; Subdossier Functioneren ICKR).

26 Verslag discussie op 13 juni 2006 tijdens POK van 12 t/m 16 juni 2006 te Den Haag (Kamerstukken I/II, 2005-2006, 30 461, D en nr. 4). Interview K.G. de Vries, 30 augustus 2011.

27 Brief P. Comenencia aan J.P. Balkenende, 13 februari 2007; Nota 30 november 2007, kenmerk 2007-0000524303; Nota aan wnd. SG, 6 februari 2008, kenmerk 2008-0000058430 (Digidoc; Dossier Beleid instelling onderraad Koninkrijkszaken 2007 t/m 2008, kenmerk 2007-0000019050; Subdossier Ambtelijk portaal Koninkrijksrelaties, kenmerk 2008-0ooooo8926).

28 Deze paragraaf is mede gebaseerd, deels letterlijk, op een uitvoeriger beschouwing over de rol van de Raad van State in het transitieproces in Oostindie 2011, alsmede op de interviews met, onder anderen, Th.C. de Graaf, 30 juni 2011, E.M.H. Hirsch Ballin, 20 april 2011, A. Nicolaï, 23 mei 2011, A. Pechtold, 23 mei 2011, J.W. Remkes, 30 mei 2011, P. Rosenmöller, 19 mei 2011, H.D. Tjeenk Willink, 12 oktober 2010, R. van der Veer, 26 oktober 2010, L.F.M. Verhey, 1 maart en 26 mei 2010, G.R. Wawoe, 19 mei 2010 in Nederland en voorts R. (Raymond) Begina, 22 maart 2011, C.P. de Haseth, 22 maart 2011, S.F.C. Römer, 21 maart 2011, J.M. Saleh, 23 maart 2011 en E.N. Ys, 21 maart 2011. 
29 Voorlichting overeenkomstig artikel 18, tweede lid, van de Wet op de Raad van State over de verhouding van de Nederlandse Antillen en Aruba tot de Europese Unie, 9 september 2003, bijlage Jaarverslag over 2003 (zaaknr. Wo4.03.0203/I/A). 30 Interview G.R. Wawoe, 19 mei 2010. Hij verwijst daarbij naar artikel $299 \mathrm{lid} 2$ van het EG-Verdrag betreffende de UPG.

31 Advies 10 december 2004 (zaaknr. Wo4.04.0425/I/K). TK, 2005-2006, 30300 IV, nr. 26 en Bijvoegsel Staatscourant, 14 maart 2006, nr. 52.

32 Voorlichting overeenkomstig artikel 18, tweede lid, van de Wet op de Raad van State inzake de hervorming van de staatkundige verhoudingen van de Antilliaanse eilanden binnen het Koninkrijk, 18 september 2006 (zaaknr. Wo4.06.0204/I/K/A); Voorlichting over mogelijkheden tot versnelling van het transitieproces naar de nieuwe staatkundige verhoudingen tussen Nederland, de Nederlandse Antillen, Curaçao en Sint Maarten, 29 augustus 2008 (zaaknr. Wo4.08.0213/I/AK); Voorlichting inzake mogelijkheden voor gefaseerde herstructurering van de BES-eilanden, 29 augustus 2008 (zaaknr. Wo4.08.0175/I/A).

33 Voorlichting 18 september 2006 (zaaknr. Wo4.06.0204/I/K/A).

34 Nader rapport (reactie op het advies) van 27 december 2005 (TK, 2005-2006, $30300 \mathrm{IV}, \mathrm{nr} .26)$.

35 Voorlichting inzake Rijkswet openbare ministeries van Curaçao, van Sint Maarten en van Bonaire, Sint Eustatius en Saba, met MvT, 11 maart 2009 (zaaknr. Wo3.08.0566/II/K). Nader rapport, 6 juli 2009 (TK, 2008-2009, 32018 (R1885), $\mathrm{nr}$. 4). Regels met betrekking tot de openbare lichamen Bonaire, Sint Eustatius en Saba (Wet openbare lichamen Bonaire, Sint Eustatius en Saba), nr. 13; Stenografisch verslag Wetgevingsoverleg Vaste Commissie NAAZ, Vaste Commissie BZK en Vaste Commissie BZ d.d. 15 januari 2010, 20 januari 2010 (TK, 2009-2010, 31 954, nr. 13). J. Leerdam, p. 8; J.W. Remkes, p. 10.

36 H.D. Tjeenk Willink, 'Ten geleide', in Raad van State van het Koninkrijk 2003:12.

37 Interviews Th.C. de Graaf, 30 juni 2011 en L.A.M. van Halder, 17 augustus 2011.

38 Verslag AO, 17 augustus 2009 (TK, 2008-2009, 31 568, nr. 51).

39 Zie bijv. HTK nr. 32, 5 december 2007, p. 2486; de Volkskrant, 3, 5 en 7 januari 2008, NRC Handelsblad, 4 januari 2008.

40 Oostindie \& Klinkers 2001, III:421 en passim.

41 Zie verder hfdst. 4.

42 Zie ook Oostindie \& Klinkers 2001, III:390-3 (E.M.H. Hirsch Ballin), 393-5 (J.J.C. Voorhoeve), 422-5 (G.M. de Vries).

43 HTK nr. 13, 16 oktober 2001, p. 669; interview G.M. de Vries, 7 september 2011.

44 Interviews J.P. Dirkse, 7 september 2011, Th.C. de Graaf, 30 juni 2011, K.G. de Vries, 30 augustus 2011.

45 Interview K.G. de Vries, 30 augustus 2011, e-mail K.G. de Vries, 31 augustus 2011.

46 Interview G.M. de Vries, 7 september 2011; e-mails G.M. de Vries, 5 september en 5 februari 2011.

47 Interviews F.P. van Beetz, 25 augustus 2011, G.E.A. van Craaikamp, 2 augustus 2011, L.A.M. van Halder, 17 augustus 2011.

48 Brief J.W. Remkes aan vz. TK, 15 november 2002 (TK, 2002-2003, 28600 IV, nr. 5, pp. 1-2). Vgl. stukken in: Papieren archief KR; Dossier Werkbezoek van het prinselijk paar aan de Nederlandse Antillen en Aruba van 11 t/m 21 augustus 2002, inv. nr. 2002054763, doos 256. 
49 Papieren archief KR; Dossier Werkbezoek van het prinselijk paar aan de Nederlandse Antillen en Aruba van 11 t/m 21 augustus 2002, inv. nr. 2002054763, doos 256.

50 Papieren archief KR; Dossier Programma bezoek plv. directeur KR aan Curaçao, 11-14 juni 2003, inv. nr. 2003054562, doos 381. Interview J.W. Remkes, 30 mei 2011.

51 Interview J.W. Remkes, 30 mei 2011, e-mail C.P. de Haseth, 22 augustus 2011. 52 Interview J.W. Remkes, 30 mei 2011, e-mail C.P. de Haseth, 22 augustus 2011. Ook zijn opvolger kreeg de indruk dat Remkes 'de deur op een klein kiertje had gezet'; interview Th.C. de Graaf, 30 juni 2011.

53 Interview Th.C. de Graaf, 30 juni 2011.

54 Brief Th.C. de Graaf aan vz. TK, 4 september 2003 (TK, 2002-2003, 28600 IV, nr. 20). Vgl. brief Th.C. de Graaf aan vz. TK, 9 oktober 2003 (TK, 2003-2004, 28 829, nr. 6).

55 NRC Handelsblad, 14 januari 2005.

56 In twee aanvaarde moties (TK, 2004-2005, 29800 IV, nr. 15 en 16; resp. moties

F. Halsema/J. Leerdam en J. Rijpstra c.s.) was verzocht om een politiek akkoord op hoofdlijnen tussen de drie landen over het rapport-Jesurun vóór het einde van 2004 .

57 Interviews R.T. Booi, 28 maart 2011, Th.C. de Graaf, 30 juni 2011, R.J. Hooker, 28 maart 2011, E.N. Ys, 21 maart 2011.

58 HEK nr. 24, 16 april 2005 (2980o-IV), p. 1033.

59 Memorandum DGKB/DKR, 19 mei 2005 (Digidoc; Dossier ICKR 20052005 t/m 2006, kenmerk 2004-0000008511; Subdossier 2005-06-09 ICKR vergadering, kenmerk 2005-0000018143).

6o Interview A. Pechtold, 23 mei 2011.

61 Interviews C.P. de Haseth, 22 maart 2011, S.F.C. Römer, 21 maart 2011.

62 Dit zou overigens op Sint Maarten volledig ten goede omslaan, met het uitroepen van Nicolaï tot 'persoon van het jaar 2006' (wegens zijn inzet voor de totstandkoming van de Slotverklaring). NRC Handelsblad, 3 januari 2007.

63 Interview R. Vermaas, 23 maart 2011.

64 'Internationaal zal de rechtstreekse band kunnen worden gekwalificeerd als een vrije associatie met Nederland.' Voorlichting overeenkomstig artikel 18, tweede lid, van de Wet op de Raad van State inzake de hervorming van de staatkundige verhoudingen van de Antilliaanse eilanden binnen het Koninkrijk, 18 september 2006 (zaaknr. Wo4.06.0204/I/K/A).

65 Interviews A. Nicolaï, 23 mei 2011, J.A.B. Larmonie, 30 maart 2011, S.F.C. Römer, 21 maart 2011.

66 Interview Th.C. de Graaf, 30 mei 2011.

67 Interviews A.Th.B. Bijleveld-Schouten, 20 mei 2011, W.I.I. van Beek, 27 mei 2011, H.G.J. Kamp, 19 mei 2011 en J.W. Remkes, 30 mei 2011.

68 Interview E.S. de Jongh-Elhage, 22 maart 2011.

69 Oostindie \& Klinkers 2001, II:184-5, III:294.

70 Oostindie \& Klinkers 2001, III:295-7.

71 Vaststelling begrotingsstaat Koninkrijksrelaties (IV), voor de jaren 2000-2010, zie www.rijksbegroting.nl. De gerealiseerde uitgaven weken, blijkens de Financiële jaarverslagen, per jaar sterk van de begroting af, maar de grote lijn bleef hetzelfde (Jaarverslagen ook op www.rijksbegroting.nl).

72 Vaststelling begrotingsstaat Koninkrijksrelaties (IV) voor 2006. MvT (TK, 2005-2006, 30300 hfdst. IV, nr. 2), meermalen in gelijke of vergelijkbare bewoordingen herhaald. 
73 Vaststelling begrotingsstaat Koninkrijksrelaties (IV) voor 2002. MvT (TK, 2001-2002, 30300 hfdst. IV, nr. 2).

74 Vaststelling begrotingsstaat Koninkrijksrelaties (IV) voor 2006. MvT (TK, 2005-2006, 30300 hfdst. IV, nr. 2), meermalen in gelijke of vergelijkbare bewoordingen herhaald.

75 Vaststelling begrotingsstaat van Koninkrijksrelaties (IV) voor 2006. MvT (TK, 2005-2006, 30300 hfdst. IV, nr. 2), meermalen in gelijke of vergelijkbare bewoordingen herhaald.

76 Vaststelling begrotingsstaat van Koninkrijksrelaties (IV) voor 2007. MvT (TK, 2006-2007, 30800 hfdst. IV, nr. 2). Vgl. Vaststelling begrotingsstaat van Koninkrijksrelaties (IV) voor 2008. MvT (TK, 2007-2008, 31200 hfdst. IV, nr. 2).

77 Daarna bleef het begrote bedrag stijgen (van de initiële 15,4 miljoen euro voor 2002 via 54,1 miljoen voor 2008 tot 60 miljoen euro voor 2010), maar het relatieve belang liep weer terug; dit is echter geheel toe te schrijven aan de op de begroting meegenomen bedragen voor de schuldsanering. Vaststelling begrotingsstaat van Koninkrijksrelaties (IV) voor 2002. Voorstel van wet (TK, 2003-2004, hfdst. IV, nr. 1); Vaststelling begrotingsstaat van Koninkrijksrelaties (IV) voor 2003. Voorstel van wet (TK, 2002-2003, hfdst. IV, nr. 1); Vaststelling begrotingsstaat van Koninkrijksrelaties (IV) voor 2004. Voorstel van wet (TK, 2003-2004, hfdst. IV, nr. 1); Vaststelling begrotingsstaat van Koninkrijksrelaties (IV) voor 2005. Voorstel van wet (TK, 2004-2005, hfdst. IV, nr. 1); Vaststelling begrotingsstaat van Koninkrijksrelaties (IV) voor 2006. Voorstel van wet (TK, 2005-2006, 30 300 hfdst. IV, nr. 1); Vaststelling begrotingsstaat van Koninkrijksrelaties (IV) voor 2007. Voorstel van wet (TK, 2006-2007, 30800 hfdst. IV, nr. 1); Vaststelling begrotingsstaat van Koninkrijksrelaties (IV) voor 2008. Voorstel van wet (TK, 2007-2008, 31200 hfdst. IV, nr. 1).

78 Brief A.Th.B. Bijleveld-Schouten aan vz. TK, 15 mei 2009 (TK, 2008-2009, 31 568, nr. 37). HTK nr. 15, 23 oktober 2008, p. 1043 (J.W. Remkes), vgl. De Grijff 2010:88.

79 Op 10 december 2008 trad het Besluit tijdelijk financieel toezicht Nederlandse Antillen, Curaçao en Sint Maarten (d.d. 10 november 2008) in werking. 80 AMVRB houdende tijdelijke voorzieningen voor het toezicht op de begroting en de bedrijfsvoering van de eilandgebieden Bonaire, Sint Eustatius en Saba van de Nederlandse Antillen (Besluit tijdelijk financieel toezicht BES, 8 november 2007).

81 Vaststelling begroting Koninkrijksrelaties (IV) voor 2011. Voorstel van wet (TK, 2010-2011, 32500 IV nr. 1); MvT, nr. 2.

82 Brief A.Th.B. Bijleveld-Schouten aan vz. TK, 29 maart 2010 (TK, 2009-2010, 31954 IV, nr. 27).

83 Vaststelling begroting Koninkrijksrelaties (IV) voor 2011. MvT (TK, 20102011, 32500 IV nr. 2); vgl. Antilliaans Dagblad, 21 september 2010. Motie J.W. Remkes, J. Leerdam, B.J. van Bochove, 26 juni 2008 (TK, 2007-2008, 31200 IV, nr. 61). Vgl. verslag AO, 13 augustus 2008 (TK, 2007-2008, 31200 IV, nr. 65). Verslag houdende een lijst van vragen en antwoorden, 14 oktober 2008 (TK, 2008-2009, 31700 IV, nr. 5).

84 Oostindie \& Klinkers 2001, II:181-97, III:292-318, 422-4.

85 Het volgende is primair gebaseerd op vele honderden documenten uit het papieren en digitale BZK-archief uit de periode 1998-2010. Er wordt uitsluitend verwezen naar geciteerde documenten.

86 Zie hierover bijvoorbeeld brieven A.Th.B. Bijleveld-Schouten aan vz. TK, 1 februari 2008 (TK, 2007-2008, 26 283, nr. 31; mede ondertekend door 
C.P. Vogelaar en E.M.H. Hirsch Ballin), brief minister voor wWI E.E. van der Laan aan vz. TK, 14 april 2009 (TK, 2008-2009, 26 283, nr. 50) en brief E.E. van der Laan aan vz. TK, 2 oktober 2009 (TK, 2009-2010, 26 283, nr. 52).

87 Medio juli 2002 verzocht de burgemeester van Rotterdam de minister van BZK het aantal Antillengemeenten uit te breiden tot achttien (plus Almere, Amersfoort, Arnhem, Breda, Capelle a/d IJssel, Eindhoven, Lelystad, Schiedam, Tilburg, Zwolle en Zoetermeer).

88 Zie ook brief R.H.L.M. van Boxtel en G.M. de Vries aan vz. TK over evaluatie notitie Migratie Antilliaanse Jongeren, 4 september 2000, kenmerk AJC2000/ U82483 (Papieren archief KR; inv. nr. 2000050420, doos 173): 'gezien de geboekte voortgang de inzet van eenzijdige juridische instrumenten, zoals een toelatingsregeling voor Antillianen, thans niet aangewezen'.

89 Interview G.M. de Vries in Middageditie (NPS/VARA), 8 mei 2000 (Papieren archief KR; inv. nr. 2001051450, doos 2).

90 Advies BSG aan G.M. de Vries en R.H.L.M. van Boxtel, 17 augustus 2000 (Papieren archief KR; inv. nr. 2000053874, doos 2). [Betreff. overleg met minister A.H. Korthals op 28 april 2000.] Ambtelijke notitie over de presentatie van Justitie inzake de toelatings- en verwijderingsregeling in de Raad voor Justitie, Bestuur en Veiligheid van 6 juni 200o. Zie ook brief A.H. Korthals aan G.M. de Vries, 14 juli 2000; Nota DGCZK aan K.G. de Vries, R.H.L.M. van Boxtel en G.M. de Vries, 5 juli 2000, kenmerk CWoo/77861 (Papieren archief KR; inv. nr. 1999053604, doos 94).

91 Papieren archief KR; inv. nr. 2000050420, doos 173.

92 De Volkskrant, 7 december 200o. Vgl. ook de Volkskrant, 8 december 2000 en NRC Handelsblad, 7 en 9 december 2000.

93 Gemeenschappelijke verklaring over de plaats van het voortraject Inburgering binnen de educatieplicht jongeren in de Nederlandse Antillen, ondertekend door C.P. de Haseth en R.H.L.M. van Boxtel, 13 december 2000 (Papieren archief KR; inv. nr. 2001051628, doos 226). De Volkskrant, 15 december 2000.

94 NRC Handelsblad, 7 april 2001, Antilliaans Dagblad, 6 oktober 2009. De Raad van State adviseerde op 1 september 2006 (zaaknr. Wo3.06.0156/l) negatief over het bij kabinetsmissive van 15 mei 2006, nr. 06.001740, aanhangig gemaakte wetsvoorstel houdende aanvullende maatregelen inzake onder meer de terugzending van Antilliaanse en Arubaanse risicojongeren en inzake inburgering van Antilliaanse en Arubaanse Nederlanders. Het wetsvoorstel werd op een aantal punten gewijzigd: voortijdige terugkeer naar Nederland van teruggezonden risicojongeren zou nu niet strafbaar worden gesteld en er zou geen inburgeringsplicht worden opgelegd aan Antillianen en Arubanen.

95 De Volkskrant, 11 april 2001.

96 Brief R.H.L.M. van Boxtel aan vz. TK, 11 juni 2001 (TK, 2000-2001, 26 283, $\mathrm{nr}$. 12). Onderzoek naar de effectiviteit van een verwijderingsregeling voor Antillianen, mei 2001 (Papieren archief KR; inv. nr. 2000050420, doos 173). Nota aan R.H.L.M. van Boxtel en G.M. de Vries, 20 juni 2001, kenmerk AJC2001/ U073979 (Papieren archief KR; inv. nr. 2000051351, doos 4).

97 C. van der Knaap, HTK nr. 13, 16 oktober 2001, pp. 657-8. De CDA-fractie vond het ook onbegrijpelijk dat de Antilliaanse overheid al die jaren te weinig oog had gehad voor de ontwrichting van de eigen samenleving ten gevolge van de voortgaande ontvolking en de inburgeringsproblemen in Nederland. Van der Knaap pleitte in navolging van PVDA'er A. Melkert (tijdens diens werkbezoek aan Amsterdam-West) voor opvoeden: 'We moeten de politie middelen geven om de 
jongens op te pakken als zij overlast geven, ook al hebben zij strafrechtelijk gezien niets gedaan. Opvoeden, we moeten die jongens opvoeden.'

98 Kabinetsreactie op Nèt Loke Falta, 20 juni 2002, p. 5 (bijlage bij de brief van staatssecretaris van Justitie N.A. Kalsbeek aan vz. TK, 20 juni 2002 (TK, 2001-2002, 28 o06, nr. 10).

99 HTK nr. 32, 11 december 2002, p. 2364.

100 In Balkenende I was Rob Hessing (LPF) staatssecretaris van BZK, Hilbrand Nawijn (LPF) minister voor Vreemdelingenzaken en Integratie.

101 A. Wolfsen (PVDA), verslag AO, 2 oktober 2003 (TK, 2003-2004, $29200 \mathrm{IV}$, nr. 4, p. 3).

102 Oostindie \& Klinkers 2001, II:225-50, III:333-56.

103 Brief I.W. Opstelten aan Th.C. de Graaf en minister van Justitie J.P.H. Donner, 12 september 2003, kenmerk 03AZ 05055; Brief I.W. Opstelten aan Th.C. de Graaf, 3 november 2003, kenmerk 03AZ 6121 (Papieren archief KR; inv. nr. 2004050693, doos 36). Zie NRC Handelsblad, 9 september en 28 oktober 2003 over de verdeeldheid tussen de Antillengemeenten.

104 W.R.C. (Mirjam) Sterk (CDA), verslag AO, 2 oktober 2003 (TK, 2003-2004, 29200 IV, nr. 4, p. 2); Sterk, HTK nr. 12, 9 oktober 2003, pp. 640-1, 645-6. Zie ook Sterk, HTK nr. 10, 7 oktober 2003, pp. 517-8. Th.C. de Graaf, HTK nr. 12, 9 oktober 2003, pp. 638-42.

105 Brief M.C.F. (Rita) Verdonk aan vz. TK, 4 oktober 2004 (TK, 2004-2005, 26 283, nr. 19). Vgl. Notitie Antilliaanse jongeren, zomer 2004 van Verdonk (Papieren archief KR; inv. nr. 2004050693, doos 36).

106 De Volkskrant, 26 augustus 2004. Zie ook verslag Contactplan $10 \mathrm{t} / \mathrm{m} 13$ januari 2005 te Oranjestad, 13 januari 2005 (Kamerstukken I/II, 2004-2005, 29 965, A en nr. 1).

107 NRC Handelsblad, 13 augustus 2004.

108 Motie M.J.M. Verhagen, medeondertekend door J.J. van Aartsen en B. Dittrich, 2 september 2004 (TK, 2003-2004, 28 689, nr. 29). NRC Handelsblad, 4 en 16 september 2004, de Volkskrant, 30 september 2004.

109 NRC Handelsblad, 16 september 2004. Vgl. brief M.C.F. Verdonk aan vz. TK, 4 oktober 2004 (aanbieding Notitie Antilliaanse jongeren) (TK, 2004-2005, 26283 , nr. 19).

110 J.J. van Aartsen, HTK nr. 5, 29 september 2004, pp. 173-4. Zie ook Van Aartsen HTK nr. 4, 28 september 2004, p. 99. Afwijzende reactie van G. Zalm (wnd. premier), p. 187.

111 Brief M.C.F. Verdonk aan vz. TK, 4 oktober 2004 (TK, 2004-2005, 26283 , nr. 19). 'Met de Antilliaanse Regering is afgesproken een gemengd AntilliaansNederlandse commissie in te stellen die zal adviseren over mogelijkheden voor een effectieve aanpak van Antilliaanse jongeren die in Nederland afglijden. Migratieregulerende maatregelen zullen in deze Commissie onderwerp van gesprek zijn.'

112 De Volkskrant, 13 november 2004. Vgl. brief M.C.F. Verdonk aan vz. TK, 4 oktober 2004 (TK, 2004-2005, 26 283, nr. 19). Antwoorden M.C.F. Verdonk (16 december 2004) op vragen J. Dijsselbloem en J. Leerdam (18 november 2004) (TK, 2004-2005, Aanhangsel nr. 578). Th.C. de Graaf (HTK nr. 14, 27 oktober 2004, p. 835), de Volkskrant, 24 en 25 september 2004, 18 mei 2005, NRC Handelsblad, 12 november 2004.

113 Zie bijv. verslag Contactplan $10 \mathrm{t} / \mathrm{m} 13$ januari 2005 te Oranjestad, 13 januari 2005 (Kamerstukken I/II, 2004-2005, 29 965, A en nr. 1). De Volkskrant, 18 maart 2005. Vgl. ambtelijke nota aan Th.C. de Graaf, 4 februari 2005, 
kenmerk 2005-0000014524 (Digidoc; Subdossier Toelatingsregeling, kenmerk ooooooo248).

114 Motie Sterk, 3 november 2003, vaststelling begrotingsstaat Koninkrijksrelaties 2004 (TK, 2003-2004, 29200 IV, nr. 82). Motie Sterk ingediend tijdens Wetgevingsoverleg op 13 december 2004 (TK, 2004-2005, $29800 \mathrm{VI}, \mathrm{nr}$. 79). Zie verslag Wetgevingsoverleg (met Algemene Commissie voor Integratiebeleid), 20 december 2004 (TK, 2004-2005, 29 800 VI, nr. 101). De Volkskrant, 11, 12 en 18 mei 2005, 27 maart 2006.

115 NRC Handelsblad, 12 mei 2005 resp. de Volkskrant, 12 en 13 mei 2005. 116 De Volkskrant, 14 mei 2005. Het voorstel behelsde daarnaast een aangescherpte voogdijregeling. Ook zou de rechter in Nederland de mogelijkheid krijgen om Antillianen van tussen de 16 en 24 jaar die zich schuldig maakten aan ernstige delicten en die minder dan drie jaar in Nederland waren ingeschreven terug te sturen.

117 De Volkskrant, 11 mei 2005, NRC Handelsblad, 14 en 18 mei, 10 en 11 juni 2005. Zie ook brief A. Pechtold aan vz. TK, 26 mei 2005 (TK, 2004-2005, 29800 IV, nr. 25). Slotverklaring Contactplan, 13 t/m 17 juni 2005 te Den Haag, 17 juni 2005 (Kamerstukken I/II, 2004-2005, 29965 C en nr. 3). Interviews F.P. van Beetz, W.W. Timmers, 25 augustus 2011.

118 Verslag AO 17 mei 2005 met de Algemene Commissie voor Integratiebeleid, Vaste Commissie NAAZ, M.C.F. Verdonk en A. Pechtold, vastgesteld 20 juni 2005 (TK, 2004-2005, 26 283, nr. 23). Zie ook Verdonks brief aan vz. TK, 13 mei 2005 over aanvullende maatregelen voor Antillianen en Arubanen (TK, 2004-2005, $26283, \mathrm{nr} .20$ ).

119 NRC Handelsblad, 10 juni 2005, de Volkskrant, 5 en 14 juni 2005. A. Pechtold in verslag AO op 9 juni 2005, vastgesteld 2 augustus 2005 (TK, 2004-2005, 29800 IV, nr. 28).

120 De Volkskrant, 24 juni 2005, NRC Handelsblad, 11, 18 en 24 juni 2005.

A. Pechtold, HTK nr. 27, 29 november 2005, p. 1844.

121 Motie R. Luchtenveld c.s. (medeondertekend door W. van Fessem (CDA), G. van As (LPF), C. van der Staaij (SGP)), 21 februari 2006 (TK, 2005-2006, 30 300 IV, nr. 27). Op 23 februari 2006 stemden VVD, CDA, SGP en LPF voor deze motie, zodat zij werd aangenomen. Vgl. ook eerder verslag AO, 2 augustus 2005 (TK, 2004-2005, 29800 IV, nr. 28). NRC Handelsblad, 24 en 28 februari 2006. Brief A. Pechtold en M.C.F. Verdonk aan vz. TK, 24 februari 2006 (TK, 2005-2006, 30 $300 \mathrm{IV}, \mathrm{nr} .35$ ).

122 NRC Handelsblad, 19 en 22 april 2006. Zie ook brief A. Pechtold aan M.C.F. Verdonk, 19 april 2006, kenmerk 2006-0000122266 (Digidoc; Subdossier Toelatingsregeling, kenmerk ooooooo248).

123 Op 1 juli 2005 adviseerde de Raad negatief over het wetsvoorstel inzake inburgering in de Nederlandse samenleving (zaaknr. Wo3.05.0101/I). Weliswaar erkende de Raad de problemen rond 'onvoldoende inburgering van - relatief kleine - groepen Nederlanders van Nederlands-Antilliaanse of Arubaanse afkomst', maar hij bestreed dat de voorgestelde wet, gezien hun Nederlanderschap, ook voor hen zou kunnen gelden. In haar reactie aanvaardde de regering deze redenering, maar gaf direct aan nu een specifieke inburgeringsregeling te zullen voorbereiden inzake 'Antilliaanse risico- en probleemjongeren'. Advies 1 juli 2005, Voorstel van wet houdende regels inzake inburgering in de Nederlandse samenleving (Wet inburgering), met MvT. Nader rapport, 18 september 2005 (TK, 2005-2006, 30 308, nr. 4). Zie vervolgens advies Raad van State, 3 augustus 2006 inzake het wetsvoorstel houdende regels inzake inburgering in de Nederlandse 
samenleving (Wet inburgering), zaaknr. Wo3.06.0236/I; TK, 2005-2006, 30 308, nr. 105 en nr. 106 en EK, 2005-2006, nr. 30: 'Inmiddels heeft het kabinet in het kader van de Wet inburgering beslist dat er geen algemene inburgeringsplicht voor personen met de Nederlandse nationaliteit wordt ingevoerd. [...] Daarmee is ook de grondslag voor een inburgeringsplicht voor personen uit de Nederlandse Antillen en Aruba weggevallen.' Overigens had de Antilliaanse Raad van Advies al eerder verplichte inburgering afgewezen voor Nederlandse staatsburgers, in verband met strijd met Europese verdragen. Interview F.P. van Beetz, 25 augustus 2011.

124 TK, 2006-2007, 30962, nr 4. Advies Raad van State, 1 september 2006 (zaaknr. Wo3.06.0156/l. Voorstel van wet houdende aanvullende maatregelen inzake onder meer de terugzending van Antilliaanse en Arubaanse risicojongeren, met MvT). Ook de voorgestelde aanpassingen werden vervolgens door de Raad onvoldoende geacht; advies 26 januari 2007 (zaaknr. Wo3.06.0566/II; Gewijzigd voorstel van wet houdende aanvullende maatregelen inzake onder meer de terugzending van Antilliaanse en Arubaanse risicojongeren, met MvT).

125 De Volkskrant, 9 februari 2007, NRC Handelsblad, 15 februari 2007. Ambtelijke nota aan A. Nicolaï, 31 januari 2007, kenmerk 2007-0000033897 (Digidoc; Subdossier Toelatingsregeling, kenmerk ooooooo248). Het ambtelijk advies luidde om, gezien de aanhoudende kritiek van de Raad van State, in de ministerraad voor te stellen de behandeling van het wetsvoorstel aan het nieuwe kabinet over te laten.

126 Debat over het voornemen van de regering tot intrekking van het wetsvoorstel 'Aanvullende maatregelen inzake onder meer de terugzending van Antilliaanse en Arubaanse risicojongeren' (30692). HTK nr. 46, 8 maart 2007. 127 NRC Handelsblad, 3 maart 2007.

128 Zie bijv. NRC Handelsblad, 8 augustus 2007, de Volkskrant, 9 augustus 2007.

129 Leppers 2010.

130 Coalitieakkoord 'Samen Werken, Samen Leven', 7 februari 2007 (p. 38 Koninkrijksrelaties): 'in aansluiting op de bestuurlijke herinrichting van de Nederlandse Antillen het personenverkeer binnen het Koninkrijk geregeld zal worden'. Brief C.P. (Ella) Vogelaar, E.M.H. Hirsch Ballin en A.Th.B.

Bijleveld-Schouten aan vz. TK, 1 februari 2008 (TK, 2007-2008, 26 283, nr. 31). Slotverklaring РОК, 16 t/m 20 juni 2008 te Den Haag (Kamerstukken I/II, 2007-2008, 31 512, A en nr. 1; Inleiding E.M.H. Hirsch Ballin). De Volkskrant, 1 en 21 februari 2008, NRC Handelsblad, 2 februari 2008, Antilliaans Dagblad, 21 januari, 12 februari, 19 maart en 6 april 2010, Amigoe, 20 maart, 13 april en 6 juli 2010.

131 Het op 14 oktober 2010 beëdigde kabinet-Rutte noemde in zijn regeerakkoord (30 september 2010) een Rijkswet personenverkeer, dit keer met inbegrip van een toelatings- en terugkeerregeling. Pag. 25: 'Het kabinet komt met een voorstel voor een Rijkswet personenverkeer die berust op het uitgangspunt van wederkerigheid en tevens de mogelijkheid omvat wederzijds eisen te stellen aan de toelating en het verblijf tot en de terugkeer naar landen van het Koninkrijk (Curaçao, Aruba, St. Maarten en Nederland).'

132 Zie bijv. Amigoe, Antilliaans Dagblad, 24 en 25 juni 2010. Ook nota aan A.Th.B. Bijleveld-Schouten, 4 juni 2008, kenmerk 2008-0000252696 (Digidoc; Subdossier Rijkswet personenverkeer, kenmerk 2008-0000035483).

133 Zie bijv. de Volkskrant, 8 september 2008, NRC Handelsblad, 3 september en 20 november 2008. Slotverklaring POK, 16 t/m 20 juni 2008 te Den Haag (Kamerstukken I/II, 2007-2008, 31 512, A en nr. 1). ECRI, 'Derde rapport over Nederland', goedgekeurd 28 juni 2007, p. 26. 
134 Nota's aan A.Th.B. Bijleveld-Schouten, 22 oktober 2008, kenmerk 2008-0000506894 en 4 november 2008, kenmerk 2008-00005368007 (Digidoc; Dossier Beleid jongeren op de Nederlandse Antillen en Aruba, kenmerk 2006-0000052799; Subdossier Beleid in Nederland, kenmerk 2006-0000052819). De Volkskrant, 11 en 19 november 2008. NRC Handelsblad, 20 november 2008.

135 De Volkskrant, 17 en 18 november 2008, NRC Handelsblad, 19 november 2008. In zijn brief van 25 november 2008 gaf de nieuwe minister voor WWI Eberhard van der Laan uitvoering aan het besluit om Vogelaars brief van 10 november 2008 (waarin zij afzag van de VIA) in te trekken (TK, 2008-2009, 26 283, nr. 47). 136 De Volkskrant, 20 december 2008, NRC Handelsblad, 20 december 2008. Slotverklaring POK van $5 \mathrm{t} / \mathrm{m} 9$ januari 2009 te Oranjestad (Kamerstukken I/II, 2008-2009, 31 854, A en nr. 1). Brief E.E. van der Laan aan vz. TK, 14 april 2009, kenmerk DGW/I\&I 2009018474 (www.rijksoverheid.nl). Brief E.E. van der Laan aan vz. TK, 2 oktober 2009 (TK, 2009-2010, 26 283, nr. 52). Antilliaans Dagblad, 6 oktober 2009, 2 en 3 februari 2010, Amigoe, 2 februari 2010.

$137 \mathrm{Vgl}$. vaststelling van de begrotingsstaten van het ministerie van Justitie (VI) voor 2010, MvT (www.rijksbegroting.nl). NRC Handelsblad, 31 januari 2008. Overeenkomst tussen de drie ministers van Justitie (E.M.H. Hirsch Ballin voor Nederland, D. Dick voor de Antillen en R. Croes voor Aruba), zie bijv. de Volkskrant, 8 januari 2007.

138 Zie bijv. NRC Handelsblad, 26 juni 2007, Antilliaans Dagblad, 17 juni 2010. 139 Vgl. Financieel jaarverslag van het Rijk 2006, nr. 15. Brief E.M.H. Hirsch Ballin aan vz. TK, 15 juni 2007 (TK, 2006-2007, 31 031, nr. 15). Vaststelling begrotingsstaten van het Ministerie van Justitie (VI) voor 2009, nr. 10 (www. rijksbegroting.nl). Verslag houdende een lijst van vragen en antwoorden, 24 oktober 2008 (TK, 2008-2009, 31700 VI, nr. 10).

140 NRC Handelsblad, 23 oktober 2009.

141 Verslag AO 28 oktober 2009, vastgesteld 27 november 2009 (TK, 2009-2010, $31568, \mathrm{nr} .60$, pp. 23-4). Bij een andere gelegenheid gaf Hirsch Ballin in antwoord op een vraag van Verdonk aan geen gegevens te hebben over de aantallen, maar hij had de indruk 'dat die aantallen aanzienlijk lager liggen [dan 90.000]'. HTK nr. 21, 5 november 2009, pp. 1779-80. Zie ook verslag houdende een lijst van vragen en antwoorden, 23 november 2009 (TK, 2009-2010, 32123 IV, nr. 3).

142 HTK nr. 32, 2 december 2009, motie nr. 14 (32123 IV), pp. 3057, 3059, 3077.

143 HTK nr. 32, 2 december 2009, motie nr. 9 (32123 IV), p. 3078. De motie werd ingediend door Van Bochove en medeondertekend door J. Leerdam, J.W. Remkes, C.A. Ortega-Martijn, A. Pechtold, C.G. van der Staaij en R. van Raak.

144 Regels met betrekking tot de openbare lichamen Bonaire, Sint Eustatius en Saba (Wet openbare lichamen Bonaire, Sint Eustatius en Saba) nr. 13, Verslag Wetgevingsoverleg Vaste Commissie NAAZ, Vaste Commissie BZK en Vaste Commissie BZ, 15 januari 2010, vastgesteld 20 januari 2010 (TK, 2009-2010, 31 954, nr. 13, B.J. van Bochove, p. 16). MvT Wijziging van de Wet Toelating en Uitzetting (WTU) BES (TK, 2009-2010, 32 282, nr. 3).

145 BZ-notitie 'Het buitenlands beleid van het Koninkrijk in de Cariben' (2009) (TK, 2009-2010, 29653, nr. 9).

146 Oostindie \& Klinkers 2003:144.

147 The Guardian, 15 december 2010, NRC Handelsblad, 19 januari 2011, 1 februari 2011, Nieuwsservice Kabinet van de Gevolmachtige Minister van Curaçao, 24 januari 2011.

148 BZ-notitie 'Het buitenlands beleid van het Koninkrijk in de Cariben' (тк, 2009-2010, 29653, nr. 9, p. 15). De actualisering uit 2011 is minder uitgesproken; 
BZ-beleidsnotitie 'Het Nederlands beleid ten aanzien van Latijns-Amerika en de Cariben', aangeboden 26 augustus 2011 (TK, 2010-2011, 29653, nr. 11). Interview R. Palacios, 19 mei 2010.

149 Trouw, 30 maart 2006.

150 Sluis 2010:25-6.

151 Werken aan vertrouwen; Een kwestie van aanpakken. Strategisch Akkoord voor kabinet van CDA, LPF, VVD, 3 juli 2002 (TK, 2001-2002, 28 375, nr. 5), p. 28. Meedoen, meer werk en minder regels. Hoofdlijnenakkoord voor het kabinet van CDA, VVD, D66, 16 mei 2003 (TK, 2002-2003, 28 637, nr. 19), p. 14. Over de voor- en nadelen van resp. LGO/UPG-status, zie ook Besselink 2004, Roos 2010:76-8. 152 Voorlichting overeenkomstig artikel 18, tweede lid, van de Wet op de Raad van State over de verhouding van de Nederlandse Antillen en Aruba tot de Europese Unie, 9 september 2003, zaaknr. Wo4.03.0203/I/A. Zie ook Inleiding H.D. Tjeenk Willink, 13 juni 2006, nr. 4, Slotverklaring POK van $12 \mathrm{t} / \mathrm{m} 16$ juni in Den Haag (Kamerstukken I/II, 2005-2006, 30 461, D en nr. 4).

153 Brieven Th.C. de Graaf aan vz. TK, 20 augustus 2003 (TK, 2002-2003, 28600 IV, nr. 19) en 9 oktober 2003 (TK, 2003-2004, 28 829, nr. 6); Verslag Mondeling Overleg Th.C. de Graaf met Vaste Commissie NAAZ op 2 december 2003, vastgesteld 8 januari 2004 (EK, 2003-2004, 29200 IV, B, p. 6). NRC Handelsblad, 13 augustus 2003. HEK nr. 20, 9 maart 2004, Th.C. de Graaf, pp. 1016-8.

154 Banden met Brussel; De betrekkingen van de Nederlandse Antillen en Aruba met de Europese Unie. Rapport van de Commissie ter bestudering van mogelijke toekomstige relaties van de Nederlandse Antillen en Aruba met de Europese Unie, 1 juli 2004. Op 8 juli bood De Graaf het rapport aan de Tweede Kamer aan (naazo40020). Van Beuge 2004:28-9, 41.

155 Slotverklaring POK, 5 t/m 9 januari 2009 te Oranjestad (Kamerstukken I/II, 2008-2009, 31 854, A en nr. 1).

156 Brief Th.C. de Graaf aan vz. TK, 9 oktober 2003 (TK, 2003-2004, 28 829, nr. 6). 157 Brief Th.C. de Graaf aan vz. TK, 2 juli 2004 (TK, 2003-2004, 29 434, nr. 4). In het Verdrag van Lissabon (2007) zou ruimte worden opgenomen om te kiezen voor een andere status bij de EU voor de eilanden. HTK nr. 14, 27 oktober 2004, p. 830. 158 A. Pechtold, HEK nr. 24, 26 april 2005, pp. 1036, 1038 en 1040. HEK nr. 18, 14 februari 2006, p. 875 .

159 Toespraak aan de Universiteit van de Nederlandse Antillen, getiteld 'De Europese Unie in het teken van vernieuwing', 20 januari 2005. Memorandum ministerie Buitenlandse Zaken, directie DWH/AK aan minister B.R. Bot, 24 januari 2005, kenmerk DWH/AK-05/007; Nota aan Th.C. de Graaf, 1 februari 2005, kenmerk 2005-0000012555 (Digidoc; Dossier Ministerieel overleg op en met Aruba en Nederlandse Antillen 2005, kenmerk 2004-0000014907; Subdossier Bezoek MinBz Bot januari 2005, kenmerk 2005-0000003369).

160 Voorlichting overeenkomstig artikel 18, tweede lid, van de Wet op de Raad van State inzake de hervorming van de staatkundige verhoudingen van de Antilliaanse eilanden binnen het Koninkrijk, 18 september 2006, zaaknr. Wo4.06.0204/I/K/A.

161 Verslag AO van A. Nicolaï met Vaste Commissie NAAZ van 19 oktober 2006, vastgesteld 22 november 2006 ( TK, 2006-2007, 30800 IV, nr. 10).

162 Het juridische onderzoek werd uitgevoerd door de Rijksuniversiteit Groningen (Faculteit Rechtsgeleerdheid, Centrum voor recht, bestuur en samenleving). SEOR van de Erasmus Universiteit Rotterdam onderzocht in samenwerking met het Franse bureau Louis Lengrand \& Associés de economische implicaties. Economische gevolgen van de status van Ultra Perifeer Gebied voor de 
Nederlandse Antillen en Aruba, 31 maart 2008. Schurende rechtsordes; Over juridische implicaties van de UPG-status voor de eilandgebieden van de Nederlandse Antillen en Aruba, 31 maart 2008. Brief A.Th.B. Bijleveld-Schouten aan vz. TK, 19 juni 2008 (TK, 2007-2008, $31200 \mathrm{IV}, \mathrm{nr}$. 56).

163 Per brief van 30 september 2008 informeerde Bijleveld de Kamer over het definitieve kabinetsstandpunt (TK, 2008-2009, 31700 IV, nr. 3).

164 Verslag AO Vaste Commissie NAAZ en Vaste Commissie BZ met A.Th.B. Bijleveld-Schouten en staatssecretaris F.C.G.M. Timmermans van BZ van 9 oktober 2008, vastgesteld 5 november 2008 (TK, 2008-2009, 31700 IV, nr. 25). 165 Verslag Algemeen Overleg Vaste Commissie NAAZ en Vaste Commissie BZ met A.Th.B. Bijleveld-Schouten en staatssecretaris F.C.G.M. Timmermans van $\mathrm{BZ}$ van 9 oktober 2008, vastgesteld 5 november 2008 (TK, 2008-2009, $31700 \mathrm{IV}$, nr. 25). Zie ook Jaarverslag Koninkrijksrelaties (IV), aangeboden 20 mei 2009 (TK, 2008-2009, 31924 IV, nr. 1).

166 Zie echter de MvT op de Rijksbegroting Koninkrijksrelaties voor 2003, 'Initiatieven zullen worden genomen om de samenwerking en de uitwisseling van ervaringen inzake de overzeese gebieden met Frankrijk en het Verenigd Koninkrijk te verdiepen.' www.rijksbegroting.nl. Er werden inderdaad wel incidenteel werkbezoeken over en weer gebracht.

167 Zie bijv. E.M.H. Hirsch Ballin, HEK nr. 32, 19 mei 2009.

168 Hillebrink 2010. Amigoe, 30 juni 2010, Antilliaans Dagblad, 12 november 2010.

169 F.E. van Kappen aangehaald door M.Y. Linthorst, HEK nr. 32, 19 mei 2009, p. 1465 . Ook in de voorlichting van de Raad van State ter gelegenheid van vijftig jaar Statuut (10 december 2004, zaaknr. Wo4.04.0425/I/K) werd ingegaan op deze situatie (toepassing van artikel 43, tweede lid als ultimum remedium) en werd gesteld dat daar iets tussenin moest zitten.

170 G.M. de Vries, HTK nr. 11, 11 oktober 2000, p. 770 ('afstofoperatie'). Vgl. begrotingsbehandeling Koninkrijksrelaties 2003, HTK nr. 31, 10 december 2002, p. 2283; HTK nr. 32, 11 december 2002, p. 2363 en p. 2366: motie F. Palm (LPF) en F. Teeven (LPF). Voor de Proeve van juni 2003, zie Oostindie \& Klinkers 2001, III:214-20.

171 Verslag Mondeling Overleg, 8 januari 2004 (EK, 2003-2004, 29200 IV, B, p. 6). HEK nr. 20, 9 maart 2004, Th.C. de Graaf, pp. 1016-8. Brief Th.C. de Graaf aan vz. TK, 9 oktober 2003 (TK, 2003-2004, 28 829, nr. 6). Zie ook notitie aan Th.C. de Graaf, 18 februari 2003; Nota DGCZK, 18 februari 2003 (Papieren archief KR; inv. nr. 2003051990, doos 3). Brief J.W. Remkes aan vz. TK, 13 maart 2003 (TK, 2002-2003, 28600 IV, nr. 14, p. 7). Nota aan DGCZK, 11 maart 2003, kenmerk CW03/N58860 (Papieren archief KR; Archief CZK/SV 2000-2004, inv. nr. 2003056262, doos 20). Verslag Parlementair Contactplan 22 t/m 26 september 2003 te Den Haag, 26 september 2003 (Kamerstukken I/II, 2003-2004, 28 829, A en nr. 4, pp. 4-6). Zie ook J.W. Remkes, HTK nr. 32, 11 december 2002, p. 2364. Nota aan J.W. Remkes, 28 april 2003, kenmerk CZK/KR2003/65044; Nota BSG aan J.W. Remkes, 14 mei 2003, z.k. (Papieren archief KR 1986-2005; Dossier Beleidsbespreking Commissie Evaluatie Statuut, inv. nr. 1999054070, doos 100). Nota aan A. Pechtold, 14 september 2005; Geannoteerde agenda bestuurlijk overleg 17 september 2005 (Digidoc; Subdossier bestuurlijk overleg 17 september 2005, Curaçao, kenmerk 2005-0000034613). Behandeling wetsvoorstel Vaststelling begrotingsstaat van Koninkrijksrelaties (IV) 2004 (29200-IV).

172 Motie E. Schuurman c.s., 14 februari 2006 (EK, 2005-2006, 30300 IV, B); Vgl. ook zijn eerdere pleidooi, HEK nr. 20, 9 maart 2004, pp. 1003-4. Motie 
J.W. Remkes c.s., 23 oktober 2008 (TK, 2008-2009, 31700 IV, nr. 10). HTK nr. 15, 23 oktober 2008, p. 1045 ('wurgcontract').

173 A.Th.B. Bijleveld-Schouten, HTK nr. 15, 23 oktober 2008, p. 1122. Zie ook Amigoe, 31 december 2009. E.M.H. Hirsch Ballin, HEK nr. 32, 19 mei 2009. Inleiding Hirsch Ballin getiteld 'De perspectieven van het Statuut voor het Koninkrijk der Nederlanden'. Verslag Parlementair Contactplan van 22 t/m 26 september 2003 in Den Haag, 26 september 2003 (Kamerstukken I/II, 2003-2004, 28 829, A en nr. 4, pp. 4-6).

174 Th.C. de Graaf over Comité 2004 in verslag Mondeling Overleg van 2 december 2003, vastgesteld 8 januari 2004 (EK, 2003-2004, 29200 IV, B, p. 7). Verslag AO van 22 juli 2003 (TK, 2002-2003, 28 829, nr. 3, p. 1). De Volkskrant, 18 juni 2002, NRC Handelsblad, 2 juli en 1 augustus 2003. Nota aan Th.C. de Graaf, 11 september 2003, kenmerk KRo3/No78043; nota aan Th.C. de Graaf, 24 oktober 2003, kenmerk KB/KR 2003/N83064 (Papieren archief KR; inv. nr. 2003055874, doos 11). Interview Th.C. de Graaf, 30 juni 2011. 175 Zie de rapporten van het Comité 2004 (2003, 2004a, 2004b). Coauteur dezes, G.J. Oostindie, was overigens lid van het Comité 2004. Zie voor het opvolgende Comité Koninkrijksrelaties www.comitekoninkrijksrelaties.org. 176 Inleiding H.D. Tjeenk Willink, 13 juni 2006, tijdens POK-bijeenkomst van 12 t/m 16 juni 2006 (Kamerstukken I/II, 2005-2006, 30 461, D en nr. 4). 177 Oostindie \& Klinkers 2001, III:194, 401-2. Notitie 'Houding van Nederland inzake staatkundige veranderingen in het Koninkrijk'; Bijlage bij nota aan K.G. de Vries en G.M. de Vries, 29 mei 2002, kenmerk KR02/074218 (Papieren archief KR; Dossier Staatkundige ontwikkeling binnen het Koninkrijk Nederland/ Nederlandse Antillen en Aruba 1999-2002, inv. nr. 2003052746, doos 94). 178 Kiezen voor het Koninkrijk 2009:31-2.

179 Tegelijk is het zo dat als een landsregering zich uitspreekt tegen een wetsvoorstel, de Kamer dit met ten minste drievijfde meerderheid van de stemmen moet aanvaarden; anders wordt het voorstel niet aan de Eerste Kamer gestuurd, maar voor akkoord voorgelegd aan de minister-president.

Ook was in het proces van staatkundige verandering de politiek-bestuurlijke afspraak gemaakt (tijdens de vergadering van de Politieke Stuurgroep van 12 november 2007) dat de gevolmachtigde minister van de Nederlandse Antillen voorafgaand aan behandeling in de RMR van voorstellen van Rijkswet of ontwerpAMVRB's die deel uitmaakten van het pakket wetgeving voor de staatkundige verandering, zich ervan moest vergewissen dat de bestuurscolleges van Curaçao en Sint Maarten expliciet met elk geagendeerd voorstel hadden ingestemd. Een 'staatsrechtelijk buitenbeentje', want in het Statuut is niet voorzien in enige invloed van de eilandsbesturen op het door de gevolmachtigde minister in de RMR in te nemen standpunt aangaande een geagendeerd onderwerp. Interview W.W. Timmers, 25 augustus 2011. Van Beetz \& Martha-Alberto 2010:94.

180 Vgl. brief A.Th.B. Bijleveld-Schouten aan vz. TK, 15 juni 2007 (TK, 2006-2007, 30 945, nr. 5).

181 Bijlage 1 Slotverklaring Contactplan te Oranjestad, 13 januari 2005 (Kamerstukken I/II, 2004-2005, 29 965, A en nr. 1). Parlementair Contactplan 2005, nr. 3, Slotverklaring Tripartiete Contactplan van 13 t/m 17 juni 2005 te Den Haag, 17 juni 2005 (Kamerstukken I/II, 2004-2005, 29965 C en nr. 3); Speech delegatievoorzitter Vaste Commissies NAAZ uit de Eerste en Tweede Kamer W.I.I. van Beek, 13 juni 2005.

182 Interviews A.Th.B. Bijleveld-Schouten, 20 mei 2011, J.W. Remkes, 30 mei 2011, R. (Raymond) Begina, 22 maart 2011, C.P. de Haseth, 22 maart 2011, J.A.B. 
Larmonie, 30 maart 2011, J.M. Saleh, 23 maart 2011, H.M. Wiels, 25 maart 2011, W.S. Johnson, 28 maart 2011. Vgl. B. van der Burg (VVD), voorzitter Vaste Kamercommissie voor Koninkrijksrelaties: 'POK is a thing of the past' (The Daily Herald, 30 maart 2011). Positiever, vanuit het oogpunt 'iets anders is er niet', zijn R.T. Booi, 28 maart 2011, E.T.M. de Lannooy, 22 maart 2011 en P. Rosenmöller, 19 mei 2011.

183 Verslag gemengde parlementaire werkgroep Democratisch Deficit Koninkrijk; Bijlage Slotverklaring Contactplan mei 2000, vastgesteld 20 juni 2000 (Kamerstukken I/II, 1999-2000, 27 198, nrs. 267 en 1). Vgl. Kiezen voor het Koninkrijk 2009:12-3, 31.

184 Brief G.M. de Vries aan vz. Vaste Commissie NAAZ, 22 augustus 2000 (naazooo070). Vgl. ook brief minister van BZ J.J. van Aartsen aan vz. Vaste Commissie NAAZ, 21 december 2000 (naazooo102).

185 Slotverklaring Contactplan mei 2000, vastgesteld 20 juni 2000 (Kamerstukken I/II, 1999-2000, 27 198, nrs. 267 en 1).

186 Slotverklaring Contactplan van $4 \mathrm{t} / \mathrm{m} 7$ januari 2006, vastgesteld 7 januari 2006 (Kamerstukken I/II, 2005-2006, 30 461, A en nr. 1).

187 Inleiding H.D. Tjeenk Willink, 13 juni 2006 (Slotverklaring POK, 12-16 juni 2006, vastgesteld 12 juni 2006; Kamerstukken I/II, 2005-2006, 30 461, D en nr. 4, p. 20). Bijlage bij TK, 2006-2007, $30800 \mathrm{IV}, \mathrm{nr} .3$, 18 september 2006 (voorlichting Raad van State van het Koninkrijk, zaaknr. Wo4.06.0204/I/K/A).

188 Notitie A.Th.B. Bijleveld-Schouten aan vz. TK, 13 december 2007 (TK, 2007-2008, 30 945, nr. 8). [Betreft, mede namens de minister van Justitie, een notitie met mogelijke opties voor versterking van de democratische legitimatie van het Koninkrijk.]

189 Het POK kwam bijeen van 16 t/m 20 juni 2008 (Kamerstukken I/II, 2007-2008, 31512 A en nr. 1, pp. 12-3). Zie brief Presidium POK, 16 februari 2009 over instelling Commissie Democratisch Deficit (TK, 2007-2008, 31863, nr. 1). Overige leden van de commissie waren Hubert C. Maduro (Staatsraad van het Koninkrijk voor Aruba) en Joop Th.J. van den Berg (emeritus hoogleraar parlementaire geschiedenis, oud-lid van de Eerste Kamer en oud-hoofddirecteur van de Vereniging van Nederlandse Gemeenten).

190 Kiezen voor het Koninkrijk 2009:15, 53; Jesurun 2004:35-6; Borman 2005: 107-8; Van der Wal 2005:392; Hirsch Ballin 2003:92-3.

191 Kiezen voor het Koninkrijk 2009:49, vgl. p. 16.

192 Kiezen voor het Koninkrijk 2009:16, Antilliaans Dagblad, 22 februari 2010, Raad van State, Jaarverslag over 2009, p. 86.

193 Brief A.Th.B. Bijleveld-Schouten aan vz. TK, 18 februari 2010 (TK, 2009-2010, 32123 IV nr. 22). Antilliaans Dagblad, 22 februari 2010.

194 Amigoe, 12, 13 en 16 november 2009, 29 januari 2010, RNW, 13 november 2009, Antilliaans Dagblad, 3 december 2009, 27 januari en 12 maart 2010.

195 Verslag discussie 13 juni 2006 tijdens het POK van 12 t/m 16 juni 2006 te Den Haag (Kamerstukken I/II, 2005-2006, 30 461, D en nr. 4).

196 Oostindie 2006.

197 Korte bezoeken aan de Bovenwindse Antillen in 2001, aan Curaçao in 2005; uitvoerig bezoek aan alle eilanden van 6-16 november 2006.

198 Vaststelling begrotingsstaat Koninkrijksrelaties (IV) voor 2010. MvT (TK, 2009-2010, 32123 hoofdstuk IV, nr. 2, p. 6).

199 Zie verder de slotparagraaf van hfdst. 5 .

200 Het gaat om de uitwerking van artikel 49 van het Statuut. De inhoud van de geschillenregeling (welke geschillen er precies onder zullen vallen, wie om 
beslechting kan vragen en welke instantie als geschillenbeslechter zal optreden) ligt nog niet vast; hierover is voorlichting gevraagd aan de Raad van State van het Koninkrijk. Zie Hillebrink 2010:49-51. Interview A.G. Croes, 29 augustus 2011. 201 Digidoc; Dossier Beleid Koninkrijksstructuur Projectgroep Koninkrijk op Maat, kenmerk 2004-0000002743; Subdossier Projectplannen, kenmerk 2004-0000003367.

202 In het referendum van juni 2000 op Sint Maarten koos 11,6 procent voor 'integratie in Nederland' (tegenover o,9 procent in 1994). Op Bonaire kreeg in september 2004 de optie 'directe constitutionele banden met Nederland' de steun van 59,45 procent van de stemmers. 86,05 procent van de Sabaanse stemmers koos in november 2004 voor dezelfde optie. Op 8 april 2005 koos 23,61 procent van de Curaçaoënaars voor 'deel worden van Nederland' (tegen 8,02 procent in 1993). Op Sint Eustatius kreeg in april 2005 de optie van directe banden met Nederland de steun van 20,6 procent van de stemmers. 203 NRC Handelsblad, 11 mei 2002, de Volkskrant, 25 juni 2002. LPF'ers Frits Palm en Fred Teeven dienden vergeefs een motie in om de provincieoptie te laten onderzoeken; pikant is dat Palm jarenlang (1986-1992) directeur was geweest van KabNA, de voorganger van de directie KR bij het ministerie van BZK. HTK nr. 31, 10 december 2002, p. 2289.

204 Behandeling wetsvoorstel Vaststelling begrotingsstaat Koninkrijksrelaties (IV) 2004 (29200-IV). HEK nr. 20, 9 maart 2004, pp. 1003-4.

205 Aanhangsel, TK, 2001-2002, p. 2955. Antwoord G.M. de Vries, 11 juli 2002 n.a.v. vragen Th.C. de Graaf, 19 juni n.a.v. de suggestie van CDA. Zo ook J.W. Remkes, HTK nr. 32, 11 december 2002, pp. 2363, 2366, De Graaf, Verslag Mondeling Overleg van 2 december 2003, vastgesteld 8 januari 2004, p. 7 (EK, 2003-2004, 29200 IV, B).

206 Nota aan K.G. de Vries en G.M. de Vries, 29 mei 2002, kenmerk KRO2/O74218, met als bijlage 'Houding van Nederland inzake staatkundige veranderingen in het Koninkrijk' (Papieren archief KR; Dossier Staatkundige ontwikkeling binnen het Koninkrijk Nederland/Nederlandse Antillen en Aruba 1999-2002, inv. nr. 2003052746, doos 94). Verslag bezoek directie KR aan het Overseas Territories Department in Londen, 16 juni 2004 (Digidoc; Dossier KR, kenmerk 2005-0000029549; Subdossier Derde vergadering, kenmerk 2005-0000030383). Zie ook HEK nr. 18, 14 februari 2008, p. 871.

207 Brief Gedeputeerde Staten Noord-Holland H.C.J.L. Borghouts en secretaris H.C.M. Oppenhuis de Jong aan A. Nicolaï, 12 december 2006; Nota KR aan A. Nicolaï, 5 februari 2007, kenmerk 2007-0000017861 n.a.v. brief Borghouts (Digidoc; Dossier Beleid Koninkrijksstructuur Projectgroep Koninkrijk op Maat, kenmerk 2004-0000002743; Subdossier GS Noord-Holland als provinciale overheid voor de drie eilanden, kenmerk 2006-0oooo69126). De Volkskrant, 21 december 2006, NRC Handelsblad, 5 januari 2007.

\section{Naar de keuze voor ontmanteling en maatwerk}

1 Oostindie \& Klinkers 2001, III:196-234.

2 De werkgroep Bestuurlijke en Financiële Verhoudingen (onder voorzitterschap van Edsel 'Papy' Jesurun) zou in zijn interim-rapportage van 5 juli 2004 hierover opmerken: 'Dat alle eilanden in een referendum in 1993 kozen voor het behoud van de Antillen van de vijf had mede te maken met het ontbreken van een realistisch alternatief op dat moment. Juist het ontbreken van een geloofwaardig 
eindperspectief heeft er toe geleid dat het Staatsverband van de Nederlandse Antillen nog steeds bestaat.' Het land kon daardoor blijven voortbestaan in een voortdurende staat van ontbinding. Digidoc; Dossier Beleid Koninkrijksstructuur Projectgroep Koninkrijk op Maat, kenmerk 2004-0000002743; Subdossier Werkgroep BFV vervolg kabinetsstandpunt, kenmerk 2004-0000009306.

3 Oostindie \& Klinkers 2001, III:242-4. Vgl. G.M. de Vries, HTK nr. 12, 16 oktober 2001, p. 666.

4 Werken aan vertrouwen, een kwestie van aanpakken. Strategisch akkoord voor kabinet van CDA, LPF, VVD, 3 juli 2002 (TK, 2001-2002, 28 375, nr. 5), p. 28. Troonrede, 17 september 2002 (http://ikregeer.nl/documenten/ h-tk-20022003-1-5).

5 Meedoen, meer werk, minder regels. Hoofdlijnenakkoord voor het kabinet CDA, VVD, D66, 16 mei 2003, p. 10 (www.rijksoverheid.nl). Brief Th.C. de Graaf aan vz. TK, 4 september 2003 (TK, 2002-2003, 28600 IV, nr. 20). Zie ook verslag Mondeling Overleg van 2 december 2003, vastgesteld 8 januari 2004, pp. 4-5 (EK, 2003-2004, 29200 IV, B).

6 G.M. de Vries, HeK nr. 24, 27 maart 2001, p. 1137. Vgl. de Volkskrant, 9 september 2000, 11 augustus 2001. Aan Nederlandse zijde startte RPF/ GPV-woordvoerder E. van Middelkoop de discussie over de referendumuitslag (HTK nr. 91, 27 juni 200o, pp. 5861-3); vgl. antwoord G.M. de Vries HTK nr. 91, 27 juni 2000, p. 5861. Afwijzende reactie K.G. de Vries in brief aan vz. TK, 30 januari 2001 (TK, 2000-2001, 27400 IV, nr. 15, p. 2). Zie ook brief S. Wescott-Williams aan K.G. de Vries, 28 februari 2001, BZK-kenmerk CW01/62197; brief K.G. de Vries aan S. Wescott-Williams, 2 april 2001, kenmerk CW01/U62198 (Papieren archief KR; Dossier Status Aparte Sint Maarten, inv. nr. 2000055921, doos 47). Interview J.P. Dirkse, 7 september 2011. Oostindie \& Klinkers 2001, III:594, n. 18.

7 Interview E.B. Holiday, 30 maart 2011.

8 Interview K.G. de Vries, 30 augustus 2011.

9 Oostindie \& Klinkers 2001, III:79, 139.

10 Brief G.M. de Vries, 27 oktober 200o, kenmerk cwoo/82 274, mede namens minister van BZ J.J. van Aartsen, aan vz. Vaste Commissie NAAZ, met notitie over het Nederlandse standpunt ten aanzien van het zelfbeschikkingsrecht. Zie ook nota DGCZK aan G.M. de Vries, 8 augustus 2000, 'Zelfbeschikkingsrecht Sint Maarten', plus Bijlage (notitie 'Zelfbeschikkingsrecht'), kenmerk cWoo/N82274 (Papieren archief KR; inv. nr. 2002055179, doos 266). Zie ook zijn brief aan vz. Vaste Commissie NAAZ, 15 maart 2001 (naazoooo18) en zijn verklaring in HTK nr. 91, 27 juni 2000, p. 5861.

11 Begrotingsbehandeling HTK nr. 11, 11 oktober 2000. Motie G. van Oven (PVDA), O. Scheltema-de Nie (D66), P. Rosenmöller (GL), E. van Middelkoop (GPV) en M. van der Hoeven (CDA) (TK, 2000-2001, 27400-IV, nr. 5). G.M. de Vries, HTK nr. 11, 11 oktober 2000, p. 770. Vaststelling begroting Koninkrijksrelaties (IV) voor 2001. nr. 22 Herdruk, verslag AO, 3 juli 2001 (TK, 2000-2001, 27400 IV, nr. 22, p. 5).

12 G.M. de Vries, HeK nr. 24, 27 maart 2001, pp. 1137, 1141. Zie ook TK, 2000-2001, 27400 IV, nr. 22, p. 2. Vgl. nota aan G.M. de Vries, 10 september 2001, kenmerk CW01/83167 (Papieren archief KR; Dossier Status Aparte Sint Maarten, inv. nr. 2000055921, doos 47).

13 Brief G.M. de Vries aan de Antilliaanse minister van Binnenlandse Zaken M. Rafaël, 5 september 2001; zie ook antwoord op Kamervragen C. van der Knaap (CDA), 4 oktober 2001, kenmerk 2010200090 (Papieren archief KR; Dossier Status Aparte Sint Maarten, inv. nr. 2000055921, doos 47). 
14 Papieren archief KR; Archief KR, 1986-2005, dossier ICKR; Vergaderstukken en verslagen september $2000 \mathrm{t} / \mathrm{m}$ december 2000, inv. nr. 2001052836, doos 230.

15 Regeerprogramma van het kabinet-Ys, juni 2002. Papieren archief KR; Dossier Advies over status aparte Sint Maarten, inv. nr. 2002055297, doos 14.

16 Vgl. nota DGCZK aan minister van BZK J.W. Remkes, 12 februari 2003, kenmerk CZK/KRO3/N55242 (Papieren archief KR; inv. nr. 2003051990, doos 3). Parlementair Contactplan september 2003, nr. 4, verslag, 26 september 2003 (TK, 2003-2004, 28 829, A en nr. 4).

17 De Vries had een informeel voorstel gedaan om over de staatkundige verhoudingen een werkgroep in te stellen, maar de Antillen en Aruba hadden daarop niet positief gereageerd. Zie W. Gortzak (PVDA), HTK nr. 13, 16 oktober 2001, p. 660; G.M. de Vries, HTK nr. 13, 16 oktober 2001, pp. 671-2: 'De landsregering is van mening dat de discussie over een eindmodel van de organisatie van de Nederlandse Antillen niet in de weg moet staan aan het bereiken van doorbraken op korte termijn. Ik deel dat standpunt. Ik zoek naar doorbraken op de korte termijn. Als wij praten over toekomstige eindmodellen, vrees ik dat wij lang bezig zijn.'

18 Hiermee werd een koppeling gelegd tussen de reorganisatie van de landsoverheid, uitgewerkt in het plan 'De Nieuwe Overheid' en de discussie over de staatkundige toekomst van de Nederlandse Antillen. Notitie DGCZK 'Staatkundige ontwikkelingen Nederlandse Antillen', 12 februari 2003 (Papieren archief KR; inv. nr. 2003051990, doos 3). Nederland reageerde afhoudend op de notitie 'Nieuwe overheid'. Brief K.G. de Vries aan vz. TK, 30 januari 2001, kenmerk CW01/52430 (Papieren archief KR; Dossier Status Aparte Sint Maarten, inv. nr. 2000055921, doos 47).

19 Notitie DGCZK 'Staatkundige ontwikkelingen Nederlandse Antillen', 12 februari 2003 (Papieren archief KR; inv. nr. 2003051990, doos 3). Zie ook inv. nr. 2001052791, doos 30. Klaas de Vries zou op 7 januari 2002 aan vz. Vaste Commissie NAAZ rapporteren (TK, 2001-2002, 28 380, nr. 12) dat het overleg onder leiding van Rafaël over 'Naar een nieuw verband' geen eenduidige uitkomst had opgeleverd.

20 G.M. de Vries, HTK nr. 12, 16 oktober 2001, p. 671.

21 G.M. de Vries in antwoord op vragen over Sint Maarten van CDA-woordvoerder C. van der Knaap, 20 september 2001 (TK, 2001-2002, Aanhangsel van de handelingen, pp. 153-4). Vgl. Financiële verantwoording Koninkrijksrelaties (IV) over 2001 (TK, 2001-2002, 28 380, nr. 12, p. 10). Zie ook brief G.M. de Vries aan vz. TK, 11 juli 2001, kenmerk KR01/U76903 (Papieren archief KR; ICKR DD, inv. nr. 2001053382, doos 235).

22 Brief G.M. de Vries aan vz. Vaste Commissies NAAZ EK en TK, 7 januari 2002, kenmerk KROVN102358 (Papieren Archief KR; Dossier Werkmap aanpak drugsproblematiek Nederlandse Antillen, 24-8-2001-13-2-2002; inv. nr. 2003053179, doos 364.

23 'Houtskoolschets modaliteiten staatkundige veranderingen', 19 maart 2002, onder embargo tot 20 maart 2002 (Digidoc; Dossier KR, kenmerk 2005-0000029549; Subdossier Presentaties, kenmerk 2005-0000030355). 24 Ambtelijke nota aan K.G. de Vries i.a.a. G.M. de Vries, 15 maart 2002, kenmerk CW01/N63515, 'Staatkundige ontwikkelingen Nederlandse Antillen, werkzaamheden commissie Begina'; zie ook notitie DGCZK, 12 februari 2003 (Papieren archief KR; inv. nr. 2003051990, doos 3).

Daarnaast werd een NU-scenario zonder Nederland gepresenteerd en een Groeimodelvariant, net als het NU-scenario gebaseerd op samenwerking en 
vrijwilligheid. De invulling van de samenwerking was in het Groeimodel echter anders: geen a priori gezamenlijke taken; geen vooraf vastgesteld kader; flexibiliteit was het uitgangspunt. Ook in dit model werden de Antillen opgeheven: het zou gaan om een institutioneel samenwerkingsverband van autonome leden, aangevuld met samenwerking op staatsrechtelijk niveau. Zonder centrale regering of Staten, maar mogelijk wel met een coördinerend lichaam om gemeenschappelijke voorzieningen te behartigen.

25 Notitie DGCZK, 'Staatkundige ontwikkelingen Nederlandse Antillen', 12 februari 2003 (Papieren archief KR; inv. nr. 2003051990, doos 3). Nota aan G.M. de Vries, 14 februari 2002 (verslag van gesprek met Ys op 7 februari 2002), kenmerk KRO2/N57417 (Papieren archief KR; inv. nr. 2002054744, doos 68).

26 Nota aan K.G. de Vries en G.M. de Vries, 29 mei 2002, kenmerk KRo2/074218, met als bijlage nota 'Houding van Nederland inzake staatkundige veranderingen in het Koninkrijk' t.b.v. de presentatie 'Staatkundige ontwikkelingen binnen het Koninkrijk', 30 mei 2002 (Papieren archief KR; Dossier Staatkundige ontwikkeling binnen het Koninkrijk Nederland/Nederlandse Antillen en Aruba 1999-2002, inv. nr. 2003052746, doos 94); notitie DGCZK 'Staatkundige ontwikkelingen Nederlandse Antillen', 12 februari 2003 (Papieren archief KR; inv. nr. 2003051990, doos 3).

27 Deze modellennotitie circuleerde sindsdien intensief, onder meer als bijlage bij nota DGCZK aan minister J.W. Remkes, 6 september 2002, kenmerk KRO2/ N86894, t.b.v. Beleidsbespreking 11 september 2002 met DGCZK (Papieren archief KR; Dossier Beleidsbespreking Koninkrijksrelatie september 2002, inv. nr. 2002054903, doos 259).

28 Notitie aan J.W. Remkes, 28 augustus 2002, kenmerk KRO2/No85791 met bijlage 'Verscheidenheid kan niet zonder eenheid'; beleidsbespreking DGCZK, 11 september 2002, geannoteerde besluitenlijst (Papieren archief KR; Dossier Beleidsbespreking Koninkrijksrelaties september 2002, inv. nr. 2002054903, doos 259).

29 Interview J.W. Remkes, 30 mei 2011.

30 http://nl.wikisource.org/wiki/Troonrede_2002.

31 Nota DGCZK aan J.W. Remkes, 1 oktober 2002, kenmerk KRo2N89989; Notitie VNW aan DGCZK, 23 september 2002, kenmerk w02/U36137 (Papieren archief KR; Dossier Gesprek/Verslag tussen de bewindslieden van Nederland/Nederlandse Antillen en Aruba 2002, inv. nr. 2002053962, doos 255).

32 Verslag gesprek J.P. Balkenende, J.W. Remkes en E.N. Ys, vergezeld van C.P. de Haseth, 14 oktober 2002 (Papieren archief KR; Gesprek/Verslag tussen de bewindslieden van Nederland/Nederlandse Antillen en Aruba 2002, inv. nr. 2002053962, doos 255).

33 Begrotingsbehandeling Koninkrijksrelaties voor 2003, HTK nr. 31, 10 december 2002, pp. 2283, 2285 (Rosenmöller), 2363-4, 2366.

34 Nota DGCZK aan J.W. Remkes, 8 januari 2003, kenmerk KRo3/N50850 (Papieren archief KR; Dossier Gesprek/Verslag tussen de bewindslieden van Nederland, Nederlandse Antillen en Aruba, inv. nr. 2003050985, doos 8). Nota DGCZK 'Politieke situatie Nederlandse Antillen', 12, 14 en 18 februari 2003 (Papieren archief KR; inv. nr. 2003051990, doos 3).

35 Brief J.W. Remkes aan vz. TK, 13 maart 2003 (TK, 2002-2003, 28600 IV, nr. 14); nota aan DGCZK, 12 maart 2003, kenmerk CZK/KRo3/N59149 (Papieren archief KR; Dossier Gesprek/Verslag tussen de bewindslieden van Nederland, Nederlandse Antillen en Aruba, inv. nr. 2003050985, doos 8). Verslag AO, 3 april 2003 (TK, 2002-2003, 28600 IV, nr. 15, p. 5). Jaarverslag Koninkrijksrelaties over 
2002, 21 mei 2003 (TK, 2002-2003, 28 880, nr. 8). Vgl. brief J.W. Remkes aan vz. TK, 15 november 2002 (TK, 2002-2003, 28600 IV, nr. 5). Interview J.W. Remkes, 30 mei 2011, e-mail C.P. de Haseth, 22 augustus 2011; zie ook de karakterisering van Remkes in hfdst. 2.

36 Verslag kennismakingsbezoek van een delegatie aan de Nederlandse Antillen (17-21 maart 2003), 3 juni 2003 (TK, 2002-2003, 28 959, nrs. 228 en 1, pp. 3-4). Aansluitend, van 24-28 maart, zou op Aruba een bijeenkomst in het kader van het parlementaire Contactplan plaatsvinden. Daarbij werd echter afgezien van de behandeling van het geplande thema in het kader van vijftig jaar Statuut, te weten: 'Een discussie over het versterken van de Koninkrijksrelaties en het waar mogelijk ontwikkelen van een gemeenschappelijke visie.' Besloten werd dit thema in een later Contactplan te behandelen.

37 Regeerakkoord Balkenende II, Meedoen, meer werk, minder regels, 16 mei 2003. Regeringsverklaring, 11 juni 2003, http://nos.nl/archief/2003/balkenende2/ paginas/regeringsverklaring/index.html: 'In de relaties binnen het Koninkrijk kan de samenwerking tussen de landen worden versterkt. Ook hier geldt dat ieders verantwoordelijkheid voorop staat.' Th.C. de Graaf, HTK nr. 12, 9 oktober 2003, p. 631.

38 Werkbezoek parlementaire delegatie aan de Nederlandse Antillen en Aruba, verslag 7 november 2003 (TK, 2003-2004, 27 916, nr. 2: bezoek 24 augustus-3 september 2003). Vgl. NRC Handelsblad, 26 en 28 augustus, 7 november 2003, 11 oktober 2004, de Volkskrant, 28 en 29 augustus 2003. Zie ook HTK nr. 10, 7 oktober 2003, p. 515 en HTK nr. 12, 9 oktober 2003, p. 638. Sluis 2004:7.

39 Brief Th.C. de Graaf aan vz. TK, 20 augustus 2003 (TK, 2002-2003, 28600 IV, nr. 19, p. 3). Parlementair Contactplan 2003, nr. 3, verslag AO, 22 juli 2003 (TK, 2002-2003, 28 829, nr. 3). Zie soortgelijk ambtelijk advies in nota DGCZK aan Th.C. de Graaf, 24 juni 2003, 'Reisdossier werkbezoek Nederlandse Antillen en Aruba juni/juli 2003', kenmerk CZK/KR2003/70796 (Papieren archief KR; inv. nr. 2003054563, doos 28).

40 Verslag AO, 2 oktober 2003 (TK, 2003-2004, 29200 IV, nr. 4, p. 11).

41 Brief Th.C. de Graaf aan vz. TK, 20 augustus 2003 (TK, 2002-2003, 28600 IV, nr. 19, p. 3).

42 Brief Th.C. de Graaf aan vz. TK, 4 september 2003 (TK, 2002-2003, 28600 IV, nr. 20). Vgl. brief Th.C. de Graaf aan vz. TK, 9 oktober 2003 (TK, 2003-2004, 28 829, nr. 6).

43 Brief Th.C. de Graaf aan vz. TK, 14 november 2003 (TK, 2003-2004, 29200 IV, nr. 11, p. 8). De Volkskrant, 11 september 2003.

44 Verslag AO, 2 oktober 2003 (TK, 2003-2004, 29200 IV, nr. 4, p. 13); HTK nr. 12, 9 oktober 2003, p. 639, NRC Handelsblad, 13 augustus 2003.

45 Verslag Mondeling Overleg, 2 december 2003, vastgesteld 8 januari 2004, pp. 4-5 (EK, 2003-2004, 29200 IV, B). Vgl. Th.C. de Graaf, HEK nr. 20, 9 maart 2004, pp. 1016-8.

46 Brieven Th.C. de Graaf aan M. Louisa-Godett, 29 augustus 2003 en 26 september 2003, kenmerk KRo3/U79443 (Papieren Archief KR; Archief KB/ KR 1995-2005, Dossier Werkgroep BFV, inv. nr. 2003055323, doos 4). Voor de werkgroep die de relaties met de EU zou onderzoeken, zie hfdst. 2.

47 Brief M. Louisa-Godett aan Th.C. de Graaf, 10 september 2003; brief Th.C. de Graaf aan M. Louisa-Godett, 26 september 2003, kenmerk KRO3/U79443 (Papieren Archief KR; Archief KB/KR 1995-2005, Dossier Werkgroep BFV, inv. nr. 2003055323, doos 4). Tijdens Algemeen Overleg met de Vaste Commissie NAAZ op 11 september 2003 hadden de fracties hun 'grote zorgen' uitgesproken over 
de situatie op de Antillen. De hoofdpunten die om een stevige aanpak vroegen, waren de financieel-bestuurlijke organisatie, de verhoudingen tussen de eilanden en het land en tussen het Koninkrijk en Nederland, de openbare financiën, het armoedebeleid en de rechtshandhaving. De commissie sprak nadrukkelijk uit dat vaart moest worden gezet achter de vernieuwing van de bestuurlijke en financiële verhoudingen. Verslag AO, 2 oktober 2003 (TK, 2003-2004, 29200 IV, nr. 4, p. 13). Godett in de Amigoe, aangehaald door B. Dittrich (D66), HTK nr. 10, 7 oktober 2003, p. 522. De Volkskrant, 4 september 2003.

48 Nota DGKB aan Th.C. de Graaf, 2 oktober 2003, kenmerk KB/KR 80425; Nota aan dKR, 14 oktober 2003, kenmerk KRo3/N81166 (Papieren Archief KR; Archief KB/KR 1995-2005, Dossier Werkgroep BFV, inv. nr. 2003055323, doos 4).

49 Hтк nr. 12, 9 oktober 2003, p. 631. Zie ook brief Th.C. de Graaf aan vz. TK, 5 maart 2004 (TK, 2003-2004, 29 434, nr. 2).

50 Persbericht, 23 januari 2004 Willemstad/Kralendijk (Papieren archief KR; Dossier Tripartiete Contactplanbijeenkomst januari 2004, inv. nr. 2004052018, doos 25). Zie ook verslag Parlementair Contactplan 2004, 17 februari 2004 (TK, 2003-2004, 29 434, A en nr. 1).

51 Nota DGKB aan Th.C. de Graaf, 21 oktober 2003, kenmerk KB/KR 2003/N80926 (Papieren Archief KR; Archief KB/KR 1995-2005, Dossier Werkgroep BFV, inv. nr. 2003055323, doos 4).

52 Protocol ter instelling van de werkgroep, op 29 oktober 2003 ondertekend door Th.C. de Graaf en E. Cova. De werkgroep diende uiterlijk op 1 februari 2004 een tussenrapportage uit te brengen en uiterlijk 1 april 2004 het eindrapport.

53 Verslag Mondeling Overleg, 2 december 2003, vastgesteld 8 januari 2004 (EK, 2003-2004, 29200 IV, B, p. 1).

54 Brief Th.C. de Graaf aan E. Cova, 6 januari 2004, kenmerk KB/KRO3U 88555 (Papieren Archief KR; Archief KB/KR 1995-2005, Dossier Voortgang Werkgroep BFV Nederlandse Antillen 1-1-2003-31-12-2003, inv. nr. 2004051153, doos 21). NRC Handelsblad, 4 maart 2004. Vgl. Verslag AO, 2 oktober 2003 (TK, 2003-2004, 29200 IV, nr. 4, pp. 10-1).

55 Nota aan Th.C. de Graaf, 20 augustus 2003, kenmerk KRo3/N76166 (Papieren Archief KR; Archief KB/KR 1995-2005, Dossier Werkgroep BFV, inv. nr. 2003055323, doos 4).

56 Interviews M.R. Cramwinckel, 5 oktober 2010, Th.C. de Graaf, 30 juni 2011 en L.A.M. van Halder, 17 augustus 2011. Aan Antilliaanse zijde werd het secretariaat geleid door R. (Raymond) Begina, voorzitter van de eerder besproken commissieBegina.

57 Notitie VNW aan DGKB, 26 oktober 2003, kenmerk KB/VNW2003/036491 (Papieren Archief KR; Archief KB/KR 1995-2005, Dossier Werkgroep BFV, inv. nr. 2003055323, doos 4). Andere namen die circuleerden, waren onder meer die van de voormalige minister-president Don Martina en van president van het Hof van Justitie Louis de Lannooy; beiden gaven aan niet geïnteresseerd te zijn. Notitie VNW aan DGKB, 29 februari 2004, kenmerk KB/VNW/04/36200 (Papieren Archief KR; Archief KB/KR 1995-2005, Dossier Werkgroep BFV, inv. nr. 2003055323, doos 4). NRC Handelsblad, 20 november 2003 (De Graaf).

58 In januari 2004 traden de WIPM (Saba) en UPB (Bonaire) uit het kabinetGodett (een coalitie van FOL, PLKP, WIPM, PNP, UPB, DP Sint Maarten en DP Sint Eustatius) omdat hun wens tot het vertrek van de veroordeelde FOL-leider Anthony Godett (Statenlid) niet gehonoreerd werd. Daarvoor in de plaats kwamen de NA van Sint Maarten en de PDB van Bonaire, zodat vanaf begin februari het kabinet weer op een meerderheid steunde van 13 van de 22 zetels. 
Saba nam echter niet deel aan de landsregering en zowel Sint Maarten als Bonaire werd vertegenwoordigd door partijen die op hun eilanden in de oppositie zaten. 59 Nota aan Th.C. de Graaf, 23 september 2003, kenmerk KRo3/N79443; nota DGKB aan Th.C. de Graaf, 21 oktober 2003, kenmerk KB/KR 2003/N80926 (Papieren Archief KR; Archief KB/KR 1995-2005, Dossier Werkgroep BFV, inv. nr. 2003055323, doos 4). Verslag AO, 4 december 2003 (TK, 2003-2004, 28829 en 29200 IV, nr. 7). NRC Handelsblad, 20 november 2003 (citaat De Graaf). Brief Th.C. de Graaf aan bestuurscolleges en landsregering, 21 november 2003 , kenmerk DGKB/KRo3N86188; vgl. DGKB aan Th.C. de Graaf, 14 november 2003, kenmerk KB/KR 2003/N84591; notitie VNW aan DGKB, 29 februari 2004, kenmerk KB/VNW/04/3620o; nota DGKB aan Th.C. de Graaf, 1 december 2003, kenmerk KB/KR 2003/N87487; vgl. advies BSG aan Th.C. de Graaf, 2 december 2003, kenmerk DGKB/KRO3N86188 (Papieren Archief KR; Archief KB/KR 1995-2005, Dossier Werkgroep BFV, inv. nr. 2003055323, doos 4). Gespreksverslag VNW met R. Gibson, 12 maart 2004 (Papieren Archief KR; Dossier Werkbezoek Minister van BZK aan de Nederlandse Antillen en Aruba van januari 2004, inv. nr. 2004051976, doos 25).

60 Bevestigd in interview Th.C. de Graaf, 30 juni 2011.

61 Brief Th.C. de Graaf aan vz. TK, 14 november 2003 (TK, 2003-2004, 29200 IV, nr. 11, p. 8).

62 Brief E. Cova aan Th.C. de Graaf, 15 november 2003, z.k. (Papieren Archief KR; Archief KB/KR 1995-2005, Dossier Werkgroep BFV, inv. nr. 2003055323, doos 4). Notitie VNW aan DGKB, 11 december 2003, kenmerk KB/VNW/2003/36(of 8?)701 (Papieren Archief KR; Archief KB/KR 1995-2005, Dossier Voortgang Werkgroep BFV Nederlandse Antillen 1-1-2003-31-12-2003, inv. nr. 2004051153, doos 21). Notitie VNP aan DGKB, 6 (of 8?) november 2003, kenmerk DGKB/VNPO3/040072; vgl. brief bestuurscollege Sint Maarten aan O. Koerten, 17 december 2003, kenmerk 21943 (Papieren Archief KR; Archief KB/KR 1995-2005, Dossier Werkgroep BFV, inv. nr. 2003055323, doos 4).

63 Nota DGKB aan Th.C. de Graaf, 'Nieuwe aanpak Werkgroep Bestuurlijke en Financiële Verhoudingen', 18 november 2003, kenmerk KB/KR 2003/70207; nota DGKB aan Th.C. de Graaf, 21 november 2003, kenmerk DGKB/KRO3N86188 (Papieren Archief KR; Archief KB/KR 1995-2005, Dossier Werkgroep BFV, inv. nr. 2003055323, doos 4).

64 Verslag AO, 4 december 2003 (TK, 2003-2004, 28829 en 29200 IV, nr. 7). De Graaf: 'Het woord respect hoor ik iets te vaak aan de andere kant van de oceaan. En dat terwijl ik in de Antilliaanse pers uitingen tegenkom over Nederlandse politici waar de honden geen brood van lusten. Laten we ons nu eens concentreren op de inhoud, en de retoriek geen al te grote rol geven.' De Volkskrant, 20 november 2003.

65 Verslag AO, 4 december 2003 (TK, 2003-2004, 28829 en 29200 IV, nr. 7). Brief E. Cova aan Th.C. de Graaf, 20 december 2003, kenmerk 1734/RVM; nota DGKB aan Th.C. de Graaf, 14 november 2003, kenmerk KB/KRO3N86188 (Papieren Archief KR; Archief KB/KR 1995-2005, Dossier Werkgroep BFV, inv. nr. 2003055323, doos 4). Nota DGKB aan Th.C. de Graaf, 16 december 2003, kenmerk KB/KRO3N88355 (Papieren Archief KR; Archief KB/KR 1995-2005, Dossier Voortgang Werkgroep BFV Nederlandse Antillen 1-1-2003-31-12-2003, inv. nr. 2004051153, doos 21).

66 Fax F.E. Richards aan Th.C. de Graaf, 28 oktober 2003 (Papieren Archief KR; Archief кB/KR 1995-2005, Dossier Werkgroep BFV, inv. nr. 2003055323, doos 4). 67 NRC Handelsblad, 20 november 2003. 
68 Verslag Mondeling Overleg van 2 december 2003, vastgesteld 8 januari 2004, pp. 4-5 (E K, 2003-2004, 29200 IV, B). Verslag AO, 2 oktober 2003, p. 3 (TK, 2003-2004, 29200 IV, nr. 4). De Volkskrant, 21 november 2003; Vgl. Th.C. de Graaf in gesprek met NRC Handelsblad, 4 maart 2004.

69 Suggesties in die richting zouden dan worden doorgegeven aan de nog in te stellen commissie ter evaluatie van het Statuut. Brief Th.C. de Graaf aan E. Cova, 17 december 2003, kenmerk KB/KRO3U 88355; brief Th.C. de Graaf aan E. Cova, 6 januari 2004, kenmerk KB/KRo3U88355 (Papieren Archief KR; Archief KB/KR, 1995-2005, Dossier voortgang Werkgroep BFV Nederlandse Antillen 1-1-2003-31-12-2003, inv. nr. 2004051153, doos 21). Reactie E. Cova, 13 januari 2004, kenmerk 0055/RVM (Digidoc; Rapport werkgroep bestuurlijke en financiële verhoudingen; Dossier Newton, 2011, kenmerk 2000038965). Brief Th.C. de Graaf aan vz. TK, 17 februari 2004 (TK, 2003-2004, 29200 IV, nr. 13).

70 Notitie VNW aan Th.C. de Graaf, 26 januari 2004 (Papieren archief KR; Dossier Tripartiete Contactplanbijeenkomst van januari 2004, inv. nr. 2004052018, doos 25).

71 Zie hierover verder hfdst. 2.

72 Papieren Archief KR; Dossier 'Beleidsverkennende notitie Koninkrijk op Maat', inv. nr. 2005050962, doos 65. Digidoc; Dossier Beleid Koninkrijksstructuur Projectgroep Koninkrijk op Maat, kenmerk 2004-0000002743; Subdossier Projectplannen, kenmerk 2004-0000003367.

73 Digidoc; Dossier Beleid Koninkrijksstructuur Projectgroep Koninkrijk op Maat, kenmerk 2004-0000002743; Subdossier Projectplannen, kenmerk 2004-0000003367.

74 In navolging van de notitie werd besloten een interne projectgroep Koninkrijk op Maat in te stellen die een position paper zou leveren aan de werkgroep-Jesurun en een nota zou opstellen met voorstellen voor de te volgen strategie nadat de werkgroep zijn advies zou hebben aangeboden. Zie notitie aan Th.C. de Graaf, 24 mei 2004, kenmerk 2004 KB/KR 65583 (Digidoc; Dossier Beleid Koninkrijksstructuur Projectgroep Koninkrijk op Maat, kenmerk 2004-0000002743; Subdossier Projectplannen, kenmerk 2004-0000003367).

75 Jesurun bezocht van 17-19 maart 2004 de eilanden om kennis te maken met de Antilliaanse leden van de werkgroep en aan de voorzitters van de bestuurscolleges de werkwijze toe te lichten; kernbegrippen in zijn presentatie waren 'transparantie', 'vertrouwen' en 'resultaatgerichtheid'. Alle eilandsbesturen zegden hun volledige medewerking toe. In een nota van KR heette het 'dat Sint Maarten en ook Saba al voor ogen heeft waar het heen wil, Curaçao inhoudelijk de kaarten nog voor de borst houdt, en Bonaire en Sint Eustatius ergens tussenin zitten'. Nota DGKB aan Th.C. de Graaf, 26 maart 2004, kenmerk KB/KR 2004N59265 (Digidoc; Dossier Beleid Koninkrijksstructuur Projectgroep Koninkrijk op Maat, kenmerk 2004-0000002743; Subdossier Eindrapport BFV, kenmerk 2004-0000016419).

76 Interviews R. (Raymond) Begina, 22 maart 2011, E.A.V. Jesurun, 21 maart 2011 en P. Rosenmöller, 19 mei 2011, uitdrukkelijk bevestigd door betrokken ambtenaren en adviseurs.

77 Toespraak E.A.V. Jesurun, openingsvergadering werkgroep BFV, 13 april 2004, Curaçao.

78 Uitkomsten self-assessments als toegelicht in de tweede vergadering van de werkgroep, 31 mei en 1 juni 2004. Werkgroep BFV, Gespreksverslagen Sint Maarten, Sint Eustatius, Saba, Bonaire en Curaçao 8/7/o4-13/7/o4 (Digidoc; 
Dossier Beleid Koninkrijksstructuur Projectgroep Koninkrijk op Maat, kenmerk 2004-0000002743; Subdossier Eindrapport BFV, kenmerk 2004-0000016419).

79 Nota aan Th.C. de Graaf, 4 juni 2004, kenmerk DGKB/KR/67197 (Papieren Archief KR; Archief KB/KR 1995-2005, Dossier Werkgroep BFV, inv.

nr. 2003055323, doos 4). Position paper met Digidoc-kenmerk 2004-0000008626.

80 Brief F.E. Richards aan E.A.V. Jesurun, [zomer 2004] (Digidoc; Rapport werkgroep bestuurlijke en financiële verhoudingen; Dossier Newton, 2011, kenmerk 2000038965).

81 Brief aan Th.C. de Graaf, 23 augustus 2004, kenmerk 2004-0000010578 (Digidoc; Rapport werkgroep bestuurlijke en financiële verhoudingen; Dossier Newton, 2011, kenmerk 2000038965).

82 Het Nederlandse lid Rosenmöller had dit in een eerder memo voor de werkgroep reeds geconcludeerd. 'Enkele gedachten die behulpzaam kunnen zijn bij de discussie over de analyse van de werkgroep', non-paper aan Werkgroep BFV, 31 mei 2004 (Digidoc; Rapport werkgroep bestuurlijke en financiële verhoudingen; Dossier Newton, 2011, kenmerk 2000038965).

83 Tussen 8 en 13 juli werd gesproken met stakeholders op de eilanden; verslag bezoek Jesurun aan Bovenwinden, 13-15 mei 2004; besluitenlijst en verslag derde plenaire vergadering Werkgroep BFV, 14 juli 2004 (Digidoc; Rapport werkgroep bestuurlijke en financiële verhoudingen; Dossier Newton, 2011, kenmerk 2000038965).

84 Interim-rapportage Werkgroep Bestuurlijke en Financiële Verhoudingen Nederlandse Antillen, 5 juli 2004. Vgl. derde plenaire vergadering werkgroep, 14 juli 2004: 'het is een goede zet gebleken om de interim-rapportage toch meer inhoud te geven dan eerst was afgesproken en deze openbaar te maken.' (Want daardoor was nu duidelijk dat het draagvlak voor de voorlopige uitgangspunten op alle eilandgebieden redelijk groot was.) Digidoc; Rapport werkgroep bestuurlijke en financiële verhoudingen; Dossier Newton, 2011, kenmerk 2000038965. 85 Op 27 september kwam nog een conceptrapportage van de werkgroep in de openbaarheid, die voortbouwde op de interim-rapportage. Hierop werd door Haagse parlementariërs positief gereageerd. De Volkskrant, 27 september 2004, NRC Handelsblad, 28 september 2004.

86 Jesurun 2004.

87 Dit was een voor het Statuut nieuwe figuur, in 1993 geïntroduceerd tijdens de Toekomstconferentie (Jesurun 2004:43). De zorg voor een aantal fundamentele aspecten van het bestuur van een Koninkrijkseiland (naast de bestaande Koninkrijksaangelegenheden) zou bij Rijkswet worden geregeld, maar overigens zou de bestaande Antilliaanse wetgeving zo veel mogelijk blijven gelden.

88 Jesurun 2004:14.

89 Jesurun 2004:8, 34.

90 Jesurun 2004:9.

91 Jesurun 2004:10.

92 Jesurun 2004:11-2.

93 Jesurun 2004:11. Uit het Solidariteitsfonds kregen de drie kleinere eilanden geld van de landsregering van de Nederlandse Antillen, Aruba en van Nederland voor het in stand houden van noodzakelijke maar gezien hun schaal dure voorzieningen.

94 NRC Handelsblad, 8 oktober 2004.

95 Jesurun 2004:15. 
96 Nota DGKB aan Th.C. de Graaf, 23 augustus 2004, kenmerk 2004-0000010578 (Papieren Archief KR; Archief KB/KR, 1995-2005, Dossier voortgang Werkgroep BFV Nederlandse Antillen 1-1-2003-31-12-2003, inv. nr. 2004051153, doos 21). 97 Besluitenlijst en verslag derde plenaire vergadering Werkgroep BFV, 14 juli 2004 (Digidoc; Rapport werkgroep bestuurlijke en financiële verhoudingen; Dossier Newton, 2011, kenmerk 2000038965). In het eindrapport (Jesurun 2004:20) werd slechts opgemerkt: 'Onder het oplossen van de bestaande problemen wordt niet alleen verstaan de problemen in het Caribische deel van het Koninkrijk: ook de problemen die in Nederland worden veroorzaakt door de migratie vanuit de Nederlandse Antillen moeten in goede samenwerking tussen de Koninkrijkspartners worden aangepakt. Er moet sprake zijn van een "win-win"-situatie voor alle entiteiten in het Koninkrijk.'

98 Interview Th.C. de Graaf, 30 juni 2011.

99 Het kabinet-Louisa-Godett was gevallen nadat was gebleken dat FOL-minister Ben Komproe in de ogen van zijn coalitiegenoten misbruik van zijn ambt had gemaakt. De regering-Ys steunde op 15 van de 22 zetels in de Staten, waaronder die van Ys' PAR (4 zetels) en van de PNP (3 zetels), de partij van Jesurun. 100 Op 10 september 2004 sprak 59 procent van de Bonairiaanse bevolking zich in een referendum uit voor een directe band met Nederland. De uitkomst werd op 22 april 2005 bevestigd door de eilandsraad. Ongeveer 25 procent wilde een status als autonoom land binnen het Koninkrijk, bijna 16 procent gaf voorkeur aan instandhouding van de huidige structuur, minder dan 1 procent koos voor onafhankelijkheid.

Op 5 november 2004 sprak in een referendum 86 procent van de Sabaanse bevolking zich uit voor een directe band met Nederland. Op 18 januari 2005 bekrachtigde de eilandsraad van Saba de uitslag. Digidoc; Dossier ICKR 2004-2005 kenmerk 2004-0000002728; Subdossier rapportages VNW/VNO, kenmerk 2005-0000000061.

101 MvT Rijksbegroting Hoofdstuk IV Koninkrijksrelaties voor 2005, p. 1. E-mail KR, 1 juli 2004 met conclusies van het overleg met Th.C. de Graaf op 30 juni 2004, Digidoc-kenmerk 2004-0000008751 (Digidoc; Dossier Beleid Koninkrijksstructuur Projectgroep Koninkrijk op Maat, kenmerk 2004-0000002743; Subdossier E-mails werkgroep BFV, kenmerk 2004-0000003948).

102 Verslag werkbezoek E. Jesurun, 5 augustus 2004 aan regering Aruba (Digidoc; Dossier Beleid Koninkrijksstructuur Projectgroep Koninkrijk op Maat, kenmerk 2004-0000002743; Subdossier Vergaderstukken; Subsubdossier Vierde vergadering, kenmerk 2004-0000009654).

103 De Volkskrant, 8 oktober 2004. Interviews R. (Raymond) Begina, 22 maart 2011, E.A.V. Jesurun, 21 maart 2011, J.A.B. Larmonie, 30 maart 2011, S.F.C. Römer, 21 maart 2011.

104 Conceptverslag ICKR, 14 oktober 2004 (Digidoc; Dossier ICKR 20042004 t/m 2005, kenmerk 2004-0000002728; Subdossier 2004-10-14 ICKR-vergadering, kenmerk 2004-0000006835).

105 Conceptverslag ICKR, 14 oktober 2004 (Digidoc; Dossier ICKR 20042004 t/m 2005, kenmerk 2004-0000002728; Subdossier 2004-10-14 ICKR-vergadering, kenmerk 2004-0000006835). Zie ook hfdst. 2.

106 Follow-up rapport Jesurun; 'Een slechte zaak: implementatie BFV, eerste concept 091104' (Digidoc; Rapport werkgroep bestuurlijke en financiële verhoudingen; Dossier Newton, 2011, kenmerk 2000038965). Verslagen ICKR 17 november en 9 december 2004 (Digidoc; Dossier ICKR 2004 2004 t/m 2005, kenmerk 2004-0000002728; Subdossier 2004-11-17 ICKR vergadering/subdossier 
2005-03-03 ICKR vergadering, kenmerk 2005-0000005132). Zie ook DGKB aan Th.C. de Graaf, 26 november 2004, kenmerk 2004-0000037048 (Digidoc; Dossier Beleid Koninkrijksstructuur Projectgroep Koninkrijk op Maat, kenmerk 2004-0000002743; Subdossier Werkgroep BFV vervolg kabinetsstandpunt, kenmerk 2004-0000009306).

107 NRC Handelsblad, 8 oktober 2004, de Volkskrant, 14 oktober 2004. Ook de in de regel zeer kritische LPF reageerde positief (HTK nr. 12, 27 oktober 2004, p. 632). TK, 2004-2005, 29800 IV, nr. 15 en nr. 16. F. Halsema (GL), J. Leerdam (PVDA), J. Rijpstra (VVD) en W. van Fessem (CDA) zouden hun moties (nrs. 11 en 15) samenvoegen tot een gewijzigde motie, ook ondertekend door B. Dittrich (D66), A. Rouvoet (CU) en C. van der Staaij (SGP), waarin de regering werd verzocht 'het sluiten van een politiek hoofdlijnenakkoord voor het einde van het jaar mogelijk te maken door tijdig haar kabinetsstandpunt gereed te houden en naar de Kamer te zenden'. HTK nr. 14, 27 oktober 2004, p. 847 (motie nr. 16). Vgl. brief Th.C. de Graaf aan vz. TK, 1 december 2004 (TK, 2004-2005, 29800 IV, nr. 17). 108 De Volkskrant, 9 en 11 oktober 2004, NRC Handelsblad, 9 oktober 2004. Notitie aan DGKB, 2 november 2004, kenmerk KB/VNW 2004/o036629 (Digidoc; Dossier Beleid Koninkrijksstructuur Projectgroep Koninkrijk op Maat, kenmerk 2004-0000002743; Subdossier Werkgroep BFV vervolg kabinetsstandpunt, kenmerk 2004-0000009306). HTK nr. 14, 27 oktober 2004, p. 826.

109 Brief Th.C. de Graaf aan vz. TK, 17 december 2004 (TK, 2004-2005, 29800 IV, nr. 18). F. Halsema (GL) waarschuwde de minister dat zorgvuldigheid ook de vijand kan zijn van daadkracht (HTK nr. 14, 27 oktober 2004, p. 829). De eilanden zouden op een Topoverleg van 24 januari 2005 hun standpunt innemen, Curaçao en Sint Eustatius onder voorbehoud van de uitslag van de later in 2005 te houden referenda (Amigoe, 16 november 2004).

110 Brief Th.C. de Graaf aan vz. TK, 17 december 2004 (TK, 2004-2005, 29800 IV, nr. 18).

111 De referenda werden gehouden op 8 april 2005. Op Curaçao verkoos 68 procent de status van land binnen het Koninkrijk. Slechts 23 procent gaf aan onderdeel te willen worden van Nederland, als gemeente of als provincie. De bevolking voelde ook weinig voor onafhankelijkheid (5 procent) of voor deel blijven van de Nederlandse Antillen (4 procent). Op 15 april 2005 bekrachtigde de eilandsraad van Curaçao unaniem de uitslag van het referendum.

Op Sint Eustatius koos 75 procent voor handhaving van het land de Nederlandse Antillen ('nieuwe stijl'). Toen echter bleek dat geen enkel ander eiland deel wilde uitmaken van het Antilliaanse staatsverband sloot Sint Eustatius zich aan bij de wens van Bonaire en Saba voor een directe band met Nederland. Zie ook brief A. Pechtold aan vz. TK, 26 mei 2005 (TK, 2004-2005, 29800 IV, nr. 25) en notitie pVNW aan DGKB, 9 april 2005, kenmerk KB/VNW05/35398 (Digidoc; Dossier Werkbezoeken Minister BVK 2005-2007, kenmerk 2004-0000016797; Subdossier Reis 18-19 april 2005, kenmerk 2005-0000010692). Zie ook Digidoc; Dossier Werkbezoeken Minister BVK 2006-2008, kenmerk 2005-0000046003; Subdossier 1-10 tot 5-10, kenmerk 2006-0000050199.

112 'Nu moet het, nu kan het ...?' Procesondersteuning bij formuleren kabinetsstandpunt over het advies van de werkgroep BFV Nederlandse Antillen, 26 oktober 2004; 'Voorbereiding kabinetsstandpunt advies werkgroep BFV; beleidsbespreking 28 oktober 2004, versie 2.0', aan Th.C. de Graaf toegezonden per nota d.d. 21 oktober 2004, kenmerk 2004-0000019638 (Digidoc; Dossier Beleid Koninkrijksstructuur Projectgroep Koninkrijk op Maat, kenmerk 2004-0000002743; Subdossier Werkgroep BFV vervolg kabinetsstandpunt, 
kenmerk 2004-0000009306). ICKR van 17 november 2004 (Digidoc; Dossier ICKR 20042004 t/m 2005, kenmerk 2004-0000002728; Subdossier 2004-11-17 ICKR vergadering/subdossier 2005-03-03 ICKR vergadering, kenmerk 2005-0000005132).

113 Voorbereiding kabinetsstandpunt advies Werkgroep Bestuurlijke en Financiële Verhoudingen, beleidsbespreking 28 oktober 2004; 'Follow-up Rapport Jesurun' voor gesprek met BZK op 30 oktober 2004; handgeschreven memo SG aan Th.C. de Graaf, 27 augustus 2004; hoofdlijnen stappenplan inzake rapportJesurun, z.d.; vertrouwelijk visiedocument 'Naar een werkbaar Koninkrijk' (strategische visie bij het kabinetsstandpunt inzake advies werkgroep BFV), 17 december 2004 (Digidoc; Dossier Beleid Koninkrijksstructuur Projectgroep Koninkrijk op Maat, kenmerk 2004-0000002743; Subdossier Werkgroep BFV vervolg kabinetsstandpunt, kenmerk 2004-0000009306).

114 Zie ook nota aan Th.C. de Graaf, 2 december 2004, kenmerk 2004-0000041137 (Digidoc; Dossier Beleid Koninkrijksstructuur Projectgroep Koninkrijk op Maat, kenmerk 2004-0000002743; Subdossier Werkgroep BFV vervolg kabinetsstandpunt, kenmerk 2004-0000009306).

115 Nota 7 december 2004, p. 2 (Digidoc; Dossier Beleid Koninkrijksstructuur Projectgroep Koninkrijk op Maat, kenmerk 2004-0000002743; Subdossier Werkgroep BFV vervolg kabinetsstandpunt, kenmerk 2004-000ooo9306). 116 Beleidsverkennende notitie 'Naar een werkbaar Koninkrijk' conceptversie 17 december 2004 (Digidoc; Dossier Beleid Koninkrijksstructuur Projectgroep Koninkrijk op Maat, kenmerk 2004-0000002743; Subdossier Werkgroep BFV vervolg kabinetsstandpunt, kenmerk 2004-0000009306). Deze notitie vormde de onderbouwing van het Nederlandse kabinetsstandpunt; in afwachting van het gesprek met de Antillen was dit stuk aanvankelijk vertrouwelijk. Brief Th.C. de Graaf aan vz. TK, 17 december 2004 (TK, 2004-2005, 29800 IV, nr. 18). Zie ook de Volkskrant, 18 december 2004.

117 Voorlichting van de Raad van State ter gelegenheid van vijftig jaar Statuut, 10 december 2004 (zaaknr. Wo4.04.0425/I/K). 'Nader rapport' ofwel regeringsreactie, 27 december 2005 in brief A. Pechtold aan H.M. de koningin, 27 december 2005, kenmerk 2005-0000326882 (Digidoc; Dossier 50 jaar Statuut, kenmerk 2004-0000014980; Subdossier Nader rapport 50 jaar Statuut, kenmerk 2005-0000039941). Bij deze brief stuurde Pechtold de koningin tevens het ongevraagde advies van 10 december 2004 met het verzoek dit (een jaar na dato) openbaar te maken. Zie ook hfdst. 2.

118 http://www.comitekoninkrijksrelaties.org/. Zie ook hfdst. 2.

119 Memorandum VNW aan VNP, 22 oktober 2004, z.k. (Digidoc; Rapport werkgroep bestuurlijke en financiële verhoudingen; Dossier Newton, 2011, kenmerk 2000038965). RNW, 8 november 2004; notitie VNW aan DGKB, 8 november 2004, kenmerk KB/VNW 2004.0036632; notitie VNW aan DGKB, 2 november 2004, kenmerk KB/VNW 2004/0036629 (Digidoc; Dossier Beleid Koninkrijksstructuur Projectgroep Koninkrijk op Maat, kenmerk 2004-0000002743; Subdossier Werkgroep BFV vervolg kabinetsstandpunt, kenmerk 2004-0000009306).

120 Rosenmöller en Jesurun hadden overigens tijdens de werkzaamheden van de werkgroep wel met het Arubaanse bestuur gesproken. Aruba zou zich in de zomer van 2005 in een motie uitspreken tegen het rapport-Jesurun. Slotverklaring tripartiete Contactplan van $13 \mathrm{t} / \mathrm{m} 17$ juni 2005 te Den Haag, vastgesteld 17 juni 2005 (TK, 2004-2005, 29965 C en nr. 3). Zie ook brief N.O. Oduber aan Th.C. de Graaf, 11 februari 2005 met eerste reactie op het rapport; nota (vertrou- 
welijk) aan Th.C. de Graaf, 9 maart 2005, kenmerk 2005-0000034144 (Digidoc; Dossier Beleid Koninkrijksstructuur Projectgroep Koninkrijk op maat, kenmerk 2004-0000002743; Subdossier Projectplannen, kenmerk 2004-0000003367). Vgl. A. Pechtold in verslag AO, 2 augustus 2005 (TK, 2004-2005, 29800 IV, nr. 28): 'Aruba is ook betrokken geweest bij het rapport-Jesurun. Aruba kan het niet beschouwen als een proces exclusief van de Antillen.' De kritiek van Donner en De Graaf in hun brief van 31 januari 2005 (Digidoc; Dossier Informatie TK 2005, kenmerk 2005-0000001328; Subdossier Reisverslag december en januari, kenmerk 2005-0000001360).

121 Nota aan Th.C. de Graaf, 27 januari 2005, kenmerk 2005-0000009942 (Digidoc; Dossier Beleid Koninkrijksstructuur Projectgroep Koninkrijk op Maat, kenmerk 2004-0000002743; Subdossier vervolgtraject Jesurun, kenmerk 2005-0000002469).

122 Digidoc; Dossier ICKR 20052005 t/m 2007, kenmerk 2004-0000008511; Subdossier Rapportages VNW-VNO, kenmerk 2005-0000000061.

123 Digidoc; Dossier ICKR 2005 2005 t/m 2007, kenmerk 2004-0000008511; Subdossier Rapportages VNW-VNO, kenmerk 2005-0000000061. Brief Th.C. de Graaf aan vz. EK, 25 februari 2005 (EK, 2004-2005, 29800 IV, C).

124 Brief Th.C. de Graaf aan E.N. Ys en R. Gibson, 2 maart 2005, kenmerk 2005-0000044874 (Digidoc; Dossier Beleid Koninkrijksstructuur Projectgroep Koninkrijk op Maat, kenmerk 2004-0000002743; Subdossier Werkgroep BFV vervolg kabinetsstandpunt, kenmerk 2004-0000009306).

125 Nota aan Th.C. de Graaf, 4 maart 2005, kenmerk 2005-0000026528 (Digidoc; Dossier Beleid Koninkrijksstructuur Projectgroep Koninkrijk op Maat, kenmerk 2004-0000002743; Subdossier vervolgtraject Jesurun, kenmerk 2005-0000002469).

126 Conceptverslag ICKR, 3 maart 2005 (Digidoc; Dossier ICKR 20052005 t/m 2006, kenmerk 2004-0000008511; Subdossier 2005-06-09 ICKR vergadering, kenmerk 2005-0000018143).

127 Slotconclusies Topoverleg Staatkundige Structuur, 26 en 27 april 2005, te Philipsburg. De Slotconclusies werden ondertekend door R. Gibson (Nederlandse Antillen), R. Dortalina (Bonaire), Z. Jesus-Leito (Curaçao), W. Johnson (Saba), S. Wescott-Williams (Sint Maarten). NRC Handelsblad, 26 en 28 april 2008, de Volkskrant, 28 april 2005.

128 De Werkgroep Voorbereiding RTC 2005 werd door de Antilliaanse regering bij landsbesluit van 13 juli 2005 ingesteld. Oduber had laten weten te willen meewerken aan de staatkundige veranderingen van de Antillen als de status van Aruba onaangetast zou blijven. Digidoc; Dossier ICKR 20052005 t/m 2007, kenmerk 2004-0000008511; Subdossier Rapportages VNW-VNO, kenmerk 2005-0000000061.

129 Brief A. Pechtold aan vz. TK, 26 mei 2005 (TK, 2004-2005, 29800 IV, nr. 25). Vgl. eerdere brief Pechtold aan de Kamer, van 4 mei 2005 (TK, 2004-2005, 29800 IV, nr. 23). HEK nr. 24, 26 april 2005, p. 1035. Zie ook Digidoc; Dossier ICKR 2005 2005 t/m 2007, kenmerk 2004-0000008511; Subdossier Rapportages VNW-VNO, kenmerk 2005-0000000061.

130 Zie hfdst. 2.

131 Zie brief A. Pechtold aan vz. TK, 24 augustus 2005 (TK, 2004-2005, 29800 IV, nr. 29), passage over Topoverleg Sint Maarten van 26 en 27 april 2005.

132 Pechtold in verslag AO, 2 augustus 2005 (TK, 2004-2005, 29800 IV, nr. 28).

133 Digidoc; Dossier Werkbezoeken Minister BVK 2005-2007, kenmerk 2004-0000016797; Subdossier Reis 18-19 april 2005, kenmerk 2005-0000010692. 
Verslag houdende een lijst van vragen en antwoorden, 10 oktober 2005 (TK, 2005-2006, 30300 IV, nr. 7). NRC Handelsblad, 28 april 2005.

134 Memo KR aan A. Pechtold, 15 april 2005, z.k. (Digidoc; Dossier

Beleid Koninkrijksstructuur Projectgroep Koninkrijk op Maat, kenmerk 2004-0000002743; Subdossier Werkgroep BFV, vervolg kabinetsstandpunt, kenmerk 2004-0000009306). Notitie aan A. Pechtold, 27 april 2005, kenmerk 2005-0000072703 (Digidoc; Dossier Beleid Koninkrijksstructuur Projectgroep Koninkrijk op Maat, kenmerk 2004-0000002743; Subdossier kabinetsstandpunt juni 2005, kenmerk 2005-0000017240).

135 HEK nr. 24, 26 april 2005, pp. 1034, 1047. Nota aan A. Pechtold, 29 april 2005, kenmerk 2005-0000072922 (Digidoc; Dossier Ministerieel overleg op en met Aruba en Nederlandse Antillen 2005, kenmerk 2004-0000014907; Subdossier Overleg met Statenleden NA, kenmerk 2005-0000014998). Memorandum DGKB/DKR aan ICKR, agendapunt 5, 19 mei 2005/JMN; conceptbegroting 2006 KR (Digidoc; Dossier ICKR 20052005 t/m 2006, kenmerk 2004-0000008511; Subdossier 2005-06-09 ICKR vergadering, kenmerk 2005-0000018143).

136 Memo aan A. Pechtold, 4 mei 2005, z.k.; beleidsinzet ten aanzien van de Nederlandse Antillen, mede ter bespreking met minister G. Zalm d.d. 25 mei, kenmerk 2005-0000085387; zie ook nota (vertrouwelijk) aan A. Pechtold, 20 mei 2005, kenmerk 2005-0000085387 (Digidoc; Dossier Beleid Koninkrijksstructuur Projectgroep Koninkrijk op Maat, kenmerk 2004-0000002743; Subdossier kabinetsstandpunt juni 2005, kenmerk 2005-0000017240).

137 Nota aan A. Pechtold, 20 mei 2005, kenmerk 2005-0000085387 (Digidoc; Dossier Beleid Koninkrijksstructuur Projectgroep Koninkrijk op Maat, kenmerk 2004-0000002743; Subdossier kabinetsstandpunt juni 2005, kenmerk 2005-0000017240). E-mail C.P. de Haseth, 22 augustus 2011.

138 Brief A. Pechtold aan vz. TK, 21 juni 2005, kenmerk 2005-0000109480 (Digidoc; Dossier Beleid Koninkrijksstructuur Projectgroep Koninkrijk op Maat, kenmerk 2004-0000002743; Subdossier kabinetsstandpunt juni 2005, kenmerk 2005-0000017240). Zie ook Digidoc; Dossier Werkbezoeken minister BVK 2005-2007, kenmerk 2004-0000016797; Subdossier Reis 26-29 juni 2005, kenmerk 2005-0000018105. Digidoc; Dossier ICKR 20052005 t/m 2007, kenmerk 2004-0000008511; Subdossier Rapportages VNW-VNO, kenmerk 2005-0000000061.

139 Verslag bezoek A. Pechtold aan Curaçao, 27-29 juni 2005 (Digidoc; Dossier Beleid Koninkrijksstructuur Projectgroep Koninkrijk op Maat, kenmerk 2004-0000002743; Subdossier Vervolgtraject Jesurun, kenmerk 2005-000002469).

140 Notitie 'Onderhandelingen over het Hoofdlijnenakkoord: posities van entiteiten en spelers', 26 juli 2005 (Digidoc; Dossier Werkbezoeken Minister BVK 2005-2007, kenmerk 2004-0000016797; Subdossier DGKB, DKR, KR-delegatie, kenmerk 2005-0000034594).

141 Toekomst in zicht!, 13 augustus 2005 (opgesteld door de Werkgroep Voorbereiding RTC 2005), p. 25. http://www.curacao-gov.an/.

142 Nota aan A. Pechtold, 12 augustus 2005, kenmerk 2005-0000165359; nota aan A. Pechtold, 25 augustus 2005, kenmerk 2005-0000209298 (Digidoc; Dossier Beleid Koninkrijksstructuur Projectgroep Koninkrijk op Maat, kenmerk 2004-0000002743; Subdossier Vervolgtraject Jesurun, kenmerk 2005-0000002469).

143 Brief W.S. Johnson aan E.A.V. Jesurun, 10 mei 2004 (Digidoc; Rapport werkgroep bestuurlijke en financiële verhoudingen; Dossier Newton, 2011, 
kenmerk 2000038965). Zie ook Digidoc; Dossier ICKR 20052005 t/m 2007, kenmerk 2004-0000008511; Subdossier Rapportages VNW-VNO, kenmerk 2005-0000000061. De Volkskrant, 11 augustus 2005.

144 'Note verbale ten behoeve van de tot standkoming van een Hoofdlijnenakkoord'; geannoteerde note verbale van 27 juli 2005 (Digidoc;

Dossier Beleid Koninkrijksstructuur Projectgroep Koninkrijk op Maat, kenmerk 2004-0000002743; Subdossier Vervolgtraject Jesurun, kenmerk 2005-0000002469).

145 Nota aan A. Pechtold, 5 september 2005, kenmerk 2005-0000218309 (Digidoc; Subdossier Werkgroep B FV, vervolg kabinetsstandpunt, kenmerk 2004-0000009306). Brief A. Pechtold aan vz. TK, 24 augustus 2005 (TK, 2004-2005, 29800 IV, nr. 29).

146 Brief A. Pechtold aan vz. TK, 24 augustus 2005 (TK, 2004-2005,

29800 IV, nr. 29). Zie ook Digidoc; Dossier ICKR 20052005 t/m 2007, kenmerk, 2004-0000008511; Subdossier Rapportages VNW-VNO, kenmerk 2005-0000000061.

147 NRC Handelsblad, 24 augustus 2005. Vervolgens zou Pechtold het uitgangspunt van de werkgroep-Jesurun inzake de Koninkrijksverantwoordelijkheid loslaten.

148 Digidoc; Dossier Beleid Koninkrijksstructuur Projectgroep Koninkrijk op Maat, kenmerk 2004-0000002743; Subdossier vervolgtraject Jesurun, kenmerk 2005-0000002469. Zie ook Digidoc; Dossier ICKR 2005 2005 t/m 2007, kenmerk 2004-0000008511; Subdossier Rapportages VNW-VNO, kenmerk 2005-0000000061.

149 NRC Handelsblad, 26 en 27 augustus 2005. Brief bestuurscollege Curaçao, 9 september 2005, kenmerk 2005/30492 en brief A. Pechtold aan bestuurscollege Curaçao, 9 september 2005, kenmerk 2005-0000220827 (Digidoc; Dossier Beleid Koninkrijksstructuur Projectgroep Koninkrijk op Maat, kenmerk 2004-0000002743; Subdossier Brief BC Curaçao sept 2005, kenmerk 2005-0000033729).

150 Brief A. Pechtold aan vz. TK, 24 augustus 2005 (TK, 2004-2005, 29800 IV, nr. 29). De in deze brief uitgezette beleidslijn had Pechtold tijdens zijn bezoeken van eind juni en juli 2005 ook besproken met de Antilliaanse regering. 151 'Hoe het op de Antillen wel heeft gewerkt'; Een reactie op de brief van 22 [sic: moet zijn: 24] augustus 2005 van de Minister van Bestuurlijke Vernieuwing en Koninkrijksrelaties aan de Tweede Kamer over de aanpak van de staatkundige vernieuwing op de Nederlandse Antillen, 6 september 2005. http://www.gov. an/. Vgl. NRC Handelsblad, 1 september 2005 en 8 oktober 2004 (interview met G. Dales).

152 NRC Handelsblad, 15 september 2005. Verslag AO, 18 oktober 2005 (TK, 2005-2006, 30300 IV, nr. 6). HTK nr. 11, 12 oktober 2005. Interview F.P. van Beetz, 26 augustus 2011.

153 Brief A. Pechtold aan vz. TK, 9 september 2005 (TK, 2004-2005, 29800 IV, nr. 30). NRC Handelsblad, 9 en 19 september 2005.

154 Digidoc; Dossier Werkbezoeken Minister BVK 2005-2007, kenmerk 2004-0000016797; Subdossier DGKB, DKR, KR-delegatie, kenmerk 2005-0000034594. Mede gebaseerd op gesprekken met betrokken ambtenaren van KR.

155 Nota DGKB aan A. Pechtold, 14 september 2005 met 'geannoteerde agenda minister Pechtold voor het bestuurlijk overleg op 17 september 2005 tussen minister Pechtold voor Bestuurlijke Vernieuwing en Koninkrijksrela- 
ties \& de eilanden van en het land de Nederlandse Antillen' en spreekpunten, toelichting en voorstellen voor de Gemeenschappelijke Verklaring (Digidoc; Dossier Beleid Koninkrijksstructuur Projectgroep Koninkrijk op Maat, kenmerk 2004-0000002743; Subdossier Bestuurlijk overleg 17 september 2005, Curaçao, kenmerk 2005-0000034613).

156 'Geannoteerde agenda minister Pechtold voor het bestuurlijk overleg op 17 september 2005 tussen minister Pechtold voor Bestuurlijke Vernieuwing en Koninkrijksrelaties \& de eilanden van en het land de Nederlandse Antillen' en spreekpunten, toelichting en voorstellen voor de Gemeenschappelijke Verklaring (Digidoc; Dossier Beleid Koninkrijksstructuur Projectgroep Koninkrijk op Maat, kenmerk 2004-0000002743; Subdossier Bestuurlijk overleg 17 september 2005, Curaçao, kenmerk 2005-0000034613). 'Slotverklaring van het bestuurlijk overleg staatkundige structuur tussen Nederland, de Nederlandse Antillen en de eilandgebieden Bonaire, Curaçao, Saba, Sint Eustatius en Sint Maarten, gehouden op 17 september 2005 in het World Trade Center te Curaçao', ondertekend door A. Pechtold, E.N. Ys (Nederlandse Antillen), R. Dortalina (Bonaire), S. Ignacio (Curaçao), W. Johnson (Saba), R. Hooker (Sint Eustatius), S. Wescott-Williams (Sint Maarten), en vz. R. Gibson.

157 Pechtold in HTK nr. 11, 12 oktober 2005, p. 622. Zie ook brief A. Pechtold aan vz. TK, 26 september 2005 (TK, 2005-2006, 30300 IV, nr. 4). Geannoteerde agenda bestuurlijk overleg 17 september 2005 (Digidoc; Dossier Beleid Koninkrijksstructuur Projectgroep Koninkrijk op Maat, kenmerk 2004-0000002743; Subdossier Bestuurlijk overleg 17 september 2005, Curaçao, kenmerk 2005-0000034613).

158 NRC Handelsblad, 19 september 2005. Vgl. de Volkskrant, 20 september 2005. Vgl. verslag houdende een lijst van vragen en antwoorden, 10 oktober 2005 (TK, 2005-2006, $30300 \mathrm{IV}, \mathrm{nr}$. 7).

159 Nota aan A. Pechtold, 21 september 2005, kenmerk 2005-0000233727 (Digidoc; Dossier Beleid Koninkrijksstructuur Projectgroep Koninkrijk op Maat, kenmerk 2004-0000002743; Subdossier bestuurlijk overleg 17 september 2005 Curaçao, kenmerk 2005-00000 34613).

160 TK, 2005-2006, 30300 IV, nr. 16; HTK nr. 11, 12 oktober 2005, pp. 630, 634-5. Motie medeondertekend door B. Dittrich (D66), R. Luchtenveld (VVD), C. van der Staaij (SGP), A. Rouvoet (CU).

161 Interviews R.T. Booi, 28 maart 2011 en A. Pechtold, 23 mei 2011. 162 HTK nr. 11, 12 oktober 2005, pp. 627, 635. Brief A. Pechtold aan vz. TK, 30 januari 2006 (TK, 2005-2006, $30300 \mathrm{IV}, \mathrm{nr} .22$ ).

163 Nota aan A. Pechtold betreff. gesprek met Curaçaose delegatie op 11 oktober 2005, 7 oktober 2005, kenmerk 2005-0000248187 (Digidoc; Dossier Beleid Koninkrijksstructuur Projectgroep Koninkrijk op Maat, kenmerk 2004-0000002743; Subdossier Bestuurlijk overleg 17 september 2005 Curaçao, kenmerk 2005-0000034613).

164 Nota aan DG, 6 oktober 2005, kenmerk 2005-0000244380 (Digidoc; Dossier Beleid Koninkrijksstructuur Projectgroep Koninkrijk op Maat, kenmerk 2004-0000002743; Subdossier Bestuurlijk overleg 17 september 2005 Curaçao, kenmerk 2005-00000 34613 betreffende Nederlandse inzet voor het Hoofdlijnenakkoord op 21 oktober 2005). Fiche 'Gesprek met het bestuurscollege van Sint Maarten: bilateraal overleg', 10 oktober 2005 (Digidoc; Dossier Werkbezoeken Minister BVK 2005-2007, kenmerk 2004-0000016797; Subdossier fiches, kenmerk 2005-0000038024). 
165 Digidoc; Dossier Werkbezoeken Minister BVK 2005-2007, kenmerk 2004-0000016797; Subdossier fiches, kenmerk 2005-0000038024.

166 Digidoc; Dossier Werkbezoeken Minister BVK 2005-2007, kenmerk 2004-0000016797; Subdossier Fiches, kenmerk 2005-0000038024.

167 Conceptverslag ICKR, 6 oktober 2005 (Digidoc; Dossier ICKR 20052005 t/m 2006, kenmerk 2004-0000008511; Subdossier 2005-12-01 ICKR vergadering, kenmerk 2005-0000000058).

168 Van Beetz \& Martha-Alberto 2010:78. Interviews A. Pechtold, 23 mei 2011, E.N. Ys, 21 maart 2011.

169 Digidoc; Dossier Beleid Koninkrijksstructuur Projectgroep Koninkrijk op Maat, kenmerk 2004-0000002743; Subdossier Bestuurlijk overleg 17 september 2005 Curaçao, kenmerk 2005-00000 34613. Brief A. Pechtold aan vz. TK, 7 november 2005 (TK, 2005-2006, 30300 IV, nr. 18 1). De Volkskrant, 22 oktober 2005, NRC Handelsblad, 24 oktober 2005. Conceptverslag ICKR van 6 oktober 2005 (Digidoc; Dossier ICKR 20052005 t/m 2006, kenmerk 2004-0000008511; Subdossier 2005-12-01 ICKR vergadering, kenmerk 2005-0000000058). 170 Brief A. Pechtold aan J.P. Balkenende, regering Nederlandse Antillen, bestuurscolleges eilandgebieden Nederlandse Antillen en regering Aruba, 17 november 2005, kenmerk 2005-0000294105 (Digidoc; Dossier Beleid Koninkrijksstructuur Projectgroep Koninkrijk op Maat, kenmerk 2004-0000002743; Subdossier V-RTC, kenmerk 2005-0000042483). Besluit tot instelling werkgroep Directe/Nieuwe Banden met Nederland; Besluit tot instelling werkgroep Rechtszekerheid en Deugdelijkheid van Bestuur; Besluit tot instelling werkgroep Algemene Financiële Positie (Digidoc; Dossier Beleid Koninkrijksstructuur Projectgroep Koninkrijk op Maat, kenmerk 2004-0000002743; Subdossier 2005-12-23 presidium en secretariaat, kenmerk 2005-0000049525).

171 Digidoc; Dossier ICKR 20052005 t/m 2007, kenmerk 2004-0000008511; Subdossier Rapportages VNW-VNO, kenmerk 2005-0000000061.

172 De weergave van de RTC is geheel gebaseerd op Conceptverslag start-RTC 26 november 2005 te Willemstad (gecorrigeerd stenografisch verslag) (Digidoc; Dossier Beleid Koninkrijksstructuur Projectgroep Koninkrijk op Maat, kenmerk 2004-0000002743; Subdossier verslag, kenmerk 2005-0000052225).

173 Conceptverslag ICKR, 1 december 2005 (Digidoc; Dossier ICKR 20052005 t/m 2007, kenmerk 2004-0000008511; Subdossier Rapportages VNW-VNO, kenmerk 2005-0000000061). Nederland was van mening dat de eilanden eerst moesten voldoen aan normen en criteria rond de openbare financiën, economie, rechtshandhaving en goed bestuur.

174 Conceptverslag ICKR, 1 december 2005(Digidoc; Dossier ICKR 20052005 t/m 2007, kenmerk 2004-0000008511; Subdossier Rapportages VNW-VNO, kenmerk 2005-0000000061).

175 Slotverklaring start-Ronde Tafel Conferentie van het Koninkrijk der Nederlanden, gehouden op 26 november 2005 in Willemstad (Digidoc; Dossier Beleid Koninkrijksstructuur Projectgroep Koninkrijk op Maat, kenmerk 2004-0000002743; Subdossier 2005-11-26 start RTC, kenmerk 2005-0000042489).

176 Conceptverslag Start-RTC te Willemstad, 26 november 2005 (gecorrigeerd stenografisch verslag) (Digidoc; Dossier Beleid Koninkrijksstructuur Projectgroep Koninkrijk op Maat, kenmerk 2004-0000002743; Subdossier verslag, kenmerk 2005-0000052225). 
177 Interviews R. (Raymond) Begina, 22 maart 2011, F.P. van Beetz, 26 augustus 2011, R.J. Hooker, 28 maart 2011, E.T.M. de Lannooy, 22 maart 2011, A. Pechtold, 23 mei 2011, W.W. Timmers, 25 augustus 2011.

178 Conceptverslag ICKR, 1 december 2005 (Digidoc; Dossier ICKR 2006 2005 t/m 2007, kenmerk 2005-0000044567; Subdossier 03 maart, kenmerk 2006-0000011460).

179 Interviews E.B. Holiday, 30 maart 2011, W.V. Marlin, 31 maart 2011.

180 Digidoc; Dossier ICKR 20052005 t/m 2007, kenmerk 2004-0000008511; Subdossier Rapportages VNW-VNO, kenmerk 2005-0000oooo61. Brief H.D. Tjeenk Willink aan A. Pechtold, 24 november 2005 (Digidoc; Dossier Beleid Koninkrijksstructuur Projectgroep Koninkrijk op Maat, kenmerk 2004-0000002743; Subdossier agenda en vergaderstukken, kenmerk 2005-0000044959).

181 De Volkskrant, 27 en 28 november 2005.

182 Slotverklaring van het bestuurlijk overleg van 17 september 2005, het Hoofdlijnenakkoord en de Intentieverklaring van 22 oktober 2005.

183 A. Pechtold, HTK nr. 27, 29 november 2005, pp. 1844-5. Brief A. Pechtold aan vz. TK, 30 januari (TK, 2005-2006, 30300 IV, nr. 22). Jaarverslag Koninkrijksrelaties (IV), aangeboden 17 mei 2006 (TK, 2005-2006, 30550 IV, nr. 1).

184 Nota DGKB, 8 december 2005, kenmerk 2005-0000318567 (Digidoc; Dossier Beleid Koninkrijksstructuur Projectgroep Koninkrijk op Maat, kenmerk 2004-0000002743; Subdossier Werkgroep Algemene Financiële Positie, kenmerk 2005-0000042484). Verslag werkgroep DNB, 17-18 januari 2005, DNB2006/01; notitie werkgroep DNB 'Raamwerk voor een constitutionele regeling voor Bonaire, Saba, St. Eustatius', 23 februari 2006, kenmerk DNB2006/o3 (Digidoc; Dossier Beleid Koninkrijksstructuur Projectgroep Koninkrijk op Maat, kenmerk 2004-0000002743; Subdossier Miniconferentie K3 oktober 2006, kenmerk 2006-0000047380). Nota aan dKR, 12 januari 2006 z.k., over 'insteek V-RTC 13 januari 2006' (Digidoc; Dossier Beleid Koninkrijksstructuur Projectgroep Koninkrijk op Maat, kenmerk 2004-0000002743; Subdossier inzet Nederland, kenmerk 2006-0000000300). Nota aan A. Pechtold, 23 januari 2006, kenmerk 2006-0000001057, over 'Criteria werkgroep Directe/Nieuwe Banden' (Digidoc; Dossier Beleid Koninkrijksstructuur Projectgroep Koninkrijk op Maat, kenmerk 2004-0000002743; Subdossier Beleid Nederland, kenmerk 2005-0000049806).

185 Brief griffier mevr. M.C.T.M. Franke aan A. Pechtold, 25 januari 2006, kenmerk 06-NAAZ-B-oo1 (Digidoc; Dossier Beleid Koninkrijksstructuur Projectgroep Koninkrijk op Maat, kenmerk 2004-0000002743; Subdossier AO TK010206, kenmerk 2006-0000004553). Brief A. Pechtold aan vz. TK, 30 januari 2006, kenmerk 2006-0000022865 (Digidoc; Dossier beleid Koninkrijksstructuur Projectgroep Koninkrijk op Maat, kenmerk 2004-0000002743; Subdossier Brief TK31106, kenmerk 2006-0000004766).

186 Voorlichting overeenkomstig artikel 18, tweede lid, van de Wet op de Raad van State inzake de hervorming van de staatkundige verhoudingen van de Antilliaanse eilanden binnen het Koninkrijk, 18 september 2006 (zaaknr. Wo4.06.0204/I/K/A). Hirsch Ballin 2006:39-48. Hirsch Ballin (2006:45) concludeerde dat 'een integratie in het Nederlandse staatsverband als overzeese gemeenten al evenmin [als het model van 'Koninkrijkseilanden'] tot een bruikbare staatsrechtelijke structuur lijkt te kunnen leiden'.

187 Brief A. Pechtold aan vz. TK, 30 januari 2006, kenmerk 2006-0000022865

(Digidoc; Dossier beleid Koninkrijksstructuur Projectgroep Koninkrijk op 
Maat, kenmerk 2004-0000002743; Subdossier Brief TK31106, kenmerk 2006-0000004766).

188 Verslag AO, 22 februari 2006 (TK, 2005-2006, $30300 \mathrm{IV}, \mathrm{nr} .33$ ).

189 NRC Handelsblad, 16 februari 2006.

190 Motie Schuurman c.s. (medeondertekend door J.J. van Heukelum (VVD), W. Lemstra (CDA), I.Y. Tan (PVDA), L.H.G. Platvoet (GL), M. Linthorst (PVDA), E. Hessing (LPF), F. de Graaf (VVD), A.G. Schouw (D66), R. van Raak (SP), H. ten Hoeve (OSF)), voorgesteld 14 februari 2006 (E K, 2005-2006, 30300 IV, B). HEK nr. 19, 21 februari 2006, p. 925 (stemming). Nota aan A. Pechtold, 16 februari 2006, kenmerk 2006-0000051618; nota A. Pechtold, 17 februari 2006, kenmerk 2006-0000053630 (Digidoc; Dossier beleid Koninkrijksstructuur Projectgroep Koninkrijk op Maat, kenmerk 2004-0000002743; Subdossier Motie Schuurman, kenmerk 2006-oooooo8915). Zie ook brief A. Pechtold aan vz. EK, 17 februari 2006 (EK, 2005-2006, $30300 \mathrm{IV}, \mathrm{C}$ ).

191 Motie Luchtenveld c.s. (medeondertekend door W. van Fessem (CDA), G. van As (LPF), C. van der Staaij (SGP)), 21 februari 2006 (TK, 2005-2006, 30300 IV, nr. 27). Op 23 februari 2006 stemden VVD, CDA, SGP en LPF voor deze motie, zodat zij werd aangenomen. Zie ook Pechtold, HTK nr. 52, 21 februari 2006, p. 3436. Brief A. Pechtold en R. Verdonk aan vz. TK, 24 februari 2006 (тк, 2005-2006, $30300 \mathrm{IV}, \mathrm{nr}$. 35).

192 Motie De Vries en Van As, voorgesteld 21 februari 2006 (nr. 29, 30300-IV). HTK nr. 52, 21 februari 2006, p. 3439.

193 A. Pechtold, HTK nr. 52, 21 februari 2006, p. 3436.

194 Brief A. Pechtold aan vz. TK, i.a.a. vz. EK, 24 februari 2006 (TK, 2005-2006, $30300 \mathrm{IV}, \mathrm{nr}$. 37). Verslag vergadering v-RTC, 24 februari 2006 (Digidoc; Dossier Beleid Koninkrijksstructuur Projectgroep Koninkrijk op Maat, kenmerk 2004-0000002743; Subdossier 2006-02-24 commissie, kenmerk 2006-0000006223). Zie brief v-RTC aan vz. RTC J.P. Balkenende, 3 maart 2006, kenmerk 06M482317 (Digidoc; Dossier Beleid Koninkrijksstructuur Projectgroep Koninkrijk op Maat, kenmerk 2004-0000002743; Subdossier bijeenkomst 24 maart 2006, kenmerk 2006-0000014630). Zie ook Digidoc; Dossier Werkbezoeken Minister BVK 2006-2008, kenmerk 2005-0000046003; Subdossier 1-10 tot 5-10, kenmerk 2006-0000050199. Digidoc; Dossier ICKR 2006 2005 t/m 2007, kenmerk 2005-0000044567; Subdossier rapportages VNW-VNO, kenmerk 2005-0000047075.

195 Brief E.N. Ys aan J.P. Balkenende, 2 maart 2006, kenmerk RVM/o203/o6 (Digidoc; Dossier Beleid Koninkrijksstructuur Projectgroep Koninkrijk op Maat, kenmerk 2004-0000002743; Subdossier 2006-03 commissie, kenmerk 2006-0000011742). Zie ook Digidoc; Dossier ICKR 20062005 t/m 2007, kenmerk 2005-0000044567; Subdossier rapportages, kenmerk 2005-0000047075. In de Slotverklaring van de start-RTC (TK, 2005-2006, 30300 IV, 21) was de doorgang van de RTC van eind maart afhankelijk gesteld van het voldoen aan bepaalde randvoorwaarden aan Antilliaanse zijde, om te bevorderen dat de conferentie ook echt concrete resultaten zou opleveren.

196 Brief E.N. Ys aan A. Pechtold, 12 maart 2006, kenmerk RvM/o263/o6; brief bestuurscollege Sint Maarten aan A. Pechtold, 24 maart 2006, kenmerk 1833-06; brief A. Pechtold, mede namens E. de Jongh-Elhage, aan H.D. Tjeenk Willink, 7 juni 2006, kenmerk 2006-0000144151 (Digidoc; Dossier Beleid Koninkrijksstructuur Projectgroep Koninkrijk op Maat, kenmerk 2004-0000002743; Subdossier correspondentie inzake bestuurlijk overleg, kenmerk 2006-0oooo12967). 
197 Slotconclusies Topoverleg Staatkundige structuur gehouden op 13 en 14 maart 2006 te Sint Maarten (www.curacao-gov.an).

198 Digidoc; Dossier ICKR 20062005 t/m 2007, kenmerk 2005-0000044567;

Subdossier rapportages, kenmerk 2005-0000047075.

199 Brief A. Pechtold aan vz. TK, 17 maart 2006 (TK, 2005-2006, 30300 IV, nr. 39).

200 Brief A. Pechtold aan vz. TK, 17 maart 2006 (TK, 2005-2006, 30300 IV, nr. 39).

201 Verslag AO van 23 maart 2006, vastgesteld 12 april 2006 (TK, 2005-2006, 30 $300 \mathrm{IV}, \mathrm{nr} .41$ ).

202 Brief A. Pechtold aan vz. TK, 21 april 2006 (TK, 2005-2006, 30300 IV, nr. 42). Spreekpunten Pechtold 13 juni 2006 over staatkundige verhoudingen en democratisch deficit, tijdens Contactplan van 12 t/m 16 juni 2006 (Kamerstukken I/II, 2005-2006, 30 461, D en nr. 4). Conceptverslagen bilaterale gesprekken, KR-intern (300306/RvD) (Digidoc; Dossier Beleid Koninkrijksstructuur Projectgroep Koninkrijk op Maat, kenmerk 2004-0000002743; Subdossier Verslag, kenmerk 2006-0000017307). Zie ook Digidoc; Dossier ICKR 20062005 t/m 2007, kenmerk 2005-0000044567; Subdossier rapportages VNW-VNO, kenmerk 2005-0000047075.

203 Parlementair Contactplan 2006 (Kamerstukken I/II, 2005-2006, 30 461, D en nr. 4). Spreekpunten Pechtold over staatkundige verhoudingen en democratisch deficit, 13 juni 2006 te Den Haag. Brief A. Pechtold aan vz. TK, 21 april 2006 (TK, 2005-2006, 30300 IV, nr. 42).

204 Verslag ICKR, 9 maart 2006 (Digidoc; Dossier ICKR 20062005 t/m 2007, kenmerk 2005-0000044567; Subdossier 03 maart, kenmerk 2006-0000011460). Geannoteerde agenda voor vergadering ICKR van 9 maart 2006 (Digidoc; Dossier ICKR 20062005 t/m 2007, kenmerk 2005-0000044567; Subdossier 03 maart, kenmerk 2006-0000011460).

205 Brief eilandgebied Sint Eustatius aan A. Pechtold, 27 april 2006, kenmerk 0507/o6 (Digidoc; Dossier Beleid Koninkrijksstructuur Projectgroep Koninkrijk op Maat, kenmerk 2004-0000002743; Subdossier AO TK mei 2006, kenmerk 2006-0000030254).

206 De Volkskrant, 31 maart 2006. Zie ook Digidoc; Dossier ICKR 20062005 t/m 2007, kenmerk 2005-0000044567; Subdossier rapportages, kenmerk 2005-0000047075. Zie ook hfdst. 2.

207 Instructie voor Nederlandse deelnemers aan de workshops op 19 en 20 april 2006 te Curaçao (Digidoc; Dossier Beleid Koninkrijksstructuur Projectgroep Koninkrijk op Maat, kenmerk 2004-0000002743; Subdossier instructie en dossier NL, kenmerk 2006-0000019137).

208 Brief R.E. Duncan aan A. Pechtold, 28 april 2006, kenmerk 0474/RVM (Digidoc; Dossier Beleid Koninkrijksstructuur Projectgroep Koninkrijk op Maat, kenmerk 2004-0000002743; Subdossier 2005-04 workshops, kenmerk 2006-0000018444). Zie ook Digidoc; Dossier ICKR 20062005 t/m 2007, kenmerk 2005-0000044567; Subdossier rapportages VNW-VNO, kenmerk 2005-0000047075. Nota aan A. Pechtold, 25 april 2006, kenmerk 2006-0000136993 (Digidoc; Dossier Beleid Koninkrijksstructuur Projectgroep Koninkrijk op Maat, kenmerk 2004-0000002743; Subdossier Terugkoppeling workshops, kenmerk 2006-0000021333).

209 Nota aan A. Pechtold, 11 mei 2006, kenmerk 2006-0000162486 (Digidoc; Dossier Beleid Koninkrijksstructuur Projectgroep Koninkrijk op Maat, kenmerk 2004-0000002743; Subdossier Bestuurlijk overleg, kenmerk 2006-0000012243). 
Zie ook Digidoc; Dossier Werkbezoeken Minister BVK 2006-2008, kenmerk 2005-0000046003; Subdossier 2006-05-14 t/m 2006-05-21 reis Min BVK, kenmerk 2006-0000018844.

210 Brief aan (plv.) leden speciale stuurgroep Beleidsinzet Nederlandse Antillen, 19 mei 2006, kenmerk 2006-0000172410, 'Overleg over het proces van staatkundige veranderingen op de Antillen 22 mei 2006', met bijlage (Digidoc; Dossier Beleid Koninkrijksstructuur Projectgroep Koninkrijk op Maat, kenmerk 2004-0000002743; Subdossier DG overleg, kenmerk 2006-0000030512).

211 Brief A. Pechtold aan MP, minFin, minEZ, minJus, minDef, ministerBz, 24 mei 2006, kenmerk 2006-0000165850, over 'Staatkundige veranderingen Nederlandse Antillen' (Digidoc; Dossier Beleid Koninkrijksstructuur Projectgroep Koninkrijk op Maat, kenmerk 2004-0000002743; Subdossier 2006-05-11 proces mei juni, kenmerk 2006-0000028932).

212 Het percentage van vijf procent van de gemiddelde overheidsinkomsten van drie voorafgaande jaren.

213 Aanknopingspunten waren verschillende overeenkomsten: dat het Gemeenschappelijk Hof van Justitie en de inrichting van het Openbaar Ministerie bij Rijkswet worden geregeld; dat de bestrijding van de internationale en grensoverschrijdende criminaliteit bij Rijkswet worden geregeld; dat er een protocol of Rijkswet komt inzake de samenwerking op het gebied van Justitie; en dat er een protocol of Rijkswet komt waarin de afspraken met betrekking tot de financiële herstructurering (waaronder begrotingsnormering) en de bewaking van het financieel-economische evenwicht (toezicht) worden geformaliseerd. Digidoc, Dossier Beleid Koninkrijksstructuur Projectgroep Koninkrijk op Maat, kenmerk 2004-0000002743; Subdossier 2006-05-30 bewindsliedenoverleg, kenmerk 2006-0000028932.

214 Verslag AO, 22 juni 2006 (TK, 2005-2006, 30300 IV, nr. 44).

215 Digidoc; Dossier Beleid Koninkrijksstructuur Projectgroep Koninkrijk op Maat, kenmerk 2004-0000002743; Subdossier 2006-05-30 bewindsliedenoverleg, kenmerk 2006-0000028932.

216 'Partners in het Koninkrijk' en voorbereidende nota aan A. Pechtold, 24 mei 2006, kenmerk 2006-0000176274, 'Het bewindsliedenoverleg van 30 mei 2006 inzake de Antillen' (Digidoc; Dossier Beleid Koninkrijksstructuur Projectgroep Koninkrijk op Maat, kenmerk 2004-0000002743; Subdossier 2006-05-30 bewindsliedenoverleg, kenmerk 2006-0oooo28932). Interview G.E.A. van Craaikamp, 2 augustus 2011.

217 Brief A. Pechtold aan MP, minBZ, minDef, minEZ, minFin, minJus, 22 juni 2006, kenmerk 2006-0000218168 over 'Stand van zaken van staatkundige veranderingen Nederlandse Antillen' (Digidoc; Dossier Beleid Koninkrijksstructuur Projectgroep Koninkrijk op Maat, kenmerk 2004-0000002743; Subdossier 2006-05-30 proces bewindsliedenoverleg, kenmerk 2006-0000028932).

218 Digidoc; Dossier ICKR 20062005 t/m 2007, kenmerk 2005-0000044567; Subdossier rapportages, kenmerk 2005-0000047075.

219 Spreekpunten Pechtold over staatkundige verhoudingen en democratisch deficit, 13 juni 2006 te Den Haag, Parlementair Contactplan 2006 (Kamerstukken I/II, 2005-2006, 30 461, D en nr. 4).

220 Digidoc; Dossier ICKR 2006 2005 t/m 2007, kenmerk 2005-0000044567; Subdossier rapportages, kenmerk 2005-0000047075. De Volkskrant, 15 en 16 juni 2006.

221 Zie "Eerste Aanzet Gezamenlijk Document "Partners in het Koninkrijk" (Digidoc; Dossier Beleid Koninkrijksstructuur Projectgroep Koninkrijk op Maat, 
kenmerk 2004-0000002743; Subdossier 2006-10 bestuurlijk overleg, kenmerk 2006-0000047308). Zie ook Digidoc; Dossier ICKR 2006 2005 t/m 2007, kenmerk 2005-0000044567; Subdossier rapportages, kenmerk 2005-0000047075. NRC Handelsblad, 17 juni 2006. Nota aan A. Pechtold, 22 juni 2008, kenmerk 2006-0000218793, over 'annotatie BWO Partners in het Koninkrijk' (Digidoc; Dossier Beleid Koninkrijksstructuur Projectgroep Koninkrijk op Maat, kenmerk 2004-0000002743; Subdossier 2006-06-23 bewindsliedenoverleg, kenmerk 2006-0000035700). Zie ook Van Beetz \& Martha-Alberto 2010:82-3.

222 Brief A. Pechtold aan MP, minBZ, minDef, minEZ, minFin, minJus, 22 juni 2006, kenmerk 2006-0000218168, over 'Stand van zaken van staatkundige veranderingen Nederlandse Antillen'; verslag bewindsliedenoverleg over de Antillen, 23 juni 2006 (Digidoc; Dossier Beleid Koninkrijksstructuur Projectgroep Koninkrijk op Maat, kenmerk 2004-00oooo2743; Subdossier 2006-06-23 bewindsliedenoverleg, kenmerk 2006-0000028932).

223 Nota aan A. Pechtold, 27 juni 2006, kenmerk 2006-00o0222441; verslag gesprek met Sint Maarten op 29 juni 2006 te BZK (Digidoc; Dossier Beleid Koninkrijksstructuur Projectgroep Koninkrijk op Maat, kenmerk 20040000002743; Subdossier 2006-05-11 proces mei juni, kenmerk 2006ooooo27944). Verslag van een wetgevingsoverleg, 26 juni 2006 (TK, 2005-2006, 30550 VII, nr. 7).

224 NRC Handelsblad, 8 juli 2006.

225 Belangrijkste punten uit gesprekken minBVK tijdens kennismakingsreis (Digidoc; Dossier Werkbezoeken Minister BVK 2006-2008, kenmerk 2005-0000046003; Subdossier Kennismakingsbezoek min BVK, kenmerk 2006-0000039792).

226 Belangrijkste punten uit gesprekken minBVK tijdens kennismakingsreis (Digidoc; Dossier Werkbezoeken Minister BVK 2006-2008, kenmerk 2005-0000046003; Subdossier Kennismakingsbezoek min BVK, kenmerk 2006-0000039792). Nicolaï sprak ook met E. Tromp, Ys, Saleh en Römer. Ys stelde dat Sint Maarten en Curaçao akkoord zouden gaan met één centrale bank. Ook voor wat betreft het toezicht zou men uiteindelijk door de bocht gaan, stelde hij, al had dat nog even tijd nodig.

227 Brief A. Nicolaï aan vz. TK, 19 september 2006 (TK, 2006-2007, 30800 IV en 30 461, nr. 3). NRC Handelsblad, 26 augustus 2006. Projectplan bestuurlijk overleg staatkundige vernieuwingen Nederlandse Antillen en Aruba, 7 september 2006 (Digidoc; Dossier Beleid Koninkrijksstructuur Projectgroep Koninkrijk op Maat, kenmerk 2004-0000002743; Subdossier projectplan, kenmerk 2006-0000047309).

228 Brief A. Pechtold, mede namens E. de Jongh-Elhage, aan H.D. Tjeenk Willink, 7 juni 2006, kenmerk 2006-0000144151. Nicolaï zou de Kamer bij brief van 29 september 2006 informeren over deze voorlichting (TK, 2006-2007, 30800 IV, nr. 4); hij gaf aan de voorlichting in grote lijnen te kunnen volgen. Voorlichting overeenkomstig artikel 18, tweede lid, van de Wet op de Raad van State inzake de hervorming van de staatkundige verhoudingen van de Antilliaanse eilanden binnen het Koninkrijk, 18 september 2006 (zaaknr. Wo4.06.0204/I/K/A): 'De afdeling adviseert deze drie eilanden [Bonaire, Saba en Sint Eustatius] in te richten als "openbare lichamen" in de zin van artikel 134 van de Grondwet.' En ook: 'Internationaal zal de rechtstreekse band kunnen worden gekwalificeerd als een vrije associatie met Nederland.' 
229 Artikel 134 van de Grondwet - over de status van openbaar lichaam - was in het verleden ook gebruikt voor het tijdelijke bestuur van de Zuidelijke IJsselmeerpolders.

230 Nota aan A. Pechtold, 23 januari 2006, kenmerk 2006-0000001057, over 'Criteria werkgroep Directe/Nieuwe Banden' (Digidoc; Dossier Beleid Koninkrijksstructuur Projectgroep Koninkrijk op Maat, kenmerk 2004-0000002743; Subdossier Beleid Nederland, kenmerk 2005-0000049806). Definitief verslag vergadering werkgroep DNB, 26-27 april 2006 te Sint Eustatius, document DNB2006/og (Digidoc; Dossier Beleid Koninkrijksstructuur Projectgroep Koninkrijk op Maat, kenmerk 2004-0000002743; Subdossier Bijeenkomst 29 en 30 mei 2006, kenmerk 2006-0000026732).

231 Brief A. Nicolaï aan MP, minBZK, minFin en minJus, 28 september 2006, kenmerk 2006-0000319257 (Digidoc; Dossier Beleid Koninkrijksstructuur Projectgroep Koninkrijk op Maat, kenmerk 2004-0000002743; Subdossier 2006-09-29 bewindsliedenoverleg, kenmerk 2006-0ooo049900). [T.b.v. overleg op 29 september 2006 tussen MinBVK, MP, MinBZK, MinFin en MinJus en marge van de ministerraad.] Zie ook brief A. Nicolaï aan vz. TK, 29 september 2006 (TK, 2006-2007, 30 800 IV, nr. 4).

232 Brief A. Nicolaï aan MP, minBZK, minFin en minJus, 28 september 2006, kenmerk 2006-0000319257 (Digidoc; Dossier Beleid Koninkrijksstructuur Projectgroep Koninkrijk op Maat, kenmerk 2004-0000002743; Subdossier 2006-09-29 bewindsliedenoverleg, kenmerk 2006-0000049900).

233 Verslag AO van 20 september 2006, vastgesteld 23 oktober 2006 (TK, 2006-2007, 30800 IV, nr. 6).

234 Brief A. Nicolaï aan MP, minBZK, minFin en minJus, 28 september 2006, kenmerk 2006-0000319257 (Digidoc; Dossier Beleid Koninkrijksstructuur Projectgroep Koninkrijk op Maat, kenmerk 2004-0000002743; Subdossier 2006-09-29 bewindsliedenoverleg, kenmerk 2006-0000049900). Zie ook Digidoc; Dossier ICKR 20062005 t/m 2007, kenmerk 2005-0000044567; Subdossier rapportages, kenmerk 2005-0000047075. Zie ook notitie VNW aan DGKB, 12 oktober 2006, kenmerk DGKB/VNW/2006/36150; notitie aan min BVK [Overzicht Papiamentstalige kranten week 40], 9 oktober 2006, kenmerk KB/ VNWo6/036113 (Digidoc; Dossier MT KB KR 2006, kenmerk 2006-000oo62957; Subdossier VNW (incl. rapportages), kenmerk 2006-00000068121).

235 Digidoc; Dossier Beleid Koninkrijksstructuur Projectgroep Koninkrijk op Maat, kenmerk 2004-0000002743; Subdossier Miniconferentie K3 oktober 2006, kenmerk 2006-ooooo47380. Zie ook Digidoc; Dossier Werkbezoeken Minister BVK 2006-2008, kenmerk 2005-0000046003; Subdossier 1-10 tot 5-10, kenmerk 2006-0000050199.

236 Interview A. Nicolaï, 23 mei 2011. Van Beetz \& Martha-Alberto 2010:84. Brief A. Nicolaï aan TK, 13 oktober 2006 (TK, 2006-2007, 30 800 IV, nr. 4). 237 De Volkskrant, 10, 11 en 12 oktober 2006. Brief A. Nicolaï aan vz. TK, 13 oktober 2006 (TK, 2006-2007, 30800 IV, nr. 5), met Slotverklaring van de Miniconferentie.

238 Brief vz. Werkgroep DNB S.B. Ybema aan A. Nicolaï en de gedeputeerden van Constitutionele Aangelegenheden van Bonaire, Sint Eustatius en Saba, 28 september 2006, met als bijlagen 'Documenten van de Werkgroep Directe/Nieuwe Banden', 28 september 2006 (Document IIA t/m Document IIF). Overhandigd door Ybema aan auteurs op 20 mei 2010. 
239 Digidoc; Dossier ICKR 20062005 t/m 2007, kenmerk 2005-0000044567; Subdossier rapportages, kenmerk 2005-0000047075. NRC Handelsblad, 12 oktober 2006.

240 Verslag AO, 22 november 2006 (TK, 2006-2007, 30 80o IV, nr. 10). NRC Handelsblad, 24 oktober 2006.

241 'Morgen voor Curaçao cruciaal: knelpunten, angst en concurrentie staan eendracht in de weg', kenmerk DGKB/VNW/2006/36150 (Digidoc; Dossier MT KB KR 2006, kenmerk 2006-0000062957; Subdossier VNW (incl. rapportages), kenmerk 2006-0000068121).

242 Nota aan A. Nicolaï, 18 oktober 2006, kenmerk 2006-0000339816, 'Strategie staatkundige veranderingen binnen Nederlandse kabinet' (Digidoc; Dossier Beleid Koninkrijksstructuur Projectgroep Koninkrijk op Maat, kenmerk 2004-0000002743; Subdossier 2006-10 bestuurlijk overleg, kenmerk 2006-0000047308).

243 Nota's aan Nicolaï, 18 en 19 oktober 2006, kenmerk 2006-oooo339816, 'Strategie staatkundige veranderingen binnen Nederlandse kabinet' (Digidoc; Dossier Beleid Koninkrijksstructuur Projectgroep Koninkrijk op Maat, kenmerk 2004-0000002743; Subdossier 2006-10 bestuurlijk overleg, kenmerk 2006-0000047308).

244 Digidoc; Dossier Beleid Koninkrijksstructuur Projectgroep Koninkrijk op Maat, kenmerk 2004-0000002743; Subdossier reacties op bestuurlijk akkoord, kenmerk 2006-0000057420. Brief A. Nicolaï aan vz. TK, 27 oktober 2006 (TK, 2006-2007, 30800 IV, nr. 7). NRC Handelsblad, 26 oktober 2006. Notitie VNW aan A. Nicolaï [Overzicht Papiamentstalige kranten week 43, 23-28 oktober 2006], 30 oktober 2006, kenmerk Kв/VNWo6036108 (Digidoc; Dossier MT KB KR 2006, kenmerk 2006-0000062957; Subdossier VNW (incl. rapportages), kenmerk 2006-0oooo68121). 'Scenario Curaçao zegt nee tegen Partners in het Koninkrijk', 20 oktober 2006 (Digidoc; Dossier Beleid Koninkrijksstructuur Projectgroep Koninkrijk op Maat, kenmerk 2004-0000002743; Subdossier 2006-10 bestuurlijk overleg, kenmerk 2006-0000047308).

245 Brief A. Nicolai aan vz. ministerraad J.P. Balkenende, 26 oktober 2006, kenmerk 2006-0000347342 (Digidoc; Dossier Beleid Koninkrijksstructuur Projectgroep Koninkrijk op Maat, kenmerk 2004-0000002743; Subdossier 2006-10 bestuurlijk overleg, kenmerk 2006-0000047308).

246 Brief A. Nicolaï aan vz. TK, 27 oktober 2006 (TK, 2006-2007, 30800 IV, nr. 7). 247 In de Curaçaose pers was forse kritiek op de omvang en de daarmee gepaard gaande kosten (128.000 NAF), ook op het feit dat de meningen onderling nog steeds zeer verdeeld waren. Overzicht Papiamentstalige kranten week 43, 23-28 oktober 2006, 30 oktober 2006, kenmerk кB/VNW06036108 (Digidoc; Dossier MT KB KR 2006, kenmerk 2006-0000062957; Subdossier VNW (incl. rapportages), kenmerk 2006-0oooo68121).

248 De Volkskrant, 7 november 2006 (hoofdartikel).

249 In de Slotverklaring van de start-RTC van 26 november 2005 (TK, 30300 IV, 21) was afgesproken dat de nieuwe landen (ook in de uitvoering) aan een aantal criteria zouden moeten voldoen; deze werden nu bestuurlijk vastgelegd in de Slotverklaring van 2 november 2006 (www.curacao-gov.an). Zie brief A. Nicolaï aan TK, 6 november 2006 (TK, 2006-2007, 30 80o IV, nr. 9). Deze Slotverklaring - ondertekend door A. Nicolaï namens Nederland, E.S. de Jongh-Elhage namens de Nederlandse Antillen, Z.A.M. Jesus-Leito namens Curaçao en $S$. Wescott-Williams namens Sint Maarten - zou vervolgens verder uitgewerkt worden in het Overgangsakkoord van 12 februari 2007. 
250 Aangezien justitie in beginsel geen Koninkrijksaangelegenheid was, was dit een bijzondere afspraak. Op 29 maart 2009 zou de VVD haar steun aan de Slotverklaring intrekken omdat de partij het oneens was met het schrappen van de juridische aanwijzingsbevoegdheid waarmee Nederland de opsporing en vervolging van strafbare feiten op Curaçao en Sint Maarten zou kunnen bevelen. Zie hierover ook hfdst. 4.

251 Notitie aan A. Nicolaï, 6 november 2006, kenmerk кB/VNWo6/o36110, 'Overzicht Papiamentstalige kranten week 4430 oktober-4 november 2006; Samenvatting van het opmerkelijke nieuws uit Papiamentstalige kranten in week 46 van 2006' (Digidoc; Dossier Beleid Koninkrijksstructuur Projectgroep Koninkrijk op Maat, kenmerk 2004-0000002743; Subdossier slotteksten, kenmerk 2006-0ooo055989). Zie ook Subdossier reacties op bestuurlijk akkoord, kenmerk 2006-0000057420. En Digidoc; Dossier ICKR 20062005 t/m 2007, kenmerk 2005-0000044567; Subdossier AAN leden, kenmerk 2006-0000004306. 252 Het debat vond plaats nadat de eilandsraad van Curaçao de Slotverklaring had verworpen. HTK nr. 29, 20 december 2006. F. Weekers (VVD), p. 1933. 253 Digidoc; Dossier ICKR 20062005 t/m 2007, kenmerk 2005-0000044567; Subdossier AAN leden, kenmerk 2006-0000004306. NRC Handelsblad, 23 december 2006. Interview R. Vermaas, 23 maart 2011.

254 Verslag AO, 13 maart 2007 (TK, 2006-2007, 30 945, nr. 2).

\section{Het proces: chronologie en resultaten}

1 Interview H.G. Senior, 29 augustus 2011. Interview Don Martina, Amigoe, 10 januari 2007.

2 Verslag AO van 13 december 2006, vastgesteld 30 januari 2007 (TK, 2006-2007, 30800 IV, nr. 21). Brief A. Nicolaï aan vz. TK, 5 december 2006 (TK, 2006-2007, 30 800 IV, nr. 11). Zie ook Digidoc; Dossier Beleid Koninkrijksstructuur Projectgroep Koninkrijk op Maat, kenmerk 2004-0000002743; Subdossier 'Na verwerping akkoord door Curaçao', kenmerk 2006-0oooo61780.

3 Verslag AO van 13 december 2006, vastgesteld 30 januari 2007 (TK, 2006-2007, 30800 IV, nr. 21). Nota aan A. Nicolaï, 1 december 2006, kenmerk 2006-0000398762 (Digidoc; Dossier Beleid Koninkrijksstructuur Projectgroep Koninkrijk op Maat, kenmerk 2004-0000002743; Subdossier 'Afwijzing akkoord door Curaçao', kenmerk 2006-0000061630). NRC Handelsblad, 18 januari 2007. Zie hfdst. 2 voor het migratiedossier.

4 Digidoc; Dossier Beleid Koninkrijksstructuur Projectgroep Koninkrijk op Maat, kenmerk 2004-0000002743; Subdossier reacties op bestuurlijk akkoord, kenmerk 2006-0000057420. Zie ook Van Beetz \& Martha-Alberto 2010:87. Regeringspartijen PAR en PNP stonden lijnrecht tegenover de oppositie van MAN, MPK en NPA. 5 Nota aan A. Nicolaï, 22 november 2006, kenmerk 2006-0000386392 (Digidoc; Dossier Beleid Koninkrijksstructuur, kenmerk 2004-0000002743; Subdossier alternatieve scenario's, kenmerk 2006-000o059486). Advies J.A.B. Larmonie aan de Commissie van Overleg van de eilandsraad, 27 november 2006 (Digidoc; Dossier ICKR 20072006 t/m 2008, kenmerk 2006-0000058188; Subdossier Rapportages, kenmerk 2006-0000059432).

6 Slotconclusies Topoverleg staatkundige structuur regering Nederlandse Antillen en eilandgebieden Bonaire, Curaçao, Saba, Sint Eustatius en Sint Maarten op 11 en 12 januari 2007 (Digidoc; Dossier ICKR 20072006 t/m 2008, kenmerk 2006-0000058188; Subdossier 01 januari, kenmerk 2007-0000009435). 
Vgl. ook geannoteerde agenda voor overleg met Bonaire, Saba en Sint Eustatius op 16 januari 2007; geannoteerde agenda voor overleg met Sint Maarten op 15 januari 2007, ambtelijk concept, 12 januari 2007; geannoteerde agenda voor overleg met Land Nederlandse Antillen, 17 januari 2007, ambtelijk concept, 12 januari 2007 (Digidoc; Dossier Werkbezoeken Minister BVK 2007, kenmerk 2006-0000050715; Subdossier Januari 2007, kenmerk 2007-0000001683). Zie ook NRC Handelsblad, 18 januari 2007; Van Beetz \& Martha-Alberto 2010:88. 7 Het omzetten van Antilliaanse in Nederlandse wetgeving, terwijl de inhoud ervan in beginsel Antilliaans bleef, zou in de uitwerking complex blijken, zie Krips 2010:105-9. Zie verder verslag ICKR, 24 januari 2007 (Digidoc; Dossier ICKR 20072006 t/m 2008, kenmerk 2006-0000058188; Subdossier 03 maart, kenmerk 2006-0000059427).

8 Brief N.O. Oduber aan E.S. de Jongh-Elhage en A. Nicolaï, 7 februari 2007 (Digidoc; Dossier Beleid Koninkrijksstructuur Projectgroep Koninkrijk op Maat, kenmerk 2004-0000002743; Subdossier 2007-02-12 bestuurlijke conferentie SXM, kenmerk 2007-0000008855). Zie ook Digidoc; Dossier Werkbezoeken Minister BVK 2007, kenmerk 2006-0000050715; Subdossier januari 2007, kenmerk 2007-0000001683. Verhey 2010:20; A.Th.B. Bijleveld, HTK nr. 32, 2 december 2009, p. 3081.

9 Geannoteerde agenda inclusief Nederlandse inzet t.b.v. bestuurlijke conferentie Nederland, Nederlandse Antillen, Sint Maarten, Bonaire, Sint Eustatius en Saba op 12 februari 2007, ambtelijke conceptversie, 8 februari 2007 (Digidoc; Dossier Beleid Koninkrijksstructuur Projectgroep Koninkrijk op Maat, kenmerk 2004-0000002743; Subdossier 2007-02-12 bestuurlijke conferentie SXM, kenmerk 2007-0000008855). Zie ook Digidoc; Dossier Beleid Koninkrijksstructuur Projectgroep Koninkrijk op Maat, kenmerk: 2004-0000002743; Subdossier Stappenplan K3, kenmerk: 2006-0000054429.

10 Overgangsakkoord; Afspraken over de inwerkingtreding van de nieuwe staatkundige verhoudingen binnen het Koninkrijk tussen Nederland, het land de Nederlandse Antillen, Sint Maarten, Bonaire, Sint Eustatius en Saba. Met aan het akkoord gehechte stappenplannen 'Land Nederlandse Antillen, Nederland, Sint Maarten' en 'Land Nederlandse Antillen, Bonaire, Sint Eustatius en Saba', 12 februari 2007 (Digidoc; Dossier Beleid Koninkrijksstructuur Projectgroep Koninkrijk op Maat, kenmerk 2004-0000002743; Subdossier 2007-02-12 bestuurlijke conferentie SXM, kenmerk 2007-0000008855). Het akkoord werd ondertekend door E.S. de Jongh-Elhage (Antillen), A. Nicolaï (Nederland), S. Wescott-Williams (Sint Maarten), R.T. Booi (Bonaire), R.J. Hooker (Sint Eustatius) en W.S. Johnson (Saba). Zie ook de Volkskrant, 13 februari 2007, NRC Handelsblad, 13 februari 2007.

11 Digidoc; Dossier Beleid Koninkrijksstructuur Projectgroep Koninkrijk op Maat, kenmerk: 2004-0000002743; Subdossier Stappenplan K3, kenmerk: 2006-0000054429. En: Subdossier Stappenplan G2, kenmerk: 2006-0000067197. Vgl. A. Nicolaï, verslag AO van 15 februari 2007, vastgesteld 13 maart 2007 (TK, 2006-2007, 30 945, nr. 2) en Jaarverslag Koninkrijksrelaties 2007. Over 1 juli 2007 zie conclusies start-RTC 26 november 2005; Weide 2010:170. Geannoteerde agenda voor overleg met Sint Maarten op 15 januari 2007, ambtelijk concept, 12 januari 2007 (Digidoc; Dossier Werkbezoeken Minister BVK 2007, kenmerk 2006-0000050715; Subdossier januari 2007, kenmerk 2007-0000001683). 12 De Politieke Stuurgroep Staatkundige Veranderingen (aanvankelijk ook genoemd 'Politieke Stuurgroep Transitieproces') werd ingesteld om de voortgang en samenhang te bewaken van de vier onderdelen van het transitieproces: 
omvorming van de BES tot openbare lichamen van Nederland (verantwoordelijkheid Nederland); omvorming van Sint Maarten (later ook Curaçao) tot land in het Koninkrijk (verantwoordelijkheid eilandsbestuur Sint Maarten; later ook Curaçao); totstandkoming consensusrijksregelgeving voor de nieuwe status van de eilanden (voortouw bij Nederland, maar gezamenlijk in twee gemengde projectgroepen voorbereid en uitgewerkt); ontmanteling van het land Nederlandse Antillen (verantwoordelijkheid land).

De stuurgroep zou bestaan uit de Nederlandse minister verantwoordelijk voor Koninkrijksrelaties, mede namens Bonaire, Sint Eustatius en Saba, de premier en de minister voor Constitutionele Zaken van de Nederlandse Antillen, en de gedeputeerde en plaatsvervangend gedeputeerde voor Constitutionele Zaken van Sint Maarten (later ook van Curaçao). In voorkomende gevallen zouden vakministers van de (ei)landen worden uitgenodigd. De BES werden door Nederland vertegenwoordigd en hadden een 'standing invitation' voor de gezamenlijke projectgroepen. $\mathrm{Zij}$ zouden zich in de praktijk echter onvoldoende gekend voelen in de activiteiten van deze projectgroepen en wensten een grotere rol in de besluitvorming. Op de wens van Sint Eustatius zou Bijleveld zich bereid verklaren ieder halfjaar een BES-overleg te voeren. Geannoteerde agenda met Nederlandse inzet voor het BES-overleg op 20 juni 2007 (Digidoc; Dossier Werkbezoeken minister BVK 2007, kenmerk 2006-0000050715; Subdossier BES overleg, kenmerk 2007-0000048380).

13 Deelnemers in de PRRC waren Nederland (BZK en Justitie), de Nederlandse Antillen, Sint Maarten (later ook Curaçao); Aruba had een 'standing invitation'. De PRRC was belast met de uitvoering van de afspraken in de Slotverklaring over rechtspleging, rechtshandhaving en het Statuut. De projectgroep Financiën coördineerde de financiële en economische trajecten van de staatkundige veranderingen (financieel beheer, financieel toezicht en schuldsanering). Teneinde het proces efficiënt te laten verlopen, was het van belang dat beide projectgroepen politieke vraagpunten, door tussenkomst van de Regiegroep, snel voorlegden aan de Politieke Stuurgroep. Een stappenplan voor de ontmanteling van de landslaag moest nog volgen. Zie bijv. Toelichting stappenplan staatkundige veranderingen Nederlandse Antillen, conceptversie 2007-02-08.1 (Digidoc; Dossier Werkbezoeken Minister BVK 2007, kenmerk 2006-0000050715; Subdossier 2007-02-12 bestuurlijke conferentie SXM, kenmerk 2007-0000008855).

14 Brief A. Nicolaï aan vz. TK, 13 februari 2007 (TK, 2006-2007, 30800 IV, nr. 22). Zie ook NRC Handelsblad, 13 februari 2007. Vgl. Digidoc; Dossier ICKR 20072006 t/m 2008, kenmerk 2006-0000058188; Subdossier Rapportages, kenmerk 2006-0000059432. Geannoteerde agenda inclusief Nederlandse inzet t.b.v. bestuurlijke conferentie Nederland, Nederlandse Antillen, Sint Maarten, Bonaire, Sint Eustatius en Saba op 12 februari 2007, conceptversie 2007-02-08.1 (Digidoc; Dossier Beleid Koninkrijksstructuur Projectgroep Koninkrijk op Maat, kenmerk 2004-0000002743; Subdossier 2007-02-12 bestuurlijke conferentie SXM, kenmerk 2007-0000008855).

15 Lijst van vragen en antwoorden, vastgesteld 7 juni 2007; Jaarverslag en slotwet Koninkrijksrelaties 2006 (TK, 2006-2007, 31 031 IV, nr. 7). Zie ook geannoteerde agenda voor overleg met Land Nederlandse Antillen, 17 januari 2007, ambtelijk concept, 12 januari 2007 (Digidoc; Dossier Werkbezoeken Minister BVK 2007, kenmerk 2006-0000050715; Subdossier Januari 2007, kenmerk 2007-0000001683).

16 Verslag AO van 15 februari 2007, vastgesteld 13 maart 2007 (TK, 2006-2007, 30 945, nr. 2). 
17 Verslag AO van 15 februari 2007, vastgesteld 13 maart 2007 (TK, 2006-2007, 30 945, nr. 2). Vgl. de Volkskrant, 3 september 2007.

18 Coalitieakkoord Tweede Kamerfracties van CDA, PVDA en ChristenUnie, 'Samen Werken, Samen Leven', 7 februari 2007 (p. 38 Koninkrijksrelaties) (TK, 2006-2007, 30 891, nr. 4). Regeringsverklaring Balkenende IV, 1 maart 2007 (www.rijksoverheid.nl).

19 Verslag ICKR, 27 maart 2007 (Digidoc; Dossier ICKR 20072006 t/m 2008, kenmerk 2006-0000058188; Subdossier 06 juni, kenmerk 2006-0000059429). Zie ook verslag AO, 26 april 2007 (TK, 2006-2007, 30 800 IV, nr. 26, p. 5). Van Beetz \& Martha-Alberto 2010:91.

20 Reactie A.Th.B. Bijleveld-Schouten, NRC Handelsblad, 23 april 2007. Geannoteerde agenda voor overleg met Sint Maarten op 15 januari 2007, ambtelijk concept, 12 januari 2007 (Digidoc; Dossier Werkbezoeken Minister BVK 2007, kenmerk 2006-0000050715; Subdossier januari 2007, kenmerk 2007-0000001683).

21 Over de Intentieverklaring van 4 mei, getiteld 'Curaçao op weg naar een autonome status in het Koninkrijk', met als belangrijkste opdracht een autonome status voor Curaçao, zie nota aan A.Th.B. Bijleveld-Schouten, 22 mei 2007, kenmerk 2007-0000184212 (Digidoc; Dossier Beleid Koninkrijksstructuur Projectgroep Koninkrijk op Maat, kenmerk: 2004-0000002743; Subdossier BC Curaçao mei 2007, kenmerk: 2007-0000043182).

22 Digidoc; Dossier ICKR 20072006 t/m 2008, kenmerk 2006-0000058188; Subdossier Rapportages, kenmerk 2006-0000059432. Zie bijv. ook de Volkskrant, 7 juli 2007.

23 'Toetreding Curaçao tot het Overgangsakkoord'. Bestuursakkoord houdende de toetreding van Curaçao tot het Overgangsakkoord en houdende nadere afspraken over de inwerkingtreding van de nieuwe staatkundige verhoudingen binnen het Koninkrijk der Nederlanden naar aanleiding van de besluiten van de Eilandsraad van Curaçao d.d. 6 juli 2007 tot instemming met de Slotverklaring van 2 november 2006. Van Beetz \& Martha-Alberto 2010:92, Sluis 2010:38-9. 24 Brief A.Th.B. Bijleveld-Schouten aan vz. TK, 19 september 2007, met Toetredingsakkoord (TK, 2007-2008, 31200 IV, nr. 4). Troonrede, 18 september 2007 ('verheugend') (www.rijksoverheid.nl). Vgl. Weide (2010:171): de voor het opstellen van de wet- en regelgeving ingeruimde tijd was de facto onhaalbaar. 25 Digidoc; Dossier ICKR 20072006 t/m 2008, kenmerk 2006-0000058188; Subdossier Rapportages, kenmerk 2006-0000059432.

26 'Koninkrijksrecord' in geannoteerde agenda voor overleg met Sint Maarten op 15 januari 2007, ambtelijk concept, 12 januari 2007 (Digidoc; Dossier Werkbezoeken Minister BVK 2007, kenmerk 2006-0000050715; Subdossier januari 2007, kenmerk 2007-0000001683). Nota aan E.M.H. Hirsch Ballin (t.b.v. PRRC), 29 juni 2007, kenmerk DDS 5492783, 'Onderhandelingsmandaat PRRC 9-13 juli' (Digidoc; Dossier Beleid Koninkrijksstructuur Projectgroep Koninkrijk op Maat, kenmerk 2004-0000002743; Subdossier Vergadering 07 '07 NL, kenmerk 2007-0000053668). Zie ook Weide 2010:170.

27 Digidoc; Dossier Werkbezoeken minister BVK 2007, kenmerk 2006-0000050715; Subdossier BES overleg, kenmerk 2007-0000048380. 28 Lezing minister van BZK J.P.H. Donner te Curaçao, 12 januari 2010. Amigoe, 13 januari 2010. Roos \& Verhey (2010:Bijlage 3) komen tot andere aantallen. 29 Verhey 2010:37 en 18 (ook Van Dijk 2010:59, 67, Leppers 2010:129, Visser 2010:81-8) geeft een sfeertekening van de gang van zaken in de Politieke Stuurgroep (2007-2010). Zie ook Algemene Nederlandse boodschap tijdens de 
Politieke Stuurgroep van 12 november 2007 in geannoteerde agenda, 8 november 2007 (Digidoc; Dossier Beleid Koninkrijksstructuur Projectgroep Koninkrijk op Maat, kenmerk 2004-0000002743; Subdossier 2007-11-12, kenmerk 2007-0000086237).

30 De Volkskrant, 23 juni 2008.

31 RNW, 28 september 2009.

32 E-mail C.P. de Haseth, 24 augustus 2011.

33 Bijv. J.W. Remkes, нтк nr. 32, 5 december 2007, p. 2481.

34 Stand van zaken staatkundig proces t.b.v. beleidsbespreking 14 juni 2007

(Digidoc; Dossier Werkbezoeken Minister BVK 2007, kenmerk 2006-0000050715; Subdossier Juni 2007, kenmerk 2007-0000045187). Zie ook Digidoc; Dossier Werkbezoeken Minister BVK 2007, kenmerk 2006-0000050715; Subdossier Juni 2007, kenmerk 2007-0000045187 en Subdossier Dossier Stas_minJus, kenmerk 2007-0000047244.

35 Geannoteerde agenda PSG 22 juni 2007 (ambtelijk concept, z.d.) (Digidoc; Dossier Werkbezoeken Minister BVK 2007, kenmerk 2006-0000050715; Subdossier agenda Politieke Stuurgroep, kenmerk 2007-0000048945 en Subdossier Juni 2007, kenmerk 2007-0000045187). Over Aruba: de Volkskrant, 25 oktober 2007; vgl. A.Th.B. Bijleveld-Schouten, HTK nr. 32, 5 december 2007, p. 2497; Jaarverslag en slotwet Koninkrijksrelaties 2008, Lijst van vragen en antwoorden, 5 juni 2009 (TK, 2008-2009, 31924 IV, nr. 5).

Op 12 februari 2007 was de eerste vergadering van de PRRC. Zie ook concepttoelichting werkplan PRRC, versie 30 maart 2007; definitief verslag PRRC, 2 april 2007 (Digidoc; Dossier Beleid Koninkrijksstructuur Projectgroep Koninkrijk op Maat, kenmerk 2004-0000002743; Subdossier Vergadering 03'07 NL, kenmerk 2007-0000030549).

36 Geannoteerde agenda met Nederlandse inzet voor het BES-overleg op 20 juni 2007 (Digidoc; Dossier Werkbezoeken minister BVK 2007, kenmerk 20060000050715; Subdossier BES overleg, kenmerk 2007-0000048380). Stand van zaken staatkundig proces t.b.v. beleidsbespreking 14 juni 2007 (Digidoc; Dossier Werkbezoeken Minister BVK 2007, kenmerk 2006-0000050715; Subdossier Juni 2007, kenmerk 2007-0000045187). De Volkskrant, 6 december 2007.

37 AMVRB houdende tijdelijke voorzieningen voor het toezicht op de begroting en de bedrijfsvoering van de eilandgebieden Bonaire, Sint Eustatius en Saba van de Nederlandse Antillen (Besluit Tijdelijk financieel toezicht BES, 8 november 2007). Zie ook www.cft.an, met online archief van documenten uit de toezichtsperiode tot $10 / 10 / 10$.

38 Brief A.Th.B. Bijleveld-Schouten aan vz. TK, 27 juni 2007 (TK, 2006-2007, 30800 IV, nr. 30). Besluitenlijst Politiek overleg Bonaire, Saba, Sint Eustatius en Nederland, 20 juni 2007, met beoordelingskader statuswijziging Bonaire, Sint Eustatius en Saba (www.ontmantelingna.org). De Volkskrant, 4 en 22 juni 2007. Vgl. A.Th.B. Bijleveld-Schouten, HTK nr. 15, 23 oktober 2008, p. 1103. Bijleveld constateerde (p. 1098) dat goede vooruitgang was geboekt m.b.t. de BES-eilanden, met afspraken over onderwijs, jeugd, volksgezondheid en veiligheid. In december zou het RSC zijn deuren openen op Bonaire.

39 Weitenberg was voormalig lid van de commissie-Biesheuvel, die in de jaren tachtig de status aparte voor Aruba voorbereidde. De overige leden waren oud-staatssecretaris Margo Vliegenthart namens Nederland, Alberto Romero van de Bank Nederlandse Antillen, namens de Antillen, later aangevuld door een gezamenlijk lid voor de BES: belastingadviseur op Sint Maarten Max Pandt, voormalig gezaghebber van de Bovenwinden. Dit laatste had enige tijd geduurd 
omdat de BES aanvankelijk ieder afzonderlijk een kandidaat wilden leveren. Zie brief A.Th.B. Bijleveld-Schouten aan vz. TK, 3 december 2007 (TK, 2007-2008, 31200 IV, nr. 25). Zie ook Digidoc; Dossier ICKR 20072006 t/m 2008, kenmerk 2006-0000058188; Subdossier Rapportages, kenmerk 2006-0000059432. Geannoteerde agenda overleg met BES op 9 november 2007 (Digidoc; Dossier Werkbezoeken Minister BVK 2007, kenmerk 2006-0000050715; Subdossier 2007-11-09, kenmerk 2007-0000091145).

40 'Start schuldsanering en wegwerken betalingsachterstanden BES' (http:// www.minbzk.nl/actueel?ActItmIdt=109408). Zie ook Digidoc; Dossier ICKR 2007 2006 t/m 2008, kenmerk 2006-0000058188; Subdossier Rapportages, kenmerk 2006-0000059432. Verslag ICKR, 15 november 2007 (Digidoc; Dossier ICKR 2007 2006 t/m 2008, kenmerk 2006-0000058188; Subdossier 12 december, kenmerk 2006-0000059431). NRC Handelsblad, 10 november en 5 december 2007.

41 TK, 2007-2008, 31200 IV, nr. 54. NRC Handelsblad, 21 maart 2008. Brief A.Th.B. Bijleveld-Schouten aan vz. TK, 11 juli 2008, betreffende eerste halfjaarlijkse rapportage Cft (TK, 2008-2009, 31200 IV, nr. 64). Verslag AO van 23 oktober 2008, vastgesteld 1 december 2008 (TK, 2008-2009, 31 568, nr. 5). 42 Geannoteerde agenda PSG 22 juni 2007, ambtelijk concept (Digidoc; Dossier Werkbezoeken Minister BVK 2007, kenmerk 2006-0000050715; Subdossier agenda Politieke Stuurgroep, kenmerk 2007-0000048945). Geannoteerde agenda PSG 12 november 2007, versie 8 november 2007; voortgangsrapportage Projectgroep Financiën peildatum 1 november 2007 (Digidoc; Dossier Beleid Koninkrijksstructuur Projectgroep Koninkrijk op Maat, kenmerk 2004-0000002743; Subdossier 2007-11-12, kenmerk 2007-0000086237); stand van zaken afspraken politiek overleg 9 oktober 2007; conceptverslag PSG van 12 november 2007, z.d. (Digidoc; Dossier Beleid Koninkrijksstructuur Projectgroep Koninkrijk op Maat, kenmerk 2004-0000002743; subdossier verslag, kenmerk 2007-0000096033); voortgangsrapportage Projectgroep Financiën peildatum 1 januari 2008 (Digidoc; Dossier Beleid Koninkrijksstructuur Projectgroep Koninkrijk op Maat, kenmerk 2004-0000002743; Subdossier 2009-01-22, kenmerk 2008-ooooooo994). Besluit Tijdelijk financieel toezicht Nederlandse Antillen, Curaçao en Sint Maarten: Besluit van 10 november 2008, houdende tijdelijke voorzieningen voor het financieel toezicht op de Nederlandse Antillen en de eilandgebieden Curaçao en Sint Maarten (een RijkskB). Ingangsdatum: 10 december 2008 en geldig tot 30 september 2010. Staatsblad 2008, nr. 512. NRC Handelsblad, 23 januari 2008.

43 Een op 26 juni 2008 door J.W. Remkes, J. Leerdam en B.J. van Bochove ingediende motie drong erop aan dat de in het conceptbesluit Financieel Toezicht opgenomen mogelijkheden voor het geven van een bestuurlijke aanwijzing en als ultimum remedium het stopzetten van de schuldsanering méér dienden te zijn dan theoretische mogelijkheden (TK, 2007-2008, 31200 IV, nr. 61). Vgl. A.Th.B. Bijleveld-Schouten, HTK nr. 102, 26 juni 2008, p. 726o. Vgl. verslag AO van 11 juni 2008, vastgesteld 13 augustus 2008 (TK, 2007-2008, 31200 IV, nr. 65). Verslag houdende een lijst van vragen en antwoorden, 14 oktober 2008 (TK, 2008-2009, 31700 IV, nr. 5).

44 Tijdens AO van 4 april 2007 (TK, 2006-2007, 30 800 IV, nr. 26) had de staatssecretaris de Kamer toegezegd viermaandelijks te zullen rapporteren over de stand van zaken in het staatkundig proces. Zie ook brieven A.Th.B. BijleveldSchouten aan vz. TK, 5 juni 2007 (TK, 2006-2007, 30 945, nr. 2) en 27 juni 2007, met eerste voortgangsrapportage ( $\mathrm{TK}, 2006-2007,30800 \mathrm{IV}, \mathrm{nr}$. 30) en discussie n.a.v. Inleiding door de staatssecretaris tijdens POK (Slotverklaring POK $25 \mathrm{t} / \mathrm{m}$ 
29 juni 2007 te Den Haag aan vz. EK en TK (Kamerstukken I/II, 2006-2007, 30 945, C en nr. 6).

Vanaf het eerste begin moest op vrijwel alle onderdelen van het proces vertraging worden geconstateerd. Zie bijv. de rapportages t.b.v. PSG van 12 november 2007, met uitgebreide beschrijvingen van de risico's per onderdeel om 15 december 2008 te halen: voortgangsrapportage uitvoering stappenplan BES versie 6 november 2007; voortgangsrapportage PRRC t.b.v. PSG 12 november 2007; voortgangsrapportage Projectgroep Financiën peildatum 1 november 2007; voortgangsrapportage opbouw land Sint Maarten per 30 september 2007; voortgangsrapportage Ontmanteling Land Nederlandse Antillen, 1 november 2007 (Digidoc; Dossier Beleid Koninkrijksstructuur Projectgroep Koninkrijk op Maat, kenmerk 2004-0000002743; Subdossier 2007-11-12, kenmerk 2007-0000086237). In de respectievelijke voortgangsrapportages t.b.v. de PSG werd op vele onderdelen uitgesproken dat 'het steeds minder waarschijnlijk [lijkt] dat 15 december 2008 gehaald gaat worden op dit onderdeel'. Zie bijv. ook voortgangsrapportage PRRC voor PSG 22 januari 2008 (Digidoc; Dossier Beleid Koninkrijksstructuur Projectgroep Koninkrijk op Maat, kenmerk 2004-0000002743; Subdossier 2008-01-22, kenmerk 2008-0000000994). Geannoteerde agenda voor overleg met Sint Maarten op 15 januari 2007, ambtelijk concept, 12 januari 2007 (Digidoc; Dossier Werkbezoeken Minister BVK 2007, kenmerk 2006-0000050715; Subdossier januari 2007, kenmerk 2007-0000001683). Brief A.Th.B. Bijleveld-Schouten aan vz. TK, 3 december 2007, met tweede voortgangsrapportage (d.d. 28 november 2007) (TK, 2007-2008, 31200 IV, nr. 22). Vgl. ook Verhey 2010:19, Weide 2010:169-74.

45 Nota aan A.Th.B. Bijleveld-Schouten, 22 mei 2007, kenmerk 2007-0000184641, met terugkoppeling tijdens PRRC te Curaçao mei 2007 (Digidoc; Dossier Beleid Koninkrijksstructuur Projectgroep Koninkrijk op Maat, kenmerk 2004-0000002743; Subdossier Vergadering 10 '07 CUR, kenmerk 2007-0000082147). Conceptverslag PRRC 17-19 april 2007 te Sint Maarten; conceptpassage algemeen deel MvT consensusrijkswet OM over de keuze voor één PG, t.b.v. PRRC 23-25 oktober 2007 (Digidoc; Dossier Beleid Koninkrijksstructuur Projectgroep Koninkrijk op Maat, kenmerk 2004-0000002743; Subdossier Vergadering 05 '07 CUR, kenmerk 2007-0000030557 en Subdossier Vergadering 10 'O7 CUR, kenmerk 2007-0000082147). Brief A.Th.B. Bijleveld-Schouten aan vz. TK, 3 december 2007 , met tweede voortgangsrapportage (d.d. 28 november 2007) (TK, 2007-2008, 31200 IV, nr. 22). Vgl. nota aan E.M.H. Hirsch Ballin, 29 juni 2007, kenmerk DDS 5492783, 'Onderhandelingsmandaat PRRC 9-13 juli' (Digidoc; Dossier Beleid Koninkrijksstructuur Projectgroep Koninkrijk op Maat, kenmerk 2004-0000002743; Subdossier Vergadering 07 '07 NL, kenmerk 2007-0000053668).

46 Brief A.Th.B. Bijleveld-Schouten aan vz. TK, 27 juni 2007 met eerste voortgangsrapportage (TK, 2006-2007, 30 800 IV, nr. 30). Vgl. Geannoteerde agenda PSG 12 november 2007, versie 8 november 2007 (Digidoc; Dossier Beleid Koninkrijksstructuur Projectgroep Koninkrijk op Maat, kenmerk 2004-0000002743; Subdossier 2007-11-12, kenmerk 2007-0000086237). 'Advies aan Stas is zorgen kenbaar maken over de voortgang [opbouw land Sint Maarten].' Zie ook Digidoc; Dossier Beleid Koninkrijksstructuur Projectgroep Koninkrijk op Maat, kenmerk 2004-0000002743; Subdossier Vergadering 10 'o7 CUR, kenmerk 2007-0000082147.

47 Verslag AO van 4 juli 2007, vastgesteld 7 augustus 2007 (TK, 2006-2007, 30945 en $30800 \mathrm{IV}, \mathrm{nr} .7$ ). 
48 Van Beetz \& Martha-Alberto 2010:94. Digidoc; Dossier Beleid Koninkrijksstructuur Projectgroep Koninkrijk op Maat, kenmerk 2004-0000002743; Subdossier Vergadering 10 '07 CUR, kenmerk 2007-0000082147. Zie ook Subdossier 'afwijzing akkoord door Curaçao', kenmerk 2006-0000061630; Subdossier Vergadering 07 '07 NL, kenmerk 2007-0000053668.

49 Gesprekspunten en draaiboek bestuurlijk overleg 9 oktober 2007; conclusies bestuurlijk overleg Staatkundige veranderingen Nederlandse Antillen tussen Nederland, Land Nederlandse Antillen, Curaçao en Sint Maarten te Den Haag op 9 oktober 2007 (Digidoc; Dossier Beleid Koninkrijksstructuur Projectgroep Koninkrijk op Maat, kenmerk 2004-0000002743; Subdossier 2007-10-09 informeel politiek overleg, kenmerk 2007-0000080015).

50 E.S. de Jongh-Elhage geciteerd in Van Beetz \& Martha-Alberto 2010:92.

51 Een delegatie uit de Tweede Kamer, bestaande uit de fractievoorzitters P. van Geel (CDA), J. Tichelaar (PVDA), M. Rutte (VVD), F. Halsema (GL), A. Slob (CU), A. Pechtold (D66), M. Thieme (PvdD) en R. Verdonk (ToN), bracht van 22 oktober tot 2 november 2007 een werkbezoek aan alle zes eilanden. Fractievoorzitter G. Wilders (PVV) en SP-fractievoorzitter J. Marijnissen namen niet deel; vlak voor de reis had Wilders in het Algemeen Dagblad opgemerkt dat de Antillen wat hem betreft op Marktplaats.nl konden worden gezet 'als ze nog een keer in de fout gaan'. Verdonk kwam later en bezocht alleen de Bovenwinden. De delegatie stond onder leiding van Kamervoorzitter G. Verbeet. Zie verslag van een werkbezoek, vastgesteld 17 december 2007 (TK, 2007-2008, 30 945, nr. 9). De Volkskrant, 25 en 30 oktober 2007.

52 Het rapport, d.d. 8 oktober 2007, was geschreven in opdracht van de Antilliaanse regering, op basis van onderzoek in de periode 2004-2007, en diende inzicht te geven in de vormen van georganiseerde criminaliteit op de Bovenwindse eilanden. Zie brief A.Th.B. Bijleveld-Schouten aan vz. TK, 8 oktober 2007 (TK, 2007-2008, 31200 IV en 29 911, nr. 6). Zie ook brief A.Th.B. Bijleveld-Schouten aan vz. TK, 2 december 2008, kenmerk 2008-0000594483 (http://www.minbzk.nl/actueel?ActItmIdt=116117) en idem, 11 december 2007 met kabinetsstandpunt over het rapport (TK, 2007-2008, 31200 IV, nr. 24). Vgl. Kamervragen A.H. Kuiken en J. Leerdam (beiden PVDA), 12 oktober 2007; antwoord A.Th.B. Bijleveld-Schouten, 31 oktober 2007, mede namens E.M.H. Hirsch Ballin (kenmerk 2007-0000430738; TK, 2007-2008, Aanhangsel, nr. 463). Verslag houdende een lijst van vragen en antwoorden, 26 november 2007 (TK, 2007-2008, 31200 IV, nr. 925). Zie ook brief A.Th.B. Bijleveld-Schouten aan vz. TK, 23 februari 2009 (TK, 2008-2009, 31 568, nr. 20). Op 31 oktober 2007 (kenmerk 007-0000401602) antwoordde Bijleveld, mede namens Hirsch Ballin, ook op vragen van R. de Roon en T. van Dijck (beiden PVV) over de rechtshandhaving op Sint Maarten (van 4 oktober 2007, kenmerk 20708012130). Zie ook de Volkskrant, 5 en 29 oktober, 12 december 2007, 12 januari 2008, NRC Handelsblad, 8 en 29 oktober, 12 december 2007.

53 Zie bijv. HTK nr. 15, 23 oktober 2008, o.a. pp. 1043, 1045, 1097. Vgl. A.Th.B. Bijleveld-Schouten, HTK nr. 32, 2 december 2009, pp. 3074-5. Verslag AO van 4 april 2007, vastgesteld 26 april 2007 (TK, 2006-2007, 30800 IV, nr. 26, p. 5). Interview A.Th.B. Bijleveld-Schouten in de Volkskrant, 23 juni 2008; verslag AO van 19 december 2007, vastgesteld 22 januari 2008 (TK, 2007-2008, 31200 IV en 30 945, nr. 27). Verslag AO van 11 december 2007 met E.M.H. Hirsch Ballin en A.Th.B. Bijleveld-Schouten over de (nog te ontvangen) kabinetsreactie op het WODC-rapport (TK, 2007-2008, 31200 IV, nr. 6), 22 januari 2008 (TK, 2007-2008, 31200 IV, nr. 26). Brief A.Th.B. Bijleveld-Schouten aan bestuurs- 
college Sint Maarten, 27 november 2007, kenmerk 2007-0000507295, en aan vz. TK, 11 december 2007 (TK, 2007-2008, 31200 IV, nr. 24) met kabinetsstandpunt WODC-rapport. Zie ook Digidoc; Dossier ICKR 20072006 t/m 2008, kenmerk 2006-0000058188; Subdossier Rapportages, kenmerk 2006-0000059432. NRC Handelsblad, 13 november 2007.

54 De Volkskrant, 30 oktober 2007, 9 en 12 januari 2008; NRC Handelsblad, 22 en 31 oktober 2007. Zie ook Digidoc; Dossier ICKR 20072006 t/m 2008, kenmerk 2006-0000058188; Subdossier Rapportages, kenmerk 2006-0000059432.

55 Zie ook Digidoc; Dossier ICKR 20072006 t/m 2008, kenmerk 2006-0000058188; Subdossier Rapportages, kenmerk 2006-0000059432. 56 Geannoteerde agenda PSG 12 november 2007, versie 8 november 2007 (Digidoc; Dossier Beleid Koninkrijksstructuur Projectgroep Koninkrijk op Maat, kenmerk 2004-0000002743; Subdossier 2007-11-12, kenmerk 2007-0000086237). Conceptverslag, z.d. (Digidoc; Dossier Beleid Koninkrijksstructuur Projectgroep Koninkrijk op Maat, kenmerk 2004-0000002743; Subdossier verslag, kenmerk 2007-0000096033). Vgl. nota aan A.Th.B. BijleveldSchouten, 8 april 2008, kenmerk 2008-0000167363, 'Terugkoppeling PRRC maart 2008' (Digidoc; Dossier Beleid Koninkrijksstructuur Projectgroep Koninkrijk op Maat, kenmerk 2004-0000002743; Subdossier Vergadering maart 2008 NL, kenmerk 2008-oooo017812), over het uitblijven van betrokkenheid van Aruba bij de crw. Over houding Aruba tegenover het Hof, zie ook nota aan A.Th.B. Bijleveld-Schouten, 15 september 2008, kenmerk 2008-0000433880, 'Vergadering PRRC september 2008 op SXM' en conceptverslag PRRC 23-25 september 2008 (Digidoc; Dossier Beleid Koninkrijksstructuur Projectgroep Koninkrijk op Maat, kenmerk 2004-0000002743; Subdossier ambtelijke projectgroep Rechtspleging, Rechtshandhaving en Constitutionele Zaken, kenmerk 2007-0000017849). Ook nota aan G. ter Horst en A.Th.B. Bijleveld-Schouten, 13 maart 2009, kenmerk 2009-0000109831 (Digidoc; Dossier Beleid Koninkrijksstructuur Projectgroep Koninkrijk op Maat, kenmerk 2004-0000002743; Subdossier Werkgroep Rechtspleging, Rechtshandhaving en Constitutionele Zaken - maart 2009, kenmerk 2009-0000014519). NRC Handelsblad, 15 december 2008.

57 Voorlichting van 18 september 2006 inzake de hervorming van de staatkundige verhoudingen van de Antilliaanse eilanden binnen het Koninkrijk (zaaknr. Wo4.06.0204/I/K/A). Vgl. Verhey 2010:28-31, Van Dijk 2010:55-68. 58 Geannoteerde agenda PSG 12 november 2007, versie 8 november 2007 (Digidoc; Dossier Beleid Koninkrijksstructuur Projectgroep Koninkrijk op Maat, kenmerk 2004-0000002743; Subdossier 2007-11-12, kenmerk 2007-0000086237). Conceptverslag, z.d. (Digidoc; Dossier Beleid Koninkrijksstructuur Projectgroep Koninkrijk op Maat, kenmerk 2004-0000002743; Subdossier verslag, kenmerk 2007-0000096033). Zie ook brief A.Th.B. BijleveldSchouten aan vz. TK, 17 februari 2010, kenmerk 2010-0000044599; nota aan E.M.H. Hirsch Ballin, 29 juni 2007, kenmerk DDS 5492783, 'Onderhandelingsmandaat PRRC 9-13 juli' (Digidoc; Dossier Beleid Koninkrijksstructuur Projectgroep Koninkrijk op Maat, kenmerk 2004-0000002743; Subdossier Vergadering 07 '07 NL, kenmerk 2007-0000053668). Nota PD SH NA aan E.M.H. Hirsch Ballin i.a.a. N. Albayrak, 19 september 2007, kenmerk DDS5506647. Vgl. Punt 6 en punt 7 uit de Verklaring m.b.t. consensus-rijksregelgeving, vastgesteld op 12 november 2007 en ondertekend tijdens PSG 22 januari 2008 (Digidoc; Dossier Beleid Koninkrijksstructuur Projectgroep Koninkrijk op Maat, kenmerk 2004-0000002743; Subdossier Verslag, kenmerk 2008-0000009742). Brief A.Th.B. Bijleveld- 
Schouten aan vz. TK, 12 februari 2008 (TK, 2007-2008, 31200 IV, nr. 29). Over de politieke verklaring van 12 november 2007 zie ook Van Dijk 2010:60-5.

59 Verslag ICKR, 6 december 2007 (Digidoc; Dossier ICKR 2008, kenmerk 2007-0000090797; Subdossier 02_februari, kenmerk 2008-0000008239). Zie ook Digidoc; Dossier ICKR 20072006 t/m 2008, kenmerk 2006-0000058188; Subdossier Rapportages, kenmerk 2006-0000059432; NRC Handelsblad, 13 november 2007. Van Beetz \& Martha-Alberto 2010:94-7, Sluis 2010:39.

6o Verslag ICKR, 6 december 2007 (Digidoc; Dossier ICKR 2008, kenmerk 2007-0000090797; Subdossier 02_februari, kenmerk 2008-0000008239).

61 J.W. Remkes, HTK nr. 32, 5 december 2007, p. 2481.

62 HTK nr. 32, 5 december 2007 (reactie A.Th.B. Bijleveld-Schouten, p. 2496). Verslag AO van 19 december 2007, vastgesteld 22 januari 2008 (TK, 2007-2008, 31 200 IV en 30 945, nr. 27). GL wilde het proces intensiveren; zie ook de Volkskrant, 6 december 2007. Zie ook Digidoc; Dossier Werkbezoeken Staatssecretaris BZK 2008, kenmerk 2007-0000081138; Subdossier Reis StassBZK 1-4 april aan Curaçao, voortgang staatkundig proces, kenmerk 2008-0000021257 over het sonderen van het idee van de fasering.

63 Motie H. Brinkman, 5 december 2007 (TK, 2007-2008, 31200 IV, nr. 21). In een motie ontzegden de Antilliaanse Staten Brinkman de toegang tot het parlementsgebouw. Hierop besloot de Nederlandse delegatie niet meer deel te nemen aan het POK. Digidoc; Dossier ICKR 20072006 t/m 2008, kenmerk 2006-0000058188; Subdossier Rapportages, kenmerk 2006-0000059432. 64 Digidoc; Dossier Werkbezoeken Staatssecretaris BZK 2008, kenmerk 2007-0000081138; Subdossier januari 2008, kenmerk 2007-0000104594. 65 Digidoc; Dossier Werkbezoeken Minister BVK 2007, kenmerk 2006-0000050715; Subdossier Juni 2007, kenmerk 2007-0000045187. Vgl. voortgangsrapportage uitvoering stappenplan BES, 15 mei 2008 (Digidoc; Dossier Beleid Koninkrijksstructuur Projectgroep Koninkrijk op Maat, kenmerk 2004-0000002743; Subdossier 2008-05-22, kenmerk 2008-0000029219). 66 Geannoteerde agenda PSG van 22 januari 2008, z.d. (Digidoc; Dossier Beleid Koninkrijksstructuur Projectgroep Koninkrijk op Maat, kenmerk 2004-0000002743; Subdossier 2008-02-22, kenmerk 2008-0000000994). Zie ook Digidoc; Dossier IWG BES 2008, kenmerk 2010-0000022836; Subdossier vergadering 21 februari 2008. Verslag ICKR, 7 februari 2008 (Digidoc; Dossier ICKR 2008, kenmerk 2007-0000090797; Subdossier 03 maart, kenmerk 2008-0000011295). Brief A.Th.B. Bijleveld-Schouten aan vz. EK en TK, 28 februari 2008 (EK, 2007-2008, 31200 IV, B). Voorstel van de Nederlands-Antilliaanse, Curaçaose en Sint Maartense delegaties om te komen tot verkorting van de ingangsdatum van de nieuwe statussen (Digidoc; Dossier Beleid Koninkrijksstructuur Projectgroep Koninkrijk op Maat, kenmerk 2004-0000002743; Subdossier 2008-05-22, kenmerk 2008-0000029219). Uiteindelijk zou besluitvorming over de nieuwe datum plaatsvinden in de PSG van 22 mei 2008 (Besluitenlijst, http:// ontmantelingna.org/nl/). Een ambtelijke nota aan de staatssecretaris van 22 februari 2008 (kenmerk 2008-0000088822) noemde eind 2010 een realistische transitiedatum (Digidoc; Dossier Beleid Koninkrijksstructuur Projectgroep Koninkrijk op Maat, kenmerk 2004-0000002743; Subdossier ambtelijke projectgroep Rechtspleging, Rechtshandhaving en Constitutionele Zaken, kenmerk 2007-0000017849).

67 Digidoc; Dossier Beleid Koninkrijksstructuur Projectgroep Koninkrijk op Maat, kenmerk 2004-0000002743; Subdossier 2007-11-12, kenmerk 2007-0000086237). Geannoteerde agenda PSG van 22 januari 2008, z.d. (Digidoc; 
Dossier Beleid Koninkrijksstructuur Projectgroep Koninkrijk op Maat, kenmerk 2004-0000002743; Subdossier 2008-02-22, kenmerk 2008-0000000994).

Vgl. Stand van zaken staatkundig proces t.b.v. beleidsbespreking 14 juni 2007

(Digidoc; Dossier Werkbezoeken Minister BVK 2007, kenmerk 2006-0000050715;

Subdossier Juni 2007, kenmerk 2007-0000045187).

68 Geannoteerde agenda PSG van 22 januari 2008, z.d. (Digidoc; Dossier Beleid Koninkrijksstructuur Projectgroep Koninkrijk op Maat, kenmerk 2004-0000002743; Subdossier 2008-02-22, kenmerk 2008-0000000994). Verslag en besluitenlijst PSG 22 januari 2008 (Digidoc; Dossier Beleid Koninkrijksstructuur Projectgroep Koninkrijk op Maat, kenmerk 2004-0000002743; Subdossier verslag, kenmerk 2008-0000009742). Brief A.Th.B. Bijleveld-Schouten aan vz. TK, 12 februari 2008 (TK, 2007-2008, 31200 IV, nr. 29). Van Beetz \& Martha-Alberto 2010:98; de Volkskrant, 23 en 25 januari 2008, NRC Handelsblad, 8 juli 2008.

69 Geannoteerde agenda PSG 22 mei 2008, ambtelijke conceptversie 22 mei 2008 10.30 uur (Digidoc; Dossier Beleid Koninkrijksstructuur Projectgroep Koninkrijk op Maat, kenmerk 2004-0000002743; Subdossier geannoteerde agenda's, kenmerk 2010-0000027592). Zie ook Besluitenlijst (http://ontmantelingna.org/ nl/). NRC Handelsblad, 24 mei 2008. Zie brief A.Th.B. Bijleveld-Schouten aan vz. TK, 5 juni 2008 (TK, 2007-2008, 31200 IV, nr. 53), met als bijlage het voorontwerp van de toezicht-AMVRB, dat nog de gebruikelijke wetgevingstoetsen moest ondergaan. Slotverklaring POK, 16 t/m 20 juni 2008 te Den Haag (Kamerstukken I/II, 2007-2008, 31 512, A en nr. 1). Vgl. verslag AO van 11 juni 2008, vastgesteld 13 augustus 2008 (TK, 2007-2008, 31200 IV, nr. 65). The Daily Herald, 23 mei 2008, geciteerd in Van Beetz \& Martha-Alberto 2010:106-7. A.Th.B. Bijleveld-Schouten in de Volkskrant, 23 juni 2008.

70 'Advies L.A.J. de Lannoy en D.W. Steenhuis over twee aspecten van de Openbare Ministeries van Curaçao, Sint Maarten en van Bonaire, Sint Eustatius en Saba, januari 2008'. Vgl. advies W.J.M. Davids (president Hoge Raad) en J.W. Fokkens (procureur-generaal Hoge Raad) aan mr. M.J.J. van den Honert (directeur Rechtsbestel ministerie van Justitie) over advies De Lannoy en Steenhuis, 30 januari 2008, kenmerk 017/o8/WD/sk. (Digidoc; Dossier Beleid Koninkrijksstructuur Projectgroep Koninkrijk op Maat, kenmerk 2004-0000002743; Subdossier ambtelijke projectgroep Rechtspleging, Rechtshandhaving en Constitutionele Zaken, kenmerk 2007-0000017849).

71 Digidoc; Dossier Werkbezoeken Staatssecretaris BZK 2008, kenmerk 2007-0000081138; Subdossier 10-15 feb o8 Reis stas Antillen (met MP Balkenende), kenmerk 2007-0000081248.

72 Digidoc; Dossier Beleid Koninkrijksstructuur Projectgroep Koninkrijk op Maat, kenmerk 2004-0000002743; Subdossier ambtelijke projectgroep Rechtspleging, Rechtshandhaving en Constitutionele Zaken, kenmerk 2007-0000017849. Zie ook ambtelijke nota aan G. ter Horst, A.Th.B. Bijleveld-Schouten en E.M.H. Hirsch Ballin, 23 januari 2008, kenmerk 2008-0000031917 (Digidoc; Dossier Beleid Koninkrijksstructuur Projectgroep Koninkrijk op Maat, kenmerk 2004-0000002743; Subdossier Vergadering januari 2008 Land NA, kenmerk 2008-0000006329). Geannoteerde agenda PSG van 22 januari 2008, z.d. (Digidoc; Dossier Beleid Koninkrijksstructuur Projectgroep Koninkrijk op Maat, kenmerk 2004-0000002743; Subdossier 2008-02-22, kenmerk 2008-0000000994).

73 Besluitenlijst PSG 16 februari 2008; brief A.Th.B. Bijleveld-Schouten aan vz. TK, 28 februari 2008, kenmerk 2008-0000099734 (Digidoc; Dossier ICKR 2008, kenmerk 2007-0000090797; Subdossier 03 maart, kenmerk 2008-0000011295). Nota aan A.Th.B. Bijleveld-Schouten, 11 maart 2008, kenmerk 2008-0000120247, 
'PRRC maart 2008', met concept-crw OM. Nota aan A.Th.B. Bijleveld-Schouten, 8 april 2008, kenmerk 2008-0000167363, 'Terugkoppeling PRRC maart 2008' (Digidoc; Dossier Beleid Koninkrijksstructuur Projectgroep Koninkrijk op Maat, kenmerk 2004-0000002743; Subdossier Vergadering maart 2008 NL, kenmerk 2008-0000017812). Vgl. nota 'Overzicht bezwaren van Sint Maarten, Curaçao en Land tegen crw OM zoals gevoegd bij besluitenlijst Politieke Stuurgroep 16 februari 2008' (Digidoc; Dossier Beleid Koninkrijksstructuur Projectgroep Koninkrijk op Maat, kenmerk 2004-0000002743; Subdossier ambtelijke projectgroep Rechtspleging, Rechtshandhaving en Constitutionele Zaken, kenmerk 2007-0000017849). Zie ook het document (t.b.v. Politieke Stuurgroep 22 mei 2008) 'De positie van Curaçao met betrekking tot de verschilpunten in de PRRC inzake het concept concensusrijkswet Openbaar Ministerie', z.d.; voorstellen St. Maarten bij crw OM versie PRRC april 2008 t.b.v. vergadering Regiegroep (Digidoc; Dossier Beleid Koninkrijksstructuur Projectgroep Koninkrijk op Maat, kenmerk 2004-0000002743; Subdossier 2008-05-22, kenmerk 2008-0000029219). Vgl. nota pDWA aan E.M.H. Hirsch Ballin, 19 maart 2008, kenmerk DDS5537253, over de tekst van de wet zoals vastgesteld op 16 februari (Digidoc; Dossier Beleid Koninkrijksstructuur Projectgroep Koninkrijk op Maat, kenmerk 2004-0000002743; Subdossier ambtelijke projectgroep Rechtspleging, Rechtshandhaving en Constitutionele Zaken, kenmerk 2007-0000017849). Zie ook de Volkskrant, 17 en 18 februari 2008, NRC Handelsblad, 19 februari 2008. De crw OM zou uiteindelijk definitief worden in de PSG van 22 mei 2008. Zie Geannoteerde agenda, ambtelijke conceptversie 22 mei 2008 10.30 uur (Digidoc; Dossier Beleid Koninkrijksstructuur Projectgroep Koninkrijk op Maat, kenmerk 2004-0000002743; Subdossier geannoteerde agenda's, kenmerk 2010-0000027592). Besluitenlijst (http://ontmantelingna.org/nl/).

74 Zie Digidoc; Dossier ICKR 2008, kenmerk 2007-0000090797; Subdossier Rapportages, kenmerk 2008-0000008233. De Volkskrant, 3 maart 2008, NRC Handelsblad, 3 en 13 maart 2008.

75 Brief A.Th.B. Bijleveld-Schouten aan vz. TK, 28 februari 2008, kenmerk 2008-0000099734; besluitenlijst PSG 16 februari 2008 (Digidoc; Dossier ICKR 2008, kenmerk 2007-0000090797; Subdossier 03 maart, kenmerk 2008-0000011295). Van Beetz \& Martha-Alberto 2010:100, 103.

76 Digidoc; Dossier Werkbezoeken Staatssecretaris BZK 2008, kenmerk 2007-0000081138; Subdossier 10-15 feb o8 Reis stas Antillen (met MP Balkenende), kenmerk 2007-0000081248. Zie ook Digidoc; Dossier ICKR 2008, kenmerk 2007-0000090797; Subdossier Rapportages, kenmerk 2008-0000008233. Vgl. verslag ICKR, 13 maart 2008 (Digidoc; Dossier ICKR 2008, kenmerk 2007-0000090797; Subdossier 03 maart, kenmerk 2008-0000011295): terugkoppeling bezoek Balkenende. Zie ook verslag ICKR, 7 februari 2008 (Digidoc; Dossier ICKR 2008, kenmerk 2007-0000090797; Subdossier 03 maart, kenmerk 2008-0000011295). Zie J.P. Balkenende in de Amigoe, 14 februari 2008, geciteerd in Van Beetz \& Martha-Alberto 2010:99. Brief A.Th.B. BijleveldSchouten aan vz. EK en TK, 28 februari 2008 (EK, 2007-2008, 31200 IV, B). Zie ook de Volkskrant, 13 en 16 februari 2008, NRC Handelsblad, 13 en 15 februari 2008. 77 Digidoc; Dossier ICKR 2008, kenmerk 2007-0000090797; Subdossier Rapportages, kenmerk 2008-0000008233. Brief A.Th.B. Bijleveld-Schouten aan vz. TK, 8 april 2008 (TK, 2007-2008, 31200 IV, nr. 37) en verslag AO van 11 juni 2008, vastgesteld 13 augustus 2008 (TK, 2007-2008, 31200 IV, nr. 65).

78 Brief A.Th.B. Bijleveld-Schouten aan vz. TK, 28 februari 2008, kenmerk 2008-0000099734, met Besluitenlijst BES bestuurlijk overleg 31 januari 2008 te 
Den Haag (Digidoc; Dossier ICKR 2008, kenmerk 2007-0000090797; Subdossier o3 maart, kenmerk 2008-0000011295). Brief A.Th.B. Bijleveld-Schouten aan de ministers, 2 april 2008, kenmerk 2008-0000157724, 'Bevindingen plannen van aanpak statuswijziging Bonaire, Sint Eustatius en Saba' (Digidoc; Dossier ICKR 2008, kenmerk 2007-0000090797; Subdossier 03 maart, kenmerk 2008-0000011295).

79 Brief A.Th.B. Bijleveld-Schouten aan vz. TK, 31 maart 2008 (TK, 2007-2008, 31 200 IV, nr. 35), met derde voortgangsrapportage, d.d. 27 maart 2008. Zie ook brief aan vz. TK, 8 april 2008 (TK, 2007-2008, 31 200IV, nr. 37). De Volkskrant, 2 april 2008.

80 De Volkskrant, 2 april 2008, NRC Handelsblad, 3 april 2008. Verslag AO van 9 april 2008, vastgesteld 20 mei 2008 (TK, 2007-2008, 31200 IV, nr. 51). Verslag ICKR, 14 april 2008 (Digidoc; Dossier ICKR 2008, kenmerk 2007-0000090797; Subdossier 04 april 2008, kenmerk 2008-0000021474). Zie ook Digidoc; Dossier ICKR 2008, kenmerk 2007-0000090797; Subdossier Rapportages, kenmerk 2008-0000008233.

81 Digidoc; Dossier Werkbezoeken Staatssecretaris BZK 2008, kenmerk 2007-0000081138; Reis StassBZK 1-4 april aan Curaçao, voortgang staatkundig proces, kenmerk 2008-0000021257. Op 8 april zou Bijleveld in een Kamerbrief stellen: 'Op de Antillen deelt men de [...] feitelijke constatering dat de staatkundige verandering per 15 december 2008 onhaalbaar is' (TK, 2007-2008, 31200 IV, nr. 37).

82 Zie verslag ICKR, 7 februari 2008 (Digidoc; Dossier ICKR 2008, kenmerk 2007-0000090797; Subdossier 03 maart, kenmerk 2008-0000011295); verslag ICKR, 14 april 2008 (Digidoc; Dossier ICKR 2008, kenmerk 2007-0000090797; Subdossier 04 april 2008, kenmerk 2008-0000021474). Verslag AO van 11 juni 2008, vastgesteld 13 augustus 2008 (TK, 2007-2008, 31200 IV, nr. 65).

83 Zie ook brief A.Th.B. Bijleveld-Schouten aan vz. TK, 4 september 2008 (TK, 2007-2008, 31 568, nr. 2).

84 Geannoteerde agenda PSG 22 mei 2008, ambtelijke conceptversie 22 mei 2008 10.30 uur (Digidoc; Dossier Beleid Koninkrijksstructuur Projectgroep Koninkrijk op Maat, kenmerk 2004-0000002743; Subdossier geannoteerde agenda's, kenmerk 2010-0000027592. Zie ook besluitenlijst (http://ontmantelingna.org/ nl/). Brief A.Th.B. Bijleveld-Schouten aan vz. TK, 5 juni 2008 (TK, 2007-2008, 31 200 IV, nr. 53). Van Beetz \& Martha-Alberto 2010:104.

85 De analyse van de werkprocessen was uitgevoerd door de Stichting Overheids Accountants Bureau (SOAB), op verzoek van de IWG (14 maart 2008). Zie ook verslag AO van 11 juni 2008, vastgesteld 13 augustus 2008 (TK, 2007-2008, 31200 IV, nr. 65). Van Beetz \& Martha-Alberto 2010:104.

86 Aanvraag voorlichting Raad van State van het Koninkrijk, Bijlage 1 bij besluitenlijst PSG 22 mei 2008; zie ook Besluitenlijst PSG 22 mei 2008. Bij brief van 2 juni 2008 werd het verzoek aan de Raad gedaan, mede namens de Antilliaanse regering (Digidoc; Dossier ICKR 2008, kenmerk 2007-0000090797; Subdossier 07 juli, kenmerk 2008-0000040011). Zie ook verslag AO van 11 juni 2008, vastgesteld 13 augustus 2008 (TK, 2007-2008, 31200 IV, nr. 65). Verslag AO van 11 juni 2008, vastgesteld 13 augustus 2008 (TK, 2007-2008, 31200 IV, nr. 65). Verslag ICKR, 3 juli 2008; zie ook besluitenlijst BES bestuurlijk overleg 18 juni 2008 (Digidoc; Dossier ICKR 2008, kenmerk 2007-0000090797; Subdossier 07 juli, kenmerk 2008-0000040011). Voorstel van de Nederlands-Antilliaanse, Curaçaose en Sint Maartense delegaties om te komen tot verkorting van de ingangsdatum van de nieuwe statussen (Digidoc; Dossier Beleid Koninkrijksstructuur Project- 
groep Koninkrijk op Maat, kenmerk 2004-0000002743; Subdossier 2008-05-22, kenmerk 2008-0000029219). De Volkskrant, 24 mei 2008: januari 2010 is de nieuwe streefdatum.

87 Brief A.Th.B. Bijleveld-Schouten aan vz. TK, 5 juni 2008 (TK, 2007-2008, 31 200IV, nr. 53). Besluitenlijst PSG 22 mei 2008 (http://ontmantelingna.org/ $\mathrm{nl} /$ ). Zie ook verslag ICKR, 3 juli 2008; besluitenlijst BES bestuurlijk overleg 18 juni 2008 (Digidoc; Dossier ICKR 2008, kenmerk 2007-0000090797;

Subdossier 07 juli, kenmerk 2008-0000040011). Digidoc; IWG BES 2008, kenmerk 2010-0000022836; Subdossier vergadering 14 oktober 2008. Verslag houdende een lijst van vragen en antwoorden, 14 oktober 2008 (TK, 2008-2009, 31700 IV, nr. 5).

88 Verslag AO van 9 april 2008, vastgesteld 20 mei 2008 (TK, 2007-2008, 31200 IV, nr. 51). NRC Handelsblad, 23 mei 2008.

89 A.Th.B. Bijleveld-Schouten, HTK nr. 15, 23 oktober 2008, p. 1061. Zie ook Digidoc; Dossier Beleid Koninkrijksstructuur Projectgroep Koninkrijk op Maat, kenmerk 2004-0000002743; Subdossier 2008-05-22, kenmerk 2008-0000029219.

90 Verslag ICKR, 3 juli 2008; besluitenlijst BES bestuurlijk overleg 18 juni 2008 (Digidoc; Dossier ICKR 2008, kenmerk 2007-0000090797; Subdossier 07 juli, kenmerk 2008-0000040011). Verslag AO van 11 juni 2008, vastgesteld 13 augustus 2008 (TK, 2007-2008, 31200 IV, nr. 65).

91 Verslag AO van 23 oktober 2008, vastgesteld 1 december 2008 (TK, 2008-2009, 31 568, nr. 5). Zie ook A.Th.B. Bijleveld-Schouten, HTK nr. 15, 23 oktober 2008, pp. 1061, 1097-8.

92 Nu of nooit; Naar een verbeterplan voor de politiekorpsen op de Nederlandse Antillen, opgesteld door de regiopolitie Rotterdam-Rijnmond in opdracht van de PRRC (maart 2008). Zie ook Digidoc; Dossier ICKR 2008, kenmerk 2007-0000090797; Subdossier Rapportages, kenmerk 2008-0000008233. Vgl. nota aan A.Th.B. Bijleveld-Schouten, 11 maart 2008, kenmerk 2008-0000120247, 'PRRC maart 2008' (Digidoc; Dossier Beleid Koninkrijksstructuur Projectgroep Koninkrijk op Maat, kenmerk 2004-0000002743; Subdossier Vergadering maart $2008 \mathrm{NL}$, kenmerk 2008-0000017812).

93 Geannoteerde agenda PSG 9 juli 2008, ambtelijke conceptversie 25XIo8 11:30 uur; conceptbesluitenlijst 9 juli 2008; conceptvoorstel GVP voor PSG 1 oktober 2008, versie 1 oktober 2008, 18.oo uur, over taken, bevoegdheden en inrichting van een in het leven te roepen GVP; opdracht tot instellen werkgroepen en opdrachtverlening gericht op verbetering politiekorpsen, versie 1 oktober 2008, 18.00 uur (Digidoc; Dossier Beleid Koninkrijksstructuur Projectgroep Koninkrijk op Maat, kenmerk 2004-0000002743; Subdossier geannoteerde agenda's, kenmerk 2010-0000027592). Zie ook nota aan A.Th.B. Bijleveld-Schouten, 3 juni 2008, kenmerk 2008-0000250475, 'Terugkoppeling PRRC mei 2008' (Digidoc; Dossier Beleid Koninkrijksstructuur Projectgroep Koninkrijk op Maat, kenmerk 2004-0000002743; Subdossier ambtelijke projectgroep Rechtspleging, Rechtshandhaving en Constitutionele Zaken, kenmerk 2007-0oooo17849). Brief A.Th.B. Bijleveld-Schouten aan vz. TK, 28 augustus 2008, met Nederlandse inzet voor de crw Politie (TK, 2007-2008, 31 568, nr. 1) en vierde voortgangsrapportage. Van Beetz \& Martha-Alberto 2010:130.

94 Zie voor de discussies rond de viA hfdst. 2.

95 Brief A.Th.B. Bijleveld-Schouten aan vz. TK, 28 augustus 2008 (тК, 2007-2008, 31 568, nr. 1), met vierde voortgangsrapportage. Zie ook Digidoc; Dossier ICKR 2008, kenmerk 2007-0000090797; Subdossier Rapportages, kenmerk 2008-0000008233. 
96 Verslag AO van 9 april 2008, vastgesteld 20 mei 2008 (TK, 2007-2008, 31200 IV, nr. 51).

97 Voorlichting over mogelijkheden tot versnelling van het transitieproces naar de nieuwe staatkundige verhoudingen tussen Nederland, de Nederlandse Antillen, Curaçao en Sint Maarten, 29 augustus 2008 (zaaknr. W04.08.0213/I/ AK). Digidoc; Dossier Werkbezoeken Staatssecretaris BZK 2008, kenmerk 2007-0000081138; Reis StassBZK 1-4 april aan Curaçao, voortgang staatkundig proces, kenmerk 2008-0000021257.

98 Vgl. nota DWA aan E.M.H. Hirsch Ballin, 12 september 2008, kenmerk DDS 5564251 over voorlichting Raad van State inzake mogelijkheden versnelling van het transitieproces (zaaknr. Wo4.08.0213/I/K) (Digidoc; Dossier Werkbezoeken staatssecretaris BZK 2008, kenmerk 2007-0000081138; Subdossier kenmerk 2008-0000055386).

99 Zie o.a. HTK nr. 15, 23 oktober 2008. Verslag AO van 23 oktober 2008, vastgesteld 1 december 2008 (TK, 2008-2009, 31 568, nr. 5). Weide 2010:172-3. 100 NRC Handelsblad, 27 augustus 2009.

101 Voorlichting inzake mogelijkheden voor een gefaseerde herstructurering van de BES-eilanden, 29 augustus 2008 (zaaknr. Wo4.08.0175/I/A). Deze voorlichting was op 24 april 2008 aangevraagd. Voor instemming met de voorlichting zie bijv. verslag gezamenlijke vergadering ICKR en IWG, 9 oktober 2008 (Digidoc; Dossier ICKR 2008, kenmerk 2007-0000090797; Subdossier 10_oktober, 2008ooooo60394) en A.Th.B. Bijleveld-Schouten, HTK nr. 15, 23 oktober 2008, p. 1121. 102 Digidoc; Dossier Werkbezoeken Staatssecretaris BZK 2008, kenmerk 2007-0000081138; Reis StassBZK 1-4 april aan Curaçao, voortgang staatkundig proces, kenmerk 2008-0000021257 en kenmerk 2007-0000081138; Subdossier september 2008, kenmerk 2008-0000055386.

103 Voorlichting inzake mogelijkheden voor een gefaseerde herstructurering van de BES-eilanden, 29 augustus 2008 (zaaknr. Wo4.08.0175/I/A). Verslag AO van 23 oktober 2008, vastgesteld 1 december 2008 (TK, 2008-2009, 31 568, nr. 5). Over de benoeming van Kamp als vertegenwoordiger voor de BES werd op 23 oktober 2008 uitgebreid gesproken in de Kamer (нTK nr. 15, 23 oktober 2008). Interview A.Th.B. Bijleveld-Schouten, 20 mei 2011.

104 Geannoteerde agenda met Nederlandse inzet voor het BES-overleg op 20 juni 2007 (Digidoc; Dossier Werkbezoeken minister BVK 2007, kenmerk 2006-0000050715; Subdossier BES overleg, kenmerk 2007-0000048380). De commissie-Havermans was in 1999 ingesteld om de onderlinge financiële relaties binnen de Antillen in kaart te brengen en te adviseren over een solidariteitsfonds ten behoeve van de drie kleinste eilanden (Oostindie \& Klinkers 2001, III:474-5, n. 382).

105 Voorlichting inzake mogelijkheden voor een gefaseerde herstructurering van de BES-eilanden, 29 augustus 2008 (zaaknr. Wo4.08.0175/I/A). Zie ook Digidoc; Dossier Werkbezoeken Staatssecretaris BZK 2008, kenmerk 2007-0000081138; Reis StassBZK 1-4 april aan Curaçao, voortgang staatkundig proces, kenmerk 2008-0000021257.

106 Digidoc; Dossier Werkbezoeken Staatssecretaris BZK 2008, kenmerk 2007-0000081138; Subdossier 10-15 feb o8 Reis stas Antillen (met MP Balkenende), kenmerk 2007-0000081248.

107 Geannoteerde agenda PSG 24 juni 2009, ambtelijke conceptversie NL 17VIo9 16.oo uur (Digidoc; Dossier Beleid Koninkrijksstructuur Projectgroep Koninkrijk op Maat, kenmerk 2004-0000002743; Subdossier geannoteerde agenda's, kenmerk 2010-0000027592). Besluitenlijst PSG 24 juni 2009 (http://ontmante- 
lingna.org/nl/). Zie ook brief A.Th.B. Bijleveld-Schouten aan vz. TK, 26 juni 2009, kenmerk 2009-0000317656 (http://www.minbzk.nl/actueel?ActItmIdt=120826). 108 Amigoe, 10 september 2009. Agenda ICKR, 14 oktober 2009 (Digidoc; Dossier ICKR 2009, kenmerk 2008-0000072396; Subdossier 2009_10_14, kenmerk 2009-0000066636). Verslag gezamenlijke vergadering ICKR en IWG, 9 oktober 2008 (Digidoc; Dossier ICKR 2008, kenmerk 2007-0000090797; Subdossier 10_ oktober, 2008-0000060394). Vaststelling begrotingsstaat Koninkrijksrelaties (IV) 2010, nr. 3 verslag houdende een lijst van vragen en antwoorden, 23 november 2009 (TK, 2009-2010, 32123 IV, nr. 3).

109 Geannoteerde agenda PSG 1 oktober 2008 (Digidoc; Dossier Beleid Koninkrijksstructuur Projectgroep Koninkrijk op Maat, kenmerk 2004-0000002743; Subdossier geannoteerde agenda's, kenmerk 2010-0000027592). Besluitenlijst PSG 1 oktober 2008 (Digidoc; Dossier Vaste Commissie Nederlands Antilliaanse en Arubaanse Zaken 2008, kenmerk 2007-0000088413; Subdossier AO 23 oktober 2008, kenmerk 2008-0000058903). Zie ook brief A.Th.B. Bijleveld-Schouten aan vz. TK, 15 oktober 2008 (TK, 2008-2009, 31700 IV, nr. 6). 'Weg vrij voor Ronde Tafel Conferentie' (http://www.minbzk.nl/actueel?ActItmIdt=115501). 'Toespraak staatssecretaris Bijleveld op persconferentie van stuurgroep op Curaçao' (http:// www.minbzk.nl/@115504/toespraak_e).Van Beetz \& Martha-Alberto 2010:131. 110 Nog even was overwogen om de BES toe te voegen aan een van de bestaande Nederlandse politiekorpsen, bijvoorbeeld aan het korps Rotterdam-Rijnmond. Zie HTK nr. 15, 23 oktober 2008.

111 Brief A.Th.B. Bijleveld-Schouten aan vz. TK, 15 oktober 2008 (TK, 2008-2009, 31700 IV, nr. 6). Van Beetz \& Martha-Alberto 2010:130-1. Nota aan A.Th.B. Bijleveld-Schouten, 14 april 2008, kenmerk 2008-0000176856, 'PRRC april 2008'; conceptverslag PRRC 23-25 september 2008; nota's aan A.Th.B. Bijleveld-Schouten en G. ter Horst, 13 oktober 2008, kenmerk 2008-0000486656, 'Vergadering PRRC 21-23 oktober 2008' en 30 oktober 2008, kenmerk 2008-0000527151, 'Terugkoppeling PRRC 21-23 oktober 2008' (Digidoc; Dossier Beleid Koninkrijksstructuur Projectgroep Koninkrijk op Maat, kenmerk 2004-0000002743; Subdossier ambtelijke projectgroep Rechtspleging, Rechtshandhaving en Constitutionele Zaken, kenmerk 2007-0000017849). J.W. Remkes, HTK nr. 15, 23 oktober 2008, p. 1043.

112 Vgl. nota aan A.Th.B. Bijleveld-Schouten, 15 september 2008, kenmerk 2008-0000433880, 'Vergadering PRRC 23-25 september 2008 op SXM' (Digidoc; Dossier Beleid Koninkrijksstructuur Projectgroep Koninkrijk op Maat, kenmerk 2004-0000002743; Subdossier ambtelijke projectgroep Rechtspleging, Rechtshandhaving en Constitutionele Zaken, kenmerk 2007-0000017849).

113 Brief A.Th.B. Bijleveld-Schouten aan vz. TK, 15 oktober 2008 (TK, 2008-2009, $31700 \mathrm{IV}, \mathrm{nr} .6$ ). Verslag gezamenlijke vergadering ICKR en IWG, 9 oktober 2008 (Digidoc; Dossier ICKR 2008, kenmerk 2007-0000090797; Subdossier 10_oktober, 2008-0000060394). Nota aan A.Th.B. Bijleveld-Schouten, 3 juni 2008, kenmerk 2008-0000250475, 'Terugkoppeling PRRC mei 2005' (Digidoc; Dossier Beleid Koninkrijksstructuur Projectgroep Koninkrijk op Maat, kenmerk 2004-0000002743; Subdossier ambtelijke projectgroep Rechtspleging, Rechtshandhaving en Constitutionele Zaken, kenmerk 2007-0000017849).

114 Zie Geannoteerde agenda PSG 1 oktober 2008 (Digidoc; Dossier Beleid Koninkrijksstructuur Projectgroep Koninkrijk op Maat, kenmerk 20040000002743; Subdossier geannoteerde agenda's, kenmerk 2010-0000027592). 115 A.Th.B. Bijleveld-Schouten, HTK nr. 15, 23 oktober 2008, p. 1105. 
116 De motie, voorgesteld 23 oktober 2008 (TK, 2008-2009, 31700 IV, nr. 13), verwees naar het WODC-rapport, een aantal problemen inzake de integriteit van het bestuur, de kwaliteit van de politieorganisatie op Sint Maarten en de bestuurlijke schaal van dat eiland. Op 28 oktober werd de motie verworpen (HTK nr. 16, 28 oktober 2008).

117 HTK nr. 15, 23 oktober 2008, pp. 1045-6. Motie B.J. van Bochove, J. Leerdam, C.A. Ortega-Martijn (TK, 2008-2009, 31700 IV, nr. 9), 23 oktober 2008. Op 28 oktober werd deze motie aangenomen; alleen de PVV stemde tegen (нтK nr. 16, 28 oktober 2008).

118 Motie H. Brinkman, 23 oktober 2008 (TK, 2008-2009, 31700 IV, nr. 21); op 28 oktober 2008 verworpen (alleen de PVV stemde voor).

119 HTK nr. 15, 23 oktober 2008, p. 1104.

120 Van Beetz \& Alberto-Martha 2010:133. Brief A.Th.B. Bijleveld-Schouten aan vz. TK, 4 december 2008, met besluitenlijst PSG 25 en 26 november (TK, 2008-2009, 31 568, nr. 7). Geannoteerde agenda PSG 25-26 november 2008, ambtelijke conceptversie 25XIo8 11:30 uur (Digidoc; Dossier Beleid Koninkrijksstructuur Projectgroep Koninkrijk op Maat, kenmerk 2004-0000002743; Subdossier geannoteerde agenda's, kenmerk 2010-00oo027592). De Volkskrant, 27 november 2008, NRC Handelsblad, 27 november 2008.

121 Geannoteerde agenda PSG 25-26 november 2008, ambtelijke conceptversie 25XIo8 11:30 uur (Digidoc; Dossier Beleid Koninkrijksstructuur Projectgroep Koninkrijk op Maat, kenmerk 2004-0000002743; Subdossier geannoteerde agenda's, kenmerk 2010-0000027592). Besluitenlijst PSG 26 november 2008 (http://ontmantelingna.org/nl/).

122 Zie ook verslag gezamenlijke vergadering ICKR en IWG, 4 december 2008 (Digidoc; Dossier ICKR 2009, kenmerk 2008-0000072396; Subdossier 08 april 2009, kenmerk 2009-0000022391). Brief A.Th.B. Bijleveld-Schouten aan vz. TK, 4 december 2008, met besluitenlijst PSG 25 en 26 november 2008 (TK, 2008-2009, 31568, nr. 7).

123 Geannoteerde agenda PSG 25-26 november 2008, ambtelijke conceptversie 25XIo8 11:30 uur (Digidoc; Dossier Beleid Koninkrijksstructuur Projectgroep Koninkrijk op Maat, kenmerk 2004-0000002743; Subdossier geannoteerde agenda's, kenmerk 2010-0000027592). Zie ook brief A.Th.B. Bijleveld-Schouten aan vz. TK, 4 december 2008, met besluitenlijst PSG (TK, 2008-2009, 31 568, nr. 7). De Volkskrant, 20 december 2008.

124 Geannoteerde agenda PSG 25-26 november 2008, ambtelijke conceptversie 25XI08 11:30 uur (Digidoc; Dossier Beleid Koninkrijksstructuur Projectgroep Koninkrijk op Maat, kenmerk 2004-0000002743; Subdossier geannoteerde agenda's, kenmerk 2010-0000027592). Brief A.Th.B. Bijleveld-Schouten aan vz. TK, 4 december 2008, met besluitenlijst PSG (TK, 2008-2009, 31 568, nr. 7). Zie ook de Volkskrant, 27 november 2008. Verslag gezamenlijke vergadering ICKR en IWG, 4 december 2008 (Digidoc; Dossier ICKR 2009, kenmerk 2008-0000072396; Subdossier 08 april 2009, kenmerk 2009-0000022391). Geannoteerde agenda PSG 25-26 november 2008, ambtelijke conceptversie 25XI08 11:30 uur (Digidoc; Dossier Beleid Koninkrijksstructuur Projectgroep Koninkrijk op Maat, kenmerk 2004-0000002743; Subdossier geannoteerde agenda's, kenmerk 2010-0000027592). Nota aan A.Th.B. Bijleveld-Schouten, 15 september 2008, kenmerk 2008-0000433880, 'Vergadering PRRC september 2008 op SXM' (Digidoc; Dossier Beleid Koninkrijksstructuur Projectgroep Koninkrijk op Maat, kenmerk 2004-0000002743; Subdossier ambtelijke projectgroep Rechtspleging, Rechtshandhaving en Constitutionele Zaken, kenmerk 2007-0000017849). 
125 Geannoteerde agenda PSG 1 oktober 2008 (Digidoc; Dossier Beleid Koninkrijksstructuur Projectgroep Koninkrijk op Maat, kenmerk 2004-0000002743; Subdossier geannoteerde agenda's, kenmerk 2010-0000027592). Besluitenlijst PSG 1 oktober 2008 (Digidoc; Dossier Vaste Commissie Nederlands Antilliaanse en Arubaanse Zaken 2008, kenmerk 2007-0000088413; Subdossier AO 23 oktober 2008, kenmerk 2008-0000058903). Instelling Toetsingsadviescommissie n.a.v. brief voorzitter en algemeen secretaris RTC, 18 september 2008, zie Geannoteerde agenda PSG 1 oktober 2008 (Digidoc; Dossier Beleid Koninkrijksstructuur Projectgroep Koninkrijk op Maat, kenmerk 2004-0000002743; Subdossier geannoteerde agenda's, kenmerk 2010-0000027592).

126 Instelling 'Toetsingsadviescommissie Ronde Tafel Conferentie' bij кв (nr. 08.003005), met als voorzitter G.R. Wawoe en als algemeen secretaris R. van Zwol. Rapportage v-RTC aan de RTC inzake de toetsing van de Staatsregelingen en organieke wetten van Curaçao en Sint Maarten, 20 november 2008, met bijlage: inzet Nederland v-RTC-bespreking TAC-rapport; rapport van de Toetsingsadviescommissie Ronde Tafel Conferentie, 20 november 2008; concept-Staatsregeling van Sint Maarten, 23 oktober 2008 met opmerkingen TAC; concept-Staatsregeling Curaçao, z.d., met opmerkingen TAC; reactie bestuurscollege Sint Maarten op het TAC-rapport, 3 december 2008 (Digidoc; Dossier beleid Koninkrijksstructuur Projectgroep Koninkrijk op Maat, kenmerk 2004-0000002743; Subdossier Conclusies en verslag, kenmerk 2008-0000074398; Subdossier Rapport TAC 2008-11-20, kenmerk 2008-0000069275). Brief A.Th.B. Bijleveld-Schouten aan vz. TK, 4 december 2008 (TK, 2008-2009, 31 568, nr. 7). Geannoteerde agenda PSG 25-26 november 2008, ambtelijke conceptversie 25XIo8 11:30 uur (Digidoc; Dossier Beleid Koninkrijksstructuur Projectgroep Koninkrijk op Maat, kenmerk 2004-0000002743; Subdossier geannoteerde agenda's, kenmerk 2010-0000027592). Brief A.Th.B. Bijleveld-Schouten aan secretaris v-RTC R. van Zwol, 2 december 2008, kenmerk 2008-0000595812, onderwerp 'Reactie op rapport Toetsingsadviescommissie' (Digidoc; Dossier beleid Koninkrijksstructuur Projectgroep Koninkrijk op Maat, kenmerk 2004-0000002743; Subdossier Correspondentie, kenmerk 2008-0000069432). Conceptagenda RTC 15 december 2008, versie 2008-11-28.1 (Digidoc; Dossier beleid Koninkrijksstructuur Projectgroep Koninkrijk op Maat, kenmerk 2004-0000002743; Subdossier dossier Nederlandse delegatie RTC 15 december 2008, kenmerk 2008-0000069144).

127 Nota aan A.Th.B. Bijleveld-Schouten, 6 augustus 2008, kenmerk 2008-0000351947, 'Planning richting RTC 15 december 2008' (Digidoc; Dossier beleid Koninkrijksstructuur Projectgroep Koninkrijk op Maat, kenmerk 2004-0000002743; Subdossier 2008-12-15 Toetsings-RTC, kenmerk 2008-0000046475).

128 Verslag gezamenlijke vergadering ICKR en IWG, 4 december 2008 (Digidoc; Dossier ICKR 2009, kenmerk 2008-0000072396; Subdossier 08 april 2009, kenmerk 2009-0000022391).

129 Verslag gezamenlijke vergadering ICKR en IWG, 4 december 2008 (Digidoc; Dossier ICKR 2009, kenmerk 2008-0000072396; Subdossier 08 april 2009, kenmerk 2009-0000022391).

130 De Volkskrant, 10 december 2008, NRC Handelsblad, 10 december 2008. 131 De Volkskrant, 12, 15, 16 en 17 december 2008, NRC Handelsblad, 15, 16 en 17 december 2008, HP De Tijd, 8 januari 2010. Zie ook Van Beetz \& Martha-Alberto 2010:135-6, Sluis 2010:39. 
132 Ongecorrigeerd stenografisch verslag RTC 15 december 2008 (Digidoc; Dossier koninkrijk op maat, kenmerk 2004-0000002743; Subdossier 2010-09-08 V-RTC (afgeschermd), kenmerk 2010-0000061512).

133 Zie ook verslag houdende een lijst van vragen en antwoorden, 14 oktober 2008 (TK, 2008-2009, 31700 IV, nr. 5). Bijleveld stelde dat in het Statuut geen wijzigingen zouden worden aangebracht $\mathrm{m}$.b.t. de autonomie van de landen of de waarborgtaak van het Koninkrijk.

134 HP/De Tijd, 8 januari 2010.

135 Ongecorrigeerd stenografisch verslag RTC 15 december 2008 (Digidoc;

Dossier koninkrijk op maat, kenmerk 2004-0000002743; Subdossier 2010-09-08 V-RTC (afgeschermd), kenmerk 2010-0000061512). Nota PD SH NA aan E.M.H.

Hirsch Ballin i.a.a. N. Albayrak, 19 september 2007, kenmerk DDS5506647 (aangehecht aan e-mail KR aan I.A.J. Klinkers, 16 juli 2010).

136 Ongecorrigeerd stenografisch verslag RTC 15 december 2008 (Digidoc; Dossier koninkrijk op maat, kenmerk 2004-0000002743; Subdossier 2010-09-08 V-RTC (afgeschermd), kenmerk 2010-00ooo61512).

137 Ongecorrigeerd stenografisch verslag RTC 15 december 2008 (Digidoc; Dossier koninkrijk op maat, kenmerk 2004-0000002743; Subdossier 2010-09-08 V-RTC (afgeschermd), kenmerk 2010-0oooo61512).

138 Zie brief A.Th.B. Bijleveld-Schouten aan vz. TK, 4 december 2008 (TK, 2008-2009, 31 568, nr. 7).

139 Ongecorrigeerd stenografisch verslag RTC 15 december 2008 (Digidoc; Dossier koninkrijk op maat, kenmerk 2004-0000002743; Subdossier 2010-09-08 V-RTC (afgeschermd), kenmerk 2010-00ooo61512).

140 NRC Handelsblad, 15 december 2008.

141 Conclusies van de toetsings-Ronde Tafel Conferentie van het Koninkrijk der Nederlanden, gehouden op 15 december 2008 te Willemstad (Digidoc; Dossier beleid Koninkrijksstructuur Projectgroep Koninkrijk op Maat, kenmerk 2004-0000002743; Subdossier 2008-12-15 Toetsings-RTC, kenmerk 2008-0000046475). De conclusies werden ondertekend door A.Th.B. BijleveldSchouten (Nederland), E.S. de Jongh-Elhage (Nederlandse Antillen), N.O. Oduber (Aruba), A.T.C. Nicolaas (Bonaire), Z.A.M. Jesus-Leito (Curaçao), J.C.A. Woodley (Sint Eustatius), S. Wescott-Williams (Sint Maarten), C. Johnson (namens Saba); Bijlage: Rapportage v-RTC, 12 december 2008. Vgl. conceptverslag PRRC 23-25 september 2008 (Digidoc; Dossier Beleid Koninkrijksstructuur Projectgroep Koninkrijk op Maat, kenmerk 2004-0000002743; Subdossier ambtelijke projectgroep Rechtspleging, Rechtshandhaving en Constitutionele Zaken, kenmerk 2007-0000017849).

142 Verslag houdende een lijst van vragen en antwoorden, 14 oktober 2008 (TK, 2008-2009, 31700 IV, nr. 5). Zie ook brief A.Th.B. Bijleveld-Schouten aan bestuurscolleges Bonaire, Sint Eustatius en Saba, 15 mei 2009, kenmerk 2009-0000244571 (Digidoc; Dossier Beleid Koninkrijksstructuur Projectgroep Koninkrijk op Maat, kenmerk 2004-0000002743; Subdossier Fenomeen BES week, kenmerk 2009-0000028570). Memo KR betreffende uitgangspunten BES-week 2 februari 2009 (www.koninkryxweb.nl).

143 Conclusies van de Toetsings-Ronde Tafel Conferentie van het Koninkrijk der Nederlanden, gehouden op 15 december 2008 te Willemstad (Digidoc; Dossier beleid Koninkrijksstructuur Projectgroep Koninkrijk op Maat, kenmerk 2004-0000002743; Subdossier 2008-12-15 Toetsings-RTC, kenmerk 2008-0000046475). 
144 De Volkskrant, 16 en 17 december 2008. Zie ook brief A.Th.B. BijleveldSchouten aan vz. TK, 16 december 2008 (TK, 2008-2009, 31 568, nr. 13).

145 Jaarverslag en slotwet Koninkrijksrelaties 2008; Lijst van vragen en antwoorden, 5 juni 2009 (TK, 2008-2009, 31924 IV, nr. 5).

146 NRC Handelsblad, 5 januari 2009.

147 Voorstel van Rijkswet houdende regeling van de inrichting, de organisatie en het beheer van de Openbare Ministeries van Curaçao, van Sint Maarten en van Bonaire, Sint Eustatius en Saba en de samenwerking daartussen (Rijkswet openbare ministeries van Curaçao, van Sint Maarten en van Bonaire, Sint Eustatius en Saba), met MvT, 11 maart 2009 (zaaknr. Wo3.08.0566/II/K). 148 Interviews Z.A.M. Jesus-Leito, 24 maart 2011, S.F.C. Römer, 21 maart 2011. 149 Besluitenlijst PSG 26 maart 2009 (Digidoc; Dossier ICKR 2009, kenmerk 2008-0000072396; Subdossier 08 april 2009, kenmerk 2009-0000022391). Brief A.Th.B. Bijleveld-Schouten aan vz. TK, 17 april 2009 (TK, 2008-2009, 31 568, nr. 35). NRC Handelsblad, 21 en 27 maart 2009, de Volkskrant, 27 en 28 maart 2009. Brief A.Th.B. Bijleveld-Schouten aan vz. TK, 26 juni 2009, kenmerk 2009-0000317656 (http://www.minbzk.nl/actueel?ActItmIdt=120826). Zie ook conceptverslag PRRC 23-25 september 2008 (Digidoc; Dossier Beleid Koninkrijksstructuur Projectgroep Koninkrijk op Maat, kenmerk 2004-0000002743; Subdossier ambtelijke projectgroep Rechtspleging, Rechtshandhaving en Constitutionele Zaken, kenmerk 2007-0000017849).

150 Geannoteerde agenda PSG 26 maart 2009; geannoteerde agenda met Nederlandse inzet PSG 26 maart 2009, versie 26 maart 2009 12h30 (Digidoc; Dossier Beleid Koninkrijksstructuur Projectgroep Koninkrijk op Maat, kenmerk 2004-0000002743; Subdossier geannoteerde agenda's, kenmerk 2010-0000027592). Besluitenlijst PSG 26 maart 2009; terugkoppeling van deze Stuurgroep in ICKR van 8 april 2009, agenda met kenmerk 2009-0000183297 (Digidoc; Dossier ICKR 2009, kenmerk 2008-0000072396; Subdossier o8 april 2009, kenmerk 2009-0000022391). Brief A.Th.B. Bijleveld-Schouten aan vz. TK, 20 april 2009, kenmerk 2009-0000213348 (http://www.minbzk.nl/ actueel?ActItmIdt=118064). Nader rapport van de regering van 6 juli 2009 (besproken in RMR, 3 juli) (TK, 2008-2009, 32018 (R1885), nr 4). Van Beetz \& Martha-Alberto 2010:140. E.M.H. Hirsch Ballin, HEK nr. 32, 19 mei 2009. Interview Z.A.M. Jesus-Leito, 24 maart 2011.

151 J.W. Remkes, HTK nr. 15, 23 oktober 2008, p. 1043. De Volkskrant, 1 april 2009. 152 HEK nr. 32, 19 mei 2009.

153 NRC Handelsblad, 17 februari en 14 mei 2009, de Volkskrant, 8 en 13 mei 2009. Zie ook brief A.Th.B. Bijleveld-Schouten aan vz. EK en TK, 22 december 2008, kenmerk 2008-0000628905 (Digidoc; Dossier beleid Koninkrijksstructuur Projectgroep Koninkrijk op Maat, kenmerk 2004-0000002743; Subdossier 2008-12-15 Toetsings-RTC, kenmerk 2008-0000046475). Nota aan J.P. Balkenende, E.H.M. Hirsch Ballin en A.Th.B. Bijleveld-Schouten, 12 januari 2009, kenmerk 2009-0000012947 over Nederlandse positie t.a.v. referendum Curaçao (Digidoc: Dossier Beleid Koninkrijksstructuur Projectgroep Koninkrijk op Maat, kenmerk: 2004-0000002743; Subdossier 2009-04 referendum Curaçao, kenmerk: 2009-0000002172).

154 A.Th.B. Bijleveld-Schouten, HTK nr. 32, 19 mei 2009, p. 1476. De Volkskrant, 31 december 2008, 8, 16 en 28 mei 2009, NRC Handelsblad, 17 februari en 14, 16 en 18 mei 2009. Brief A.Th.B. Bijleveld-Schouten aan vz. TK en EK, 26 mei 2009, kenmerk 2009-0000279776 (Digidoc; Dossier beleidssamenwer- 
king NA 2007-2009, kenmerk oooo013921; Subdossier algemeen, kenmerk 2010-0000043009).

155 Geannoteerde agenda PSG 24 juni 2009, ambtelijke conceptversie NL 17VIo9 16.0o uur (Digidoc; Dossier Beleid Koninkrijksstructuur Projectgroep Koninkrijk op Maat, kenmerk 2004-0000002743; Subdossier geannoteerde agenda's, kenmerk 2010-0000027592). Zie ook brief A.Th.B. Bijleveld-Schouten aan vz. TK, 26 juni 2009, kenmerk 2009-0000317656 (http://www.minbzk.nl/ actueel?ActItmIdt=120826). Vgl. brief G.R. Wawoe (vz. TAC) aan leden TAC, 28 januari 2009, kenmerk 3411418, 'Toetsing ontwerp-wetgeving'; brief bestuurscollege Sint Maarten aan R. van Zwol, 28 februari 2009, kenmerk 1378-09, 'Reactie BC op verzoek om nieuwe ontwerpen' (Digidoc; Dossier beleid Koninkrijksstructuur Projectgroep Koninkrijk op Maat, kenmerk 2004-00ooo02743; Subdossier Correspondentie, kenmerk 2008-ooooo69432). Zie ook 'Resultaten TAC-vergadering 18 februari 2009' (Digidoc; Dossier beleid Koninkrijksstructuur Projectgroep Koninkrijk op Maat, kenmerk 2004-00oooo2743; Subdossier Rapportage TAC, kenmerk 2008-00ooo68261). Geannoteerde agenda met Nederlandse inzet PSG 24 juni 2009 versie 24VIog ghoo (Digidoc; Dossier Beleid Koninkrijksstructuur Projectgroep Koninkrijk op Maat, kenmerk 2004-0000002743; Subdossier geannoteerde agenda's, kenmerk 2010-0000027592).

156 Geannoteerde agenda PSG 9 december 2009, z.d. (Digidoc; Dossier Beleid Koninkrijksstructuur Projectgroep Koninkrijk op Maat, kenmerk 2004-0000002743; Subdossier geannoteerde agenda's, kenmerk 2010-0000027592. Besluitenlijst PSG 9 december 2009 (http://ontmantelingna. $\mathrm{org} / \mathrm{nl} /)$.

$157 R N W$, 9 juni 2009, NRC Handelsblad, 12 november 2008, 22 mei 2009. 158 Ambtelijke nota aan A.Th.B. Bijleveld-Schouten, 29 mei 2009, kenmerk 2009-0000292058, 'videoconference' 28 mei 2009 (Digidoc; Dossier Ministerieel overleg op en met Aruba en Nederlandse Antillen 2009, kenmerk 2008-0000071412; Subdossier 2009-06-02 videoconference minpres De Jongh-Elhage, kenmerk 2009-0000033510). Zie ook geannoteerde agenda PSG 24 juni 2009, ambtelijke conceptversie NL 17VIo9 16.00 uur (Digidoc; Dossier Beleid Koninkrijksstructuur Projectgroep Koninkrijk op Maat, kenmerk 2004-0000002743; Subdossier geannoteerde agenda's, kenmerk 2010-0000027592). NRC Handelsblad, 25 juni 2009.

159 Geciteerd in Van Beetz \& Alberto-Martha 2010:141.

160 Geannoteerde agenda PSG 24 juni 2009, ambtelijke conceptversie NL 17 VIo9 16.oo uur; vgl. geannoteerde agenda met Nederlandse inzet Politieke Stuurgroep 24 juni 2009 versie 24VIog ghoo (Digidoc; Dossier Beleid Koninkrijksstructuur Projectgroep Koninkrijk op Maat, kenmerk 2004-0000002743; Subdossier geannoteerde agenda's, kenmerk 2010-0000027592). Besluitenlijst PSG 24 juni 2009 (http://ontmantelingna.org/nl/). Brief A.Th.B. Bijleveld-Schouten aan vz. TK, 26 juni 2009, kenmerk 2009-0000317656 (http://www.minbzk.nl/ actueel?ActItmIdt=120826).

161 Brief A.Th.B. Bijleveld-Schouten aan vz. TK, 26 juni 2009, kenmerk 2009-0000317656 (http://www.minbzk.nl/actueel?ActItmIdt=120826). Zie ook brief A.Th.B. Bijleveld-Schouten aan vz. TK, 5 oktober 2009, kenmerk 2009-0000564097 (http://www.minbzk.nl/actueel?ActItmIdt=122946). Vgl. IWG BES, kenmerk 2010-0000022836; Subdossier vergadering 17 februari 2009. 
162 Digidoc; Dossier Werkbezoeken staatssecretaris BZK 2009, kenmerk 2008-0000073498; Subdossier Oktober 2009 reis naar Antillen en Aruba, kenmerk 2009-0000064691.

163 Interviews E.S. de Jongh-Elhage, 22 maart 2011, A.Th.B. Bijleveld-Schouten, 20 mei 2011; e-mail A. Dalenoort, 6 september 2011. Antilliaans Dagblad, 28 september 2009. In deze brief legde het bestuurscollege zich vast op 10/10/10. 164 Bijlage bij besluitenlijst PSG 30 september 2009, bijlage bij brief 2009-0000564097 (Digidoc; Dossier ICKR 2009, kenmerk 2008-0000072396; Subdossier 2009_10_14, kenmerk 2009-0oooo66636). Geannoteerde agenda PSG 30 september 2009, ambtelijke conceptversie 29 september 2009 19:45 uur (Digidoc; Dossier Beleid Koninkrijksstructuur Projectgroep Koninkrijk op Maat, kenmerk 2004-0000002743; Subdossier geannoteerde agenda's, kenmerk 2010-0000027592).

165 Brief A.Th.B. Bijleveld-Schouten aan vz.TK, 5 oktober 2009, kenmerk 2009-0000564097, met besluitenlijst PSG 30 september 2009 en de overeenkomst over de beoogde transitiedatum van 10/10/10 (Digidoc; Dossier ICKR 2009, kenmerk 2008-0000072396; Subdossier 2009_10_14, kenmerk 2009-0000066636). Zie ook brief A.Th.B. Bijleveld-Schouten aan vz. TK, 23 oktober 2009 (TK, 2009-2010, 31 568, nr. 57). Antilliaans Dagblad, 1 oktober 2009. Vgl. Digidoc; Dossier Werkbezoeken staatssecretaris BZK 2009, kenmerk 2008-0000073498; Subdossier Oktober 2009 reis naar Antillen en Aruba, kenmerk 2009-0000064691.

166 Vgl. M. Linthorst (PVDA) tijdens debat EK over staatkundige vernieuwing 19 mei 2009, nr. 32, p. 1466.

167 Besluitenlijst PSG 30 september 2009, bijlage bij brief 2009-0000564097 (Digidoc; Dossier ICKR 2009, kenmerk 2008-0000072396; Subdossier 2009_10_14, kenmerk 2009-0000066636). Geannoteerde agenda PSG 30 september 2009, ambtelijke conceptversie 29 september 2009 19:45 uur (Digidoc; Dossier Beleid Koninkrijksstructuur Projectgroep Koninkrijk op Maat, kenmerk 2004-0000002743; Subdossier geannoteerde agenda's, kenmerk 2010-0000027592). Brief A.Th.B. Bijleveld-Schouten aan vz.TK, 5 oktober 2009, kenmerk 2009-0000564097, met bijgevoegd de concept-AMVRB 'houdende tijdelijke voorzieningen voor de samenwerking bij en de waarborging van de uitvoering van de plannen van aanpak door de landen Curaçao en Sint Maarten' (TK, 2008-2009, 31 568, nr. 55). Vgl. brief A.Th.B. Bijleveld-Schouten aan vz. TK, 23 februari 2009 (TK, 2008-2009, 31 568, nr. 20). Antilliaans Dagblad, 1 oktober 2009. Van Beetz \& Alberto-Martha 2010:142.

168 Zie agenda ICKR 14 oktober 2009 (Digidoc; Dossier ICKR 2009, kenmerk 2008-0000072396; Subdossier 2009_10_14, kenmerk 2009-0000066636). Vgl. notitie BES-legal over gevolgen transitiedatum 10/10/10 voor de BES-wetgeving, 21 september 2009 (Digidoc; Dossier ICKR 2009, kenmerk 2008-0000072396; Subdossier 2009_10_14, kenmerk 2009-0000066636).

169 Memo KR aan IWG, 3 november 2009, betreffende inventarisatieproblematiek 10/10/10 (www.koninkryxweb.nl). ICKR 16 december 2009 (Digidoc; Dossier ICKR 2009, kenmerk 2008-0000072396; Subdossier 2009_10_14, kenmerk 2009-0000066636). Zie ook IWG BES 2008, kenmerk 2010-0000022836; Subdossier vergadering 24 november 2009.

170 NRC Handelsblad, 2 september 2009. De Volkskrant, 2 september 2009. Antilliaans Dagblad, 2 november 2009. Weide 2010:173.

171 Verslag AO van 15 oktober 2009, voortgezet op 28 oktober 2009. Verslag AO van 28 oktober 2009, vastgesteld 27 november 2009 (TK, 2009-2010, 31 568, 
nr. 6o, p. 3). Zie ook brief A.Th.B. Bijleveld-Schouten aan vz. Tweede Kamer, 23 oktober 2009 (TK, 2009-2010, 31 568, nr. 57).

172 Verslag AO van 15 oktober 2009, voortgezet op 28 oktober 2009. Verslag AO van 28 oktober 2009, vastgesteld 27 november 2009 (TK, 2009-2010, 31 568, nr. 6o, p. 3). Bijlage bij brief aan vz. TK, 23 oktober 2009 (TK, 2009-2010, 31 568, nr. 56). Brief A.Th.B. Bijleveld-Schouten aan vz. TK, 23 oktober 2009 (TK, 2009-2010, 31 568, nr. 57).

173 Motie B.J. van Bochove, J. Leerdam en C.A. Ortega-Martijn, 23 oktober 2008 (TK, 2008-2009, 31700 IV, nr. 9). Verslag AO van 28 oktober 2009, vastgesteld 27 november 2009 (TK, 2009-2010, 31 568, nr. 60). Brief A.Th.B. BijleveldSchouten aan vz. TK, 23 oktober 2009 (TK, 2009-2010, 31 568, nr. 57). Vaststelling begrotingsstaat Koninkrijksrelaties (IV) 2010, nr. 3 verslag houdende een lijst van vragen en antwoorden, 23 november 2009 (TK, 2009-2010, $32123 \mathrm{IV}, \mathrm{nr} .3$ ). Amigoe, 16 oktober 2009.

174 Verslag AO van 28 oktober 2009, vastgesteld 27 november 2009 (TK, 2009-2010, 31 568, nr. 60). Zie ook HTK nr. 32, 2 december 2009. Antilliaans Dagblad, 28 en 29 oktober, 17 en 19 november 2009.

175 HTK nr. 32, 2 december 2009.

176 Zie ook A.Th.B. Bijleveld-Schouten, HTK nr 32, 2 december 2009, pp. 3074-5. 177 J.W. Remkes, HTK nr. 32, 2 december 2009, pp. 3064-5. J.W. Remkes, A. Pechtold, R. van Raak, C. van der Staaij, J. Leerdam, B.J. van Bochove (TK, 2009-2010, 32123 IV, nr. 20; gewijzigde motie, ter vervanging van nr. 11). Bijleveld (HTK nr. 32, 2 december 2009, p. 3088) had de eerdere versie van deze motie ernstig ontraden omdat deze naar haar mening voor het in 2010 beoogde proces destructief zou zijn. Vgl. J.W. Remkes, p. 3088. Zie ook motie Remkes, Van Raak, Van der Staaij (TK, 2009-2010, 32123 IV, nr. 10).

178 Zie verder par. 'Bonairiaans referendum'.

179 Motie I. van Gent en J.W. Remkes (TK, 2009-2010, 32123 IV, nr. 18) over de gelijke behandeling van alle burgers (waaruit voortvloeide dat vanaf 10/10/10 homoseksuelen in het gehele Koninkrijk moesten kunnen trouwen). Deze motie werd door Bijleveld ontraden (HTK nr. 32, 2 december 2009, p. 3087). Op 15 december 2009 steunde een Kamermeerderheid (GL, PVDA, SP, VVD, PVV, D66, PvdD, Verdonk) de aangepaste, minder dwingende motie van GroenLinks die het kabinet opriep zich in te zetten om het mogelijk te maken dat homoseksuele paren straks ook op de Antillen en Aruba zouden kunnen trouwen (motie I. van Gent, J.W. Remkes en J. Leerdam; TK, 2009-2010, 32123 IV, nr. 21). Per brief van 28 december 2009 deelde Bijleveld aan de Tweede Kamer mee dat homoparen op de BES-eilanden gelijke rechten zouden krijgen als in Nederland.

$180 \mathrm{Zie}$ bijv. motie over het Bonairiaans referendum van B.J. van Bochove, J. Schinkelshoek, J. Leerdam, J.W. Remkes, A. Pechtold, I. van Gent, C. van der Staaij, R. van Raak (TK, 2009-2010, 32123 IV, nr. 8). Motie Van Bochove, Leerdam, Remkes, Ortega-Martijn, Pechtold, Van der Staaij, Van Raak (тк, 2009-2010, 32 123 IV, nr. 9) over de bestrijding van illegaal verblijf en uitzetting van illegalen. Bijleveld had geen bezwaar tegen de motie Remkes, Van Raak, Pechtold, Van der Staaij (TK, 2009-2010, 32123 IV, nr. 12) die de regering verzocht 'nog in deze kabinetsperiode op korte termijn een terzake dienend voorstel tot herziening van de Grondwet bij de Tweede Kamer in te dienen'. Motie nr. 16 van H. Brinkman (zie onder de par. 'Bonairiaans referendum'), die vroeg eerst de uitslag van het referendum af te wachten, werd door Bijleveld afgeraden. 181 Zie ook Telegraaf.nl, 2 december 2009, Antilliaans Dagblad, 3 en 4 december 2009, RNW, 3 december 2009. 
182 Brief A.Th.B. Bijleveld-Schouten aan vz.TK, 5 oktober 2009, kenmerk 2009-0000564097 (Digidoc; Dossier ICKR 2009, kenmerk 2008-0000072396; Subdossier 2009_10_14, kenmerk 2009-0oooo66636). Geannoteerde agenda PSG 30 september 2009, ambtelijke conceptversie 29 september 2009 19:45 uur (Digidoc; Dossier Beleid Koninkrijksstructuur Projectgroep Koninkrijk op Maat, kenmerk 2004-0000002743; Subdossier geannoteerde agenda's, kenmerk 2010-0000027592). Besluitenlijst PSG 30 september 2009, bijlage bij brief 2009-0000564097 (Digidoc; Dossier ICKR 2009, kenmerk 2008-0000072396; Subdossier 2009_10_14, kenmerk 2009-0000066636).

183 Geannoteerde agenda PSG 30 september 2009, ambtelijke conceptversie 29 september 2009 19:45 uur (Digidoc; Dossier Beleid Koninkrijksstructuur Projectgroep Koninkrijk op Maat, kenmerk 2004-0000002743; Subdossier geannoteerde agenda's, kenmerk 2010-0000027592).

184 Aantekening van R. Vermaas, 10 december 2010, interview 23 maart 2011. Van Beetz \& Alberto-Martha 2010:142. Interviews F.P. van Beetz en W.W. Timmers, 26 augustus 2011.

185 Geannoteerde agenda PSG 9 december 2009, z.d. (Digidoc; Dossier Beleid Koninkrijksstructuur Projectgroep Koninkrijk op Maat, kenmerk 2004-0000002743; Subdossier geannoteerde agenda's, kenmerk 2010-0000027592). Besluitenlijst PSG 9 december 2009 (http://ontmantelingna. org/nl/). Zie ook brief A.Th.B. Bijleveld-Schouten aan vz. TK, 17 december 2009, kenmerk 2009-0000734647 (http://www.minbzk.nl/actueel?ActItmIdt=124854). Vanwege het agendapunt over de politie nam minister van BZK G. ter Horst ook deel aan de besprekingen. Brief A.Th.B. Bijleveld aan vz. TK, 17 december 2009, kenmerk 2009-0000734647 (http://www.minbzk.nl/actueel?ActItmIdt=124854). Geannoteerde agenda PSG 9 december 2009, z.d. (Digidoc; Dossier Beleid Koninkrijksstructuur Projectgroep Koninkrijk op Maat, kenmerk 2004-0000002743; Subdossier geannoteerde agenda's, kenmerk 2010-0000027592. Besluitenlijst PSG 9 december 2009 (http://ontmantelingna.org/nl/). Zie ook brief A.Th.B. Bijleveld-Schouten aan vz. TK, 1 maart 2010, kenmerk 2010-0000138349 (http:// www.minbzk.nl/actueel?ActItmIdt=125690); brief A.Th.B. Bijleveld-Schouten aan vz. TK, 1 maart 2010, kenmerk 2010-0000138349 (http://www.minbzk.nl/ actueel?ActItmIdt=125690).

186 Geannoteerde agenda PSG 11 februari 2010; besluitenlijst PSG 11 februari 2010 (Digidoc; Dossier Beleid Koninkrijksstructuur Projectgroep Koninkrijk op Maat, kenmerk 2004-0000002743; Subdossier geannoteerde agenda's, kenmerk 2010-0000027592). RNW, The Daily Herald, Antilliaans Dagblad, 12 februari 2010. 187 Besluitenlijst PSG 11 februari 2010; brief A.Th.B. Bijleveld-Schouten aan vz. TK, 1 maart 2010, kenmerk 2010-0000138349 (http://www.minbzk.nl/ actueel?ActItmIdt=125690). Zie brief Vaste Commissie NAAZ aan A.Th.B. Bijleveld-Schouten, 17 februari 2009 (TK, 31568-66/2010Do9072).

$188 R N W, 10$ december 2010.

$189 R N W, 12$ februari 2010, Antilliaans Dagblad, 13 februari 2010, The Daily Herald, 12 februari 2010.

190 Onderhandelingen eind 2008 tussen Nicolaas en Abraham waren mislukt. In mei 2009 stapte Nicolaas alsnog over en leken veel van zijn eerdere eisen ingewilligd (het 'wensenlijstje' raakte begin 2010 openbaar). Bijleveld verzocht gouverneur Goedgedrag om een onderzoek naar de totstandkoming van het nieuwe bestuurscollege omdat zij vreesde dat de integriteit van het bestuur in het geding was. 
191 Zie ook Onafhankelijk Statenlid Nicolaas tijdens verslag, Wijziging van het Statuut voor het Koninkrijk der Nederlanden in verband met de wijziging van de staatkundige hoedanigheid van de eilandgebieden van de Nederlandse Antillen (Rijkswet wijziging Statuut in verband met de opheffing van de Nederlandse Antillen). nr. 8 Verslag van de Staten van de Nederlandse Antillen, ontvangen 22 januari 2010 (TK, 2009-2010, 32213 (R1903) nr. 8).

192 Brief bestuurscollege Bonaire aan mrs. A.G. van Dijk en S. Hillebrink van het Nederlandse ministerie van Justitie (Directie Wetgeving, Sector Staats- en Bestuursrecht), 24 september 2009, kenmerk 29013034; agenda ICKR 14 oktober 2009 (Digidoc; Dossier ICKR 2009, kenmerk 2008-0000072396; Subdossier 2009_10_14, kenmerk 2009-0000066636). Brief A.Th.B. Bijleveld-Schouten aan VZ.TK, 6 oktober 2009 (TK, 2009-2010, 31 568, nr. 55). Verslag AO van 28 oktober 2009, vastgesteld 27 november 2009 (TK, 2009-2010, 31 568, nr. 60), pp. 21-2. Zie bijv. ook Amigoe, 16, 17 en 30 september 2009, Antilliaans Dagblad, 7 en 16 september 2009, de Volkskrant, 16 september 2009, NRC Handelsblad, 21 oktober 2005. Zie ook Verhey 2010:33-4.

193 Antilliaans Dagblad, 13 en 15 oktober 2009, Trouw, 14 oktober 2009. Vgl. A.Th.B. Bijleveld-Schouten in HTK nr. 32, 2 december 2009, p. 3075. Verslag AO van 28 oktober 2009, vastgesteld 27 november 2009 (TK, 2009-2010, 31 568, nr. 6o), p. 3. Zie ook motie H. Brinkman (TK, 2009-2010, 32123 IV, nr. 16) die de regering verzocht de uitslag van het referendum op Bonaire af te wachten alvorens verder te gaan met het hervormingsproces.

194 Verslag AO van 28 oktober 2009, vastgesteld 27 november 2009 (TK, 2009-2010, 31 568, nr. 60), pp. 21-2. A.Th.B. Bijleveld-Schouten, HTK nr. 32, 2 december 2009, pp. 3075-6; zie ook J.W. Remkes (VVD), p. 3059. Vgl. motie B.J. van Bochove, medeondertekend door J. Schinkelshoek, J. Leerdam, J.W. Remkes, A. Pechtold, I. van Gent, C. van der Staaij en R. van Raak, 2 december 2009 (TK, 2009-2010, 32123-IV, nr. 8) die de regering verzocht, met het oog op het Bonairiaanse voornemen een referendum te organiseren, 'niet van de afspraken over de staatkundige toekomst van de Nederlandse Antillen af te wijken dan na vooraf de Kamer te hebben geconsulteerd'. Brief A.Th.B. BijleveldSchouten aan vz.TK, 5 oktober 2009, kenmerk 2009-0000564097 (Digidoc; Dossier ICKR 2009, kenmerk 2008-0000072396; Subdossier 2009_10_14, kenmerk 2009-0000066636). Zie ook bijv. Amigoe, 11 november 2009, 4 en 8 januari 2010, Antilliaans Dagblad, 5, 7 en 9 januari 2010. Zie ook verslag houdende een lijst van vragen en antwoorden, 23 november 2009 (TK, 2009-2010, 32123 IV, nr. 3). Volgens Rijksvertegenwoordiger H. Kamp was 10/10/10 nog 'goed haalbaar', ondanks de situatie op Bonaire. Antilliaans Dagblad, 23 november 2009, 18 december 2009.

195 Antilliaans Dagblad, 14 oktober 2009. A.Th.B. Bijleveld-Schouten, HTK nr. 32, 2 december 2009, p. 3075. Vgl. RNW, 2 oktober 2009. IWG BES 2008, kenmerk 2010-0000022836; Subdossier vergadering 8 december 2009. IWG-vergadering 8 december 2009. B.J. van Bochove in Antilliaans Dagblad, 19 november 2009. 196 Vgl. ook brief A.Th.B. Bijleveld-Schouten, 26 september 2008 betreffende juridische keuzes regelgeving BES (TK, 2008-2009, 31 568, nr. 3). Verslag AO van 23 oktober 2008, vastgesteld 1 december 2008 (TK, 2008-2009, 31 568, nr. 5). Amigoe, 11 november 2009, Antilliaans Dagblad, 3 en 5 november 2009. Brief bestuurscollege Bonaire aan A.Th.B. Bijleveld-Schouten, 3 september 2009, kenmerk 29011961, 'voorstellen taakverdeling' (Digidoc; Dossier Beleid Koninkrijksstructuur Projectgroep Koninkrijk op Maat, kenmerk 2004-0000o02743; Subdossier Bestuurlijk overleg, kenmerk 2006-oooo012243). Over de taakverde- 
ling Rijk-BES, zie ook brief A.Th.B. Bijleveld-Schouten, voor deze Dir. KR J.H. Gerritsen, aan bestuurscolleges Bonaire, Sint Eustatius en Saba, 9 september 2009, kenmerk 2009-0000509129 (Digidoc; Dossier Beleid Koninkrijksstructuur Projectgroep Koninkrijk op Maat, kenmerk 2004-0000002743; Subdossier Bestuurlijk overleg, kenmerk 2006-0000012243). Geannoteerde agenda incl. Nederlandse inzet (ambtelijk concept) voor bestuurlijk overleg Nederland, Bonaire, Sint Eustatius en Saba op 3 november 2009 te Curaçao (Digidoc; Dossier Beleid Koninkrijksstructuur Projectgroep Koninkrijk op Maat, kenmerk 2004-0000002743; Subdossier Bestuurlijk overleg, kenmerk 2006-0000012243). Vgl. IWG BES 2008, kenmerk 2010-0000022836; Subdossier vergadering 24 november 2009.

197 Antilliaans Dagblad, 18 december 2010, in reactie op uitlatingen van rechter B. Wit van het Caraïbische Hof en staatsrechtdeskundige D. Boersema (tevens voorzitter van het in mei 2009 gehouden referendum op Curaçao). Zie ook Amigoe, 10 november 2009. B. Wit, Antilliaans Dagblad, 21 december 2010. Ook hoogleraar Staatsrecht D.J. Elzinga noemde in Binnenlands Bestuur (aangehaald in Antilliaans Dagblad, 18 november 2009) de BES-formule 'ingewikkeld', 'met een reeks van voetangels en klemmen'. Kennelijk hadden Gerritsens gesprekken met politieke leiders op Bonaire op 11 december aanleiding gegeven tot aanscherping van de lijn richting Bonaire. Zie ICKR 16 december 2009 (Digidoc; Dossier ICKR 2009, kenmerk 2008-0000072396; Subdossier 2009_12_16, kenmerk 2009-0000066639).

198 Antilliaans Dagblad, 27 en 29 januari 2010, RNW, 29 januari en 2 februari 2010. 199 Zie bijv. Amigoe, ANP, Nos.nl, Nu.nl, 1 en 2 februari 2010; Trouw, NRC Handelsblad, Antilliaans Dagblad, 2 februari 2010, RNW, 3 februari 2010. Vgl. Antilliaans Dagblad en RNW, 25 juni 2010.

200 Zie bijv. Amigoe, 13 februari en 17 maart 2010, Antilliaans Dagblad, 15 en 16 februari 2010 (reactie Abraham). Zie ook Verhey 2010:33-4.

201 Zie voor reacties Booi en Abraham bijv. Amigoe, 13 februari 2010. Nicolaas in Antilliaans Dagblad, 17 februari 2010. Vgl. een kritische Van Raak bij de RNW, 13 februari 2010; ook RNW, 15 februari 2010, Amigoe, 17 maart 2010: Statenleden Abraham en Nicolaas willen uitspraak VN in referendumkwestie. Amigoe, 17, 18 en 19 februari 2010, Antilliaans Dagblad, 6 maart 2010.

202 Amigoe, 16 en 17 maart 2010, Antilliaans Dagblad, 16, 18 en 23 maart 2010.

203 Antilliaans Dagblad, 18 maart 2010.

204 Amigoe, 3 en 4 maart 2010, Antilliaans Dagblad, 3, 4 en 5 maart 2010. Antilliaans Dagblad, The Daily Herald, Amigoe, 3 maart 2010. Zie ook RNW, 3 en 15 maart 2010.

205 Antilliaans Dagblad, Amigoe, 10 en 11 maart 2010, RNW, 10 maart 2010, 12, 13 november 2009, RNW, Amigoe, 20 november 2009. Zie ook memo aan ICKR, 26 maart 2010, 'Richtlijn omgang Bonaire' (Digidoc; Dossier ICKR 2009, kenmerk 2008-0000072396; Subdossier 2009_12_16, kenmerk 2009-0000066639).

206 Amigoe, 17 maart 2010, RNW, Antilliaans Dagblad, 18 maart 2010, RNW, 26 maart 2010. IWG BES 2008, kenmerk 2010-0000022836; Subdossier vergadering 2 maart 2010.

207 Besluitenlijst bestuurlijk overleg 22 april 2010, te Bonaire (met bijlagen). Antilliaans Dagblad, 15 april 2010. RNW, 23 april 2010. Brief A.Th.B. BijleveldSchouten aan Vz. TK en EK, 6 mei 2010 (Digidoc; Dossier beleids samenwerking NA 2007-0000013921; Subdossier algemeen 2007-0000046898). Antilliaans Dagblad, 10 april 2010 (excuses Booi). Interview J. Abraham, 28 maart 2011. $208 R N W, 2,26$ en 28 juni 2010. 
209 RNW, Amigoe, 2 en 3 juni 2010, Antilliaans Dagblad, 3 juni 2010.

210 Brief minister van BZK J.P.H. Donner aan vz. TK, 22 december 2010 (TK, 2010-2011, 31568 IV, nr. 83).

211 Digidoc, dossier MT DGBK KR 2010, kenmerk 2009-0000064068; Subdossier 26 januari 2010, kenmerk 2010-0000005909.

212 Geannoteerde agenda voor tripartiete overleg MP's van het Koninkrijk op 14 december 2009 (Digidoc; Dossier Ministerieel overleg op en met Aruba en Nederlandse Antillen 2009, kenmerk 2008-0000071412; Subdossier 2009-12-14 tripartiet overleg MP's, kenmerk 2009-0000075377).

213 Vgl. A.Th.B. Bijleveld-Schouten, HTK nr. 32, 2 december 2009, p. 3075. 'Sint Maarten wordt alleen een zelfstandig land als het voldoet aan de overeengekomen criteria. Hierbij is het op orde zijn van de rechtshandhaving en rechtspleging een zeer belangrijk onderdeel. Het gaat erom dat men het zelfstandig kan doen.'

214 De Wet openbare lichamen Bonaire, Sint Eustatius en Saba (Wolbes), de Wet Financiën Openbare Lichamen, de Wijziging Kieswet in verband met de nieuwe staatsrechtelijke positie BES, de Invoeringswet BES (I-BES), de Aanpassingswet BES (A-BES) en de Wet goedkeuring en voornemen tot opzegging verdragen BES. Het meeste werk was verricht in de BES-legal, de IWG en de ICKR. Met de I-BEs bleef een groot deel van de Antilliaanse regelgeving na aansluiting bij Nederland als Nederlandse regelgeving op de BES gelden. Deze regelgeving zou via de A-BES worden aangepast. Zie ook RNW, 18 januari 2010.

215 Zie J.W. Remkes, HTK nr. 32, 2 december 2009, pp. 3059-6o. Eilandsraadleden van de BEs kregen in de voorstellen indirect kiesrecht voor de Eerste Kamer. Een Kamermeerderheid had op 15 december 2009 al een motie aangenomen ter bevordering van het homohuwelijk op de Antillen, wat onder meer op Bonaire tot commotie had geleid. Over het aanvankelijk strafbaar willen laten van euthanasie en abortus op de BES zie Knape 2010:111-4.

216 Verslag wetgevingsoverleg Vaste Kamercommissie nAAZ, Vaste Commissie BZK en Vaste Commissie BuZa, 15 januari 2010, vastgesteld 20 januari 2010 (TK, 2009-2010, 31 954, nr. 13). Zie ook bijv. RNW, 15 januari 2010, Antilliaans Dagblad, 15 januari 2010. Van Bochove sprak echter van de wetsteksten in 'hapklare brokken'.

217 CDA'er Van Bochove vond het 'per decreet' invoeren van het homohuwelijk onverstandig. RNW, 18 januari 2010. Amigoe, 15 januari 2010, The Daily Herald, 18 januari 2010.

218 Op 8 februari 2010 bevestigde Bijleveld in een Kamerbrief dat het kabinet binnen afzienbare tijd uitvoering zou geven aan het amendement van Remkes om een voorstel tot Grondwetsherziening in te dienen met het oog op de toetreding van de BES-eilanden tot het Nederlandse staatsbestel. Zolang de Grondwetsherziening niet in werking was getreden, hadden de ingezetenen van de BES-eilanden onder meer geen invloed op de samenstelling van de Eerste Kamer. Zie ook A.Th.B. Bijleveld-Schouten, HTK nr. 32, 2 december 2009, p. 307: toezegging versnelde Grondwetswijziging. A.Th.B. Bijleveld-Schouten, HTK nr. 59, 4 maart 2010, p. 5306 e.v. Zie ook brief E.M.H. Hirsch Ballin en A.Th.B. Bijleveld-Schouten aan vz. TK, 11 april 2010, kenmerk 5648841/10/6.

219 Brief A.Th.B. Bijleveld-Schouten aan vz. TK, 9 februari 2010 (TK, 2009-2010, 31 568, nr. 66). Antilliaans Dagblad, 11, 16 en 17 februari 2010. Als tegemoetkoming aan de Kamer zou Bijleveld de fiscale voorstellen uit de BES-wetten apart laten behandelen, samen met de rest van de belastingwetten. In november 2009 was ook gesproken over parallelle behandeling van de Antillenwetten in beide 
Kamers, maar dit was door de Senaat afgewezen. Zie ook J.W. Remkes, HTK nr. 32, 2 december 2009, pp. 3084-5. De Kamer kreeg 'het gevoel dat zij op een rare manier onder druk wordt gezet'.

220 De kranten kopten pessimistisch over het nu nog behalen van 10/10/10, zie bijv. Amigoe, 21 februari 2010 ('10-10-10 op losse schroeven na val Nederlands kabinet'), Antilliaans Dagblad, 21, 22, 24 februari 2010 ('Val kabinet-Balkenende zet streep door 10-10-10'). Voorzitter van de Vaste Commissie NAAZ W. van Beek verklaarde nu eerder te denken aan 11/11/11. Van Bochove rekende op een verschuiving van 10/10/10 met minimaal 14 maanden. Het werkbezoek van de Commissie NAAZ aan de Antillen, gepland voor begin april, werd afgeblazen. Juist op de dag van de val van het kabinet-Balkenende sloot De Jongh-Elhage II een regeerakkoord.

221 De Jongh-Elhage riep voorafgaand aan het debat per brief koningin Beatrix, Balkenende, Van Beek en diverse andere Haagse politici op om het proces van ontmanteling van de Antillen niet te laten vertragen door de val van het kabinet. Zie bijv. Amigoe, 22, 25 februari 2010, RNW, ANP, 23 februari 2010, Antilliaans Dagblad, 23, 24, 25 februari 2010. Zie ook Van Beetz \& MarthaAlberto 2010:146-9. Zie ook Antilliaans Dagblad 25, 26 februari 2010: 'een legertje bollebozen' op BZK en Justitie en externe staatsrechtdeskundigen waren druk doende om een constructie te bedenken waarmee kon worden voorkomen dat het proces tot na de Kamerverkiezingen moest worden opgeschort. Ook de RvS zou 'achter de schermen' een rol spelen.

222 Bijleveld had het oordeel over dit laatste amendement, na het eerst te hebben ontraden, uiteindelijk aan de Kamer gelaten (zij achtte het wenselijk dat legaal op de BES verblijvende niet-Nederlanders actief kiesrecht kregen voor de eilandsraden). Vooral tegen het binnen een jaar legaliseren van abortus verzette zij zich; liefst zag zij dit uitgesteld tot aan de evaluatie van de nieuwe status na vijf jaar. Zie bijv. Amigoe, $R N W, 5$ maart 2010. In aanvulling op de zes in januari besproken wetten lag nu ook de Wet bescherming persoonsgegevens BES ter behandeling voor.

223 Motie nr. 11 van J.W. Remkes, medeondertekend door A. Pechtold, R. van Raak, C. van der Staaij, J. Leerdam en B.J. van Bochove, HTK nr. 32, 2 december 2009, met als doel het RST nieuwe stijl 'vooralsnog een permanente rol' te laten spelen als belangrijk onderdeel van de GVP. De regering werd verzocht het overleg daarover te heropenen en daarop aangepaste wettelijke voorstellen aan de Kamer aan te bieden.

224 J.W. Remkes, HTK nr. 59, 4 maart 2010, pp. 5296, 5298. Ook drong Remkes aan op een financieel plaatje van het hele proces.

225 J. Abraham i.s.m. H. Bruijne, Ongepubliceerd document, 'Staatkundig proces Bonaire naar "directe banden", 28 maart 2011, p. 17. RNW, Amigoe, 10 maart 2010. De eilandsraad van Sint Eustatius nam in april 2010 unaniem een motie aan tegen de 'anti-sociale' wetten van het homohuwelijk, abortus en euthanasie en stuurde deze naar de Tweede Kamer. Antilliaans Dagblad, 21 april 2010. (Nederland zou Sint Maarten en Curaçao slechts 'dwingend' verzoeken de wetten in te voeren, vanwege hun autonome status.) Zie ook Amigoe, 22 april 2010, Antilliaans Dagblad, 5, 9 maart, 21, 23, 28, 29 april 2010, NRC Handelsblad, RNW, 22 april 2010. A.Th.B. Bijleveld-Schouten, HTK nr. 59, 4 maart 2010, p. 5322. Bijleveld was niet bereid - verzoek van Van der Staaij - om de op de BES omstreden amendementen tegen te houden. Amigoe, 18 mei 2010, Antilliaans Dagblad, 19 mei 2010.

226 Vgl. motie I. van Gent, gesteund door de VVD, van eind mei 2010: Nederland moest meer doen voor de rechten van homoseksuelen in de Antillen en Aruba en 
er moest een onderzoek komen naar het homo-emancipatiebeleid. Alleen CU en SGP waren tegen deze motie. Een ruime Kamermeerderheid stemde in met de motie. Amigoe, 19, 21 en 24 mei 2010, Antilliaans Dagblad, 20 en 21 mei 2010.

227 Voortgangsrapportage plan van aanpak BZK-BES, interne rapportage, 10 maart 2010 (Digidoc; Dossier Beleid Koninkrijksstructuur Projectgroep Koninkrijk op Maat, kenmerk 2004-0000002743; Subdossier BES_BZK, kenmerk 2007-0000067659).

228 Vgl. motie J.W. Remkes, R. van Raak en C. van der Staaij (nr. 10, 32123-IV; HTK nr. 32, 2 december 2009, pp. 3084-5), die de regering verzocht de datum van 10/10/10 te verschuiven indien de 'sterke verbetering van de politieorganisatie' nog niet dan wel onvoldoende daadwerkelijk was gerealiseerd. Zie Antilliaans Dagblad, 10 en 11 maart 2010.

229 Verhey 2010:21; Antilliaans Dagblad, 24 februari 2010; Van Beetz \& MarthaAlberto 2010:149. Op voorstel van Remkes zouden voorafgaand aan het wetgevingsoverleg 'hoorzittingen' worden gehouden, om voordat de Kamer over de wijziging van het Statuut en de Politiewet zou oordelen de opvattingen te horen van deskundigen, staatsrechtgeleerden en experts uit de politiepraktijk. Zie ook De Grijff 2010:88.

230 Zie bijv. RNW, 29 maart, 8 april 2010, Amigoe, 6, 7, 8 april 2010.

231 Antilliaans Dagblad, 26 maart, 12 april 2010.

$232 R N W, 12$ april 2010. Jesus-Leito wilde geen water bij de wijn doen. 'We willen dat de wetten blijven zoals ze zijn en dat we de Kamerleden ervan overtuigen dat de huidige opzet voldoende is.' Ook Hirsch Ballin wilde vooralsnog geen water bij de wijn doen; het wetsvoorstel was volgens hem goed.

233 Zie bijv. RNW en Antilliaans Dagblad, 10, 12 april 2010. Van Beetz \& MarthaAlberto 2010:150-1.

234 De Politiewet en het inrichtingsplan van de GVP waren nog uitgebreid besproken tijdens de PSG van 11 februari op Curaçao. Geannoteerde agenda en besluitenlijst PSG 11 februari 2010 (Digidoc; Dossier Beleid Koninkrijksstructuur Projectgroep Koninkrijk op Maat, kenmerk 2004-0000002743; Subdossier geannoteerde agenda's, kenmerk 2010-0000027592). Zie ook Amigoe, Antilliaans Dagblad, 9 april 2010, RNW, 14 april 2010.

$235 \mathrm{TK}, 32019 / \mathrm{R} 1886 \mathrm{nr}$. 10. ANP, NOS, RNW, The Daily Herald, 15 april 2010, Antilliaans Dagblad, NRC Handelsblad, 16 april 2010. Zie ook Van Beetz \& MarthaAlberto 2010:152. Interview W.W. Timmers, 26 augustus 2011, e-mail W.W. Timmers, 25 augustus 2011.

236 Antilliaans Dagblad, 8, 12 april 2010, Amigoe, The Daily Herald, 7, 8 april 2010, RNW, 8 april 2010.

237 нтк nr. 32, 2 december 2009.

238 Van Raak had ook gevraagd om een Nederlandse visie op de waarborgfunctie (TK, 2009-2010, 32500 IV, nr. 9). Bijleveld zegde toe hierover een notitie aan de Tweede Kamer te zullen sturen. Zie ook brief E.M.H. Hirsch Ballin en A.Th.B. Bijleveld-Schouten aan vz. TK, 11 april 2010, kenmerk 5648841/10/6, met beantwoording vragen.

239 The Daily Herald, 9, 16 april 2010, RNW, 9, 10, 16 april 2010, Antilliaans Dagblad, 7, 10, 12, 17 april 2010, Amigoe, 6, 10, 13 april 2010. Het eilandsbestuur van Sint Eustatius distantieerde zich nadrukkelijk van Zaandams inbreng. 240 De tien (consensus)rijkswetten waarover op 15 april in de Tweede Kamer werd gestemd (en op 6 juli in de Eerste Kamer): 1. het wetsvoorstel Regeling van de inrichting, de organisatie en het beheer van de Openbare Ministeries van Curaçao, van Sint Maarten en van Bonaire, Sint Eustatius en Saba en de 
samenwerking daartussen (Rijkswet Openbare Ministeries van Curaçao, van Sint Maarten en van Bonaire, Sint Eustatius en Saba) (32018, R1885); 2. het wetsvoorstel Regeling van de inrichting, de organisatie, het gezag en het beheer van de politie van Curaçao, van Sint Maarten en van Bonaire, Sint Eustatius en Saba en de onderlinge samenwerking tussen de politie van Curaçao, van Sint Maarten en van Bonaire, Sint Eustatius en Saba (Rijkswet politie van Curaçao, van Sint Maarten en van Bonaire, Sint Eustatius en Saba) (32019, R1886); 3. het wetsvoorstel Regeling van de instelling, taken en bevoegdheden van de Raad voor de rechtshandhaving van Curaçao, van Sint Maarten en van Bonaire, Sint Eustatius en Saba (Rijkswet Raad voor de rechtshandhaving) (32020, R1887); 4. het wetsvoorstel Regels voor het financieel toezicht op de landen Curaçao en Sint Maarten (Rijkswet Financieel toezicht Curaçao en Sint Maarten) (32026, R1888); 5. het wetsvoorstel Vaststelling van een zeegrens tussen Curaçao en Bonaire, en tussen Sint Maarten en Saba (32041, R1890); 6. het wetsvoorstel Regeling van taken en bevoegdheden van het Gemeenschappelijk Hof van Justitie van Aruba, Curaçao, Sint Maarten en van Bonaire, Sint Eustatius en Saba (Rijkswet Gemeenschappelijk Hof van Justitie) (32017, R1884); 7. het wetsvoorstel Reglement voor de Gouverneur van Curaçao (32178, R1898); 8. het wetsvoorstel Reglement voor de Gouverneur van Sint Maarten (32179, R1899); 9. het wetsvoorstel Wijziging van verschillende rijkswetten in verband met de verkrijging van de hoedanigheid van land binnen het Koninkrijk door Curaçao en Sint Maarten en de toetreding van Bonaire, Sint Eustatius en Saba tot het Nederlandse staatsbestel (Rijkswet aanpassing rijkswetten aan de oprichting van de nieuwe landen) (32186, R1901); 10. het wetsvoorstel Wijziging van het Statuut voor het Koninkrijk der Nederlanden in verband met de wijziging van de staatkundige hoedanigheid van de eilandgebieden van de Nederlandse Antillen (Rijkswet wijziging Statuut in verband met de opheffing van de Nederlandse Antillen) (32213, R1903). Voor de behandeling, zie o.a. Amigoe, Antilliaans Dagblad, RNW, NRC Handelsblad, Trouw, 15 en 16 april 2010. Ook Amigoe, Antilliaans Dagblad, 17 april 2010.

241 Van Beetz \& Martha-Alberto 2010:152-6.

242 Andere aanvaarde moties: van J.D.E. Yrausquin en R. Herdé (AVP) over een geschillenregeling en een motie van Yrausquin c.s. over optimale samenwerking bij de implementatie van verdragen; motie C.A. Ortega-Martijn over de stem van de BES-eilanden in het staatsbestel; motie B.J. van Bochove en J. Leerdam over het voorleggen van de voordracht voor het кB aan de Staten-Generaal, de Staten van Curaçao en de Staten van Sint Maarten; motie J. Leerdam c.s. over een regeling zoals bedoeld in artikel 38 Statuut.

243 Verworpen werden: voorstel C.A.S.D. Wever (MEP) en J.E. Thijsen (MEP) om een kamer bij de Hoge Raad te belasten met geschillenbeslechting; voorstel Wever en Thijsen om ingrijpende Rijkswetten niet vast te stellen alvorens het ontwerp door de Staten van Aruba was goedgekeurd met tweederde meerderheid; amendement Ortega-Martijn dat opriep tot een voorziening ingeval de uitslag van een referendum op de BES-eilanden negatief uitviel over de de status als openbaar lichaam; amendement G.R. Herdé en C.G. Dammers en amendement Wever en Thijsen om het voorgestelde artikel 27, derde lid Statuut (instrumenten om de bekrachtiging van internationale verplichtingen voortvloeiende uit verdragen te doen naleven) te laten schrappen; amendement Wever en Thijsen om een onderlinge geschillenregeling in artikel 38, eerste lid Statuut op te nemen en dat Aruba iedere consensusrijkswet met betrekking tot Aruba kon laten vervallen met een landsverordening; hun voorstel dat de inwerkingtreding van een landsverordening die een wijziging van het Statuut beoogde en die door de Staten 
was goedgekeurd, slechts zou plaatsvinden nadat de bevolking hiermee had ingestemd bij referendum; motie van A.C.G. Bikker om een jaarlijks soortgelijk interparlementair overleg te houden; motie I. van Gent over monitoring van de ontwikkelingen op Curaçao en Sint Maarten; motie C.A. Ortega-Martijn over invulling van de evaluatiebepalingen.

244 The Daily Herald, RNW, 15 april 2010: 'De Jongh-Elhage: "Ik voel me 30 kilo lichter." RNW, Antilliaans Dagblad, NRC Handelsblad, 16 april 2010.

245 Op 12 mei behandelde de Tweede Kamer twee BES-wetten die essentieel waren voor 10/10/10: de Wet Geldstelsel BES (invoering dollar per 1/1/11) en de Veiligheidswet BES (taken en verantwoordelijkheden in crisissituaties en bij de hulpverlening door politie en brandweer). Deze wetgeving kon op $18 \mathrm{mei}$ rekenen op een grote meerderheid; alleen de PVV en Verdonk stemden tegen. Het nieuwe fiscale systeem zou op de BES in werking treden op 1/1/11. Bijleveld kwam de Kamer tegemoet door een gefaseerde invoering van de Veiligheidswet te overwegen.

246 De Senaatsfractie van het CDA toonde zich geschokt door de goedkeuring in de Tweede Kamer (9 maart) van de drie amendementen en vroeg de regering deze met prudentie, in nauw overleg met de eilandsbesturen, uit te voeren - wat Bijleveld toezegde. Ook de VVD en de christelijke partijen hadden weinig waardering voor het 'opdringen' van deze regelgeving aan de eilanden. Voorzitter van de Vaste Commissie NAAZ in de Eerste Kamer M. Linthorst (PVDA) zei begrip te hebben voor de weerstand, maar volgens haar was het een kwestie van geven en nemen. Er was geen meerderheid voor het voorstel van CU-Tweede Kamerlid C. Ortega-Martijn voor een staatkundige novelle waarmee de senatoren invoering van de ethische kwesties uit de wet zouden kunnen halen.

247 Zie ook brief A.Th.B. Bijleveld-Schouten aan vz. TK en vz. EK, 6 mei 2010, kenmerk 2010-0000306792 (Digidoc; Dossier beleids samenwerking NA 2007-0000013921; Subdossier algemeen 2007-0000046898). Antilliaans Dagblad, 11, 12 mei 2010. Amigoe, NRC Handelsblad, RNW, 12 mei 2010. De TAC had de aangepaste ontwerp-Staatsregelingen en organieke wetten goedgekeurd. De PSG had vervolgens vastgesteld dat ze volledig voldeden aan de criteria. Op 21 mei waren ze voorgelegd aan de RMR om het 'gevoelen' in te winnen. Nadat de bestuurscolleges de adviezen hadden verwerkt in een aangepast concept besprak de RMR de regelingen in een extra vergadering op 28 mei. Daarna zouden de eilandsraden de Staatsregelingen moeten vaststellen, waarna ze door de RMR formeel behandeld en goedgekeurd zouden worden.

248 Besluitenlijst PSG 20 april 2010 (http://ontmantelingna.org). Zie ook The Daily Herald, 19 en 21 april 2010, Amigoe, RNW, 20 april 2010, Antilliaans Dagblad, 21 april 2010.

249 Brief A.Th.B. Bijleveld-Schouten aan vz. TK, 23 februari 2009 (TK, 2008-2009, 31 568, nr. 20). Een van de criteria was de realisatie van het rapport Konfiansa uit 1999, opgesteld door het land Nederlandse Antillen, met concrete integriteitsmaatregelen voor het ambtelijk apparaat en het bestuur.

250 De commissie bestond uit M.L. Alexander, H. Arends en J.J. van Eck. Zie bijv. Antilliaans Dagblad, 28 juli 2010.

251 The Daily Herald, Antilliaans Dagblad, RNW, Amigoe, 22 juni 2010; RNW, 2 juli 2010. De Sint Maartense delegatie was onder leiding van W.V. Marlin naar Den Haag gekomen voor de Stuurgroep van 21 juni, om in rechtstreeks contact te pogen de zorgen naar aanleiding van het kritische rapport van het aangevulde presidium van de V-RTC weg te nemen. Antilliaans Dagblad, 21 juni 2010. De Stuurgroep bereikte overeenstemming over allerlei plannen rond de in het leven 
te roepen Raad voor de Rechtshandhaving, waarmee voldoende zicht was op een goed functionerende raad, zodat een plan van aanpak hiervoor niet noodzakelijk was. Brief A.Th.B. Bijleveld-Schouten aan vz. TK en vz. EK, 5 juli 2010, kenmerk 2010-0000467076 (Digidoc; Dossier beleids samenwerking NA 2007-0000013921; Subdossier algemeen 2010-0000043009). Zie ook besluitenlijst PSG 21 juni 2010 en WTC 1 juli 2010; verslag houdende een lijst van vragen en antwoorden, 23 november 2009 (TK, 2009-2010, 32123 IV, nr. 3).

252 De Antilliaanse pers reageerde teleurgesteld op de uitslag, zie bijv. Antilliaans Dagblad, 10 juni 2010. De mislukte kabinetsformaties zouden de zittende Nederlandse bewindslieden in staat stellen het proces tot het einde te begeleiden. 253 Als hoofdelijk was gestemd, was de motie wel aangenomen en was de WTU aangehouden totdat er ook een Rijkswet personenverkeer zou zijn. Tot drie keer werd geschoven met het tijdstip waarop de motie in stemming zou worden gebracht, zodat zo veel mogelijk Kamerleden konden stemmen. De WTU werd nu voor behandeling aangeboden aan de Eerste Kamer. Vgl. E.M.H. Hirsch Ballin, HEK nr. 36, 6 juli 2010, pp. 1600-1. RNW, 24 juni, Antilliaans Dagblad, 24 en 25 juni 2010. Zie ook Amigoe, 22 juni 2010. Twee moties van Brinkman werden eveneens afgewezen: een over het opsporen van alle illegalen op de BES-eilanden en een voor het afschaffen van de toelatings- en verblijfseisen voor Europese Nederlanders op de BES.

Zie ook Antilliaans Dagblad, 22 juni 2010. Ook heerste er bezorgdheid dat met name Bonaire een toestroom van onder meer Curaçaoënaars te verwerken zou krijgen omdat welzijn en welvaart op het eiland een flinke impuls zouden krijgen. De regering wilde dit voorkomen door voor inwoners van Curaçao, Sint Maarten en Aruba per 10 oktober dezelfde toelatingseisen in te voeren als deze landen hanteren voor Europese Nederlanders. Zie ook RNW, 26 maart 2010. Op 28 september 2010 zou de Senaat unaniem de WTU BES aannemen, waardoor een 'machtiging tot voorlopig verblijf' nodig is voor wie uit Nederland, Aruba, Curaçao of Sint Maarten op een van de BES-eilanden wil gaan wonen. Een meerderheid in de Eerste Kamer was voorstander van scherpere toelatingseisen voor Antillianen die naar Nederland wilden, bijvoorbeeld door een betere naleving van de voogdijregeling en het aanbrengen van een verband met de Sociale Vormingsplicht. Voor de mogelijkheid om jongeren uit te zetten was er minder steun (PVDA, GL, SP en Kamerlid H. ten Hoeve, die D66 en de OSF (Onafhankelijke Senaatsfractie) vertegenwoordigde, waren tegen). De Eerste Kamerfractie wilde de Rijkswet personenverkeer pas beoordelen wanneer het voorstel er zou liggen.

254 Eind april had Bijleveld besloten de behandeling van de fiscale wetgeving voor de BES uit te stellen tot na de verkiezingen van 9 juni, waarmee zij tegemoet was gekomen aan de bezwaren tegen de grote tijdsdruk. Eind september behandelde de Tweede Kamer de wetsvoorstellen Fiscaal Stelsel BES, de Belastingwet, de Douane- en Accijnswet en de Invoeringswet fiscaal stelsel BEs. Aangezien de wetsvoorstellen ook in een overgangssituatie voor de periode van 10/10/10 tot 1/1/11 voorzagen, regelde Bijleveld nu met een technische ingreep dat de Nederlandse Belastingdienst na de transitiedatum bevoegd was de oude, in de Antilliaanse periode ontstane belastingschulden en -vorderingen af te wikkelen. Op 6 oktober vond in de Tweede Kamer de plenaire behandeling plaats van de Belastingwet voor de BES; op 7 oktober was de stemming. Het wetsvoorstel werd aangenomen. Tegen stemden de SP, PVV en Verdonk.

255 Op 19 juni werd - midden in de nacht - de Curaçaose Staatsregeling verworpen met twaalf stemmen voor en negen stemmen tegen. De oppositie 
wilde bijna unaniem een toevoeging waardoor politici onder verdenking van het OM of die gedetineerd waren, automatisch konden worden geschorst. RNW, Amigoe, 19, 22, 24 juni 2010, Antilliaans Dagblad, 19, 21, 25 juni 2010, Trouw, 21 juni 2010, Amigoe, 25 juni 2010. In tweede lezing zou een gewone meerderheid wel voldoende zijn om de Staatsregeling te kunnen aanvaarden.

256 Digidoc; Dossier Ministerieel overleg op en met Aruba en Nederlandse Antillen 2009, kenmerk 2008-0000071412; Subdossier 2009-06-02 videoconference minpres De Jongh-Elhage, kenmerk 2009-0000033510. Antilliaans Dagblad, 23 juni 2010, $R N W$, 30 juni 2010.

$257 R N W, 23$ juni 2010.

258 A.Th.B. Bijleveld-Schouten, HEK nr. 36, 6 juli 2010, pp. 1595, 1597. Besluitenlijst 21 juni 2010 en WTC 1 juli 2010. Zie ook verslag houdende een lijst van vragen en antwoorden, 23 november 2009 (TK, 2009-2010, 32123 IV, nr. 3). J.W. Remkes, HTK nr. 32, 2 december 2009, p. 3064; Amigoe, 24, 25, 30 juni 2010, The Daily Herald, Antilliaans Dagblad, RNW, 23, 28, 30 juni 2010.

$259 \mathrm{Na}$ instemming door de RMR op 2 juli met de aangepaste AMVRB zou de TAC de plannen van aanpak toetsen aan de criteria, zodat ze ten slotte konden worden bekrachtigd in de slot-RTC. Overigens bereikten de Nederlands-Arubaanse relaties tijdens de RMR-vergadering van 2 juli een dieptepunt, met het weglopen van gevolmachtigde minister Frido Croes omdat hij als enige het Gemeenschappelijk Hof van Justitie op Aruba wilde laten vestigen. $R N W, 2$ juli 2010. A.Th.B. Bijleveld-Schouten, HEK nr. 36, 6 juli 2010, p. 1598. De Arubaanse Staten hadden een motie van wantrouwen aangenomen tegen Bijleveld.

260 E.M.H. Hirsch Ballin (HEK nr. 36, 6 juli 2010, p. 1601) sprak de breed gedeelde overtuiging uit dat het nodig was om het Statuut toekomstbestendig te maken.

261 W.V. Marlin, HEK nr. 36, 6 juli 2010, p. 1606. Op Curaçao waren op 15 maart de eerste landstaken van de Nederlandse Antillen overgedragen aan het eilandgebied Curaçao. RNW, 15 maart 2010.

$262 R N W, 6$ juli 2010.

263 F. van Kappen, HEK nr. 36, 6 juli 2010, p. 1598. Bijleveld zegde toe over andere instrumenten te willen nadenken. Interview N.O. Oduber, 29 maart 2011.

264 F. van Kappen, HEK nr. 36, 6 juli 2010, p. 1604; Van Beetz \& Alberto-Martha 2010:161. A.Th.B. Bijleveld-Schouten, HEK nr. 36, 6 juli 2010, p. 1599. RNW, 29 juni, 2 juli 2010, Antilliaans Dagblad, 30 juni, 1, 7 juli en Amigoe, 30 juni, 3, 6 juli, The Daily Herald, 7 juli 2010.

265 ANP, RNW, 6 juli 2010, Antilliaans Dagblad, Amigoe, 7 juli 2010.

266 Zie ook brief A.Th.B. Bijleveld aan vz. TK, 1 maart 2010, kenmerk 2010-0000138349 (http://www.minbzk.nl/actueel?ActItmIdt=125690).

267 Niettemin waren ook op Sint Maarten nieuwe verkiezingen (17 september) nodig, omdat de eilandsraad - die na 10/10/10 het eerste parlement van het land Sint Maarten zou worden - werd uitgebreid van elf naar vijftien leden. Wel moest nog een omstreden artikel, waarin stond dat in het verleden veroordeelde politici hun zetel konden behouden, uit het ontwerp worden gehaald. $R N W, 22$ juli 2010. 268 Van Beetz \& Alberto-Martha 2010:166-7, RNW, 5, 6 september 2010. Amigoe, 4 september 2010, de Volkskrant, The Daily Herald, Antilliaans Dagblad, 6 september 2010. MAN en PS stemden wel voor alle organieke wetten van het toekomstige land Curaçao. Het aanpassen van een eenmaal aangenomen Staatsregeling is echter geen eenvoudige zaak. Niet alleen vereist dit in de nieuwe Staten altijd een tweederde meerderheid voor de wijzigingsvoorstellen, ook de Rijksministerraad moet met de veranderingen instemmen. 
Een ingelaste Rijksministerraad zou beide Staatsregelingen op 7 september vaststellen, waarbij de laatste gouverneur van de Nederlandse Antillen, Frits Goedgedrag, werd voorgedragen als gouverneur van het nieuwe land Curaçao en Eugene Holiday - sinds 2000 namens Sint Maarten nauw betrokken bij de onderhandelingen - als gouverneur van Sint Maarten.

269 Interview R. Vermaas, 25 maart 2011.

270 Anders dan bij de verkrijging van de status aparte door Aruba werd bij deze Statuutwijziging niet de instemming van de vijf betrokken eilandsraden gevraagd. Zie nota aan A.Th.B. Bijleveld en G. ter Horst, 13 oktober 2008, kenmerk 2008-0000486656, 'Vergadering Projectgroep Rechtshandhaving, Rechtspleging en Constitutionele Zaken 21-23 oktober 2008' (Digidoc; Dossier Beleid Koninkrijksstructuur Projectgroep Koninkrijk op Maat, kenmerk 2004-0000002743; Subdossier ambtelijke projectgroep Rechtspleging, Rechtshandhaving en Constitutionele Zaken, kenmerk 2007-0000017849). 'De Antilliaanse delegaties hebben ingestemd met het vervallen van het vetorecht van de eilandsraden bij de Statuutwijziging.'

De Staten van de Nederlandse Antillen stemden na een lange vergadering in met de wijziging, met zeventien stemmen vóór en vier tegen. Zaandam van DP Statia ging niet akkoord (Sint Eustatius had voor behoud van de Antillen gekozen), Robby Beukeboom (PDB) stemde tegen (nog te veel onduidelijkheid over het personenverkeer en de fiscale wetgeving voor de BES), de twee tegenstemmende Ps'ers, L. Willems en H. Wiels, spraken van een 'staatkundige misdaad'. Antilliaans Dagblad, Amigoe, 22 augustus 2010. Van Beetz \& Alberto-Martha 2010:166. Voor stemden PAR, PNP, NA, WIPM en UPB; ook LDK (MAN) en de onafhankelijke leden G. Schotte (MFK) en G. Damoen (FK) steunden de Statuutwijziging. Eisden stemde voor uit respect voor het zelfbeschikkingsrecht van de andere eilanden. Pierre (NDP) was afwezig. Trouw, de Volkskrant, Antilliaans Dagblad, 6 september 2010, RNW, 5 september 2010, Amigoe, 4 september 2010. 271 Amigoe, 5 september 2010. Zie ook Van Beetz \& Alberto-Martha 2010:179.

272 Interview H.G. Senior, 29 augustus 2011.

273 RNW, 7 september 2010. The Daily Herald, Antilliaans Dagblad, Amigoe, 8 september 2010. Van Beetz \& Alberto-Martha 2010:180. Besluitenlijst PSG 7 september 2010 (www.curacao-gov.an).

274 Alles draaide nu om één cruciaal artikel: de datum van inwerkingtreding van de nieuwe verhoudingen. Het enige artikel van het $\mathrm{KB}$ stelde dat, 'De artikelen I en II van de Rijkswet wijziging Statuut in verband met de opheffing van de Nederlandse Antillen treden in werking met ingang van 10 oktober 2010, om oo.oo uur in Aruba, Curaçao, Sint Maarten, Bonaire, Sint Eustatius en Saba en om 06.00 uur in het Europese deel van het Koninkrijk'. Het ontwerp was ondertekend door Balkenende, Hirsch Ballin (als minister van Justitie en tijdelijk ook minister van BZK) en Bijleveld. Op 17 augustus 2010 was het ontwerpInwerkingtredings-KB voor de wijziging van het Statuut aan de Tweede Kamer aangeboden. Antilliaans Dagblad, 18 augustus, 6 september 2010.

275 De brief lekte op 1 augustus uit: na twee jaar van financieel toezicht liet de situatie rond het begrotingsproces en het financieel beheer nog zoveel te wensen over dat het Cft vreesde dat deze situatie zich zou voortzetten met de begroting voor 2011. Antilliaans Dagblad, 30 juli 2010, 17 augustus 2010, Amigoe, RNW, 2, 10 augustus 2010. Het $\mathrm{Cft}$ had al eerder aangegeven dat het geen positief advies kon geven over de begroting van Sint Maarten voor 2010. Zie bijv. Amigoe, The Daily Herald, 9, 11 februari 2010, Amigoe, 4 maart 2010. 
276 Antilliaans Dagblad, 8, 9 september 2010, RNW, 8, 9 september 2010. De motie van A. Bosman werd aangenomen met 73 stemmen voor (VVD, CDA, inclusief Bijleveld, die inmiddels beëdigd was als Tweede Kamerlid, en PVV), versus 62 stemmen tegen. PVDA en GL wilden de motie ongrondwettelijk laten verklaren. De Krom had in de zomer al gedreigd dat de VVD het slot-KB niet zou afhameren als de toelating en uitzetting van kansarme en criminele Antillianen en Arubanen niet goed was geregeld. Antilliaans Dagblad, 4 juni 2010. Een andere motie, van E. Lucassen, om de schuldsanering per direct stop te zetten omdat Curaçao 'stappen heeft gezet naar onafhankelijkheid' kreeg alleen nog de steun van de SP. De motie van Van Raak om van de slot-RTC een 'noodconferentie' te maken haalde het evenmin. De Jongh-Elhage deed in een brief een dringend beroep op de Nederlandse regering om geen uitvoering te geven aan de motie Bosman. Amigoe, 29 september 2010.

Zie ook Wijziging van het Statuut voor het Koninkrijk der Nederlanden in verband met de wijziging van de staatkundige hoedanigheid van de eilandgebieden van de Nederlandse Antillen (Rijkswet wijziging Statuut in verband met de opheffing van de Nederlandse Antillen). Nr. 6 Nota regering (E.M.H. Hirsch Ballin) naar aanleiding van het verslag (van de TK van 24 december 2009 (32 213 (R 1903), nr. 5)), ontvangen 18 januari 2010 (TK, 2009-2010, 32213 (R 1903), nr. 6). De preambule van het gewijzigde Statuut vermeldt dat Curaçao en Sint Maarten vrijwillig zijn toegetreden tot de groep van landen die gezamenlijk in het Statuut een regeling hebben getroffen over de behartiging van de gemeenschappelijke belangen. De BES-eilanden worden niet in de preambule vermeld omdat zij niet toetraden tot de groep van landen die gezamenlijk het Koninkrijk vormen, maar tot het staatsbestel van Nederland.

277 Met name vanuit Curaçao was - tot verrassing van BZK - de delegatie omvangrijk. Antilliaans Dagblad, 31 augustus 2010.

$278 R N W$, 9 september 2010. De conclusies van de slot-RTC werden ondertekend door E.S. de Jongh-Elhage voor het land, M.G. Eman voor Aruba, A.Th.B. Bijleveld-Schouten voor Nederland, S. Osepa voor Curaçao, J.E. Abraham voor Bonaire, J.C.A. Woodley voor Sint Eustatius, W.V. Marlin voor Sint Maarten, C.S.B. Johnson voor Saba.

279 RNW, 28, 31 augustus 2010, Amigoe, Antilliaans Dagblad, 31 augustus 2010, 1, 10 september 2010. Ter voorbereiding had de premier eind augustus alle eilanden bezocht om ervoor te zorgen dat alle resterende punten van zorg afgestemd werden.

280 Nederlands Dagblad, 10 september 2010, The Daily Herald, 9 september 2010. Van Beetz \& Alberto-Martha 2010:168.

281 De Jongh-Elhage geciteerd in Van Beetz \& Alberto-Martha 2010:170-3. RNW, Antilliaans Dagblad, 10 september 2010. RNW, 9 september 2010. Zie ook RNW, 6 september 2010.

282 Zie bijv. Antilliaans Dagblad, Amigoe, The Daily Herald, RNW, 9, 10 september 2010. NRC Handelsblad besteedde in een kritisch commentaar aandacht aan het staatkundig proces. Op de voorpagina prijkte op 10/9/2010 berichtgeving over overlast veroorzakende Antillianen in Nederland - in de week voorafgaand aan de RTC waren in Nederland schietincidenten geweest met dodelijke afloop waarbij Antillianen betrokken waren. Trouw van 10 september 2010 ging onder de kop 'Bijleveld klaart Antillenklus na 3,5 jaar onderhandelen' in een positief getoonzet stuk uitgebreid in op de rol van de staatssecretaris.

283 The Daily Herald, 8 september 2010, Amigoe, Antilliaans Dagblad, 11 september 2010, RNW, 10 september 2010. 
284 Aruba stemde uiteindelijk in met het voorstel de zetel van het Hof in Willemstad te behouden, zodat de basis van deze wet alsnog in consensusrijkswetgeving ligt. Wel heeft Aruba de voorwaarde gesteld dat het Hof uiterlijk binnen drie jaar na de ontmanteling in Aruba zetelt; geen van de andere betrokken partijen heeft hierin toegestemd.

\section{Epiloog}

1 Bordewijk 191:51 (Baud), respectievelijk Alofs 2011 (ter perse; petitie van Philipsburg, uitspraak Koloniale Raad); vgl. Oostindie \& Klinkers 2001, I:15. 2 Interviews op Curaçao: R. (Raymond) Begina, 22 maart 2011, C.P. de Haseth, 22 maart 2011, E.A.V. Jesurun, 21 maart 2011, Z.A.M. Jesus-Leito, 24 maart 2011, E.S. de Jongh-Elhage, 22 maart 2011, E.T.M. de Lannooy, 22 maart 2011, J.M. Saleh, 23 maart 2011, H. Wiels, 25 maart 2011, E.N. Ys, 21 maart 2011. In gelijke zin op Sint Maarten: E. Holiday, 30 maart 2011, op Sint Eustatius R.J. Hooker, 28 maart 2011, op Saba: W.S. Johnson, 25 maart 2011 en ook op Aruba: M. Eman, 29 maart 2011, N.O. Oduber, 29 maart 2011.

3 Motie Luchtenveld c.s., 21 februari 2006 (medeondertekend door W. van Fessem, G. van As, C. van der Staaij) (TK, 2005-2006, 30300 IV, nr. 27). Op 23 februari werd de motie aangenomen. Interviews E.M.H. Hirsch Ballin, 20 april 2011, W.I.I. van Beek, 27 mei 2011, Th.C. de Graaf, 30 juni 2011, H.G.J. Kamp, 19 mei 2011, A. Nicolaï, 23 mei 2011, A. Pechtold, 23 mei 2011, J.W. Remkes, 30 mei 2011; e-mail C.P. de Haseth, 23 augustus 2011.

4 http://www.rijksoverheid.nl/regering/het-kabinet/regeerakkoord/immigratie; http://www.rijksoverheid.nl/regering/het-kabinet/gedoogakkoord/immigratie 5 http://www.rijksoverheid.nl/regering/het-kabinet/regeerakkoord/inleiding. 6 Interview H.G.J. Kamp, 19 mei 2011; Leers geciteerd in Antilliaans Dagblad, 3 mei 2011.

7 Geciteerd in Oostindie \& Klinkers 2001:III, 199.

8 Interview E.M.H. Hirsch Ballin, 20 april 2011.

9 Interviews R. (Raymond) Begina, 22 maart 2011, C.P. de Haseth, 22 maart 2011, Z.A.M. Jesus-Leito, 24 maart 2011, E.A.V. Jesurun, 21 maart 2011, E.S. de JonghElhage, 22 maart 2011, E.T.M. de Lannooy, 22 maart 2011, S.F.C. Römer, 21 maart 2011, J.M. Saleh, 23 maart 2011, E.N. Ys, 21 maart 2011; e-mail H.G. Senior, 1 september 2011.

10 Interview $\mathrm{H}$. Wiels, 25 maart 2011.

11 Interviews H.G. Senior, 29 augustus 2011, J. Larmonie, 30 maart 2011.

12 Oostindie \& Klinkers 2001:III, 223-4. Protocol Aruba-Nederland 1993. Bijv. interviews R. (Raymond) Begina, 22 maart 2011, E.S. de Jongh-Elhage, 22 maart 2011, E.T.M. de Lannooy, 22 maart 2011, Z.A.M. Jesus-Leito, 24 maart 2011, J.M. Saleh, 23 maart 2011.

13 Interviews A.G. Croes, 29 augustus 2011, M. Eman, 29 maart 2011 en N.O. Oduber, 29 maart 2011; e-mail A.G. Croes, 9 september 2011.

14 Interview J.H. de Sola, 25 maart 2011, vgl. Amigoe, 9 april 2011.

15 Interview H.G. Senior, 29 augustus 2011, e-mail H.G. Senior, 1 september 2011. 16 Interview R.J. Hooker, 28 maart 2011.

17 Interviews A.Th.B. Bijleveld-Schouten, 20 mei 2011, Th.C. de Graaf, 30 juni 2011, A. Nicolaï, 23 mei 2011, A. Pechtold, 23 mei 2011, J.W. Remkes, 30 mei 2011. 18 Interview K.G. de Vries, 30 augustus 2011.

19 Interview W.I.I. van Beek, 27 mei 2011. 
20 Interviews op Curaçao E.S. de Jongh-Elhage, 22 maart 2011, E.T.M. de Lannooy, 22 maart 2011, J.M. Saleh, 23 maart 2011; ook H. Wiels, 25 maart 2011; op Bonaire R.T. Booi, 28 maart 2011.

21 Interviews E.B. Holiday (destijds onderhandelaar voor Sint Maarten, nu gouverneur), 30 maart 2011, J. Larmonie (destijds onderhandelaar voor Curaçao, nu ambtenaar op Sint Maarten), 30 maart 2011, W.V. Marlin, 31 maart 2011.

22 The Daily Herald, 27 april 2011 (Heyliger), 16 januari 2010 (stemgerechtigden).

23 Vgl. hierover ook Nauta 2011.

24 Geciteerd uit verslag aan Tweede Kamer in Oostindie \& Klinkers 2001:III, 210.

25 Vgl. ook Hillebrink 2010; Newton 2010; Hillebrink, Roos \& Verhey 2011.

26 Geciteerd in Sluis 2010:132.

27 Interview R.T. Booi, 28 maart 2011.

28 Interview J.E. Abraham, 28 maart 2011; J. Abraham i.s.m. H. de Bruijne, Ongepubliceerd document 'Staatkundig proces Bonaire naar "directe banden", 28 maart 2011, p. 32. Brieven J.E. Abraham aan J.P.H. Donner, 22 juni 2011 en aan TK Commissie voor Koninkrijksrelaties, 16 augustus 2011. Directeur KR Gerritsen was tot 1 mei 2011 waarnemend Rijksvertegenwoordiger na het terugtreden van Henk Kamp. Vgl. ook Knape 2010.

29 Interviews R.J. Hooker en W.S. Johnson, 28 maart 2011.

30 Interviews R. (Raymond) Begina, 22 maart 2011, A.G. Croes, 29 augustus 2011, E.S. de Jongh-Elhage, 22 maart 2011, E.N. Ys, 21 maart 2011; ook E.T.M. de Lannooy, 22 maart 2011, J. Larmonie, 30 maart 2011, J.M. Saleh, 23 maart 2011. 31 Raad van State 2010:112. Interviews A.Th.B. Bijleveld-Schouten, 20 mei 2011, E.M.H. Hirsch Ballin, 20 april 2011, H.G.J. Kamp, 19 mei 2011, A. Nicolaï, 23 mei 2011, J.W. Remkes, 30 mei 2011.

32 Interview J.M. Saleh, 23 maart 2011.

33 Interviews A.Th.B. Bijleveld-Schouten, 20 mei 2011, H.G.J. Kamp, 19 mei 2011. 34 Interview L.A.M. van Halder, 17 augustus 2011; Verhey 2010b:37.

35 Voorlichting over mogelijkheden tot versnelling van het transitieproces naar de nieuwe staatkundige verhoudingen tussen Nederland, de Nederlandse Antillen, Curaçao en Sint Maarten, 29 augustus 2008 (zaaknummer Wo4.08.0213/I/AK). www.raadvanstate.nl.

36 Interviews A. Nicolaï, 23 mei 2011, A. Pechtold, 23 mei 2011, J.W. Remkes, 30 mei 2011. Interview E.M.H. Hirsch Ballin, RNW, 22 september 2011.

37 Verhey 2010b:37.

38 Interview A.Th.B. Bijleveld-Schouten, 20 mei 2011.

39 Interviews R. (Raymond) Begina, 22 maart 2011, R.T. Booi, 28 maart 2011, G.E.A. van Craaikamp, 2 augustus 2011, L.A.M. van Halder, 17 augustus 2011, E.S. de Jongh-Elhage, 22 maart 2011, R.J. Hooker, 28 maart 2011, A. Pechtold, 23 mei 2011, E.N. Ys, 21 maart 2011; ook E.T.M. de Lannooy, 22 maart 2011, J. Larmonie, 30 maart 2011, J.M. Saleh, 23 maart 2011.

40 Interviews R.T. Booi, 28 maart 2011, J. Larmonie, 30 maart 2011, S.F.C. Römer, 21 maart 2011, H. Wiels, 25 maart 2011.

41 Interviews C.P. de Haseth, 22 maart 2011, E.N. Ys, 21 maart 2011, E.B. Holiday, 30 maart 2011, Verhey 2010a:16. Interview E.M.H. Hirsch Ballin, 20 april 2011; vgl. Oostindie \& Klinkers 2001:III, 206 (Toekomstconferentie 1993, Lubbers en Hirsch Ballin versus minister van Binnenlandse Zaken Ien Dales).

42 Interviews J.W. Remkes, 30 mei 2011, K.G. de Vries, 30 augustus 2011.

43 Interview A.Th.B. Bijleveld-Schouten, 20 mei 2011.

44 Interviews R. (Raymond) Begina, 22 maart 2011, A.Th.B. Bijleveld-Schouten, 20 mei 2011, Z.A.M. Jesus-Leito, 24 maart 2011, E.S. de Jongh-Elhage, 22 maart 
2011, E.T.M. de Lannooy, 22 maart 2011; interview S. Wescott-Williams, RNW, 23 september 2010.

45 Interviews W.I.I. van Beek, A.Th.B. Bijleveld-Schouten, 20 mei 2011, H.G.J. Kamp, 19 mei 2011, A. Pechtold, 23 mei 2011.

46 Interview A.G. Croes, 29 augustus 2011.

47 'De visie op het Koninkrijk', openingswoord A. van Es, ministerie van BZK, 2 februari 2010; interview A.Th.B. Bijleveld-Schouten, 20 mei 2011.

48 Toespraak J.P.H. Donner, Amsterdam, 20 mei 2011 (Amigoe, 21 en 23 mei 2011, Antilliaans Dagblad, 23 mei 2011, The Daily Herald, 23 mei 2011).

49 Interviews Th.C. de Graaf, 30 juni 2011, A. Nicolaï, 23 mei 2011.

50 Onder meer interviews R.T. Booi, 28 maart 2011, R.J. Hooker, 28 maart 2011, E.S. de Jongh-Elhage, 22 maart 2011, W.V. Marlin, 31 maart 2011, N.O. Oduber, 29 maart 2011, S.F.C. Römer, 21 maart 2011; e-mail H.G. Senior, 1 september 2011. 51 Interviews Z.A.M. Jesus-Leito, 24 maart 2011, S.F.C. Römer, 21 maart 2011; vgl. ook Römer 2011.

52 Motie Leerdam, medeondertekend door B.J. van Bochove, J.W. Remkes en I. van Gent, 14 april 2010 (TK, 2009-2010, nr. 26, 32213 (R1903)). De motie werd op 15 april aangenomen. Voor stemden: PVDA, GroenLinks, D66, PvdD, VVD, ChristenUnie, SGP, CDA en het lid R. Verdonk.

53 Interviews E.S. de Jongh-Elhage, 22 maart 2011, M. Eman, 29 maart 2011, H. Wiels, 25 maart 2011.

54 Interview A.G. Croes, 29 augustus 2011, M. Eman, 29 maart 2011; e-mail M. Eman, 30 augustus 2011. Document 'Visie Arubaanse regering op het Koninkrijk'.

55 Oostindie \& Klinkers 2003:29-41, Damen 2009.

56 Interview A. Nicolaï, 23 mei 2011; zie 'Het Nederlandse buitenlandse beleid ten aanzien van Latijns-Amerika en de Cariben', 11 december 2009, TK 2009-2010, $29653 \mathrm{nr}$. 3. Mede gebaseerd op overleg in 2011 op het ministerie van BZ over een nieuwe BZ-beleidsnotitie 'Het Nederlands beleid ten aanzien van Latijns-Amerika en de Cariben', aangeboden 26 augustus 2011 (TK 2010-2011, 29653, nr. 11).

57 Op de eilanden leeft ongemak en ook wel enige rancune over de voorgenomen beperkingen op het onderlinge personenverkeer binnen de voormalige Nederlandse Antillen.

58 Interview H.G.J. Kamp, 19 mei 2011. Opiniepeilingen in Nederland: Oostindie \& Klinkers 2001, II:38-9, 73-5, III: 67-8, de Volkskrant, 7 januari 2008.

59 Interview E.S. de Jongh-Elhage, 22 maart 2011; interviews met Radio Nederland Wereldomroep, Z.A.M. Jesus-Leito, 25 september 2011, S. WescottWilliams, 23 september 2010. Oostindie 2008; Oostindie \& Klinkers 2003.

60 Interviews W.S. Johnson, 28 maart 2011, H.G. Senior, 29 augustus 2011, H. Wiels, 25 maart 2011; e-mail W.S. Johnson, 12 augustus 2011.

61 World bank Report 'Crime, violence and development; Trends, costs, and policy options in the Caribbean', 3 mei 2007, http://go.worldbank.org. 62 Interviews J.P. Dirkse, 7 september 2011, G.M. de Vries, 7 september 2011, K.G. de Vries, 30 augustus 2011.

63 Interviews W.I.I. van Beek, 27 mei 2011, A. Pechtold, 23 mei 2011, J.W. Remkes, 30 mei 2011. Vgl. Oostindie \& Klinkers 2001, III, hfdst. 10 en Verhey 2010b:39-40.

64 Vgl. ook voormalig DG op het ministerie van Justitie R.K.Visser 2010:84.

65 A.Th.B. Bijleveld-Schouten, toespraak bij Emancipatieviering, Amsterdam, Oosterpark, 1 juli 2009, respectievelijk Antilliaans Dagblad, 14 oktober 2009. Interview S.F.C. Römer, 21 maart 2011. 
66 Brief Vaste Commissie van Koninkrijksrelaties, 7 april 2011 (TК 2010-2011, 32500 IV, nr. 34).

67 Besselink 2004; Roos 2010:76-8; l'Express, 14 mei 2009, NRC Handelsblad, 11 januari 2010 ('Franse Antillen tegen autonomie').

68 'De toekomst van het Koninkrijk', notitie van de minister van BZK J.P.H.

Donner, aangeboden aan de TK, 15 juli 2011, kenmerk 2011-2000289238.

69 Dat loslaten wordt onder meer bepleit in interviews met A.Th.B. BijleveldSchouten, 20 mei 2011, Th.C. de Graaf, 30 juni 2011 en J.W. Remkes, 30 mei 2011. De uitspraak 'geen vrijblijvend arrangement' is van K.G. de Vries, 30 augustus 2011. 


\section{Bibliografie}

Digidoc (2005-2010), ministerie van BZK

Papieren archief (2000-2004), ministerie van BZK

Online archieven

www.rijksbegroting.nl

www.raadvanstate.nl

http://parlando.sdu.nl

www.rijksoverheid.nl/ministeries/bzk

http://wetten.overheid.nl

http://eerstekamer.nl

http://tweedekamer.nl

https://zoek.officielebekendmakingen.nl

www.ikregeer.nl

www.minbzk.nl

http://ontmantelingna.org

e-mail nieuwsservice Kabinet van de Gevolmachtigde Minister van de

Nederlandse Antillen/Curaçao

\section{Interviews}

In Nederland

W.I.I. van Beek, 27 mei 2011

F.P. van Beetz, 25 augustus 2011

A.Th.B. Bijleveld-Schouten, 20 mei 2011

J. van Bochove, 5 maart 2010

G.E.A. van Craaikamp, 2 augustus 2011

M.R. Cramwinckel, 5 oktober 2010

A.G. (Mito) Croes, 29 augustus 2011

A.A. Dalenoort, 4 maart 2010

J.P. Dirkse, 7 september 2011

H. Gerritsen, 5 augustus 2009

Th.C. de Graaf, 30 juni 2011

J.J.C.M. Gudde, 26 mei en 13 oktober 2010 
L.A.M. van Halder, 17 augustus 2011

E.M.H. Hirsch Ballin, 20 april 2011

H.G.J. Kamp, 19 mei 2011

J. Newton, 26 mei 2010

A. Nicolaï, 23 mei 2011

E. Noorman, 19 mei 2010

R. Palacios, 19 mei 2010

A. Pechtold, 23 mei 2011

B. van Poelgeest, 26 mei 2010

J. Rademaker, 20 september 2011

J.W. Remkes, 30 mei 2011

P. Rosenmöller, 19 mei 2011

H.G. Senior, 29 augustus 2011

W.W. Timmers, 25 augustus 2011

H.D. Tjeenk Willink, 12 oktober 2010

R. van der Veer, 26 oktober 2010

L.F.M. Verhey, 1 maart en 26 mei 2010

K. de Vey Mestdagh, 20 mei 2010

K.G. de Vries, 30 augustus 2011

G.M. de Vries, 7 september 2011

G.R. Wawoe, 19 mei 2010

G. van der Wulp, 7 juni 2011

S.B. Ybema, 20 mei 2010

Op Aruba

M. Eman, 29 maart 2011

N.O. Oduber, 29 maart 2011

Op Bonaire

J.E. Abraham, 28 maart 2011

R.T. Booi, 28 maart 2011

Op Curaçao

R. (Raymond) Begina, 22 maart 2011

R.J. Cornax, 23 maart

F.M. de los Santos Goedgedrag, 24 maart 2011

C.P. de Haseth, 22 maart 2011

E.A.V. Jesurun, 21 maart 2011

Z.A.M. Jesus-Leito, 24 maart 2011

E.S. de Jongh-Elhage, 22 maart 2011

E.T.M. de Lannooy, 22 maart 2011

S.F.C. Römer, 21 maart 2011

J.M. Saleh, 23 maart 2011

J.H. de Sola, 25 maart 2011

R. Vermaas, 23 en 25 maart 2011

H.M. Wiels, 25 maart 2011

E.N. Ys, 21 maart 2011

Op Sint Maarten

E.B. Holiday, 30 maart 2011

M. Jonkers, 31 maart 2011 
J.A.B. Larmonie, 30 maart 2011

W.V. Marlin, 31 maart 2011

Op Saba

W.S. Johnson, 28 maart 2011

Op Sint Eustatius

R.J. Hooker, 28 maart 2011

\section{Literatuur}

ALOFS, L.J.

2011 Onderhorigheid en separatisme; Koloniaal bestuur en lokale politiek op Aruba, 1816-1955. Proefschrift Universiteit Leiden.

BALDACCHINO, G. \& D. MILNE (EDS)

2009 The case for non-sovereignty; Lessons from sub-national island jurisdisctions. London: Routledge.

BEETZ, F. VAN \& J. MARTHA-ALBERTO

2010 Het laatste kabinet en kroniek van de ontmanteling van de Nederlandse Antillen 10-10-'10. Fort Amsterdam, Curaçao: Raad van Ministers en Regering van de Nederlandse Antillen.

BESSELINK, L.F.M.

2004 'De Europese Unie en de Koninkrijksrelaties', in: L.J.J. Rogier \& H.G. Hoogers (red.), 50 jaar Statuut voor het Koninkrijk der Nederlanden; Bijdragen voor het congres 50 jaar Statuut voor het Koninkrijk der Nederlanden, pp. 109-22. Rotterdam: Erasmus Universiteit Rotterdam. BEUGE, CH.R.

2004 Banden met Brussel; De betrekkingen van de Nederlandse Antillen en Aruba met de Europese Unie. S.1.: Rapport van de Commissie ter bestudering van mogelijke toekomstige relaties van de Nederlandse Antillen en Aruba met de Europese Unie.

BORDEWIJK, H.W.C.

1911 Ontstaan en ontwikkeling van het staatsrecht van Curaçao. 's-Gravenhage: Nijhoff.

BORMAN, C.

2005 Het Statuut voor het Koninkrijk. Deventer: Tjeenk Willink.

BROEK, A.G. (RED.)

2005 Antillen/Aruba: uit de gunst. Amsterdam: Boom Tijdschriften.

[Themanummer Christen Democratische Verkenningen winter 2005.]

BRÖRING, H.E., D. KOCHENOV, H.G. HOOGERS \& J.H. JANS (RED.)

2008 Schurende rechtsordes; Over de Europese Unie, het Koninkrijk en zijn Caribische gebieden. Groningen: Europa Law Publishing.

CLEGG, P. \& E. PANTOJAS-GARCÍA (EDS)

2009 Governance in the non-independent Caribbean; Challenges and opportunities in the twenty-first century. Kingston: Randle.

COMITÉ 2004

2003 Investeren in gezamenlijkheid; Een aanzet tot debat door het Comité 2004. Amsterdam: Stichting ABC Advies. 
2004a Investeren in gezamenlijkheid; Deel 1: Een visie op de toekomst van ons Koninkrijk naar aanleiding van de vijftigste verjaardag van het Statuut voor het Koninkrijk der Nederlanden. Voorburg: Comité 2004.

2004b Investeren in gezamenlijkheid; Een aanzet tot debat door het Comité 2004. Deel II. [s.l.]: [s.n.].

CROES, A.G.

2005 'De "reinvention" van het Koninkrijk', in: L. de Jong \& D. Boersema (eds), The Kingdom of the Netherlands in the Caribbean: 1954-2004; What's next?, pp. 65-8o. Amsterdam: Rozenberg Publishers.

2006 De herdefiniëring van het Koninkrijk. Nijmegen: Wolf Legal Publishers.

2007 'De desintegratie van de Nederlandse Antillen', Ars Aequi 56(4):316-22.

DAMEN, A.

2009 'Onrust in de Franse Caraïben', Internationale Spectator 63(7/8): 360-3.

DIJK, A.G. VAN

2010 'Consensusrijkswetgeving; Een bijzonder concept', in: A.L.C. Roos \& L.F.M. Verhey (red.), Wetten voor de West; Over de wetgeving in het vernieuwde Koninkrijk der Nederlanden, pp. 55-68. 's-Gravenhage: Ministerie van Veiligheid en Justitie.

GRIEKEN, P.G. VAN \& N.M. KÖPER

2007 Naar een salsa op klompen; Over de toekomst van het Koninkrijk der Nederlanden. 's-Gravenhage: Wetenschappelijk Instituut voor het CDA.

GRIJFF, E. DE

2010 'In de ban van de Commissie NAAZ', in: A.L.C. Roos \& L.F.M. Verhey (red.), Wetten voor de West; Over de wetgeving in het vernieuwde Koninkrijk der Nederlanden, pp. 87-8. 's-Gravenhage: Ministerie van Veiligheid en Justitie.

HILLEBRINK, $S$.

2008 The right to self-determination and post-colonial governance; The case of the Netherlands Antilles and Aruba. The Hague: Asser Press.

2010 'De wijziging van het Statuut voor het Koninkrijk', in: A.L.C. Roos \& L.F.M. Verhey (red.), Wetten voor de West; Over de wetgeving in het vernieuwde Koninkrijk der Nederlanden, pp. 43-52. 's-Gravenhage: Ministerie van Veiligheid en Justitie.

HILLEBRINK, S., A.L.C. ROOS \& L.F.M. VERHEY

2011 'Een nieuwe rechtsorde binnen Nederland; De toetreding van Bonaire, Sint Eustatius en Saba tot het Nederlandse staatsbestel', NJB Nederlands Juristenblad 2011(519): 613-9.

HIRSCH BALLIN, E.M.H.

2003 'De Koninkrijksgemeenschap', TAR-Justicia 2:92-3.

2006 'Een constitutionele kwadratuur van de cirkel', in: Gronding recht; Opstellen voor Dr. Seerp B. Ybema bij zijn afscheid als Directeur Juridische Zaken van het Ministerie van Defensie, 21 september 2006, pp. 39-48. 's-Gravenhage: Ministerie van Defensie.

JANSEN VAN GALEN, J.

2004 De toekomst van het koninkrijk; Over de dekolonisatie van de Nederlandse Antillen. Amsterdam/Antwerpen: Contact.

JESSURUN D'OLIVEIRA, H.U.

2003 'Nederlandse secessie uit het Koninkrijk; Oftewel: Fifty ways to leave your lover(s)', in: J.L. de Reede \& J.H. Reestman (red.), Op het snijvlak van recht en politiek; Opstellen aangeboden aan prof.mr. L. Prakke, pp. 111-30. Deventer: Kluwer. 
JESURUN, E.A.V.

2004 Nu kan het... nu moet het! Advies Werkgroep Bestuurlijke en Financiële Verhoudingen. Willemstad/'s-Gravenhage: Werkgroep BFV.

JONG, L. DE \& D. BOERSEMA (EDS)

2005 The Kingdom of the Netherlands in the Caribbean: 1954-2004; What's next? Amsterdam: Rozenberg Publishers.

JONG, L. DE \& D. KRUIJT (EDS)

2005 Extended statehood in the Caribbean; Paradoxes of quasi colonialism, local autonomy and extended statehood in the USA, French, Dutch and British Caribbean. Amsterdam: Rozenberg Publishers.

JUSTITIËLE VERKENNINGEN

2009 Themanummer 'De Nederlandse Cariben', Justitiële Verkenningen 35(5).

KIEZEN VOOR HET KONINKRIJK

2009 Kiezen voor het Koninkrijk; Democratische legitimiteit van besluitvorming en controle op Koninkrijksniveau. 's-Gravenhage: Rapport van de Commissie Democratisch Deficit.

KLINKERS, I.A.J.

1999 De weg naar het Statuut; Het Nederlandse dekolonisatiebeleid in de Caraiben (1940-1954) in vergelijkend perspectief. Proefschrift Universiteit Utrecht.

KNAPE, C.A.

2010 'Abortus en euthanasie op de BES-eilanden', in: A.L.C. Roos \& L.F.M. Verhey (red.), Wetten voor de West; Over de wetgeving in het vernieuwde Koninkrijk der Nederlanden, pp. 111-4. 's-Gravenhage: Ministerie van Veiligheid en Justitie.

KRIPS, F.J.E.

2010 'De aanpassing en invoering van de (straf)wetgeving op de BES-eilanden; Antilliaans of Nederlands?', in: A.L.C. Roos \& L.F.M. Verhey (red.), Wetten voor de West; Over de wetgeving in het vernieuwde Koninkrijk der Nederlanden, pp. 105-9. 's-Gravenhage: Ministerie van Veiligheid en Justitie.

LEPPERS, J.

2010 'Enkele korte beschouwingen over het vreemdelingenrecht op de BES-eilanden en de Rijkswet personenverkeer', in: A.L.C. Roos \& L.F.M. Verhey (red.), Wetten voor de West; Over de wetgeving in het vernieuwde Koninkrijk der Nederlanden, pp. 125-9. 's-Gravenhage: Ministerie van Veiligheid en Justitie.

NAUTA, O.

2011 Goed bestuur in de West; Institutionele en maatschappelijke beperkingen voor goed bestuur in de Caribische Rijksdelen. Proefschrift Universiteit Utrecht.

NEWTON, J.M.

2010 'Van directe band met Nederland naar staatsrechtelijke positie binnen het Nederlandse staatsbestel', in: A.L.C. Roos \& L.F.M. Verhey (red.), Wetten voor de West; Over de wetgeving in het vernieuwde Koninkrijk der Nederlanden, pp. 97-102. 's-Gravenhage: Ministerie van Veiligheid en Justitie.

OOSTINDIE, G.J.

2005 'Het Statuut; Geschiedenis en perspectief', in: L.J.J. Rogier \& H.G. Hoogers (red.), 50 jaar Statuut voor het Koninkrijk der Nederlanden, pp. 13-25. Rotterdam: Erasmus Universiteit Rotterdam. 
2006 De parels en de kroon; Het koningshuis en de koloniën. Amsterdam: De Bezige Bij.

2009 'Dependence and autonomy in sub-national island jurisdictions; The case of the Netherlands Antilles and Aruba', in: G. Baldacchino \& D. Milne (eds), The case for non-sovereignty; Lessons from sub-national island jurisdisctions, pp. 121-37. London: Routledge.

2011 'De Raad van State als adviseur in een veranderend Koninkrijk', in: H.D. Tjeenk Willink et al. (red.), De Raad van State in perspectief, pp. 139-61. Den Haag: Boom Juridische Uitgevers.

OOSTINDIE, G.J. \& I.A.J. KLINKERS

2001 Knellende Koninkrijksbanden; Het Nederlandse dekolonisatiebeleid in de Caraïben, 1940-2000. Deel I t/m III. Amsterdam: Amsterdam University Press.

2003 Decolonising the Caribbean; Dutch Policies in a Comparative Perspective. Amsterdam: Amsterdam University Press.

1998 Ki sorto di Reino?/What kind of Kingdom? Visies en verwachtingen van Antillianen en Arubanen omtrent het Koninkrijk. 's-Gravenhage: Sdu Uitgevers.

RAAD VAN STATE VAN HET KONINKRIJK

2003 Verdieping of geleidelijk uiteengaan? De relaties binnen het Koninkrijk en met de Europese Unie. 's-Gravenhage: Raad van State.

2011 Jaarverslag 2010. 's-Gravenhage: Raad van State.

ROGIER, L.J.J. \& H.G. HOOGERS (RED.)

200550 jaar Statuut voor het Koninkrijk der Nederlanden. Rotterdam: Erasmus Universiteit Rotterdam.

RÖMER, S.F.C.

2006 'Enkele suggesties voor een vernieuwd Koninkrijk', in: D.J. Elzinga (red.), De Nederlandse constitutionele monarchie in een veranderend Europa, pp. 155-68. Alphen aan den Rijn: Kluwer.

2011 De Raad als adviseur in een veranderend Koninkrijk; De visie van een politica', in: H.D. Tjeenk Willink et al. (red.), De Raad van State in perspectief, pp. 163-87. Den Haag: Boom Juridische Uitgevers.

ROMONDT, A. VAN [ET AL.]

2005 Gedenkboek 50 jaar Statuut; Een Koninkrijksbundel. Zutphen: Walburg Pers. ROOS, A.L.C.

2010 'Enkele overwegingen over de internationale en Europese aspecten', in: A.L.C. Roos \& L.F.M. Verhey (red.), Wetten voor de West; Over de wetgeving in het vernieuwde Koninkrijk der Nederlanden, pp. 71-8. 's-Gravenhage: Ministerie van Veiligheid en Justitie.

ROOS, A.L.C. \& L.F.M. VERHEY (RED.)

2010 Wetten voor de West; Over de wetgeving in het vernieuwde Koninkrijk der Nederlanden. 's-Gravenhage: Ministerie van Veiligheid en Justitie.

ROSHEUVEL, D.A.R.

2005 De toekomst van de Nederlandse Antillen in staatsrechtelijke verhouding; Een verkenning voor de constitutionele agenda van de 21ste eeuw. Proefschrift Universiteit Leiden.

SLUIS, M.

2004 De Antillen bestaan niet; De nadagen van een fictief land. Amsterdam: Bert Bakker. 
2010 Een koloniale speeltuin; De Antillen achter de schermen. Amsterdam: Bert Bakker.

SOCIETAS IURIDICA ANTILIANA ET ARUBANA

2004 Symposium 50 jaar Statuut; Verleden, heden en toekomst. Leiden: Societas Iuridica Antiliana et Arubana.

STAATKUNDIGE VERANDERINGEN

2011 Staatkundige veranderingen in beeld; Het wetgevingstraject van de staatkundige hervormingen van het Koninkrijk. 's-Gravenhage: Ministeries van BZK en van Justitie.

VERHEY, L.F.M.

$2010 a$ 'De Antillenwetgeving, een bijzonder project', in: A.L.C. Roos \& L.F.M. Verhey (red.), Wetten voor de West; Over de wetgeving in het vernieuwde Koninkrijk der Nederlanden, pp. 15-24. 's-Gravenhage: Ministerie van Veiligheid en Justitie.

2010b 'Slotakkoord of nieuw begin; Enkele algemene beschouwingen over het nieuwe Koninkrijk', in: A.L.C. Roos \& L.F.M. Verhey (red.), Wetten voor de West; Over de wetgeving in het vernieuwde Koninkrijk der Nederlanden, pp. 27-40. 's-Gravenhage: Ministerie van Veiligheid en Justitie.

VISSER, R.K.

2010 'Sfeertekening van een politiek proces; Staatkundige veranderingen van het Koninkrijk der Nederlanden', in: A.L.C. Roos \& L.F.M. Verhey (red.), Wetten voor de West; Over de wetgeving in het vernieuwde Koninkrijk der Nederlanden, pp. 81-4. 's-Gravenhage: Ministerie van Veiligheid en Justitie.

WAL, H.A. VAN DER

2005 'De relatie binnen het Statuut voor het Koninkrijk', in: A. van Romondt et al., Gedenkboek 50 jaar Statuut; Een Koninkrijksbundel, pp. 385-96. Zutphen: Walburg Pers.

WEIDE, L.E.

2010 'Kan het nog sneller?', in: A.L.C. Roos \& L.F.M. Verhey (red.), Wetten voor de West; Over de wetgeving in het vernieuwde Koninkrijk der Nederlanden, pp. 169-74. 's-Gravenhage: Ministerie van Veiligheid en Justitie. 


\section{Fotoverantwoording}

p. 24 Spaarnestad, fotograaf onbekend.

p. 28 Spaarnestad, fotograaf onbekend.

p. 34 ANP, fotograaf Lex van Lieshout.

p. 42 ANP, fotograaf Cor Mulder.

p. 56 ANP, fotograaf Ed Oudenaarden.

p. 74 ANP, fotograaf Govert Coebergh.

p. 86 ANP, fotograaf Robin Utrecht.

p. 98 ANP, fotograaf Raúl Henriquez.

p. 116 ANP, fotograaf Hennie Keeris.

p. 132 Privécollectie, fotograaf Marcel Cramwinckel.

p. 148 Privécollectie, fotograaf Jan Rademaker.

p. 164 ANP, fotograaf Marcel Antonisse.

p. 174 ANP, fotograaf Lex van Lieshout.

p. 182 ANP, fotograaf Prince Victor.

p. 198 Privécollectie, fotograaf Jan Rademaker.

p. 214 Ministerie van BZK, fotograaf Jannes Linders.

p. 230 Ministerie van BZK, fotograaf Jannes Linders.

p. 246 Ministerie van BZK, fotograaf Jannes Linders.

p. 252 Ministerie van BZK, fotograaf Jannes Linders.

p. 258 ANP, fotograaf Phil Nijhuis.

p. 264 ANP, fotograaf Lex van Lieshout.

p. 270 ANP, fotograaf Lex van Lieshout.

p. 276 ANP, fotograaf Lex van Lieshout. 


\section{Afkortingen}

$\begin{array}{ll}\text { ADB } & \text { Aliansa Demokratika Bonairiana } \\ \text { AFP } & \text { Algemene Financiële Positie } \\ \text { AMV(R)B } & \text { Algemene Maatregel van (Rijks)bestuur } \\ \text { AO } & \text { Algemeen Overleg } \\ \text { AVP } & \text { Arubaanse Volkspartij } \\ \text { AZ } & \text { Algemene Zaken } \\ \text { BES } & \text { Bonaire, Sint Eustatius, Saba } \\ \text { BFV } & \text { Bestuurlijke en Financiële Verhoudingen } \\ \text { BNP } & \text { Bruto Nationaal Product } \\ \text { BSG } & \text { Bureau Secretaris-Generaal } \\ \text { BVK } & \text { Bestuurlijke Vernieuwing en Koninkrijksrelaties } \\ \text { BZ } & \text { Buitenlandse Zaken } \\ \text { BZK } & \text { Binnenlandse Zaken en Koninkrijksrelaties } \\ \text { CBP } & \text { College Bescherming Persoonsgegevens } \\ \text { CDA } & \text { Christen-Democratisch Appèl } \\ \text { Cft } & \text { College financieel toezicht } \\ \text { CRW } & \text { consensusrijkswet } \\ \text { CU } & \text { ChristenUnie } \\ \text { CZK } & \text { Constitutionele Zaken en Koninkrijksrelaties (directoraat-generaal) } \\ \text { CZW } & \text { Constitutionele Zaken en Wetgeving } \\ \text { D66 } & \text { Democraten 66 } \\ \text { DG } & \text { Directeur-generaal } \\ \text { DNB } & \text { Directe/Nieuwe Banden met Nederland } \\ \text { DOM } & \text { Département d'outre-mer } \\ \text { DP } & \text { Democratic Party } \\ \text { DWA } & \text { Directie Wetgeving Antillen (Justitie) } \\ \text { DWH (BZ) } & \text { Directie Westelijk Halfrond (Buitenlandse Zaken) } \\ \text { ERNA } & \text { Eilandenregeling Nederlandse Antillen } \\ \text { EU } & \text { Europese Unie } \\ \text { FDA } & \text { Fondo Desaroyo Aruba } \\ \text { FK } & \text { Forsa Kòrsou } \\ \text { FOL } & \text { Frente Obrero Liberashon 3o di Mei } \\ \text { FOLs } & \text { Forward Operating Locations } \\ \text { GL } & \text { GroenLinks } \\ \text { GVP } & \text { Gemeenschappelijke Voorziening Politie } \\ \text { HBSG } & \text { Hoofd Bureau Secretaris-Generaal } \\ & \\ \text { C }\end{array}$




\begin{tabular}{|c|c|}
\hline IMF & Internationaal Monetair Fonds \\
\hline IPC & Interparlementaire Commissie \\
\hline IWG & Interdepartementale Werkgroep \\
\hline KabNA & Kabinet voor Nederlands-Antilliaanse en Arubaanse Zaken \\
\hline КB & Koninklijk Besluit \\
\hline $\mathrm{KR}$ & (directie) Koninkrijksrelaties \\
\hline LDK & Lista di Kambio \\
\hline LGO & Landen en Gebieden Overzee \\
\hline LPF & Lijst Pim Fortuyn \\
\hline LTU & Landsverordening Toelating en Uitzetting \\
\hline MEP & Moviemento Electoral di Pueblo \\
\hline MFK & Movementu Futuro Kòrsou \\
\hline MPK & Movementu Politiko Kòrsou \\
\hline $\mathrm{MvT}$ & Memorie van Toelichting \\
\hline NA & National Alliance \\
\hline NAA & Nederlandse Antillen en Aruba \\
\hline NAAZ & Nederlands Antilliaanse en Arubaanse Zaken \\
\hline NDP & National Democratic Party \\
\hline NPA & Niun Paso Atras \\
\hline MFK & Movementu Futuro Kòrsou \\
\hline NU & Nieuwe Unie \\
\hline OCAN & Overlegorgaan Caraïbische Nederlanders \\
\hline OLA & Orghanisashon Liberal Arubiano \\
\hline $\mathrm{OM}$ & Openbaar Ministerie \\
\hline OSF & Onafhankelijke Senaatsfractie \\
\hline PAR & Partido Antias Restrukturá \\
\hline $\mathrm{PDB}$ & Partido Demokrátiko Boneriano \\
\hline PLKP & Partido Laboral Krusada Popular \\
\hline PNP & Partido Nashonal di Pueblo \\
\hline POK & Parlementair Overleg Koninkrijksrelaties \\
\hline РОт & Programma Organisatie Transitieproces \\
\hline PPA & Partido Patriotico Arubana \\
\hline PPK & Partido Pais Kórsou \\
\hline PRRC & $\begin{array}{l}\text { Projectgroep Rechtspleging, Rechtshandhaving en Constitutionele } \\
\text { Zaken }\end{array}$ \\
\hline PS & Pueblo Soberano \\
\hline PSG & Politieke Stuurgroep Staatkundige Veranderingen \\
\hline PVDA & Partij van de Arbeid \\
\hline PVDD & Partij voor de Dieren \\
\hline PVV & Partij voor de Vrijheid \\
\hline $\mathrm{RCN}$ & Rijksdienst Caribisch Nederland \\
\hline $\mathrm{RDB}$ & Rechtszekerheid en Deugdelijkheid van Bestuur \\
\hline RMR & Rijksministerraad \\
\hline RPV & Rijkswet personenverkeer \\
\hline RSC & Regionaal Service Centrum \\
\hline RST & Recherche Samenwerkingsteam \\
\hline RTC & Rondetafelconferentie \\
\hline RVS & Raad van State \\
\hline SEA & Sint Eustatius Alliance \\
\hline SG & secretaris-generaal \\
\hline SGP & Staatkundig Gereformeerde Partij \\
\hline
\end{tabular}




$\begin{array}{ll}\text { SOAB } & \text { Stichting Overheids Accountants Bureau } \\ \text { SP } & \text { Socialistische Partij } \\ \text { TAC } & \text { Toetsingsadviescommissie } \\ \text { TK } & \text { Tweede Kamer } \\ \text { TON } & \text { Trots op Nederland } \\ \text { UPB } & \text { Union Patriotiko Bonaireano } \\ \text { UPG } & \text { Ultra Perifere Gebieden } \\ \text { V\&I } & \text { Vreemdelingenzaken en Integratie } \\ \text { VBC } & \text { Vereniging Bedrijfsleven Curaçao } \\ \text { VIA } & \text { Verwijsindex Antillianen } \\ \text { VIR } & \text { Verwijsindex Risicojongeren } \\ \text { VNG } & \text { Vereniging van Nederlandse Gemeenten } \\ \text { VNO } & \text { Vertegenwoordiging van Nederland in Aruba (Oranjestad) } \\ \text { VNP } & \text { Vertegenwoordiging van Nederland in Philipsburg, Sint Maarten } \\ \text { VNW } & \text { Vertegenwoordiging van Nederland in Willemstad, Curaçao } \\ \text { V-RTC } & \text { Voorbereidingscommissie Rondetafelconferentie } \\ \text { VVD } & \text { Volkspartij voor Vrijheid en Democratie } \\ \text { VWS } & \text { Volksgezondheid, Welzijn en Sport } \\ \text { WIPM } & \text { Windward Islands People's Movement } \\ \text { WODC } & \text { Wetenschappelijk Onderzoek- en Documentatiecentrum } \\ \text { WOLBES } & \text { Wet Openbare Lichamen Bonaire, Sint Eustatius en Saba } \\ \text { WTU } & \text { Wet Toelating en Uitzetting } \\ \text { WWI } & \text { Wonen, Wijken en Integratie } \\ \text { z.d. } & \text { zonder datum } \\ \text { z.k. } & \text { zonder kenmerk }\end{array}$




\section{Index}

Aartsen, Jozias van 81, 89, 121, 122

Abraham, Jopie 223, 225-227, 232, 247, 258, 263, 268

Adriaens, Maurice 84

Alcalá-Wallé, Marilyn 132

Arion, Frank Martinus 167

As, Gerard van 158

Atacho, Pedro 242

Balkenende, Jan Peter 48, 50, 67, 69, $83,119,141,148,151,152,155,161$, 164, 166, 180, 189, 196-198, 209, 210, 213-215, 229, 247, 255, 258, 268, 269, 274

Baud, J.C. 251

Beatrix 84, 103, 174, 175, 247, 248

Beek, Willibrord van 41, 69, 99, 252, 261, 266, 271, 279

Beetz, Freek van 148, 198

Begina, Raymond 114, 115, 117, 132, 148, 265, 270

Berkel, Ralph 132

Beuge, Ronald van 92, 93

Bijl, Bob van der 132

Bijleveld-Schouten, Ank 44, 48, 49, 56, 58, 60, 63, 68, 69, 73, 84-89, 94, 97, 101, 102, 186-203, 206, 207, 210, 211, 213-222, 224, 226-233, 235, 237-239, 241-243, 245, 247, 249, 250, 252, 258, 261, 265, 267269, 271, 272, 275, 280

Bikker, Andy 246

Blackman, Xavier 185

Blankert, Hans 125, 132

Bochove, Bas Jan van 207, 225, 227, 230, 234-237
Bolkestein, Frits 29

Bommel, Harry van 123, 146

Booi, Ramonsito 47, 65, 149, 152, 164, 223, 227, 228, 247, 251, 261, 263, 265, 274

Borghouts, Harry 106

Bos, Wouter 48, 122

Bosman, André 246

Bot, Ben 93

Boxtel, Roger van 63, 76-79, 82

Brete, Eric 98

Brinkman, Hero 57, 88, 98, 99, 105, 189, 195, 219, 227, 236, 246

Brooks-Salmon, Mavis 88, 89, 101

Buitendijk, Gert-Jan 47

Carolus, Norwin 198

Chávez, Hugo 35, 89, 90

Comenencia, Paul 49

Cooper, Charles 90, 259

Cova, Errol 90, 124, 126, 127, 140, 145

Craaikamp, Gea van 46, 47, 198, 268

Cramwinckel, Marcel 125, 132

Croes, Betico 28

Croes, Duke 100

Croes, Hendrik 166

Croes, Mito 105, 259, 265

Curiel, Freddie 148, 214

Dales, Geert 125, 132, 134

Dijk, Anneke van 214

Dindial, Liza 276

Dirkse, Jan-Paul 42, 45, 47, 61, 62, 267, 279

Donner, Piet Hein 138, 272, 275, 282 
Duncan, Roland 161, 163, 264

Eisden, Eunice 236

Eman, Henny 29, 276

Eman, Mike 37, 40, 180, 243, 247, 258, 259, 272, 276

Es, Andrée van 47, 272

Fessem, Wim van 148, 157, 169

Fortuyn, Pim 103, 106

Gent, Ineke van 219, 230, 232, 236

Gerritsen, Hans 47, 214, 225, 264, 268

Gibson, Richard 126, 129, 130, 134, 136, 141, 214

Godett, Anthony 90, 121

Goedgedrag, Frits de los Santos 34, 41, 174, 217, 226, 264, 276

Goedgedrag-Terborg, Dulcie 174, 276

Graaf, Thom de 41, 44-46, 55, 61, 64-82, 86, 92, 93, 96, 97, 99, 110, 121-130, 132, 134-139, 141, 156, $254,260,261,268,274$

Halder, Leon van 46, 55, 148, 266, 268

Haseth, Carel de 64, 78, 119, 188, 255

Havermans, Ad 71, 205

Heyliger, Theo 248, 262

Hillen, Hans 149

Hirsch Ballin, Ernst 26, 27, 29, 48, $54,56,68,69,73,85,97,109,117$, $134,157,171-174,188,197,198$, 212-214, 240, 242, 256, 257, 262, 265-269

Hoekstra, Rein Jan 54

Holiday, Eugene 41, 112, 148, 155, 214

Hooker, Roy 65, 148, 153-155, 164, 26o, 264

Horst, Guusje ter 48, 221

Ignacio, Sedney 148, 152

Jacoba, Magali 88, 264

James, Vance 132

Jesurun, Edsel 'Papy' 29, 52, 120, $125-130,132,135,140,258$

Jesus-Leito, Zita 187, 211, 270, 274, 278
Johnson, Chris 211, 247, 258

Johnson, Will 27, 132, 144, 153, 154, $164,264,278$

Jonckheer, Efrain 24, 243

Jongh-Elhage, Emily de 34, 36, 58, $60,66,69,84,161,164-167,172$, 181, 186, 192, 210, 215-218, 221, 230, 232-236, 243, 247-249, 251, 252, 258, 264, 270, 274, 276, 277

Juliana 8, 24, 246

Kalsbeek, Ella 79

Kamp, Henk 44, 69, 90, 116, 204, 227, 256, 264-266, 271, 277

Kappen, Frank van 96, 215, 242

Knaap, Cees van der 79, 106

Koerten, Onno 44, 119

Kok, Wim 42, 69, 141

Komproe, Ben 58

Koning, Jan de 61, 64

Lannoy, L.A.J. de 196, 197

Lannooy, Ersilia 'Zus' de 264

Larmonie, Julien 132, 148, 259, 268

Laveist, Louie 216

Leeflang, Omayra 264

Leerdam, John 47, 98, 234-237, 240, 275

Leers, Gerd 256

Leeuwen, Boelie van 266

Liberia-Peters, Maria 29

Linthorst, Marijke 241

Louisa-Godett, Mirna 58, 121, 135

Lourens, Winston 126

Lubbers, Ruud 26, 27, 69, 109, 158, 256

Luchtenveld, Ruud 83, 158, 175

Macaay, Urvin 182

Marlin, William 216, 234, 239, 242, 243, 247, 248, 258

Martha, Rutsel 78

Martina, Don 29, 100, 182

Máxima 103, 248, 276

Nicholson, Shamara 264

Nicolaas, Anthony 132, 211, 223-227

Nicolaï, Atzo 15, 46, 47, 67-69, 82, $93,156,164,167-172,174,181-186$, 213, 237, 261, 265, 267, 269, 274, 277 
Oduber, Nel 16, 37, 40, 86, 92, 153, $161,162,164,166,180,184,210$, 211, 242, 259

Opstelten, Ivo 80

Ortega-Martijn, Cynthia 227

Osepa, Sheldry 245, 247, 258

Oven, Gerrit Jan van 100

Palm, Frits 79

Pechtold, Alexander 15, 46, 49, 63, $65,66,68,69,82,83,93,96,116$, 141-151, 153-167, 237, 255, 261, 267, 268, 271, 280

Peper, Bram 112

Pietersz, Jurdric 264

Plank, Marcel van der 17, 252

Pourier, Miguel 16, 29, 36, 42, 58, 61, $62,74,77,78$

Putten, Clive van 148

Raak, Ronald van 56, 96, 189, 207, 219, 220, 227, 231, 234, 236, 237, 240, 246

Rafaël, Magda 114

Refunjol, Fredis 17, 41

Remkes, Johan 15, 41, 45, 49, 63, 64, $69,72,79,89,96,97,118-121,167$, 171, 192, 194, 207, 220, 230-236, 239, 246, 255, 260, 265, 267-269, 279

Richards, Franklyn 129

Richardson, Dennis 155

Rijpstra, Jan 99

Römer, Suzy 29, 47, 68, 74, 78, 167, 171, 172, 198, 214, 230, 257, 258, 268, 274, 280

Rosenmöller, Paul 120, 125, 126, 129, 132, 136

Rouvoet, André 86,87

Rutte, Mark 84, 85, 193, 255, 256, 271

Salden, Gita 148

Saleh, Jaime 16, 41, 97, 126, 140, 174, 265

Schotte, Gerrit 58, 59, 243, 244, 260

Schuiling, Hanneke 45

Schuurman, Egbert 41, 96, 106, 157

Senior, Humphrey 182, 245, 259

Simmons, Erny 264

Staaij, Kees van der 96

Steenhuis, D.W. 196, 197
Sterk, Mirjam 82

Sulvaran, Glenn 237

Thodé, Glenn 226

Thomas, Papito 264

Tjeenk Willink, Herman 12, 47, 54, 56, 97, 101, 154

Tromp, Ensley 17, 143

Veeris, Jacques 79

Verdonk, Rita 8o-84, 86, 88, 142, 158, 162, 193, 232, 237

Verhagen, Maxime 81, 121, 122

Verhey, Luc 48, 188, 198, 214, 266, 267

Vermaas, Rob 44, 67, 244

Vogelaar, Ella 85-87

Vollenhoven, Pieter van 97, 140

Voorhoeve, Joris 13, 29, 42, 43, 45, 60

Vries, Gijs de 45, 61-63, 68-6o, 74, 76, 77, 79, 100, 106, 112-114, 118, 135, 268, 279

Vries, Klaas de 42, 49, 62, 102, 112, 118, 158, 170, 261, 269, 279

Wawoe, Gilbert 30, 51, 54

Weitenberg, Hans 190

Wescott-Williams, Sarah 64, 121, 148, 152, 211, 216, 243, 247, 248, 270, 278

Wiels, Helmin 44, 210, 243, 258, 268, 276, 278

Wijers, Hans 71

Wilders, Geert 237

Wilhelmina 8, 23

Willem I 21

Willem-Alexander 103, 248, 276

Willemsen, Frank 214

Windt, Gilbert de 214

Woodley, Julian 211, 247, 258

Ys, Etienne 36, 58, 65, 81-83, 86, $106,113,116,119,120,135,136$, 142-144, 146, 148, 150, 153-155, 159, 167, 171, 172, 214, 216, 230, 249, 258, 265

Zalm, Gerrit 68, 143, 155, 171, 185

Zwol, Richard van 48,148 

